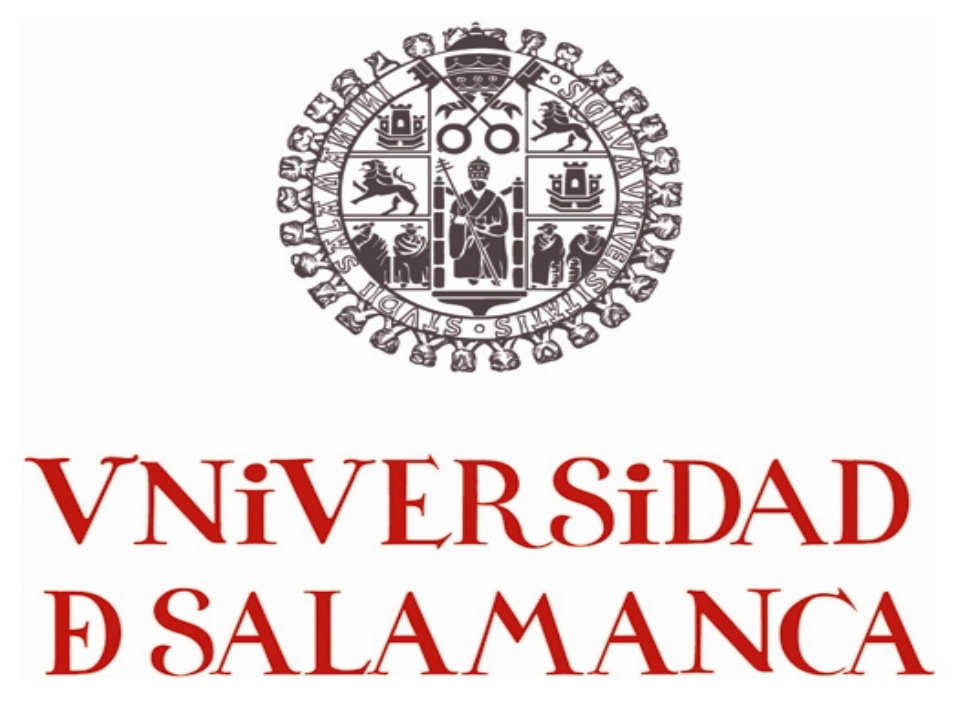

Departamento de Derecho Público General Área de DEREcho PENAL

\title{
SOBORNO DE LOS GOBERNANTES \\ Análisis comparativo del delito de cohecho pasivo en Derecho penal español, francés y malgache
}

Autor:

HENRI NIRINA ANDRIAMAMPIANINA

Director:

EDUARDO A. FABIÁN CAPARRÓS 

El doctorando,

HENRI NIRINA ANDRIAMAMPIANINA

El director de la tesis,

EDUARDO A. FABIÁN CAPARRÓS 



\section{ÍNDICE}

\section{ÍNDICE}

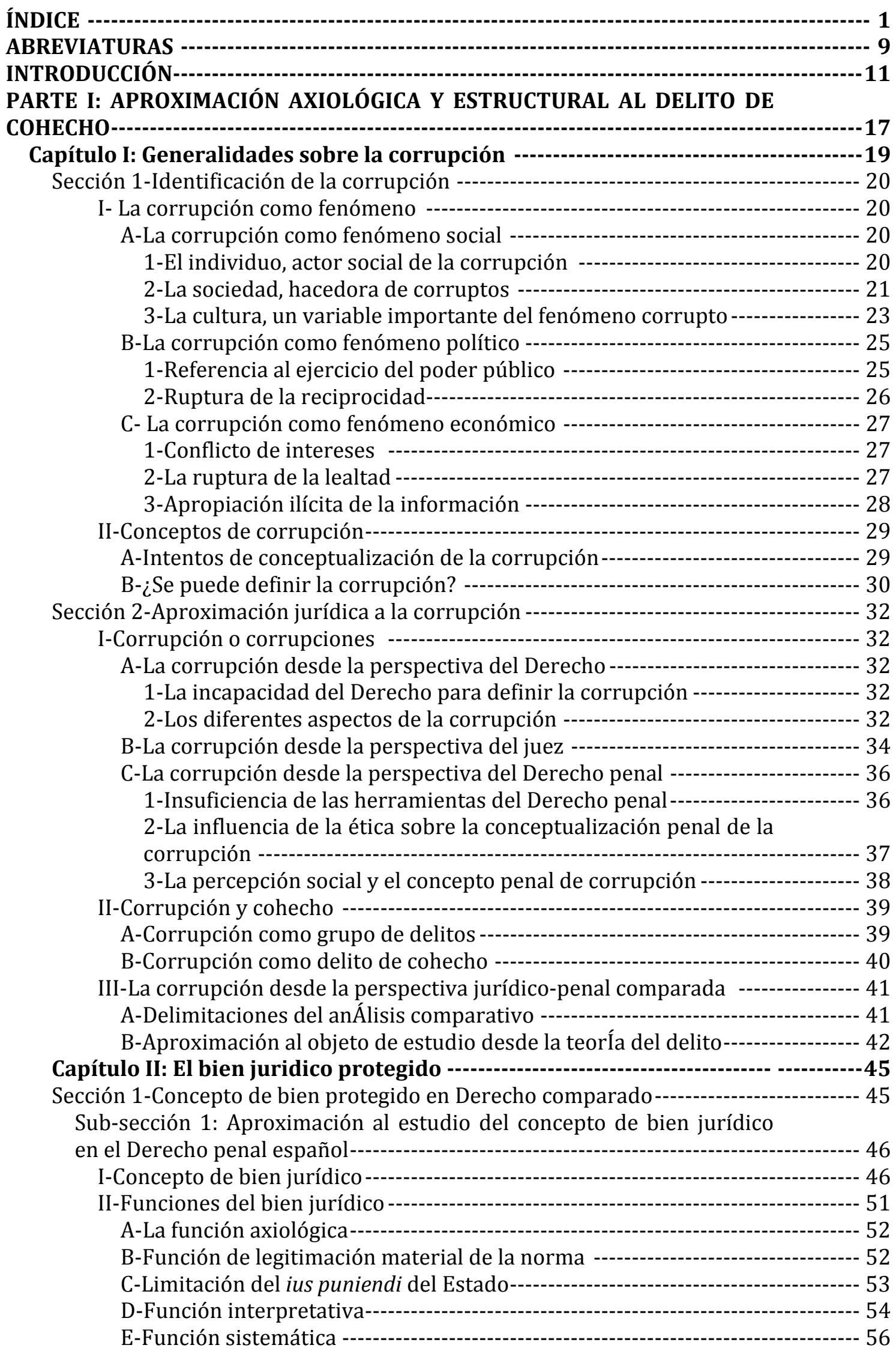




\section{SOBORNO DE LOS GOBERNANTES}

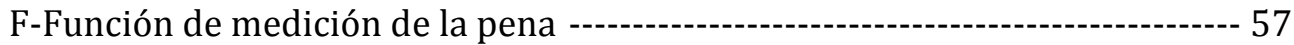

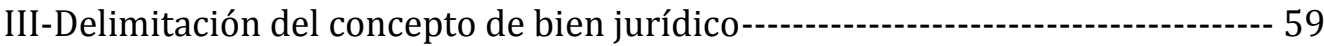

A-Las teorías constitucionales del bien jurídico en la doctrina

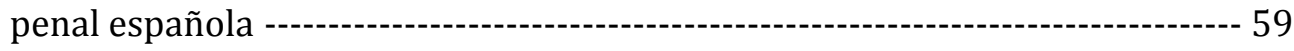

B- Las teorías del bien jurídico con fundamento sociológico en la

doctrina penal española--------------------------------- 64

Sub-sección 2: Aproximación al estudio de los valores protegidos en el

Derecho francés ---------------------------------------------------------- 71

I-Ausencia del concepto técnico de bien jurídico en la doctrina penal

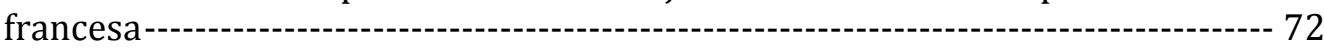

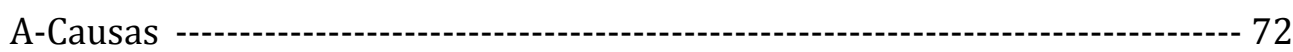

1- Recepción incompleta del concepto de antijuridicidad----------------- 72

2- Razones relacionadas a los juristas ------on 75

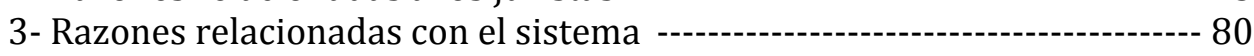

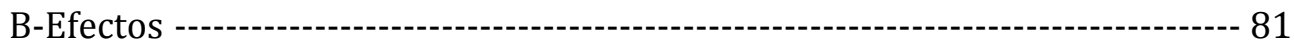

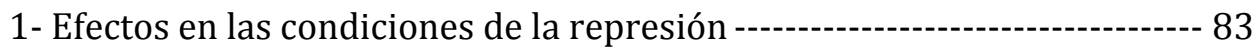

2- Efectos en las causas de justificación---- 84

II-Supervivencia del concepto de bien jurídico -----o- 85

A-Premisa del planteamiento ---.-- 85

B-Supervivencia en la doctrina penal francesa ----------------------------- 87

C-Supervivencia del concepto en el trabajo legislativo ---------------------- 90

D-Supervivencia del concepto en el trabajo del juez -------------------------- 93

1- El bien jurídico en el mecanismo de calificación -------------------- 93

2- Los bienes jurídicos y la resolución de los conflictos de

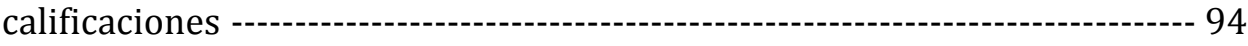

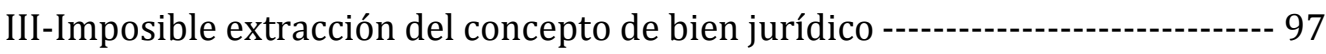

Sección 2-El ámbito de estudio: la Administración Pública ---------------------100

III-La Administración Pública en el ordenamiento jurídico-penal

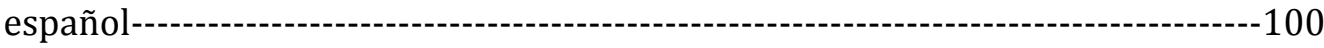

A-Evolución del concepto de administración pública -----------------------100

1-La Administración pública y delitos del cargo -----------------------100

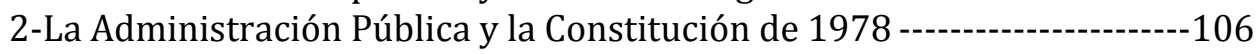

B-El bien jurídico protegido en el Título XIX del Código penal

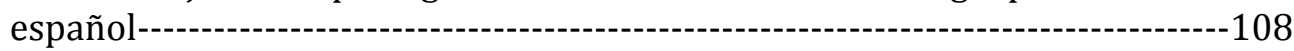

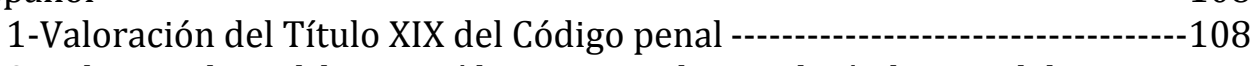

2-Debate sobre el bien jurídico protegido en el Título XIX del

Código penal---o--on

II-La Administración según la perspectiva del ordenamiento penal

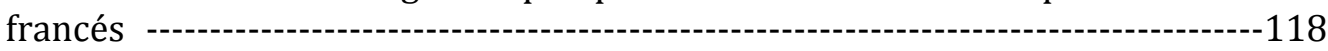

A-Concepto de Administración pública ---

1-Evolución del concepto ---

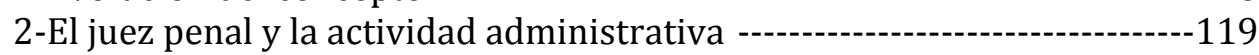

B-Estudio del bien jurídico en los capítulos II y III del título III del

libro IV del Código penal francés (CPF) ----:-

1- Aproximación constitucional a la noción de Administración y

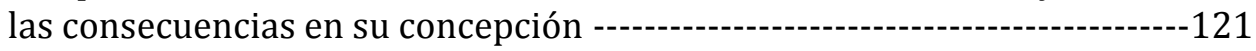

2-Elementos a considerar: la autoridad del Estado versus la

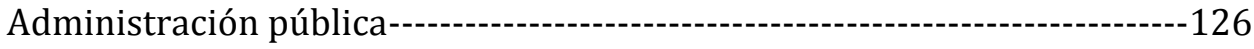

a-Consideración de la reforma legislativa del año 1992 en

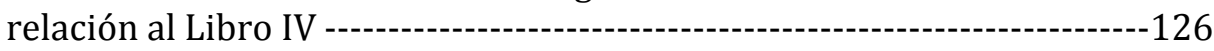

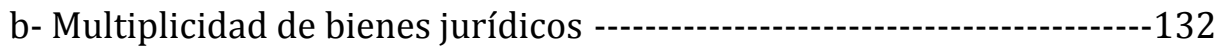

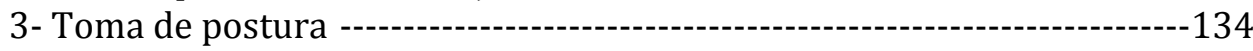

III-La protección penal de la Administración en el Derecho malgache -----------141 


\section{ÍNDICE}

A-Repaso de la evolución de la protección penal desde una

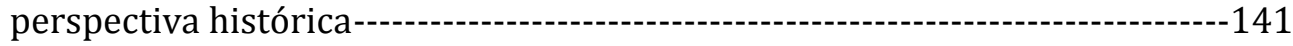

1-La Administración del reino merina ------------------142

2- La protección de la función pública en el Derecho penal colonial

B-De la "forfaiture" y de los crímenes y delitos de los funcionarios

en el ejercicio de sus cargos

1- Sistemática de la sección II

2- Algunas aportaciones de la reforma legislativa de 2004 en la sección II

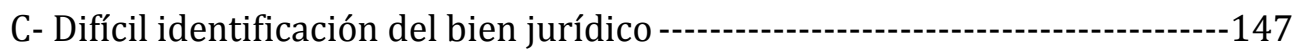

1- La protección de la integridad o de la probidad ---

2- Los parámetros constitucionales sobre la Administración --------------150

Sección 3-El bien jurídico protegido en los delitos de cohecho y de corrupción

I-El bien jurídico protegido en el delito de cohecho en el ordenamiento español-

A- Evolución doctrinal del bien jurídico en materia de cohecho

B- Las propuestas doctrinales actuales en cuanto al bien jurídico

del delito de cohecho

1- El correcto funcionamiento de la Administración pública -

2-El abuso del cargo en beneficio propio y la prohibición de venalidad o comerciabilidad en el desempeño de la función pública -

3-El principio de imparcialidad en el ejercicio de las funciones públicas

II-El bien jurídico protegido en el delito de corrupción en los ordenamientos francés y malgache

A-Los bienes jurídicos protegidos en el delito de corrupción en el

marco de la protección de la Administración pública ----------------------175

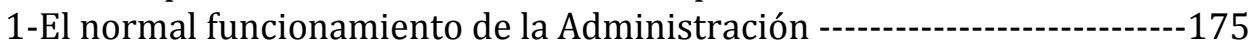

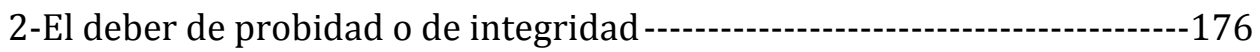

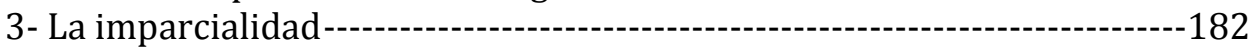

B- La tendencia hacia una concepción economista del interés

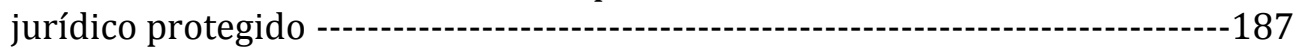

1-Cambio de enfoque: del sector público hacia el sector privado ----------187

2-Protección de la economía de mercado ----188

Capítulo III: La estructura de los tipos de cohecho y de corrupción pasiva

Sección 1-Naturaleza jurídica del delito de cohecho según el número de sujetos participantes

I-El delito de cohecho como delito bilateral----

II-El delito de cohecho como delito unilateral -----.--193

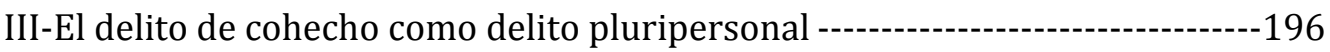

Sección 2-Naturaleza del delito de cohecho según las modalidades de acción -

I-El delito de cohecho como delito formal o de mera actividad ---:----:-----204

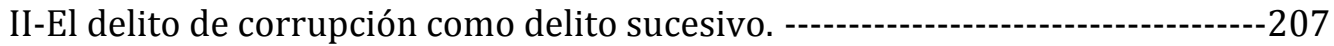

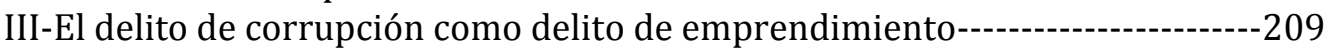

PARTE II: ESTUDIOS DE LOS ELEMENTOS TÍPICOS DEL DELITO DE

Capítulo IV: Tipo objetivo (I). Los sujetos activos

Sección 1- El concepto de funcionario a efectos penales en Derecho penal español- 


\section{SOBORNO DE LOS GOBERNANTES}

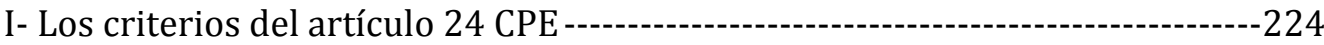

A- Participación en el ejercicio de funciones públicas --------------------------225

1- Las propuestas de la doctrina española respecto al concepto

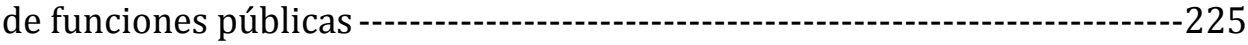

2- Observaciones y toma de postura------------------------229

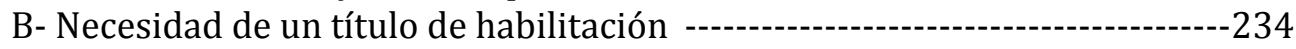

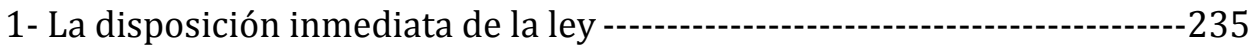

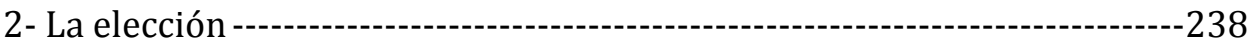

3- El nombramiento por la autoridad competente -------------------239

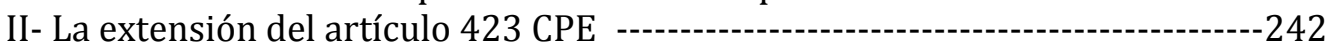

A- Relación entre los artículos 423 (anterior artículo 422) y 24.2

del CPE

B- Las consecuencias de la ubicación del anterior artículo 422 CPE para las figuras del delito de cohecho antes de la reforma penal de

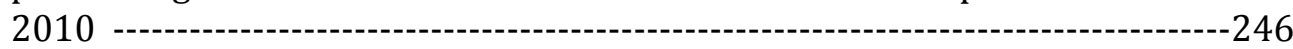

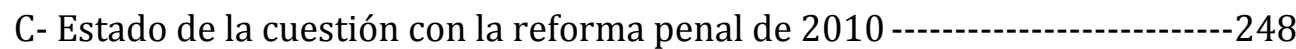

Sección 2- Ausencia de la noción de funcionario público en materia penal en Derecho francés y malgache

I-. Los criterios de identificación de la persona que desempeña una

función pública según los artículos 432-11 CPF y 177 CPM

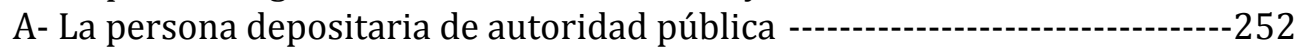

B-Las personas que ostenten un mandato electivo público-------------------254

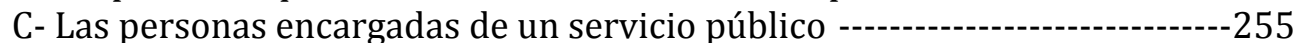

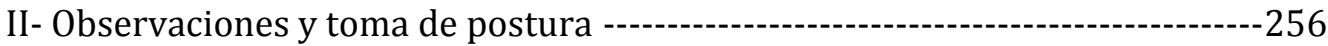

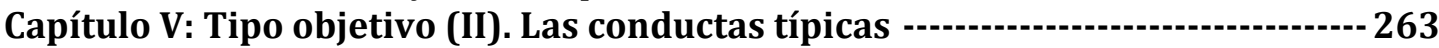

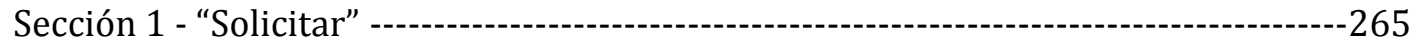

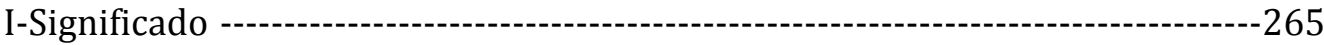

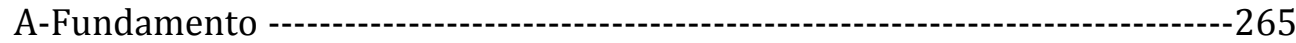

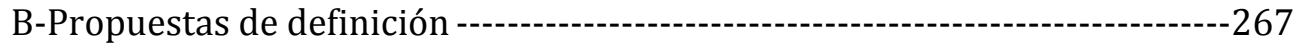

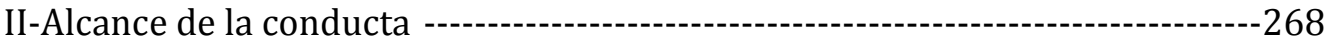

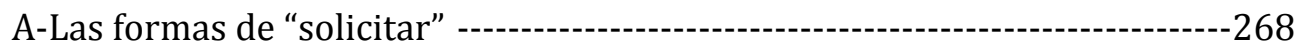

B-La expresión "sin tener derecho a ello" en el Derecho francés y

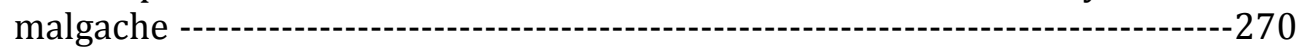

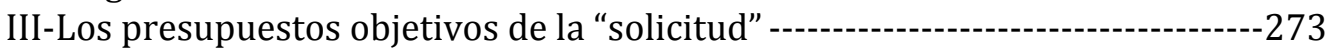

A-La solicitud como declaración de voluntad recepticia -------------------274

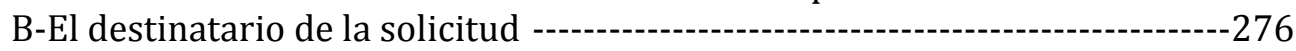

C-Otros caracteres de la solicitud ---.--on

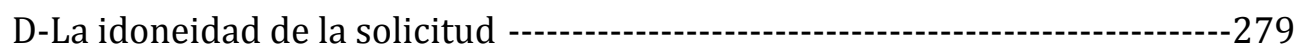

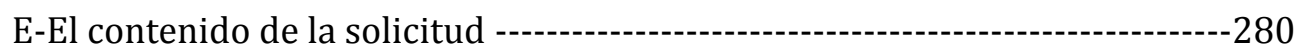

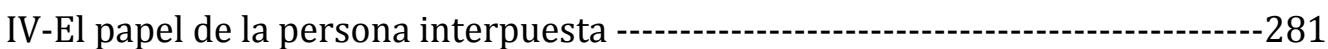

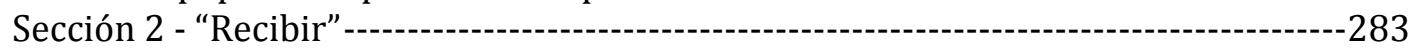

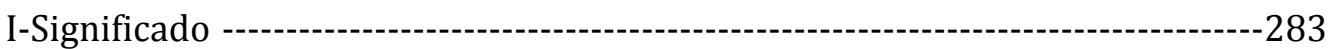

II-Presupuestos objetivos y subjetivos de la recepción típica ------------------285

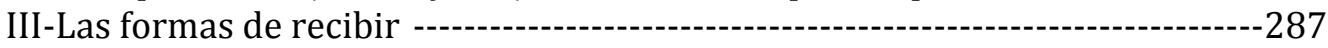

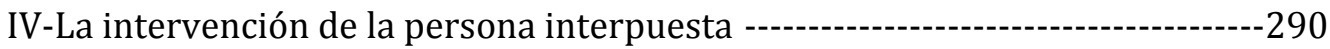

A-Cuando el sujeto realiza labores de mediación entre el

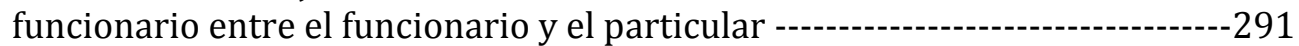

B-Cuando el tercero se limita a recibir las dádivas, sin participar de ningún otro modo en la realización de las diversas conductas

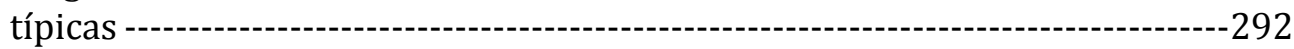

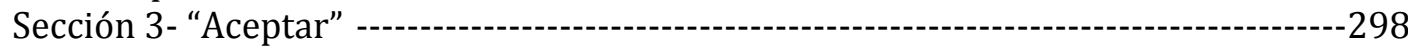

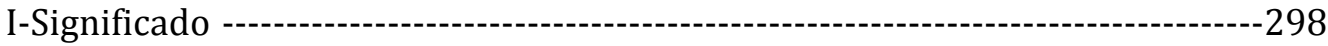

II-Requisitos objetivos y subjetivos de la aceptación --------------------------301

III-La necesaria idoneidad de la promesa o del ofrecimiento --------------------304 


\section{ÍNDICE}

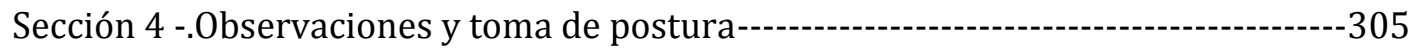

I-Observaciones sobre la técnica legislativa en materia de cohecho

pasivo -----------------------------------------------------------305

II-Observaciones sobre la técnica legislativa francesa y malgache ----------------307

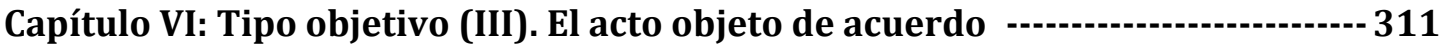

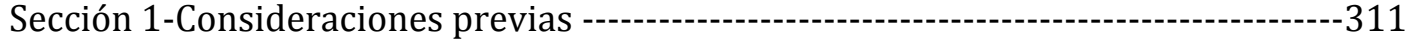

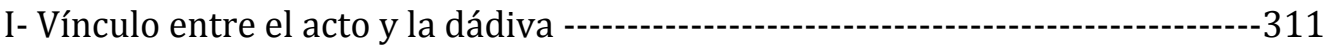

A- La necesaria relación entre el acto y la dádiva -------------------------311

B- ¿Acto objeto del acuerdo como elemento objetivo del tipo u

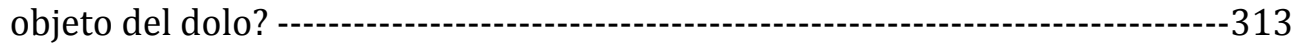

I- La competencia del sujeto activo ---ons

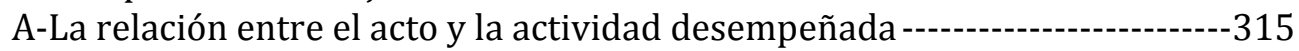

B- El problema de la incompetencia -----on

III-El acto administrativo y el acto en el ejercicio del cargo -----------------320

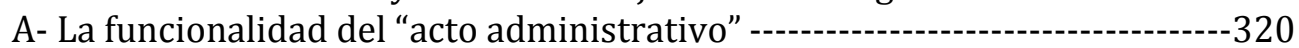

B-La inoperabilidad del concepto de "acto adminitrativo" a efectos

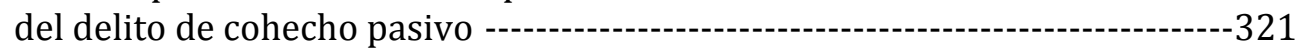

Sección 2- Momento de la ejecución del acto objeto del delito de cohecho-----------322

I-El principio de la anterioridad -------

A-La relación remuneratoria entre el acto del objeto del acuerdo y

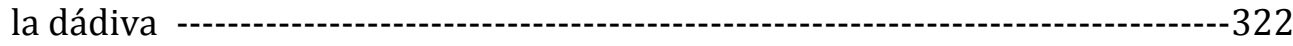

B-Vigencia del principio de anterioridad del pacto corruptor en el

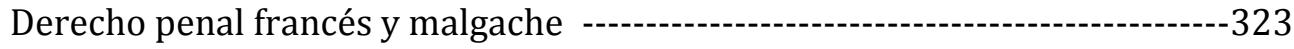

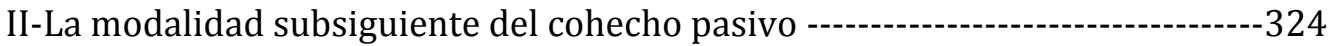

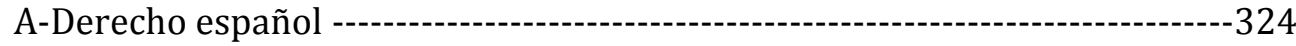

1-Situación con el CPE 1944/1973. ----------------------------324

2-Situación a partir del CPE 1995 ----------------------------------326

3-Situación a partir de la reforma penal de 2010 --------------------332

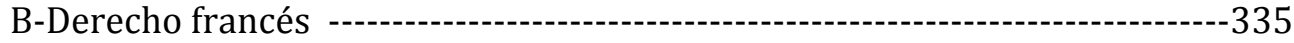

1-Situación antes de la reforma penal de junio de 2000 -----------------335

2-Situación a partir de la reforma de junio de 2000 ---

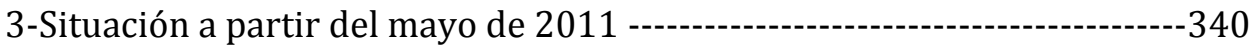

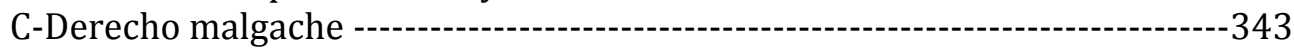

Sección 3-Los diferentes actos en Derecho comparado español, francés y

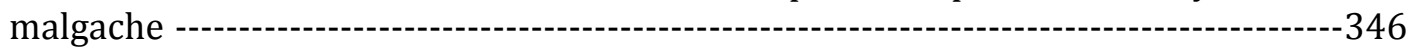

I-Acto contrario a los deberes inherentes del cargo y acto de la

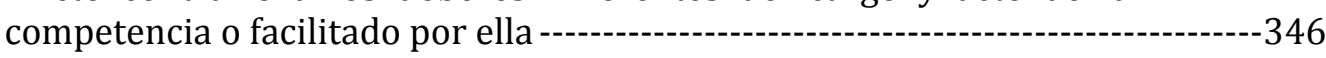

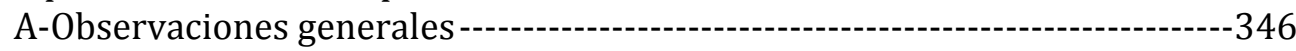

1-Los cambios introducidos por la reforma legislativa de 2010

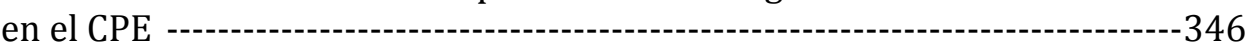

2-Dificultad en la comparación entre el Derecho penal español y

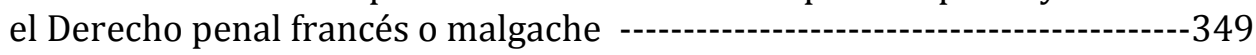

B-Los presupuestos de acto contrario a los deberes del cargo y su

equivalencia en el Derecho penal francés -------------------------------351

1-El alcance de la expresión "deberes propios del cargo" -------------351

2-El alcance de la contrariedad a Derecho ---------------------------355

3-Los actos discrecionales ---------------------------------359

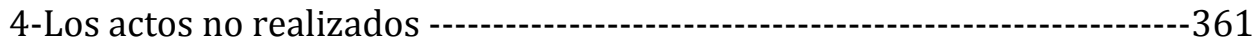

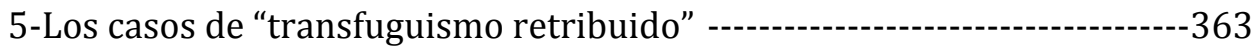

6-Abstención y retraso ------366

II-Acto propio del cargo y acto de la competencia o facilitado por ella -----------370

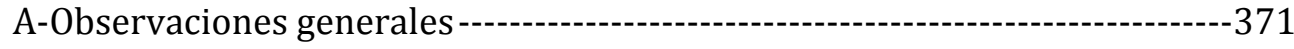

1-Evolución legislativa en el Derecho penal español------------------------371 


\section{SOBORNO DE LOS GOBERNANTES}

2-Inexistencia de la llamada "corrupción impropia" en Derecho

penal francés y malgache

B-Significado de la expresión "acto propio del cargo" y equivalencia en Derecho penal francés y malgache -------------------------372

1-Acto conforme a Derecho -----------------------------372

2-Acto de la competencia en Derecho penal francés y malgache -----------373

3-Acto conforme a Derecho y actos discrecionales y reglados -------------375

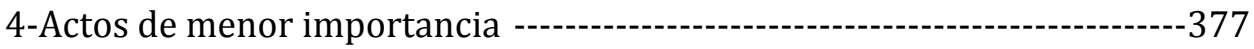

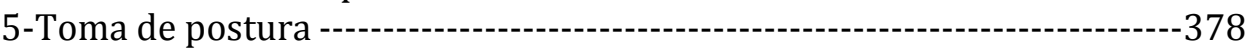

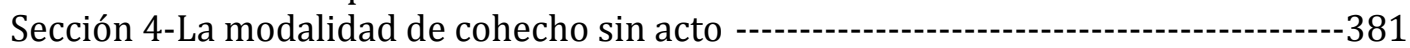

I-El cohecho llamado "de facilitación" en Derecho penal español --------------381

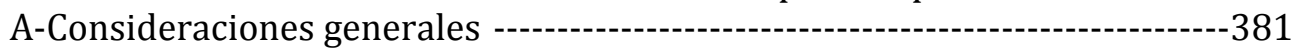

1-Fundamentación del precepto -------

2-La técnica legislativa adoptada por la última reforma -------------------382

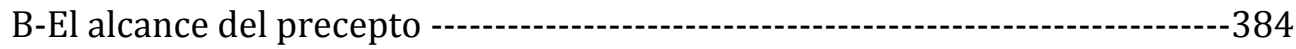

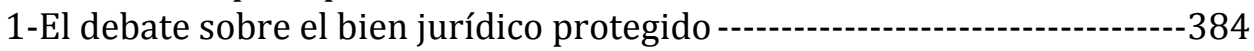

2-Las condiciones de aplicación del artículo 422 CPE --------------385

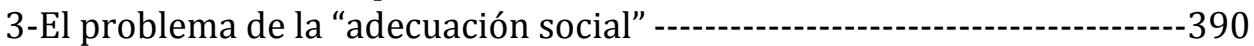

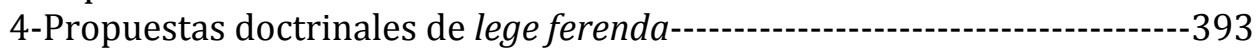

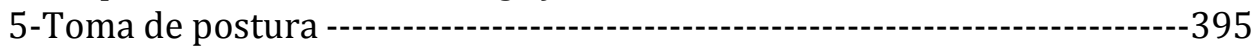

II-Estado de la cuestión en Derecho penal francés y malgache-------------------399

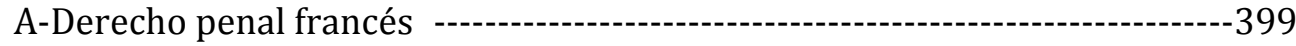

B-Derecho penal malgache -------

Capítulo VII: Tipo objetivo (IV). El objeto del cohecho --- 405

Sección 1-Características cualitativas del objeto material de la conducta -------------405

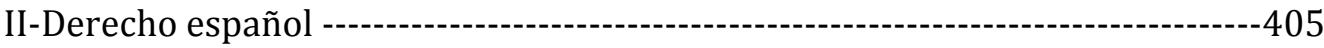

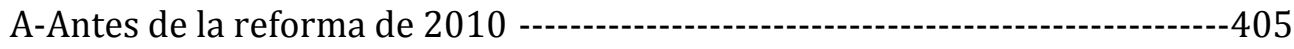

1-Los puntos de convergencia dentro de la doctrina española---------------405

2-Debate doctrinal sobre el alcance de los términos "dádiva" y

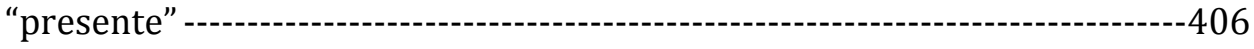

3-Algunas cuestiones destacadas en el debate doctrinal --------------------410

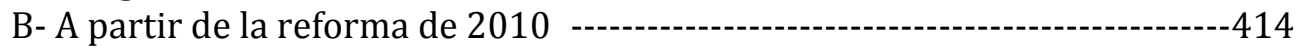

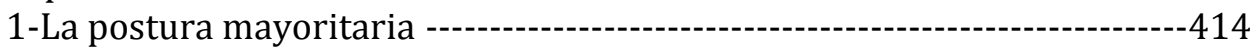

2-La postura minoritaria-----------------------------------------------------415

3-Las críticas a la técnica utilizada por el legislador español de

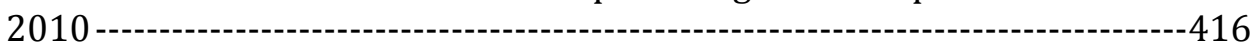

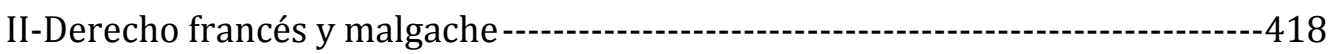

A-Estado de la cuestión antes de las reformas de 1994 y 2004 -------------418

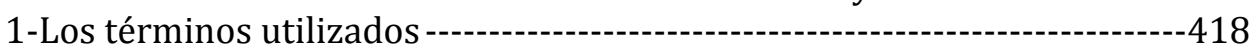

2-El alcance de los términos "ofertas", "promesas", "dádivas" y

"presentes" según la jurisprudencia francesa ------------------419

B-El ámbito de aplicación de los artículos 432-11 CPF y 177 CPM -----------420

Sección 2-Características cuantitativas del objeto material de la conducta -----------421

I-El problema de la existencia de un mínimo cuantitativo -------------------421

A-Principales debates dentro de la doctrina española ---------------------421

B-Ausencia de este debate dentro de la doctrina francesa y

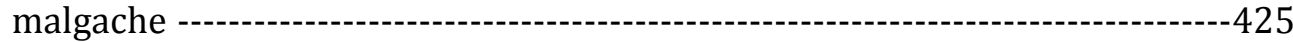

II-La irrelevancia de un mínimo cuantitativo en todas las

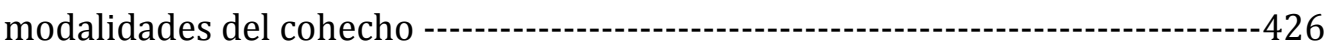

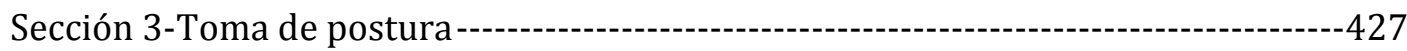

II-Respecto a las características cualitativas --------------------------------427

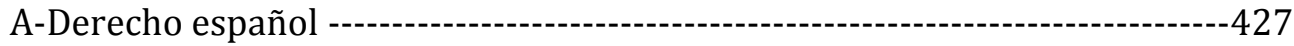

B-Derecho francés y malgache -------------------------------------430

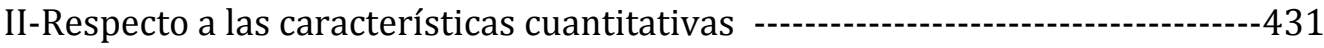




\section{ÍNDICE}

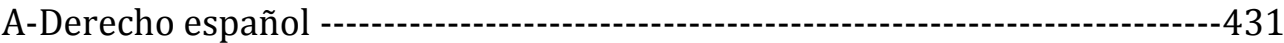

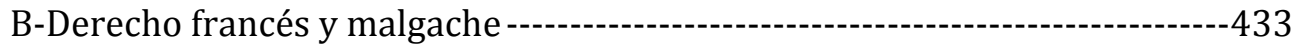

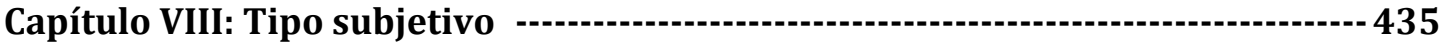

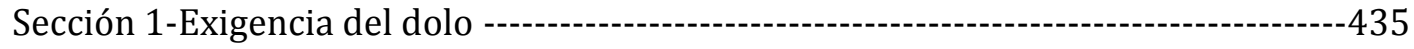

I-El delito de cohecho desde la perspectiva subjetiva o del elemento

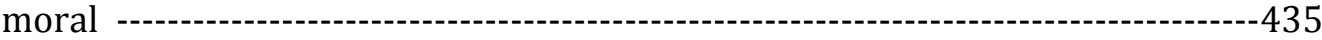

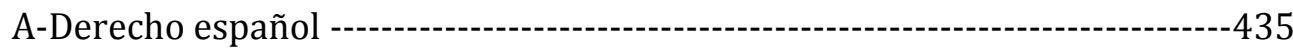

1-El delito de cohecho como tipo subjetivamente incongruente ------------435

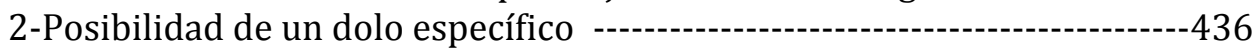

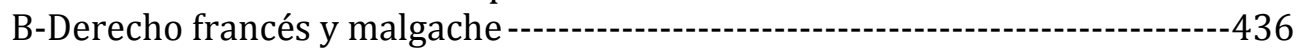

1-El delito de corrupción como delito intencional---a--436

2-Posibilidad de un dolo especial ----

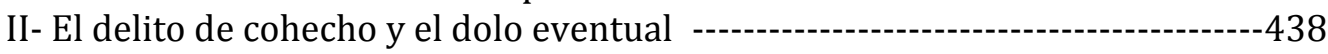

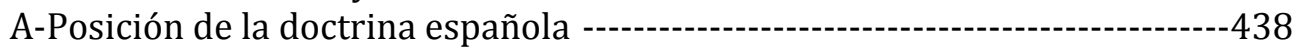

B-Ausencia del debate en la doctrina francesa y malgache ------------------439

III-El problema de los actos simulados---

A-La falta de voluntad por parte del funcionario de dar

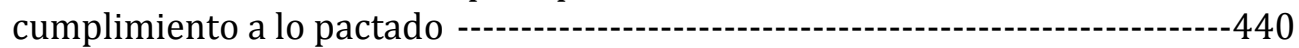

B-La imposiblidad de realizar el acto objeto del delito de cohecho ------------441

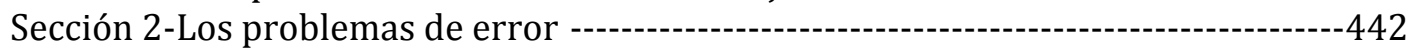

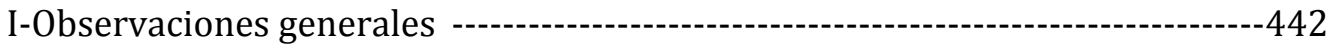

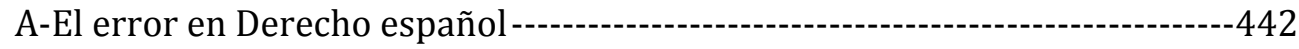

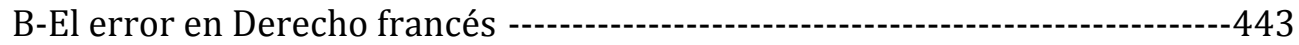

C-Ausencia del error en Derecho malgache --------------------------------445

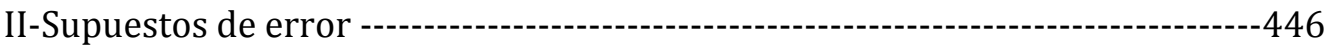

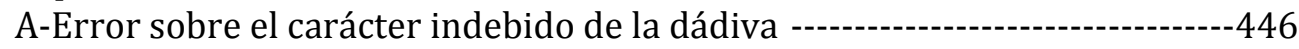

B-Error sobre la conformidad a Derecho del acto objeto del delito

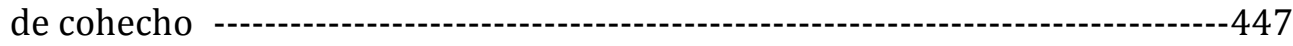

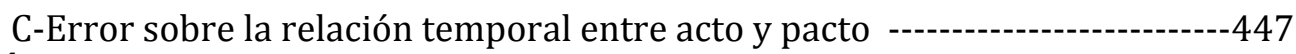

CONCLUSIÓN -- 451

APÉNDICE ---:-

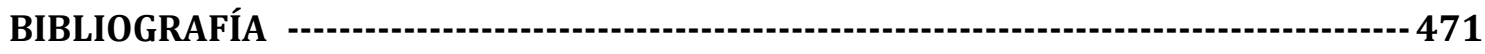





\section{ABREVIATURAS}

\section{Abreviaturas}

A: $\quad$ Arazandi

A.D.P.C.P: $\quad$ Anuario de Derecho penal y Ciencias Penales

AJFP: $\quad$ Actualité juridique-Fonctions publiques

art.: $\quad$ artículo

arts.: $\quad$ artículos

Ass. Plén.: Assemblée plénière

Bull. Crim.: Bulletin des arrêts de la Chambre criminelle

CA: $\quad$ Cour d'appel

CAA: $\quad$ Cour d'appel administrative

Cass. Crim.: Chambre criminelle o Sala de lo penal de la Corte de casación francesa

CE: $\quad$ Constitución española

CF: $\quad$ Constitución francesa

CM: $\quad$ Constitución malgache

Cons. Const.: Conseil consitutionnel

Cons. Et: $\quad$ Conseil d'Etat

CPE: $\quad$ Código penal español

CPF: $\quad$ Código penal francés

CPM: $\quad$ Código penal malgache

DC: $\quad$ Decisión del Consejo constitucional francés sobre el control de constitucionalidad de las leyes ordinarias, leyes orgánicas, tratados, reglamentos de las Asambleas

Doc. Ass. Nat.: Document Assemblée nationale

Gaz. Pal.: Gazette du Palais

JCP: Jurisclasseur périodique 


\section{SOBORNO DE LOS GOBERNANTES}

JCP, éd. G: Jurisclasseur périodique, Édition générale

Jur. Crim.: Jurisprudencia Criminal

Rec. CE: Recueil des décisions du Conseil d'Etat

Ss.: $\quad$ siguientes

S(S)TS: $\quad$ Sentencia(s) del Tribunal Supremo

T. o Trib.: Tribunal

T. corr.: $\quad$ Tribunal correctionnel 


\section{INTRODUCCIÓN}

\section{INTRODUCCIÓN}

Hablar de la corrupción está cada vez más de moda. Es un fenómeno tan viejo como la historia del mundo pero a la vez de actualidad. Ningún modelo de sociedad que ha existido alguna vez se ha salvado de él. Además de no ser un fenómeno nuevo, la corrupción tiene la capacidad de actualizarse en la época y en el lugar donde esté. Quizá sea la razón por la cual no se podía acabar con ella ya que los métodos para combatirla deben renovarse incesantemente. En la actualidad, la globalización de la sociedad y, sobre todo, de las actividades económicas y comerciales, ha permitido que la corrupción se convierta en un fenómeno transnacional, lo cual complica aún más las tareas de la lucha contra ella.

Una mirada hacia el pasado permite apreciar que cuando se habla de corrupción, nos encontramos ante multitud de actos y de prácticas. Los estudios científicos al respecto intentan dar propuestas para unificar los criterios de identificación de este fenómeno pero los resultados no son satisfactorios. Las medidas que los gobiernos han tomado al respecto parecen dar respuestas contundentes tanto para prevenir como para sancionar los considerados actos corruptos. Sin embargo, su eficacia no está a la altura de la expectativa social.

En vez de hablar de respuestas conjuntas contra la corrupción, la evolución histórica ha demostrado más bien unas importaciones y exportaciones de valores desde las sociedades occidentales del Norte hacia las sociedades tradicionales y "subdesarrolladas" del Sur. Esta transferencia de valores ha causado una incomprensión general de las nuevas normas impuestas desde fuera, las cuales chocaban con las normas culturales por parte de las segundas. Una confrontación de códigos de valores paralizaba por ejemplo en el continente africano las iniciativas de luchar contra la corrupción. Esta incomprensión es debida al hecho de que estas sociedades tradicionales no han entendido lo que se debe proteger o preservar cuando, en las sociedades modernas, se considera que la corrupción es algo malo y condenable. Los países africanos ya tenían una idea vaga de lo que puede ser un acto corrupto. Sin embargo, la aún reciente descolonización de las potencias europeas afecta a la comprensión del Estado, de los principios democráticos, de lo que es el bien común, etc. Las herencias administrativas y políticas de la colonización han sido consideradas por muchas sociedades africanas como reliquias de la opresión que esa suponía, por lo tanto, se constataba una reticencia casi sistemática de las normas emitidas por la joven y nueva administración independiente. Con el tiempo, estos países se han visto impuestos una serie de normas con la esperanza de recibir ayudas extranjeras para su desarrollo. Esta importación de valores del Norte al Sur se ha hecho con intensidad pero sin lograr la asimilación requerida para la eficacia de las normas para la lucha contra la corrupción. Con este transfondo, se puede entender fácilmente las dificultades de aplicar los convenios y los tratados al respecto. 
Ya han pasado algo más de cincuenta años desde los movimientos de descolonización europea y el continente africano ha ido entendiendo lo que está en juego cuando se habla de corrupción. La aproximación cultura al fenómeno se ha enfocado en el estado de desarrollo social y la protección del bien común tanto a nivel local como a nivel nacional. El relativo éxito en esta materia ha despertado la consciencia colectiva para dar un paso más adelante en esta lucha.

Eso no significa que la sociedad europea este libre de corrupción ya que se ha convertido en importadora de valores sociales.

En el momento en que se redactan estas líneas, la sociedad española está confrontando situaciones particularmente difíciles en su historia democrática. Parece que los escándalos políticos ya forman parte del cotidiano del ciudadano. Los hechos son tan variados que el estigma social va intensificándose. Se intenta entender el por qué de los regalos costosos aceptados por un gobernante regional. No se explica el por qué de los regalos sistemáticos de algunas empresas a un partido político, aprovechando las lagunas del sistema de financiación de los partidos, para que un responsable declare que repartía sobres de dinero a los barones de dicho partido y que él mismo tiene una cantidad escondida en una cuenta bancaria en el extranjero.

En Francia, después de haber dejado su cargo como jefe de Estado, los antiguos mandatarios de ese país han tenido que enfrentarse a la Justicia por caso de empleo ficticio y de financiación ilegal de las campañas electorales por medio de dinero ofrecido por algunas personas y familias adineradas que han sido objeto de favores especiales durante el ejercicio de su cargo.

En la actual transición de Madagascar, varios políticos con cargos importantes en las instituciones transitorias son objeto de la investigación de la Oficina Anticorrupción del país por malversación de fondos públicos, por comisiones ilícitas y por abusar de sus influencias en diversos sectores económicos. En efecto, cuando nociones como transparencia o rendición de cuentas no forman parte de la cultura política de un país, todo está permitido, pues las posibilidades de que estos casos lleguen hasta los tribunales son bastante pocas. Como se trata de instituciones transitorias, es decir, no gozan de ninguna legitimidad democrática, la Corte Constitucional de Madagascar ha decidido no conceder a los miembros del Parlamento de la transición los beneficios de la inmunidad parlamentaria. Esta situación ha permitido a los órganos de investigación vinculados a la lucha contra la corrupción que se procesen estos políticos sin ningún impedimento debido a su cargo. Puede que esta decisión del Alto Tribunal pueda ser criticable, sin embargo, de otra manera, muchos casos se hubieran quedado en el silencio y luego en el olvido. En el marco de la preparación de las elecciones generales para salir de la transición política y entrar en la cuarta república, muchos de estos políticos ya están condenados por una sentencia firme pero espe- 


\section{INTRODUCCIÓN}

ra que por acuerdo político se les pueda amnistiar de actos corruptos. La amnistía se ha interpretado como una impunidad de los abusos y de los enriquecimientos injustificados. El beneficio de este tipo de medida legal debería ser acompañado de otras medidas (por ejemplo, la restitución de los fondos malversados) que puedan condicionar la elegibilidad de los amnistiados.

En general, se constata actualmente en la sociedad que los ciudadanos ven cada vez con más desconfianza a la clase política. En efecto, si la representación política en las instituciones democráticas se basa en la confianza de los representados en los representantes, los actos considerados socialmente de corrupción deslegitiman a estos últimos. La situación es aún más dura, cuando, como en España, la mayoría o casi todos los ciudadanos deben apretarse el cinturón y hacer sacrificios en todos los aspectos para que, entre todos, el país pueda recuperarse económicamente, estos hechos escandalosos no tranquilizan ni aseguran un futuro brillante para la sociedad en general.

La presión social aumentada por los medios de comunicación tiene la capacidad, en un país democrático, de empujar a los gobernantes a buscar cambios o mejoras normativas. Las iniciativas para combatir la corrupción tienden a reducir o a compensar los costes políticos generados por los escándalos. Pero, el problema no se encuentra en estas iniciativas sino en la necesidad de tomar nuevas medidas. ¿Acaso España no ha modificado su Código penal y sus artículos sobre la corrupción en 2010 y Francia, en 2011 como para hablar en la actualidad de nuevo pacto de Estado y de nuevas medidas más punitivas o, por lo menos, disuasivas? ¿Hasta qué punto las nuevas medidas después de esos incidentes pueden ayudar a luchar contra el fenómeno de la corrupción?

Son algunas de las muchas preguntas que se pueden plantear pero lo que se ha dicho anteriormente es suficiente para justificar un trabajo de investigación sobre este fenómeno.

El presente trabajo no pretende, ni mucho menos, aportar un nuevo análisis a la corrupción ni fórmulas novedosas de lucha contra ella. La literatura sobre estos temas es demasiado densa como para que se pueda añadir algo más de ella. Las disciplinas sociales han estudiado estos temas con bastante profundidad y sus aportaciones, aunque diferentes, orientan sin duda al investigador hacia una aproximación adecuada al fenómeno de la corrupción. Este trabajo se dedicará a la comparación de tres modelos y sistemas de prevención de los actos que legisladores de diferentes sensibilidades jurídicas han considerado como corruptos. La comparación tiene la virtud de aclarar las nociones y los conceptos, y además, ayuda a entender las instituciones insuficientemente atendidas por un sistema jurídico. Comparar no es sólo descifrar las diferencias sino también aportar análisis que contribuye a resolver problemas. Les tres legislaciones que se va a comparar son la malgache, la francesa y la española. El Derecho malgache en la mayoría de su con- 
figuración tiene una similitud con el Derecho francés. Eso se debe a vínculos históricos y afinidad lingüística. La diferencia entre ambos es que el sistema francés es mucho más desarrollado. En materia penal, y sobre todo, en cuanto a los artículos que se refieren al delito de corrupción, la redacción es casi la misma, reflejando aquí un puro mimetismo jurídico del legislador malgache y afirmando su pertenencia a la gran familia jurídica francesa en este ámbito. El interés de la comparación entre estas dos legislaciones con el Derecho español, es el desarrollo dogmático que este último ha experimentado desde el siglo pasado al adoptar el modelo alemán, lo cual enriquece los debates. El presente trabajo es pionero en la comparación del delito de corrupción pasiva en el Código penal francés y malgache con el delito de cohecho pasivo previsto en el Código penal español. Lo que significa que es la primera vez que la doctrina malgache tiene la oportunidad de conocer con más profundidad los debates doctrinales entre los autores españoles acerca del delito de cohecho pasivo. Con las recientes reformas legislativas en España y en Francia, este trabajo es uno de los primeros en valorar las últimas aportaciones de ambos legisladores en términos de comparación, entre otros. Sin embargo, a pesar de las diferencias que pueda haber, se puede constatar que nos encontramos ante un fenómeno universal y multidimensional, por lo tanto, no existen diferencias políticocriminales sustanciales entre las tres legislaciones en estudio. Podemos incluso hablar de una cierta aproximación entre las tres ya que tienen como base común los convenios internacionales ratificados por los gobiernos de estos tres países.

Hay que precisar que la palabra "gobernante" a la que se refiere en el título de este trabajo debe ser entendida en su sentido amplio. Es decir, designará tanto a los que ostentan mandato electivo público como los altos cargos de la Administración pública en general. Sin embargo, cuando se habla de cohecho pasivo hay que considerar otra categoría de concepto ya que el delito en estudio ha previsto, además, algunos tipos de sujetos activos. La diferencia es que generalmente los pequeños casos cometidos por sujetos desconocidos no llegan a los medios de comunicación y no alarman de igual manera a la sociedad. Lo que se pretende es simplemente ofrecer un tratamiento global al problema destacando que estos actos afectan de manera especial a los ciudadanos cuando son cometidos por sus gobernantes. Es socialmente inaceptable que los "peces gordos" cuenten con más posibilidades de escapar de la aplicación igualitaria de la ley penal.

A largo de este trabajo se destacarán las preguntas más importantes a fin de traer los debates doctrinales más interesantes.

Una de ellas consiste en plantear la manera de tratar el delito en general. Es decir cuando un delito recibe tratamiento de diferentes maneras ¿es posible comparar? Desde un punto de vista formal la comparación no es posible. Sin embargo, si se acude a una equivalencia funcional de los conceptos hay más elementos comparables. 


\section{INTRODUCCIÓN}

Otro problema que se plantea es la elección del valor protegido por cada legislador. En efecto, el análisis en este aspecto depende de los instrumentos dogmáticos con los que cuente cada país. La pregunta es: si el bien jurídico protegido difiere de un legislador a otro, ¿esa situación podrá influir en la aplicación del precepto en estudio $\mathrm{y}$, en última instancia, de la pena? La comparación da la oportunidad de valorar el alcance de cada tipo en los ordenamientos estudiados.

Con independencia de lo que la doctrina opine respecto a la estructura del delito en estudio, las tres legislaciones comparadas coinciden en adelantar la barrera y sancionar las conductas unilaterales que pueden ser considerados generalmente como actos preparatorios, sin depender de la existencia de un acuerdo. Parece una tendencia generalizada y llama la atención sobre el frágil equilibrio entre la eficacia preventiva del tipo y el respeto de principios limitadores tales como los de lesividad, proporcionalidad o intervención mínima. Sin embargo, más problemáticos son los casos de regalos a posteriori o cuando estos no tienen ninguna relación con algún acto del cargo. La perspectiva comparativa ensancha los debates y aporta nuevas contribuciones.

En este trabajo sería determinante saber qué tipo de acto será relevante para la intervención del Derecho penal. Pero esta dificultad viene con la de identificar a los sujetos activos. Y, aunque se llegue a resolver esta última, hay que buscar la manera de aislar entre los actos que pueden llevar a cabo, los que se podrán calificar de actos corruptos.

Cuando se habla de corrupción, un elemento importante es el regalo o la retribución. Sin embargo, estamos ante una duda: ¿cualquier regalo puede valer para ser sancionado penalmente? Si en su afán de luchar contra la corrupción el legislador no da las precisiones oportunas, podemos enfrentarnos a casos muy complicados de resolver. En una sociedad como la española o la malgache, en la que dar regalos por la buena disposición del agente público, no está mal visto, la dificultad sería de medir hasta qué punto esas prácticas son corruptas o no.

El estudio del delito de cohecho suscita preguntas que muchas veces no son tan fáciles encontrarles respuestas contundentes. Algunas de ellas son: ¿Las leyes sobre la lucha contra la corrupción son leyes de circunstancias o han sido diseñadas para cumplir realmente objetivos de política-criminal bien definidos en el tiempo? ¿La técnica legislativa utilizada por cada legislador ha sido la más adecuada a la hora de plantear estos mismos objetivos? Y con relación al presente trabajo la pregunta es ¿el Derecho comparado es capaz de aportar algo nuevo en la resolución de los problemas que plantean la aplicación de las leyes sobre el delito de cohecho? 

PARTE I: APROXIMACIÓN AXIOLÓGICA Y ESTRUCTURAL AL DELITO DE COHECHO 



\section{CAPÍTULO I: GENERALIDADES SOBRE LA CO- RRUPCIÓN}

La corrupción ha sido objeto, en las últimas décadas, de todo tipo de estudios sobre todo por parte de las ciencias sociales. La preocupación generada por el fenómeno de la corrupción ha dado lugar a una densa literatura ${ }^{1}$ y ha incitado a los gobiernos de muchos países a tomar medidas para combatirlo. Sin embargo, las numerosas contribuciones escritas, en vez de ayudar a identificarlo, han hecho su identificación más complicada. Por otra parte no es que la corrupción aparezca como un nuevo fenómeno sino que desde los años 70 del siglo pasado sus consecuencias negativas tanto nacionales como internacionales han alarmado a los poderes estatales"2. En efecto, como bien ha subrayado NIETO, "la corrupción acompaña a la sociedad como la sombra al cuerpo. La cuestión, según el autor, no estriba, por tanto, en si ahora hay más o menos corrupción que antes, sino en la diferencia de sus calidades y en el cambio de actitud ante la misma"3. "La corrupción no es un fenómeno pensado sino latente, no es voluntario sino irresistible, no es provisorio sino continuo y persistente" 4 .

El problema que plantea la corrupción es la dificultad de someterla a un concepto preciso y unívoco. Cada autor de las diferentes disciplinas sociales estudia este fenómeno sin saber o sin precisar previamente lo que se entiende por corrupción ${ }^{5}$. Como toda noción vinculada al hombre y a la sociedad, la corrupción recibe muchas definiciones que varían según las disciplinas, las culturas y los intereses ${ }^{6}$. Desde luego, llama la atención el hecho de que se hable de "lucha contra la corrupción" si no se puede definir lo que es y si no se llega a un consenso científico en cuanto al objeto de dicha lucha.

\footnotetext{
${ }^{1}$ G. D. M. CERINA, "La lucha contra la corrupción en el siglo XXI: el papel del derecho penal. Estudio crítico del delito de cohecho en Italia y en España", Tesis doctoral, dir. E. A. FABIÁN CAPARRÓS, Universidad de Salamanca, 2010, pp.37, 38

2 Es cierto que bien antes de la década de los 70 , las disciplinas sociales y jurídicas hacían de la corrupción su objeto de estudio, pero en dicha década la dimensión del fenómeno alcanzó un nivel que afectaba hasta las transacciones internacionales (Véase, entre otros, P. FITZGERALD, "Les dispositifs juridiques internationaux de lutte contre la corruption des agents publics étrangers", Thèse de droit public, dir. M. GOUNELLE, Université du Sud Toulon-Var, 2011, pp.24 y ss.

${ }^{3}$ A. NIETO, Corrupción en la España democrática, Ariel, Barcelona, 1997, p.64.

${ }^{4}$ G. KOENIG, Les discrètes vertus de la corruption, Grasset, 2009, p.164.

5 G. D. M. CERINA, La lucha contra la corrupción, op.cit., pp.41 y ss. En el mismo sentido R. PIÑEYRO, "La corruption entre le désir et la mort du politique", Thèse de sociologie, dir. B. LAUTIER, Université Paris 1-Panthéon-Sorbonne, p.70

${ }^{6} \mathrm{P}$. RAFOLISY, La protection juridique de l'intégrité morale et développement durable: le cas de Madagascar, Thèse de droit privé et sciences criminelles, dir. M. BAYLE, Université de Limoges, 2008, p.15.
} 
Antes de estudiar este fenómeno desde la perspectiva jurídica, conviene hacer un repaso aunque sea excesivamente breve, de las diferentes posturas de las ciencias sociales sobre el fenómeno de la corrupción. De esta manera se podrá tener alguna idea de la elección de los legisladores en cuanto a la noción jurídica de corrupción.

\section{Sección 1-Identificación de la corrupción}

\section{I- La corrupción como fenómeno}

Para entender los diversos aspectos de lo que es la corrupción, las contribuciones de las disciplinas sociales no jurídicas han destacado que la corrupción es, en realidad, un fenómeno con múltiples facetas ${ }^{7}$. Sólo se pretende aquí destacar algunos elementos explicativos en el intento de identificar la corrupción desde tres perspectivas: social, política y económica.

\section{A-LA CORRUPCIÓN COMO FENÓMENO SOCIAL}

\section{1-El individuo, actor social de la corrupción}

Los estudios sociológicos sobre la corrupción consideran en primer lugar el individuo como parte de su objeto de investigación. Señala PIÑEYRO que el hombre es un ser indisociablemente razonable y pasional aunque el pensamiento racional nos lo haga olvidar ${ }^{8}$. Defiende la autora que las diferentes teorías y definiciones sobre la corrupción enfrentan una dificultad esencial debido al carácter abstracto de este objeto de estudio que no puede considerarse como un objeto físico y no parece accesible más que por la experiencia interna del pensamiento, de manera que la identificación del fenómeno depende siempre de un conocimiento de los casos en que se debería aplicar una cierta normatividad. En efecto, el fenómeno de la corrupción debe ser analizado desde los aspectos emotivos del individuo como motor de los procesos de deliberación racional, la exploración de la vía compleja del deseo con sus diversas estratificaciones, las pasiones como soporte socio-afectivo en la creación de toda forma de organización social, por muy racional que sea. Por lo tanto, el individuo no tiene muchas opciones: deberá enfrentarse al dualismo constitutivo de la moral a través de la solidaridad de los "buenos" y "malos" instintos". En términos económicos, concluye la autora que la economía de las pasiones y su subordinación al interés es el punto de partida para la interpretación de la corrupción contemporánea. Si la racionalidad económica me ordena que yo actúe para maxi-

7 Entre otros, L. FERNÁNDEZ RÍOS, Psicología de la corrupción y los corruptos, Grupo Editorial Universitario, 1999, p.39.

${ }^{8}$ R. PIÑEYRO, La corruption entre le désir..., op. cit., p.12

${ }_{9}^{9}$ Ibídem, op. cit., p.14. 


\section{CAPÍTULO I: GENERALIDADES SOBRE LA CORRUPCIÓN}

mizar mi propio interés, ¿cómo podría obligarme, buscando ese interés, a respetar una regla de imparcialidad? ${ }^{10}$

Las observaciones de esta autora nos parecen diferentes entre los varios autores de las disciplinas sociales ya que la mayoría de ellos suelen enfocar el análisis del fenómeno de la corrupción a partir de planteamiento del abuso o de la instrumentalización del poder, con lo cual sólo se refiere al que se beneficia de un acto corrupto y deja sin estudiar el que toma la iniciativa para corromper.

\section{2-La sociedad, hacedora de corruptos}

El individuo si se convierte en corrupto es porque su entorno social ha favorecido la propensión hacia este tipo de conducta. Observa FERNÁNDEZ RÍOS que siempre nos encontramos con la paradoja de que el individuo cuenta, pero lo que en última instancia condicionará y determinará lo que un sujeto es, será el contexto sociomaterial en el cual se socializa. El contexto en el cual viven los seres humanos tiene que ser nómico, lo que significa que el individuo o los individuos deben vivir en un mundo sociocultural ordenado y significativo, donde el caos del significado y la ausencia de normas sociales honestas y éticas no tengan lugar. El individuo se siente necesitado de encontrar sentido al contexto en el que vive ${ }^{11}$. Advierte el autor que en ninguna circunstancia debe suponerse que un sistema sociocultural y sociopolítico en el cual la corrupción sea algo generalizado, puede considerarse como un buen sistema sociopolítico. La corrupción puede ser lo normal en un determinado contexto pero no suele ser lo mejor para la sociedad ${ }^{12}$.

Se reconoce que la corrupción es un fenómeno contagioso y se reproduce a sí mima ${ }^{13}$. Señala KOENIG que no se puede aislar "un sector corrompido", lo mismo que no se puede distinguir a los individuos entre puros y corruptos. Es la propia sociedad la que es corrupta ${ }^{14}$.

No se puede justificar ni legitimar la corrupción. Aun así, FERNÁNDEZ RÍOS admite que es difícil imaginar una sociedad futura sin corrupción. Es factible planificar una sociedad o un sistema cultural futuro mejor que el actual, pero siempre con algunas prácticas corruptas ${ }^{15}$. En el

\footnotetext{
10 Ibídem, op. cit., p.73.

11 L. FERNÁNDEZ RÍOS, Psicología de la corrupción..., op. cit., p.20

12 Ibídem, op. cit., p.21. En contra de esta postura G. KOENIG, Les discrètes vertus..., op.cit., pp.87 y 94.

13 L. FERNÁNDEZ RÍOS, Psicología de la corrupción..., op. cit., p.22; E. DEMETRIO CRESPO, La corrupción como freno decisivo a la consolidación del Estado de Derecho: respuesta penal; en I. BERDUGO DE LA TORRES y R RIVERO ORTEGA (Eds), El Estado de derecho latinoamericano: integración económica y seguridad jurídica en Iberoaméri$c a$, Ediciones Universidad de Salamanca, Salamanca, 2003, p.47.

${ }^{14}$ G. KOENIG, Les discrètes vertus..., op.cit., p.65.

15 L. FERNÁNDEZ RÍOS, Psicología de la corrupción..., op. cit., p.22. El autor señala que la legitimación de la corrupción no sólo constituye la propia destrucción del sistema social, sino que haría inútiles muchas de las prácticas corruptas.
} 
mismo sentido se ha pronunciado KOENIG quien defiende que en toda sociedad, un cierto nivel de corrupción es sin duda necesario ${ }^{16}$.

Aunque este tipo de postura no es aislada dentro de las disciplinas sociales, se puede preguntar hasta qué nivel las prácticas corruptas pueden ser necesarias y benéficas al sistema social. Abundan las teorías que descartan completamente la existencia de este fenómeno ya que sólo es portador de efectos nefastos ${ }^{17}$.

Por último se puede preguntar si la corrupción es un problema social. Para poder responder a esta interrogación hay que precisar lo que significa problema social. FERNÁNDEZ RÍOS presenta 3 criterios. Según el autor un problema social constituye una realidad sociocultural: 1) construida que afecta a un número significativo de personas, 2) que es considerada como individualmente y socialmente indeseable, 3) que, se supone, que la gente debe y puede hacer algo para tratar de reparar o eliminar dicha situación a través de la acción individual y colectiva ${ }^{18}$.

Conforme a estos criterios no cabe duda de que el fenómeno de la corrupción es realmente un problema social ${ }^{19}$. Pero el problema va más allá de la preocupación social. En efecto, las practicas de la corrupción no se agotan en si mismas, sino que suelen transcender más allá del individuo. Es decir, los casos de corrupción, cuando son hechos públicos, pasan a formar parte, independientemente de la voluntad de los individuos, de lo que se suele denominar opinión pública; y cuando esto sucede, los ciudadanos ya no pueden controlar sus efectos y repercusiones sobre la dinámica social. Se reconoce que los casos de corrupción tienen una clara repercusión negativa sobre la conciencia colectiva. Negativa, en el sentido de que las prácticas de corrupción generalizada desmoralizan a los individuos, provocan nuevos casos de corrupción y generan un clima de desorganización o indefensión colectiva ${ }^{20}$. Sin embargo, lo peor es que esos casos afectan el proceso de socialización del individuo.

Explica FERNÁNDEZ RÍOS que el proceso de socialización se incardina con el de la psicología cultural. Así, por ejemplo, si un sujeto se desarrolla en un contexto de corrupción, mayores probabilidades tiene de llegar a considerar positivamente las prácticas corruptas. Evidentemente, la socialización de los miembros más pequeños de la sociedad en tal

\footnotetext{
${ }^{16}$ G. KOENIG, Les discrètes vertus..., op.cit., p.80.

17 Entre otros M. V. MURIEL PATINO, "Economía, corrupción y desarrollo" en E. A. FABIÁN CAPARRÓS (coord.), La corrupción: aspectos jurídicos y económicos, Ratio Legis, Salamanca, 2000, pp.30 y 31; E. A. FABIÁN CAPARRÓS, La corrupción de agente público extranjero e internacional, Tiranch lo blanch, Valencia, 2003, pp.29 y ss.

18 L. FERNÁNDEZ RÍOS, Psicología de la corrupción..., op. cit., pp.47 y 48.

${ }^{19}$ En España, el barómetro del CIS (Centro de Investigaciones Sociológicas) publicado en diciembre de 2012, demuestra que la corrupción ocupa el cuarto lugar como principal problema de la sociedad española después del paro, la situación económica y la clase política. Disponible en la red: http://www.huffingtonpost.es.

${ }^{20}$ L. FERNÁNDEZ RÍOS, Psicología de la corrupción..., op. cit., p.86.
} 


\section{CAPÍTULO I: GENERALIDADES SOBRE LA CORRUPCIÓN}

cultura de la corrupción sólo puede generar a su vez ciudadanos claramente motivados para llevar a cabo comportamientos corruptos. Y si la corrupción es ya en sí misma muy perniciosa individual y colectivamente, todavía es más perjudicial y nocivo el socializar a las nuevas generaciones en un clima sociocultural lleno de estas prácticas. De esta forma, la corrupción no sólo daña la sociedad actual, sino que también se está garantizando su propagación a las nuevas generaciones ${ }^{21}$. Concluye el autor que al individuo corrupto sólo se le puede considerar responsable de aquellos comportamientos que se hallan bajo su control y que los comportamientos corruptos son aprendidos a lo largo del proceso de socialización, ya sea a través de los mecanismos del condicionamiento operante o del aprendizaje observacional ${ }^{22}$.

Ante esta conclusión desalentadora, parece que no nos quedan muchas opciones, el mismo autor finaliza uno de sus capítulos con bastante escepticismo y señala que si algunos se corrompen y no somos capaces de erradicar las prácticas corruptas, todos nos debemos corromper ${ }^{23}$. KOENIG, al defender las virtudes discretas de la corrupción, llega a la misma conclusión. Según este autor cuando las prácticas corruptas se hacen parte de lo cotidiano, estas transforman radical y completamente al individuo ${ }^{24}$.

Este panorama hace resonar aún con más fuerza las palabras de la exjueza franco-noruega EVA JOLY, registradas en su libro sobre las investigaciones de los grandes casos de corrupción en Francia, quien decía: "nuestro adversario, es el sentimiento universal de fatalidad"25.

\section{corrupto}

\section{3-La cultura, un variable importante del fenómeno}

Se ha discutido el problema de la cultura cuando se trata de identificar la corrupción. Es cierto que según las sociedades estudiadas una determinada conducta puede ser calificada de corrupta o no ${ }^{26}$. Sin embargo, aun reconociendo lo movedizo que es este fenómeno, se puede preguntar si no hay manera de reducir los extremos alegando que la corrupción no es ni más ni menos que un fenómeno cultural y que no parece posible identificar de manera uniforme las conductas consideradas corruptas.

\footnotetext{
21 Ibídem, op. cit., p.190

22 Ibídem, op. cit., p.198. En el mismo sentido G. KOENIG, Les discrètes vertus..., op.cit., p.64

${ }^{23}$ Ibídem, op. cit., p.199

${ }^{24}$ G. KOENIG, Les discrètes vertus..., op.cit., p.164.

25 E. JOLY, Est-ce que dans ce monde-là que nous voulons vivre?, Les arènes, 2003, p.259.

26 J.-F. MÉDARD, "La corruption politique et administrative et les différenciations du public et du privé" en M. BORGHI y P. MEYER-BISCH (eds.), La corruption, l'envers des droits de l'homme, Éditions Universitaires Fribourg Suisse, Friburgo, 1995, pp.42 y ss.
} 
Según PIÑEYRO, la cultura se convierte en un concepto central para el estudio de la corrupción. Nos obliga a pensar desde un extremo sociohistórico a otro centrado en el individuo, a fin de entender a través de sus articulaciones, las transformaciones o la desnaturalización del sistema social y político que la corrupción nos está indicando. Su significado nos es dado sólo cuando tomamos en cuenta por un lado la historia y las estructuras de la sociedad y por otro lado la voluntad de los actores. Añade la autora que para entender la corrupción, hay que comprender la transformación de los sentimientos morales que han conducido progresivamente a transformar conductas tradicionalmente censuradas en objetos de elogio, o actitudes condenadas por ser peligrosas en ejemplos que imitar ${ }^{27}$. Concluye la misma autora que la corrupción se sitúa en la zona más importante de interpenetración entre los sistemas social y cultural. Las transformaciones de la sensibilidad necesarias para prevenirla son mecanismos de integración cultural de la orientación individual con las existencias del funcionamiento de la vida social ${ }^{28}$.

De manera más concreta, las ciencias sociales recurren al caso del continente africano. Plantea MÉDARD la diferencia de la concepción de lo público y de lo privado en este continente. Según el autor existe una diferenciación estructural de lo público y de lo privado pero no se ha acompañado de una diferencia funcional. En efecto hay contradicción parcial no sólo entre las normas jurídicas y las normas éticas-culturales, sino también entre las mismas normas éticas-culturales. Es la razón por la cual instaurar un Estado de Derecho en África es muy difícil. Si las normas públicas no pueden apoyarse en normas culturales, entonces las primeras se quedarán ampliamente inoperantes ${ }^{29}$.

Por otra parte advierte el autor que también existe contradicción entre las normas culturales de origen tradicional y las normas culturales de origen extranjero en la medida en que estas últimas han sido interiorizadas en parte ${ }^{30}$. Es un error pensar que la cultura africana contemporánea se reduce a lo que se llama la cultura tradicional. Estamos ante una mezcla de normas de origen tradicional y de origen moderno, y unos resultados de la interacción entre ambas, con matices variables según las épocas, los lugares, los individuos y dentro de estos últimos. Es incorrecto decir que el africano ignora la corrupción, es decir no es consciente de ello. Se trata de un concepto inaplicable porque es propio de culturas occidentales. En la medida en que los africanos han interiorizado, parcialmente y con grados variables, las normas públicas, se

\footnotetext{
27 R. PIÑEYRO, La corruption entre le désir..., op. cit., p.327.

${ }^{28}$ Ibídem, op. cit., p.328.

${ }^{29}$ J.-F. MÉDARD, "La corruption politique..., op. cit., p.42.

$30 \mathrm{El}$ autor toma el ejemplo del acceso a la función pública en una sociedad africana. La norma jurídica importada exige el mérito y la capacidad para pretender ser funcionario, la norma jurídica exige que se ayude a un miembro de la familia en virtud de la lealtad debida a la familia antes de la debida al Estado. Se seguirá exigiendo un diploma tal como se prevé en la norma jurídica pero su obtención dará lugar a todo tipo de "atajos" para poder reclutar a un familiar.
} 


\section{CAPÍTULO I: GENERALIDADES SOBRE LA CORRUPCIÓN}

puede hablar perfectamente de corrupción ${ }^{31}$. Concluye el autor que la noción de corrupción supone la percepción de un bien común, supone la consciencia de una norma pues consiste precisamente en no respetar la norma del bien común de referencia, pero que la percepción de lo que es corrupto, o no, depende de la extensión de lo que se percibe como bien común ${ }^{32}$.

Estas contribuciones son realmente valiosas, sin embargo la complejidad que presenta el fenómeno de la corrupción se articula con la dificultad de aprehender el contenido de estos sentimientos morales que pueden ser afectados por la transformación de las sensibilidades y de las percepciones. La interiorización de las normas del bien común dependerá siempre del nivel de conflicto entre las normas que coexisten, lo cual complica no sólo la identificación de la corrupción sino también la manera de prevenirla.

\section{B-LA CORRUPCIÓN COMO FENÓMENO POLÍTICO}

\section{1-Referencia al ejercicio del poder público}

La mayoría de los estudios sobre la corrupción asocia este fenómeno con el marco del poder político o la situación de poder que un servidor público utiliza para sacar algún tipo de beneficio personal. En este sentido, MURIEL PATINO define corrupción como el abuso de un puesto público con el fin de obtener una ganancia privada ${ }^{33}$. Desde la perspectiva política, los intereses privados condicionan el funcionamiento de los poderes públicos, perjudicando el ejercicio de los derechos individuales y colectivos garantizados por el propio Estado, que se deslegitima $^{34}$. Según NIETO, para identificar la corrupción hay que acudir a su estructura. Para el autor, la relación se traba entre dos personas: el desviador del poder público y el beneficiario de la desviación, que se conectan sinalagmáticamente: la autoridad pública entrega un favor arrancado de las potestades administrativas y el particular corresponde con un precio. De esta forma se produce una retroalimentación constante y una corriente circular ${ }^{35}$. Concluye el autor que hay corrupción cuando se produce una desviación de poder y, como consecuencia de ella, un enriquecimiento particular ${ }^{36}$. Sus efectos son devastadores tanto para las instituciones políticas como para la democracia en sí misma ${ }^{37}$.

Desde otros aspectos, señala PIÑEYRO, el fenómeno de la corrupción está vinculado con el fenómeno del poder. La fenomenología del poder

\footnotetext{
${ }^{31}$ J.-F. MÉDARD, “La corruption politique..., op. cit., p.43.

32 Ibídem, op. cit., p.44.

${ }^{33}$ M. V. MURIEL PATINO, “Economía, corrupción..., op. cit., p.27

34 E. A. FABIÁN CAPARRÓS, La corrupción..., op. cit., p.23.

${ }^{35}$ A. NIETO, Corrupción ..., op. cit., p.87.

${ }^{36}$ Ibídem, op. cit., p.88.

37 P. FITZGERALD, "Les dispositifs juridiques..., op. cit., p.11; E. A. FABIÁN CAPARRÓS, La corrupción..., op. cit., pp.28-29; E. DEMETRIO CRESPO, La corrupción..., op. cit., p.46.
} 
implica tanto a los detentores del mismo como a los que aspiran a serlo. La lucha contra la corrupción se convierte en la lucha por el poder porque se asume que el poder es inestable y que la idea de un poder social absolutamente reconocido, automáticamente obedecido, es una contradicción en sí misma. El adversario político es otro tipo de poder político que entra en una relación dialéctica con los que están en el poder si se quiere entender el fenómeno de la corrupción ${ }^{38}$. Concluye la autora que el problema de la corrupción contemporánea es político por la desnaturalización de los principios políticos, la división de los espacios políticos y una forma de corrupción a partir de esas dimensiones políticas. La evolución de la sociedad contemporánea y de los hechos sociales es marcada por el déficit de lo político. De hecho, la corrupción contemporánea es el lado oscuro de los fallos políticos y la marca de la avería del Estado $^{39}$.

\section{2-Ruptura de la reciprocidad}

Como se ha señalado con anterioridad, la corrupción perjudica el ejercicio de los derechos individuales y colectivos. BORGHI explica ese punto y señala que desde un punto de vista estructural la corrupción pervierte la noción de reciprocidad que conlleva esos derechos porque son productos inevitables de la formación de las estructuras mentales del hombre. La corrupción, nota el autor, es el producto de una ética invertida. Llama la atención el respeto del compromiso mutuo entre corruptor y corrupto, en un contexto sociopolítico desarrollado, a través de una norma social no escrita que permite al corruptor prever y contar con que la persona corrompida "cumplirá" su promesa, aunque sea por el hecho de esperar renovar la experiencia ${ }^{40}$. El corrompido descuida los intereses que tiene que representar y asegura un vínculo corrupto de reciprocidad con el corruptor. En efecto, todo poder de representación contiene el riesgo o la posibilidad virtual de un conflicto entre los intereses del representado y los propios del representante. Lo que es determinante, desde una perspectiva ética, es el abuso de poder de representación, la apropiación indebida de una "renta de situación" y, desde un punto democrático, es la violación del principio de confianza ${ }^{41}$. Ahora bien, la buena fe, condición esencial de toda relación individual, es, al mismo tiempo, un elemento "constitutivo" del Estado, pues una sociedad que institucionaliza la mala fe representaría la negación del Estado de Derecho ${ }^{42}$. Así las cosas, advierte el autor que la corrupción modifica las reglas del juego de la "igualdad de las oportunidades" al asentar una desigualdad oculta y el mecanismo perverso de su desarrollo. Esta tendencia a la generalización del fenómeno genera igualmente una pro-

\footnotetext{
${ }^{38}$ R. PIÑEYRO, La corruption entre le désir..., op. cit., p.25.

${ }^{39}$ Ibídem, op. cit., p.317

40 M. BORGHI, Droits de l'homme: fondement universel pour une loi anti-corruption; le cas de la Suisse; en M. BORGHI y P. MEYER-BISCH (eds.), La corruption, l'envers des droits de l'homme, Éditions Universitaires Fribourg Suisse, Friburgo, 1995, p.4.

${ }^{41}$ En este mismo sentido se ha pronunciado R. PIÑEYRO, La corruption entre le désir..., op. cit., p.318.

${ }^{42}$ M. BORGHI, Droits de l'homme..., op. cit., pp.5-6.
} 


\section{CAPÍTULO I: GENERALIDADES SOBRE LA CORRUPCIÓN}

pensión a la preservación de las situaciones adquiridas, a la consolidación de los vínculos simbióticos de complicidad; en otras palabras, favorece el conservadurismo. De ello se deriva una desigualdad política que desnaturaliza el núcleo central del Estado de Derecho, el carácter representativo del mandato político y el principio de legalidad ${ }^{43}$. Por lo tanto, con estas consecuencias devastadoras, no se puede admitir ni tolerar los argumentos a favor de la corrupción ${ }^{44}$.

\section{C- LA CORRUPCIÓN COMO FENÓMENO ECONÓMICO}

\section{1-Conflicto de intereses}

Desde la perspectiva económica, el Estado que representa "lo público" decide de la forma para intervenir según la demanda de la sociedad que los mercados no son capaces de satisfacer en la forma deseada. El proceso requiere la participación activa de los individuos, que son obviamente miembros de la sociedad aunque no por ello cabe esperar que sus intereses coincidan totalmente con los del planificador. Indica RODRÍGUEZ LÓPEZ que es precisamente la existencia de diferencias en este sentido la responsable de comportamientos corruptos, en los que un funcionario público trata de enriquecerse ilícitamente abusando del puesto que ocupa como servidor del Estado ${ }^{45}$.

En este sentido se ha pronunciado también MURIEL PATINO quien indica que se trata de un problema de doble agencia, en el que el interés de las partes principales podrían no coincidir; en concreto, el empresario o el ciudadano, dependiendo del caso, podrían preferir un comportamiento corrupto del funcionario si ello les beneficiara, aunque tal comportamiento generaría un efecto externo que perjudicaría al grupo, de tal forma que el resultado colectivo preferido podría ser el de la intervención pública contra la corrupción ${ }^{46}$.

Estas posturas ponen de relieve la intervención de tres sujetos: el Estado, su agente y el individuo o la empresa. Cuando persiguen diferentes objetivos, surge la posibilidad de una conducta corrupta.

\section{2-La ruptura de la lealtad}

CARTIER-BRESSON plantea la corrupción como la ruptura de lealtad del mandatario (el servidor público) para con el mandante (el Estado) en la que interviene una tercera persona cuyas ganancias o pérdidas dependen del primero. El autor considera que la corrupción es el resultado de las motivaciones originadas por las rupturas de lealtad. Hay que preci-

43 Ibídem, op. cit., p.7.

44 Ibídem, op. cit., p.8.

45 F. RODRÍGUEZ LÓPEZ, "Introducción al análisis económico de la corrupción", en E.

A. FABIÁN CAPARRÓS (coord.), La corrupción: aspectos jurídicos y económicos, Ratio Legis, Salamanca, 2000, p.21

${ }^{46}$ M. V. MURIEL PATINO, “Economía, corrupción..., op. cit., p.27. 
sar que el estudio se ha hecho en una economía capitalista ${ }^{47}$. Para explicar estas rupturas, indica el autor que el corrupto o el corruptor no es ni egoísta ni altruista, sino una construcción compleja de diversas motivaciones y de diferentes formas de socialización. La ruptura de la lealtad para con el sistema puede venir entonces de un principio de oportunismo, de solidaridad o de obediencia.

Por otra parte, el modelo de comunidad presenta los axiomas que deben ser respetados para establecer las reglas de justicia de toda comunidad. El respeto de estos garantiza la lealtad de los agentes que las han aceptado. Pero el modelo puede también explicar, de un lado, los riesgos de la defección colectiva, es decir la ruptura de lealtad para con una autoridad legal y, por otro lado, la manera en que se puede formarse la autoridad alternativa ${ }^{48}$.

Concluye el autor que la decisión de ruptura de la lealtad viene tanto de la reacción ante un sistema de autoridad como de un cálculo consciente. Para que haya traición, el agente no debe (o no debe más) considerar como suyos los objetivos de la organización. La falta de lealtad es el resultado de un fallo o de un fracaso de la organización que no ha sabido crear una concordancia y una convergencia entre objetivos personales y objetivos de la organización. En esta situación cada uno se siente libre de buscar soluciones adecuadas a sus problemas y se desarrolla la racionalidad de las conductas corruptas ${ }^{49}$.

\section{3-Apropiación ilícita de la información}

Desde otro planteamiento, VILLET y NERDUM constatan que la evolución de los sistemas económicos y sobre todo su rapidez son la plataforma favorita de la corrupción. Para los agentes de dichos sistemas, las transacciones económicas constituyen un aprendizaje de las reglas y dictan la conducta de los mismos. Más allá de la transacción mercantil pura, hay una multitud de informaciones que se intercambian con diferentes grados de transparencia. Cuanto más rápida es la evolución del sistema económico, menos informaciones tienen los actores económicos para actuar de manera "justa" y mayor es el valor de la información. Los obstáculos a la circulación de estas informaciones pueden ser numerosos y el sistema económico enfrenta en ese momento una disfunción que perjudica al conjunto de los actores económicos. Desde este punto de vista, la corrupción se presenta como una forma de apropiación privada e ilícita de un bien que debería pertenecer a la colectividad, a saber la información ${ }^{50}$.

${ }^{47} \mathrm{~J}$. CARTIER-BRESSON, Les réseaux de corruption et la stratégie des «3S » : SleepSilence-Smile, en M. BORGHI y P. MEYER-BISCH (eds.), La corruption, l'envers des droits de l'homme, Éditions Universitaires Fribourg Suisse, Friburgo, 1995, p.84.

48 Ibídem, op. cit., p.88.

${ }^{49}$ Ibídem, op. cit., pp.91-92.

${ }^{50} \mathrm{M}$. VILLET y L. NERDRUM, La corruption : un dysfonctionnement du marché de l'information, en M. BORGHI y P. MEYER-BISCH (eds.), La corruption, l'envers des droits de l'homme, Éditions Universitaires Fribourg Suisse, Friburgo, 1995, p.108. 


\section{CAPÍTULO I: GENERALIDADES SOBRE LA CORRUPCIÓN}

Por tanto, si hay que definir la naturaleza del mercado de la corrupción pues se entenderá como un seudo-mercado en el que se intercambian bienes que no deberían legalmente intercambiarse ${ }^{51}$.

Concluyen estos autores que los numerosos estudios económicos y sociológicos han mostrado que las medidas jurídicas eran insuficientes y aun con sanciones y controles muy severos, la corrupción no desaparece. El problema es de carácter estructural. Se trata de la modificación de las estructuras económicas y sociales dentro de las cuales operan los individuos y, especialmente, las estructuras de información ${ }^{52}$.

\section{II-Conceptos de corrupción}

Después de repasar los diversos aspectos del fenómeno de la corrupción, se puede preguntar si es posible llegar a un concepto de corrupción. La respuesta es obvia. La variedad de su fenomenología impide esta unidad conceptual. La reagrupación de ideas o denominadores comunes han ayudado a intentos de conceptualización de la conducta corrupta. Sin embargo, a pesar todos estos intentos, la conclusión a la que se llega, es lo que GARCÍA MEXÍA señala: "los ensayos para alcanzar una noción generalizadamente aceptada de «corrupción» son tan numerosos como infructuosos: así de escurridizo es el concepto."53

\section{A-INTENTOS DE CONCEPTUALIZACIÓN DE LA CORRUPCIÓN}

Los intentos de conceptualización de la corrupción parten de postulados comunes necesarios para llegar a una definición válida.

Por una parte, se ha considerado la corrupción como "algo malo"54. Su extraordinaria "maldad" parece justificar el interés de las ciencias sociales en ella. Así como se ha dicho que "habrá quizá pocos términos más evocadores en la ciencia política que la palabra corrupción. Todo un sistema de valores sociales se resquebraja ante su simple enunciado y una amplia gama de reacciones, casi siempre apasionadas, se suscita por el solo el hecho de su traída a colación." 55 También se ha comparado la corrupción como una "patología" que, además de socavar la estructura social y las reglas del juego democrático, "puede llegar a tener consecuencias devastadoras, tan devastadoras como frágiles y vulnerables sean los cimientos del Estado de Derecho." 56 A partir de estas afirmaciones se ha enfocado la conceptualización de la corrupción desde una perspectiva ética que se refiere a la violación de normas y de valo-

\footnotetext{
51 Ibídem, op. cit., p.110.

52 Ibídem, op. cit., p.116.

53 P. GARCÍA MEXÍA, Los conflictos de intereses y la corrupción contemporánea, Arazandi, Pamplona, 2001, pp.57-58.

${ }^{54}$ R. PIÑEYRO, La corruption entre le désir..., op. cit., p.16. Para la autora, "el mal es el señal unificador de todas las teorías sobre la corrupción".

55 Entre otros, A. SABÁN GODOY, El marco jurídico de la corrupción, Civitas, Madrid, 1991, p.13.

56 E. DEMETRIO CRESPO, La corrupción como freno decisivo..., op. cit., p.46.
} 
res que presiden la administración de los intereses comunes ${ }^{57}$. En este orden de ideas, se ha dicho que la corrupción es la vulneración de los principios y reglas que en una sociedad determinada deberá servir para cohonestar lo público y lo privado ${ }^{58}$. Esta vulneración es la que explica el abuso de poder desde el punto de vista ético ${ }^{59}$. Por lo tanto, si hay que combatir la corrupción será a partir del respeto de una ética ${ }^{60}$.

Por otra parte, algunos intentos de conceptualizar la corrupción acuden a nociones diversas tales como la desviación de poder ${ }^{61}$, la violación de un deber posicional ${ }^{62}$ o el intercambio de prestaciones ${ }^{63}$, entre otras. Cada disciplina social utilizan estas nociones sin entrar en consideraciones morales o éticas. Observa NIETO que se puede partir de una corrupción sin ética con la que se violan fundamentalmente normas jurídicas, y en su caso, económicas y políticas. Una corrupción, en definitiva, que perturba la convivencia social, aunque no necesariamente la conciencia personal de cada individuo ${ }^{64}$. No obstante, los defensores de la conceptualización de la corrupción desde la ética defienden que esas nociones sólo se pueden explicar con la falta de ética ${ }^{65}$.

Sin entrar en esta discusión, se puede preguntar si es posible llegar a una definición de la corrupción.

\section{B-¿SE PUEDE DEFINIR LA CORRUPCIÓN?}

Hay acuerdo mayoritario en considerar la imposibilidad de definir con exactitud y de manera unívoca la corrupción. Esta imposibilidad se debe a varias razones. En primer lugar, el concepto de corrupción es cambiante a través de la historia y entre las diversas culturas pues su conceptualización varía de una sociedad a otra, dependiendo, por un lado, de sus estructuras económicas y políticas, y por otro lado de sus cambios históricos ${ }^{66}$. Con la enorme variedad de sus manifestaciones reales, la tarea de conceptualizar se complica ya que esta consiste en abstraer los elementos comunes de fenómenos concretos y generalizarlos para

\footnotetext{
${ }^{57}$ A. SABÁN GODOY, El marco jurídico..., op. cit., p.57.

${ }^{58}$ E. DEMETRIO CRESPO, La corrupción..., op. cit., p.47.

59 M. BORGHI, Droits de l'homme..., op. cit., p.5

${ }^{60} \mathrm{H}$. XIAO-YING, La lutte contre la corruption en politique criminelle, étude comparée entre la France et la Chine, Thèse de Droit, dir. H. MATSOPOULOU, Université de Paris 1-Panthéon Sorbonne, 2005, p.21.

${ }^{61}$ A. NIETO, Corrupción..., op. cit., p.67; E. DEMETRIO CRESPO, La corrupción..., op. cit., p.49; P. FITZGERALD, "Les dispositifs juridiques..., op. cit., p.16.

62 P. RAFOLISY, La protection juridique..., op. cit., p.15; E. DEMETRIO CRESPO, La corrupción..., op. cit., p.49; L. FERNÁNDEZ RÍOS, Psicología de la corrupción..., op. cit., pp.39-40

${ }^{63}$ P. FITZGERALD, "Les dispositifs juridiques..., op. cit., p.16; H. XIAO-YING, La lutte contre la corruption..., op. cit., p.12; E. DEMETRIO CRESPO, La corrupción..., op. cit., p.49.

${ }^{64}$ A. NIETO, Corrupción ..., op. cit., pp.66-67.

${ }^{65}$ R. PIÑEYRO, La corruption entre le désir..., op. cit., p.27.

${ }^{66}$ L. FERNÁNDEZ RíOS, Psicología de la corrupción..., op. cit., p.26; E. A. FABIÁN CAPARRÓS, La corrupción..., op. cit., p.22.
} 


\section{CAPÍTULO I: GENERALIDADES SOBRE LA CORRUPCIÓN}

aplicarlos a todos los que existen o aparezcan. Lo que significa que cuanto mayor sea la heterogeneidad de las variedades que se tengan en cuenta tanto más difuso habrá de ser el concepto resultante ${ }^{67}$. En segundo lugar, la corrupción es un intercambio social que se confunde en el conjunto de los intercambios sociales para hacerse imperceptible. Además, las formas modernas de la corrupción pueden a menudo revestir todas las apariencias de la legalidad y de la respetabilidad68. Por último, se ha dicho que la corrupción es un desvalor y, en cuanto tal, depende de los criterios subjetivos de cada persona; pero también es un concepto social, es decir, algo generalmente aceptado independientemente de las peculiaridades de juicio que tenga cada uno de sus miembros. Lo que en cualquier caso resulta imprescindible es contar con un concepto preciso de corrupción que es condición necesaria de un análisis teórico útil y además, de una práctica razonable. Esto último debe tenerse en cuenta, ya que la carencia conceptual banaliza la corrupción de tal manera que cualquiera puede acusar a cualquiera de corrupción dado que en rigor, no está diciendo nada preciso ${ }^{69}$.

Ante esta imposibilidad de definir la corrupción, la pregunta es: ¿puede ser estudiada si no se tiene alguna definición?

Los autores que han estudiado este fenómeno se han enfrentado a esta pregunta y han reconocido que si existe algún concepto esquivo a la sistematización científica, ése es el de corrupción ${ }^{70}$. Admite FERNÁNDEZ RÍOS que no conocemos cómo establecer una definición universal de corrupción. No debe desalentarnos pues, aunque no sepamos definir qué es la corrupción, sin embargo, logramos aproximarnos a su estructura. Muy posiblemente se trata de un concepto multidimensional ${ }^{71}$.

A efectos de nuestro trabajo, está claro que no se trata aquí de proponer otra definición de la corrupción sino de aproximarnos a su estructura desde la perspectiva jurídica. Por lo tanto, en el ámbito estrictamente jurídico, corrupción será lo que la normativa defina como tal en cada momento y en cada sector ${ }^{72}$.

\footnotetext{
${ }^{67}$ A. NIETO, Corrupción..., op. cit., pp.81-82.

${ }^{68}$ H. XIAO-YING, La lutte contre la corruption ..., op. cit., pp.12 y 14; M. MEYER, Corruption et coopération au développement: que faire pour en réduire l'incidence ? en $\mathrm{M}$. BORGHI y P. MEYER-BISCH (eds.), La corruption, l'envers des droits de l'homme, Éditions Universitaires Fribourg Suisse, Friburgo, 1995,p. 140.

${ }^{69}$ A. NIETO, Corrupción..., op. cit., p.77.

70 P. GARCÍA MEXÍA, Los conflictos de intereses..., op. cit., p.63.

${ }^{71}$ L. FERNÁNDEZ RÍOS, Psicología de la corrupción..., op. cit., pp.38-39.

72 E. A. FABIÁN CAPARRÓS, La corrupción..., op. cit., p.22.
} 


\section{Sección 2-Aproximación jurídica a la co- rrupción}

\section{I-Corrupción o corrupciones}

\section{A-LA CORRUPCIÓN DESDE LA PERSPECTIVA DEL DERECHO}

ción

1-La incapacidad del Derecho para definir la corrup-

Como lo hemos visto en apartados anteriores, la variedad de las manifestaciones de la corrupción impide todo intento de sistematización científica. Esta dificultad ha sido admitida por algunos autores de la doctrina jurídica que afirman que realmente la corrupción, por naturaleza, no constituye un concepto jurídico ${ }^{73}$. En efecto se ha dicho que la corrupción es un concepto cuyo análisis pertenece principalmente al ámbito de la sociología y de la ciencia política pero adquiere además directo interés para la Ciencia jurídica, y en particular el Derecho penal74.

Por otra parte, se ha reconocido que, aunque el Derecho y, en particular el Derecho penal, pueda jugar un papel importante en la aproximación al fenómeno de la corrupción, ni la perspectiva jurídica es la única, ni se han valorado debidamente las aportaciones de otras disciplinas no jurídicas $^{75}$. Además, ninguna de las definiciones expuestas, tanto anterior como posteriormente, puede darse por válida con exclusión de las demás ${ }^{76}$. Añade PIÑEYRO que como la corrupción es un hecho social y moral, la aproximación jurídica debe ser enriquecida por las ciencias sociales, por la puesta en tela de juicio de la legitimidad de los sistemas $^{77}$.

\section{2-Los diferentes aspectos de la corrupción}

Dentro de la densa literatura jurídica que trata sobre la corrupción, los autores distinguen diferentes aspectos según el sector de actividad o el ámbito en el que surge este fenómeno.

En primer lugar, se ha hecho una diferencia entre la corrupción pública y la corrupción privada. La tentación para simplificar sería grande al admitir que la corrupción pública sería la que sucede en el sector público y la corrupción privada sería la que pertenece al sector privado. Sin embargo, la ecuación no es así de sencilla. Según CARBAJO CASCÓN, la

\footnotetext{
73 Ibídem, op. cit., p.22.

${ }^{74}$ E. DEMETRIO CRESPO, La corrupción..., op. cit., p.48.

${ }^{75}$ E. A. FABIÁN CAPARRÓS, La corrupción..., op. cit., p.22.

${ }^{76}$ P. GARCÍA MEXÍA, Los conflictos de intereses..., op. cit., p.63.

77 R. PIÑEYRO, La corruption entre le désir..., op. cit., p.28. En el mismo sentido P. RAFOLISY, La protection juridique..., op. cit., p.20.
} 


\section{CAPÍTULO I: GENERALIDADES SOBRE LA CORRUPCIÓN}

corrupción supone una utilización desviada, desleal o perversa de potestades públicas para satisfacer intereses privados o particulares del titular de esas potestades y/o de uno o varios terceros relacionados con el mismo por cualquier relación económica o de confianza menoscabando la satisfacción objetiva de los intereses generales. Así se habla de conflictos de intereses entre intereses públicos e intereses privados. "El fenómeno de corrupción se traduce por tanto, en la interposición de un interés privado sobre el interés público o general"78.

Observa el autor que "este fenómeno no puede considerarse exclusivo del ámbito público de la administración. Así se han constatado graves escándalos ocurridos en torno a los mercados financieros, en las grandes empresas (sociedades cotizadas) y en organizaciones internacionales y el llamado tercer sector que han perturbado la confianza y el funcionamiento del mercado y han generado un malestar entre los ciudadanos y las instancias del poder político por las graves consecuencias que tales escándalos conllevan." Por eso se habla de corrupción en el sector privado, fruto de comportamientos desviados por parte de los centros de poder y decisión de las empresas privadas generalmente con proyección pública ${ }^{79}$. La corrupción privada sería una desviación fraudulenta o abusiva de control y de decisión en la empresa privada que genera conflictos de intereses dentro del sector privado ${ }^{80}$.

A pesar de que la expresión corrupción privada no reciba la misma aceptación de parte de la doctrina jurídica ${ }^{81}$, NIETO afirma que "la eventual corrupción privada está tan claramente ligada con las actividades públicas que cabe preguntarse si es posible una corrupción privada que no sea al tiempo pública en cuanto que la tolerancia de ciertas corrupciones privadas implican la presencia de una correlativa corrupción pública"82. En efecto, podríamos decir que la corrupción pública y la corrupción privada no son más que dos caras de una misma moneda ya que en muchas ocasiones los grandes escándalos en el sector privado tienen vínculos con el sector público y el poder político.

En segundo lugar, hay que distinguir la corrupción pública y corrupción política. No coinciden exactamente puesto que el sector público es más ancho que el político al referirse solamente a un segmento muy concreto de aquél. Según BUSTOS GISBERT para hablar de corrupción política habrá que considerar a los políticos elegidos y los partidos políticos, entre otros criterios $^{83}$. En efecto, la vida pública está descompuesta en

\footnotetext{
${ }^{78}$ F. CARBAJO CASCÓN, Corrupción pública, corrupción privada y derecho patrimonial., en E. A. FABIÁN CAPARRÓS y N. RODRÍGUEZ GARCÍA (coords.), La corrupción en un mundo globalizado, Ratio legis, Salamanca, 2003, p.127.

${ }^{79}$ Ibídem, op. cit., p.129. La cursiva es del autor.

80 Ibídem, op. cit., p.130.

81 E. A. FABIÁN CAPARRÓS, La corrupción..., op. cit., pp.24-26.

82 A. NIETO, Corrupción..., op. cit., p.71. La cursiva es del autor.

${ }^{83}$ R. BUSTOS GISBERT, La recuperación de la responsabilidad política en la lucha contra la corrupción de los gobernantes: una tarea pendiente, en E. A. FABIÁN CAPARRÓS y N. RODRÍGUEZ GARCÍA (coords.), La corrupción en un mundo globalizado,
} 
diversos sectores: unos exclusivamente políticos y otros donde conviven lo político y lo administrativo combinados en proporciones diversas según la relevancia del órgano de que se trate. Señala NIETO que, en cualquier caso, la función administrativa está subordinada a la política. Aún así insiste el autor en que "el referente de la corrupción política son las reglas del juego político (que prohíben, por ejemplo, el transfuguismo parlamentario o la provocación), mientras que el de la corrupción pública es el ejercicio - correcto o desviado - de las potestades públicas. Se trata, por tanto, de fenómenos distintos pero no antónimos y, desde luego, íntimamente conexionados ya que la corrupción política puede ser también pública y ésta es igualmente política desde el momento en que afecta al sistema político en el que opera" 84 .

En tercer lugar, se puede también diferenciar la corrupción administrativa de la corrupción penal. La corrupción administrativa es la que afecta a la organización y funcionamiento de las Administraciones públicas. Se ha observado que dentro del amplio repertorio de conductas sospechosas la ley selecciona unas cuantas las que considera más graves y las califica de delitos, esto es, las tipifica con tal carácter en el Código penal. Ésta es la corrupción penal, que comprende, por tanto, una parte de las conductas consideradas corruptas. Ahora bien, junto a ellas existen otras, también declaradas legalmente corruptas pero no incluidas en el Código penal y que constituyen la corrupción meramente administrati$v^{85}$. Hay que distinguir entre el "hecho corrupto", que es un fenómeno que aparece en la vida real y el "delito de corrupción", que es una declaración jurídica que el legislador ha anudado a la acción real. No obstante, en el plano normativo abstracto ocurre en efecto que el legislador, después de haber detectado que determinadas prácticas reales son corruptas, no se decide a tipificarlas como delito en el Código penal, pero tampoco las quiere dejar impune y encomienda su corrección tanto a los órganos estatales como a la propia Administración. Por consiguiente, hay actividades concretas que pueden y deben ser declaradas oficialmente corrupción administrativa sin necesidad de que intervenga un juez (quien, además, no tendría competencia para hacerlo al no tratarse de un delito) ${ }^{86}$.

\section{B-LA CORRUPCIÓN DESDE LA PERSPECTIVA DEL JUEZ}

El juez juega un papel importante en la identificación de la corrupción. El problema existe cuando la sentencia dictada por el juez no corres-

Ratio legis, Salamanca, 2003, p.68. Los demás criterios según el autor son: la actividad realizada debe ser representativa; el cargo ocupado debe implicar el ejercicio de autoridad pública; el acto corrupto debe perseguir un interés personal del sujeto; la conciencia de que sus actos son o pueden ser considerados ilegales o impropios.

${ }^{84}$ A. NIETO, Corrupción..., op. cit., p.68. La cursiva es del autor.

85 Ibídem, op. cit., p.85. Añade el autor que esta distinción es esencial porque su desconocimiento está dando lugar a un confusionismo no sólo conceptual sino práctico en cuanto que distorsiona las medidas de represión de la corrupción y en general todas las prácticas anticorrupción.

${ }^{86}$ Ibídem, op. cit., p.86. 


\section{CAPÍTULO I: GENERALIDADES SOBRE LA CORRUPCIÓN}

ponde con los hechos constatados por los ciudadanos ${ }^{87}$. En palabras de NIETO, "es común, el error de identificar corrupción con corrupción penal o, lo que es lo mismo, afirmar que las únicas conductas corruptas son las que están tipificadas en el Código penal y que, por tanto, no hay más prácticas corruptas concretas que las que un juez ha declarado; y por lo mismo, fuera del Código penal no hay corrupción y fuera de una sentencia condenatoria no hay personas corruptas." Las consecuencias de este error son múltiples. En primer lugar, la única represión posible es la que realizan los jueces y tribunales paralizando la acción sancionadora de la Administración. En segundo lugar, se considera que mientras no haya una sentencia condenatoria, ninguna conducta puede ser calificada de corrupción. Y, por último, mientras no haya una sentencia condenatoria, nadie puede ser tenido por corrupto, ya que todos estamos protegidos por una presunción de inocencia que sólo una resolución puede romper ${ }^{88}$. Destaca CERINA que el problema radica en que mientras los juristas nos nutrimos de sentencias sin preocuparnos demasiado por su desmesurado tamaño y por su prosa, los ciudadanos prefieren la más liviana visión del televisor y, cada vez en menor medida, la lectura de los periódicos, en donde las "crónicas enfermedades del Estado" se mezclan con las cuestiones de corazón, dejando poco espacio a los aburridos e inútiles tecnicismos jurídicos. Se pierde de vista que al juez penal no se le pide sino decidir acerca de la aplicabilidad al caso concreto de una sanción establecida por el Código penal, observando lo dispuesto por las leyes procesales e, inevitablemente, sus propias convicciones. De ahí que en realidad, una sentencia absolutoria no equivale necesariamente a una declaración de ausencia de corrupción, sino que significa simplemente la no aplicabilidad al caso de la sanción prevista por la ley penal. Desde luego, considerar corrupción y corrupción penal como equivalentes no tiene otra consecuencia que la atribución al juez penal en exclusiva del poder de decretar la aplicación de una sanción penal para el imputado corrupto ${ }^{89}$.

La valoración del juez puede no coincidir con la valoración de los ciudadanos sobre la absolución del supuesto corrupto o corruptor. Sin embargo, la absolución por el juez penal no significa la exención de responsabilidad ante la sociedad. El que se ha librado de la responsabilidad penal no se va a escapar de su responsabilidad política si el sujeto en cuestión ostenta un mandato electivo o político ${ }^{90}$. Lo relevante aquí es considerar que el juez penal no puede añadir ni restar nada al concepto penal de la corrupción, lo cual puede causar una incomprensión general según la percepción de los ciudadanos sobre el fenómeno en cuestión. Eso nos lleva a valorar si el Derecho penal puede ser portador de un concepto aceptable de la corrupción.

\footnotetext{
${ }^{87}$ M. BORGHI, Droits de l'homme..., op. cit., p.14.

${ }^{88}$ A. NIETO, Corrupción..., op. cit., p.85. La cursiva es del autor.

${ }^{89}$ G. D. M. CERINA, La lucha contra la corrupción, op cit., pp.52-53

${ }^{90}$ R. BUSTOS GISBERT, La recuperación de la responsabilidad política..., op. cit., pp.74 yss.
} 


\section{C-LA CORRUPCIÓN DESDE LA PERSPECTIVA DEL DERECHO PE-} NAL

El fenómeno de la corrupción ha sido un objeto de estudio del Derecho penal. Se puede entonces hablar de corrupción penal cuando se trata de una noción deducida de criterios legales penales ${ }^{91}$. Formarían parte de la corrupción penal aquellas conductas graves que la ley califica como delitos ${ }^{92}$. Sin embargo, más allá de las definiciones legales previstas por el Código penal, deberíamos considerar otros aspectos que de alguna manera influyen en la creación y en la aplicación de estas figuras delictivas.

\section{1-Insuficiencia de las herramientas del Derecho penal}

Como ya lo hemos señalado con anterioridad la corrupción ha sido considerada como algo extremadamente malo, lo cual justifica la intervención de la herramienta más dura del ordenamiento jurídico que es el Derecho penal. La pregunta que siempre se plantea es la posibilidad de limitar el ius puniendi frente a los derechos de los ciudadanos. La amenaza que supone el fenómeno de la corrupción no justifica la invasión estatal de las garantías individuales ${ }^{93}$. Debe tenerse en cuenta que los límites de la prerrogativa del Estado se suelne encontrar en el principio de legalidad y el principio de taxatividad. El primero significa, según el artículo 25.1 de la Constitución española, que "nadie puede ser condenado o sancionado por acciones u omisiones que en el momento de producirse no constituyan delito, falta o infracción administrativa, según la legislación vigente en aquel momento". Esta primera exigencia debe ser acompañada del segundo principio que requiere que el legislador formule la ley penal con la máxima precisión ${ }^{94}$.

Ante la corrupción y sus consecuencias devastadoras será lógico esperarse que el Estado actúe con todas sus fuerzas para erradicarla, inclusive utilizando su extrema ratio: el Derecho penal. Por otro lado, la utilización de esta herramienta en el Estado de Derecho presupone o implica la delimitación de la forma más clara posible de lo que se quiere prohibir así que, para penar hechos corruptos, deberá fijarse con claridad, exactitud y precisión qué significa la palabra corrupción ${ }^{95}$.

Si se piensa que el Código penal identifica con claridad lo que es corrupción a tales efectos ${ }^{96}$ cabe preguntarse la razón por la cual el concepto

\footnotetext{
${ }^{91}$ A. NIETO, Corrupción..., op. cit., p.84.

92 Ibídem, op. cit., p.85.

93 M. DELMAS-MARTY y S. MANACORDA, La corruption, un défi pour l État de Droit et la société démocratique. Revue de science criminelle et de droit pénal comparé, juliosept. 1997, pp701-702.

94 I. BERDUGO DE LA TORRE y otros, Curso de Derecho Penal, Parte General, Ediciones Praxis, Barcelona, 1999, p.47.

95 G. D. M. CERINA, La lucha contra la corrupción, op cit., p.45.

96 Entre otros A. SABÁN GODOY, El marco jurídico..., op. cit., pp.16 y ss.; A. NIETO, Corrupción..., op. cit., pp.76 y ss.
} 


\section{CAPÍTULO I: GENERALIDADES SOBRE LA CORRUPCIÓN}

penal de corrupción no se considera suficiente ${ }^{97}$ y, por ende, los motivos por los cuales se reconoce la necesidad de ir más allá de lo legalmente establecido. Sintetiza CERINA que el problema reside en que el Código penal sancionaría como corruptos tan sólo una parte de los comportamientos que socialmente son percibidos como tales ${ }^{98}$.

\section{2-La influencia de la ética sobre la conceptualización penal de la corrupción}

Se ha preguntado si todo lo legal es ético y si todo lo ético es legal ${ }^{99}$. Es opinión común que, entre todas las ramas del Derecho, el ordenamiento penal se acerca más a la ética ya que no faltan autores que afirman que el fenómeno de la corrupción es un problema ético ${ }^{100}$. DELMAS-MARTY reclama una ética universal relevada por el Derecho penal cuando los derechos del individuo se encuentran amenazados por la globalización de lo económico. Advierte la autora del riesgo de una excesiva penalización frente a un derecho instrumentalizado a favor de los actores más poderosos ${ }^{101}$. Lo que quiere decir la autora, en sentido general, es que el Derecho penal debe ser un instrumento para dar fuerza jurídica a la ética. De otra manera, ésta no serviría más que rellenar los códigos de valores y deontológicos. GODOY afirma también que "la presencia de la corrupción en la vida pública está directamente vinculada a los componentes éticos de los grupos sociales que la conforman, entendidos aquéllos como los valores que, partiendo del plano personal, se traducen en normas de conducta valoradas positivamente por esos grupos. La corrupción no es, en consecuencia, sino la alteración de esos valores en lo que atañe a la administración de los intereses comunes"102.

Sin embargo la literatura jurídica advierte sobre los inconvenientes que conllevan intentar balancearse sobre un terreno tan resbaladizo con el

\footnotetext{
${ }^{97}$ P. RAFOLISY, La protection juridique..., op. cit., p.20; R. PIÑEYRO, La corruption entre le désir..., op. cit., p.70; E. A. FABIÁN CAPARRÓS, La corrupción..., op. cit., p.22; P. GARCÍA MEXÍA, Los conflictos de intereses..., op. cit., p.63.

${ }^{98}$ G. D. M. CERINA, La lucha contra la corrupción, op cit., p.47

${ }^{99}$ R. PIÑEYRO, La corruption entre le désir..., op. cit., p.27.

${ }^{100}$ H. XIAO-YING, La lutte contre la corruption..., op. cit., p.21.

101 M. DELMAS-MARTY, Le droit pénal comme éthique de la mondialisation, Revue de science criminelle, enero-marzo 2004, pp.1-10, citado por H. XIAO-YING, La lutte contre la corruption..., op. cit., pp.21 y 22.

102 A. SABÁN GODOY, El marco jurídico..., op. cit., p.57. Añade el autor que, sin menoscabo del fundamento ético, bien que se matice éste hacia su vertiente social, el Derecho, como traducción de aquél en conjunto racional de normas imperativas, juega un papel en la materia que excede con mucho de la traslación formal de valores que se le asigna. Así, no sólo puede llegar a alterar el conjunto de esos valores, y ello tanto por necesidades de las técnicas articuladoras como por la propia rudeza de toda praxis, sino que a la postre motiva una serie de conductas, ya sea por imitación, favorecimiento o, incluso, rechazo, que de por sí tienen una incidencia autónoma en el difuso límite de los intereses públicos con los privados. Por otra parte, el Derecho es el único instrumento con que la sociedad cuenta para influir en los propios valores sociales que, si bien deberían ser su exclusivo fundamento, actúan también en ocasiones como baluartes inasequibles a los legítimos deseos de cambio social al servicio de una eventual idea de progreso (p.58).
} 
de la moralidad o de la ética. En efecto, "el inevitable subjetivismo de los valores y de su ponderación relativa"103 y "la generalización de la doble moral" 104 llevan, demasiado a menudo, a conclusiones válidas exclusivamente para quien se empeña en defenderlas. Observa NIETO que "en los tiempos que corremos la ética (individual, social, sexual) se ha refugiado - como la religión - en el seno de la privacidad: es una cuestión íntima, una elección individual que no debe transcender a la sociedad. Pero, además, y sobre todo por inanidad (...). Los principios morales son el producto de un determinado cuerpo social, cuyos ideológicos teorizan para mantener su coherencia y proporcionarle sus señas de identidad; no a la inversa."105 Por eso, constata CERINA que los intentos de definir la corrupción erigiendo a parámetro normativo de referencia este o aquel ordenamiento normativo "moral" no han dado, en términos de precisión, resultados aceptables ${ }^{106}$.

\section{ción}

\section{3-La percepción social y el concepto penal de corrup-}

Hablando de la percepción social de la corrupción, se ha hecho la distinción entre la corrupción social y la corrupción penal. La corrupción social se refiere a conductas manifestadas en la vida real que cada individuo o grupo reprocha con arreglo a sus propios criterios. La corrupción penal se refiere exclusivamente, por el contrario, a conductas que el legislador ha seleccionado y tipificado con carácter previo. La tipificación legal es el dato que caracteriza a la corrupción penal. Son conductas corruptas las que el Código penal ha calificado de tales con independencia de la valoración personal de ciudadano o incluso del juez. Sin tipificación legal no hay delito de corrupción, pero como no toda conducta corrupta está tipificada en el Código, no toda corrupción puede ser considerada como delito ${ }^{107}$. En otras palabras, hay algo que la sociedad percibe como corrupción pero que el Código penal ignora. En este orden de ideas, se ha notado que al considerar la "dañosidad social" como criterio de selección de los "bienes" merecedores de tutela penal, se puede llegar a dos consecuencias. Por un lado, se puede situar un ulterior límite al ius puniendi del Estado precisamente en lo socialmente percibido como merecedor de sanción. Por otro lado, será razonable esperarse, por parte del legislador una respuesta penal fiel a las exigencias trasmitidas por sus electores. Es decir, el legislador, a la hora de tipificar una conducta como delito, entre otras cosas, se hace intérprete del sentimiento social mayoritario vigente entre los destinatarios de la propia disposición ${ }^{108}$.

\footnotetext{
103 A. NIETO, Corrupción..., op. cit., p.79.

104 Ibídem, op. cit., p.79.

105 Ibídem, op. cit., p.80.

106 G. D. M. CERINA, La lucha contra la corrupción, op cit., p.48.

107 A. NIETO, Corrupción..., op. cit., pp.74-75.

108 BORGHI denuncia la perversión de los principios del Estado de Derecho y sobre todo del papel del legislador afectado por las "negociaciones legislativas". El autor señala los abusos de los considerados principios democráticos cuando se dejan la interpretación y la aplicación de la ley a autoridades administrativas con poderes
} 


\section{CAPÍTULO I: GENERALIDADES SOBRE LA CORRUPCIÓN}

Así las cosas, cuando se dice que el concepto de corrupción adoptado por el Código penal no se corresponde con la percepción que de este fenómeno mantiene la sociedad, se está significando, o bien que el legislador no ha cumplido con su función de intérprete de las exigencias de los destinatarios de las disposiciones que produce y que, por lo tanto, es oportuno que se amplíe el abanico de conductas objeto de sanción penal, o bien que existen casos de corrupción de menor gravedad frente a los cuales se considera innecesaria la intervención del Derecho penal, extrema ratio del ordenamiento ${ }^{109}$. Subraya CERINA cómo el Derecho penal actual parece padecer, más bien, de cierta hipertrofia legislativa que se manifiesta también en materia de corrupción. Se ha denunciado según el autor la excesiva sensibilidad del legislador que, demasiadas veces, preocupado por satisfacer la demanda de "justicia" o de "seguridad" de los electores excede en la utilización del Derecho penal y se olvida de que esta poderosa herramienta ha de ser empleada cum grano salis, representando la ultima ratio del ordenamiento jurídico ${ }^{110}$.

\section{II-Corrupción y cohecho}

\section{A-CORRUPCIÓN COMO GRUPO DE DELITOS}

Dentro de la literatura jurídica se ha considerado la corrupción no como una noción única para una conducta definida sino como una "amalgama delictiva" que refleja la complejidad de las conductas corruptas ${ }^{111}$. En efecto, cada autor intenta presentar según su propio criterio lo que considera como conductas delictivamente corruptas eligiendo todo un abanico de delitos ${ }^{112}$. Se ha dicho que la ley penal no define verdaderamente lo que es la corrupción sino que cita las nociones que este término puede abarcar, por tanto, no se habla de corrupción si no de actos de corrupción ${ }^{113}$. La doctrina francesa admite que no hay una incriminación de corrupción sino incriminaciones. Sin embargo debido a las confusiones que eso podía causar, en la actualidad se habla de "incriminaciones vecinas" de la corrupción ${ }^{114}$. Podría ser de ayuda para identificar la corrupción aislarla de los "delitos emparentados"115 con ella. De esta manera, se pueden evitar confusiones o asimilaciones rápidas "ante una variedad de conductas que, bajo diferentes denominaciones y modali-

discrecionales para hacer reglamentos especiales o de excepción (M. BORGHI, Droits de l'homme..., op. cit., pp.8 y ss.).

109 G. D. M. CERINA, La lucha contra la corrupción, op cit., p.50.

110 Ibídem, op. cit., p.51. En el mismo sentido J. WALTHER, L'antijuridicité en droit pénal comparé franco-allemand, Thèse de Droit privé, dir A. VITU, Université de Nancy II, 2003, p.177; C. FAURE-GAUSSEL, Droit pénal des affaires: étude comparative francoespagnole de l'infraction, Fondation Varenne y L.G.D.J., 2006, p.45, nำ74.

111 E. DEMETRIO CRESPO, La corrupción..., op. cit., p.54.

112 Ibídem, op. cit., pp.54-55; A. NIETO, Corrupción..., op. cit., pp.112 y ss.

113 P. RAFOLISY, La protection juridique..., op. cit., p.23.

114 Entre otros, P. BONFILS, «La corruption en droit pénal», en La corruption, Librairie de l'Université d'Aix-en-Provence, éd. 2005, pp.225 y ss.

115 P. GARCÍA MEXÍA, Los conflictos de intereses..., op. cit., pp.63 y 77. El autor reconoce que los conflictos de intereses son fruto de una variedad de corrupción. 
dades - corrupción, cohecho, concusión, tráfico de influencias, etc. -, comparten un contenido material semejante, orientado a la protección de la Administración pública."116 Se ha dicho que el problema, una vez más, parece ser metodológico. Las diferencias entre estos planteamientos inducen la sospecha de que, en realidad, no se esté deduciendo una noción de corrupción del dictado del Código penal, sino que, más bien, los autores citados mueven una idea preconcebida de corrupción de la que luego buscan confirmación en las normas que sancionan las conductas abstractamente subsumibles en su propia idea. Por consiguiente, la "corrupción", como categoría dogmática, pierde gran parte de su interés y utilidad, adquiriendo un valor meramente descriptivo ${ }^{117}$.

\section{B-CORRUPCIÓN COMO DELITO DE COHECHO}

Llama la atención el uso alternativo por el legislador español de las palabras "cohecho" y "corrupción". Se puede preguntar si tienen el mismo significado o son simplemente similares sin ser iguales. La doctrina española ha tomado posición al expulsar la palabra "corrupción" del léxico técnico-jurídico. Se ha dicho que "la corrupción, por naturaleza no constituye un concepto jurídico" y que su real significado, así como su investigación, es tarea de la ciencia política, de la sociología política y de la criminología ${ }^{118}$. De hecho, se ha reconocido también que el Derecho no es un ámbito del saber cerrado a las aportaciones de las demás áreas de conocimiento; todo lo contrario: la perspectiva jurídica no es la única y es necesario "valorar debidamente las aportaciones de otras disciplinas no jurídicas" 119 .

Sin negar que las aportaciones de otras disciplinas sociales puedan contribuir a definir el concepto de corrupción para que entre todas se pueda hablar en el "mismo idioma", eso no explica todavía la elección del legislador español al preferir el uso de la palabra "cohecho" en vez de "corrupción". CERINA habla de "agnosticismo" legislativo cuya causa se encontraría en la incapacidad de la doctrina jurídica para proporcionar una respuesta unívoca sobre el concepto de corrupción o en la reticencia del legislador que, a su vez, ha causado la confusión doctrinal en término de concepto ${ }^{120}$. Se pregunta el autor la razón por la cual en el delito de cohecho (activo) anteriormente se ha utilizado el verbo "corromper" y no "cohechar" y que luego se ha rubricado el Título XIX bis "de los delitos de corrupción en las transacciones comerciales internacionales" sin mantener la palabra "cohecho" sabiendo que ambas figu-

\footnotetext{
116 E. A. FABIÁN CAPARRÓS, La corrupción..., op. cit., p.24.

117 G. D. M. CERINA, La lucha contra la corrupción, op cit., pp.58-59. En el mismo sentido P. RAFOLISY, La protection juridique..., op. cit., p.18.

118 E. DEMETRIO CRESPO, La corrupción..., op. cit., p.48; E. A. FABIÁN CAPARRÓS, La corrupción..., op. cit., p.22.

119 E. A. FABIÁN CAPARRÓS, La corrupción..., op. cit., p.22. En el mismo sentido P. GARCÍA MEXÍA, Los conflictos de intereses..., op. cit., pp.63; P. RAFOLISY, La protection juridique..., op. cit., p.20; R. PIÑEYRO, La corruption entre le désir..., op. cit., p.70.

120 G. D. M. CERINA, La lucha contra la corrupción, op cit., p.63.
} 


\section{CAPÍTULO I: GENERALIDADES SOBRE LA CORRUPCIÓN}

ras tienen la misma configuración material ${ }^{121}$. Concluye el autor que "más que agnosticismo conceptual, parece denotar cierta confusión terminológica"122.

De todos modos, a efectos de nuestro trabajo, los elementos típicos entre los tipos rubricados como "cohecho pasivo" en el Código penal español y como "corrupción pasiva" en el Código penal francés y malgache están configurados con bastante coincidencia, por tanto, no cabe duda de que se trata de la misma figura delictiva aunque tengan una rúbrica o un nomen iuris distinto. Esta diferencia será respetada a lo largo de este trabajo para mantener la identidad y la sensibilidad de cada legislador.

\section{III-La corrupción desde la perspectiva jurídico-penal comparada}

\section{A-DELIMITACIONES DEL ANÁLISIS COMPARATIVO}

Se puede estudiar la corrupción desde varias perspectivas, como se ha señalado al principio de este capítulo introductorio. El presente trabajo estudiará este fenómeno desde la perspectiva jurídico-penal comparada. Esta afirmación supone la presencia de dos o más sistemas jurídicos que comparar. En efecto, se van a comparar tres ordenamientos penales (el español, el francés y el malgache). Pero estos tres ordenamientos no significan tres sistemas penales. Estamos ante solamente dos sistemas penales diferentes: de un lado, el sistema penal español y por otro lado el sistema penal francés que incluye en él el sistema penal malgache. Esta inclusión significa que se comparte la teoría general del delito. En otras palabras, el delito será tratado con las mismas categorías conceptuales.

Por otra parte, para evitar confusiones, este trabajo se enfocará exclusivamente en el delito de cohecho o de corrupción. Esta precisión es necesaria para los ordenamientos, en este caso el francés y el malgache, que tipifican en el mismo artículo los delitos de corrupción y de tráfico de influencias. En otras palabras, a efectos de este trabajo la palabra "corrupción" y la expresión "delito de corrupción" se referirá a los delitos que el Código penal precisa como tal. Dentro de la misma figura de cohecho o de corrupción, se puede haber otro tipo de clasificación, sin embargo, se dará una énfasis particular a la vertiente pasiva de dicho delito. Eso no impide recurrir a la vertiente activa cuando sea necesaria para las explicaciones.

Por último, es evidente que estamos en una investigación de microcomparación ya que se estudia una figura delictiva de la parte especial del Código penal. Se han dado argumentos que reducen su importancia

\footnotetext{
121 Ibídem, op. cit., pp.63-88.
}

122 Ibídem, op. cit., p.87. 
respecto a la macro-comparación ${ }^{123}$ defendiendo que la mayoría de los comparatistas se dedican a la comparación de incriminaciones penales con un resultado que ni siquiera alcanza lo que se podría calificar de micro-comparatismo, en vez de abrir líneas de investigación de macrocomparación que beneficiarán al sistema y que no se quedarán obsoletas ${ }^{124}$. Defiende CONSTANTINESCO que "es pasando de la microcomparación a la macro-comparación, única escala capaz de revelar las estructuras características y las morfologías específicas, que puede aprehenderse la realidad jurídica. Sólo la macro-comparación puede conseguir que destaquen las verdaderas características de los órdenes jurídicos. El objeto de la investigación en la Ciencia de los Derechos comparados no debe ser un microhecho o un elemento jurídico aislado, sino las estructuras fundamentales de los órdenes jurídicos estudiados." 125

No compartimos este último argumento ya que la macro-comparación no tiene objeto de estudio sino los resultados de la micro-comparación de las instituciones de la rama jurídica estudiada. Además, desde el microcomparatismo se puede proyectar el contenido de las estructuras determinantes que influyen en los resultados de la macro-comparación. Si es cierto que la comprensión y la eficacia del trabajo analítico de la comparación vienen de la comprensión de la estructura general, abogamos, desde este trabajo, por una investigación micro-comparativa precedida siempre de la comparación de elementos de la parte general del Derecho penal.

\section{B-APROXIMACIÓN AL OBJETO DE ESTUDIO DESDE LA TEORÍA DEL DELITO}

La figura del cohecho pasivo o de la corrupción pasiva ha sido estudiada de manera diferente en los sistemas español y francés. Reconociendo la fuerte influencia del sistema alemán en el español ${ }^{126}$, se debe reconocer que esta influencia no ha sido recibida en Francia. WALTHER reconoce que el Derecho penal francés se encuentra en una situación de diferencia, marcada sobre todo por su formulación que favorece la simplicidad y claridad y su contenido se pretende positivista, realista y pragmáti-

\footnotetext{
123 J. WALTHER, L'antijuridicité..., p.1. Este autor califica el micro-comparatismo de "desoladora banalidad".

124 Ibídem, op. cit., p.2.

125 L.-J. CONSTANTINESCO, Tratado de Derecho comparado, Tecnos, Madrid, 1981, p.314. Añade el autor que la finalidad de la comparación es aquí el descubrir los elementos que caracterizan los órdenes jurídicos, es decir, las estructuras determinantes que forman el núcleo central de los órdenes jurídicos.

126 C. FAURE-GAUSSEL, Droit pénal des affaires, op.cit., p.4; J. WALTHER, L'antijuridicité..., p.5, el autor comparatista señala que el Derecho penal español como el de otros latinos (como Portugal y también Grecia) se caracteriza por su adhesión al modelo alemán hasta revestir una dimensión de relación de maestro a discípulo. Pues, hay menos trabajo de comparación de sistema a sistema que de estudio de las diferencias entre un "sistema-padre" y "sistemas-hijos". Y ello, precisa el autor, es fuertemente visible para el Derecho penal español.
} 


\section{CAPÍTULO I: GENERALIDADES SOBRE LA CORRUPCIÓN}

co $^{127}$. La antijuridicidad material implica la determinación de lo que el legislador pretendía proteger. Se supone que de su parte, considerando las consideraciones de política criminal del momento, se ha definido la acción o la conducta que lesiona o por lo menos pone en peligro algún valor necesario para la viabilidad del modelo de Estado a considerar ${ }^{128}$. En el caso español sería un modelo de Estado social y democrático de Derecho. La antijuridicidad en su aspecto material plantea la intervención del Derecho penal conforme a la protección de ese valor. Sin identificar éste, tampoco cabe la posibilidad de medir la intensidad de esta intervención ${ }^{129}$. No es cuestión de repasar aquí los grandes estudios sobre este punto que seguramente podría ser objeto de otro trabajo de tamaño considerable, sino que por la finalidad comparatista de este estudio se tratarán de destacar varios puntos de los dos sistemas lo que puede aportar el uno al otro. Como se ha señalado con anterioridad, el sistema penal malgache se muestra por su configuración (a parte de sus lazos históricos con el Derecho francés) parecido al sistema francés del cual forma parte el primero de la familia jurídica del segundo ${ }^{130}$, por lo tanto no habrá muchos puntos de comparación entre ambos.

Por otro lado es clásico que, dada la estructura de la teoría del delito en el sistema español, similar al sistema alemán, todo estudio de una figura delictiva destaca los aspectos que derivan de la antijuridicidad (formal y material) cuyo punto fundamental es el valor o el interés protegido. El concepto de antijuridicidad es central en la estructura del delito porque presume la contrariedad de una conducta al ordenamiento jurídico y a la vez identifica el valor que la norma pretende proteger ${ }^{131}$. Este valor protegido se reconoce como merecedor de tutela y le corresponde al Derecho penal llevar a cabo esta misión sobre todo cuando estos valo-

127 J. WALTHER, L'antijuridicité..., op cit, p.5. Recuerda la afirmación sentenciosa de VON LISZT en su formulación severa: ¡ “No hay doctrina penal francesa”!

128 S. MIR PUIG, Derecho penal, parte general, Editorial Reppertor, Barcelona, 2005, (7a Ed.), p.167, no37; M. CUGAT MAURI, La desviación del interés general y el tráfico de influencia, Cedecs, Barcelona, 1997, pp57-73, demuestra el cambio del valor protegido según el modelo de Estado.

129 M. COBO DEL ROSAL y T.S. VIVES ANTON, Derecho penal: parte general, Tirant lo blanch, Valencia, 1991, (3ra ed.), p.248, cuando hablan del principio de ofensividad, se trata de determinar a partir del concepto de Estado considerado qué es lo que se lesiona para merecer protección. No basta con pretender que se parte de un Estado de concepción Social si se relega este valor que proteger en segundo plano y enfocar la punibilidad no en la contradicción de este valor sino por la lesividad social del comportamiento.

130 Tiene validez aquí la observación de WALTHER con respecto a la relación de comparación entre los sistemas francés y malgache que sin duda aparecerá como "sistema-padre" y "sistema-hijo". Sin prejuicio de las especificidades que pueden presentar cada uno de ellos, acertadamente los africanistas hablan del "mimetismo jurídico" entre las ex-potencias colonizadoras y las ex-colonias o también de "aculturación jurídica" que marca la influencia de las primeras sobre el sistema jurídico y sobre todo penal de las segundas. H. SARASSORO, La corruption des fonctionnaires en Afrique, Étude de Droit pénal comparé, Economica 1980, pp.12 y 65.

${ }^{131}$ F. MUÑOZ CONDE y M. GARCÍA ARÁN, Derecho penal, parte general, Tirant lo Blanch, Valencia, 2010, (9a Ed.), pp.299 y ss. Afirma el autor que la antijuricidad formal y material no son sino aspectos del mismo fenómeno. 
res tienen relevancia constitucional ${ }^{132}$. El estudio de la antijuridicidad o ilicitud en materia penal no ha sido desarrollado por la doctrina francesa; por lo tanto el Derecho francés no la encuentra más que de manera incidente y accesoria con motivo de la teoría general de la justificación ${ }^{133}$. Otra diferencia como consecuencia de esta falta del desarrollo del concepto de antijuridicidad se encuentra en el análisis de la naturaleza del delito. La elaboración de cada figura típica responde a una sistemática en la cual la antijuridicidad juega un papel importante porque orienta lo que es digno de proteger y tiene la función de formular y realizar el tipo ${ }^{134}$. Por lo tanto, no es de extrañar que si la doctrina penal española ha desarrollado una construcción dogmática a partir del concepto de antijuridicidad material, el estudio de cada tipo de infracción conllevará análisis más profundo y detallado, lo cual delatará el desequilibrio en el estudio de la naturaleza del delito aquí estudiado respecto de la doctrina francesa. La misma observación se puede hacer en cuanto al estudio de los tipos de cohecho pasivo o de corrupción pasiva dado que las herramientas de análisis ${ }^{135}$ son diferentes aunque al final tienen un trasfondo, un mecanismo común que sigue una orientación política criminal cada vez más cercana.

A parte de la comparación de los debates doctrinales, a lo largo de este trabajo se confrontarán los textos legales en la materia y sus aplicaciones jurisprudenciales, aunque se tendrá que prescindir de la jurisprudencia malgache.

132 J.C. CARBONELL MATEU, Derecho penal: concepto y principios constitucionales, Tirant lo Blanch, Valencia, 1996, (2 Ed.), p.31.

133 J. WALTHER, L 'antijuridicité..., op cit, p.21, 22. El autor destaca la complejidad y la abundante elaboración hecha por la doctrina alemana sobre este concepto de antijuridicidad. Cosa que, sin embargo, sólo, en el mejor de los casos, ha sido objeto de una recepción truncada en Francia. Metodológicamente, dado la ausencia de un concepto global de ilicitud en Francia, una confrontación puramente conceptual, abstracta y teórica de ambos ordenamientos jurídicos no basta. Una aproximación funcional debe tomar el relevo del estudio conceptual. A nuestro parecer tiene validez esta observación al comparar los sistemas español y francés. En este sentido se ha pronunciado BACIGALUPO al plantear la cuestión de si la teoría del bien jurídico legitima la ley penal como objeto de la dogmática penal. Afirma el autor que: "ni en Francia ni en Bélgica, donde el juez no está facultado para enjuiciar la legitimidad de la ley dictada por el Parlamento, se reconoce a la teoría del bien jurídico una función legitimante del Derecho penal. En esto países la teoría del bien jurídico no ha tenido aceptación."(E. BACIGALUPO, Teoría y práctica del derecho penal, Tomo I, Instituto Universitario de Investigación Ortega y Gasset, Marcial Pons, Madrid 2009, pp. 167,168).

134 M. COBO DEL ROSAL y T.S. VIVES ANTON, Derecho penal: parte general, Tirant lo blanch, Valencia, 1999, (5 a ed.), p.302.

135 Ibídem, op. cit., p. 430, estos dos autores declaran que "para la clasificación de los tipos ha de tener en cuenta, a modo de criterio inspirador, cada uno de los momentos en que se ha detenido el análisis genérico del tipo de injusto: el bien jurídico, la formulación típica y los diversos elementos del hecho." Aunque hay que reconocer que la doctrina penal francesa conoce estos tres elementos de clasificación y de análisis, la doctrina penal francesa no los ha desarrollado o no los ha profundizado. Por lo tanto, la deficiencia de conceptualización en la estructura de la infracción acarrea otro tipo análisis que para los juristas españoles o los que siguen el sistema alemán de la teoría del delito les parecerá superficial y demasiado pragmático, con las consecuencias que pueda implicar eso. 


\section{CAPÍTULO II: EL BIEN JURÍDICO PROTEGIDO}

Como ya se ha señalado anteriormente todo estudio de una figura típica debe ser precedido de la identificación de lo que el legislador pretendió proteger al configurar incriminaciones y sanciones penales ${ }^{1}$. Por lo tanto la cuestión del bien jurídico protegido es la primera que se plantea cuando se examina una infracción ${ }^{2}$ sobretodo para todos los sistemas penales que siguen el modelo teórico alemán. Pero antes de precisar cuál es el bien jurídico protegido del delito objeto de este trabajo en cada ordenamiento jurídico estudiado debemos repasar lo que la doctrina penal ha elaborado respecto del concepto de bien jurídico para, en un segundo tiempo, delimitar el ámbito de estudio que es la Administración pública.

\section{Sección 1-Concepto de bien protegido en Derecho comparado}

No se trata aquí de hacer un estudio de la teoría del bien jurídico que la doctrina española ha dedicado, además de una explicación bastante completa en los manuales de Derecho penal, estudios monográficos exclusivamente al respecto ${ }^{3}$; o del valor protegido que en la doctrina francesa apenas si se ha aludido y por lo tanto no ha sido objeto de ningún estudio en particular, con el riesgo de desequilibrar los apartados. Con la finalidad comparatista del presente estudio, presentaremos los puntos más destacables elaborados por los autores de cada sistema e intentaremos deducir las aportaciones que un sistema pueda sugerir al otro.

\footnotetext{
${ }^{1}$ H. HORMAZÁBAL MALARÉE, Bien jurídico y Estado Social y Democrático de Derecho, (El objeto protegido por la norma), LexisNexis, Santiago de Chile 2006, (2ª Ed.), pp.151 y 152. Explica el autor que de acuerdo con el sistema penal español el sujeto sólo responderá de sus realizaciones lesivas de un bien jurídico. Pero no basta con esa vinculación personal en una situación social típica. Es necesario que esa situación sea socialmente significativa. En efecto, los tipos penales recogen momentos singulares lesivos de los bienes jurídicos protegidos por la norma que los precede. El bien jurídico da contenido material a la tipicidad. También FERNÁNDEZ destaca la función dogmática del bien jurídico y declara "la función dogmática reviste gran trascendencia, en la medida en que permite avanzar más allá de la mera comprensión exegética y literal de la ley, según el procedimiento dilecto del positivismo jurídico y en especial, de la escuela técnico-jurídica de Derecho penal, pues lleva al intérprete a otro campo de análisis más fecundo, que rebasa si se quiere el estricto análisis semántico del texto positivo."( G. D. FERNÁNDEZ , Bien jurídico y sistema del delito, B de F , Buenos Aires, 2004, pp. 151, 152)

${ }^{2}$ J. WALTHER, L'antijuridicité..., op cit, p.360

${ }^{3}$ La obra de M. POLAINO NAVARRETE, El bien jurídico en el derecho penal, Anales de la Universidad Hispalense, Publicación de la Universidad de Sevilla, № 19, 1974, parece pionera en este sentido.
} 


\section{Sub-sección 1: Aproximación al estudio del concepto de bien jurídico en el Derecho penal español}

Es de reconocer que la doctrina española seguía con interés la evolución de este concepto desde su formulación en Alemania4. La mayoría de los manuales al respecto siempre repasa su evolución histórica encontrando su origen con BINDING y Von LISZT. El primero se ha considerado como defensor del jusracionalismo positivista y el segundo sostiene el positivismo naturalista ${ }^{5}$. Efectivamente el presente trabajo no pretende emprender estudios profundos ni originales de la dogmática alemana, aunque incidentalmente se le puede hacer alusión. Se trata aquí de ver cómo la doctrina española ha recibido y desarrollado esta herencia dogmática. Ello se verá en el concepto sugerido para definir lo que se entiende por bien jurídico. Importa en segundo lugar en este párrafo precisar sus funciones para luego delimitarlo dándole una aproximación material.

\section{I-Concepto de bien jurídico}

Según FERNÁNDEZ la pregunta sobre el sustrato material del bien jurídico apunta a responder qué es. Si se trata de derechos, bienes, intereses, $o$ valores o estados 6 , a los cuales añadiremos objetos. Se trata para la dogmática penal de intentar desentrañar cuál es su autentica materialidad. El bien jurídico ha sido definido según criterios que efectivamente no encuentran unanimidad: sociológicos, funcionalistas y constitucionales. Pero los esfuerzos doctrinales en este ámbito permiten destacar que la mayoría de los autores están de acuerdo en que algo valioso merece ser protegido por el Derecho penal. La concepción inicial del bien jurídico pretendía servir de base a la elaboración de una definición de delito independiente de la contenida en el Derecho positivo ${ }^{7}$. Para LUZON PEÑA, se trata de objeto valioso merecedor de protección jurídica y del objeto efectivamente protegido o tutelado por el Derecho ${ }^{8}$. A su juicio quizá se pueda formular un concepto amplio y general de los bienes jurídicos como condiciones necesarias para el desarrollo de la vida del individuo y de la sociedad. Añade que tales condiciones pueden consistir en objetos, materiales o inmateriales, relaciones, intereses o dere-

\footnotetext{
${ }^{4}$ G. D. FERNÁNDEZ, Bien jurídico..., op. cit., p.69. Declara el autor en este sentido que en el seno de la doctrina española, siempre tan influenciada por la dogmática alemana, se reproduce a grandes rasgos la misma evolución hacia un concepto sociológico del bien jurídico.

${ }^{5}$ H. HORMAZÁBAL MALARÉE Bien jurídico..., op. cit., pp.33-46.

${ }^{6}$ G. D. FERNÁNDEZ, Bien jurídico..., op. cit., p. 6

${ }^{7}$ I. BERDUGO DE LA TORRE y otros, Curso de Derecho Penal, Parte General, Coordinación: CRISTINA RODRÍGUEZ YAGÜE, Ediciones Experiencia, 2004, p.7

8 D.-M. LUZÓN PEÑA, Curso de Derecho Penal, Parte General I, Editorial Universitas, 1996, p 326. Pero al sugerir esta primera aproximación el autor entiende que no hay unanimidad en la caracterización exacta de lo que es el bien jurídico. p.327.
} 
chos, que en cualquier caso han de ser socialmente valiosos y por ello dignos de protección penal ${ }^{9}$. Sostiene MIR PUIG que se utiliza el concepto de bien jurídico en dos sentidos: en primer lugar en el sentido político-criminal (de lege ferenda) de lo único que merece ser protegido por el Derecho penal (en contraposición, sobre todo, a los valores solamente morales) y en el sentido dogmático (de lege lata) de objeto efectivamente protegido por la norma penal vulnerada ${ }^{10}$. Las aproximaciones del concepto del bien jurídico propuestas por la doctrina española contienen algún sustrato material, algo que, según el mismo autor, no deben confundirse. Defiende que los bienes jurídicos descansan a veces en una realidad material, como la vida, y otros en una realidad inmaterial, como el honor, pero en ningún caso se identifican conceptualmente con su substrato ${ }^{11}$. Podemos diferenciar el bien jurídico con su sustrato al aportar algunas precisiones terminológicas. Además, se produjo alguna confusión o sino identificación del bien jurídico con otros conceptos importantes tales como los derechos subjetivos y el objeto material del delito u objeto de la acción. En lo que se refiere a los primeros, sostienen COBO DEL ROSAL y VIVES ANTON que bien jurídico y derecho subjetivo son conceptos distintos ${ }^{12}$. Con MEZGER ${ }^{13}$ están de acuerdo para indicar que existe "numerosos delitos en los que no es posible demostrar la lesión de un derecho subjetivo" y en los que, sin embargo, se lesiona o pone en peligro un bien jurídico. El concepto técnico de derecho subjetivo implica que el derecho objetivo se pone, en cierto modo, a disposición de una voluntad o un interés particular. Representa así un

\footnotetext{
${ }^{9}$ Ibídem, op. cit., p.327.

10 S. MIR PUIG, Derecho penal..., op cit., pp.166, 167, no 36. Añade el autor que los dos conceptos de bien jurídicos pueden hallarse más o menos próximos, según el grado de realización por parte del Derecho positivo del ideal político-criminal que se mantenga. El concepto político-criminal de bien jurídico tenderá a tener un contenido muy cercano al del concepto dogmático para quien sustente la misma concepción políticocriminal que inspira al Derecho penal vigente y al contrario (no37). D.-M. LUZÓN PEÑA, Curso de Derecho Penal, op. cit., p.326. Este autor explica que, del deber ser y del ser, de lo que debería ser protegido (perspectiva político-criminal, de lege ferenda) y de lo que realmente es protegido jurídicamente (perspectiva de estudio dogmático del Derecho positivo, de lege lata), está inseparablemente unida a la génesis y a la historia de la posterior discusión sobre el concepto de bien jurídico.

${ }^{11}$ S. MIR PUIG, Derecho penal..., op. cit., pp.167, no 38, el autor explica que la realidad de la vida no constituye, en cuanto tal, un "bien" jurídico, sino que, como mero dato biológico, todavía no encierra en sí mismo conceptualización axiológica alguna, es valorativamente neutra; pero dicha realidad de la vida puede contemplarse, además de como tal realidad empírica, como "bien", si se atiende a su valor funcional. Aun cuando el bien descanse en una cosa corporal, su concepto no se agotará en el de ésta, puesto que requiere algo más que su ser cosa: "los bienes...son las cosas más el valor que se les ha incorporado."

${ }_{12}$ M. COBO DEL ROSAL y T.S. VIVES ANTON, Derecho penal..., op. cit., p.317

13 E. MEZGER, Tratado de Derecho Penal, Tomo I, nueva ed., revisada y puesta al día por J. A. RODRIGUEZ MUÑOZ, Editorial revista de derecho privado, Madrid, 1955. p. 399. Señala el autor que esta concepción fue utilizada por el Derecho Penal de la "época de las luces", en el siglo XVIII, en su lucha contra la extensión desmedida que la pena había alcanzado en el derecho común precedente. Añade que es una concepción desechada. Pues el derecho subjetivo no podía ser entendido sino como emanación y reverso del Derecho objetivo, y con ello nada se diría sobre el contenido positivo de éste.
} 
mecanismo de distribución y protección de los bienes jurídicos, pero no necesariamente se identifica con ellos ${ }^{14}$. LUZON PEÑA entiende que se escoge el término bien jurídico para indicar que se designa algo más amplio que el concepto de «derecho» 0 «derecho subjetivo»: hay bienes jurídicos que coinciden con derechos reconocidos por otras ramas jurídicas o incluso constitucionalmente tutelados, como el derecho a la vida, a la salud, a la libertad, al honor, la intimidad o el derecho de propiedad, pero también pueden ser bienes jurídicos intereses o relaciones, individuales o sociales que no tengan la conceptuación estricta de derechos..$^{15}$ En cuanto a los conceptos de objeto de delito y objeto de la acción, señala POLAINO NAVARRETE que la doctrina mayoritaria ha entendido por objeto del delito el concreto objeto de protección, o bien jurídico-penalmente tutelado en cada tipo, en contraposición con el objeto externo de la acción. El autor critica esta falta de precisión y defiende que la utilización del objeto del delito en el sentido de objeto protección no es correcta en los términos expresados, porque en todo caso carece de matización terminológica y conceptual suficiente. Añade que no parece correcta la equiparación sin ninguna ulterior explicación clarificadora de objeto del delito y objeto de protección, porque el delito es distinto de la protección jurídico-penal, aunque ésta se provea precisamente mediante la descripción legal de los singulares tipos de delito. De otra parte, tampoco es acertada, por razones similares la identidad de objeto del delito y objeto de la acción, pues en todo caso aquél representa un concepto de mayor amplitud que éste, toda vez que el objeto de la acción integra, en rigor, sólo el objeto de uno de los elementos esencialmente: el delito, que no admite ser empleada técnicamente en el sentido del delito, considerado en su totalidad ${ }^{16}$.

Otro sustrato a diferenciar del bien jurídico es la idea de interés ${ }^{17}$. El interés en su sentido más propio, comporta la idea de utilidad, afirman COBO DEL ROSAL y VIVES ANTÓN. Todo estado de cosas que de cualquier modo puede beneficiar a alguien es, para él, un interés. Esta consideración puede ayudar a poner de manifiesto la diferencia existente

\footnotetext{
${ }^{14}$ Sobre el mismo tema y más detallado vid G. D. FERNÁNDEZ, Bien jurídico..., op. cit., pp.11-15; H. HORMAZÁBAL MALARÉE Bien jurídico..., op.cit., pp.11-17.

${ }_{15}$ D.-M. LUZÓN PEÑA, Curso de Derecho Penal, op. cit., pp.326, 327.

16 M. POLAINO NAVARRETE, El bien jurídico en el derecho penal, Anales de la Universidad Hispalense, Publicación de la Universidad de Sevilla, № 19, 1974, pp.68, 69; S. MIR PUIG, Derecho penal..., op. cit., p.168, no 39 da el ejemplo en delitos como el de atentado a Autoridad, agente de la misma o funcionario, en que el bien jurídico es la seguridad interior del Estado (en cuanto depende del principio de autoridad), que carece de substrato empírico, mientras que el objeto de la acción es la persona de la Autoridad, agente o funcionario, sobre el cual recae el delito. También resulta esclarecedor, según el autor, el ejemplo del hurto. En este delito el objeto de la acción es la cosa sustraída y el bien jurídico, en cambio, la propiedad de la misma.

17 G. QUINTERO OLIVARES, Curso de derecho penal, parte general, Cedecs, Barcelona, 1996, p.52. Indica el autor que para entender lo que es el bien jurídico hay que plantearlo a partir del mantenimiento de una compleja red cuya base es la voluntad mayoritaria y de ello depende la existencia misma del Estado de Derecho. Este mantenimiento impone la necesidad de que ciertos intereses sean custodiados penalmente.
} 
entre interés y bien jurídico ${ }^{18}$. Precisa, a su vez, POLAINO NAVARRETE que el interés no consiste sin más en lo que la persona considera apto, idóneo o adecuado para la satisfacción de una necesidad humana, sino, antes bien, precisamente en lo que por su caracterizadora cualidad o aptitud objetiva para satisfacer una necesidad tiene que ser garantizado por el legislador: es decir, en aquello que desde la perspectiva del ordenamiento jurídico, se presente como digno de una favorable acogida positiva, en cuanto útil para los titulares de derechos conforme a un juicio de valor externo y objetivo. Indica el mismo autor que el interés, en Derecho penal, denota la relación que media entre un sujeto y un bien, y que precisamente posibilita a aquél el disfrute de éste en orden a la satisfacción de una necesidad ${ }^{19}$.

Se ha apoyado el concepto de bien jurídico sobre la idea de valor ${ }^{20}$, que expresa de modo más adecuado las exigencias éticas que se hallan o habrían de hallarse en la base de ordenamiento jurídico que merezca ese nombre ${ }^{21}$. Según FERNÁNDEZ, en principio, debe partirse de la idea de que el bien jurídico es un valor. Hablar de "intereses" o de "unidades funcionales de valor", por ejemplo, quiere significar - en el fondo- la misma cosa. El término valor le parece más ajustado y engloba cualquier otra variable semántica22. Por lo tanto, deducen COBO DEL ROSAL y VIVES ANTÓN, se puede definir el bien jurídico como todo valor de la vida humana protegido por el Derecho ${ }^{23}$. Señala POLAINO NAVARRETE la concepción de RUDOLPHI, según la cual el bien jurídico se entiende como unidad de función social portadora de valor. ${ }^{24}$ Pero sostiene que

18 M. COBO DEL ROSAL y T.S. VIVES ANTON, Derecho penal.., op. cit., p.317

${ }^{19}$ M. POLAINO NAVARRETE., El bien jurídico..., p.35. Concluye que el concepto de interés constituye en esencia, el exponente de una singular situación subjetivo-objetiva: precisamente, la integrada por la relación jurídica existente entre un hombre y un bien que hace posible a aquél, ya el efectivo señorío (en el puro sentido de disponibilidad jurídica no subsumible en un título más específico) sobre éste, ya la mera expectativa del mismo. (p.36)

${ }^{20}$ F. MUÑOZ CONDE, Teoría general del delito, Tirant lo blanch, Valencia, 2007, (4a Ed.), p.64. Explica el autor que todo tipo penal debe incluir un comportamiento humano capaz de provocar la puesta en peligro o la lesión de un bien jurídico. En ese sentido, bien jurídico es el valor que la ley quiere proteger de las conductas que puedan dañarlo. Este valor es una cualidad positiva que el legislador atribuye a determinados intereses.

${ }^{21}$ M. COBO DEL ROSAL y T.S. VIVES ANTON, Derecho penal..., op. cit., p.318. Aquí estos autores acuden a ROCCO, L'oggeto del reato e della tutela giuridico penale en Opere giuridiche, Vol I, Roma: Società editrice del "Foro italiano", 1933, p.259; F. VELÁSQUEZ VELÁSQUEZ, Derecho penal parte general, Temis, Santa fe de Bogotá, 1995, (2 ${ }^{\mathrm{a}}$ ed.), p.32. Según este autor cuando se habla del "bien jurídico" se hace referencia a determinados valores sociales, que según la opinión del legislador, merecen especial protector.

22 G. D. FERNÁNDEZ, Bien jurídico..., op. cit., p.142.

${ }^{23}$ M. COBO DEL ROSAL y T.S. VIVES ANTON, Derecho penal..., op. cit., p.318.

${ }^{24}$ M. POLAINO NAVARRETE, El bien jurídico..., op. cit., p. 246. La tarea legítima del legislador penal sólo se puede estribar en la protección de determinadas funciones imprescindibles en la concreta estima de las mismas para la vida social, es decir, en la garantía de bienes jurídicos. Con la descripción típica, se hace frente a conductas socialmente lesivas a través de conminaciones penales, en tanto ello es exigido por la tutela debida a las personas individuales y a la sociedad. De este modo, la misión y el 
este valor tiene que venir y estar conforme a la Constitución con la finalidad de que no abarquen las meras contrariedades a la moral. No se puede entender la noción de bien jurídico como situaciones o estados valorados en un sentido puramente estático y ser representada sobre una base invariable, sino que, por le contrario, ha de ser configurada como momentos dinámico-evolutivos que contribuyen a una coherente satisfacción de las necesidades de la convivencia social dentro del respectivo círculo de regulación de los singulares supuestos típicos. ${ }^{25}$ Pero no faltan autores que admiten que el bien jurídico no es "sustancialidades" ni "valores" ni "bienes" casi "cosificados", sino participación en la sociedad $^{26}$. En el mismo sentido se ha pronunciado MIR PUIG para quien no se puede caer en la "espiritualización"27, al considerar el bien jurídico como interés o como valor y la necesidad de distinguir entre dicho concepto de bien jurídico y el de la realidad que constituye su sustento, que supone a la larga la "evaporización" del concepto de bien jurídico, al privarle de la referencia a los concretos objetos existenciales que el Derecho penal desea proteger. Ello no significa que deban identificarse el bien jurídico y su substrato empírico. Por el contrario, un «bien» es siempre algo más que una «cosa». Pero también es esa «cosa», sólo que contemplada en su valor funcional: el bien es una cosa valiosa, entendiendo aquí por cosa toda realidad existencial con independencia de su carácter material o inmaterial. El concepto de bien jurídico es, pues, expresión de una relación dialéctica de realidad y valor ${ }^{28}$. Y concluyen COBO DEL ROSAL y VIVES ANTÓN que definir el bien jurídico como valor no comporta asignarle un contenido determinado. Los bienes jurídicos no constituyen un género de objetos reales o de ideales:

margen de libertad del legislador penal se limitan a reconocer como necesitadas de garantía, total o parcialmente, las unidades funcionales portadoras de valor en este ámbito jurídico, haciéndolas objeto de una protección muy elevada frente a ataques a las mismas.

25 Ibídem, op. cit., pp.248, 249. Añade que es positiva la aportación integrada por el aprecio de las decisiones de valor de la Constitución en cuanto pauta ineludible para justificar las conminaciones penales y delimitar el alcance de las mismas. Ello no supone correlativa comprensión de que cada uno de los bienes jurídicos, cuya tutela provee el Derecho penal, debe encontrar concreto reflejo en respectivas decisiones constitucionales de valor.

26 J. BUSTOS RAMÍREZ, Manual de derecho penal. Parte general, Promociones y Publicaciones Universitarias, Barcelona, 1994, (4⿳亠丷a ed.), p.109. El autor señala a CALLIESS en esta postura.

27 Ibídem, op. cit., pp.104,105, el autor recuerda que la espiritualización del bien jurídico se produce por el hecho de la colocación por v. LISZT del bien jurídico en la «lógica jurídica abstracta» pero sobre todo por la influencia del neokantismo en la doctrina penal alemana, en especial de la Escuela Sudoccidental alemana (y en menor medida de la escuela de Marburgo), que para superar al positivismo y su traspolación mecánica de los conceptos y métodos de las ciencias naturales a las ciencias del espíritu, colocaba como fundamento de estas últimas a la filosofía de los valores.

28 S. MIR PUIG, Derecho penal..., op. cit., p.168, no 40. Añade que un Derecho penal protector de bienes jurídicos no tutela puros valores en sí mismos, sino realidades concretas: ninguna protección jurídico-penal merecería el "valor vida" si no se encarnase en la vida de una persona real; el Derecho penal no ha de proteger el "valor vida" en cuanto tal valor, sino las vidas concretas de los ciudadanos. Pero por supuesto que estas vidas reales no constituyen bienes jurídicos en cuanto meros datos biológicos, sino por su valor funcional para sus titulares y para la sociedad. 


\section{CAPÍTULO II: EL BIEN JURÍDICO PROTEGIDO}

por eso, las diversas tentativas de formular un concepto material de bien jurídico presentan visibles deficiencias. ${ }^{29}$

A pesar de que haya controversia en el intento sobre la caracterización del concepto de bien jurídico y sobre su contenido material ${ }^{30}$, hay un acuerdo mucho mayor en la doctrina española en destacar la importancia de la teoría del bien jurídico a partir de sus funciones ${ }^{31}$.

\section{II-Funciones del bien jurídico}

Estas funciones vienen de la importancia que tiene el concepto de bien jurídico en la teoría del Derecho penal. El negar esta importancia llevaría a situaciones, como en Alemania, durante las cuales, en un momento histórico se ha negado el concepto de bien jurídico para sustituirlo por otro concepto la "lesión del deber", el cual ha mezclado el bien jurídico con la finalidad de la ley y lo ha reducido a una categoría interpretati$\mathrm{va}^{32}$, perdiendo todo su carácter garantista $\mathrm{y}$, consecuentemente, su carácter de fundamento material del injusto. Esas situaciones de "turbulencia” por las que pasó el bien jurídico durante la época del Estado na-

${ }^{29}$ M. COBO DEL ROSAL y T.S. VIVES ANTON, Derecho penal..., op. cit., p.318. Para ellos, los bienes jurídicos no pueden concretarse mediante una definición "per genus proximum et diferentiam specificam"; sino que, más bien, han de identificarse por el papel que desempeñan: son lo que fundamenta "prima facie", el castigo. Parece, pues, más acertado que atribuirles un contenido concreto, delimitarlos atendiendo a la función procedimental que cumplen en el discurso jurídico. El bien jurídico es, desde esa perspectiva, lo que constituye el primer momento justificativo de la injerencia penal en la libertad.

${ }^{30}$ G. D. FERNÁNDEZ, Bien jurídico..., op. cit., p.3.

${ }^{31}$ Ibídem, op. cit., p.7.

32 J. BUSTOS RAMÍREZ, Manual de derecho penal, op. cit., pp.105, 106. El autor repasa la doctrina de la escuela de Marburgo de Derecho penal cuyos representantes son HONIG, SCHWINGE y ZIMMERL. Estos últimos afirman que el bien jurídico es el fin reconocido por el legislador en los preceptos penales individuales en su fórmula más sucinta o bien como una síntesis categorial con la cual el pensamiento jurídico se esfuerza en captar el sentido y el fin de las prescripciones penales particulares. Sostienen también que «la teoría del bien jurídico en su configuración actual ve en la idea del bien jurídico u objeto de protección aquel concepto fundamental del Derecho penal que es expresión para el principio directriz de toda interpretación y constitución de conceptos». Es decir, el bien jurídico es sólo una categoría lógico-formal, su función es sólo interpretativa, con cual pierde toda su autonomía y trascendencia dentro del Derecho penal. En realidad ya se puede cuestionar la utilidad de seguir discutiendo y manteniendo un tal concepto que queda absorbido dentro de la lógica jurídica en general o bien dentro de una teoría general de la interpretación. Para la escuela de Kiel el concepto de bien jurídico es totalmente inútil. Lo fundamental es el pueblo, es una totalidad real (de sangre, suelo, generaciones pasadas, presentes y futuras), por lo cual no se puede separar realidad y valor como hacían liberales positivistas y neokantianos. Por eso el Derecho es el ordenamiento de la vida del pueblo, pero no como una ensambladura de normas exteriores, sino de carácter interno y vital, surge del pueblo mismo, del «espíritu del pueblo». Por eso el «espíritu del Pueblo» es la fuente del Derecho. , De este modo no sólo se niega el bien jurídico, sino que se borra todo su contenido garantista, ya que el concepto que lo viene a sustituir, la «lesión del deber», por el contrario, está traspasado de autoritarismo. En el mismo sentido vid. H. HORMAZÁBAL MALARÉE Bien jurídico..., op. cit., pp.60-62, S. MIR PUIG, Derecho penal..., op. cit., p.168, no 40, M. POLAINO NAVARRETE, El bien jurídico..., op. cit., pp. 164-171. 


\section{PARTE I: APROXIMACIÓN AXIOLÓGICA Y ESTRUCTURAL...}

cionalsocialista, son similares a lo que está sucediendo en la doctrina francesa en la actualidad. ${ }^{33}$

A pesar de las diferencias que presenta la doctrina española al clasificar las funciones del bien jurídico, se pueden repasar las más destacadas.

\section{A-LA FUNCIÓN AXIOLÓGICA}

Sostiene FERNÁNDEZ que el análisis encarado desde la perspectiva del bien jurídico posibilitaría indicar, ante cada ley penal, qué es lo que se protege a través de la pena pública y por qué se lo protege penalmente, lo cual habilita, por supuesto, una amplia revisión sobre la efectiva necesidad e idoneidad de la intervención penal. ${ }^{34}$ Con más detenimiento se pronuncia en este sentido POLAINO NAVARRETE para quien la función axiológica del bien jurídico se halla, íntimamente relacionada con la naturaleza del Derecho penal como ciencia valorativa, a cuya esencia pertenece el proceso de estimación de determinados bien y valores en cuanto necesarios para el próspero desenvolvimiento de la vida humana en sociedad. Añade que el bien jurídico asume una ineludible función de carácter axiológico de singular relevancia en el plano científico del Derecho penal, principalmente con referencia al momento de la ponderación de los singulares objetos estimados por la ley merecedores de tutela, así como en la esfera de determinación del fin de las normas jurídico-penales y de los singulares tipos delictivos, tanto en el ámbito del injusto como en el de las causas excluyentes de la antijuricidad de la conducta típica. ${ }^{35}$

\section{B-FUNCIÓN DE LEGITIMACIÓN MATERIAL DE LA NORMA}

Esta función necesita ser justificada racionalmente en el contexto de un Estado democrático de Derecho. Dicha legitimación se obtendría cuando el ejercicio crítico demuestra el fundamento real de la punibilidad; esto es la auténtica necesidad de intervenir en la tutela de un bien jurídico a través de la conminación penal, sobre la base de la importancia de aquél y de la idoneidad de la protección penal, en ausencia de otras vías alternativas de tutela. ${ }^{36}$

\footnotetext{
${ }^{33}$ E. BACIGALUPO, Teoría y práctica..., op. cit., p.168. Efectivamente la no aceptación del concepto de bien jurídico no permite dogmáticamente construir esas funciones.

${ }^{34}$ G. D. FERNÁNDEZ, Bien jurídico..., op. cit., pp.7, 8.

${ }^{35}$ M. POLAINO NAVARRETE, El bien jurídico..., op. cit., pp.286, 288

36 G. D. FERNÁNDEZ, Bien jurídico..., op. cit., p.8; H. HORMAZÁBAL MALARÉE Bien jurídico..., op. cit., p.8, el autor señala que esta función es de añadir con las funciones tradicionales las cuales son la función de límite al ius puniendi estatal, la función teleológica, la sistemática y la garantizadora. Se entiende de esa manera una cierta evolución de la doctrina española en esta materia. Sin embargo, tal propuesta doctrinal no está al abrigo de la crítica. Precisa BACIGALUPO, que la cuestión fundamental que, hoy en día, plantea la teoría de bienes jurídicos en la teoría jurídico-penal española e italiana se refiere a la pretensión de ser el único criterio material legitimante del Derecho penal de un Estado de Derecho. Señala el autor que inicialmente la teoría del bien jurídico tal como fue presentada por VON LISZT, no atribuía a la noción de bien jurídico un carácter material en el sentido de sociológico puro, sino que en última instancia
} 


\section{CAPÍTULO II: EL BIEN JURÍDICO PROTEGIDO}

\section{C-LIMITACIÓN DEL IUS PUNIENDI DEL ESTADO}

Esta función también ha sido llamada función garantizadora o crítica. Se recuerda en la doctrina que se suele concebir el Derecho penal como un instrumento de control social, al que sólo ha de acudirse en aquellos casos en los que, por la importancia de los bienes en juego o por la especial virulencia con la que determinados bienes son atacados, se hace necesaria la aplicación de la más enérgica de las intervenciones que el Estado puede desplegar. ${ }^{37}$ Recuerda LUZÓN PEÑA que si no se utiliza un concepto puramente positivista del bien jurídico, éste, ya antes de la labor dogmática de interpretación y sistematización del tipo de injusto, desempeña una importantísima función político-criminal de límite y orientación del ius puniendi, exigiendo la supresión de tipos penales que realmente protejan bienes jurídicos y, a la inversa, la creación de nuevos tipos penales cuando haya bienes jurídicos que necesiten protección penal (bienes jurídico-penales) pero carezcan de ella ${ }^{38}$.

Sin embargo, observan COBO DEL ROSAL y VIVES ANTÓN, que el énfasis en torno a la función garantizadora del bien jurídico, no debe ser exagerado. Incluso en el seno del totalitarismo nazi pudo obtenerse un acuerdo doctrinal en torno al "dogma" del bien jurídico. El reconocimiento del bien jurídico como concepto central de la dogmática penal puede realizarse implicando, exclusivamente, la afirmación de que en efecto, se concibe el ordenamiento como un sistema valorativo. Pero las garantías individuales no dependen sólo de que se reconozca que las normas jurídicas cumplen una función valorativa, sino que requieren, además, que las valoraciones contenidas en ellas sean conformes a un régimen de libertades. ${ }^{39}$

identificaba el bien jurídico con el Derecho. En consecuencia, es difícil comprender que en el marco de un pensamiento que identifica lo jurídico con lo formal, se considere que la protección de bienes jurídicos constituye un criterio material de legitimación del Derecho penal. Añade que la teoría de la protección de bienes jurídicos en la variante seguida en España tiene consecuentemente la pretensión de legitimar y de limitar el poder penal del Estado. No obstante, esta tesis no ha afectado tanto a la noción de bien jurídico como a los criterios de selección de los bienes jurídicos protegibles por el Derecho penal. (E. BACIGALUPO, Teoría y práctica..., op. cit., p. 163)

37 I. OLAIZOLA NOGALES, El delito de cohecho, Tirant lo blanch, Valencia, 1999, pp.3941, I. DE LA TORRE y otros, Curso de Derecho Penal, op. cit., p.7, COBO DEL ROSAL y T.S. VIVES ANTON, Derecho penal..., op. cit., p.324.

38 D.-M. LUZÓN PEÑA, Curso de Derecho Penal, op. cit., p 328. H. HORMAZÁBAL MALARÉE Bien jurídico..., op. cit., p. 7.

39 M. COBO DEL ROSAL y T.S. VIVES ANTON, Derecho penal..., op. cit., p.325. Añaden que un sistema de valores modelado sobre pautas transpersonalistas, difícilmente podrá garantizar al individuo los derechos que, como ser humano, le corresponden. La simple admisión del bien jurídico no representa pues, en absoluto, una condición suficiente para la obtención de un adecuado sistema penal, aunque pueda considerarse una condición necesaria. En este sentido se han pronunciado también MUÑOZ CONDE y GARCÍA ARÁN cuando hablan de una "perversión" del concepto de bien jurídico. Explican que la elevación a la categoría de bien jurídico, es decir, de valor respetable y que hay que respetar, de determinadas ventajas e intereses en beneficio de unos pocos y en prejuicio de la mayoría es una forma evidente de mantener el status de reaccionar frente a todo lo que signifique progreso y conservar a toda costa la actual situa- 


\section{PARTE I: APROXIMACIÓN AXIOLÓGICA Y ESTRUCTURAL...}

\section{D-FUNCIÓN INTERPRETATIVA}

Generalmente es una función de carácter teleológico en el sentido de construir un criterio de interpretación de los tipos penales que condicionará su sentido y alcance conforme a la finalidad de protección de un determinado bien jurídico ${ }^{40}$. Según LUZÓN PEÑA dentro de la interpretación teleológica y valorativa, el bien jurídico desempeña un papel importante de orientación sobre el sentido y la finalidad protectora de los tipos y puede excluir de la tipicidad conductas que, aunque aparentemente encajen en el tenor literal del tipo, realmente no lesionen ni pongan en peligro el correspondiente bien jurídico ${ }^{4}$. Explica POLAINO NAVARRETE que el bien jurídico constituye un criterio de relevante significado en la fijación del tenor de la ley y de los límite propios de los singulares tipos delictivos ${ }^{42}$. En este sentido, añade FERNÁNDEZ, que sin mengua de su función limitadora, parece claro que el bien jurídico es un concepto comunicacional entre el Derecho penal y la política criminal. ${ }^{43}$

Sin embargo, precisan COBO DEL ROSAL y VIVES ANTÓN que si en la actualidad es opinión pacífica que, en sentido propio, sólo cabe denominar bien jurídico al objeto formal, inmediatamente protegido por la norma concreta, afirmar que el bien jurídico ha de ser criterio determinante de la interpretación conduce a una suerte de circularidad en el proceso interpretativo: hay que analizar la norma concreta para determinar cuál es el bien jurídico, y una vez determinado éste, iniciar el proceso exegético ${ }^{44}$. Los mismos autores sostienen que mejores razones asisten a quienes, sin negar la insustituible función exegética del bien jurídico, afirman que la interpretación ha de realizarse atendiendo también a otros criterios. En este sentido se ha pronunciado POLAINO NAVARRETE para quien el bien jurídico representa, en suma, un postulado de elevada importancia en la determinación del sentido que el or-

ción. Ante ese fenómeno el penalista tiene que elaborar un concepto material, no simplemente formal, de bien jurídico que, comparado con las concepciones extrajurídicas, le permita una función crítica de los bienes jurídicos protegidos por el legislador (F. MUÑOZ CONDE y M. GARCÍA ARÁN, Derecho penal..., op. cit., p. 60).

${ }^{40}$ H. HORMAZÁBAL MALARÉE Bien jurídico..., op. cit., p. 7.

41 D.-M. LUZÓN PEÑA, Curso de Derecho Penal, op. cit., p 329, S. MIR PUIG, Derecho penal..., op. cit., p.169, no 44. Este autor toma el ejemplo de los delitos de lesiones que atacan al bien jurídico de la salud o integridad física de una persona, en cuanto sirve de base a sus posibilidades de participación social. La intervención quirúrgica curativa realizada con éxito no puede dar lugar al tipo de lesiones, porque no agrede en aquel sentido a la salud ni a la integridad física, sino todo al contrario. Falta, por ello, la antijuridicidad material de la conducta.

42 M. POLAINO NAVARRETE, El bien jurídico..., op. cit., p.312. Según el autor, en la mayoría de los supuestos típicos no puede llegarse a aprehender con exactitud el sentido de la descripción legal sin una precedente estima del objeto de tutela jurídica, cuya importancia en este sentido viene concretada por el hecho de que la protección del mismo integra un momento en esencia constitutivo del fin de ley penal.

${ }^{43}$ G. D. FERNÁNDEZ, Bien jurídico..., op. cit., pp. 8, 9. H. HORMAZÁBAL MALARÉE Bien jurídico..., op. cit., p. 9.

${ }^{44}$ M. COBO DEL ROSAL y T.S. VIVES ANTON, Derecho penal..., op. cit., p.320. De algún modo, notan los autores, al captar el bien jurídico, se interpreta antes de interpretar. Pero esta circularidad es inherente a la tarea hermenéutica. 
denamiento general confiere a los singulares tipos legales de delito, pero en modo alguno puede ser considerado como postulado único de la compresión de éstos ${ }^{45}$. Indican COBO DEL ROSAL y VIVES ANTÓN que particular importancia reviste en tal sentido el recurso a la llamada "ratio legis", esto es, la finalidad objetiva de la norma. "Ratio legis" y bien jurídico no son, pese a lo que a veces se afirma, criterios idénticos ni absolutamente coincidentes, pues no siempre la protección penal otorgada a un determinado bien jurídico constituye la finalidad última perseguida por el ordenamiento al otorgarla. Aun admitiendo pues que la "ratio legis" pueda desempeñar algún papel a la hora de interpretar las leyes penales, éste ha de ser forzosamente, secundario. El punto de partida de la estructura del delito es el tipo de injusto. Y el tipo de injusto, representa la lesión o puesta en peligro del bien jurídicamente protegi$\mathrm{do}^{46}$. Considera M. POLAINO NAVARRETE, al rechazar las teorías que tienen la pretensión de identificar las dos entidades: objeto de tutela y finalidad perseguida la ley, que el fin de la ley que en esencia pertenece a la esfera de la justificación del Derecho penal, mantiene intrínsecas implicaciones con los principios de política criminal, y rebasa el mero círculo de aseguramiento positivo de los bienes y valores que constituyen objeto de protección típica. Recalca que por trascendente y decisiva que la importancia del bien jurídico sea en orden a la aclaración del fin de la ley penal, de ningún modo pueden ser confundidos ambos conceptos, habida cuenta de que el fin de la ley contiene la meta que se trata de alcanzar a través de la norma positiva protegido mediante cada descripción legal de conductas típicas. Y añade que es de constatar la circunstancia de que, si ni siquiera son plenamente asimilables finalidad

${ }^{45}$ M. POLAINO NAVARRETE, El bien jurídico..., op. cit., p.313. A modo de ver del autor, el objeto de protección no debe ser considerado cómo el único principio interpretativo de las normas penales, no tanto porque la garantía de ciertos bienes o valores no representa exclusivo fin de la ley, cuanto porque en la misma se tienen presentes además las exigencias de consideración relativas a los diversos momentos codeterminantes del concepto esencialmente unitario del delito. A la pluralidad de las características constitutivas de éste ha de atender, de forma ineludible, la función exegética aplicada a la norma penal y a los concretos tipos legales del delito en la misma configurados. Reducir el ámbito de la interpretación de la ley penal al contenido material del injusto típico, como supondría toda exégesis realizada sobre la base exclusiva del bien tutelado en la norma penal, significaría conferir una prevalencia en la misión clarificadora del precepto al carácter antijurídico del comportamiento típico, con la que no se lograría constatar el alcance exacto de los tipos legales de delito entendidos en su totalidad.

46 M. COBO DEL ROSAL y T.S. VIVES ANTON, Derecho penal..., op. cit., pp.320, 321. Señala que en ocasiones se protege un determinado bien jurídico en aras de la obtención de ciertos resultados, más o menos remotamente conectados con él. Las razones motivadoras de la incriminación de una conducta como delito no son, necesariamente, coincidentes con el bien jurídico, ni tampoco lo son las variadas causas políticocriminales tenidas en cuenta por el legislador. Pueden, ciertamente, encontrarse tras él y conferirle incluso sus últimas precisiones, pero no deben ser confundidas con el bien jurídico, pues éste perdería su certeza y concreción, es decir, su utilidad. La "ratio legis" puede verse o no cumplimentada o satisfecha desde la previsión legislativa, en tanto que el bien jurídico siempre ha de resultar lesionado, o en su caso, puesto en peligro, por la realización del delito, y esta existencia, por su rigor lógico, aleja toda posibilidad de disminuir la importancia de su función interpretativa en favor de la de la "ratio legis". 
de la norma y protección de bienes jurídicos, es evidente que en modo alguno puede sustentarse con fundamento suficiente un entendimiento del bien jurídico, conforme a un sentido teleológico que le presente simplemente como el fin perseguido por el legislador ${ }^{47}$.

\section{E-FUNCIÓN SISTEMÁTICA}

Sistemáticamente el bien jurídico desempeña una doble función: de una parte, constituye el fundamento de la infracción, desde el momento en que el delito es, ante todo lesión o puesta en peligro de un bien jurídico; de otra parte, representa un criterio adecuado para clasificar las diferentes especies de infracciones, cuyas semejanzas y diferencias se concretan, en primer término, en el objeto de protección. Así, señalan COBO DEL ROSAL y VIVES ANTÓN, el bien jurídico aparece como el fundamento básico de la estructura abstracta de la infracción y, a la vez, como criterio ordenador del conjunto de las infracciones particulares contenidas en la parte especial ${ }^{48}$. La propia legislación penal sistematiza y clasifica los grupos de delitos en atención a los bienes jurídicos afectados ${ }^{49}$. Pero a veces, señala LUZÓN PEÑA esta sistematización legal no es del todo correcta o completa, y puede perfeccionarse por la doctrina acudiendo al criterio del bien jurídico ${ }^{50}$. A pesar de esta imperfección, afirma QUINTANO RIPOLLÉS que "las diversas y poco afortunadas tentativas de clasificación de delitos y estructura de la Parte especial fuera del cauce objetivo del bien jurídico, apenas si merecen otra mención que la de carácter informativo." 51

\footnotetext{
47 M. POLAINO NAVARRETE, Derecho Penal, Parte General, Tomo I: Fundamentos científicos del Derecho Penal, BOSCH, Barcelona, 1996, pp.316-318. Concluye el autor que el concepto de bien jurídico no admite ser configurado, en la dogmática penal, como el fin de los tipos delictivos en su más breve promulgación. Por el contrario, deben mantenerse separados, de un lado, el momento teleológico del legislador, reconocido en los singulares preceptos con referencia al aseguramiento de determinados bienes jurídicos, y de otro, el propio objeto jurídico al que se provee la oportuna tutela penal.

${ }^{48}$ COBO DEL ROSAL y T.S. VIVES ANTON, Derecho penal..., op. cit., p. 321.

${ }^{49}$ S. MIR PUIG, Derecho penal..., op. cit., p.169, no 43, H. HORMAZÁBAL MALARÉE Bien jurídico..., op. cit., p. 7, G. D. FERNÁNDEZ, Bien jurídico..., pp. 9, 10 Señala este autor en particular que esta función sistemática del bien jurídico consiste en servir de elemento de aglutinación, clasificación y jerarquización de los distintos tipos delictivos, diseñando la arquitectura y el ordenamiento temático de la Parte Especial del derecho penal. Se la utiliza, en efecto, para clasificar grupos de figuras delictivas conforme a la homogeneidad del bien jurídico tutelado de acuerdo a un criterio universal, utilizado en todos los códigos. En este como ya veremos en Francia la clasificación de los delitos de la parte especial del Derecho penal sigue la sistematización conforme al objeto de tutela, aun cuando no hay una aceptación del concepto de bien jurídico.

${ }^{50}$ D.-M. LUZÓN PEÑA, Curso de Derecho Penal, op. cit., pp.328, 329. El autor toma un ejemplo destacando que en los incendios el aspecto más importante del bien jurídico afectado no es la propiedad, sino el riesgo para la seguridad colectiva, y proponiendo por ello que los delitos de incendios no se regulen en el título de delitos patrimoniales, sino junto con otros delitos de peligro para la seguridad colectiva.

${ }^{51}$ A. QUINTANO RIPOLLÉS, Tratado de la Parte Especial del Derecho Penal, Tomo I, Editorial Revista de Derecho Privado, Madrid, 1972, (2ª ed.), p.16. Unas páginas más adelante el autor señalan las propuestas excéntricas de las pretensiones sistemáticas exclusivamente asentadas sobre los medios comisitos, cuyos postulados se han califi-
} 
No obstante, precisan COBO DEL ROSAL y VIVES ANTÓN, se ha objetado la aptitud del bien jurídico para desempeñar la función sistemática, pues este concepto resulta insuficiente para explicar todas las características de las infracciones e innecesario para fundamentar muchos delitos contenidos en las legislaciones positivas. Contestando a estas objeciones, los mismos autores defienden que la primera ni siquiera es tal, pues en ningún momento se pretendió extraer del bien jurídico una explicación de la totalidad de los momentos de la infracción. ${ }^{52}$ La segunda en cuanto se refiere a los delitos que consisten en la infracción del deber la interpretación exacta del párrafo inicial del numero 5o del artículo 20 del Código Penal lleva a entender la referencia a la infracción de un deber no como la violación de un deber de obligación, sino como la puesta en peligro de un bien jurídico. Quedan las infracciones que deben proteger directamente la paz social sin pasar por la protección de bienes. Pero, antes de proclamar, en base a ellas, la insuficiencia del concepto de bien jurídico, sería preciso admitir su legitimidad constitucional, que es más que dudosa ${ }^{53}$.

\section{F-FUNCIÓN DE MEDICIÓN DE LA PENA}

Según LUZÓN PEÑA, una vez establecido que se cumplen los requisitos de un tipo de injusto, para la determinación de la pena, aunque no concurran atenuantes ni agravantes, el artículo 61,4. ${ }^{\text {a }}$ del Código Penal español (CPE) de 1944 o 66,6. $\mathrm{\text {CPE}} 1995$ prevé como uno de los criterios que deben tenerse en cuenta el de «la mayor o menor gravedad del hecho»; ésta vendrá determinada por la gravedad del injusto y por el grado de culpabilidad, y, dentro de lo primero, el grado de injusto o de antijuridicidad material dependerá en buena medida de la intensidad y gravedad de la lesión o puesta en peligro del bien jurídico, o de si adicionalmente se ve afectado algún otro bien jurídico ${ }^{54}$. Dicho de otra manera, y esta vez con las palabras de MIR PUIG, la mayor o menor gravedad de la lesión del bien jurídico, o la mayor o menor peligrosidad de su ataque, influyen decisivamente en la gravedad del hecho. Dentro del margen de arbitrio judicial que la ley concede, ello puede servir de base a la concreta determinación de la pena (especialmente cuando no concurran circunstancias agravantes ni atenuantes o ambas a la vez, su-

cado como confusos, arbitrarios, y contrarios al común pensar y sentir de la doctrina (p.24 y ss.).

52 Se ha pronunciado más claramente en este sentido M. POLAINO NAVARRETE, El bien jurídico..., op. cit., p. 302. Destaca que se alude a la necesidad de reconocimiento de la circunstancia de que el bien jurídico no debe ser estimado, en sentido unilateral y excluyente, como el único criterio válido fundamentador de la sistemática del Derecho penal en el círculo de consideración de los singulares tipos del delito. Por el contrario, preciso es reconocer esporádicamente junto al mismo, con análoga relevancia metódica, determinados elementos particulares, como la naturales de las relaciones entre el autor y el delito, la posición social del culpable, la índole del deber jurídico infringido, la forma de ataque del objeto protegido, la gravedad de la infracción, la naturaleza del comportamiento legalmente descrito o la estructura peculiar de los singulares tipos penales, entre otros.

${ }^{53}$ M. COBO DEL ROSAL y T.S. VIVES ANTON, Derecho penal..., pp.323, 324.

${ }^{54}$ D.-M. LUZÓN PEÑA, Curso de Derecho Penal, p. 329. 
puesto en el que el artículo 66, 6⿳亠 CPE permite al Juez o Tribunal imponer la pena «en atención a las circunstancias personales del delincuente y a la mayor o menor gravedad del hecho»). En cambio, nótese que si la antijuridicidad fuese sólo formal no podría graduarse, pues sólo podría afirmarse su presencia o ausencia (la relación de contradicción entre hecho y Derecho únicamente se da o no se da) ${ }^{55}$.

La presentación de estas funciones del bien jurídico manifiesta el interés y la importancia que la doctrina española concede a este concepto. Y si hay acuerdo en destacarlas, la determinación del contenido del bien jurídico no alcanza un mayor consenso entre los autores. Se trata entonces de repasar las grandes posiciones existentes en este sentido. Este repaso es interesante en la medida en que el cumplimento de las finalidades atribuidas al bien jurídico, especialmente la referida finalidad de garantía o limitación al ius puniendi del Estado ${ }^{56}$, exige una adecuada determinación del contenido del concepto de bien jurídico. Ésta habrá de impedir que el mismo sirva de mera pantalla para la protección penal de todo tipo de intereses, estrategias o convicciones morales cuya

${ }^{55}$ S. MIR PUIG, Derecho penal..., op. cit., pp.169, 170, no45, Con más detalle explica M. POLAINO NAVARRETE, El bien jurídico..., op. cit., p. 377. En la afirmación de la característica de la punibilidad de los comportamientos incluidos en el ámbito de descripción de los tipos legales, han de tenerse presente, no sólo la naturaleza y la índole del bien jurídico en ellos protegido, sino también la intensidad, la forma y la eficacia de la incidencia negativa sobre el mismo por el actuar típico. Otras circunstancias, no vinculadas con carácter inmanente al bien jurídico, sino portadoras de una naturaleza puramente fáctico-objetiva o subjetivo-personal, influyen también en el sí y en el cuánto de la determinación del contenido de la punibilidad. Las formas principales que en sentido técnico asumen relevancia en la determinación de la punibilidad de la conducta, en base a la negativa del bien jurídico, están constituidas por la lesión y puesta en peligro de éste. En suma, debe reputarse válida la genérica consideración de que del lugar que ocupe el bien jurídico respectivo en el ordenamiento social depende la extensión de la garantía penal, y la intensidad de la sanción jurídica con la que se conmina la correspondiente gravedad del delito.

56 También destaca BUSTOS RAMÍREZ que el principio de la necesidad de la intervención corre el peligro de ser demasiado abstracto y vago, requiere pues de una base concreta de sustentación, que señale cuáles son los hitos y límites fundamentales del sistema. De ahí que no baste con el principio de necesidad de la pena, sino que resulta indispensable señalar qué es lo protegido, problema que la teoría penal ha intentado solucionar mediante el desarrollo de la teoría del bien jurídico. Es decir, la intervención del Estado sólo es posible y necesaria cuando se trata de la protección de bienes jurídicos. Luego este principio también entra a limitar materialmente el poder punitivo del Estado. Página más adelante el autor explica que el bien jurídico aparece como un principio garantizador de carácter cognoscitivo; la sociedad toda y cada sujeto en particular por su intermedio sabe claramente qué es lo que se está protegiendo y además tiene la posibilidad de examinar las bases sobre las cuales se asienta esa protección y puede entonces hacer una revisión del porqué de la protección. En esa medida el bien jurídico permite un sistema crítico y participativo extensivo a las bases mismas de sociedad, a lo cual no puede estar ajeno el jurista. A nuestro parecer, investigar lo que se pretende proteger y las bases de esta protección era la preocupación de la doctrina desde el conocimiento del concepto de bien jurídico, por lo tanto merece ser señaladas aunque sea brevemente las posturas doctrinales al respecto. (J. BUSTOS RAMÍREZ, Manual de derecho penal, op. cit., p.99) 
lesión, sin embargo, carecería de una auténtica repercusión negativa en la realización de los individuos como seres sociales ${ }^{57}$.

\section{III-Delimitación del concepto de bien jurídico}

La evolución de la teoría del bien jurídico denota las fases por las que pasaba dicha teoría ${ }^{58}$. No se trata aquí de detallarla desde su origen, sino de destacar la recepción que ha tenido esta teoría en la doctrina penal española en la época moderna. La época antes de la guerra estuvo marcada por el intento de superar el positivismo naturalista y el positivismo jurídico en la teoría del delito. Sólo superada la inmediata posguerra resurge renovada la política criminal que plantea límites al ius puniendi con principios programáticos tales como la necesidad y utilidad de la pena, la dignidad de la persona y la exclusiva protección de bien jurídicos. Desde ahí se ha concebido la idea generalizada de basar la teoría penal con un trasfondo de teoría social ${ }^{59}$, con lo cual estamos ante dos grandes teorías del bien jurídico: las teorías de bien jurídico con fundamento sociológico y las que dan fundamento constitucional ${ }^{60}$.

\section{A-LAS TEORÍAS CONSTITUCIONALES DEL BIEN JURÍDICO EN LA DOCTRINA PENAL ESPAÑOLA}

En paralelo con la evolución del concepto de bien jurídico en Alemania o en Italia, en España el nuevo modelo democrático queda centrado en la fórmula del "Estado social y democrático de Derecho"; una cláusula de hondas repercusiones para la teoría del Derecho penal, que se incorpora años después -tras la caída del régimen franquista y su modelo de Estado autoritario- también a la Constitución española de 1978. Añade FERNÁNDEZ que la inflexión de la dogmática penal hacia una orientación jurídico-constitucional abarca por supuesto la teoría del bien jurí-

${ }^{57}$ I. OLAIZOLA NOGALES, El delito de cohecho, op. cit., p. 43, G. D. FERNÁNDEZ, Bien jurídico..., op. cit., pp.5, 6. Habla de "parábola involutiva" aludiendo al proceso de "perversión" del bien jurídico.

${ }^{58}$ Es de reconocer que es una teoría de origen alemana con lo cual la historia de este concepto no puede separarse de autores desde FEUERBACH, BIRNBAUM pasando por BINDING y VON LISZT. Para más detalle sobre la evolución del bien jurídico, vid, H. HORMAZÁBAL MALARÉE Bien jurídico..., pp.11-114, G. D. FERNÁNDEZ, Bien jurídico..., pp.11-144, J. BUSTOS RAMÍREZ, Manual de derecho penal, op. cit., pp.100-110. , I. BERDUGO DE LA TORRE y otros, Curso de Derecho Penal, op. cit., pp.8, 9

${ }^{59}$ H. HORMAZÁBAL MALARÉE Bien jurídico..., op. cit., pp.81. Explica el autor que en esta condiciones de renovación de la política criminal , bajo la idea ya generalizada y aceptada de que hoy una teoría penal no puede concebirse sin el trasfondo de una teoría social, así como ayer tampoco podía concebirse sin la filosofía se han ido desarrollando en particular las teorías del bien jurídico. Estas teorías de carácter social con aquellas que buscan en la Ley Fundamental la base de sustentación del referente material del delito, conforman las dos grandes categorías bajo las cuales pueden englobarse la mayoría de las teorías del bien jurídico en el Estado Social y Democrático de Derecho.

${ }^{60}$ Efectivamente lo que se pretende aquí es repasar estas teorías dentro de la doctrina penal española, sin intención de estudiar estas teorías con detalles, y con sus respectivas críticas. 
dico, la cual también se adecua al nuevo paradigma ${ }^{61}$. El bien jurídico pasa a orbitar, por lo tanto, en el ámbito de la ley fundamental. Procurando fijar una noción más clara del bien jurídico, el cual a veces parece inaprensible, los juristas penales buscan respaldarse en la Constitución; postura que da nacimiento a las teorías constitucionales del bien jurídico. La reacción es plausible; demuestra que una adecuada interpretación de ius poenale sólo logra consumarse, basándose en el programa penal de la Constitución ${ }^{62}$.

Entre estas tendencias, resume BUSTOS RAMÍREZ, se pone de relieve que hay dos órdenes de valores dentro del ordenamiento jurídico, uno estaría fijado en la Constitución y el otro en la legislación penal. El orden de valores de lo penal sólo coincidiría en lo nuclear (vida, libertad, patrimonio) con los valores constitucionales, pero habría otros que no estarían estructurados como tales en la Constitución. Es decir, en la Constitución al consagrarse el Estado de Derecho, se ha puesto de relieve también la finalidad protectora del Estado y por tanto la obligatoriedad de su vinculación a la protección de determinados bienes valiosos para la vida en común ${ }^{63}$. ESCRIVÁ GREGORY en su oportunidad hizo presente la necesidad de hacer un replanteamiento del Derecho penal español como consecuencia de la promulgación de la Constitución de 1978, señalando que el nuevo contexto jurídico-político "ha de suponer una nueva política penal respecto a la valoración de los bienes jurídicos, gradación entre los mismos, determinación de cuales no exigen o no merecen protección penal, de cuáles otros sí la requieren, etc."64. Según el mismo autor, si bien es cierto que la Constitución no explicita una pro-

${ }^{61}$ J.C. CARBONELL MATEU, Derecho penal... op. cit., pp.31, 35, 36. Afirma el autor que la función del Derecho penal es proteger valores e intereses con relevancia constitucional. La intervención del poder punitivo se realiza para evitar comportamientos que vengan a negar tales valores. Cuando alude a la relevancia constitucional de los bienes jurídicos, precisa que por relevancia constitucional no ha de entenderse que el bien haya de estar concreta y explícitamente proclamado por la Norma fundamental. Eso sí habría de suponer una negación de las competencias propias del legislador ordinario. La interpretación que se realice de la norma fundamental no ha de ser estática, sino dinámica; esto es, adecuada a los cambios sociales y de cualquier otra índole que se vayan produciendo. De esta manera, puede decirse que el derecho penal desarrolla, tutelándolos, los valores proclamados en la Constitución y los que de ella emanan; puede decirse, en fin que cada precepto penal debe haber un valor con relevancia constitucional. Termina su explicación sosteniendo que lo único que el legislador democrático no puede hacer es inventarse nuevos valores que en absoluto emanen del sistema constitucional, y limitar o incluso negar, con el fin de protegerlos, los que sí emanan del sistema.

62 G. D. FERNÁNDEZ, Bien jurídico..., op. cit., pp.46 y ss.

${ }^{63} \mathrm{~J}$. BUSTOS RAMÍREZ, Manual de derecho penal, op. cit., p.108. Estas posiciones en mayor o menor medida tienden a confundir los derechos fundamentales constitucionales con los bienes jurídicos. Para ver más detalles. H. HORMAZÁBAL MALARÉE Bien jurídico..., op. cit., pp.106-114, G. D. FERNÁNDEZ, Bien jurídico..., op. cit., pp.45-53.

${ }_{64}$ J. M. ESCRIVÁ GREGORY, Papers, 13, Barcelona, 1980, p 157. Esta postura viene de autores italianos y entre uno de ellos, considerado más lúcido, es BRICOLA para el cual "el ilícito penal puede concretarse exclusivamente en una lesión significativa de un valor constitucional relevante" y hay que entender como relevancia constitucional de un bien "la asunción del mismo entre los valores explícita o implícitamente garantizados por la Carta Constitucional." in Novissimo Digesto italiano XIX, 1973, pp. 15 y ss. 
tección penal de los bienes que enumera a partir del artículo 15, ni tampoco ninguna otra protección en el ordenamiento jurídico, está claro que estos están jerarquizados dentro de la propia Constitución e implícitamente su propio rango estaría indicando las pautas de su nivel de protección. Ahora bien añade, "de lo dicho anteriormente cabría derivar un reconocimiento implícito o explícito por parte de la Constitución de la protección de bienes jurídicos por el Derecho penal", lo que sin prejuicio de su importancia político criminal, acarrea notorias consecuencias en el campo de la dogmática penal, ya que habría una base constitucional para reafirmar el peso del llamado desvalor de resultado (es decir, el desvalor de afectación del bien jurídico) ${ }^{65}$. Sintetiza FERNÁNDEZ que esta dirección dogmática, por tanto, procura establecer un mayor nivel de garantía. Porque, aun cuando se admite un concepto valorativocultural del bien jurídico, o se le adjudique una materialidad de naturaleza social funcional, lo cierto es que cualquier ambigüedad significará, fuera de dudas, un debilitamiento de las garantías contra el ius puniendi, en la medida en que la protección de bienes jurídicos importa, a decir verdad, una teoría sobre el proceso de criminalización. Dicho de otro modo: nadie niega en el fondo la caracterización del bien jurídico como una entidad o unidad funcional de valor social; pero malogrado esa valoración (v. gr.: el bien jurídico debe responder a las necesidades esenciales de convivencia en sociedad), se trata de encuadrar los bienes jurídicos, de todas maneras, como entes "portadores de valor, conforme a la Constitución"66. Explica OLAIZOLA NOGALES que los autores que defienden tesis constitucionalistas establecen como bienes jurídicos defendibles: a) los directamente reconocidos a los ciudadanos en la Constitución; b) los recogidos en convenciones internacionales incorporadas al Derecho vigente; c) los tutelados en sí mismo sin referencias personales (salud pública, patrimonio artístico, etc.); los constitucionalmente "integrables", es decir, los relacionados con un bien constitucional de manera tal que su lesión supone poner en peligro necesariamente estos. Esta categoría debe ser utilizada de manera restrictiva, porque sólo excepcionalmente puede dispensarse tutela penal a un bien jurídico que no esté expresa o implícitamente reconocido por la Constitución. Frente

65 J. M. ESCRIVÁ GREGORY, Papers, op. cit., p 158.

66 G. D. FERNÁNDEZ, Bien jurídico..., op. cit., p.54. Al respecto señala POLAINO NAVARRETE que la misión y el margen de libertad del legislador penal se limitan a reconocer como necesidades de garantía, total o parcialmente, las "unidades funcionales portadoras del valor conforme a Constitución", en un ámbito jurídico en que se las hace objeto de la más elevada protección frente a graves ataques injustos a las mismas (M. POLAINO NAVARRETE, Derecho Penal..., op. cit., p.161). ÁLVAREZ GARCÍA nota que el Estado de derecho ha de someterse al principio de exclusiva protección de bienes jurídicos. Ello, en el ámbito legislativo de materialización de este principio, es tanto como aceptar que el quid de la cuestión reside en la forma de Estado: en la imposición a éste de esa forma un a priori (social, histórico) que permite hablar de un límite (externo) en sentido propio a la actuación estatal. Pero, a la vez, se trata de un límite interno, en el sentido de un límite jurídico, porque la Constitución se integra en el ordenamiento como norma superior y por ello es capaz de establecer no solamente cómo se tiene que legislar y qué límites tiene la obra legislativa, sino también quién es el legislador (F. J. ÁLVAREZ GARCÍA, Bien jurídico y Constitución, Cuadernos de Política Criminal (CPC), no 43, 1991, pp. 5 y ss. sobre todo p.19). 
a la simple "no incompatibilidad" de estos bienes con la Constitución, estos autores propugnan la "integrabilidad" en la misma del bien jurídico que se pretende tutelar ${ }^{67}$. Resaltando la pertinencia de las tesis constitucionalistas, afirma ÁLVAREZ GARCÍA que es lo cierto que semejante teorización, y por ir referida a la Ley fundamental, resulta la más idónea para adquirir un significado de contraposición respecto a procesos de tipo neocorporativo y a una selección autoritaria de las necesidades y de los bienes merecedores de tutela en los cuales se manifiestan las características peculiares del Estado tardo-capitalistas; de esta forma la Constitución pasa a ejercer un papel de intermediación entre los conflictos culturales y el legislador ordinario, proporcionando así una base coherente y relacionada de objetos a proteger por el Derecho penal 68 . Por su parte, GONZÁLEZ RUS después de analizar las diferentes ponencias que tuvieron lugar en un Seminario que se llevó a cabo en Siracusa entre el 15 y 18 de octubre de 1981 donde predominaron las ponencias que planteaban una tesis constitucionalista del bien jurídico, señala la necesidad de armonizar las teorías constitucionales estrictas con las que plantean que la Constitución ofrece un sistema abierto de valores ya que "un empeño de este tipo que en principio, aunque dificultoso, ofrece posibilidades de un resultado fructífero"69.

${ }^{67}$ I. OLAIZOLA NOGALES, El delito de cohecho, op. cit., p. 46; J. M. ESCRIVÁ GREGORY, Papers, op. cit., p 157 y ss., este autor describe que unos criterios a tener en cuenta pueden derivarse de la enumeración de bienes que se hace a partir del artículo 15 de la Constitución: vida e integridad física y moral, libertad ideológica y religiosa, libertad y seguridad personales, honor, etc. Aunque no se explicita la protección penal de los mismos ni se indique otro nivel de protección en el Ordenamiento jurídico, del rango que se otorga a los mismos podría deducirse un interés primordial en la protección de tales bienes. Por otra parte, y precisamente por este rango, no es necesario que se formule expresamente que bienes como la vida y la integridad, por ejemplo, requieren protección incluso a nivel penal; F. J. ÁLVAREZ GARCÍA, Bien jurídico..., op. cit., pp. 20 y ss., reinvidica, junto con otros, la necesaria referencia a la Constitución para delimitar los bienes jurídicos susceptibles de protección penal; J. J. GONZÁLEZ RUS, Bien jurídico y Constitución, Fundación Juan March, Madrid 1983, pp. 40, 41. Declara que la relación del bien protegido con la Constitución no puede entenderse simplemente en términos de "no incompatibilidad" si se tiene en cuenta que en nuestra norma básica siempre que se limita un derecho o libertad se hace en función del simultáneo respeto de otro valor también constitucional. Y, siendo así, resultaría extraño que para aspectos menos transcendentes que la libertad personal la Constitución no admita más límites que los que se derivan de otro bien constitucionalmente reconocido, y que para ella considerara suficiente la simple "no incompatibilidad" del bien jurídico para cuya protección se priva al ciudadano de la misma. La importancia primaria de la libertad personal, la diferenciación entre los límites básicos de carácter general y los límites referidos a bienes concretos constitucionalmente contemplados y la necesidad de reducir la aplicación de la pena privativa de libertad, son elementos que pueden y deben servir para orientar la cuestión en el caso español. En cuanto al primer tema, porque esa prevalencia debe hacer que seamos especialmente rigurosos respecto de ella en el respeto a la Constitución, de manera que la privación de la libertad personal no puede producirse como no sea para tutelar un bien jurídico expresa o implícitamente contemplado en el texto constitucional.

${ }^{68}$ F. J. ÁLVAREZ GARCÍA, Bien jurídico..., op. cit., pp. 42, 43.

${ }^{69} \mathrm{~J}$. J. GONZÁLEZ RUS, Seminario sobre bien jurídico y reforma de la parte especial, Crónicas extranjeras, Anuario de Derecho Penal, no 35, 1982, p. 717. 
En cuanto a las críticas de esta postura, señala FERNÁNDEZ que es verdad que la estricta categorización constitucional de la teoría del bien jurídico no es la llave maestra que permite clarificar, de una vez para siempre todos los problemas ${ }^{70}$. Como reflexiona GARCÍA-PABLOS, si bien la Constitución constituye un punto de referencia obligado aunque no el único- para la selección y jerarquización de los valores que el Derecho penal está llamado a proteger, no es correcto confundir los derechos fundamentales, reconocidos por la Constitución, con los bienes jurídicos: porque, mientras aquellos encuentran su tutela en la Constitución, sólo algunos de ellos - y exclusivamente respecto a cierta clase de ataques - se convierten en bienes jurídicos y alcanzan protección penal71. Para OCTAVIO DE TOLEDO, en la Constitución se encuentran las limitaciones negativas a la hora de determinar el concepto de bien jurídico y que éste sirve de protección al ius puniendi del Estado, lo cual se refleja en la labor legislativa al no poder amparar con sus normas intereses incompatibles con los acogidos por la Constitución, ésta no puede servir de límite positivo por lo que ella tiene de marco insuperable y por lo tanto muy amplio, por lo que chocaría con los principios de subsidiariedad y fragmentariedad. Y además, no es esperable de ella el don de la adivinación perfecta y completa ni la omnisciencia para poder prever todas las relaciones sociales a las que puede dar lugar el desarrollo de la sociedad. Lo que rechaza cualquier pretensión de ver en ella un catálogo de bienes jurídicos a tutelar (obligatoriamente y con exclusión de otros) por la ley punitiva ${ }^{72}$. Según BUSTOS RAMÍREZ, en la Constitución y en el derecho constitucional los derechos fundamentales cumplen una función muy específica, que es regular las relaciones entre la sociedad política y la sociedad civil, y por tanto constituir un límite a la intervención del Estado respecto de los ciudadanos. En cambio, los bienes jurídicos tienen una función mucho más amplia y compleja, pues implican relaciones sociales concretas de los individuos respecto de todos posibles sujetos u objetos que pueden entrar dentro de esa relación en ese sentido también el Estado, pero no sólo éste. Luego evidentemente no son lo mismo ni tienen la misma función los bienes jurídicos y los derechos fundamentales y libertades consagradas en la Constitución; la tendencia a una identificación total conduce nuevamente a una

${ }^{70}$ G. D. FERNÁNDEZ, Bien jurídico..., op. cit., p.55

${ }^{71}$ A. GARCÍA-PABLOS DE MOLINA, Introducción al Derecho Penal, Editorial universitaria Ramón Areces, Madrid, 2005, p.571.

72 E. OCTAVIO DE TOLEDO Y UBIETO, Función y límites del principio de exclusiva protección de bienes jurídicos, Anuario de Derecho Penal y Ciencias Penales, no 43, 1990, pp. 10 y ss. Nota el autor que aunque no quepa ignorar que, como lugar de proclamación e imposición supremas de las grandes reglas por las que ha de regirse el resto del sistema normativo, la Constitución juega también un importante papel respecto de esa función: el de dar expresión a los logros máximos que, en el momento histórico correspondiente, se han alcanzado en la conformación del Estado y en la estructuración jurídica de la sociedad civil. Pero la cuestión atinente a la imposición de un contenido positivo, identificable como bien jurídico, al ejercicio del poder punitivo estatal, me parece que supera el marco constitucional. Y el discurso para su solución no cree el autor que deba seguir ópticas meramente hermenéuticas y "panaceísticas" de la Constitución. En definitiva, a su juicio dicha cuestión nuevamente ha de ponerse en clave histórica y materialista. 


\section{PARTE I: APROXIMACIÓN AXIOLÓGICA Y ESTRUCTURAL...}

formalización de los bienes jurídicos, aunque ya no a nivel penal, sino Constitucional73.

Defiende SILVA SÁNCHEZ que la exigencia de una consagración constitucional directa o indirecta de los bienes penalmente protegibles está plenamente justificada, en la medida en que pone de manifiesto que una intervención tan intensa sobre el individuo como la penal sólo puede justificarse en caso de afectación de un elemento esencial de la vida común, al que ha alcanzado el consenso plasmado en la Constitución. Desde este punto de vista, opina el autor, que la idea de plasmación constitucional debe, pues, ser acogida por añadir un nuevo elemento limitador a las ideas de afectación al individuo y dañosidad social. Sin embargo el ámbito de las realidades consagradas explícita o implícitamente por la Constitución resulta describir un marco flexible y ambiguo, demasiado amplio todavía para los efectos de concretar el concepto de bien jurídico. Así, si bien es cierto que realidades que no hayan sido consagradas expresa o implícitamente en la Constitución deben quedar por principio cerradas a la protección penal, también lo es que no todas aquellas realidades contempladas en la misma adquieren, en virtud de ello, la cualidad de penalmente protegibles. Sentada la consagración constitucional, es preciso, pues, proseguir en la labor de concreción de las características de los objetos penalmente protegibles, para lo cual será preciso tener en cuenta los principios político-criminales que han de inspirar de modo general el ejercicio del ius puniendi del Estado ${ }^{74}$.

A modo de transición, cabe citar la conclusión y postura conciliadora de MORALES PRATS quien afirma que el bien jurídico debe ser analizado como un concepto de raíz sociológica o social, ubicado en el sistema social y confrontado dinámicamente con el mismo; pero, a su vez, la teoría del bien jurídico no debe obviar la escala de valores que ha sido recogida en la Constitución, porque la norma fundamental constituye una premisa político-criminal de gran trascendencia para la modelación del sistema penal ${ }^{75}$.

\section{B- LAS TEORÍAS DEL BIEN JURÍDICO CON FUNDAMENTO SO- CIOLÓGICO EN LA DOCTRINA PENAL ESPAÑOLA}

Analizando la mayoría de la corriente doctrinal, señala BUSTOS RAMIREZ la orientación propuesta por JÄGER para quien protección de bie-

\footnotetext{
73 J. BUSTOS RAMÍREZ, Manual de derecho penal, op. cit., p.108. Añade que en todo caso estas posiciones, cuando no pretenden caer en una posición formalista, no señalan qué es el bien jurídico, sino solamente establecen las consecuentes y necesarias relaciones entre los bienes jurídicos y los valores consagrados en la Constitución, que evidentemente en un Estado de derecho democrático resulta un recurso ineludible y especialmente significativo por el carácter y naturaleza de la Carta Constitucional (p.109).

${ }^{74}$ J. M. SILVA SÁNCHEZ, Aproximación al derecho penal contemporáneo, BOSCH, Barcelona, 1992, pp. 274 y ss.

75 F. MORALES PRATS, en G. QUINTERO OLIVARES, Manual de Derecho Penal, Parte General, Arazandi, 2002, (3를. ed.), p. 288.
} 
nes y configuración de bienes son opuestos inconciliables, pues la protección sólo es concebible racionalmente cuando antes del acto legislativo ya existía un bien vital o cultural. La teoría del bien jurídico se basa por tanto en la premisa que bien jurídico sólo puede ser lo que ya antes era bien (valor social). Este tipo de planteamiento ha tenido una gran proyección y profundización en varios autores españoles ${ }^{76}$.

Así para MIR PUIG su punto de partida es el concepto de "nocividad social" del delito que se enfrenta con la legitimación de la pena y de la medida de seguridad "cuando son necesarios para la protección de la sociedad"77. A la hora de concretar el contenido de tal protección, la función social del Derecho, como la condición de la vida social de los individuos, lleva a referirla no a valores morales, no susceptibles de imposición coactiva, sino a la subsistencia de los sistemas sociales. En este punto el autor adopta las categorías de acciones funcionales o disfuncionales al modelo social y encuentra una base de sustentación racional para excluir de la sanción penal las conductas éticas o moralmente reprochables, ya que ellas no tendrían "efectivas consecuencias para el funcionamiento de los sistemas sociales" y para fijar un límite al ius puniendi estatal ${ }^{78}$. Este mismo autor puntualiza que el bien jurídico expresa una relación dialéctica entre la realidad y valor, la cual interesa por su dimensión social al Derecho ${ }^{79}$. A partir de aquí MIR PUIG destaca la necesidad del bien jurídico que sería el portador de la función social del Derecho penal y con ello la consideración del individuo y su libertad que median, como sujetos y objetos concretamente protegidos, en la protección de la estructura social ${ }^{80}$. En cierta ocasión recalcó el autor que es ciertamente conveniente postular que el bien jurídico no sólo importe al sistema social, sino que se traduzca además en concretas

\footnotetext{
${ }^{76}$ J. BUSTOS RAMÍREZ, Manual de derecho penal, op.cit., p.109.

${ }_{77}$ S. MIR PUIG, Introducción a las bases del derecho penal, concepto y método, BOSCH, Barcelona, 1976, p.135. En efecto el autor al compartir el planteamiento de AMELUNG, sostiene que lo que legitima la intervención coactiva que supone el Derecho no es la realización por la fuerza de cometidos religiosos ni morales sobre la tierra, sino la creación y mantenimiento de un determinado sistema social en beneficio de los individuos que lo integran. Ello significa que la pena y las medidas de seguridad sólo se justifican cuando son necesarias para la protección de la Sociedad.

${ }^{78}$ Ibídem, op. cit., p. 137. Resume el autor que lo decisivo no es la valoración moral, sino las efectivas consecuencias para el funcionamiento de los sistemas sociales.

${ }^{79}$ S. MIR PUIG, Derecho penal..., op. cit., pp.168, 169 no 40 y 41. Señala el autor que le interesa al Derecho esta dimensión social del bien jurídico: la medida en la que la indemnidad de aquellos objetos reales constituye una necesidad social y condiciona las "posibilidades de participación" del individuo en los sistemas sociales.

${ }^{80}$ S. MIR PUIG, Introducción..., op. cit., pp.137, 138. El autor sigue a CALLIESS, y con él defiende que si el Derecho penal protege la estructura social, entendida como red de distribución de posibilidades de participación recíprocas en los sistemas sociales, los bienes jurídicos no pertenecerán a la categoría de los "sustánciales", ni son "valores" quasicosificados, ni "bienes", sino aquella estructura social, en general, y las posibilidades de participación que supone en particular. El Derecho penal protege la seguridad de expectativas de participación, la confianza en el funcionamiento del sistema.
} 
posibilidades para el individuo ${ }^{81}$. Los bienes jurídicos no son valores ni materiales ni espirituales, sino "posibilidades de participación" en los sistemas sociales, y lo que la ley penal protege es la concreta posibilidad de que un individuo puede participar o no en una relación social. Explica que "posibilidad de participación" no se entiende aquí sólo como posibilidad de incidencia activa en la vida colectiva, sino también como posibilidad de vivir en sociedad en el respecto de la esfera de libertad particular por parte de los demás ${ }^{82}$ La defensa del sistema sólo se justifica en cuanto supone la defensa del individuo y precisamente la idea de bien jurídico obliga a la concreción de los objetos y de los sujetos de protección penal, más allá de la sola referencia, excesivamente abstracta, al funcionamiento de los sistemas sociales ${ }^{83}$. De esta interrelación entre la defensa de la sociedad y de las posibilidades concretas de participación del individuo en la relación social, deriva el presupuesto político necesario del bien jurídico: "el Estado democrático al servicio de los ciudadanos" 84 .

MUÑOZ CONDE, por su parte, critica enérgicamente las teorías del funcionalismo sistémico ${ }^{85}$ y comienza sosteniendo que el bien jurídico es el valor que la ley quiere proteger de las conductas que puedan dañarlo. Este valor es una cualidad positiva que el legislador atribuye a determinados intereses ${ }^{86}$. Pero, a la vez defiende, la postura que define el bien jurídico como "los presupuestos que la persona necesita para su autorrealización en la vida social". ${ }^{87}$ La autorrealización humana necesita de unos presupuestos existenciales que, en tanto son de utilidad para el hombre, se denominan "bienes jurídicos" y reciben protección penal: se

81 S. MIR PUIG, El derecho penal en el Estado social y democrático de derecho, Ariel Derecho, Barcelona, 1994, p. 161. Explica que "posibilidad de participación" no se entiende aquí sólo como posibilidad.

${ }^{82}$ S. MIR PUIG, Introducción..., op. cit., p.140

83 Ibídem, op. cit., p.138. Añade que si este funcionamiento es el objeto genérico de la tutela penal, los bienes jurídicos son sus concretos objetos, que ofrecen la necesaria especificación de qué particulares procesos de interacción y de participación en los sistemas sociales merecen ser protegidos por el Derecho penal.

${ }^{84}$ Ibídem, op. cit., p.140. Concluye el autor que hay dos clases de límites al poder punitivo. Por una parte, que éste no puede ejercerse más allá de lo absolutamente necesario, lo que se desdobla en los principios de la naturaleza subsidiaria y fragmentaria del Derecho penal. Por otra parte, que la protección penal sólo pueda extenderse a los bienes jurídicos. En cuanto éstos se han concebido a partir de las necesidades funcionales de los sistemas sociales, este segundo límite encuentra la necesaria coherencia con el fundamento (funcional) de la necesidad de defensa de la Sociedad. Pero en la medida en que además se refiere el bien jurídico a las posibilidades de participación del individuo, se hace preciso añadir una fundamentación política que parta de un Estado democrático al servicio del ciudadano.

85 F. MUÑOZ CONDE, Derecho penal y control social, Temis, Bogotá, 2004, p.24. Según el autor, no existe una contraposición individuo-sociedad, sino una contraposición entre diversos sistemas sociales que inciden sobre el comportamiento del individuo. Igual que no es imaginable un lenguaje absolutamente individual, tampoco existe un sistema de valores que lo sea. "Los valores son siempre adquisiciones del sujeto en la comunidad", y por eso mismo, no puede darse una discordancia absoluta entre el sistema de valores un individuo y el del grupo social al que pertenece.

${ }^{86}$ F. MUÑOZ CONDE, Teoría general del delito, op. cit., p.64.

87 F. MUÑOZ CONDE, Introducción al Derecho penal, BOSCH, Barcelona, 1975, p.48. 
tratan, entonces de "aquellos presupuestos que la persona necesita para su autorrealización y el desarrollo de su personalidad en la vida social." 88 Advierte el autor matizando con el objeto de precisar un concepto material, que la consideración de intereses de grupo o de clase dominante constituyen una "perversión" del concepto de bien jurídico y denunciando la instrumentalización en beneficio de los intereses de clase del Derecho penal bajo el amparo de una ideología encubridora como los derechos "naturales"89. Por ello, destaca la necesidad de esta definición material, en contraposición a la forma, que permite una función crítica tanto de los bienes jurídicos ya protegidos como del modo de protegerlos, "para desembocar finalmente en una función político criminal que determine qué bienes jurídicos deben protegerse y cómo deben protegerse por la norma penal"90.

OCTAVIO DE TOLEDO critica la postura de MIR PUIG para quien sólo podrá ejercitarse el ius puniendi respecto de hechos disfuncionales para los sistemas sociales, de tal modo que sólo pueden considerarse delito aquellos hechos disfuncionales para tales sistemas. Se nota la ausencia en su teoría de un desarrollo sobre las bases materiales en que se asienta la calificación de "funcional" o "disfuncional" respecto a un sistema dado y, en particular, sobre la "funcionalidad de la reacción social, del castigo mediante la pena ${ }^{91}$. Con BARATTA, señala el autor que esta ausencia se pone de manifiesto sobre todo porque la investigación de la sociedad demuestra que en su seno alberga "junto a valores y reglas sociales comunes, también valores y reglas sociales específicas de grupos diversos o antagonistas", por lo que toda referencia genérica a lo que es funcional o disfuncional a un sistema social presupone el contraste con las pautas de comportamiento de sólo un sector prevalente de ella. Por eso, entre otras razones en relación con las teorías de las subculturas, hay que estar prevenido respecto de toda referencia genérica a "sociedad" o "sistema social" que se haga sin ulteriores especifica-

${ }^{88}$ F. MUÑOZ CONDE y M. GARCÍA ARÁN, Derecho penal... p.59. Señalan estos autores la necesidad de convivencia que supone la protección de esa convivencia, pues sólo en ella puede la persona autorrealizarse y desarrollarse. Haciendo la distinción entre los bienes jurídicos según sus titulares (individuales y comunitarios), concluye que la convivencia pacífica, asegurada por un orden social o estatal adecuado, es también un jurídico del individuo, en tanto es la única forma de éste pueda autorrealizarse.

${ }^{89}$ F. MUÑOZ CONDE y M. GARCÍA ARÁN, Derecho penal..., p.60; F. MUÑOZ CONDE, Introducción..., op. cit., p.49. Indica el autor que la elevación a la categoría de bien jurídico, es decir, de valor respetable y que hay que respetar, de determinadas ventajas e intereses en beneficio de unos pocos y en perjuicio de la mayoría es una forma evidente de mantener el status, de reaccionar frente a todo lo que significa progreso y de conservar a toda costa la actual situación. De este modo se abusa del derecho penal como sistema de represión en defensa de las minorías dominantes.

${ }^{90}$ F. MUÑOZ CONDE y M. GARCÍA ARÁN, Derecho penal..., p.60; F. MUÑOZ CONDE, Introducción..., op. cit., pp.49 y 50.

${ }^{91}$ E. OCTAVIO DE TOLEDO Y UBIETO, Sobre el concepto del Derecho penal, Universidad de Madrid, Agisa, Madrid, 1981, p.347. Explica el autor que esta aparente contradicción, debiera exigir una mayor matización, por parte de MIR PUIG, respecto a su tesis; un desarrollo sobre las bases materiales en que se asiente la calificación de "funcional" o "disfuncional" respecto a un sistema dado y, en particular, sobre la "funcionalidad" de la "reacción social", del castigo mediante la pena. 
ciones. ${ }^{92}$ Esta comprobación de la realidad social le permite a OCTAVIO DE TOLEDO desechar los criterios de funcionalidad o disfuncionalidad de la conducta para fundamentar un límite al ius puniendi estatal. Estos criterios sólo dan una explicación de cómo es el ejercicio del ius puniendi y del por qué es ejercido en tal sentido y no en otros en una sociedad, teniendo en cuenta los antagonismos sociales que hay dentro de ella y su estructura de dominantes y dominados que determina la funcionalidad o disfuncionalidad en la dirección de los intereses de los primeros. ${ }^{93}$ No obstante, señala el mismo autor, "aparecen también definidos como delitos comportamientos funcionales al sistema, a la acumulación de beneficios dentro del sistema de producción capitalista (como las defraudaciones alimentarias, las contaminaciones, la evasión de capitales, etc.) o "al sistema de gestión de poder de la clase dominante y de sus expresiones políticas" (como determinados delitos de funcionarios: prevaricación, cohecho, negociaciones prohibidas, etc.). Sobre la base de que este fenómeno se explica por el hecho de que las transformaciones en la superestructura jurídica depende y se vincula con las transformaciones materiales de la sociedad OCTAVIO DE TOLEDO afirma que de esta manera "se pone de manifiesto la auténtica posibilidad de que, hasta cierto punto, el concepto de bien jurídico pueda limitar el ejercicio del ius puniendi estatal. ${ }^{94}$

92 Ibídem, op. cit., pp.347, 348. Observa el autor que la genérica referencia a que lo protegido por el Estado, por el legislador a través de la ley, es la sociedad o el sistema social, en el sentido de aquello que sea funcional para su mantenimiento, parece presuponer que las pautas de comportamiento reflejadas en la legislación penal se corresponden a aquellas que "el legislador encuentra preconstituidas y que son aceptadas por la mayoría de los coasociados" (según las palabras de BARATTA). Sin embargo, acudiendo a las investigaciones de este criminólogo italiano sobre las teorías de las subculturas, la investigación sociológica muestra que a) en el interior de una sociedad moderna existen, en correspondencia a su estructura pluralista y conflictual, junto a valores y reglas sociales comunes, también valores y reglas sociales específicas de grupos diversos o antagonistas, b) el derecho penal no refleja solamente valores y reglas aceptadas unánimemente por la sociedad, sino que selecciona entre valores y modelos alternativos, de acuerdo con los grupos sociales que en su constitución (legislador) y en su aplicación tienen un peso prevalerte; c) el sistema penal no sólo conoce valoraciones y normas conformes a las vigentes en la sociedad, sino también discordancias respecto a las mismas; d) finalmente, una sociología historicista y crítica muestra la relatividad de cualquier sistema de valores y reglas sociales en una fase dada del desarrollo de la estructura social, de las relaciones sociales de producción y su antagonismo entre grupos sociales y, por ello, también la relatividad del sistema.

${ }^{93}$ Ibídem, op. cit., p 348. Defiende el autor que hay que tener en cuenta que los grupos en que existen criterios y reglas de conductas contrapuestos a los que dominan en aquellos otros que han conseguido la protección penal para los mismos, son igualmente funcionales que los segundos para el conjunto "sistema social" dado y, en esta situación, debiera aclararse cuál y por qué es la "funcionalidad" preferida por la ley penal para otorgarle su protección. En definitiva, deben esclarecerse las razones del que el poder de criminalización se ejerza en determinados sentidos y no en otros: cuáles son los criterios que rigen su acción selectiva de comportamientos y, por tanto, de selección de los intereses afectados por tales comportamientos y, por medio de la norma penal, protegidos de esos ataques.

${ }_{94}^{94}$ Ibídem, op. cit., p 352. El autor, estudiando a MARX quien sostenía que la relaciones legales y criminales se vinculan con las transformaciones materiales de la sociedad, y dependen de ellas, destaca que esas transformaciones materiales de la sociedad se corresponden con las sucesivas transformaciones del modelo de Estado y, del mismo 
GÓMEZ BENÍTEZ constata que en su evolución, las teorías funcionalistas del bien jurídico se han canalizado por dos vías diferentes las que plantean la dañosidad social única y exclusivamente en relación al sistema como fundamento del injusto y a los bienes jurídicos como concreciones de la funcionalidad del sistema y aquellas que conservando los aspectos liberales del concepto, legitiman la defensa del sistema sólo en cuanto significa protección del individuo ${ }^{95}$. Este último planteamiento, que se identifica con el de CALLIESS y MIR PUIG y que se distingue de ROXIN, según GÓMEZ BENÍTEZ, concibe que "el bien jurídico tiene siempre un contenido social" y que la "protección de bienes jurídicos es - en todo caso - protección del sistema social..."pero señala en seguida que las diferencias son de matiz, que "las concepciones son muy próximas, y que ambas enraízan con el sistema de garantías liberales, por lo que siguen configurando un Derecho penal afecto también, y consecuentemente, al principio de culpabilidad". Su máxima virtualidad "se concreta - exclusivamente - ... en la inicial evitación de la persecución de conductas (¿resultados?) meramente amorales". Sin embargo, opina este autor que se puede ir más lejos en esta pretensión y que la complementación del concepto de bien jurídico no podía entenderse desvinculada de la teoría de la pena, pues se trata de "definir materialmente el perjuicio social como necesidad preventivo-general de pena", dirigida al colectivo social ${ }^{96}$.

modo, se reflejan en los progresivos avances que, en el terreno normativo y, por tanto, en relación a los objetos de protección de tales normas, se verifican en pugna con los intereses de la clase dominante. Estos "avances" son irreversibles en la mayor parte de los casos (p.353). Estos avances sociales producto de la lucha social, como los derechos individuales y las obligaciones asistenciales del Estado interventor, se reflejan en el sistema normativo y su función, del que es paradigmático el artículo 9.2 de la Constitución. La norma del Estado social ya no es garantizadora, sino que es promocional, por lo que se acentúa cada vez la función promocional del sistema normativo. Esta función promocional también afecta al derecho penal "precisamente, en lo referido a los bienes jurídicos y su capacidad limitadora del ius puniendi estatal", a partir de la consideración del carácter social y democrático del derecho del Estado. Dicho carácter obliga a una asistencia real de todos los individuos integrados en el sistema social regidos por el nuevo modelo del Estado, por lo que del mismo modo el Estado liberal puro se ve precisado a proteger penalmente sus obligaciones asistenciales (medio ambiente, vivienda, salud, etc.) (p.354). Según el autor, sería este contenido material de las normas de protección penal, en cuanto producto de la tensión entre los grupos sociales que están por el mantenimiento del sistema social y los que están por su transformación, el que daría al bien jurídico su carácter del limite al ius puniendi estatal, capacidad en todo caso respecto de la cual se manifiesta escéptico.

95 J.M. GOMÉZ BENÍTEZ, Estudios penales, Colex, 2001, pp. 25 y ss. Ahora bien resalta el autor, al presentar las nuevas teorías del perjuicio social, la cuestión central será buscar el acomodo del concepto del bien jurídico la teoría sobre la disfuncionalidad social y pensar que la pretensión de las nuevas doctrinas se centra en la definición e investigación del bien jurídico como concepto de contenido social. No pretende pues, renunciar a la definición de la función del Derecho penal como "protección de bienes jurídicos", sino complementar tal función como "protección del funcionamiento de los sistemas sociales", protección frente a perjuicios sociales y no frente a desvalores morales, espirituales o culturales. En este contexto, los concretos bienes jurídicos han de ser la concreción de los elementos de funcionalidad; así podrá decirse que la protección de esa funcionalidad se realiza a través de la protección de los bienes jurídicos.(p.32)

96 Ibídem, op. cit., p 35. 
Los autores críticos con estas posiciones extremas afirman que el peligro de las tesis se puede corregir a través de la inclusión en el concepto de bien jurídico de una referencia central al individuo $0^{97}$. Así, a partir de la referencia individual del concepto de bien jurídico, hechos disfuncionales que no afecten a las posibilidades de autorrealización del individuo no serán punibles. En cuanto a los hechos funcionales para la "práctica" del sistema, si lesionan posibilidades de autorrealización del individuo, en la medida en que el sistema se declare establecido en beneficio de éste, podrán, con otros requisitos, ser estimados punibles, en tanto que disfuncionales con el "programa" del sistema ${ }^{98}$. La idea clave para estos autores va a ser que sólo pueden ser bienes jurídicos aquellos objetos que el ser humano precisa para su libre autorrealización (que obviamente tiene lugar en la vida social), determinados objetos se convierten en bienes jurídicos, por tanto, en la medida en que están dotados de un contenido de valor para el desarrollo personal del hombre en sociedad. Para OLAIZOLA NOGALES, resumiendo estas posturas críticas, destaca que estos autores aluden a la importancia del individuo en la concepción del bien jurídico desde diferentes perspectivas, con distintos matices, pero lo importante es que todos coinciden en la idea fundamental de que el concepto de bien jurídico debe girar en torno al individuo como sujeto integrante de un sistema social. Se combina así la idea funcionalista al considerar el bien jurídico como un valor social pero en la medida que ello influya en la autorrealización del individuo ${ }^{99}$.

Si es éste el estado de la cuestión en la doctrina penal española, sería interesante hacer el estudio de este concepto del bien jurídico en la doctrina francesa al señalar, de antemano, su casi inexistencia para quedarse en principios menos técnicos tal como la idea de valor o de interés.

${ }^{97}$ S. MIR PUIG, Introducción..., op. cit., p.152

98 E. OCTAVIO DE TOLEDO Y UBIETO, Sobre el concepto..., op. cit., p.350, J. M. SILVA SÁNCHEZ, Aproximación..., op. cit., pp. 269 y ss. F. MUÑOZ CONDE y M. GARCÍA ARÁN, Derecho penal..., op. cit., p.61; S. MIR PUIG, Derecho penal..., op. cit., p.169, nํ41.

${ }^{99}$ I. OLAIZOLA NOGALES, El delito de cohecho, op. cit., p.51. La autora tomando posición resalta tres puntos. 1) La doctrina moderna, rechaza , en su mayoría las concepciones formales de bien jurídico, porque una de las funciones principales, por no decir la más importante, es la función de límite al ius puniendi del Estado, función que únicamente puede ser cumplida a través de una concepción material del bien jurídico que sirva de barrera al legislador. 2) Las concepciones extremas tantos las teorías constitucionalistas como las funcionalistas, precisamente por su carácter extremo no aportan un concepto de bien jurídico que sea manejable. Explica la autora que las primeras, porque tratan la Constitución como una "varita mágica" capaz de resolver cualquier problema, y la alusión a la Constitución es necesaria, pero como límite negativo que no se puede traspasar. Las teorías funcionalistas extremas, por su parte, no tienen en cuenta a la parta más importante del sistema, esto es, al individuo, siendo además teorías que finalmente sirven únicamente para consolidar lo ya existente, y comportando el peligro de poder considerar funcional y por tanto no punible aquello lesivo para el individuo. 3) Considera, la autora, más correctas aquellas teorías que desde diversas perspectivas tratan de englobar el aspecto social y el individual y que hacen girar el concepto de bien jurídico básicamente en torno a la persona (p.55). La postura de esta autora nos parece la adecuada para el desarrollo de este trabajo y sobretodo su manejo en el marco del estudio del delito de corrupción o de cohecho. 


\begin{abstract}
Sub-sección 2: Aproximación al estudio de los valores protegidos en el Derecho francés
\end{abstract}

No cabe duda alguna que el concepto de bien jurídico nació en Alemania desde los estudios de FEUERBACH, para quien los derechos subjetivos eran objeto de protección del Derecho penal y a la vez límite del ius puniendi estatal pasando por BIRNBAUM y seguido por los de BINDING y Von LISZT, los cuales han aportado planteamientos nuevos ${ }^{100}$. Estos estudios dogmáticos, entre ellos el concepto de bien jurídico, hechos en Alemania han sido recibidos en otros países europeos (Italia, España, Portugal, Grecia) pero no en Francia101. LACAZE afirma que aunque el concepto de bien jurídico haya aparecido en Francia en el principio del siglo XX bajo la pluma de GARRAUD ${ }^{102}$ y que hoy día sea utilizado de manera furtiva, "el bien jurídico" nunca ha interesado verdaderamente la doctrina francesa y no ha sido objeto de estudios profundos. ${ }^{103} \mathrm{El}$ Derecho francés, muy positivista y práctico, impregna a los juristas franceses con su esencia a menudo pragmática y cuando el jurista examina el Derecho penal alemán, se encuentra desconcertado por la aproximación muy conceptual adoptada por los autores alemanes. ${ }^{104}$ Efectivamente, esta reacción puede ser la misma ante la doctrina penal de los países que han recibido y luego seguido el modelo alemán. A estas diferencias de fondo se añade dificultad terminológica. Al querer traducir y explicar tal o cual concepto alemán, nos encontramos ante dos escollos, ansias constantes de los "comparatistas": o bien aceptar la fealdad eficaz de la traducción estricta, o bien elegir perder la concisión en beneficio de la traducción explicativa más elegante. El relevo que ha tomado la doctrina española al traducir estos conceptos alemanes puede ser de gran ayuda al comparatista pero la transposición se ve dificultada por el arraigamiento de conceptos muy diferentes de los alemanes, con lo cual el Derecho penal francés se encuentra en una situación diferente y por el hecho de que su formulación privilegia simplicidad, claridad y su contenido que pretende ser positivista, realista y bastante pragmático ${ }^{105}$. Por lo tanto, a partir de esta constatación general sería

\footnotetext{
${ }^{100}$ H. HORMAZÁBAL MALARÉE, Bien jurídico..., op.cit. pp.11-51

${ }^{101} \mathrm{~J}$. WALTHER, $L$ 'antijuridicité..., op cit, p.5

102 R. GARRAUD, Traité théorique et pratique du droit pénal français, Tome II, Sirey, 1914, (3 ${ }^{\text {a }}$ ed.).

103 M. LACAZE, Réflexions sur le concept de bien juridique protégé par le droit pénal, Thèse Droit privé et sciences criminelles, dir. A. D'HAUTEVILLE, Université de Montpellier I, 2009, p.9.

104 J. WALTHER, $L$ 'antijuridicité..., op cit, p.4. Se ha reprochado al derecho penal alemán de sumergirse - incluso perderse - en los arcanos de la filosofía del derecho y de faltar una aproximación concreta.

$105 \mathrm{~J}$. WALTHER, $L$ 'antijuridicité..., op cit, p.5. El autor precisa que no para tanto merece el reproche de superficialidad que ha formula Von LISZT en su severa formulación: “ $¡$ no hay doctrina penal francesa!".
} 
interesante estudiar las causas de la ausencia del concepto de bien jurídico en el sistema penal francés. Pero se debe relativizar esta ausencia para constatar la supervivencia no de la apelación sino de la idea de bien jurídico en su estadio pre-jurídico y no como aspecto ya técnico ${ }^{106}$. $\mathrm{Y}$ aunque podamos encontrar esta idea de bien jurídico en su aspecto rudimentario, ésta no deja de desarrollar funciones que se reconocen en la dogmática penal francesa.

\section{I-Ausencia del concepto técnico de bien jurídico en la doctrina penal francesa}

Aunque acabamos de repasar unos motivos generales de la reticencia de los autores franceses con respecto al estudio y a la recepción de la dogmática alemana, lo que interesa en nuestro trabajo sería entender algunas causas de la ausencia del concepto de bien jurídico y ver sus efectos. Esta ausencia de teorización del concepto de bien jurídico, señala LACAZE, puede a primera vista parecer relativamente indiferente, puesto que el Derecho francés no parece sufrir de lagunas particulares y da la impresión de poder explicar sus soluciones sin acudir a ello. Pero el contraste entre esta ausencia en Derecho francés y la multitud de estudios elaborados por las doctrinas de inspiración germánica no puede, no obstante, sino interpelarnos, ya que el Derecho francés, alemán, español e italiano son a priori muy cercanos por pertenecer todos a la gran familia de Derechos romano-germánicos de Derecho escrito.107

\section{A-CAUSAS}

\section{dad}

\section{1- Recepción incompleta del concepto de antijuridici-}

\footnotetext{
106 M. LACAZE, Réflexions..., op. cit., pp. 9,10. La autora explica que más a menudo utilizado como sinónimo de "interés" o de "valor" protegido, el bien jurídico no aparece como un verdadero componente de la infracción francesa y su naturaleza jurídica no es más precisado que su contenido material. La sola asimilación de las ideas de bien protegido, de interés protegido y de valor protegido revela ya en efecto la inexistencia de un concepto verdadero, el cual, en cuanto "representación mental general y abstracta", permitiría reunir el conjunto de los objetos de protección del derecho penal por una operación de calificación.

107 J. PRADEL, Droit pénal comparé, Dalloz, 2008, p.38, M. LACAZE, Réflexions..., op. cit., pp. 29, 30. Explica la autora que la virulencia de los debates suscitados por la idea defendida por la doctrina minoritaria de los vecinos europeos de suprimir este concepto parece, además indicar que el concepto reviste una importancia particular, superando de lejos su pura función técnica. Frente a las teorías sistémicas posmodernas, tachadas de normativismo radical, la doctrina mayoritaria manifiesta en efecto que hay preservar absolutamente el concepto de bien jurídico, indispensable para salvaguardar el derecho penal democrático de la amenaza del autoritarismo. Y la misma autora se pregunta: ¿Cómo limitar el campo del derecho penal sin una referencia externa constituida por su objeto de protección? ¿Cómo afirmar la necesidad de la responsabilidad del sujeto si el derecho se define por su única función de preservación del mismo sistema? Pero estas preguntas que plantea la doctrina de los países de inspiración germánica llaman a otra: ¿la ausencia de teorización del bien jurídico en Francia significa una adhesión implícita al positivismo estatal o al funcionalismo sistémico?
} 
Destaca WALTHER que la noción de "ilicitud" o de "antijuridicidad" no tiene más que un papel relativo en el Derecho penal francés ${ }^{108}$. Esta noción ha sido parcialmente estudiada, pero sin integrar las distinciones propuestas por la doctrina alemana. Para algunos autores, es un componente negativo de la infracción o un fundamento del mecanismo de la justificación ${ }^{109}$. Sin embargo, hay que precisar que esta noción se queda completamente marginal por el hecho de que, en la historia de los elementos de la infracción, el elemento injusto ha llegado tardíamente en Francia. La crónica de la antijuridicidad en Francia es la de una desgraciada transposición con doble motivo: la mayoría de los autores ignoraron esta noción y los que se interesaron a ella, la truncaron hasta el punto de matar el injerto.

Señala el mismo autor que una de las causas de esta recepción incompleta de la antijuridicidad en la construcción teórica de la infracción es el desconocimiento debido a las reticencias culturales. Los autores franceses no conocían y siguen sin conocer la concepción alemana de antijuridicidad. Que sea hoy o en la época de la aparición en Alemania de este concepto, la teoría del Derecho penal general alemana no ha sido nunca objeto de un gran apasionamiento de parte de los autores franceses $^{110}$. Y eso parece extraño porque, al principio del siglo XX, en otras ramas del Derecho como el Derecho civil los autores sí que habían sido influenciados por la ciencia jurídica alemana. Sin embargo, el Derecho penal es una excepción. ¿Cuáles son las razones? Las doctrinas alemanas y francesas se contentaron de constatar el hecho sin dar explicaciones verdaderamente convincentes ${ }^{111}$. La pregunta es si son los mismos motivos que se invocan hoy para explicar la ausencia del Derecho penal en la legislación europea, a saber que los derechos represivos están más marcados por la idea de soberanía nacional, la expresión de las prerrogativas de regalía más fuertes. ¿Cómo explicar que Francia haya elegido aislarse completamente de la tendencia general del fin del siglo XIX que se abría muy ampliamente a la inspiración alemana? En realidad, la doc-

108 J. WALTHER, L 'antijuridicité..., op cit, p.121.

109 R. GARRAUD, Précis de droit criminel, Larose et Forcel, 1888, (1ํaㄹ ed) y 15aㅡ éd. 1934, éd. Sirey ; J.-A. ROUX, Cours de Droit pénal et de procédure pénale, Sirey, 1920, (1aa ed) ; G. LEVASSEUR/A. CHAVANNE/J. MONTREUIL, Droit pénal général et procédure pénale, Sirey, 1994 ; M. R.VOUIN, Droit pénal général et criminologie, Thémis, PUF, 1956; M.-L RASSAT, Droit pénal général, PUF, 1987 ; J. LARGUIER, Droit pénal général, Mémento, Dalloz, 2001, (18 a ed.); P. SALVAGE, Droit pénal général, P.U.G, 2001,(5ª ed.).

110 J. WALTHER, $L$ 'antijuridicité..., op. cit, p.123

111 J.-H. ROBERT, Droit pénal général, Thémis, P.U.F, 2001, p.104. Este autor señalaba que aunque, en general, los juristas franceses fueron fuertemente influenciados por la doctrina alemana entre 1880 y 1914, los penalistas franceses no adoptaron la terminología alemana en su construcción de los elementos de la infracción. Incluso prefirieron designar la incriminación como "el elemento legal de la infracción" (mientras los alemanes utilizaban los términos Tatbestand o fattispècie en italiano o tipo en español). Esta expresión, según el mismo autor, ha sido considerado hoy como torpe: en efecto, los otros dos "elementos" que componen la infracción son calificados de "material" y de "moral", para designar el comportamiento físico y la actitud psicológica del delincuente; el conjunto de los tres elementos no es pues coherente, puesto que pone en el mismo plano el elemento legal, que describe y los otros dos elementos que son descritos. 
trina francesa eligió en algún momento replegarse en "el análisis clásico francés" y no seguir más la evolución común en materia de teoría de la infracción ${ }^{112}$. Es cierto que dentro de la doctrina francesa hubo autores que intentaron introducir el concepto de antijuridicidad casi tal como se lo había estudiado en Alemania, pero el intento no resultó. GARRAUD fue uno de los artesanos de ese intento. Se esforzó en añadir un elemento injusto en su construcción de los elementos de la infracción ${ }^{113}$. Ésta última supone un acto ilícito amenazado por la ley y señala el mismo autor que se sabe que la noción de injusticia (in jus) es inseparable de toda violación de la regla (normen) constitutiva de un delito, que se trate de delito civil o de delito penal. Advierte que si es bastante difícil determinar las circunstancias que excluyan el carácter antijurídico de una acción, ordinariamente incriminada, no lo es menos dar a la noción de ilicitud su verdadero sitio entre las causas eximentes de responsabilidad $^{114}$. ROBERT critica esta postura por haber quitado a la noción de ilicitud o antijuridicidad su coherencia, puesto que la definición que GARRAUD ha dado a los hechos justificativos se refiere al ejercicio de un derecho o de un deber que impide destacar la noción de interés protegido ${ }^{115}$. La nueva y moderna lectura de la antijuridicidad la encontramos en los trabajos de VITU. Este autor da una definición de la ilicitud con doble dimensión: la formal y la material y considera que "es la transgresión, manifestada por uno de las conductas definidas por una disposición legislativa o reglamentaria, de la norma de civilidad, contemplada a través de uno u otro de los bienes jurídicos que los poderes públicos han considerado como dignos de protección penal"116. En este sentido también se ha pronunciado ROBERT y lamenta la falta de éxito de la noción en la dogmática francesa. Insiste sobre la dimensión objetiva y material de la antijuridicidad. "El elemento injusto de la infracción

$112 \mathrm{~J}$. WALTHER, $L$ 'antijuridicité $\ldots$,., op cit, pp.124, 125.

113 R. GARRAUD, Traité théorique et pratique du droit pénal français, Tome I, Larose et Forcel, Paris, 1888, p.161. El autor distingue dos cosas necesarias para la existencia de la infracción: la perpetración de hecho de acción o de omisión previsto y castigado por la ley; la culpabilidad del agente a quien este hecho es imputable, se entiende que los elementos esenciales de la infracción se sacan en el hecho punible y en la persona que lo ha cometido. Por lo tanto, hay cuatro elementos necesarias para que un tribunal penal declare un individuo culpable: $1^{\circ}$ ) que tal individuo haya participado de la perpetración de tal hecho (elemento material); $2^{\circ}$ ) que haya participado con discernimiento y libertad (elemento moral); 3 - )que este hecho haya sido previsto y castigado por la ley a la que el individuo debía obediencia (elemento legal); $4^{\circ}$ ) que este acto no se justificara por el ejercicio de un derecho (elemento injusto).

114 R. GARRAUD, Traité..., Tome II, op. cit., pp.1,2.

115J.-H. ROBERT, Droit pénal général, op. cit., p.245, R. GARRAUD, Traité..., Tome I, no 238, p.391. En efecto, la ilicitud en la concepción de GARRAUD se basa en el deber o en el ejercicio de un derecho para justificar la exclusión de la responsabilidad. Con lo cual no ha podido ir más allá de un aspecto negativo y formal de la antijuridicidad sin contemplar en el medio de su construcción su aspecto material que es la consideración de los bienes jurídicos.

116 A. VITU, L' illicéité comme élément de la responsabilité en Droit pénal, in 2èmes journées juridiques franco-helléniques,( Nancy, 14-18 mai 1984), Revue International de droit comparé, 3-1984, p.631. La totalidad de la intervención de este autor se puede ver en la red con el enlace siguiente: http://ledroitcriminel.free.fr/, con el título: "De l' illicéité en droit criminel français". 
es la lesión al interés protegido por una norma extra-penal"117. El autor proporciona un ejemplo interesante de la infracción imposible. Tratado según la antijuridicidad positiva y material que supone la violación de un interés protegido, el "homicidio de un cadáver" debería quedarse impune: "la aplicación de la noción de antijuridicidad habría conducido a la absolución, puesto que no se trata de lesionar un interés socialmente protegido golpear un cuerpo sin vida"118. Es verdad que al vincular este problema al de la tentativa, éste es "manoseado" y se le introducen concepciones subjetivas. Es preferir una hipótesis favorable a la represión frente a una objetividad respetuosa de las garantías fundamentales del individuo, favoreciendo en este sentido "una justicia absoluta". Una vez más, el Derecho penal general pierde su objetividad por razones de política-criminal. Se reduce la parte de la objetividad, y eso es lo que ha criticado ROBERT119. Según WALTHER, la controversia persiste en el debate doctrinal, aunque no parece tan útil para la doctrina actual, tiene su importancia respecto del debilitamiento de la parte objetiva de la infracción y la desaparición de mecanismos que contribuyen a la protección de los individuos. Vincularlo todo con el individuo aumenta la parte de incertidumbre relacionada al estudio de un sujeto con subjetividad absoluta, a saber la apreciación del psique del autor por el juez. Los protagonistas de esta noción de antijuridicidad material no limitan sus aplicaciones a la justificación. Muestran que la noción de antijuridicidad y su referencia al bien jurídico protegido tienen numerosas consecuencias y aplicaciones prácticas como en materia de complicidad y de concurso de infracciones. ${ }^{120}$

\section{2- Razones relacionadas a los juristas}

El término jurista aquí se refiere a todos los actores que operan en el ámbito del Derecho, pero podemos distinguir en este apartado a los miembros de la doctrina y luego a los jueces.

En cuanto a los miembros de la doctrina en general, como ya se ha dicho, hay razones eminentemente subjetivas y que tienen que ver con la sensibilidad. Generalmente la dogmática alemana parece muy abstracta para los autores franceses. Se evoca a menudo la inspiración kantiana del pensamiento jurídico alemán que se opondría con otra sensibilidad, más cartesiana, de estos mismos autores. Aunque es exacto, debe ser relativizado. La técnica de DESCARTES en su búsqueda de la lógica propone un análisis estructural y sistemático, la cual puede ser aplicable al estudio de la infracción. La necesidad de aplicar una estructura coherente y racional es evidente. Por lo tanto, la búsqueda de una coheren-

117J.-H. ROBERT, L'histoire des éléments de l'infraction, Revue de science criminelle et de droit pénal comparé, 1977, p.278.

118J.-H. ROBERT, Droit pénal général, op. cit., p.245.

${ }^{119}$ Ibídem, op. cit., p.245. El autor explica que sin embargo al vincular este problema con la tentativa, ella misma penetrada de concepciones subjetivas, se concluye que el agente es bastante peligroso o bastante mal intencionado para merecer la represión penal.

120 J. WALTHER, L 'antijuridicité..., op cit, pp. 133 y 134. 
cia sistemática y estructural, tan importante para la doctrina alemana, es entonces por definición uno de los primeros objetivos del jurista formado con el método de inspiración cartesiana. ${ }^{121}$

LACAZE, por su parte, constata la capa positivista de los autores "conforme a la tradición francesa"122. En efecto, reivindican una neutralidad axiológica, aunque sería erróneo negar toda consideración de la doctrina francesa para las cuestiones filosóficas o de política criminal ${ }^{123}$. Es de admitir, según la autora, que si los autores franceses se interesaron mucho en la cuestión de la finalidad de la pena no ocurrió lo mismo en cuanto a los fundamentos del Derecho penal y sus aspectos axiológicos, sin duda, innegables 124 . Una barrera infranqueable parece ser erigida entre la reflexión del jurista sobre la infracción, donde aprecia las elecciones del legislador desde un punto de vista técnico (legalidad formal, coherencia interna del sistema...) y la apreciación axiológica de ésas, reservada a los estudios, desde luego separados, de política criminal. Por lo tanto, es frecuente encontrar un análisis cuyo autor interrumpe el transcurso con el motivo de que llega en el terreno de la política criminal, terreno que no es de su competencia. La tradición francesa quiere que la doctrina no emita juicio de valor sobre la política criminal del legislador y que el estudio del proceso normativo sea dejado entre las manos de los sociólogos del Derecho o de los autores de política criminal. El carácter justo o injusto de la ley, una cuestión que el jurista francés se niega a tratar, cuando, fiel a la concepción de la racionalidad indudable de la ley, afirma perentoriamente que "la solución justa no es la que es oportuna sino la que es legal”125. Además, señala la misma autora

121 J. WALTHER, L 'antijuridicité..., op cit, pp. 136, 137.

122 A.-C. DANA, Essai sur la notion d'infraction pénale, Librairie général de Droit et de Jurisprudence, Paris, 1982, p.9. El autor, en la introducción de su obra, precisa que su ensayo iba a ser de naturaleza estrictamente jurídica. $Y$ añade que para hacer un estudio estrictamente jurídico había que descartar la criminología y disciplinas que gravitan en su alrededor (haciendo alusión a la filosofía, campo predilecto de los autores alemanes).

${ }^{123}$ M. LACAZE, Réflexions..., op. cit., p.159. Señala que los autores, en la introducción o en las primeras páginas de su manual, sitúan el derecho penal en este contexto global y hacen referencia a la existencia de una "infracción natural", al lado de la infracción jurídica entendida como violación de una regla jurídica sancionada por una pena. Es, sin embargo, esta última la que es considerada luego como objeto de estudio, puesto que el análisis de la primera o de sus relaciones respectivas están dejadas a los filósofos o sociólogos del derecho.

124 Ibídem, op. cit. Si bien es cierto, matiza la autora, que numerosas son las referencias a los "valores protegidos", sobre todo en la distinción entre crímenes y delitos, de una parte, y contravenciones de otra parte, esos valores no son verdaderamente estudiados como tales, que se trate de su origen o de su naturaleza. Ver por ejemplo el estudio de Y. MAYAUD, "Ratio legis et incrimination", Revue de science criminelle et de droit pénal comparé, 1983, pp. 596 y ss. y precisamente p.603.

125 M. LACAZE, Réflexions..., op. cit., p.160. La autora nota que de una manera más general, se puede decir que la doctrina penalista se interesa a la filosofía penal o a la política criminal pero que las reflexiones que ella desarrolla en este tema hacen, a menudo, parte de publicaciones separadas; esas no se integran verdaderamente en los manuales o en los estudios doctrinales de derecho positivo. Quizá sea debida esta separación a la falta de reconocimiento verdadero del bien jurídico cuyos países de 
que la vocación pragmática del Derecho penal francés es totalmente asumida por la doctrina. Las monografías francesas guardan una vocación práctica y ponen en primer plano las soluciones legales y jurisprudenciales que el Derecho positivo trae a los diferentes problemas jurídicos. Los autores aportan a menudo una aclaración o incluso una crítica teórica pero éstas son, en general, bastante sucintas y sólo aparecen secundariamente para explicar el Derecho positivo y sus evoluciones ${ }^{126}$. Esta situación es muy distinta de lo que sucede en el sistema de tradición germánica como España ${ }^{127}$. Por lo tanto no es de extrañar también que la doctrina se incline ante el Derecho positivo. Sería excesivo, defiende LACAZE, negar a la doctrina francesa todo gusto para las construcciones teóricas pero rehúsa a menudo proponer construcciones rechazadas por el Derecho positivo y se muestra a veces reticente para defender posturas distintas, aunque éstas no son incompatibles con ése ${ }^{128}$.

De otro lado, se ha avanzado la formación intelectual de los criminalistas franceses. VITU insiste sobre el hecho de que la mayoría de los penalistas extranjeros reciben una formación de publicistas, mientras que los penalistas franceses son privatistas. Por lo tanto el Derecho criminal (o penal) se ha vinculado con el Derecho privado. Por consiguiente, los especialistas del Derecho criminal no se han preocupado por efectuar un análisis parecido al de la doctrina alemana y cuya utilidad no les parecía evidente ${ }^{129}$.

inspiración germánica, como España, entienden que es la llave de comunicación entre el derecho y la política criminal.

126 J.- P. DOUCET, «La doctrine est-elle une source du droit? ? disponible en la red: http://ledroitcriminel.free.fr. El autor lamenta la modestia de la ciencia jurídica y del derecho natural frente al derecho positivo con la consecuencia de hacer que la doctrina ya no sea una fuente del derecho. Subraya también las consecuencias prácticas nefastas que provoca esta posición epistemológica descuidando los principios generales en beneficio de estudio de soluciones precisas de un derecho positivo válido en un solo lugar y en un solo tiempo, lo que hace necesario el reciclamiento de los profesionales del derecho para asegurar que partimos sobre la base de principios generales universales y eternos, en vez de un llano conocimiento del derecho local presente y ello debido a la aceleración de nuestra civilización y la internacionalización de la vida social. J. WALTHER, L'antijuridicité..., op cit., p.18. Señala que de manera general, la doctrina alemana desde el siglo XIX es rica en construcciones teóricas, a veces desconcertantes, pero ineludibles. Ineludibles en el sentido de que son representativas del espíritu y de la sistemática alemanas. Ineludibles sobretodo porque han originado directamente construcciones jurisprudenciales muy prácticas. Este origen es fácil de constatar puesto que los jueces alemanes citan en sus decisiones los autores que los inspiran.

127 M. LACAZE, Réflexions..., op. cit., pp.161, 162.

128 Ibídem, op. cit., p.162. El ejemplo citado por la autora es la distinción por la doctrina de las causas objetivas y subjetivas de irresponsabilidad. Sin embargo, el CPF de 1992 ha seguido la corriente minoritaria de la doctrina que defendía la unicidad de las causas de irresponsabilidad con su fórmula "no es responsable penalmente".

129 A. VITU, "De l'illicéité en droit criminel français", op. cit., p.2. J. WALTHER, L'antijuridicité..., op cit., pp. 137, 138. Sin embargo, este autor critica esta postura de VITU por cuatro motivos. 1) Actualmente, el derecho penal en Francia es cada vez más considerado como una materia autónoma. 2) Los autores extranjeros francófonos, sobretodo belgas y suizas, cercanos a las estructuras y la reflexión francesas, no se han 
En lo que se refiere a la jurisprudencia, nota LACAZE que la debilidad de los límites materiales al Derecho penal se debe, entre otras razones, a la admisión por el Consejo Constitucional francés como valor constitucional principios enunciados en la Declaración de los Derechos de 1789 y su competencia a censurar las leyes penales que le serían sometidas. Si es cierto que este Consejo vigila la aplicación de la ley penal en el tiempo, se muestra mucho más reservado a la hora de ejercer un control sobre el límite material del Derecho penal. En efecto, si exige que el legislador defina las infracciones en "términos suficientemente claros y precisos para limitar el arbitrario"130, el Consejo Constitucional censura escasamente y prefiere acudir a la técnica de reservas de interpretación, las cuales se imponen al juez en la interpretación de los textos ${ }^{131}$. Pero son los principios de necesidad y de proporcionalidad los que sobretodo podrían permitir al guardián de la Constitución francesa restringir el campo del Derecho penal. Ahora bien, desde la admisión, por la decisión llamada "Seguridad y libertad"132, de la sumisión del legislador al principio de necesidad de la ley penal, el Consejo Constitucional ha precisado en seguida que el legislador debía beneficiarse de la mayor libertad en la apreciación de esta necesidad y que sólo "el error manifiesto de apreciación" podría ser censurado. Varias veces reafirmado, el Consejo Constitucional considera que "no le incumbe sustituir su propia apreciación a la del legislador"133.

En cuanto al juez penal, la concepción francesa del principio de legalidad lo ha reducido en la mera "boca de la ley". Este principio aboga por una manera de interpretar la ley penal. Después de muchos años de silencio sobre el método de interpretación que debía adoptar el juez, y a

\footnotetext{
impedido por ninguna clasificación concerniente el derecho penal preguntarse sobre las nociones de injusto o de ilícito (y desde luego el aspecto material que conlleva la referencia a los bienes jurídicos) y reconocerles un sitio, como en Alemania. 3) La doctrina alemana es generalista. Los autores alemanes a pesar de la vinculación del derecho penal al derecho público, son, por su formación, generalistas del derecho. Las teorías del derecho civil no les son desconocidos, al contrario. Los estudios alemanes sobre la noción de ilicitud o antijuridicidad - extendida uniformemente en virtud del principio de la unidad del ordenamiento jurídico- y sus efectos no son limitados a la esfera penalista, y tanto menos que el propio concepto de antijuridicidad material es de inspiración civilista. 4) Por último, la concepción de la ilicitud civil no es desconocida en derecho civil francés. De ahí a estudiar ese concepto en derecho penal, no hay más que un paso que dar, bien fácilmente.

130 Cons. Const., 19-01-1981, $n \div$ o 80-127 DC.

${ }^{131}$ Cons. Const., 13-03- 2003, nํㅡㄹ 2003-467 DC.

132 Cons. Const., 20-01-1981, no 80-127 DC. «Loi renforçant la sécurité et protégeant la liberté des personnes».

${ }^{133}$ Cons. Const., 3-09-1986, $n^{\circ}$ 86-214 DC ; M. LACAZE, Réflexions..., op. cit., p.147. Afirma la autora que la doctrina apoya en general la prudencia y análisis del Consejo Constitucional e, incluso, analiza su rechazo a substituirse al legislador como la puesta en marcha de la protección de los justiciables contra el arbitrario. (J.-P. DELMAS SAINT-HILAIRE, "Sans nécessité, la loi pénale ne vaut», Politeïa oㅡ 5, 113-124, ver p.117). C. FAURE-GAUSSEL, Droit pénal des affaires, op.cit., p.41, no 59, 60,61. Lamenta la autora la falta de censura en la creación de tipos penales, lo que explica la falta de autolimitación del legislador para respetar el principio de intervención mínima del derecho penal.
} 
pesar de que el CPF de 1994 precisara en su artículo111-4 que "la ley penal es de interpretación estricta", ello no puso fin a los debates doctrinales al respecto puesto que todavía es posible optar otras opciones de interpretación aun respetando el principio "toda la ley pero solamente la ley". De todas formas, lo importante es destacar que, en todos los casos, la ratio legis es determinada por la voluntad del legislador, explicita o supuesta y no por una referencia al bien jurídico ${ }^{134}$. Otra consecuencia de este principio de interpretación estricta de la ley es la imposibilidad para el juez penal de fundamentar sobre una definición pre-jurídica del objeto de protección del texto de incriminación para justificar su interpretación ${ }^{135}$. No puede reconocer acudir a consideraciones axiológicas, ni tampoco puede contestar la validez (material) de la ley. En efecto, si en España el Código penal español (CPE) en su artículo $4^{136}$ ha previsto el posible fallo del legislador y habilita un procedimiento particular que permite al juez comunicar al gobierno lo que considera como laguna legislativa o un exceso de represión, el juez penal francés no tiene ningún recurso ante una imperfección del trabajo del legislador ${ }^{137}$. Ni siquiera puede pedir el control de constitucionalidad de la disposición en cuestión. Aunque la ley constitucional del 23 de julio de 2008 acaba de permitir a las partes plantear la inconstitucionalidad de una ley, el juez no puede plantearla de oficio y hasta esa última reforma constitucional, se presumía que la ley era perfecta una vez promulgada. Fuera de esta nueva posibilidad, limitada, de remisión ante el Consejo Constitucional, el juez no tiene sin embargo ninguna voz en el capítulo: tiene que, por un acto de conocimiento, destacar la voluntad del legislador y esta última no es susceptible de apreciación axiológica $^{138}$.

134 M. LACAZE, Réflexions..., op. cit., pp. 154, 155. Contrasta que una referencia al bien jurídico supondría en efecto, para ser eficaz, la admisión de un contenido a priori del bien jurídico protegido, es decir anterior a la ley... o dicho de otra manera, la introducción, en la interpretación, de referencias externas a la ley y superiores a ella, choca fuertemente con la concepción francesa del principio de interpretación estricta.

135 Ibídem, op. cit., p. 156. Tiene que atenerse a la descripción legal del tipo y sería añadir a la voluntad del legislador exigir una lesión o una amenaza para un bien jurídico predeterminado y sustancialmente definido. Sin embargo, en Alemania es posible referirse al derecho natural como fuente del derecho.

${ }^{136}$ Art.4 del CPE: "2- En el caso de que un Juez o Tribunal, en el ejercicio de su jurisdicción, tenga conocimiento de alguna acción u omisión que, sin estar penada por la ley, estima digna de represión, se abstendrá de todo procedimiento sobre ella y expondrá al Gobierno las razones que le asistan para creer que debiera ser objeto de sanción penal.

3- Del mismo modo acudirá al Gobierno exponiendo lo conveniente sobre la derogación o modificación del precepto o la concesión del indulto, sin perjuicio de ejecutar desde luego la sentencia, cuando de la rigurosa aplicación de las disposiciones de la ley resulte penada una acción u omisión que, a juicio del juez o Tribunal, no debía serlo, o cuando la pena sea notablemente excesiva, atendidos el mal causado por la infracción y las circunstancias personales del reo."

${ }^{137}$ J. PRADEL, Manuel de droit pénal général, Cujas, 2002, (14 éd), p. 168. El juez penal no puede apreciar la constitucionalidad de una ley. El abogado general VOYSIN DE GARTEMPE en sus conclusiones sobre el recurso de casación, el cual originó la sentencia del 11 de mayo de 1833, (S. 1833.I.357) sostuvo que: "el derecho de los tribunales se limita a la aplicación de las leyes, su deber es ejecutarlas, aunque sean deficientes."

138 M. LACAZE, Réflexions..., p. 157. J. PRADEL, Manuel..., op. cit., p. 174, nota que la sala de lo criminal de la Corte de Casación ha decidido expresamente adoptar las interpre- 


\section{PARTE I: APROXIMACIÓN AXIOLÓGICA Y ESTRUCTURAL...}

\section{3- Razones relacionadas con el sistema}

Se trata en primer lugar de una falta de definición uniforme de la infracción en Derecho penal francés. Si las nociones de infracción y de elementos de la infracción son irreemplazables y han sido consagrados por la codificación de 1992 y la jurisprudencia, ningún artículo de los Códigos franceses jamás ha definido la infracción, ni precisado su contenido. El trabajo de definición de la infracción ha sido pues doctrinal y, a pesar de algunas indicaciones jurisprudenciales, permanece controvertido ${ }^{139}$. Según WALTHER, varias tendencias doctrinales preocupadas por llevar la totalidad del Derecho penal a la persona del agente (Derecho penal del autor) han podido contribuir al debilitamiento de la teorización de la infracción en Derecho penal. La doctrina muy ampliamente subjetivista ha reducido tanto la infracción que se ha visto amenazada de decaimiento en Francia. Forzoso es, por tanto, constatar que no hay en Francia definición legislativa o jurisprudencial de la infracción, y ni siquiera un consenso doctrinal para proponer una. Una de las consecuencias indirectas de esta ausencia de definición de la infracción es que el conjunto de la doctrina francesa descuida la otra faceta de la antijuridicidad que es la referencia a normas meta-jurídicas ${ }^{140}$ y a los bienes jurídicos, protegidos por el Derecho penal y sus incriminaciones ${ }^{141}$.

taciones del Consejo Constitucional (Cass. crim. 25-04-1985, 2 arrêts, JCP., 1985.II.20465, concl. DONTENVILLE y nota W. JEANDIDIER.). Así, las ideas del Consejo Constitucional pueden pasar en la jurisprudencia penal. Como ya hemos visto que el control que hace el Alto tribunal es mínimo sobre el acto legislativo, el margen de interpretación del juez penal se verá más reducido.

139 K. AMBOS, Observaciones a la doctrina francesa del hecho punible desde la perspectiva alemana, Indret, julio 2008, no 3/2008, disponible en: http://www.indret.com. Destaca el autor que para analizar la teoría del hecho punible en derecho penal francés hay que partir de la premisa de que en esta materia reina "un grand désordre". En efecto, al repasar la doctrina francesa, observa siete tendencias doctrinales que intentan conceptualizar la teorías de los elementos del hecho punible.(pp.4, 5)

140 J.-H. ROBERT, L'histoire..., op. cit., pp.277, 278. El autor lamenta que los esfuerzos de introducir el elemento injusto y su equivalente Unrecht no han sido seguidos por los autores después de GARRAUD. Según el autor, los trabajos de este último constituyen, a ellos solos, un importante período de la doctrina porque entre 1881, fecha de la primera ed. de su manual y su muerte, en 1930, se han hecho quatorce ediciones de este manual y tres ediciones de su tratado. Era GARRAUD el que por primera vez en la doctrina francesa se había inspirado de los trabajos de BINDING para defender que la norma penal tiene como función de sancionar otra norma, extra-penal y que establece para los ciudadanos una obligación o una prohibición de manera a imponerles el respeto de un interés legalmente protegido.

141 J. WALTHER, $L$ 'antijuridicité..., op. cit, pp. 141, 142. Efectivamente hay excepciones tales como Y. MAYAUD, “Ratio legis...”, p.598, quien continuó su análisis para llegar a la "ratio legis" clasificando según los intereses amenazados o defendiendo incluso el interés de la noción de bienes jurídicos; J.-H. ROBERT, Droit pénal général, op. cit., pp. 222 y ss.; K. AMBOS, Observaciones..., op.cit., p.14, ve en PIN la única excepción dentro de los autores de manuales quien hace la distinción entre la ilicitud material e ilicitud formal ("illicéité matérielle et formelle") y quiere distinguirla en función de la violación de un interés protegido y el equilibrio entre el interés atacado y el interés salvaguardado; X. PIN, Droit pénal général, Dalloz, Paris, 2005, no 193. 
En segundo lugar cabe señalar una razón relacionada con la evolución del Derecho penal general. Doctrina y jurisprudencia, según la constatación de WALTHER, han preferido teorías más subjetivistas de la responsabilidad, lo cual ha tendido a la reducción cada vez más acusada de la parte objetiva. Las reticencias respecto de esta tendencia son evidentes, puesto que una teoría objetiva de la infracción ofrece garantías inestimables ${ }^{142}$. Precisa DOUCET, en este sentido, que "la teoría de la infracción (...) presenta, ella también, este carácter (abstracto), que constituye un nuevo amparo contra lo arbitrario. De esta manera parece que la primera fase del razonamiento penal es por naturaleza objetiva y abstracta"143. Y concluye WALTHER que el Derecho francés no destaca la noción de infracción, y, por lo tanto, la antijuridicidad no ha podido inevitablemente desarrollar su papel. El delincuente al ser esencial, se entiende la preeminencia de causas subjetivas de irresponsabilidad sobre hechos justificativos objetivos ${ }^{144}$.

Se ha pronunciado en este mismo sentido LACAZE en su estudio y señala que si la ausencia de reconocimiento verdadero de un concepto formal de bien jurídico en Francia parece poder explicarse por la posibilidad técnica de recurrir a otras nociones para resolver los problemas que se plantean al jurista, la ausencia de una concepción material del bien jurídico parece, sin embargo, mucho más significativa. Si el Derecho francés no considera positivamente dotarse de un concepto que promete delimitar a priori el campo del Derecho penal, es que sin duda no lo desea y entiende, al contrario, la infracción ante todo como una lesión a la ley ${ }^{145}$.

\section{B-EFECTOS}

Como se ha constatado que el elemento injusto figura únicamente en la construcción doctrinal de algunos escasos autores franceses, WALTHER sugiere la posibilidad de introducir este elemento en la construcción francesa de la infracción ${ }^{146}$. En su argumentación al respecto, el mismo autor destaca que se ha calificado el Derecho penal como una rama que tiene un contenido normativo implícito tras un contenido descriptivo aparente. Este contenido normativo implícito tiene una triple función para la puesta en marcha de la represión de toda infracción: calificación, ilicitud e imputabilidad. Si bien la calificación es la primera operación que debe hacer la autoridad penal, esto es la relación de identidad entre la acción y el tipo penal, ella no se podrá efectuar teniendo únicamente en cuenta la forma legal. Cabe, a menudo, agregar con ello una reflexión

\footnotetext{
142 J. WALTHER, $L$ 'antijuridicité..., op cit, pp. 143.

143 J.-P. DOUCET, Précis de droit pénal général, éd. Faculté de Liège, 1976, p. 47. Sin embargo, AMBOS matiza esta postura, al estudiar el elemento moral de la construcción francesa y destaca que "la posición objetiva debe ser rechazada, porque algunos tipos penales no pueden ser explicados sin la dimensión subjetiva." (K. AMBOS, Observaciones..., op. cit., p.12)

${ }^{144}$ J. WALTHER, $L$ 'antijuridicité..., op. cit, pp. 145.

145 M. LACAZE, Réflexions..., op. cit., p.120.

${ }^{146} \mathrm{~J}$. WALTHER, L 'antijuridicité... op cit, pp. 178.
} 
sobre lo que el legislador pretende proteger por la incriminación. Se pregunta el autor sobre la posibilidad de elegir entre las diferentes incriminaciones, como en la hipótesis a veces compleja de las calificaciones múltiples sin recurrir a la voluntad de protección subyacente a la forma, esto es, el elemento injusto como referencia al bien jurídico protegido. El descuido al colocar propiamente las incriminaciones y las sanciones en su contexto normativo más amplio y en un corpus de reglas generales agravará el fenómeno paradójico siguiente: una profusión de incriminaciones de circunstancias, una inflación penal acompañada de una "anomia" sustancial, en pocas palabras, sanciones sin fundamento normativo general sólido ${ }^{147}$. En este sentido advierte el autor que hay un doble fundamento constitucional y sistemático en la exigencia de limitar las incriminaciones penales a lo necesario: no hay que desafilar el arma más poderosa del Derecho por una profusión abusiva de textos sancionadores de circunstancias. Esos textos reducen efectivamente el Derecho penal al papel poco glorioso de "simple gendarme del Derecho", de ejecutor de viles tareas. De ello resultan dos consecuencias. Por un lado, eso debilita el conjunto del sistema jurídico, y desliza los valores, su posición relativa, en "una cuesta empinada"; por consiguiente aparece una confusión entre lo importante y lo benigno en la mente del justiciable. Por otro lado, cabe asistir, ni más ni menos, a la destrucción del Derecho penal general. Resulta de ello una situación absurda, una profusión de Derechos penales especiales con regímenes también especiales. Pero estos últimos no pueden funcionar sin los conceptos del Derecho penal general ${ }^{148}$. Se pregunta DELMAS-MARTY: “¿qué decir, en efecto, de un Código penal renovado, modernizado, aclarado, pero cuya parte especial - o sea el catálogo, la lista de las infracciones - sería doblado de un "Derecho penal salvaje" que obedece a su propia lógica o que no obedece a ninguna lógica perceptible?"149. Añaden MERLE y VITU que "el Derecho penal especial tiende a predominar en muchas campos sobre el Derecho penal general. La síntesis elaborada por los grandes penalistas clásicos está diluyéndose en análisis particularistas. Lo que ciertamente no marca un gran siglo jurídico. La predominancia de las reglas de excepción sobre las reglas de principio en

147 Ibídem, op. cit., p.177; C. FAURE-GAUSSEL, Droit pénal des affaires, op. cit., p.45, no 74 , la autora destaca la actitud del legislador francés en cuanto al respeto del principio de la intervención mínima y de la última ratio del derecho penal. Efectivamente esta actitud se puede explicar por la ausencia del concepto de bien jurídico al momento de diseñar los tipos penales o incriminaciones. Entender lo que se pretende proteger ayuda en el respeto de esos principios. Es la función de garantía del bien jurídico, desarrollada por la doctrina española como se ha estudiado arriba.

148 J. WALTHER, $L$ 'antijuridicité..., op. cit, pp.382. Recalca el autor que la necesidad de reservar una sanción penal a los valores más dignos de protección atañe tanto a un principio de economía juiciosa de medios jurídicos como a exigencias de la legalidad criminal, entendiendo aquí a la vez precisión en la redacción del texto y concisión, concisión ejercida en las selecciones de los intereses a proteger, es decir en el mismo sentido donde apunta tal texto (p.381).

149 M. DELMAS-MARTY, "L'enjeu d'un Code pénal, réflexions à propos de l'inflation des lois pénales en France», Mélanges Legros, éd. de l'Université de Bruxelles, 1985, pp. 165 y ss (sobre todo p.167). 
una legislación, no es ni señal de salud, ni señal de seguridad para los justiciables"150.

Repasando, aun por encima, el Derecho penal positivo francés, LACAZE detalla los efectos de una concepción formal de la infracción. Sería interesante poder estudiarlos aquí con los detalles pertinentes, pero eso superaría el límite del presente trabajo con lo cual resumiríamos los grandes puntos ${ }^{151}$.

\section{1- Efectos en las condiciones de la represión}

Se trata aquí de ver la manifestación de la concepción francesa del delito como violación de la ley. En materia de tentativa y de complicidad, esta concepción rechaza la gradación del injusto, y lo mismo en materia de concurso de delitos que casi no se toma en cuenta la multiplicidad de los bienes jurídicos afectados.

En efecto el artículo 121-4 del Código penal francés (CPF) estipula que "es autor de la infracción la persona que $1^{\circ}$ comete los hechos incriminados, $2^{\circ}$ intenta cometer un crimen o, en los casos previstos por la ley, un delito" y en el artículo 121-6 "será castigado como autor el cómplice de la infracción." Resulta de estos artículos que en Derecho francés, el autor de una tentativa punible incurre la misma pena que el autor de la infracción consumada correspondiente, lo que demuestra cierta indiferencia en cuanto a la gravedad de la lesión sufrida por el bien jurídico y que el cómplice incurre en la misma pena como si fuera el mismo culpable del delito, puesto que el carácter indirecto de la lesión al bien jurídico no tiene consecuencia ${ }^{152}$.

Por otra parte el principio previsto por el CPF de 1992 es el cúmulo de las penas para los crímenes (delitos graves) y delitos (delitos menos

\footnotetext{
${ }^{150}$ R. MERLE et A. VITU, «Traité de Droit criminel, problèmes généraux de la science criminelle, Droit pénal général », Tome I, Cujas, 1997, (7 éd.) no 382. Estos autores son conscientes del declive contemporáneo del derecho penal general francés. Lamentan el poco número de reglas comunes reunidas en la parte "general" del código penal.

151 M. LACAZE, Réflexions..., op. cit., pp.121 y ss.

152 Ibídem, op. cit., pp.122 y ss. La autor explica que hay que determinar el objeto de protección de la infracción. Si se considera que su objeto de protección es el bien jurídico concreto, la infracción simplemente tentada no lo lesiona y entonces desprovisto de resultado (concreto). En cambio, si se considera que el objeto de protección es la ley, la infracción tentada conlleva en sí misma ese resultado (abstracto), puesto que el comienzo de ejecución ya es una violación de la ley. Se trata aquí de castigar un riesgo para el bien jurídico. Sin embargo, parece más significativo todavía la posibilidad de castigar las infracciones llamadas "imposibles". Una concepción material basada sobre el bien jurídico consideraría la impunidad del "asesinato" de la victima ya muerta o el robo en un bolsillo ya vacío por ausencia del bien jurídico. Pero en derecho francés se admite la represión de la infracción imposible como tentativa aun en el caso de ausencia del bien jurídico concreto lo cual afirma una concepción de la infracción como violación de la ley. En cuanto a la asimilación del cómplice al autor es evidente que el derecho francés rechaza tomar en cuenta la naturaleza del vínculo que une el cómplice al bien jurídico. Se ha considerado que el cómplice sabía que favorecía la comisión de una infracción, de ahí ha querido violar la ley, al igual que el autor principal.
} 
graves), salvo penas de la misma naturaleza de las cuales sólo una puede ser pronunciada "en el límite del máximum legal más elevado". La solución de este código podía ser analizado como la señal de una indiferencia total a la multiplicidad de bienes jurídicos lesionados por la infracción; no importa que estos sean de naturaleza jurídica diferente o igual ${ }^{153}$.

\section{2- Efectos en las causas de justificación}

Aunque se ha tratado de elaborar una concepción francesa de "elemento injusto", la noción francesa del delito como violación de la ley contempla el hecho justificativo como conflicto de normas y se muestra extremadamente reticente ante los justificativos extra-legales.

En efecto se resalta entre las causas objetivas de responsabilidad la preeminencia de la autorización legal. El artículo 122-4 al.1 del CPF estipula que "no es penalmente responsable la persona que cumple un acto prescrito o autorizado por disposiciones legislativas o reglamentarias". La autorización legal es un justificativo general. Se nota aquí que se trata de conflicto de leyes. No se trata de dos bienes jurídicos o dos valores sociales que entran el conflicto sino dos normas: una debe borrarse ante otra. No es cuestión de ponderación de intereses sino de conflicto de leyes ${ }^{154}$. En cuanto al estado de necesidad y la legítima defensa, considerados como "casos particulares de autorización de la ley", es innegable su fundamento material ${ }^{155}$, hasta convertirlos en justificativos generales por la doctrina y la jurisprudencia. Sin embargo la balanza de intereses en beneficio del interés preservado no es la condición única del estado de necesidad y cabe duda si esta causa justificativa es realmente dominada por esta idea. Además, existen restricciones legales al respecto. Entre otras es el hecho de que no haya ninguna referencia ni a bienes jurídicos ni a la noción de antijuridicidad o ausencia del elemento injusto sino al contrario se hace hincapié en la conducta. El artículo 127-7 apunta "el acto necesario para la salvaguardia de la persona o del bien": no se trata de una ponderación entre los resultados posibles sino entre "los medios empleados y la amenaza". Otra restricción, según ROBERT, es que el texto no ha previsto sino la defensa de la persona y de los bienes, con lo cual el estado de necesidad o la legítima defensa no podría ser invocado en la protección de la seguridad del Estado y del medio ambiente por ejemplo ${ }^{156}$. LACAZE deduce que el hecho

\footnotetext{
153 M. LACAZE, Réflexions..., pp.130 y 131.

154 Ibídem, op. cit., p.136. La previsión del texto de la impunidad del acto mandado o permitido por la ley puede parece superfluo, pero la lógica del derecho francés entiende que el legislador no puede sancionar de un lado lo que ha prescrito o permitido por otro lado.

${ }_{155}$ Ibídem, op. cit., p.137. Recuerda la autora el fundamento material del estado de necesidad, cuando "bajo el efecto de la necesidad, el agente elige salvaguardar un bien cuyo valor es superior al del bien sacrificado, o incluso en último extremo un bien de valor equivalente".

156 J.-H. ROBERT, Droit pénal général, op. cit., p.259. Señala que desde la promulgación del nuevo código penal, la legítima defensa no permite más proteger interés otros que
} 
justificativo no haría referencia al concepto genérico de bien jurídico sino al contrario excluiría los bienes jurídicos "colectivos"157.

Estrictamente enmarcada por la ley, la justificación es limitada en Derecho francés y la jurisprudencia se niega a menudo a justificar una conducta que podría ser justificada desde el punto de vista de la ponderación de los intereses, pero que no corresponde a ningún hecho justificativo textual. Esta situación sufre escasas excepciones en virtud del principio de la especialidad de las causas de irresponsabilidad el cual admite muy excepcionalmente causas justificativas extra-legales ${ }^{158}$. Pero, en general, la costumbre no puede ser hecho justificativo general a menos que la ley la haya previsto o que tal costumbre se manifieste en una ley civil, con lo cual el hecho justificativo de autorización de ley interviene implícitamente. Por otro lado, se ha rechazado el consentimiento de la víctima como justificativo, es indiferente, alegando que una voluntad individual, no importa que sea de la víctima, no podría en ningún caso neutralizar los efectos que la voluntad general ha deseado atribuir a una conducta prohibida ${ }^{159}$.

A pesar de esta falta de consideración del elemento injusto y sobretodo de la antijuridicidad material, se debe relativizar la ausencia del concepto de bien jurídico en la dogmática penal francesa.

\title{
II-Supervivencia del concepto de bien jurídico
}

\author{
A-PREMISA DEL PLANTEAMIENTO
}

El Estado castiga para proteger ciertos bienes, ciertos valores. Eso es uno de los fundamentos del Derecho penal. Partiendo de la pregunta

la integridad de las personas y la conservación de los bienes, tales como medio ambiente o seguridad del Estado: el art.122-5 no es en efecto un texto particular, sino un texto que enuncia un principio y le asigna al mismo tiempo límites, la defensa de las personas y de los bienes. Así, no se admiten a ciudadanos a alegar la legítima defensa del medio ambiente para ocupar fábricas contaminantes e interrumpir su funcionamiento, (...); la protección de estos intereses pertenecen exclusivamente a las autoridades públicas. Los ciudadanos ordinarios, no por ello, son privados del derecho de implicarse en estos asuntos, ya que disponen del derecho constitucional de manifestación.

157 M. LACAZE, Réflexions..., op.cit., p.139.

158 Ibídem, op. cit., p.140. por ejemplo en materia de abuso de bienes sociales o de difamación de buena fe.

159 Ibídem, op. cit., pp.142, 143. Comparando con el sistema alemán o español del consentimiento justificativo, cuando se trata de bienes jurídicos personales, el consentimiento de la víctima tiene un efecto justificativo en cuanto el bien jurídico es disponible con alguna condición. El titular del bien jurídico puede entonces justificar la lesión a un bien jurídico disponible como la integridad física pero no la lesión a un bien jurídico indisponible como la vida. Concluye la autora que la doctrina ( P. CONTE , P. MAISTRE DU CHAMBON, Droit pénal général., Coll.Sirey, Armand Collin, 2004, (7 éd), p.159, n²77, F. DESPORTES y F. LE GUNEHEC, Droit pénal général, coll. Corpus droit privé, Economica, , 2008, (15 éd.), pp. 690-692, no 714, saluda la posición francesa y subraya que el derecho penal es de orden público, sería inconcebible que un interés particular justifica la lesión del interés general que constituye la infracción. 
“ipor qué castigar?” que se conteste que se quiere disuadir directamente o proteger ciertos valores indirectamente, incluso asociar estas dos finalidades, admite WALTHER que siempre queda por definir el destinatario de la regla (penal): ¿los profesionales del Derecho, el juez, el justiciable? La respuesta tiene una consecuencia muy importante. Nota el mismo autor que aceptar en el Derecho francés la idea de función preventiva del Derecho penal supone la accesibilidad y la inteligibilidad como objetivos de valor constitucional ${ }^{160}$. Pero hay que darse cuenta que este primer objetivo está condenado a permanecer quimérico dado el número increíble de calificaciones penales existentes. En cambio, si la accesibilidad se hace difícil por la inflación penal, la inteligibilidad de la prohibición saldría fortalecida de una infracción definida objetivamente. Reforzar el carácter objetivo de la infracción es hacer que su comprensión esté menos sujeta a una apreciación forzosamente subjetiva, menos tributarias de las idiosincrasias individuales ${ }^{161}$. En este sentido se ha pronunciado VERHAEGEN para quien no importa la complejidad de los factores que llevan a un legislador a incriminar (cabe entender tipificar) un acto, dado que lo que él pretende en todo caso es disuadir al justiciable; el acto considerado indeseable es el acto que conlleva cierto potencial de lesión o de peligro, suficiente en todo caso para merecer sanción penal. Añade el mismo autor que la realización efectiva de tal tipo de lesión causada por la conducta prohibida exigida para reprimir se explica para limitar en la elección del legislador, es decir, como elemento "selectivo" destinado a reducir la represión al estricto mínimo indispensable ${ }^{162}$. Esta preocupación por la objetividad de la infracción encuentra su respuesta en su componente objetivo reforzado por la antijuridicidad, la cual ha sido considerada como material, objetiva y valorativa ${ }^{163}$. Efectivamente la reflexión francesa sobre el fundamento de la norma no ha sido tan desarrollada como en la doctrina alemana o española pero se puede considerar que el "por qué" de la norma es recurrente en todo paso del estudio de un delito. Constata WALTHER que hay surgimiento de la norma porque se siente la necesidad de proteger

160 Es una exigencia del Consejo Constitucional francés, Cons. Const., 16-12-1999, nº 99-421 DC., « Loi portant habilitation du Gouvernement à procéder, par ordonnances, à l'adoption de la partie législative de certains codes ». Precisa el Alto tribunal que el Gobierno podía acudir al artículo 38 de la Constitución, dado el interés general que se relacionaba con la finalización de los nueve códigos y el volumen del orden del día del Parlamento..., "(...) esta finalidad responde, por lo demás, al objetivo de valor constitucional de accesibilidad y de inteligibilidad de la ley (...)". Decisión disponible en la red: http://www.conseil-constitutionnel.fr .

161 J. WALTHER, L 'antijuridicité..., op. cit., pp. 373, 374.

162 J. VERHAEGEN, "Le fait qualifié infraction », Mélanges LEGROS, éd. de l'Université de Bruxelles, 1985, pp.749 y ss., ver pp.750, 751. Precisa el autor que al repasar la descripción de las diversas conductas prohibidas, se constata que todos son esencialmente caracterizadas por una lesión que esas conductas causan o son susceptibles de causar a intereses públicos o privados. La descripción de los hechos se refiere a menudo a circunstancias cuya conjunción hace que el hecho sea perjudicial o suficientemente perjudicial para merecer la sanción penal. En definitiva, concluye el mismo autor que no importa la forma incriminación retenida, es siempre la lesión o la puesta en peligro creadas por un comportamiento humano lo que se queda en el centro de las preocupaciones del legislador, cuando prohíbe, autoriza o manda.

163 J. WALTHER, L 'antijuridicité..., op. cit., p. 374. 
un bien jurídico y la protección de éste último viene de la norma y de su sanción por las reglas jurídicas. Concluye LACAZE que el bien jurídico, entendido como un concepto material, podría ser un criterio de determinación del Derecho penal en el sentido de que podría reafirmar la exigencia de una legitimidad material de la ley y la necesidad de un marco del derecho de castigar. Al exigir que el Derecho penal persiga una finalidad de protección de bienes jurídicos, los cuales son definidos como una emanación de valor, se puede salir sin duda del posicionamiento acrítico generalmente defendido por la doctrina penal francesa. Sin embargo, en lugar de ostentar una neutralidad axiológica de fachada que puede conducir, por ceguera ideológica, a la legitimación de cualquier contenido normativo, incluso autoritario o totalitario, cabe preferir asumir la defensa de una concepción material del Estado de Derecho y la adhesión a un Derecho penal liberal que debe asegurar su supervivencia ${ }^{164}$. Los términos utilizados por la jurisprudencia y doctrina francesa no deben inducir a error: ambas hablan de valores, intereses y de bienes jurídicos, los tres términos parecen, en Francia, abarcar la misma noción, a semejanza de lo que se encuentra en el caso de la antijuridicidad y la ilicitud ${ }^{165}$. Aunque el bien jurídico no ha sido teorizado, es innegable que, definido como el objeto de protección del Derecho penal, exista en el Derecho francés. El estudio de este objeto de protección podrá, sin duda, entonces, enseñar mucho sobre sus presupuestos teóricos y filosóficos ${ }^{166}$.

\section{B-SUPERVIVENCIA EN LA DOCTRINA PENAL FRANCESA}

Como ya se ha dicho el concepto de bien jurídico no ha sido objeto de teorización pero ello no significa que la idea esté ausente dentro de la doctrina. Sin mencionar a GARRAUD, a quien hemos citado en apartados anteriores, podemos repasar el uso que han hecho algunos autores de la idea de valor o de interés protegido, fundamento del Derecho penal. En este sentido se ha pronunciado el Decano CARBONNIER en su comentario sobre la sentencia de la Corte de Casación del 29 de junio de $2001^{167}$. En efecto, hace transparentarse cierta gradación en la percepción y el tratamiento jurídico de lo que es digno - o susceptible de la dignidad - de la protección penal. Hablando de la vida, a la vez el más bello y el más complejo de los ejemplos, el Decano CARBONNIER precisa que "...la vida es suficiente en su desnudez biológica, vista como un fenómeno, como una esencia, un valor o incluso un derecho subjetivo". De la simple percepción cognitiva de la vida como fenómeno a la expre-

\footnotetext{
164 M. LACAZE, Réflexions..., op. cit., pp. 34 y 35.

165 J. WALTHER, $L$ 'antijuridicité... op. cit., p. 375.

166 M. LACAZE, Réflexions..., op. cit., p. 34. Aunque matiza la autora que si bien es cierto que las diferentes manifestaciones no sean coherentes y parece poco probable que se consiga sacar un verdadero concepto, francés, del bien jurídico protegido por el derecho penal, ellas podrán sin duda por lo menos aclararnos sobre los fundamentos y la finalidad de ése.

167 Citado por el consejero y vocal Pierre SARGOS, «L'enfant à naître peut-il être victime d'un homicide involontaire? ? rapport Ass. Plén. 29-06-2001, JCP, éd. G., 2001, II, 10569 .
} 
sión de la protección penal por el Derecho, precisamente penal en este caso - por el ejercicio de un derecho subjetivo - , pasa por la esencia, entendida aquí por la descripción filosófica y moral, y el valor, entendido como el umbral de la moral al Derecho. De manera concisa el autor ha formulado la gradación que conduce al bien jurídico, objeto indirecto e implícito de la incriminación - ejercido como derecho subjetivo ${ }^{168}$, ya que éste se entiende como un interés jurídicamente protegido. Analizando esta postura, destaca WALTHER que la vida - y el respeto a la vida - es en primer lugar un principio abstracto, un valor que puede ser expresado en un interés que proteger, esto es, un bien jurídico protegido. Efectivamente, aunque el planteamiento parece partir de una buena base, el hecho de que no pudiese profundizarse en la reflexión, impidió el matiz que se debe de hacer al mencionar el derecho subjetivo como equivalente del valor o del interés como sustrato del bien jurídico ${ }^{169}$. Pero desde luego, precisará el mismo autor que lo que está en juego en la discusión sobre el bien jurídico parece menos referirse a la denominación a dar a este concepto que a las elecciones de lo que conviene proteger y a la construcción de un sistema que articule de manera satisfactoria estos conceptos ${ }^{170}$.

Si la doctrina alemana y española está de acuerdo en que el papel del Derecho penal es la protección auxiliar de los bienes jurídicos en virtud del principio de subsidiariedad, el Derecho francés también sugiere un planteamiento en el mismo sentido. SALVAIRE defiende que "a pesar de una profunda unidad, el Derecho penal no protege un orden público abstracto y formando bloque, sino cierto número de intereses bien definidos: seguridad del Estado, paz social, libre ejercicio del trabajo, inte-

\footnotetext{
168 J. WALTHER, $L$ 'antijuridicité... op. cit, pp. 376, 377. El autor señala que la indisociabilidad entre los bienes jurídicos y los derechos subjetivos apareció ya desde BINDING quien sostuvo que "todas las lesiones contra los derechos subjetivos se realizan por una lesión contra los bienes jurídicos y son impensables sin ellos." Sin embargo hemos destacado en el marco del estudio del bien jurídico en la doctrina español que toda tentativa para confundir o igualar bien jurídico y derecho subjetivo es de rechazar. Sin embargo, BINDING reconoce en última instancia que lo se lesiona con el delito no es la norma ni el mencionado derecho subjetivo sino el bien jurídico, que expresa concreta, material y objetivamente lo que realmente se lesiona o pone en peligro por la acción delictiva. Vid H. HORMAZÁBAL MALARÉE, Bien jurídico..., op. cit., pp.33-41.

169 Con razón sostiene LACAZE que la doctrina penal mayoritaria en Francia está arraigada en los preceptos positivistas y marcada en su vínculo profunda con el derecho penal resultante de la Revolución y de ahí la persistencia de las teorías del contrato social como fundamento del derecho penal "moderno". Lamenta la autora que a partir de ahí no se operó ninguna evolución de la doctrina penal francesa (M. LACAZE, Réflexions..., op. cit., p. 170). Estudiando los trabajos de FEUERBACH, estos tienen como premisa la limitación de las prohibiciones legales sólo a "las acciones perjudiciales a la sociedad" y ello con referencia a la lesión de un derecho subjetivo. La consideración material del delito como una lesión de un derecho no es más que la expresión de la teoría del contrato social en el derecho penal: los hombres ante la inseguridad que supone vivir aislados, deciden organizarse en sociedad y confiar al Estado la conservación del nuevo orden creado. Entonces el Estado se erige como garante de las condiciones de vida en común (Vid H. HORMAZÁBAL MALARÉE, Bien jurídico..., pp.1117).

${ }^{170}$ J. WALTHER, L 'antijuridicité... op. cit., p.377.
} 
gridad de las personas físicas, respeto debido a la infancia, salvaguardia de la propiedad, salud pública, conservación del dominio vial, protección de los emplazamientos, etc."171

Si es cierto que la terminología utilizada puede ser más fluctuante, pero la misma idea de valores protegidos, de intereses lesionados por los actos delictivos no puede ser contestada. Y aunque controvertida ${ }^{172}$, afirma WALTHER, la noción específica de bien jurídico no es desconocida en Francia y cuenta con cierto número de partidarios ${ }^{173}$. Uno de ellos es el profesor ROBERT quien da al interés protegido, pues al bien jurídico, un papel central en su construcción doctrinal. Así empieza un capítulo de su manual: "Cuando el legislador incrimina una conducta, es para imponer a los ciudadanos el respeto de un valor social que considera particularmente valioso. Se lo llama el interés protegido y reviste la incriminación de la "necesidad" requerida por el artículo 8 de la Declaración de los Derechos Humanos"174. Como el Consejo Constitucional reconoce que la Declaración de los Derechos Humanos forma parte del "bloque de constitucionalidad"175, podemos sacar que habría, para el autor, una exigencia constitucional de necesidad de reservar la sanción penal a los valores más eminentes del ordenamiento jurídico.

171 J. SALVAIRE, «Le concours idéal de contraventions », JCP éd. G. 1960, I, 1588.

172 J.Y. MARÉCHAL, "Essai sur le résultat dans la théorie de l'infraction pénale», L'Harmattan, 2003, p.85. Según el autor no cabe duda de que se trata de un pleonasmo puesto que la palabra "bien" tiene una acepción exclusivamente jurídica y designa una cosa aprehendida por el derecho, cuando el bien posee una naturaleza corporal, o, por extensión, derechos sobre una cosa, cuando el bien es incorporal. 0 sea, no puede haber bienes "no jurídicos". Además el eso del término "bien" se revela en sí mismo inadecuado porque el bien del que se habla ni es una cosa, ni un derecho y no es susceptible de apropiación. Aparece, de manera inmediata que el uso de un vocabulario tan mal adaptado, fuente de ambigüedad y de confusión, deja mal augurar del interés de la noción como herramienta de razonamiento.

173 J. WALTHER, L 'antijuridicité..., op cit, pp.380, 381.

174 J.-H. ROBERT, Droit pénal général, op. cit., p.221. El autor destaca el beneficio de la existencia de un interés protegido por la ley penal. Destaca que utilizando este concepto es posible clasificar las incriminaciones según el valor social del que el legislador ha deseado la protección. Señala también que los frutos interesantes y más prácticos de la noción de bien protegido está en la explicación de una familia de causas objetivas de exoneración: tienen como rasgo común el hecho de beneficiar a acusados que, aunque aparentemente hayan consumado un hecho delictivo, no merecen ser declarados culpables porque han actuado en circunstancias en que el interés que inspira la incriminación no merece más la protección legal o bien no existe en absoluto. En última instancia, había que recurrir a la noción de interés protegido para resolver la situación que se presenta cuando una misma persona, por el mismo gesto, realiza la conducta descrita en dos o varios textos de incriminación a la vez: el contenido de la declaración de culpabilidad varía, depende de si esos diversos textos tienden o no a la conservación del mismo valor social.

175 Cons. Const. 11-08-1960, no 60-8 DC, Cons. Const. 16-07-1971, no 71-44 DC, Cons. Const. 27-12-1973, $n^{\circ}$ 73-51DC, Cons. Const. 15-01-1975, no 74-54 DC, Cons. Const. 1601-1982, no 81-132 DC, Cons. Const. 28-04-2005, no 2005-514 DC, Cons. Const. 27-072006, $n^{\circ}$ 2006-540 DC. 
Si a la doctrina le incumbe darle un contorno teórico al concepto de bien jurídico, este mismo concepto servirá al legislador en el momento de la elaboración de la reglas penales.

\section{C-SUPERVIVENCIA DEL CONCEPTO EN EL TRABAJO LEGISLATI-} VO

Antes de ver la manera en que, a pesar de su falta de teorización doctrinal y su falta de reconocimiento, el concepto del bien jurídico se refleja en el trabajo del legislador, hay que resolver la cuestión de su selección. Para ello, es particularmente llamativo el artículo de DARGENTAS quien defiende que el legislador procede a una evaluación de valores y de intereses. En este sentido, se trata de la afirmación del carácter voluntarista de la prescripción de los bienes jurídicos. Existe una valoración axiológica sobre lo que parece ser digno de protección penal. Por lo tanto, parece evidente que es el legislador el que fija el contenido de los bienes jurídicos. Así, esta valoración precede a la obligación de respetar los bienes jurídicos. Hay que admitir, según el autor, que el legislador penal, en el momento de la creación de la norma se encuentra ante una multitud de valores o intereses. En función de su eventual capacidad de contribuir al progreso social o a la seguridad de la vida en común de los hombres en sociedad, habrá valores e intereses que contribuyan a esta "comunicación axiológica"176. Lamenta el autor que la falta del estudio sobre el elemento injusto que apunta hacia una valoración objetiva y abstracta haya impedido la introducción de ese elemento axiológico, tan útil, entre otras cosas, para una construcción armoniosa de los justificativos de la infracción ${ }^{177}$.

Sin embargo, podemos ver el esfuerzo del legislador francés para reconocer la necesidad de elemento axiológico en su clasificación tripartita de la infracción. LACAZE afirma que está adquirido que existe una jerarquía, por un lado, entre crímenes (delitos graves) y delitos (delitos menos graves), los crímenes son los que lesionan a los valores más importantes, y por otro lado, dentro de cada una de estas categorías. Aunque haya algunas excepciones se puede admitir que la jerarquía de las penas corresponde aproximadamente a la jerarquía de los bienes jurídicos protegidos ${ }^{178}$.

\footnotetext{
176 E. DARGENTAS, «La norme pénale et la recherche autonome des valeurs dignes de la protection pénale », Revue pénitentiaire et de droit pénal, 1977, p. 411 y ss, particularmente ver pp.412, 414, 415. J. WALTHER, $L$ 'antijuridicité... op. cit., pp.383-385, destaca que esta posición puede ser contrastada con otro corriente doctrinal que defiende que los bienes jurídicos no son el resultado de la selección del legislador sino el reflejo de los valores materiales preexistentes a la ley y que sólo el legislador los transpuso en la norma penal. Además aunque hay siempre una influencia de esos valores pre-legislativos, la elección del legislador está siempre y ciertamente condicionado, por parte, por sus concepciones culturales y morales.

177 E. DARGENTAS, «La norme... », op. cit., p.421.

178 M. LACAZE, Réflexion...l, op. cit., pp.184, 185. No es sorprendente que las penas más severas sean incurridas para lesiones graves contra la dignidad humana, la seguridad del Estado, la especie humana y la vida de la persona.
} 
Si es reconocido en la doctrina de inspiración germánica que el bien jurídico es el fundamento de la disposición de las incriminaciones y permite la clasificación en el seno del Derecho penal, esta cuestión también se ha planteado en el Código penal francés, el cual está dividido en diferentes partes directamente en relación con los bienes jurídicos protegidos. Sostiene WALTHER que si toda codificación pasa por un trabajo de clasificación de las incriminaciones (entendamos tipos), la edificación de un código necesita una reflexión sobre lo que se pretende proteger, las elecciones de políticas criminales proceden obligatoriamente de un trabajo de análisis de valores, de prescripción o de selección de bienes jurídicos. Estos puntos son comunes entre ambos sistemas jurídicos y lleva, al autor, a deducir que el concepto de antijuridicidad material está presente de manera subyacente, por equivalencia de funciones, en el sistema jurídico francés ${ }^{179}$. Se puede operar una clasificación horizontal y vertical: es decir, es posible proceder a un esquema con jerarquía. Si se clasifican las infracciones según el mismo principio, es posible hasta ir más lejos al clasificar idénticamente los bienes jurídicos. ROBERT declara que es posible clasificar las incriminaciones según el valor social del cual el legislador ha deseado la protección ${ }^{180}$. Los bienes jurídicos están en el medio del concepto de incriminación y de ahí es una ayuda muy importante en materia de interpretación. Y los autores franceses entienden su utilidad en Derecho penal sobre todo en la parte especial. ${ }^{181}$ En materia de clasificación de las incriminaciones, el Derecho francés también conoce y hace la distinción entre intereses privados e intereses públicos de otra parte, la cual corresponde a nociones como bienes jurídicos individuales y bienes jurídicos colectivos de otra parte en la doctrina alemana y española.

LACAZE demuestra en su trabajo que efectivamente en el momento de la elaboración del nuevo código penal francés el legislador ha operado una jerarquización de los valores. A lo largo de los trabajos parlamenta-

\footnotetext{
179 J. WALTHER, L 'antijuridicité... op. cit., p.390. El autor, sin embargo, manifiesta su insatisfacción en cuanto al Libro V del CPF. Constata que es verdaderamente un "cajón de sastre" sin verdadera lógica inherente. La elección de las infracciones que lo componen parece más bien condicionado por olvidos, correctivos de un legislador vacilante, preocupado por ponerse al día, a la busca y captura de vacíos legales y políticos interesantes para colocar incriminaciones de circunstancias, sin, por tanto, vincularse con lógica del sistema, la indispensable clasificación cuidadosa de bienes jurídicos, valores fundamentales dignos de protección penal. Hay, paralelamente un desorden de incriminaciones nuevas tal como lo describía DELMAS-MARTY, quien afirma la existencia de una producción galopante de leyes penales, una verdadera "anomia" jurídica de fondo (M. DELMAS-MARTY, "L'enjeu d'un Code pénal... », op. cit., pp. 165, 167),

El legislador, añade WALTHER, ya no hace leyes que dan orientación a la sociedad, no pronuncia más lo que es justo y bueno, sino sigue las modas de nuestras sociedades heterogéneas y versátiles. Pero señala también que incluso en Alemania donde reina la doctrina del bien jurídico el legislador se refiere a los jueces, a su "sabiduría", descargando su responsabilidad queriendo que el juez "haga" la ley además de su tarea de decir el Derecho, un verdadero "gobierno de los jueces" fundado sobre la deficiencia de las instituciones legislativas y reglamentarias.

180 J.-H. ROBERT, Droit pénal général, op. cit., p.221.

181 J. WALTHER, $L$ 'antijuridicité..., op. cit., p.391.
} 
rios, se ha reflejado esta voluntad de hacer un código "expresivo de los valores", fundado en una "filosofía de los derechos humanos". Esta voluntad se ha manifestado por una búsqueda más profunda en la elaboración del plan y de los enunciados del CPF a fin de demostrar los "nuevos valores" que debe proteger el código como la libertad y la dignidad de las personas, la solidaridad, el medio ambiente o la justicia social y económica. Por ello, ha invertido de manera notable el orden de la presentación de las incriminaciones para evidenciar una nueva jerarquía de valores: encabezan la parte especial las lesiones a la persona antes de las contra la Nación, el Estado y la paz pública, relegadas a la tercera posición, detrás las lesiones contra los bienes. ${ }^{182}$

Consciente de la utilidad del concepto del bien jurídico en la clasificación que opera el legislador, DOUCET responde a la pregunta sobre si las incriminaciones están concebidas en función de uno o varios bienes jurídicos. El autor sugiere tres reglas que seguir por el legislador para la indicación del interés protegido:

-En primer lugar, el legislador debe apuntar un interés preciso ${ }^{183}$. Sugiere WALTHER que eso corresponde al principio de la legalidad criminal, aplicado al contenido normativo implícito ${ }^{184}$.

-En segundo lugar, el legislador no debe proteger más que un interés a la vez. Aquí DOUCET critica los delitos complejos o compuestos, "modo torpe de resolver un concurso real"185.

-En tercer lugar, el interés jurídico debe ser protegido en sí mismo ${ }^{186 .}$

182 M. LACAZE, Réflexions..., op. cit., pp. 184-187. Señala la autora que el interés del legislador por la función sistemática del objeto protegido no se ha desmentido desde la entrada en vigor del nuevo código. En efecto, en 2001 desplazó de manera simbólica las incriminaciones de interrupción ilegal de embarazo de los antiguos artículos 22311 y 223-12 del CPF hacia el Código de salud pública, al quedarse únicamente en el CPF y en la "puesta en peligro de la persona" la interrupción ilegal de embarazo operada sin el consentimiento de la mujer embarazada. Y más recientemente, y en el sentido de una confirmación de la existencia de un bien jurídico supra-individual relativo a la humanidad, el legislador ha modificado el título I del segundo libro del CPF para añadir, al lado de los crímenes contra la humanidad, un sub-título 2 dedicado a los "crímenes contra el especie humano" para sancionar la eugenesia y el clonaje reproductivo.

183 J.-P. DOUCET, Précis..., op. cit., p. 58. Precisa el autor que esta primera regla resulta de la simple observación que el propio fundamento de una incriminación debe ser perfectamente establecido. Desde un punto de vista legislativo, ¿cómo definir en un segundo o en un tercer lugar los actos perjudiciales y la intención criminal si no se conoce con precisión la meta hacia la cual deben tender? Desde un punto de vista judicial, ¿cómo penetrar el sentido de una incriminación y aplicarlo en su espíritu si el fin al cual responde no está claro?

${ }^{184}$ J. WALTHER, $L$ 'antijuridicité... op. cit,, p.393. Efectivamente, el principio de legalidad criminal aplicado al contenido normativo corresponde a esta exigencia de precisión. Sin embargo, este interés lo define la política criminal o por lo menos le da contorno para ayudar al legislador a precisarlo. Y por ello el bien jurídico es la llave de comunicación entre la política criminal y el derecho.

185 J.-P. DOUCET, Précis..., op. cit., pp.60, 61. 


\section{D-SUPERVIVENCIA DEL CONCEPTO EN EL TRABAJO DEL JUEZ}

El concepto de bien jurídico puede verse en el mecanismo de calificación y de la resolución de conflictos de calificación.

\section{1- El bien jurídico en el mecanismo de calificación}

Se trata aquí de resolver el problema de los modos de selección de la norma apropiada. La doctrina reconoce a los bienes jurídicos su función de interpretación y su papel en la aplicación puntual de la regla penal. El juez alemán o español entiende que los bienes jurídicos son los fundamentos de la clasificación de los tipos, con lo cual toda interpretación teleológica llevará a examinar la intención y las metas del legislador en materia de selección de valores a proteger. Y este proceso lo lleva de manera explícita, contrariamente al juez francés quien hará lo mismo pero con una discreción inquietante para el lector. Acude también a los objetivos de ley penal o ratio legis para su aplicación. ${ }^{187}$ A pesar del papel que se le reconoce a la ratio legis, entiende la doctrina francesa que los bienes jurídicos tienen un rol fundamental para la operación de calificación y de interpretación de la regla penal ${ }^{188}$. PUECH precisa que la calificación se hace también según la naturaleza del interés penalmente protegido al cual el hecho incriminado va a lesionar ${ }^{189}$. El bien jurídico va a proveer dos indicaciones valiosas en materia de calificación: permitirá encontrar uno de los criterios de calificación al contestar así a la pregunta del factor de selección de la regla aplicable y, de otra parte, precisa las condiciones de selección de la calificación. Procederá el juez a la "subsunción" de los hechos al tipo penal descrito y ello con la ayuda del bien jurídico y otros criterios de selección de la premisa del silogismo ${ }^{190}$. Entiende la doctrina francesa que el juez se dejará guiar por el bien jurídico protegido para contestar a las preguntas: ¿qué es lo que se protege por el tipo? ¿Dónde está este tipo? ¿Entre las lesiones contra los bienes, las personas o el Estado? Aquí se ve el papel mínimo del bien jurídico, condicionado por la meta proseguida por el legislador al dise-

\footnotetext{
186 Ibídem, op. cit., p.61. Precisa el autor que la ley, por naturaleza abstracta, general e impersonal, debe incriminar en las condiciones conformes a su naturaleza. Sucede, a menudo, que el legislador olvida esta tercera regla y distingue en el nivel de la incriminación según la gravedad de la lesión ocasionada por la violación del interés protegido.

187 M. GAËTAN DI MARINO, «Recours aux objectifs de la loi pénale pour ce qui est de son application », Revue de science criminelle et droit pénal comparé, 1991, pp.505 y ss. Y. MAYAUD, "Ratio legis...", op. cit., p.608. El autor declara que es todavía sobre la ratio legis que descansan numerosas interpretaciones. Se puede decir incluso que es el aspecto más desarrollado de sus servicios, el cual ha sido reconocido.

188 M. LACAZE, Réflexions..., op. cit., pp. 188-196 . La autora describe la creciente emancipación de la jurisprudencia respecto a la voluntad del legislador en su función de interpretación y su tendencia a acudir a la ratio legis para una interpretación teleológica fundada sobre la voluntad del legislador y el bien jurídico. X. PIN, Droit pénal général, op. cit., pp. 104-106, 113-121, utiliza la noción de resultado pero de manera regular acude a la idea de lesión al interés protegido.

189 M. PUECH, Droit pénal général, Litec, 1988, p. 249.

190 J. WALTHER, L 'antijuridicité..., op. cit., pp. 402 y 403.
} 
ñar el texto ${ }^{191}$. Eso es el corolario lógico del papel del bien jurídico en lo que se refiere a la interpretación de los textos ${ }^{192}$.

\section{2- Los bienes jurídicos y la resolución de los conflictos de calificaciones ${ }^{193}$}

Éste es uno de los claros ejemplos en el que el bien jurídico se ha utilizado como criterio de aplicación de la ley por la jurisprudencia. El caso aquí es el de una situación a la que varias incriminaciones podrían aplicarse. En el momento del examen y de la selección previa del texto a aplicar, antes de proceder a la calificación propiamente dicha, aparecen, a menudo, hipótesis en las que varias calificaciones parecen posibles. En efecto hay que encontrar un criterio que permita preferir con la mayor eficiencia posible el texto más adaptado a los que no serían tan precisamente ideales. Este criterio podría ser el del bien jurídico protegido por el texto seleccionado, averiguando también el objetivo proseguido por el legislador o la ratio legis ${ }^{194}$. Un primer índice en este sentido se puede encontrar en la formulación elegida por GRAVEN cuando introduce el apartado que trata de los concursos de calificación en su obra sobre la infracción: “(...) se puede preguntar cómo tratar al que por uno o varios actos, lesiona varios bienes jurídicos o más de una vez el mismo bien jurídico (...)"195. Constatará WALTHER que, aunque el concepto de bien jurídico no haya sido conceptualizado en Derecho francés, la referencia al valor protegido opera de la misma manera que en el Derecho de inspiración germánica ${ }^{196}$. En efecto, no se tratará aquí de estu-

191 M. LACAZE, Réflexions..., op. cit., pp. 195-212. La autora detalla las posibilidades y ocasiones en las que el bien jurídico ha sido utilizado por la jurisprudencia como criterio de aplicabilidad de la ley: en el derecho penal sustantivo, el bien jurídico ha sido utilizado como criterio de calificación al determinar la naturaleza de la infracción, en la selección de la calificación en caso de conflicto, pero también como factor agravación debido a la multiplicidad de los bienes jurídicos lesionados. En materia de justificación, el juez ha tenido la oportunidad de utilizar el bien jurídico. Y en materia procesal la autora analiza que el bien jurídico es un criterio de modalidades de la acción pública, y un criterio para la apertura de la acción civil.

${ }^{192}$ J. WALTHER, L 'antijuridicité..., op. cit., p.404. Entendiendo lo que es la "subsunción", DOUCET deduce algunas reglas que deben ser observadas por el juez. Las llama "reglas generales de calificación". 1) El juez no puede calificar si ningún texto no corresponde a los hechos, y ello aun si el sujeto activo ha creído cometer un delito. 2) El juez no puede calificar al fundamentarse sobre un texto que contempla simplemente hechos análogos a los reprochados. 3) El juez no puede calificar hasta después de haber averiguado la coincidencia de los hechos con todos los elementos constitutivos de la incriminación (J.-P. DOUCET, Précis..., op. cit., pp. 105 y ss.).

193 M. LACAZE, Réflexions..., op. cit., pp. 197-200.

194 Y. MAYAUD, “Ratio legis...”, p.607. Defiende el autor que la ratio legis guía las técnicas y los principios de resolución de las dificultades que implican los conflictos de calificación y los problemas de interpretación: por su alcance esencialmente declarativo, esos sólo traducen las motivaciones y las selecciones de la incriminación, y la ratio legis al ser el mejor intérprete, es naturalmente que se revela también el mejor instrumento de la calificación judicial.

195 P. GRAVEN y B. STRAÜLI, L'infraction pénale punissable,), Staempfli+Cie, Berne, 1995, (2 ${ }^{\mathrm{a}}$ ed), pp.333, 334.

196 J.-H. ROBERT, Droit pénal général, op. cit., p.224. El autor precisa que hay que acudir a la noción de interés protegido para resolver la situación que se presenta cuando 
diar el problema concursal o de cúmulo de delitos en Derecho francés, lo que superaría el marco de este trabajo, sino más bien observar en unas sentencias la manera en que la jurisprudencia utilizó el bien jurídico con su acepción pre-jurídica de valor o de interés. Así, para resolver caso de cúmulo de calificaciones la Sala de lo criminal desde su sentencia del 3 de marzo de 1960, "Ben Haddadi"197, precisa criterios tales como que no debe haber calificaciones incompatibles y que se tiene que sancionar una "violación de intereses distintos"198, de "valores sociales distintos", "intenciones culpables diferentes" extrayéndose como consecuencia una "doble declaración de culpabilidad". En palabras de LÉGAL, "(la sentencia) está en armonía con la concepción que está en la base de esta teoría doctrinal: con la idea, en particular, de que cuando un individuo ha violado textos diferentes que sancionan lesiones a intereses colectivos o individuales distintos, no importa que estas transgresiones procedan de un acto material único, a partir del momento que traducen una dirección de la voluntad hacia metas antisociales múltiples." Con estos criterios jurisprudenciales se acepta en Derecho positivo el principio del cúmulo de calificaciones con un límite formulado por la propia jurisprudencia en una sentencia del 5 marzo de 1992 en un caso de robo con deterioros: "Es de principio constante que cuando un hecho material único es susceptible de recibir varias calificaciones penales, el tribunal conocedor del caso no debe aceptar sino la calificación más grave cuando el uno u otro de estos hechos proceden de la protección de un mismo valor social, individual o colectiva y que la actitud psicológica del autor puede ser considerada como indivisible en el acto que pone en peligro ese valor." En este caso, "proceden de la lesión de un solo y mismo valor social, a saber el derecho de propiedad, y no podrían ser , pues, contemplados más que bajo la única calificación más elevada, hechos susceptibles de ser cualificados sustracción fraudulenta de la cosa ajena y deterioro voluntario de objetos mobiliarios ajenos"199. Aquí hay un único bien jurídico en causa - el derecho de propiedad - pues nos hallamos ante una hipótesis no de cúmulo de calificaciones sino de conflicto de calificaciones, un concurso aparente. WALTHER nota que en paralelo con el bien jurídico compite la intención como criterio de-

una misma persona, por el mismo gesto, realiza la conducta descrita en dos o varios textos de incriminación a la vez: el contenido de la declaración de culpabilidad varía según que estos diversos textos tiendan o no a la conservación del mismo valor social. Ve en ello la solución menos contestable del problema (p.280). J. WALTHER, L'antijuridicité..., op. cit., p. 406. Se pregunta el autor: ¿por qué aceptar tal incriminación en vez de otra? Contesta que porque cada incriminación existe para proteger tal bien en aplicación de tal norma. Eso resulta ya intrínsecamente de la propia naturaleza del derecho penal y su finalidad protectora de los valores reconocidos como fundamentales para la sociedad civil.

197 Revue de science criminelle et droit pénal comparé, 1961, pp. 105 y ss, obs. A. LÉGAL.

198 Cass. crim. 20-12-1985, D. 1986, p. 500, nota F. CHAPAR, Revue de science criminelle et droit pénal comparé, 1987, pp. 275 et 937, obs. C. LOMBOIS.

199 CA Bordeaux, 5-03-1992, D. 1994, p.305, nota S. MIRABAIL. En este caso unos agricultores enfadados habían inmovilizado camiones de mercancías procedentes del extranjero, luego descargado esos últimos y destruido su contenido, pedazos de carne. La Corte de Casación consideró que había aquí despojo temporal constitutivo de robo. 
terminante utilizado por la jurisprudencia. Y defiende que la intención puede ser finalizada, ser entendida como tendiente hacia una meta particular, la de lesionar un interés protegido. Sin embargo el autor prefiere que éste último sea el único criterio ya que es lo único que puede superar el problema que plantea la intención de distinguir entre dos calificaciones, sobre todo si se trata de hipótesis de infracciones no intencionales ${ }^{200}$.

En cuanto a las hipótesis de cúmulo ideal, DOUCET distingue si la intención es de lesionar a uno o varios intereses protegidos ${ }^{201}$. MAYAUD añade que todo se determina en función de los valores sociales protegidos por los textos y ve en la ratio legis el instrumento del reglamento de los concursos ideales de calificaciones ${ }^{202}$. Si estas calificaciones comprometen el mismo valor, no es necesario acumularlas. Si al contrario, por un acto único, el delincuente lesiona varios intereses protegidos cada uno por una calificación diferente, es lógico para MAYAUD, retener todas estas calificaciones, a fin de dar a la conducta delictiva toda su expresión penal. La jurisprudencia reconoce la realidad de este criterio fundado en el número de valores sociales, de bienes jurídicos lesionados. Así el Tribunal de Policía de Mâcon precisa que: "cuando el mismo hecho puede y debe ser sancionado dos veces, es que en realidad ha infringido dos categorías distintas penalmente protegidas" 203 . 0, como lo dice SALVAIRE, "dos estructuras diferentes de nuestro patrimonio material y moral"204. El mismo autor vio "el germen de esta solución buscada" en la decisión de la Sala criminal del 3 de marzo de 1960 y la del 3 de mayo de 1960 y comentó que: "a raíz de este cambio de postura ¿no se puede proponer al juez de policía la fórmula siguiente: un acto material único que cae bajo el peso de varios textos será sancionado con cuantas penas como ha infringido tantas categorías penalmente protegidas?"205. Para la Corte de casación, la respuesta depende del hecho de

\footnotetext{
${ }^{200}$ J. WALTHER, $L$ 'antijuridicité..., op cit, pp. 416, 417 ; J. PRADEL, Traité de Droit pénal et de science criminelle comparée, Tome 1, Introduction général, Droit pénal général, Cujas, 1999, (12 éd.), pp.308-312. Para el autor, los tribunales franceses distinguen voluntariamente según el estado mental del delincuente, esto es, que si ha pretendido cometer una infracción o varias, lesionar a un valor social o varios. Afirma el mismo autor que esta distinción a veces es difícil poner en marcha pero aun así ha sido reconocida por la jurisprudencia.

201 J.-P. DOUCET, Précis..., op. cit., p. 137.

202 Y. MAYAUD, "Ratio legis...", pp.608, 609. Precisa el jurista que se pide al juez que se quede en la lógica de la selección de la incriminación, al preguntarse sobre las razones que pueden conducir al legislador a tratar con una misma actitud frente a varias calificaciones: le toca a la ratio legis dar la respuesta, puesto que estas situaciones de concurso entre calificaciones son escasamente sinónimos de doble empleo.

203 Tribunal de Police Mâcon, 28-06-1960, Gaz. Pal. 1966, 2, 256.

204 J. SALVAIRE, «Le concours...», op. cit., 1588.

205 Ibídem, op.cit., El autor se remite a la sentencia Lasne (Cass. Crim. 3 de mayo de 1960, JCP éd. G. 1960 IV, p.94) "en la que el acto generador del accidente, la falta de iluminación, lesiona dos categorías penales distintas, la seguridad ajena y el orden del tráfico." Amonesta al lector: "ique se diga que se confundan en una sola!”.
} 
saber si los textos en concurso tienden a proteger los mismos o diferentes intereses. La puesta en práctica de esta idea parece a veces difícil ${ }^{206}$.

\section{III-Imposible extracción del concepto de bien jurídico}

Estas apariciones del bien jurídico en Derecho francés pueden llevar a pensar que con un esfuerzo de síntesis se podía sacar un concepto subyacente. Los autores que prestaron atención al concepto se han conformado con superponer las diferentes concepciones, sin ir más lejos al buscar si es realmente posible conciliar dos visiones de la infracción o si eso presenta un interés. La utilización de la noción, defiende MARÉCHAL, tal como se ha enunciado por un sector de la doctrina, se revela muy ampliamente estéril puesto que sólo sirve para decir de otra manera lo que se puede explicar sin hacer referencia a la noción de bien jurídico ${ }^{207}$. Pero estas apariciones son numerosas, sus caras lo son también y parecen variar según los papeles que el legislador o el juez quieren que juegue este concepto ${ }^{208}$. En efecto, en la parte especial del Derecho penal, llama la atención el Libro V llamado por WALTHER "un cajón de sastre" 209 sin verdadera lógica inherente. LACAZE habla de un abandono al estado de baldío a pesar de la ambición del legislador para sintetizar los valores dichos "nuevos"210. Destaca la autora que en el origen de

206 A. MARON, J.-H ROBERT, M. VÉRON, Chronique de droit pénal, JCP éd. G. 2001, I, 289. Estos autores destacan con dos ejemplos la dificultad para aplicar este criterio según el número de interés protegido. En una sentencia del 26 de abril de 2000, en el caso "Le Pen", el Tribunal sostiene que "las dos calificaciones en concurso - apología de crímenes contra la humanidad y contestación de crímenes contra la humanidad con motivo de un mismo hecho, procedente del mismo estado de espíritu, de la defensa de los mismos valores, no pueden recibir una aplicación simultánea." La expresión "espíritu" no ha dejado de sorprender a los comentadores y VERON ¿no decía en su apreciación crítica de este término, que el código en su totalidad procede del mismo espíritu? Precisa WALTHER que en la medida en que es posible discernir ciertos valores, aislar ciertos bienes jurídicos protegidos, el término "espíritu" es sin embargo demasiado vago y no se sabe lo que contiene, tanto sustancial como conceptualmente. Además de este término ambiguo, el Tribunal utiliza mucha sutilidad en las dos sentencias sobre el caso "Garaudy" el 12 de septiembre de 2000. Rechaza los recursos dirigidos contra las sentencias que han dictado una doble incriminación del acusado. "Los intereses protegidos por esta incriminación (difamación de carácter racial) y los protegidos por la de contestación de crímenes contra la humanidad son de una naturaleza diferente." La acusación de "lobbying" practicado por el Estado de Israel "adecuado a poner en peligro la unidad del mundo" y "la paz" proferida por el Sr. GARAUDY no podía confundirse con la contestación de crímenes cometidos por los nacionales-socialistas contra la misma comunidad. El Tribunal excluye el cúmulo ideal porque las dos infracciones no conciernen a las mismas personas o grupos de personas. Los intereses, los valores protegidos parecen bien diferentes, se habría podido concluir, contrariamente a la primera sentencia estudiada, que las reglas del cúmulo ideal podrían aplicarse. Pero como no hay identidad de las personas concernidas, y por lo tanto había que, según los jueces, quizá deducir una ausencia de unidad de hechos, el Tribunal descarta el cúmulo ideal y permite la doble diligencia (J. WALTHER, L'antijuridicité... op. cit., p.418).

${ }^{207}$ J.-Y. MARÉCHAL, «Essai... », op. cit., pp.87 y 88.

208 M. LACAZE, Réflexions..., op. cit., p.213.

${ }^{209}$ J. WALTHER, $L$ 'antijuridicité... op. cit., p.390.

210 M. LACAZE, Réflexions..., op. cit., p.215. 
su proyecto la intención era poder introducir en el mismo código unas figuras delictivas dispersas pero finalmente la sensibilidad política de la cuestión, entre otras razones, acabó por poder con la ambición legislativa y el Libro $\mathrm{V}$ fue casi abandonado y finalmente se intituló "otros crímenes y delitos" 211 . Es alarmante también la multitud de infracciones sin codificar que se encuentran diseminadas en leyes especiales, sobre todo los delitos que forman el Derecho penal económico. Señala la autora que el CPF no distingue de manera fundamental los bienes jurídicos y hasta demuestra ambigüedad en las relaciones entre persona y especie humana ${ }^{212}$. En la clasificación del Libro IV, se presenta el problema de la multiplicidad de bienes jurídicos para una incriminación y con la complicación que conllevan las circunstancias agravantes ${ }^{213}$.

Por otro lado, en el ámbito del Derecho penal general, es imposible inducir la existencia de un concepto de bien jurídico. LACAZE considera dos posibilidades para entender el bien jurídico: como el objeto de protección por el texto de incriminación y como el objeto lesionado o puesto en peligro por la conducta prohibida. Considerado como la primera posibilidad el bien jurídico sería una condición previa a la infracción mientras que la segunda sería el resultado de la infracción. Pero parece que, según la autora, estas dos pistas no permiten destacar la naturaleza jurídica ni el lugar del bien jurídico en la concepción francesa de la infracción y su asimilación al resultado presenta numerosas carencias ${ }^{214}$. El rechazo de la primera opción se ve en la admisión de la represión de la infracción imposible acudiendo a la teoría de la tentativa ${ }^{215}$. En cuanto a la segunda opción, los autores sienten la necesidad de referirse a un concepto que se puede asimilar al de bien jurídico protegido aunque lo

\footnotetext{
211 Ibídem, op. cit., pp.216, 217. Este libro sólo contenía en 1992 los maltratos graves o actos de crueldad con los animales. A pesar del esfuerzo que se pretendía hacer para un verdadero libro $V$, no se ha realizado nada y en la actualidad este libro sólo contiene dos títulos, el primero, dedicado a "las infracciones en materia de salud pública" que conlleva las principales incriminaciones en materia de "ética biomédica" y el segundo titulado "otras disposiciones", el cual contiene los maltratos graves y actos de crueldad contra los animales.

212 Ibídem, op. cit., pp.220, 221.

${ }^{213}$ Ibídem, op. cit., pp.221-223.

${ }^{214}$ Ibídem, op. cit., pp. 226 y ss.

215 Ibídem, op. cit., pp. 229-232. Explica la autora que como condición previa el bien jurídico condiciona la existencia de la infracción. En el caso de la ausencia de esta condición sería imposible admitir la consumación de la infracción y sobre todo acudir a la teoría de la tentativa. (Véase J.-H. ROBERT, Droit pénal général, op. cit., p.245). Añade la autora que la imposibilidad de la infracción en cuanto a los medios utilizados o como resultado, que sea simplemente de hecho o de derecho, que sea absoluta o relativa, el autor de una tentativa de infracción imposible puede ser castigado igual que el autor de una infracción fallida o inacabada, ya que la única restricción es la infracción imposible proyectada pertenece al campo de la tentativa punible. Concluye que si el comienzo de ejecución puede ser caracterizado en ausencia de toda posibilidad de alcanzar el resultado prohibido, o sea el bien jurídico que no existe o ya no existe, es necesariamente que la existencia de este bien jurídico no es una condición previa a la infracción.
} 
designan con otro vocablo 216 , pero si el concepto de resultado penal necesita el de bien jurídico ${ }^{217}$, ése no llega a precisar la naturaleza jurídica de éste ${ }^{218}$. La indeterminación persistente de la naturaleza jurídica del bien jurídico protegido tal como aparece en Derecho francés no permite sacar todas las consecuencias sobre la clasificación de las infracciones fundadas sobre el umbral de la consumación ni determina $a$ priori el campo del Derecho penal.

Al concluir, hacemos nuestras las palabras de LACAZE para quien el bien jurídico aparece sin ser designado en múltiples circunstancias en Derecho francés y parece cumplir, a veces de manera imperfecta, toda clase de funciones (dogmática, sistemática o de interpretación). Sin embargo, si se puede revelar por sus diferentes facetas, la influencia de las grandes teorías del delito y del Derecho penal general sobre ciertos mecanismos del Derecho positivo, su análisis no permite de ninguna manera sacar un verdadero concepto. En efecto, se ha visto el rasgo de varias concepciones cercanas a diferentes teorías elaboradas en Alemania y en los países que han seguido su modelo pero sin conseguir extraer una que correspondería a la totalidad de sus manifestaciones. Abstracto o concreto, puramente formal o dotado de un contenido material, el bien jurídico, por su carácter proteiforme, puede incluso aparecer más como un factor de confusión que como un instrumento, permitiendo ayudar a la coherencia del Derecho positivo. Pues, los hechos parecen confirmar bien la hipótesis de una concepción francesa como un ataque a la ley o a la sociedad en su conjunto y una utilización oportunista del concepto de bien jurídico, portadora del fracaso de toda búsqueda de un concepto verdadero y no puramente formal ${ }^{219}$.

\footnotetext{
${ }^{216 X .}$ PIN, Droit pénal général, op. cit., pp.104-106. El resultado penal para el autor existe en toda infracción aunque puede ser diferente. El resultado legal es el que coincide con el resultado apuntado por el texto de incriminación; Y. MAYAUD, "Ratio legis...", op. cit., pp.602. Para este autor el "resultado jurídico" sería un daño perjudicial que la conducta delictiva provoca sobre el valor social protegido; J.-Y. MARÉCHAL, "Essai... », op. cit., pp.103-104. Este autor repasa toda la doctrina francesa en materia de resultado del delito. En un apartado analiza el concepto de resultado como componente de la infracción y muestra que para ciertos autores el bien jurídico, y no importa el vocablo utilizado, está incluido para dar sustancia al concepto de resultado.

${ }^{217}$ J. PRADEL, Traité... Tome 1, op. cit., p.369 y ss. Dedica el autor un apartado para el resultado pero resalta que el resultado debe ser estudiado desde la perspectiva de la víctima como perjuicio entendido de manera amplia. El autor no señala la necesidad de acudir a algún concepto de valor o interés protegido para defender su concepto de resultado.

218 M. LACAZE, Réflexions..., op. cit., pp.232-237. Si los autores están de acuerdo en ver en "el resultado legal" el umbral de la consumación de la infracción, el "resultado jurídico", mucho más vinculado al concepto de bien jurídico, se entiende a la vez como lesión a la ratio legis, como violación del orden jurídico y como lesión efectiva al bien jurídico y los autores no convienen sobre el tipo de infracción en las cuales aquel aparece.

${ }^{219}$ Ibídem, op. cit., p.239. J.-Y. MARÉCHAL, «Essai... » op. cit., p. 89. El autor, defendiendo el concepto de resultado como concepto autónomo en la estructura de la infracción penal, sostiene que la introducción efectiva de la teoría de los "bienes jurídicos" pone en tela de juicio las bases del derecho penal (francés) consideradas como adquiridas. El alcance de esta teoría no puede ser más que limitado.
} 


\section{Sección 2-El ámbito de estudio: la Adminis- tración Pública}

Aunque la Administración Pública pueda ser objeto de estudio de muchas disciplinas sociales y en el mismo ámbito de la ciencia jurídica, $\mathrm{y}$, en concreto, el tema predilecto del Derecho administrativo, parece necesario repasar el tratamiento que le dispensa el Derecho penal en función del marco constitucional vigente. En efecto, el presente trabajo no pretende hacer de ello un estudio detallado sino simplemente un rápido repaso de la evolución reciente en este ámbito.

\section{III-La Administración Pública en el ordenamiento jurídi- co-penal español}

\section{A-EVOLUCIÓN DEL CONCEPTO DE ADMINISTRACIÓN PÚBLICA}

\section{1-La Administración pública y delitos del cargo}

La mayoría de la doctrina española repasa la consideración de la Administración desde la perspectiva de la evolución constitucional. Desde la Constitución española de 1812 se ha considerado la Administración como entidad de los poderes ejecutivos y titular de la atribución de hacer ejecutar las leyes con extensión de su autoridad a la conservación del orden público en el interior y a la seguridad del Estado en el exterior. Las constituciones sucesivas añadían a estas prerrogativas, por lo tanto se ha constatado cada vez más su presencia en diferentes sectores de la sociedad. La doctrina observaba que la Administración, como toda persona jurídica, puede sufrir agresiones de todo tipo, agresiones que, de vez en cuando, merecen respuesta del Derecho penal. No obstante, dadas las características propias de la misma, unidas a sus funciones de interés público y a las prerrogativas y facultades exorbitantes que posee, en el marco de la citada Administración se pueden cometer delitos específicos que afectan a múltiples bienes jurídicos ${ }^{220}$. A partir de ahí,

220 P. RODRÍGUEZ LÓPEZ y A. I. SOBRINO MARTÍNEZ, Delitos contra la administración pública, delincuencia administrativa. Cuando el representante de la Administración participa en el delito, BOSCH, 2008, pp.21, 22. Estos autores señalan que la crisis del orden liberal a partir de mediados del siglo XIX, llevó a la burguesía a redefinir y a reinterpretar en sentido material y efectivo los principios de libertad y de igualdad y a rectificar la concepción individualista de la sociedad y el Derecho. Nació una solidariedad social de nuevo cuño, basada en al agrupación de las personas en entidades infra-estatales, lo que rompe el teórico aislamiento de los individuos propio de la sociedad civil liberal y abre paso al pluralismo en todos los ámbitos de la vida. Consecuencia de esa ruptura es el nuevo concepto de Administración que comienza a surgir, 
se observa la relevancia de los delitos de los funcionarios públicos en los sucesivos códigos penales y ello conforme a las Constituciones vigentes $^{221}$. Por otro lado, VÁZQUEZ-PORTOMEÑE SEIJAS, después de repasar el tratamiento legislativo del concepto de empleado público y agente del Estado con las diferentes figuras creadas, suprimidas, agrupadas, mejoradas, 222 concluye que la literatura ha venido subrayando que el proceso de formación y consolidación del grupo de los delitos contra la Administración Pública a través de los diversos textos punitivos se implica históricamente con la irrupción del Poder Judicial en el campo de acción propio del Poder Ejecutivo y con el establecimiento de mecanismos para la revisión jurisdiccional de la legalidad de las actuaciones administrativas completamente independientes de la hipotética declaración de responsabilidad penal individual del funcionario. Pero, añade el mismo autor que la caracterización formal del sistema que históricamente han constituido los delitos de los funcionarios públicos en el ejercicio de sus cargos es tributaria, asimismo, del modelo de tratamiento de la responsabilidad funcionarial adoptado por el Código de Napoleón, dato, quizá, insuficientemente destacado por la doctrina ${ }^{223}$. Se había destacado que los delitos de los funcionarios públicos no entrañaban, en el pensamiento del legislador francés de 1810, meras infracciones de los deberes dimanantes de la relación de servicio que vinculaba al Estado con sus agentes, sino acciones perjudiciales para los intereses de la comunidad. Ésa habrá de ser también la filosofía que inspire la decisión de abandonar toda referencia estamental en la presentación de la materia en el Código español de 1822, que se nutre de las nuevas concepciones liberales sobre la función pública224. A pesar de la evolución conceptual que habían hecho las diferentes constituciones sobre la función de la Administración, constata el autor que el inmovilismo legislativo en la materia, su impermeabilidad a todo proceso de adaptación a las vicisitudes políticas y económicas sufridas por el Estado a lo largo de dos siglos, perpetuarán en las rúbricas de los Títulos de los correspondientes textos punitivos la referencia al ejercicio del cargo como criterio sistematizador ${ }^{225}$.

intervencionista, en cuanto garantista de una serie de situaciones de los particulares, y sobretodo, con un mayor campo actuación para desarrollar nuevas competencias esenciales a la hora de enfrentarse a la nueva cultura de igualdad y libertad (p.23).

${ }^{221}$ J. VIZUETA FERNÁNDEZ, Delitos contra la administración pública: estudio crítico del delito de cohecho, Comares, 2003, pp.7-26.

${ }^{222}$ F. VÁZQUEZ-PORTOMEÑE SEIJAS, Delitos contra la Administración Pública. Teoría general, INAP, Universidade de Santiago de Compostela, 2003, pp.87-95.

${ }^{223}$ Ibídem op. cit., p.97. Buena prueba de ello la constituyen tanto la sistemática inaugurada por el Código penal de 1870, al trasladar al Capítulo II del su Título II reproduciendo los esquemas sistemáticos del texto punitivo francés- los delitos dirigidos contra los derechos individuales sancionados por la Constitución, como la rúbrica que encabeza la Parte Primera del Título VI del Código penal de 1822

("delitos y culpas de los funcionarios públicos en el ejercicio de sus cargos"), muy similar a la que precedía a la Sección Ir del Título I, Capítulo IV, del Libro III del Código de Napoleón ("De la forfaiture et des crimes et délits des fonctionnaires publics dans l' exercice de leurs fonctions").

${ }^{224}$ Ibídem op. cit., p.98.

225 Ibídem op. cit., p. 99. 
En efecto, tal referencia ha recibido críticas de la mayoría de la doctrina. COBO DEL ROSAL, al realizar un estudio sistemático del Título VII ("de los delitos de los funcionarios públicos en el ejercicio de sus cargos") y el concepto de funcionario público recogido en el párrafo $3^{\circ}$ del artículo 119 del penúltimo Código penal, pone en duda si es técnicamente adecuado la utilización de la rúbrica en cuestión. Y es que, según este autor, con ella lo que realmente hace el legislador es extender aún más el ya amplísimo concepto de funcionario público del párrafo $3^{\circ}$ del artículo 119 , quebrantando de esta forma "la armonía que debe reinar entre el concepto de la Parte general y los tipos concretos de la Parte especial". Por otra parte, el autor destaca que no hace falta una detenida lectura de las figuras recogidas bajo el título del estudio para percatarse de la existencia de los delitos cuyo sujeto activo es un particular y no un funcionario público. ${ }^{226}$ Afirma VÁZQUEZ-PORTOMEÑE SEIJAS que la literatura española ha visto tradicionalmente en la atención dispensada por el Código penal al funcionario como sujeto activo del delito un importante factor de confusión con vistas a la comprensión del sistema. El Derecho español no le reserva exclusivamente infracciones cometidas "contra la Administración Pública", sino que acusa - con respecto a la delincuencia que le es propia - un marcado proceso de dispersión sistemática en cuyo origen se identifica la influencia ejercida por la Constitución liberal de 1869 sobre el Código penal de 1870, que por vez primera disoció los delitos de los funcionarios "contra el ejercicio de los derechos de las personas reconocidos por las leyes" de los delitos perpetrados "en el ejercicio de sus cargos". La consolidación de esta subdivisión formal y la previsión en otros Títulos de tipos y causas personales de agravación asimismo dirigidos a esta clase de sujetos cualificados (artículos 131, 159, 222.1으. 241, 302, 305 y 308, entre otros) hicieron de la delincuencia funcionarial en el Código penal de 1973 un terreno inconexo, no sujetable a principios generales y de distribución residual227. Observa CUGAT MAURI que los fundamentos jurídico-positivos del Título VII del Código penal de 1973 se basaban en la referencia a la protección de la voluntad o de la expectativa de la comunidad que lleva consecuentemente a la protección del honor o prestigio de la Administración, pues no es sino la otra cara de la moneda de la confianza de la comunidad en ella. De ello se deriva subjetivismo, formalismo y estatalismo en todos sus elementos cuyas características básicas pueden resumirse en la priorización del desvalor del acto sobre el de resultado, inclusión de elementos subjetivos del injusto, que permitan valorar directamente la existencia de la adhesión interna a la norma y la inclusión de la causa de justificación de la obediencia debida, la cual constituye la definición de la conducta típica como infracción del deber de obedien-

${ }^{226}$ M. COBO DEL ROSAL, Examen crítico del párrafo 3. o del art. 119 del Código penal español (sobre el concepto de funcionario público a efectos penales), Revista General de Legislación y Jurisprudencia, 1962, pp.249, 250.

${ }^{227}$ F. VÁZQUEZ-PORTOMEÑE SEIJAS, Delitos..., op. cit. pp.100 y 101. 
cia $^{228}$. ASÚA BATARRITA, por su parte, critica las referencias a la deslealtad e infidelidad del funcionario para con el Estado o la Administración que resultan demasiado ambiguas si no se conectan a lo que constituye la legitimación de las instituciones democráticas ${ }^{229}$.

Sin embargo, según OCTAVIO DE TOLEDO, la rúbrica del Título VII ("De los delitos de los funcionarios en el ejercicio de sus cargos") no es impedimento para realizar una correcta interpretación de las distintas figuras delictivas que bajo ella se albergan ${ }^{230}$. Aunque admite que la rúbrica peca de opacidad, considera que "tal oscuridad no responde a un propósito legislativo de expresarse con una fórmula alambicada; más bien ocurre todo lo contrario: que ha buscado una formulación simple, vulgar, perfectamente transparente en el momento de su aparición (1822) y aún inmediatamente después. La distancia y la superposición de modificaciones legislativas hacen perder la perspectiva de claridad sobre una fórmula más vulgar que técnica"231. Si bien muchos autores abogan por un cambio de rúbrica, el mismo autor considera que de un lado "se puede decir que el título VII, su contenido en relación con su rúbrica, no tiene más deficiencias que las habituales en los demás títulos del Código", y por otro, "nada insuperable (...) impide que siga manteniéndose como hipótesis de trabajo que el bien jurídico protegido por los delitos contenidos en el Título VII (...) es la función pública”232.

228 M. CUGAT MAURI, La desviación..., op. cit., p.67. Añade la autora que en la expresión «de los funcionarios públicos en el ejercicio de sus cargos» se veía la alusión al deber del cargo como rasgo distintivo y unificador de todos los tipos, con la que se justificaba el carácter subjetivista de la protección penal.

${ }^{229}$ A. ASUA BATARRITA, La tutela penal del correcto funcionamiento de la Administración, en Delitos contra la Administración Pública, IVAP, 1997, p.20. Precisa que el enjuiciamiento penal no se dirige a valorar la "bondad" o "maldad" general de una decisión o de un comportamiento sino su adecuación a los parámetros que deben regir la actividad administrativa. Este es el único patrón de medida de la "moralidad pública", que es la única perspectiva que interesa, porque es la única que garantiza una referencia segura para su control democrático.

230 E. OCTAVIO DE TOLEDO Y UBIETO, La prevaricación del funcionario público, Ed. Civitas, Madrid, 1980, pp.135-150.

231 Ibídem, op. cit., p.143. El autor entiende que el legislador mantiene invariada la fórmula legal "en el ejercicio de su cargo", y la sigue manteniendo en el mismo sentido amplio que antes y con idéntico propósito; señalar que aquí sólo le interesa agrupar las conductas de los funcionarios públicos (funcionarios públicos en el sentido penal) que, atentando contra la función pública, se llevan a cabo precisamente por realizar esa participación en el ejercicio de tal función; no le interesan (...) las que atacando dicho bien jurídico, se realizan fuera de esa actividad (de los particulares que ni siquiera participan del ejercicio de la función pública). En suma, finaliza el autor, estamos ante un título que recoge los delitos contra la función pública, cometidos por aquellos que pueden atacarla desde dentro (quienes participan de su ejercicio), precisamente cuando actúan desde su interior (cuando realizan esa participación). No ante todos los delitos cometidos por funcionarios públicos; no ante todos los delitos que atacan a la función pública; no ante delitos que no atacan dicho bien jurídico, aunque el sujeto activo reúna la cualidad de funcionario público a efectos penales, precisamente porque no es actuando en dicha cualidad cuando los comete; no, por último, ante delitos que, atacando tal valor, son cometidos por quienes ni siquiera participan del ejercicio de funciones públicas (no son funcionarios públicos a efectos penales, sino, llanamente, particulares).

232 Ibídem, op. cit., p.150. 
Matizando la postura de este autor, señala VIZUETA FERNÁNDEZ que a pesar de su meritorio esfuerzo, los verdaderos problemas para OCTAVIO DE TOLEDO surgen cuando tiene que comprobar, caso por caso, que las diferentes figuras recogidas en el Título VII se adecuan, responden a la interpretación que ha dado de su rúbrica. Y es que, una cosa es decir, con carácter general, que la intención del Legislador es agrupar en el Título VII "las conductas de los funcionarios públicos (funcionarios públicos en sentido penal) que, atentando contra la función pública, se llevan a cabo precisamente por realizar esa participación en el ejercicio de tal función", y otra, muy distinta, mantener con éxito tal idea después de realizar un análisis detenido de las variadas figuras delictivas recogidas en tal título 233 . En consecuencia, concluye el autor, admitir como OCTAVIO DE TOLEDO, que el Título VII del Código penal de 1973 no tiene más deficiencias que las habituales en los demás títulos del Código, es un ejercicio de buena voluntad que aquél no merece, pues son demasiadas las figuras en él cobijadas que pugnan con su rúbrica "De los delitos de los funcionarios públicos en el ejercicio de sus cargos", bien por tratarse de particulares los sujetos que realizan la correspondiente conducta, bien porque ésta se ejecuta en un ámbito estrictamente privado, esto es, sin participar en el ejercicio de la función pública. Por ello, sostiene el mismo autor, debemos mostrarnos favorables a la idea, mantenida por muchos, de la modificación de tal rúbrica, postura adoptada también por el Código penal de 1995 en su Título XIX ("Delitos contra la Administración pública")234.

En cuanto al bien jurídico protegido, se ha propuesto que estos delitos del Título VII tienen en común, según una parte de la doctrina la "infracción del deber del cargo" como único, o, al menos principal elemento que configura "los delitos de funcionarios" y ha sido, asimismo defendida por la doctrina penal española ${ }^{235}$. Explica OCTAVIO DE TOLEDO que la rúbrica, haciendo aparentemente una evidente llamada a un criterio personal de agrupación, nada más lógico parece que buscar elementos fundamentalmente personales para caracterizar el objeto de protección de los tipos. Habida cuenta de la especial relación que une a esos sujetos con los organismos en que se integran y la referencia, expresamente resaltada en la propia rúbrica, al cargo, no parece difícil seguir el proceso mental que ha llevado a determinar que el deber (o deberes) del cargo es lo que encuentra protección con la existencia de tales delitos, que la infracción de tal deber (o de cada particular deber) es lo que configura completamente la antijuridicidad de los respectivos tipos $^{236}$. Otros autores como GROIZARD, ${ }^{237}$ CASTEJÓN Y MARTÍNEZ DE

\footnotetext{
${ }^{233}$ J. VIZUETA FERNÁNDEZ, Delitos..., op. cit., p.31. El autor realiza este análisis con unas figuras (pp.31-34).

${ }^{234}$ Ibídem op. cit., p.34. No sin avisar la cuestión de la conveniencia de esta nueva rúbrica y ver si resiste a un análisis detenido como el que realizó con el Título VII del Código penal de 1973.

${ }^{235}$ Ibídem, op. cit., p.85. El autor demuestra que es también la postura del Tribunal Supremo a partir de numerosas sentencias: SSTS 16-01-1960, 10-10-1989, 14-101997, 2-03-1973, etc.

236E. OCTAVIO DE TOLEDO Y UBIETO, La prevaricación..., op. cit., pp.254, 255.
} 
ARIZALA $^{238, ~ L O P E Z-R E Y ~ Y ~ A R R O J O 239, ~ H E R N A ́ N D E Z ~ H E R N A ́ N D E Z 240 ~}$ hablan de "infidelidad al cargo", "quebranto de la lealtad", "abuso de confianza" y "traición a los deberes que lleva consigo el desempeño de cargos públicos". Otros autores, como es el caso RODRÍGUEZ DEVESA ven el "abuso de poder" como peculiaridad de estos delitos en relación con el bien jurídico lesionado o puesto en peligro ${ }^{241}$.

Ante estas posturas defiende OCTAVIO DE TOLEDO que sostener el "deber del cargo" como objeto de protección de los "delitos de funcionarios" implica "una concepción política incompartible, una visión formalista y abstracta del bien jurídico reñida con la necesidad de determinación, y una función del bien jurídico exactamente contraria a la función limitadora que éste debe cumplir"242. Tal objeto con un tipo de discurso subjetivista, explica CUGAT MAURI, no se considera adecuado a los principios constitucionales de dignidad humana y pluralismo político en la medida en que exige la adhesión interna y personal a los valores constitucionales. De modo que a pesar de que en ocasiones el uso terminológico es irreflexivo o producto de la tradición y no implica ningún tipo de adhesión a ideologías de signo autoritario, ni incluso llega a repercutir en la interpretación de los elementos del delito, el recurso a la idea de fidelidad al Estado como adhesión personal se considera contraria a la misma esencia de los principios de la Constitución españo$\mathrm{la}^{243}$.

Estos mismos autores, entre otros, después de rechazar "el deber del cargo" como bien jurídico de este Título VII del penúltimo Código penal, defienden que "el bien jurídicamente protegido o, mejor dicho, el bien jurídico que la rúbrica del Título VII entiende que se protege con la existencia de los delitos en él contenido es la función pública"244. Pero no faltan autores, aunque es postura minoritaria, que cuestionan la existencia de un bien jurídico compartido por todos los delitos recogidos,

${ }^{237}$ A. GROIZARD Y GÓMEZ DE LA SERNA, El código penal de 1870 concordado y comentado, Tomo IV, Salamanca, 1891, p.76.

${ }^{238}$ F. CASTEJÓN Y MARTÍNEZ DE ARIZALA, Derecho Penal, Tomo I, (1aed.). Reus, Madrid, 1931, p.324.

239 M. LOPEZ-REY Y ARROJO, Derecho Penal, Tomo II, Parte Especial, (1aㅡ ed.) Reus, Madrid, 1935, p.172.

${ }^{240}$ R. HERNÁNDEZ HERNÁNDEZ, Malversación, La Ley 2/1996, D-112, p.1454.

${ }^{241}$ J. M. RODRÍGUEZ DEVESA y A. SERRANO GÓMEZ, Derecho penal español, Parte general, 17ạ ed., Ed. Dykinson, Madrid, 1994, p.1131. Declaran que "allí donde no hay abuso del poder que la Administración confiere al funcionario debe intervenir solamente el derecho disciplinario para traerle al cumplimiento de sus obligaciones".

${ }^{242}$ E. OCTAVIO DE TOLEDO Y UBIETO, La prevaricación..., op. cit., p.261. En este sentido se han pronunciado: A. ASUA BATARRITA, La tutela penal..., op. cit., p.20, M. CUGAT MAURI, La desviación..., op. cit., pp.67, 68,72. E. DEMETRIO CRESPO, “Corrupción y delitos contra la Administración Pública", en E. A. FABIÁN CAPARRÓS (coord.), La corrupción: aspectos jurídicos y económicos, Ratio Legis, Salamanca, 2000, p.69.

243 M. CUGAT MAURI, La desviación..., op. cit., p.69.

${ }^{244}$ E. OCTAVIO DE TOLEDO Y UBIETO, La prevaricación..., op. cit., pp.136 y ss., M. GARCÍA ARÁN, La prevaricación judicial, Ed. Tecnos Madrid, 1990, p.30 y ss., sostiene que la "función pública puede individualizarse como bien jurídico común a todos los tipos del Título VII". 
bien en el Título VII del CP de 1973, bien en el Título XIX del Código de 1995 y de 2010. Entre ellos se puede mencionar a MUÑOZ CONDE, quien, tanto para la regulación pretérita como para la actual, considera difícil encontrar un bien jurídico común a todos estos delitos ${ }^{245}$.

De acuerdo con ASÚA BATARRITA, la tradicional explicación de la "infracción de los deberes del cargo" como núcleo esencial de los delitos de funcionarios, no puede satisfacer las exigencias de un Derecho penal cuyo ámbito de incidencia se contrae a la protección de intereses fundamentales que repercutan en las expectativas básicas de los ciudadanos. La infracción de un "deber" de funcionario será relevante a efectos penales únicamente si afecta a las expectativas legítimas de los ciudadanos en su relación con la Administración, sea porque impide u obstaculiza el ejercicio de un derecho concreto, sea porque pone en serio peligro las posibilidades de acceso y participación en el disfrute de servicios o desarrollo de actividades que las instituciones deben garantizar, o en su caso promover ${ }^{246}$.

\section{2-La Administración Pública y la Constitución de}

\section{8}

El actual Código penal ha dado un paso adelante respecto a las críticas de la doctrina y la evolución de la jurisprudencia ${ }^{247}$ en la valoración de lo que se pretende proteger conforme a los parámetros constitucionales en vigor. A partir de ahí se defiende que es el modelo constitucional el que sirve de pauta de referencia. Según MORALES PRATS y RODRÍGUEZ PUERTA, este cambio de rumbo responde a la necesidad de adecuar la tutela penal de la Administración pública a parámetros constitucionales. En los últimos tiempos el debate en torno a estos delitos había puesto de manifiesto la insuficiencia de aquellas posturas que mantenían como única vinculación entre las distintas figuras contenidas en el Título VII penúltimo Código Penal la referencia al funcionario como sujeto

${ }^{245}$ F. MUÑOZ CONDE, Derecho penal, Parte especial, Tirant lo Blanch, Valencia, 2009, (17르 ed.), p.984.

${ }^{246}$ A. ASUA BATARRITA, La tutela penal..., op. cit., p.20; M. CUGAT MAURI, La desviación..., op. cit., p.72, precisa esta autora que, en definitiva, la función del bien jurídico de límite material al ius puniendi lleva al rechazo de la identificación del bien jurídico con el mero criterio de la "infracción del deber", puesto que su reconocimiento jurídico-positivo no sirve de límite material si en él puede incluirse teóricamente cualquier contenido." En consecuencia, se propone el traslado de las meras infracciones de deber de carácter «interno» al ámbito administrativo-disciplinario."

${ }^{247}$ M. CUGAT MAURI, La desviación..., op. cit., pp.74, 75. observa la autora que si bien la característica general de las definiciones judiciales es, como se ha dicho, el eclecticismo, pueden distinguirse diversas tendencias en la definición de bien jurídico. En primer lugar cabe decir que la última Jurisprudencia apunta sobre todo a la protección de la función pública, Con referencias expresas a los artículos. 103 y 106 CE, y en concreto al principio de objetividad e imparcialidad. Esta concepción, a veces se completa con la de la protección de la honestidad." En otras sentencias aparece de modo prevalente la protección del honor, prestigio o dignidad, que entonces se refiere a la pureza o integridad en la función publica." No faltan las tradicionales referencias al quebrantamiento de la confianza de los ciudadanos en la Administración," así como tampoco la idea de infracción del deber." 
activo del delito, y de aquéllas otras que situaban secularmente el elemento aglutinador en la infracción de los deberes del cargo. Superada esta visión de los delitos cometidos por funcionarios públicos, resultaba ineludible vincular su estudio al modelo de Estado constitucionalmente definido, y situar el punto de referencia, no en el cumplimiento de los deberes propios del cargo, sino en su repercusión sobre el correcto funcionamiento de la Administración Pública y de las diversas actividades prestadas por ésta ${ }^{248}$.

En el mismo sentido se ha pronunciado ASÚA BATARRITA sosteniendo que el modelo de Administración consagrado en la Constitución establece el programa básico de lo que "debe ser" el funcionamiento institucional, y por ello la pauta de referencia para delimitar lo que pueda ser el objeto de tutela penal. Desde la vocación de "última ratio" del Derecho penal, como cierre del sistema de controles que operan en cada sector de actividad, la presencia del instrumento punitivo debe reservarse para incidir sobre los supuestos que impliquen agresiones de mayor alcance contra el corazón del modelo ${ }^{249}$. Explica la misma autora que las notas esenciales que caracterizan ese modelo vienen explicitadas en el artículo 103 de la carta constitucional: "La Administración sirve con objetividad los intereses generales", y actúa "con sometimiento pleno a la ley y al Derecho", de acuerdo con los "principios de eficacia, jerarquía, descentralización, desconcentración y coordinación". La sumisión al interés general con "objetividad" constituye la nota nuclear que deriva del principio fundamental de "interdicción de arbitrariedad de los poderes públicos" (artículo 9,3). La trascendencia de esta característica se subraya de nuevo al ordenar el artículo 103.3 que la ley reguladora del estatuto de los funcionarios públicos recoja "las garantías para la imparcialidad en el ejercicio de sus funciones" 250 .

${ }^{248}$ F. MORALES PRATS y M. J. RODRÍCUEZ PUERTA, "Delitos contra la Administración Pública" en G. QUINTERO OLIVARES (dir.), Comentarios a la Parte Especial del Derecho Pena, 7aed. Thomson/Arazandi, 2008, p. 1585.

${ }^{249}$ A. ASUA BATARRITA, La tutela penal..., op. cit., pp.20, 21.

250 Ibídem, op. cit., p.21; M. CUGAT MAURI, La desviación..., op. cit., pp.77-100. La autora estudia detalladamente estos parámetros desde la aproximación del interés general que ya no consiste en el interés del Estado sino en el de los ciudadanos y todo eso para dar un contenido objetivo al bien jurídico en este título. Destaca entre todos los demás el principio de objetividad, ello es así porque, en un Estado de derecho las instituciones no pueden dirigirse a la satisfacción de intereses generales no reconocidos en la ley," así como tampoco decidir acerca de la eficacia de determinadas medidas para la satisfacción de los primeros si no existe base legal para ello. De modo que, intereses generales y eficacia constituyen el fundamento de legitimación material de la legalidad y objetividad, en la misma medida en que el principio democrático y el principio social son los fundamentos de legitimación material del principio del Estado de Derecho. Respecto a la referencia del principio constitucional de legalidad de la actuación administrativa, reconocido con carácter general en los artículos 9.1 y103.1 CE y que goza de pleno reconocimiento doctrinal," se completa con la prescripción de determinación legal de la actividad y fines de la de la Administración pública en los artículos 3.3 así como 53.2 de la LRJAP. Por último y en garantía de la eficacia jurídica del principio de legalidad, el artículo 106 CE prevé la sumisión al control judicial de todos sus actos, sin el cual el principio en cuestión sería papel mojado. Añade, en cuanto a la racionalidad que la cristalización de este entramado de relaciones administrativas mediatiza- 


\section{B-EL BIEN JURÍDICO PROTEGIDO EN EL TÍTULO XIX DEL CÓDI- GO PENAL ESPAÑOL}

\section{1-Valoración del Título XIX del Código penal}

En primer lugar, cabe destacar los avances operados por el legislador español de 1995 según la pretensión declarada en la Exposición de Motivos del nuevo código de lograr un equilibrio entre "el principio de intervención mínima y las crecientes necesidades de tutela en una sociedad cada vez más compleja". En esta materia se ha decantado por dar satisfacción a las denominadas demandas sociales, que no siempre coinciden con necesidades de tutela penal. Según ASÚA BATARRITA a pesar de los defectos que pueda tener el título estudiado, presenta algunas novedades en la ordenación y en la ubicación bajo epígrafes más acordes con las pautas constitucionales de las todavía demasiadas numerosas previsiones de delitos relacionados con el ejercicio de la función pública ${ }^{251}$.

Observan, en este sentido, MORALES PRATS y RODRÍGUEZ PUERTA, en primer lugar, la supresión de algunas de las figuras típicas que tradicionalmente habían formado parte de este Título. Entre las conductas que desaparecen definitivamente del Código Penal se encuentran los delitos de anticipación, prolongación y abandono de funciones (artículos 373 a $376 \mathrm{CPE}$ /1973), el delito de renuncia o negativa a desempeñar un cargo público obligatorio sin excusa legal (artículo 372 CPE /1973) -cuyo fundamento se encontraba exclusivamente en la infracción de los deberes propios del cargo - y las formas imprudentes de prevaricación (artículo 358.2 CPE /1973) y malversación (artículo 395 CPE/1973). Con la despenalización de este tipo de conductas, el Legislador de 1995 opta por un modelo de intervención penal acorde con los principios de subsidiariedad y fragmentariedad, al transferir a otras ramas del ordenamiento jurídico la sanción de comportamientos de escasa trascendencia desde la perspectiva de los servicios que los poderes públicos prestan a la comunidad. De este modo, la sanción penal queda reservada únicamente para aquellos ataques más graves al modelo constitucional de Administración ${ }^{252}$.

En segundo lugar, notan la incorporación de nuevas figuras delictivas. La inclusión en este Título de nuevos tipos penales responde, a su juicio, a una doble finalidad. Por un lado, superado el obstáculo que representa-

das por la ley y por lo tanto marcadas por la objetividad, conducen a un modelo de Administración racional, en la medida en que el funcionario debe dar cuenta de su respeto por la ley y por lo tanto debe fundamentar sus decisiones. Por ello, con este término de innegable cuño weberiano. en principio no se hace referencia más que a la necesidad de motivación de las decisiones públicas, que es lo exigido expresamente por el ordenamiento jurídico, en tanto que instrumento útil a su control y que por lo tanto garantiza el derecho a la tutela judicial efectiva, que se reconoce en el artículo 24 CE.

251 A. ASUA BATARRITA, La tutela penal..., op. cit., pp.28 y 29.

252 F. MORALES PRATS y M. J. RODRÍGUEZ PUERTA, Delitos..., op. cit., p. 1587. 
ba la única mención en la rúbrica del Título VII anterior Código Penal del funcionario como sujeto activo del delito, el nuevo Código Penal aborda de forma plausible la inclusión en el Título XIX de determinadas figuras delictivas cometidas por particulares. De otro, el Código Penal de 1995 pretende ofrecer un adecuado tratamiento penal de conductas delictivas que se habían revelado lesivas de los principios y valores propios de una Administración democrática, cuyo encaje en los tradicionales delitos de funcionarios resultaba difícil ${ }^{253}$.

En tercer lugar, constatan la reubicación de algunos delitos incluidos en el Título VII CPE/1973. El legislador ha realizado un esfuerzo de depuración del contenido del Título XIX, al objeto de dotar al articulado de una mayor coherencia interna, mediante la exclusiva inclusión de modalidades delictivas cuyo común denominador es la afección a la función pública. Así, entre los delitos que habían formado parte del Título VII CPE/1973 y que han sido trasladados a otros títulos del Código Penal de 1995 se encuentran: la prevaricación judicial (artículos 351-357 CPE /1973), la prevaricación de abogados y procuradores (artículos 360 y $361 \mathrm{CPE} / 1973$ ), la infidelidad en la custodia de presos (artículos 362 y 363 CPE /1973) y la usurpación de atribuciones (artículos 377-380 CPE $/ 1973)^{254}$.

Por último, señalan una nueva organización de los delitos contra la Administración pública. Junto a las novedades antes indicadas, se advierte

\footnotetext{
${ }^{253}$ Ibídem, op. cit., p.1588. Explican que a satisfacer el primero de los objetivos se dirigen los nuevos delitos de aceptación o toma de posesión de un cargo público a sabiendas de carecer de los requisitos legales establecidos para ello (art. $406 \mathrm{CP}$ ), la destrucción o inutilización de los medios puestos para impedir el acceso a documentos (are $414.2 \mathrm{CP}$ ) y el delito consistente en aprovecharse del secreto o información privilegiada obtenido de un funcionario (art. $418 \mathrm{CP}$ ). A la cumplimentación del segundo de los objetivos reseñados -la adecuación a los nuevos principios y valores sobre los que descansa el modelo constitucional de Administración pública-, se endereza todo el conjunto de modificaciones introducidas en este Título y de forma específica las nuevas figuras delictivas incluidas en el Capítulo IX (abusos en el ejercicio de la función pública). Estos delitos se articulan sobre una doble «ratio» teleológica: por un lado, garantizar que la Administración está al servicio de los intereses generales. y, por otro, reprimir abusos verificados en los últimos tiempos en el ejercicio de la función pública, que se insertan en el contexto del tráfico jurídico-económico, marco en el que de forma creciente la Administración desempeña actividades inversoras y de contratación.

254 Ibídem, op. cit., pp.1588 y 1589. Añaden que las dos formas de prevaricación, así como la infidelidad en la custodia de presos han pasado a formar parte del Título XX, de los delitos contra la Administración de justicia, mientras que las distintas modalidades de usurpación de atribuciones se han trasladado al Título XXI, relativo a los delitos contra la Constitución. De esta forma, quedan superadas las críticas que un sector de la doctrina había dirigido a la inclusión de esta clase de ilícitos entre los delitos de los funcionarios públicos en el ejercicio de sus cargos, por cuanto suponen atentados específicos a la Administración de justicia, ámbito perfectamente identificable y autónomo en el seno de la función pública «lato senso», Por lo que respecta a los delitos de usurpación de atribuciones, también se había destacado la conveniencia de revisar su ubicación legal. Pues este tipo de comportamientos se revela ante todo lesivo del principio de división de poderes; es correcto así su nuevo acomodo legal entre los delitos contra la Constitución.
} 
también una nada despreciable modificación de los criterios de agrupación de las distintas figuras delictivas que responden a una lógica interna más o menos plausible. En este sentido, el legislador ha optado por situar en primer lugar los atentados más graves al principio de legalidad en el ejercicio de funciones públicas (prevaricación y otros comportamientos injustos y abandono de funciones públicas). En segundo lugar, la tutela penal se ha articulado sobre otros principios básicos para el correcto funcionamiento de la Administración, en este caso de carácter organizativo, como son, entre otros, el principio de eficacia, jerarquía y coordinación. En esta dirección se inscriben los Capítulos III y IV (desobediencia, denegación de auxilio, infidelidad en la custodia de documentos, violación de secretos), sin perjuicio de que, sobre todo en este último, se tutelen también derechos de los propios administrados frente a los abusos de la Administración, o incluso se proteja la esfera íntima del ciudadano. El tercer y último gran grupo de modalidades delictivas está integrado por aquellos delitos en los que el móvil principal de la conducta típica se sitúa en la obtención de una ganancia ilícita; se trata de aquellas infracciones que coloquialmente reciben la denominación de «corrupción» (cohecho, tráfico de influencias, malversación...). Así, en los Capítulos V al IX, se tipifican los delitos en los que el funcionario actúa con ánimo de lucro, cuya perpetración puede suponer una conculcación del principio de imparcialidad o bien un perjuicio económico para la Administración y los administrados. En todo caso, estas figuras delictivas revelan que la actuación del funcionario ha venido motivada por intereses ajenos a los públicos ${ }^{255}$.

Sin embargo, ante esta apreciación positiva, no faltan autores que afirman que el legislador de 1995 ha aportado muy poco en su intento de reformar el Título XIX en cuestión. VÁZQUEZ-PORTOMEÑE SEIJAS considera, con la literatura especializada, la construcción de los delitos contra la Administración pública como un grupo técnico, esto es, no meramente legislativo y se revela como una tarea compleja, mediatizada por una pluralidad de factores técnicos y político-criminales. Respecto a su aspecto técnico, lamenta el autor al afirmar que la literatura española ha visto tradicionalmente en la atención dispensada por el Código penal al funcionario como sujeto activo del delito un importante factor de confusión con vistas a la comprensión del sistema, que el Código penal de 1995 sustenta el sistema clasificatorio del Derecho derogado, si bien las modificaciones secundarias y matices de redacción han reformado el contenido global de los capítulos más significativos ${ }^{256}$. Ante esta situación, señala el mismo autor que la doctrina, que tradicionalmente había puesto de relieve la conveniencia de revalorizar el punto de vista siste-

255 Ibídem, op. cit., p. 1589. Advierten que esta nueva clasificación de los delitos contra la Administración pública supone un intento de racionalizar la casuística y, en ocasiones, heterogénea y anárquica agrupación que, hasta la fecha había ofrecido el anterior Código Penal. Los nuevos criterios sistemáticos responden en mayor medida a los principios o valores propios de una Administración democrática.

${ }^{256}$ F. VÁZQUEZ-PORTOMEÑE SEIJAS, Delitos..., op. cit., pp.100-103. El autor hace la comparación del contenido del Título XIX del actual Código penal con el de los anteriores demostrando la similitud de la clasificación operada. 
mático como criterio preferente en la reconstrucción interpretativa del grupo de los "delitos en el ejercicio del cargo", hablará de "profesionalidad" y "dispersión" para caracterizar el sistema punitivo español de tratamiento de la responsabilidad funcionarial". Si bajo la vigencia del Título VII del Código penal de 1973 el criterio legislativo de agrupación sistemática fundamentaba la ya conocida observación crítica de que "ni todos los delitos cometidos por funcionarios constituían delitos en el cargo, ni todos los delitos en el cargo tenían por sujetos activos a los funcionarios públicos", a la vista de los criterios de reorganización introducidos por el Código de 1995 un sector de opinión rescata dicha apreciación como característica estructural de los delitos contra la Administración Pública. En este sentido se ha pronunciado POLAINO NAVARRETE para quien el Título XIX del CP 1995, pese a la amplitud de su regulación positiva, no agota la conminación de la totalidad de los delitos propios de los funcionarios públicos. Muchos de los delitos de los funcionarios públicos, y precisamente no pocos de los más graves, son dejados fuera del presente Título, en perseverancia normativa de una extraña estrategia de dispersión típica, siendo radiados a los más diversos lugares del Libro II del Código. El presente Título de los «Delitos contra la Administración Pública» resulta incompleto e imperfecto, y además manifiestamente asistemático y carente de respeto a las exigencias de la proporcionalidad punitiva. Numerosos comportamientos de los funcionarios públicos que el Código ha estimado preciso tipificar han sido dejados extramuros del ámbito incriminador del Título XIX, dedicado a los delitos contra la Administración pública ${ }^{257}$.

Otra crítica de parte de la doctrina es la enorme complejidad y la heterogeneidad de los contenidos típicos del Título en cuestión. Muestras de ello, indica VÁZQUEZ-PORTOMEÑE SEIJAS son el carácter pluriofensivo de algunas de las figuras y, sobre todo, la integración en él, en algún caso como figuras verdaderamente emblemáticas, de conductas protagonizadas por sujetos que en modo alguno pueden representar a la Administración Pública, al no haber accedido a la condición de funcionario público ni siquiera en el sentido más amplio del Derecho penal ${ }^{258}$. Reconoce el mismo autor la extraordinaria dificultad de esta contraposi-

257 Ibídem, op. cit., pp.103, 104; M. POLAINO NAVARRETE, "Delitos contra la Administración pública" en COBO DEL ROSAL (Dir.), Curso de Derecho penal. Parte especial II, Marcial Pons, Madrid, 1997, p. 268; A. ASUA BATARRITA, La tutela penal..., op. cit., p.29.

${ }^{258}$ F. VÁZQUEZ-PORTOMEÑE SEIJAS, Delitos..., op. cit. pp.104, 105. En este contexto, la idiosincrasia, en tanto delitos de sujeto indiferenciado, del cohecho activo de los anteriores artículos 423 y 424 y del tráfico de influencias del artículo 429 parece de obligada mención; M. POLAINO NAVARRETE, “Delitos...”, op. cit., p. 268. Explica el autor que los Delitos contra la Administración Pública, comprendidos en el Título XIX, constituyen supuestos de comportamientos de ilícito ejercicio de la actividad funcionarial, que atentan prioritariamente contra bienes jurídicos de titularidad individual de los ciudadanos. Los tipos delictivos ubicados bajo esta rúbrica legal, en su mayoría, asumen el carácter de delitos funcionariales pluriofensivos. La garantía penal de diversas esferas jurídicas privadas se compatibiliza con la protección típica de la función pública estatal circunscrita al ejercicio de aquellos específicos cometidos que resultan legalmente asignados a los funcionarios públicos. 
ción formal a la hora de afirmar el carácter técnico de la categoría al impedir, cabalmente, hacer del ejercicio abusivo del cargo el núcleo de la tipicidad de todas las figuras que la integran. Sólo podrá hablarse de una cierta coherencia sistemática entre todas ellas apelando a la dirección objetiva que presentan las conductas, como agresiones a un ejercicio de la función pública respetuoso con los cánones constitucionales originadas en el interior o en el exterior de la organización administrativa, esto es, adoptando como eje del sistema un principio teleológico, no estructural. Ésa será, entonces, la razón que explique y justifique la ubicación en el Título XIX del subgrupo normativo de los delitos de los particulares, al margen de que algunos de ellos puedan presentar adicionalmente conexiones normativas con los abusos de los funcionarios 259 . Como rasgo altamente significativo, en el sistema punitivo español la Administración Pública, el Estado o los aparatos estatales reciben, pues, protección ya no sólo frente a las desviaciones en el ejercicio de los cargos públicos, sino también a los ataques conducidos ab externo, por extranei 260 .

Otro problema que señala el mismo autor son las dificultades que supone la identificación en todas y cada una de ellas de comportamientos que importen la lesión o puesta en peligro de un bien jurídico habilitado para cumplir el rol de límite del poder punitivo del Estado y que actúe, además, como factor de propulsión de aquellos valores políticoconstitucionales que deben hacerse operativos en este terreno ${ }^{261}$.

Por otro lado, desde aspectos de tipo técnico y político-criminales, los motivos de insatisfacción son variados. Se señala, en primer lugar, que, a pesar de que los principios y reglas que integran el estatuto constitucional de la Administración representan un criterio altamente utilizable en sede de diferenciación entre ilícito penal y disciplinario, al inducir a reservar éste para los incumplimientos o transgresiones de pautas de organización interna marcadas por la propia Administración o por el

${ }^{259}$ F. MORALES PRATS y M. J. RODRÍGUEZ PUERTA, “Delitos...”, op. cit., p. 1588: “Con la incorporación al catálogo de delitos contra la Administración pública de estos comportamientos, adquiere refrendo legal la concepción doctrinal según la cual la infracción de los deberes del cargo no constituye el objeto jurídico de tutela en el actual Título XIX. Por consiguiente, el bien jurídico tutelado no es otro que la función pública, merecedora de tutela penal tanto frente a los ataques que, en el seno interno de la Administración, protagonizan quienes desempeñan funciones públicas, como frente a los atentados externos perpetrados por personas ajenas a esa función"; M. POLAINO NAVARRETE, "Delitos...", op. cit., p. 268: "El legislador considera, no obstante, que determinadas formas de incidencia de los particulares en la Administración Pública, bien en connivencia

con los funcionarios públicos bien en contra de los mismos y en propio provecho personal, por lesionar esencialmente los intereses públicos, asimismo merecen ser incorporadas entre los supuestos típicos incluidos en el presente Título XIX"; MUÑOZ CONDE, Derecho penal Parte Especial, 2009, op. cit., p. 904: "estos delitos no son delitos cometidos por funcionarios públicos, pero sí delitos contra la Administración Pública, que lógicamente no requieren la incorporación del sujeto a la actividad pública, aunque su conducta pretenda conculcar el recto funcionamiento de la misma".

${ }^{260}$ F. VÁZQUEZ-PORTOMEÑE SEIJAS, Delitos..., op. cit., pp.106, 107.

${ }^{261}$ Ibídem, op. cit., pp.108-115. 
legislador ordinario ${ }^{262}$, éste no ha conseguido dibujar una línea de demarcación entre ambos que respete el sentido que la amenaza punitiva debe revestir en un Estado de Derecho.

En segundo lugar, a la reforma cabrá probablemente reprocharle su escaso éxito en la consecución de lo que se anunciaba como uno de sus objetivos primarios: la plena cohonestación de la regulación de la delincuencia relacionada con la Administración Pública con los nuevos principios y valores constitucionales. A pesar de hacerse eco de la sustancial modificación de las relaciones entre la ciudadanía y el Estado operadas por la Constitución española de 1978, el articulado del Código penal de 1995 no respalda, ni

mucho menos, dicha alternativa. El legislador ha modelado los diversos delitos a la vista de un concepto monolítico de organización estatal, en el que la máxima de la división de poderes parece quedar reducida a una simple regla de distribución de las competencias en el seno de la burocracia pública y la figura del funcionario a una noción formal que abarca indistintamente al personal de la organización administrativa, a los parlamentarios y a los jueces ${ }^{263}$.

\section{XIX del Código penal \\ 2-Debate sobre el bien jurídico protegido en el Título}

La evolución constitucional y la reforma del Código penal han llevado a la doctrina a considerar de manera objetiva el objeto tutelado en el Título en estudio conforme a los parámetros constitucionales en vigor. Como lo explican MORALES PRATS y RODRÍGUEZ PUERTA, en este contexto es obligada la remisión a los preceptos constitucionales en los que se determina el modelo de Administración pública, y los principios y valores inherentes a su funcionamiento. En especial cabe destacar, de entre las previsiones constitucionales en esta materia, el artículo 9.1 y 3 CE por el que se somete a los poderes públicos a la Constitución y al resto del ordenamiento jurídico, y se sitúa su actuación en el marco propio de un Estado social y democrático de Derecho. Pero el modelo constitucional de Administración Pública no queda colmado con el sometimiento de la actividad prestacional de ésta a los principios formales del Estado de Derecho. El texto constitucional además instituye la finalidad de promover las condiciones necesarias para que la libertad e igualdad del ciudadano sea real y efectiva. Junto a esta previsión constitucional de alcance general, el artículo 103 CE dispone que la Administración pública se enderece al servicio de los intereses generales, con objetividad y eficacia y, además, con pleno sometimiento a la ley y al

262 I. VALEIJE ÁLVAREZ, El tratamiento penal de la corrupción del funcionario: el delito de cohecho, Edersa, Madrid, 1996, p.28; I. OLAIZOLA NOGALES, El delito de cohecho, op. cit., p.88; M… J. RODRÍGUEZ PUERTA, El delito de cohecho: Problemática jurídicopenal del soborno de funcionarios, Arazandi, Pamplona, 1999, p.67; A. ASUA BATARRITA, La tutela penal..., op. cit., pp.25 y 29.

${ }^{263}$ F. VÁZQUEZ-PORTOMEÑE SEIJAS, Delitos..., op. cit., pp.116 y 117. 
Derecho. Asimismo, la Constitución refrenda otros principios de carácter organizativo, como el

de jerarquía, descentralización, desconcentración y coordinación, criterios todos ellos subordinados a los referidos principios del Estado de Derecho, que revisten también trascendencia en la configuración de algunos de los tipos penales incluidos en este Título (por ejemplo, en el delito de desobediencia y denegación de auxilio) ${ }^{264}$. Y concluyen estos mismos autores que en definitiva, el bien jurídico común a los delitos incluidos en el Título XIX, no es otro que el correcto desempeño de las distintas actividades públicas desde la perspectiva de una Administración prestacional, plenamente sometida al Derecho y al resto de principios constitucionales que ordenan su funcionamiento 265 . Añade ASÚA BATARRITA que la tutela de la Administración en sus características de actividad, no significa proteger los entes en sí mismos, sino precisamente preservar sus funciones y sus cometidos valiosos para la organización social articulada conforme a la Constitución democrática. La Administración se convierte en un ente necesitado de protección no por constituir parte de uno de los poderes del Estado, sino por constituir instrumento necesario, presupuesto de acceso de los ciudadanos a los servicios públicos en condiciones de igualdad, transparencia, objetividad, conforme a Derecho, etc. Los titulares de ese bien jurídico ahora genéricamente formulado como "comportamiento correcto de la Administración" son los ciudadanos, cuyas legítimas expectativas frente a la Administración son las que se ven perjudicadas cuando se altera la función que ésta debe cumplir en el sistema de organización social dado. Con lo cual, sostiene la misma autora que no se pueden defender como objeto de protección el prestigio de las instituciones, la confianza de los ciudadanos en el correcto funcionamiento de estas o hablar de dignidad cuyas referencias pueden resultar equívocas si no se les asocia a lo que debe ser la fuente del prestigio institucional, esto es, su adecuado funcionamiento conforme a los parámetros constitucionales ${ }^{266}$. Esta orien-

${ }^{264}$ F. MORALES y M. J. RODRÍGUEZ PUERTA, “Delitos...”, op. cit., pp. 1586 y 1587. Añaden que de la interpretación conjunta de estos preceptos pueden inferirse las notas esenciales de la actividad administrativa, que coinciden en lo sustancial, con las que corresponden al resto de actividades públicas, y que podrían sintetizarse del siguiente modo: servicio a los intereses generales, sometimiento pleno a la ley y al Derecho y objetividad en el cumplimiento de sus fines. No obstante, la actividad pública comprende además de la administrativa -en sentido estricto- la judicial y legislativa, por lo que a su vez deberán tomarse en consideración aquellas características propias de cada una de ellas, a las que también se refiere nuestra norma fundamental. En concreto, lo dispuesto en el artículo $117 \mathrm{CE}$, referido al poder judicial, y en los artículos 66 y ss. CE, relativos a la actividad legislativa y política.

265 Ibídem, op. cit., p. 1587.

${ }^{266}$ A. ASUA BATARRITA, La tutela penal..., op. cit., p.22. Explica que no pueden por ello mantenerse como objeto de protección en sí mismos el "prestigio" de las instituciones, ni siquiera la "confianza" de los ciudadanos en el correcto funcionamiento de éstas. Las referencias al "prestigio" o a la "dignidad" pueden resultar equívocas si no se les asocia a lo que debe ser la fuente del prestigio institucional, esto es, su adecuado funcionamiento conforme a los parámetros constitucionales. De otra forma se convierten en fórmulas vacías que pueden servir de coartada para defender la intangibilidad de ciertos espacios de poder. El prestigio y la confianza de la generalidad en sus institu- 
tación a los ciudadanos, destaca CUGAT MAURI, lleva a la concepción de un bien jurídico cuyo contenido material radica en su instrumentalidad a la protección de bienes jurídicos de aquellos. De ahí que se defina el bien jurídico como "función" de servicio a los ciudadanos ${ }^{267}$.

Concreta RODRÍGUEZ PUERTA que el bien jurídico común a todas las figuras delictivas contenidas en el Título XIX, "Delitos contra la Administración Pública", es la función pública, y más concretamente los principios esenciales a cada una de las actividades prestadas por el Esta$\mathrm{do}^{268}$. En este sentido se ha pronunciado GONZALEZ CUSSAC para quien el bien jurídico categorial estaría constituido por la función pública ejercida correctamente, esto es, dentro de la legalidad ${ }^{269}$.

Esta postura ha sido criticada por VIZUETA FERNÁNDEZ quien no cree acertado considerar las funciones públicas bien jurídico común a todos los delitos del Título XIX, por mucho que se adicione a la expresión bien jurídico los calificativos categorial o genérico ${ }^{270}$. Que el bien jurídico protegido sirva de criterio para agrupar un conjunto de delitos bajo una misma rúbrica, y que ésta utilice una, más o menos afortunada expresión genérica con la pretensión de condensar en ella la rica variedad de todas las infracciones y, si es posible, reflejar un rasgo o nota común a todas ellas, no permite, por mucho que se recuerde la función clasificadora que cumple el bien jurídico, que tal rúbrica, o lo que ella expresa se convierta en bien jurídico común a todos los delitos que alberga. Quiere el autor decir con ello que el hecho de que el legislador de 1995 haya

ciones deben entenderse como efecto derivado del correcto funcionamiento de la actuación administrativa. Un prestigio a costa del ocultamiento de irregularidades, o una confianza del público ignorante de los niveles de corrupción interna, pueden ser funcionales para el desarrollo de un sistema opaco, lo cual precisamente es lo contrario a las exigencias de transparencia y de sumisión a legalidad impuestas por la Constitución. La importancia de ese efecto de confianza en las instituciones debe ser tomada en cuenta para valorar la gravedad de los efectos de la conducta delictiva, pero en sí mismo no es el objeto de tutela en sentido jurídico-penal; I. OLAIZOLA NOGALES, El delito de cohecho, op. cit., p.87; P. RODRÍGUEZ LÓPEZ y A. I. SOBRINO MARTÍNEZ, Delitos..., op. cit., p.39.

267 M. CUGAT MAURI, La desviación..., op. cit., pp.70, 71. Señala que la doctrina hace depender la corrección de este servicio de las notas de objetividad, imparcialidad y eficacia en el ejercicio de la función pública. Precisamente son estos principios los que han animado las últimas reformas concernientes a los delitos contra la Administración pública, aunque no siempre de modo satisfactorio.

268 Mํ. J. RODRÍGUEZ PUERTA, El delito de cohecho..., op. cit., pp.37, 38: "No se trata de tutelar la Administración como entidad, sino la actividad pública, los servicios que los distintos poderes del Estado prestan a los ciudadanos, en el marco de un Estado Social y Democrático de Derecho."

269 J. L. GONZALEZ CUSSAC, El delito de prevaricación de autoridades y funcionarios públicos, Tirant Lo Blanch, Valencia, 1997, p.22. Indica el autor que esta esencia común, autentico bien jurídico protegido en todas esas infracciones, "se halla representado por el servicio que los poderes públicos han de prestar a la comunidad. Bien entendido que con ello nos referimos al bien jurídico categorial, puesto que también resulta posible concretar éste en cada figura delictiva, pudiendo hablar entonces de bien jurídico específico.

270 J. VIZUETA FERNÁNDEZ, Delitos..., op. cit., p.179. El autor afirma que esta postura es de la mayoría de la doctrina. 
ordenado bajo el Título XIX una serie de infracciones atendiendo fundamentalmente al criterio de bien jurídico, esto es, teniendo en cuenta la afinidad que presentan los específicos bienes jurídicos protegidos por cada una de aquéllas, no da pie para erigir en bien jurídico la expresión, o lo que ella representa - funciones públicas -, utilizada en la rúbrica como criterio aglutinante de todo el grupo de los delitos. Sería más conveniente, sugiere el mismo autor, referirse a las funciones públicas con otras expresiones distintas a la de bien jurídico: característica genérica, rasgo común, elemento general, etc. Así se evita de una parte, la confusión, salvada solo parcialmente con el empleo de opuestos adjetivos (categorial y específico), que supone la utilización de una misma expresión (bien jurídico) con distinto contenido, y de otra, la tentación de convertir el bien jurídico categorial en particular objeto de protección de alguno o algunos delitos, generalmente aquellos que más problemas plantean a la hora de precisar su verdadero y específico bien jurídico, o que simplemente carecen de él, siendo entonces lo más oportuno reclamar su desaparición. En fin, el autor no encuentra utilidad alguna a la expresión bien jurídico categorial que merezca su fomento 271 . Después de una comprobación de los delitos en el Título en estudio ${ }^{272}$, concluye el autor que se pedía que el criterio de agrupación no atendiera a la identidad del sujeto activo, sino al, más comúnmente aceptado del bien jurídico. Pues bien, en el actual Código penal ha variado el criterio de sistematización, pero, en la nueva realidad legislativa, surge un problema semejante y con él la crítica: ¿cómo aplaudir un título - el XIX- donde, según opinión mayoritaria, las funciones públicas son consideradas bien jurídico categorial, cuando existen fuera de él delitos que protegen única y preferentemente aspectos o características de las mismas? Parte de la beligerancia usada con aquél ha de servir para atacar a éste ${ }^{273}$.

También se ha mostrado crítico VÁZQUEZ-PORTOMEÑE SEIJAS quien comparte el escepticismo con relación al rendimiento interpretativo de un concepto de Administración Pública formulado desde los principios constitucionales y con la exclusiva atención a su capacidad prestacional274. Defiende el autor que de lo que no cabe duda alguna es de que a través de estas concepciones se da entrada a un objeto jurídico que, al poner de relieve los servicios que la ciudadanía ha de recibir de la Administración, permite fiscalizar la "legitimidad material" de todas las decisiones de aquélla ha de prestar a la ciudadanía. Ésta no representa tal y como resulta configurada en el modelo estatal sancionado en los artículos 1.1, 9 y 10 de la Constitución- un bien jurídico genérico o for-

\footnotetext{
${ }^{271}$ Ibídem, op. cit., pp.183, 184. Este desacuerdo no impide al autor comprobar si las funciones públicas constituyen, al menos, rasgo, característica o denominador común de los delitos en el Título XIX.

272 Ibídem, op. cit., pp.184-197.

273 Ibídem, op. cit., p.198. Añade que la problemática de estos ilícitos no se resuelve con un mero cambio de rúbrica, un quitar de aquí esta figura y ponerla allá o con simples variaciones de matiz de alguno de los delitos. Procediendo así, sin una revisión profunda y meditada de esta materia, ni la casualidad hubiera hecho posible una rúbrica plausible, coherente con el contenido del Título y con otros delitos del Código.

${ }^{274}$ F. VÁZQUEZ-PORTOMEÑE SEIJAS, Delitos..., op. cit., p.111
} 
mal, privado de todo contacto con la esfera de bienes e intereses de los particulares. Bien al contrario, la previsión de una disciplina penal específicamente destinada a ella encuentra su razón de ser en su significado de "mecanismo prestacional", de cauce de satisfacción -con "eficacia indiferente"- de intereses generales -y no de intereses del Gobierno, de partido o de la organización burocrática administrativa- y; en última instancia, de garante del libre desarrollo de la personalidad de los ciudadanos. A esas referencias cabe reconocerles, por lo tanto, el rango axiológico y la sustantividad de los que carece la tradicional noción de "deberes del cargo". Cabe cuestionarse, no obstante, si no merece ninguna clase de reproche la apelación, en el marco del Derecho penal propio de un Estado social y democrático de Derecho, a nociones que no permiten medir, escalonar o graduar en absoluto la ofensa acarreada por las figuras delictivas a cuya interpretación teleológica se orientan. ${ }^{275}$ En España, en línea con estos posicionamientos, la configuración de la Administración Pública como objeto de protección global ha intentado explicarse dogmáticamente acudiendo a la tesis de los delitos con "bien jurídico intermedio espiritualizado" o con bien jurídico "con función representativa", con la que se pretende poner en relación el concepto tradicional de "delito de peligro abstracto" con las técnicas de tipificación seleccionadas por el legislador para tutelar aquellos bienes jurídicos cuya perturbación se produce únicamente a través de una repetición generalizada de comportamientos delictivos. Con arreglo a ella, sería a las "condiciones básicas de funcionamiento de la Administración imprescindibles para su vigencia e indemnidad" -el "bien jurídico representante" de estos delitos-, a las que le correspondería desempeñar el papel técnico y político-criminal del concepto bien jurídico, un papel que el "bien representado" -la Administración Pública, el "buen funcionamiento" de los aparatos del Estado- se muestra incapaz de asumir por su desmesurada extensión. Pero no parece que con ello se haya obtenido ganancia alguna para solventar el problema, pues, al margen de merecer otras consideraciones de orden material e incluso ético-social, la adopción de un planteamiento de estas características arrastraría numerosas perturbaciones en orden a la construcción lógico-científica del presente conjunto de delitos ${ }^{276}$.

Otra postura sostiene MUÑOZ CONDE quien se inclina por pensar en la no existencia de un bien jurídico común a todos estos delitos. Ya que

\footnotetext{
275 Ibídem, op. cit., pp.113, 114. Añade que No hay que olvidar que ninguno de los ámbitos o sectores de la realidad abarcados por los precitados conceptos constituye un objeto afectable -ideal o materialmente- por lo que hace o provoca cualquiera de los autores de un delito del cargo.

${ }^{276}$ Ibídem. op. cit., pp.114, 115. Concluye que la caracterización de estos delitos como meras infracciones formales de deberes estatutarios ni siquiera se acomoda al Derecho vigente, desde el momento en que ninguno de los coeficientes presentados para medir la adecuación de las conductas típicas para perjudicar a lo "básico en la función pública" (v.gr., en el ámbito del cohecho, la concreta naturaleza del acto a cuya ejecución se ha comprometido el funcionario, la cuantía de la dádiva, el rango jerárquico del agente público) guarda relación con los criterios de graduación de las penas previstos por el legislador para las figuras del Título XIX.
} 
ello sólo sería posible si se aceptase una concepción de los mismos como infracciones de un especial deber de cargo. Este autor se decanta por la búsqueda en cada figura del bien jurídico allí específicamente tutelado 277 .

\section{II-La Administración según la perspectiva del ordena- miento penal francés}

\section{A-CONCEPTO DE ADMINISTRACIÓN PÚBLICA}

\section{1-Evolución del concepto}

Desde una aproximación histórica, el concepto de "administración" en la historia jurídica tuvo ya embrión desde la edad medieval por medio de organismos con origen y estatuto variables a los cuales se les asignaba la satisfacción de los intereses colectivos ${ }^{278}$. A partir del siglo XVI, período de la monarquía absoluta, se observa la introducción de una "privatización" de las concepciones tendientes a aceptar las pautas del ejercicio de los poderes de orden administrativo y cuya violación puede justificar reclamaciones. Pero en este intento de someter la actividad administrativa a pautas de Derecho privado se destacó que la satisfacción del interés general con las prerrogativas públicas que eso puede conllevar, implica reglas diferentes y reglamentos de conflictos especiales. A partir de ahí se comenzó formar el régimen administrativo con una jurisdicción diferente. El Parlamento en aquel momento ejercía un control sobre la administración real, ya que todo conflicto que ella podía protagonizar tenía como juez uno que viene de ella misma. Por lo tanto había una confusión entre las funciones administrativas y jurisdiccionales. El equilibrio de fuerza entre el monarca y los parlamentos marcaba estos momentos pero la falta de garantías suficientes, el sentimiento de arbitrario y la lesión a los intereses privados acababan con la monarquía para entrar en una nueva etapa de la historia ${ }^{279}$.

En el período de la Revolución, la Administración se inscribió en el marco de la separación de los poderes. Su papel se limitó a la ejecución de la

277 MUÑOZ CONDE, Derecho penal Parte Especial, 2009, op. cit., p.902. Defiende que se hace difícil encontrar un bien jurídico común a todos los delitos recogidos ahora en el Título XIX, que sólo puede hallarse en un vago quebrantamiento de deberes profesionales o en la confianza de la sociedad en el correcto funcionamiento de la Administración pública en general, conceptos poco indicativos, en realidad, de la naturaleza de estos delitos. En realidad, la Administración pública de la que se habla en la rúbrica XIX no es más que el marco en el que realizan los delitos que en él se tipifican pero luego hay que identificar en cada caso el aspecto de la Administración que en cada uno de ellos se cuestiona.

278 P.-L. FRIER, Précis de droit administratif, Montchrestien, 2004, pp.13, 14.

${ }^{279}$ Ibídem, op. cit., pp.14, 15 
ley, la cual le servía de credencial jurídica a su intervención. Ya no tenía competencia normativa para determinar su propio Derecho. Además, la Revolución prohibió al nuevo poder judicial conocer de los litigios que involucran la Administración. Se admitió entonces el principio de la separación de las autoridades administrativas y judiciales. La Revolución, cuyo detonante se debió, parcialmente, a la obstrucción sistemática de los Parlamentos, rechazó de parte de la autoridad judicial toda perturbación en la acción de los demás poderes, en adelante separados. La ley de los 16 y 24 de agosto de 1794, todavía en vigor, le deniega todo derecho de intervenir en el ejercicio del poder legislativo, o de impedir la administración cumplir su misión ${ }^{280}$. Así, el principio de separación de las autoridades administrativas y judiciales ha sido afirmado pero no parecía provocar, a priori, ninguna consecuencia en cuanto a la existencia de un contencioso administrativo específico. Sólo le prohíbe al juez obrar de administrador tomando actos reglamentarios, le obliga a limitarse en su función jurisdiccional sin participar del poder ejecutivo. Pero se pregunta FRIER: ¿los tribunales judiciales no pueden ser jueces de los asuntos administrativos sin que haya incompatibilidad con la prohibición así puesta?281

\section{2-El juez penal y la actividad administrativa}

El siglo XIX desarrolló el principio de la separación de los dos poderes. Pero a la vez fue el inicio de la creación de una jurisdicción autónoma competente para conocer de los actos administrativos. En lo que concierne a nuestro estudio, es interesante revelar que la primera fase de esta construcción, que se llama justicia retenida, constituye también un

280 Ibídem, op. cit., pp.15, 16. El artículo 13 de esta ley estipula que "las funciones judiciales son distintas y se quedarán separadas de las funciones administrativas. Los jueces no podrán, so pena de prevaricación, perturbar, de forma cualquiera, las operaciones de los cuerpos administrativos, ni citar ante ellos los administradores por razón de sus funciones".

${ }^{281}$ Ibídem, op. cit., p.16. Contesta el autor que en los Estados Unidos, el principio de la separación de los poderes no prohíbe en absoluto al poder judicial juzgar tanto a la administración como al legislador. En Francia, al contrario, avisado por los comportamientos anteriores de los Parlamentos, se ha puesto en marcha, de manera implícita, un precepto solamente formalizado en el siglo XIX: "Juzgar la administración, es todavía administrar". Se trata de proteger siempre el poder, lo que a partir de ahí es legítimo porque llega a ser democrático. Por eso, el legislador suprimía lo que iba a ser la ley de los 16-24 de agosto de 1790, un título 13 que preveía confiar este contencioso a un tribunal administrativo especial en el seno del orden judicial. $Y$, como consecuencia de esta elección, la ley del 6, 7-11 de septiembre de 1790 atribuye, a nivel territorial, el tratamiento de ciertas reclamaciones contra la administración a las autoridades locales; la de los 7-14 octubre reserva al Rey, jefe de la administración general las reclamaciones de incompetencia para con cuerpos administrativos. Por último, el decreto (con valor de ley) del 16 fructidor año III estipula de manera clara: "Se prohíbe insistentemente a los tribunales conocer de los actos administrativos, por cualquier clase que fuere". En esta concepción "francesa" de la separación de los poderes, el juez "ordinario" no puede, entonces, decidir sobre el contencioso administrativo et particularmente sobre los actos administrativos, aunque la ley le atribuye algunas competencias reales (impuestos indirectos, expropiación desde del Imperio). En cuanto al derecho sustancial, los poderes excepcionales de la Administración subsistían y crecían en las fases más críticas de la Revolución francesa. 
primer paso en la separación de la jurisdicción administrativa y de la administración activa. Como ya se ha explicado, el contencioso administrativo escapa al orden judicial ${ }^{282}$. Y este mecanismo ha sido completado por el artículo75 de la Constitución del año VIII que instituye "la garantía de los funcionarios". Para evitar los riesgos de intromisión del juez ordinario, está prohibido demandar a un funcionario ante los tribunales de Derecho común, salvo autorización dada por el Consejo de Estado, lo que es extremadamente difícil de obtener. La víctima de un comportamiento administrativo no tiene otra solución que dirigirse, de forma amistosa, a la Administración para que dictamine o vuelva a examinar la cuestión ${ }^{283}$. La evolución de esta situación se reflejó también en el ámbito penal. El Derecho histórico y la cultura administrativa tradicional francesa se oponían a la idea de que un servidor público pudiera ser procesado por los tribunales penales por causa de decisiones presuntamente tomadas en el interés de la ciudadanía. De esta forma, si el régimen penal sustantivo no se hacía eco de ninguna clase de reticencias a la hora de admitir que un funcionario pudiera ser penalmente sancionado por la realización de actos propios de su cargo, sí se habían arbitrado prerrogativas jurisdiccionales especiales que dificultaban su persecución. La atracción del funcionariado ante los órganos de la justicia penal ha precisado, por ello, de importantes reformas legislativas, fundamentalmente de la abrogación del artículo 75 de la Constitución del año VIII, que condicionaba la apertura de un proceso penal contra cualquier funcionario a la existencia de la correspondiente autorización por parte del Consejo de Estado, y de los artículos 679 a 688 del Código de enjuiciamiento penal, que ordenaban el reenvío automático de la causa a la Sala de lo penal de la Corte de Casación para que aquélla designase, a su vez, la jurisdicción encargada de la instrucción y el enjuiciamiento ${ }^{284}$. En la actualidad, la condición de los funcionarios públicos como "ciudadanos de Derecho común", sometidos a las reglas del Derecho penal general y especial, resulta tanto de las declaraciones conteni-

\footnotetext{
282 Es de precisar que los tribunales franceses se categorizan en orden jurisdiccional. El orden judicial aquí se refiere a los tribunales de derecho común: civil, penal, etc. ${ }^{283}$ Ibídem, op. cit., p.17. Era evidentemente imposible al jefe supremo de la Administración, el jefe del Estado, de "apelación" de los ministros qui habían decidido primero sobre el litigio, zanjar tales cuestiones. Por eso, tomó el costumbre de consultar el Consejo de Estado instituido por la Constitución del año VIII, dentro del cual se creó, a partir del decreto del 11 de junio de 1886, una comisión del contencioso. Las decisiones tomadas en nombre del jefe del Estado están preparadas y tomadas por el Consejo de estado, compuesto de altos funcionarios y juristas, distintos ya del personal de los propios ministerios. Ellas benefician de la autoridad del jefe del Estado, aunque no hace más que retomar la decisión del consejo. Así, en el seno del ejecutivo, se va desarrollando una función contenciosa especializada, fuera del campo del juez ordinario y exterior a la administración activa.

${ }^{284}$ Las mencionadas abrogaciones se hicieron operativas a través del decreto legislativo de 19 de septiembre de 1870 y de la Ley 93-2, de 4 de enero de 1893. Con la entrada en vigor de ésta última, dichos sujetos se someten a las jurisdicciones territorialmente competentes, si bien la propia ley prevé que, en interés de una buena administración de justicia, la Corte de Casación, a requerimiento del procurador general o del procurador general territorialmente competente, pueda ordenar la remisión de la causa a otra jurisdicción
} 
das en ciertos textos legales especialmente significativos ${ }^{285}$, como de la letra y el espíritu del Código penal, que le atribuye un sentido claramente agravatorio. ${ }^{286}$

\section{B-ESTUDIO DEL BIEN JURÍDICO EN LOS CAPÍTULOS II Y III DEL TÍTULO III DEL LIBRO IV DEL CÓDIGO PENAL FRANCÉS (CPF)}

Antes de emprender este estudio que corresponde a este apartado, sería interesante destacar el transfondo constitucional que puede apoyar dicho estudio así como la concepción contemporánea de la Administración según la doctrina, en su mayor parte administrativista, ya que la penalista no ha desarrollado ninguna consideración propia. Es de reconocer, como ya se ha dicho anteriormente, que la identificación del bien jurídico no ha sido y no es siempre parte de las reflexiones doctrinales francesas, con lo cual, a pesar de existir indicios en la sistemática clasificación de los delitos según el valor protegido, el intento aquí propuesto no goza de algún apoyo sustancial por parte de los autores.

\section{1- Aproximación constitucional a la noción de Admi- nistración y las consecuencias en su concepción}

La organización constitucional francesa desde la Revolución se basa en el principio de separación de los poderes, fundamentado sobre la distinción de las funciones que deben ser aseguradas para un funcionamiento harmonioso de la sociedad. Según una concepción material, se distinguen tres funciones específicas, en principio confiadas, cada una, a un órgano distinto. La función legislativa tiene como objeto crear, al expresar la voluntad de la soberanía de la Nación ${ }^{287}$, las normas generales que rigen el conjunto de las actividades públicas o privadas. Pero ella no tiene que participar de su aplicación concreta. La función judicial, o jurisdiccional, tiene como misión "decir" el Derecho cuando conoce, con la fuerza de la cosa juzgada, de los litigios a ella sometidos. Por fin, la función ejecutiva se encarga de la ejecución de las leyes, de la aplicación de las normas tomadas por el legislador. Hoy en día, el ejecutivo no se conforma más con aplicar sin margen alguna de maniobra los actos del Parlamento. Se beneficia de un poder importante de selección en cuanto a las medidas que tomar, ostentando la facultad de dictar normas de carácter general, pero siempre situadas a un nivel inferior al de las leyes. Por eso, el artículo 20 de la Constitución de 1958, primer artículo del título III dedicado al Gobierno establece: "El Gobierno determina y dirige la política de la Nación.” Más allá de la pura ejecución

\footnotetext{
${ }^{285}$ Cfr. artículo 29 de la Ley 83-634 de 13 de julio de 1983, que aprueba el estatuto general de la función pública: "toda falta cometida por un funcionario en la ejecución o con ocasión de la ejecución de sus funciones lo expone a una sanción disciplinaria sin perjuicio, dado el caso, de las penas previstas por la ley penal".

${ }^{286}$ F. VÁZQUEZ-PORTOMEÑE SEIJAS, Delitos..., op. cit., pp.60 y 61.

${ }^{287}$ Cfr. Artículo 3 de la Declaración de los derechos humanos: "El principio de toda soberanía reside esencialmente en la Nación. Ningún cuerpo, ningún individuo, pueden ejercer una autoridad que no emane expresamente de ella."
} 
de las leyes, tiene, entonces, la responsabilidad global de una política que toma en cuenta el conjunto de los intereses de la vida nacional.

Al lado de estas tres funciones, parece posible poner en evidencia una función administrativa. Es instrumental y secundaria. Consiste, en conformidad con su sentido etimológico de administración-sierva, en preparar y asegurar la puesta en marcha cotidiana, en las situaciones particulares, elecciones hechas por las autoridades políticas que se imponen a ella. Ello se manifiesta por la emisión de actos jurídicos subordinados o también por actividades materiales de prestación ${ }^{288}$.

El ejercicio de esta función necesita un conjunto de recursos humanos y materiales, en el seno de una estructura burocrática, puesto a disposición de las autoridades políticas. La Administración, considerada desde un punto de vista orgánico, es, por tanto, diferente del político, lo que supone a la vez subordinación y separación, única solución compatible con el sistema democrático liberal. Como el poder político pertenece a los representantes del titular de la soberanía, la Administración no podría más que ejecutar las orientaciones definidas por ellos, excluyendo toda posibilidad de aportar algún cambio ${ }^{289}$. Para ello, ella debe estar subordinada o al Parlamento o al Gobierno. En el caso francés, está sometida al Gobierno, aunque el primero controla su buen funcionamiento. El Gobierno es, además, responsable políticamente de "su" administración. La constitución francesa de 1958 expresa con perfecta claridad este principio. El artículo 20 declara que el Gobierno "dispone de la administración y de las fuerzas armadas"290. Para actuar, se apoya sobre un poderoso aparato administrativo, distinto, que prepara sus decisiones y las ejecuta, situado, en la administración del Estado, bajo su autoridad directa por el poder jerárquico del ministro.

El principio de la separación de la administración, para asegurar la continuidad del Estado ante las fluctuaciones de lo político y garantizar la neutralidad de la acción, exige una distinción entre los dos aparatos, entre los elegidos y los funcionarios permanentes ${ }^{291}$.

\footnotetext{
288 M. HAURIOU, Précis de droit administratif, Dalloz, 2002, pp.14 y 15. Propone una definición según la cual la función administrativa consiste en la satisfacción de las necesidades públicas. Es una misión compleja que implica para el poder administrativo encargarse de hacer reinar el orden público y proveer a la utilidad pública por la aplicación de las leyes, por la policía y por la gestión de los servicios públicos.

${ }^{289}$ P.-L. FRIER, Précis..., op. cit., pp. 2, 3.

290 Con la finalidad de destacar el aspecto orgánico de la Administración preferimos traducir "administration" por "administración" y no "los servicios administrativos" como lo han hecho ARÁNGUEZ SÁNCHEZ y ALARCÓN NAVÍO (C. ARÁNGUEZ SÁNCHEZ y E. ALARCÓN NAVÍO en El código penal francés, traducido y anotado, Comares, Granada, 2003, p. 255).

${ }^{291}$ P.-L. FRIER, Précis..., op. cit., p.3. Añade que el estatuto de la función pública, por las garantías que concede a los funcionarios, al prohibir sobretodo la consideración de sus opiniones políticas tanto en su reclutamiento como en el desarrollo de su carrera profesional, juega un papel esencial en este sentido.
} 
Sin embargo, hay que relativizar estas distinciones. Si la separación de las funcionas legislativa y judicial en relación a las funciones administrativas es relativamente simple, aunque algunas dificultas pueden existir ${ }^{292}$, la dificultad existe cuando se trata de distinguir la función gubernamental y la administrativa. La manera más simple sería apoyarse en la vaga idea de que la primera correspondería a las decisiones esenciales y la segunda se limitaría a la ejecución cotidiana hasta los niveles más modestos. Intuitivamente, se entiende bien que hay una diferencia, por ejemplo, entre un decreto que decide la revalorización general de las prestaciones sociales, poco tiempo antes de una gran elección, y un orden ministerial que concede un permiso. Pero las autoridades políticas supremas en el seno del ejecutivo (Presidente de la República, Primer ministro, ministros) aseguran también la dirección de la acción administrativa del Estado. Sus actos, por ejemplo las órdenes, son considerados, sin importar su alcance político, como decisiones administrativas. Sólo algunos actos llamados de gobierno tienen un estatuto contencioso particular y sin embargo podrían aparecer como expresión de la función gubernamental. Los criterios de diferenciación son tan inciertos que todo intento puramente conceptual está condenado al fracaso ${ }^{293}$. La distinción no tiene real alcance jurídico. ${ }^{294}$ La relativización también se debe hacer a nivel de los órganos. Hay más confusión entre un órgano político y otro administrativo que separación contrastada. Es difícil oponer claramente, en el nivel supremo, autoridades políticas

\footnotetext{
${ }^{292}$ Ibídem, op. cit., pp.276-278. Se trata aquí de diferencia los actos administrativos tomados por el Parlamento. Efectivamente unos actos no legislativos pero que concierne actos de gobierno de la cámara parlamentaria suponen un criterio para decidir cuáles son los actos que pueden escapar al control del juez administrativo. CE (Conseil d'État), 1-07-1960, FNOSS, R.41, CE 4-11-1987, Ass. Nat/Mme Cazes, R.343 y CE 1901-1996, Escriva, R. 10. Otra confusión posible es la constitución de unos organismos administrativos como órgano jurisdiccional. CE Sect. 20-10-2000. Soc. Habib Bank Ltd, R. 433, concl. Lamy (a propósito de la comisión bancaria).

${ }^{293}$ Ibídem, op. cit., pp.273- 276. Para la jurisprudencia los actos de gobierno, aunque tomados por órganos administrativos (presidente de la República, Primer ministro, ministros) no son administrativos. Por consiguiente, escapan a todo control jurisdiccional tanto en el control del contencioso de legalidad como de responsabilidad. Estos actos se toman respecto a las relaciones entre los poderes públicos y las relaciones con las organizaciones internacionales y Estados extranjeros. Tienen como fundamentos la finalidad puramente política de algunas decisiones aunque difícilmente separable de la función administrativa del poder ejecutivo. Se ha propuesto también que son actos de naturaleza mixta en los intervienen otras autoridades con lo cual debe escapar al control del juez administrativo abriendo así la posibilidad de recurso ante otro orden jurisdiccional como el constitucional. 0 también se ha defendido el principio de conciliación entre los intereses de la administración y los derechos de los administrados y que el juez administrativo desea dejar una margen importante de maniobra para cierto tipo de decisiones "políticas", en campos sensibles, en los que, más a menudo, ningún motivo jurídico prohíbe ejercer un control jurisdiccional. Así, la regularidad del nombramiento de un miembro del Consejo constitucional podía ser verificado respecto a ciertos principios constitucionales, sin poner en tal de juicio, para el resto, la libre elección de la autoridad de nominación. De igual modo, la decisión del Presidente Chirac de retomar las pruebas nucleares francesas, aplicable sólo en el territorio nacional, ha sido girada hacia el solo orden interno, y perfectamente controlable, aun con tacto y mesura (sentencia Ass. Greenpeace)

${ }^{294}$ Ibídem op. cit., pp.3, 4.
} 
gubernamentales y aparato administrativo del Estado. Además, durante la $\bigvee$ a República en particular, el papel creciente de los altos funcionarios en el ejercicio del poder político ha llevado a una imbricación constante de ambas esferas. Por fin, la relación de subordinación de lo administrativo a lo político comienza a relajarse fuera de la administración del Estado por medio de las colectividades locales, situadas en el seno del poder ejecutivo y haciendo parte de la administración, las cuales se benefician de cierta autonomía garantizada por la Constitución ${ }^{295}$.

Al cerrar este apartado, algunos puntos llaman la atención respecto a esta aproximación constitucional de la Administración. En primer lugar, la constitución francesa sólo ha dedicado una línea para referirse a ella. Efectivamente la previsión constitucional no nos permite sacar más conclusiones de lo que contiene el artículo 20, la única disposición de referencia. Sin embargo, y a pesar de lo poco que se ha dicho, se pueden intentar definir los rasgos elementales que el constituyente ha concedido a la Administración. Se destaca el principio de subordinación de ésta al Gobierno. Se entiende que la existencia de la función administrativa supone un instrumento de ejecución entre las manos del Gobierno. Eso nos puede llevar a pensar que la Administración, como instrumento y como subordinada, no puede tener una personalidad jurídica diferente del Estado o por lo menos de la función ejecutiva. Aunque esta deducción tiene una consagración constitucional, también tiene su límite. Los demás órganos del Estado pueden tener competencia administrativa cuyos actos no escapan al control del juez administrativo. Por lo tanto la Administración es la cara permanente del Estado y no sólo del Gobierno 296 .

En segundo lugar, la constitución francesa no ha definido los parámetros que rigen las actuaciones de la Administración, pero se entiende que su carácter instrumental a disposición del Gobierno aclara el asunto. En efecto, la primera línea del artículo 20 declara que "El Gobierno determina y dirige la política de la Nación". De este texto la doctrina

\footnotetext{
${ }^{295}$ Ibídem op. cit., p.4; J. CHEVALLIER, L'administration subordonnée? en La Constitution de la V République, Réflexions pour un cinquantenaire (dir. PASCAL JAN), La documentation française, París, 2008, pp.93-96. Este autor describe el proceso de emancipación en relación a lo político a partir de la aparición de nuevas estructuras bautizadas "autoridades administrativas independientes". Una de ellas se creó en 1978 y se llama la Comisión nacional informática y libertades (CNIL). Existen en la actualidad una cuarentena de estas instituciones cuyo papel es, entre otros, regular el funcionamiento de las licitaciones abiertas a la competencia o proteger las libertades públicas y los derechos de los ciudadanos, etc.

296J. RIVERO y J. WALINE, Droit administratif, Dalloz, 2004, p.42. Explican que los efectos de la personalidad jurídica moral son: 1) todos los actos relativos a los intereses atendidos o protegidos están vinculados a un único y mismo centro erigido en sujeto de derecho: es la persona moral; 2) este sujeto se ve reconocer la permanencia, a pesar de la renovación incesante de los individuos interesados; 3) unos órganos son creados para actuar en nombre del sujeto de derecho. P.-LAURENT FRIER, Précis de droit administratif, op. cit., pp.271-280, describe los actos de las tres funciones del Estado susceptibles de participar de la función administrativa y así atacables ante la jurisdicción administrativa.
} 
concluye que gobernar es determinar soberanamente los objetivos del Estado - objetivos políticos, económicos, sociales - y dirigir el Estado hacia la realización de estos objetivos. No se trata simplemente de asegurar el funcionamiento cotidiano de la máquina administrativa sino también la determinación y la puesta en marcha de un gran proyecto político en conjunto ${ }^{297}$. Para ello, se necesita una subordinación política que implica, por parte de los funcionarios, una lealtad sin reserva, una obediencia sin fallo, una estricta disciplina ${ }^{298}$. Los agentes públicos son sometidos a cierto número de obligaciones que no son sino que explicaciones del principio general de la organización jerárquica. Particularmente, están obligados al deber de obediencia al cual no pueden escapar salvo si se reúnen condiciones estrictas que la jurisprudencia recuerda con nitidez ${ }^{299}$ : una orden manifiestamente ilegal cuyo cumplimiento lleva a comprometer gravemente el funcionamiento del servicio o el interés público ${ }^{300}$. La consecuencia de este sistema, por mucho que la doctrina hable de la búsqueda de un equilibrio entre el deber de obediencia y la neutralidad de los funcionarios, es el riesgo de la politización de la Administración. Los partidos políticos con vocación gubernamental se han asegurado siempre unos puntos de arraigamiento en la alta administración ${ }^{301}$. DUPUIS indica que las relaciones entre el Gobierno y su "instrumento" han sido denunciadas como un aspecto del "Mal francés". Es verdad que los políticos tienen, a veces, el sentimiento de ser traicionados por los administrativos y piensan más o menos en el spoil system. Es exacto también que los funcionarios soportan cada vez peor ser considerados como responsables de todos los fracasos del Gobierno ${ }^{302}$. A esta altura podemos ver la fuerte vinculación del funcionario a sus superiores políticos. Su subordinación, la que le exige lealtad y obediencia, hace que su actuación deba ser conforme a orientaciones políticas. Y sí es cierto que como agente público, es servidor del interés general por su misión pero también es servidor de la Administración como instrumento político. La interpretación estricta de las disposiciones constitucionales estudiadas hace resaltar más una relación privile-

\footnotetext{
297 M. DUVERGER, comentando la primera línea del art.20, en La constitution de la république française, dir. F. LUCHAIRE et G. CONAC, Economica, 1980, p.363.

298 J. CHEVALLIER, L'administration subordonnée? op. cit., p.89. Es la concepción que tenía el General de Gaulle de la administración según la Constitución de 1958. Excluye toda idea de "poder administrativo": las tareas que incumben a la Administración son siempre segundarias y de naturaleza subordinada.

${ }^{299}$ CE, 4 de enero de 1964, Ministro de Interior contra Sres. Limoniers y otros, Actualité juridique (Droit administratif), 1964, p.447.

$300 \mathrm{G}$. DUPUIS, comentando la segunda línea del art.20, en La constitution de la république française, dir. F. LUCHAIRE et G. CONAC, op. cit., p.366. Añade que, sin embargo, el sistema francés asegura también a los agentes públicos diversos derechos y sobretodo su libertad de opinión. Busca solución de los problemas planteados por las relaciones de la política y de la administración en una conciliación compleja que descarta a la vez la exigencia del conformismo (como en los regimenes dictatoriales) o la de neutralidad (impuesta al civil service británico). El cuerpo administrativo encuentra su independencia relativa en la dialéctica de la libertad de opinión y de la reserva exigida en cuanto a la expresión de las convicciones ideológicas.

301 J. CHEVALLIER, L'administration subordonnée? op. cit., pp.91 y 92.

302 G. DUPUIS, comentando..., op. cit., p.369.
} 
giada entre el funcionario y la Administración y por consiguiente se ha prescindido de destacar una relación prestacional entre la Administración y los administrados, tal como se ha constatado en el sistema español. Esta situación lleva consecuencias en el estudio del interés protegido en los delitos correlacionados con la Administración.

En último lugar, es de destacar que la previsión constitucional sobre la subordinación política de la Administración ha sido considerada como novedosa. La doctrina se pregunta por qué proclamar en la Constitución lo que no sería más que un puro truismo. Las repuestas apuntan hacia la evitación del desarrollo de una Administración que ejerce la realidad y la totalidad del poder, el rechazo de una burocracia y de una tecnocracia, expresión de la perversión del liberalismo en un laxismo que habrá que denunciar. Otros hablan del peligro de la hipotética formación de un "poder administrativo" que encontraría su fuerza en las cualidades de los expertos y que debería adquirir su autonomía para mejor servir el interés general. Sin embargo, se puede entender que una previsión constitucional de la Administración sería un tipo de promoción: hace parte de los órganos constituidos ${ }^{303}$. La tradición jurídica francesa no ha cambiado y ello desde las leyes constitucionales de 1875. Las anteriores constituciones ni siquiera aluden a la Administración porque ya se ha asumido que su relevancia tiene sentido en cuanto sierva de los órganos políticos. Esta situación tiene su explicación histórica, como se ha resumido en apartados anteriores, pero lo más obvio es la falta de evolución del sistema jurídico francés en esta materia y sobretodo su impermeabilidad a toda influencia de cualquier otro sistema extranjero. Lo que es de lamentar es la ausencia de las garantías constitucionales de los derechos de los ciudadanos ante el poder de la Administración y la falta de fundamento básico, a este nivel, de los deberes y de las obligaciones de ésta, que constituyen criterios objetivos en la relación entre los administrados y los administradores.

\section{2-Elementos a considerar: la autoridad del Estado versus la Administración pública}

Antes de analizar los elementos básicos necesarios para destacar el interés protegido en la cuestión que nos interesa, parece necesario repasar el transfondo de elaboración del libro IV y la particularidad de la reforma legislativa emprendida por el legislador francés en el año 1992.

\section{2 en relación al Libro IV}

a-Consideración de la reforma legislativa del año

Aunque toda reforma supone un cambio, la doctrina nota una fidelidad al antiguo Código penal. Ejemplo de ello se nota cuando retiene el crite-

\footnotetext{
303 Ibídem, op. cit., pp. 366, 367. La ley fundamental francesa ha sido elaborada en su forma por funcionarios y ha sido pensada por el General de Gaulle que sabe la importancia de la administración y quien proclamó que: "en la era moderna, la vida misma del país depende de la función pública".
} 
rio que subyacía a la abrogada figura de la forfaiture del Código de $\mathrm{Na}$ poleón, si bien que no recurre para ello a la creación de delitos especiales impropios ${ }^{304}$. Al comentar el carácter de la reforma penal en general, DELMAS-MARTY habla de prudencia de las explícitas elecciones. Eso se llama permanencia porque el espíritu del Código penal de 1810 está preservado en lo esencial; pero también se trata de continuidad para marcar esta lenta evolución que amplia la represión por el juego de incriminaciones nuevas, relacionadas a los progresos técnicos y/o a la emergencia de los derechos nuevos protegidos en caso de violación pero que marca también un alejamiento progresivo respecto a las concepciones legalistas de 1810 al reconocer al juez poderes cada vez más importantes en la determinación de la pena ${ }^{305}$. En este sentido se ha pronunciado VÁZQUEZ-PORTOMEÑE SEIJAS al valorar el Libro IV del nuevo Código. Señala que el primordial de los objetivos del legislador de 1992 y de las mencionadas reformas y modificaciones parciales ha sido el de cohonestar el régimen penal con las nuevas realidades de la Ad-

${ }^{304}$ G. GIUDICELLI-DELAGE, Livre IV. Les crimes et les délits contre la nation, l'Etat et la paix publique, Revue de science criminelle et de droit pénal comparé, no 3 , 1993, p.493 : “...el libro IV no es una revolución mas bien una reescritura, formal y sustancial, de los crímenes y delitos contra la cosa pública : una adaptación al vocabulario, a los modos de expresión de nuestro tiempo, pero también a las realidades y a las sensibilidades modernas.”; F. VÁZQUEZ-PORTOMEÑE SEIJAS, Delitos..., op. cit. pp.61, 62. explica que de hecho, la agravación subyacente a dicha cualidad se hace efectiva bajo la forma de una circunstancia específica, tal y como sucede en los delitos de tortura y agresión con ensañamiento (art. 222-3 7"), lesiones (arts. 222-3 7a , 222-10 7ํㅡ y 222-

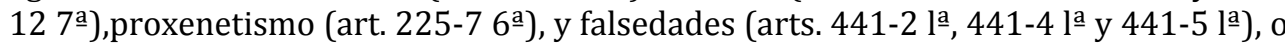
de una pena facultativa complementaria, que es lo que sucede con la previsión de la inhabilitación de empleo o cargo público en los artículos 313-7 2ª (en relación con la estafa y las infracciones afines a ella),314-10 2a (para la apropiación indebida), 324-7aㅡ (para el blanqueo simple y agravado) y 422-3 2ª (para el terrorismo). En él, la represión de las conductas penalmente relevantes protagonizadas por los funcionarios públicos en el ejercicio de sus cargos descansa en los artículos 432-1 a 432-17, integrados en el Capítulo II, Título III, de su Libro IV, que lleva por rúbrica "De los delitos contra la Administración Pública cometidos por personas que desempeñen una función pública". Dicho Capítulo trata la materia a lo largo de cuatro secciones; dedicadas, además de a las "penas accesorias" (sección 4⿳a arto 432-17), a "los abusos de autoridad dirigidos contra la Administración" (sección la de autoridad dirigidos contra particulares" (sección 2ª arts. 432-4 a 432-9) y a la "corrupción pública" (sección 3aㅗ arts. 432-10 a 432-16). En ésta última se comprende una no muy extensa lista de delitos que coinciden con las figuras más significativas del Título XIX del Código penal español: el cohecho (§ 1, art.432-10), la corrupción pasiva y el tráfico de influencias cometido por personas ejercen una función pública $(\S 2$, art. 432-II), el cobro ilegal de comisiones ( $(3$, arts. 432-12 y 432-13) y los delitos contra la libertad de acceso y la igualdad de los candidatos en los mercados públicos y en las delegaciones de servicio público ( $(4$, arto 432-14) y la sustracción y malversación de bienes ( $(5$, arts. 432-15 y 432-16); S. JOISSAINS en Les options fondamentales du livre IV du nouveau code pénal, Mémoire de DEA de droit pénal et sciences criminelles, dir. M.G. Di MARINO, Université d'Aix-Marseille, 1992/1993, pp.9-26, defiende que el libro IV lleva las imprentas del contexto socio-intelectual post revolucionario con la tendencia severa de represión y también residuos de la doctrina penal clásica con la supresión de la exigencia del elemento moral en la incriminación lo cual puede generar muchas infracciones materiales. No ha faltado lo que queda de la doctrina positivista con la incriminación del estado peligroso y así anticipar la barrera penal.

305 M. DELMAS-MARTY, Avant-propos, Revue de science criminelle et de droit pénal comparé, no 3, 1993, p.433. 
ministración Pública del período contemporáneo. Como se ha señalado, las disposiciones relativas a la "cosa pública" habían recibido contadas modificaciones desde los tiempos del Imperio, resultando en su mayor parte desfasadas o incluso contrarias al orden legal vigente. En favor de una tajante intervención legislativa prevenía, en particular, la situación legal de "desamparo" de la ciudadanía ante las infracciones perpetradas por funcionarios contra la inviolabilidad del domicilio, el derecho a la no discriminación y la libertad individual del ciudadano, habida cuenta de la excesiva lenidad de las sanciones previstas en el Código de Napoleón. Junto con ello, se había puesto de manifiesto, asimismo, el dato de la inidoneidad de la jurisdicción administrativa a la hora de individualizar las responsabilidades personales, explicativo del importante incremento del número de procesos penales abiertos contra funcionarios públicos ${ }^{306}$. Los grandes referentes "de fondo" para esa labor de adecuación han sido, pues, la acentuación de la naturaleza "vicaria" del poder que la Administración ejerce en nombre del Estado, su nueva realidad jurídica en términos de derechos y deberes del funcionariado y de su sujeciones y prerrogativas frente al juez penal, la satisfacción de las crecientes exigencias de confianza y transparencia dirigidas por la ciudadanía en el marco de las nuevas relaciones Administraciónadministrado y también la acomodación del texto punitivo a la masiva penetración del Derecho francés por los reglamentos, directivas y decisiones comunitarios ${ }^{307}$. La nueva ley penal se inscribe decididamente en esa corriente de "revalorización" de la imagen de la jurisdicción penal a los ojos de la ciudadanía, incorporando nuevos principios jurídicos y argumentos de práctica judicial y de evolución política económica del Estado que hacen valer el valor de los tiempos ${ }^{308}$.

El grueso de las modificaciones reviste tintes formales o sistemáticos. Así, en el plano estrictamente formal; junto con la desaparición de la terminología tradicional, destaca la reubicación sistemática de la materia ${ }^{309}$. Los "crímenes y delitos contra la nación, el Estado y la paz públi-

306 M. FORGES, Droit de la fonction publique, Paris, 1986, p. 261. Señala la tradicional baja frecuencia en la aplicación de las disposiciones penales (Ej. Delitos de desasimiento y de ingerencia de los arts. 175 y 175-1) motivada por la excesiva dureza de las sanciones de carácter profesional y el consecuente retraimiento de las autoridades administrativas a la hora de denunciar los hechos.

307 M. E. CARTIER y C. MAURO, La loi relative à la lutte contre la corruption des fonctionnaires étrangers, Revue de science criminelle et de droit pénal comparé, no 4, 2000, pp. 737 y ss.

${ }^{308}$ F. VÁZQUEZ-PORTOMEÑE SEIJAS, Delitos..., op. cit. pp.64, 65. Este cambio de política legislativa viene perfectamente ilustrado con el nuevo régimen punitivo de las figuras de la Sección $2^{\underline{a}}$ del mencionado Capítulo IV, comprensiva de los delitos contra la libertad individual ( $§ 1$, arts. 432-4 a 432-6), de las discriminaciones ( $\$ 2$, art. 432-7), de los delitos contra la inviolabilidad del domicilio ( $\$ 3$, art. 432-8) y de los delitos contra el secreto de la correspondencia ( $§ 4$, art. 432-8), en los que se ha operado una significativa exasperación del régimen punitivo para estimarlos más graves que los correlativos atentados producidos inter privatos.

${ }^{309}$ Ibídem, op. cit., p.66. En una regulación carente de lógica interna; el Código Penal de 1810 dedicaba a los atentados contra el orden administrativo perpetrados por agentes públicos la sección segunda del Capítulo IV ("De los crímenes y delitos contra la paz pública") del Título 1 de su Libro III, integrada por los artículos 166 a 198). 
ca", en los que se enmarca la materia, no inauguran ya la Parte Especial del Código de 1992, ubicándose, en cambio, con posterioridad a los "crímenes y delitos contra las personas" y a "los crímenes y delitos contra los bienes", en el Título III del Libro IV, que disciplina, por este orden, los atentados a la paz pública (Capítulo I, artículos. 431-1 a 43121), los atentados a la Administración Pública cometidos por personas que ejercen una función pública (Capítulo II, artículos 432-1 a 432-17), los atentados a la Administración Pública cometidos por particulares (Capítulo III, artículos 433-1 a 433-25) y, finalmente, los atentados a la Administración de Justicia (Capítulo IV; artículos 434-1 a 434-47). En la escala de valores suscrita por el legislador reciben, por lo tanto, una consideración secundaria frente a los derechos fundamentales y cívicos del individuo ${ }^{310}$.

Entre otros aspectos positivos de la reforma, la doctrina suele destacar la readaptación del vocabulario legal a los modos de expresión modernos, así como la mayor claridad y sencillez de la presentación de la materia. Ésa es la filosofía que parece haber inspirado, por ejemplo, la distinción sentada por el Título III entre las infracciones protagonizadas por los funcionarios (Capítulo II) y aquéllas otras que tienen como autores a los particulares y a través de las cuales se incriminan comportamientos que constituyen una puesta en peligro tanto de la autoridad y credibilidad estatales (Capítulo III, artículos 433-1 a 433-25) ${ }^{311 .}$

Las diferencias entre la regulación de los "crímenes y delitos de los funcionarios públicos en el ejercicio de sus funciones", de la Sección II del Capítulo IV; Título I, Libro IV; del Código de 1810, y la de los delitos contra la Administración Pública del nuevo texto punitivo son sustanciales. Por lo que se refiere a su factura formal, la sección no se ha mostrado ajena a las directrices reformistas que han inspirado la redacción del Libro IV; plasmándose nuevamente en ella la voluntad de modernizar y simplificar estos delitos, y de hacerlos fácilmente reconocibles. Ello explica la decisión de unificar en el artículo 431-11 el tratamiento del cohecho pasivo y del tráfico de influencias, anteriormente contemplados en los artículos 177 y $178 \mathrm{CP}^{312}$. La misma disciplina del cohecho sirve, además, para poner de manifiesto que el pensamiento del bien jurídico ha sido determinante a la hora de proceder a la ordenación de la materia, toda vez que el cometido por un magistrado en beneficio o perjuicio de un procesado por un delito grave, por los miembros de los jurados o por cualquier otra persona que integre un órgano jurisdiccional, así como por los peritos o por las personas encargadas por la autoridad judicial de misiones de conciliación o mediación viene contemplado

310 G. GIUDICELLI-DELAGE, Livre IV..., op. cit., p.494. Sostiene que lo que tiene la apariencia de una audacia, ciertamente, no es más que la mera manifestación de una filosofía nueva. En el orden de las preocupaciones legislativas y de la reforma, la cosa pública sólo se ha contemplado después de las personas y de los bienes. Eso refleja la inspiración de los derechos humanos con un deseo de armonizar el código penal con este texto fundamental, entre otros.

311 Ibídem, op. cit., pp. 498, 505.

312 Ibídem, op. cit., pp. 495, 503. 
como delito contra la Administración de Justicia en la Sección 2a ("obstrucción del ejercicio de la acción de la Justicia"), artículo 434-9, del Capítulo IV. Por otra parte, si la protección del Estado había llevado al legislador a crear incriminaciones de contornos claramente mal definidos, deliberadamente vagas, el nuevo texto se cohonesta mejor con las exigencias del principio de legalidad, en un afán por aportar mayores grados de concisión y uniformidad a las figuras ${ }^{313}$.

En cuanto a las objeciones dirigidas a las nuevas disposiciones podemos destacar tres puntos. En primer lugar, el hecho de que, si el Código penal francés contiene numerosos preceptos destinados a los funcionarios públicos, no proporciona, sin embargo, definición alguna aplicable a dicho término. A diferencia de los Códigos italiano, alemán y español, el francés no se ha esforzado tradicionalmente, en efecto, en precisar el sentido de la expresión "funcionario público" para la aplicación de sus disposiciones. Según interpretación constante de la jurisprudencia, la cualidad concernía a todos los ciudadanos depositarios, por cualquier título, de una parcela del poder, con independencia de su nivel jerárquico y de la naturaleza técnica o jurídica de sus actividades: la prestación de servicios públicos, el ejercicio de potestades de naturaleza pública o la detentación de alguna clase de mandato público ${ }^{314}$. En segundo lugar, en el terreno de la interpretación teleológica del grupo, el pensamiento de la infracción de obligaciones inherentes a la condición de representante del Estado como elemento clave en la interpretación teleológica del grupo ha ido dejando paso a la idea de servicio al interés general, a cuyo efecto se ha hecho valer su naturaleza de delitos cometidos en el ejercicio de la función pública, esto es, protagonizados por quien dispone, sólo o formando parte de un órgano colegiado, de un poder de decisión con el que puede afectar los interés de la colectividad pública ${ }^{315}$; como el dato de que la mayor parte de las obligaciones profesionales que reciben tutela penal en el Capítulo II vinculan al conjunto de los agentes públicos, y no sólo a los funcionarios ${ }^{316}$. Por otra parte, los límites de la jurisdicción reconocida al juez penal para el examen de la legalidad administrativa en relación con los actos discrecionales, la necesaria precisión de los principios que deben regir la distribución de responsabilidades penales en el seno de la estructura jerarquizada de la Administración Pública, con vistas a prevenir la creación de espacios de irresponsabilidad en el seno de las estructuras administrativas, y la relación en que se hallan los conceptos de falta personal y responsabilidad administrativa en el marco de los delitos ahora reagrupados en el Capítulo II del Título III del Libro IV, componen otros focos de atención

\footnotetext{
313 Ibídem, op. cit., pp.494, 495 y 497.

${ }^{314}$ F. VÁZQUEZ-PORTOMEÑE SEIJAS, Delitos..., op. cit. p.72. La tesis era admitida, en general, por la doctrina, en la que existía acuerdo a la hora de atribuir en este punto una gran autonomía al Derecho penal, manifestada en su no supeditación a las definiciones que puedan ofrecer los textos legales relativos al régimen de la función pública o las elaboraciones teóricas del Derecho administrativo. Véase A. VITU, en R. MERLE / A. VITU, Traité de Droit Criminel, Droit pénal spécial, Paris, 1982, p.209.

${ }^{315}$ A. VITU, Traité..., op. cit., p.269

316 M. FORGES, Droit de la fonction publique, op. cit., p. 261.
} 
en los estudios de la literatura jurídica francesa sobre el régimen jurídico-penal de la función pública ${ }^{317}$. A este último respecto, se ha puesto de manifiesto cómo el tradicional criterio jurisprudencial de privar de todo vínculo con el servicio a las infracciones más graves, haciendo de ellas instrumentos de depuración de las responsabilidades penales de su autor, se ve en alguna medida contradicho por la propia realidad normativa, en la medida en que algunas de ellas impiden, por causa de naturaleza, que la Administración se libere de su responsabilidad subsidiaria frente al particular perjudicado ${ }^{318}$. Y por último, DELMASMARTY reprocha al nuevo Código penal por la verdadera miopía del legislador al rehusar ver que el entorno jurídico ha cambiado y que una codificación para el siglo XXI no se puede concebir sobre el modelo del principio del siglo XIX. Un Código no puede ser construido como un monumento aislado sino que debe ser concebido como un elemento de un conjunto orientado a otras disciplinas sancionadoras además del Derecho penal y abierto a otras influencias que el Derecho nacional ${ }^{319}$. Además, añade la misma autora la falta de principios directores de selección, vía seguida por en varios países europeos (sobretodo Alemania, Italia, Portugal) cuya lógica conduce a una reorganización del conjunto. Concebidos como una ayuda a la decisión, tales principios habrían podido aparecer a la cabeza del Código penal o en un simple comunicado interministerial. El objetivo no es limitar los poderes del legislador sino proveer un instrumento para darle coherencia al conjunto de los Derechos sancionadores destinados a aclarar la elección del legislador al

317 A tenor de la Circular 14 de mayo de 1993. citada por ARÁNGUEZ SÁNCHEZ y ALARCÓN NAVÍO, "las disposiciones del artículo 111-5 son. sin lugar a dudas. las más innovadoras del capítulo primero. En la actualidad. ningún otro texto fija el alcance de los poderes del Juez sancionador en cuanto a la interpretación y al control de la legalidad de los actos administrativos. Dichos poderes, [...] están delimitados por la jurisprudencia del Tribunal de conflictos y del Tribunal de Casación (T.S.) y presentan numerosos puntos divergentes. El artículo 111-5 resuelve las incertidumbres actuales dándole un fundamento legal a la excepción de ilegalidad. Al margen de las restricciones previstas por la jurisprudencia. les confiere a las jurisdicciones penales los más amplios poderes. Éstas podrán interpretar y valorar la legalidad de todos los actos administrativos con la única condición de que de este examen dependa el resultado del proceso penal. De esta manera, ya no se mantendrá la distinción entre actos individuales y reglamentarios. o entre los actos penalmente sancionados y los demás. En efecto, el Parlamento ha decidido que prevalezca sobre cualquier consideración la protección de la libertad individual. que el juez penal debe salvaguardar. A este respecto conviene precisar que al conferirles a las jurisdicciones penales el derecho de dictaminar "la legalidad" de un acto administrativo, el Parlamento no ha pretendido privarlos del derecho de valorar su constitucionalidad. La expresión de control de la legalidad implica la posibilidad de controlar que el Reglamento se ajuste al conjunto de normas jurídicas superiores bajo reserva. de que este control no implique una apreciación de la constitucionalidad de un texto legislativo. No se cuestionan, pues. las soluciones contempladas al respecto por la Jurisprudencia". (C. ARÁNGUEZ SÁNCHEZ y E. ALARCóN NAVÍO, El código penal francés, op. cit., p.36, nota 6.) Véase también G. HÉZARD, Le juge pénal et l'acte administratif, Mémoire de DEA de droit pénal et de sciences criminelles, dir. A. DECOCQ, Université de Panthéon-Assas (Paris II), 1999/2000, pp.50 y ss., 68 y ss.

318 F. VÁZQUEZ-PORTOMEÑE SEIJAS, Delitos..., op. cit. pp.75, 76.

319 M. DELMAS-MARTY, Avant-propos, op. cit., pp.440, 441. Esta observación es particularmente cierta respecto al Libro IV, por el monopolio de la sanción penal. 
definir indicadores de gravedad de las conductas y de utilidad de las sanciones que permiten situar la proximidad o la lejanía respecto a la categoría penal. Concluye que en vez de hablar de arcaísmo se podría sugerir que es la capacidad de anticipación la que más le falta a este Código. Un Código demasiado preocupado por responder a las expectativas inmediatas de la opinión pública, y, en suma demasiado inscrito en el presente para ser el verdadero acto fundador del Derecho penal del futuro ${ }^{320}$.

\section{b-Multiplicidad de bienes jurídicos}

Clasificar las incriminaciones con la ayuda del criterio del bien jurídico protegido supone que a cada incriminación corresponde un bien jurídico único; ahora bien, no cabe duda alguna que eso no es el caso del libro IV aun con un vistazo rápido. En efecto, según LACAZE los títulos que lo componen, tienen en común la protección de la Autoridad pública pero estos delitos protegen también las personas y sus bienes, es decir, bienes jurídicos individuales. Ejemplo de ello son las incriminaciones de la Sección II del Capítulo II del Título III que llevan por rúbrica "de los abusos de la autoridad cometidos contra particulares". Parece ciertamente, sin preguntarse quién es la víctima de estas infracciones, que éstas protegen varios bienes jurídicos, uno público y otro privado 321 . Centrándonos en el Título III "De los delitos contra la autoridad del Estado", a pesar del esfuerzo del legislador de agrupar los delitos en un sentido lógico-sistemático, sería inapropiado defender que la clasificación se hizo por la consideración de la situación de los sujetos activos, como servidor público o que tenga alguna vinculación en una misión de interés general. En efecto, la dificultad reside en la mezcla de los bienes protegidos en el mismo Libro o en el mismo Título. La presencia de elementos privados, esto es, bienes jurídicos individuales o sujetos activos que no tienen la condición de funcionario público, hace que la identificación de un bien jurídico común al grupo de los delitos Título III no pueda hallarse fácilmente en la misma autoridad del Estado. Habrá que justificar el por qué de la protección de la autoridad del Estado. La doctrina, al comparar la noción de Estado con la de Nación, entiende que la definición de la segunda incluye la noción implícita de solidaridad para construir una cohesión nacional ${ }^{322}$ y el Estado entonces sería un componente de ella ${ }^{323}$. De hecho la Constitución francesa asigna misiones no al Estado sino a la Nación. En el preámbulo de la Constitución francesa de 1946 que forma parte del bloque de constitucionalidad de la Va república se precisa en su línea 10 que: "La Nación proporciona al individuo y a la familia las condiciones necesarias para su desarrollo"324.

\footnotetext{
320 Ibídem op. cit., pp.442, 443.

${ }^{321}$ M. LACAZE, Réflexions..., op. cit., pp.223, 224.

322 S. JOISSAINS, Les options fondamentales..., op. cit., pp. 28, 29.

323 G. GIUDICELLI-DELAGE, Livre IV ..., op. cit., p.496 ; C. AMBROISE-CASTÉROT, Droit pénal spécial et des affaires, Lextenso éditions, 2008, p.329.

${ }^{324}$ C. ARÁNGUEZ SÁNCHEZ y E. ALARCÓN NAVÍO, El código penal francés, op. cit., p.36. $\mathrm{Al}$ enunciar los principios contenidos en el preámbulo se alterna la palabra "Nación" con "Francia".
} 
Por lo tanto, con estas misiones encomendadas a la Nación se necesita la protección penal del Estado porque es él el que las lleva a cabo a través de sus funciones con el concurso de la Administración pública, también digna de protección.

Enfocándonos en los Capítulo II ("De los delitos contra la Administración pública cometidos por personas que desempeñan una función pública) y Capítulo III ("De los delitos contra la Administración pública cometidos por particulares) que aluden de manera directa a los delitos contra la Administración, sería interesante repasar las propuestas de la doctrina sobre el valor protegido en estos dos grupos. Así, destaca GIUDICELLI-DELAGE que si el legislador ha puesto en primer lugar los delitos del funcionario es porque el Estado, en su autoridad, tiene que sufrir más las ilegalidades de sus representantes que las de los particulares. El objetivo es afirmar, de un lado, que los abusos de autoridad cometidos contra los particulares son aún más graves cuando emanan de un detentor de la autoridad pública y, de otro lado, que la detención de la autoridad pública impone a sus titulares un deber de probidad. Todo el reordenamiento de estos delitos obedece a la conciliación de la necesaria moralización de la función pública y de las realidades económicas. Tratándose de los particulares, son incriminadas las conductas que lesionan directamente la autoridad del Estado (la oposición a la ejecución de obras públicas, la rebelión, el desacato); las que socavan la autoridad del Estado al lesionar la moralidad de sus funcionarios (corrupción activa, tráfico de influencias); y por fin, las que debilitan la credibilidad del Estado, y, por consiguiente, su autoridad, por actos susceptibles de generar confusión entre las actividades de las personas privadas y las actividades de la Administración (usurpación de funciones, títulos, signos, etc.) ${ }^{325}$. Un sector de la doctrina defiende, como interés protegido, el deber de probidad la cual no debe ser confundida con honestidad incluso con la moral. Hay que superar la definición que los moralistas dan de ella como una virtud. Este deber de probidad se impone, más precisamente, a toda persona que actúa por cuenta de una autoridad y parece que la encarna ante los ojos del público. Esta definición permite subrayar el interés protegido por las diferentes incriminaciones en la materia: en primer lugar, es necesario que una autoridad que no existe más que a través de sus agentes esté asegurada de su lealtad, y, en segundo lugar, que la confianza del público para con esta autoridad no sea puesta en tela de juicio por las actuaciones de los que la encarnan. La probidad se impone entonces para hacer respetar una doble relación de confianza. Al respecto, aparece necesaria para el buen funcionamiento de toda autoridad. Se habla aquí de "deber" en vez de "obligación" de probidad, para subrayar que su fundamento no es contractual sino social: este deber de probidad no concierne más que a algunos pero oponible a todos ${ }^{326}$. Indican LUCAS de LEYSSAC y MIHMAN que este deber

325 G. GIUDICELLI-DELAGE, Livre IV..., op. cit., p.505

${ }^{326}$ E. DREYER, Cours magistral, Droit pénal spécial, Ellipses, 2008, pp.557, 558. Añade que en los intentos de modernización del Estado han aparecido prácticas políticas y económicas inaceptables con lo cual no se puede tolerar sin arriesgar gravemente el 


\section{PARTE I: APROXIMACIÓN AXIOLÓGICA Y ESTRUCTURAL...}

de probidad es inherente al ejercicio de la función de los profesionales del interés general y garantiza a los ciudadanos tanto la igualdad de trato como la imparcialidad para alcanzar una sola meta: la satisfacción del interés general ${ }^{327}$.

Otro sector, representado por autores como VITU, en el marco del anterior Código penal francés, recuerda que la actividad administrativa se desdobla en actividad política o de gobierno, que abarca todo lo que se refiere a la orientación política del régimen, y en actividad de administración, con un carácter menos elevado y que consiste en la gestión de los servicios públicos a fin de asegurar el orden y la paz pública, la satisfacción de las diferentes necesidades de la colectividad. La función administrativa, tal como se acaba de definir su significado, es cuantitativamente la actividad más importante del Estado; el buen cumplimiento de esta función constituye lo que llama el autor el orden administrativo. La noción de lesión a este orden implica el funcionamiento normal de la Administración que exige que los depositarios de la potestad pública $y$, más generalmente, las personas encargadas de actuar en nombre de la colectividad, sean íntegros y no hagan mal uso de los poderes que detienen. Por otro lado, es importante que los administrados sean respetuosos con las funciones públicas y no demuestren ninguna insubordinación para con las autoridades. Añade que es comprensible que la represión se imponga cuando el orden administrativo es gravemente amenazado. Lo que está en juego es el interés de la Administración, que no debe tolerar un mal uso de la autoridad pública, lo cual puede poner en peligro el buen funcionamiento de los servicios públicos, ni admitir que los ciudadanos se inmiscuyan en los poderes de los funcionarios o se subleven contra su autoridad. El interés de los propios administrados debe ser tomado en consideración si no se quiere ver alterada la confianza del público en los órganos administrativos. La represión de los ataques contra el orden administrativo se explica, sustancialmente, por la necesidad de luchar contra la puesta en peligro y la desconsideración de la función administrativa ${ }^{328}$.

\section{3- Toma de postura}

Al analizar las propuestas doctrinales que acabamos de repasar, se constata una multiplicidad de bienes jurídicos que para la doctrina francesa merecen ser protegidos por el Derecho penal. Aunque no se ha

\footnotetext{
buen funcionamiento de la Administración la perversión de los mecanismos institucionales más esenciales. La falta de probidad está sancionada por sí mismo, es decir, por lo que representa de traición para con la autoridad y el público.

327 M-P. LUCAS de LEYSSAC y A. MIHNAN, Droit pénal des affaires, Manuel théorique et pratique, Economica, 2009, no 1003, 1004.

328 A. VITU, Traité..., op. cit., pp.206, 207. Las infracciones que protegen el orden administrativo son la sección II que se refiere a la "forfaiture" y los crímenes y delitos de los funcionarios en el ejercicio de sus funciones" (arts. 166 a 198) y la sección IV que castiga "resistencias, desobediencias y otros incumplimiento hacia la autoridad pública (arts. 209 a 264) del Libro III, Título I "De los crímenes y delitos contra la paz pública", del anterior código penal.
} 
emprendido ningún estudio particular reflexionando sobre el bien jurídico de esta categoría de delitos ${ }^{329}$, se observa que en su intento de definir los objetos dignos de protección en la categoría, la doctrina ofrece una escala entre ellos. La reforma legislativa ha consagrado la manera de clasificar los delitos conforme a un interés protegido según su categoría. Por lo tanto, el hecho de que el legislador acepte abandonar la clasificación según la cualidad de los sujetos activos y adoptar una según el bien jurídico, se deduce de un esfuerzo de proteger un bien categorial de dimensión institucional y ello con la razón de dar una coherencia sistemática al grupo por la existencia de las conductas de sujeto activo no funcionario. Con ello podemos recuperar aquí la teoría de los bienes jurídicos supraindividuales institucionalizados o espiritualizados, que no son reconducibles a bienes individuales y que cumplen una función instrumental puesto que un concreto acto delictivo no lesiona o pone en peligro dichos bienes. La técnica legislativa aquí utilizada es la de los delitos de peligro abstracto mediante la tipificación de la afectación a un "bien intermedio con función representativa", lo que los convierte formalmente en delitos de lesión (del objeto o bien representante); resultando esta técnica legítima únicamente en aquellos casos en los que el bien mediatamente protegido tiene suficiente entidad para ser considerado merecedor de tutela penal. En los delitos contra la Administración Pública habrá que determinar, dentro de los parámetros de la Constitución francesa cuál es el bien jurídico inmaterial mediatamente protegido para deducir luego que lo que se castiga no es la "lesión" de dicho bien jurídico sino la del "objeto representante" en cada delito 330 .

A falta de parámetros constitucionales claros sobre la actuación de la Administración Pública, la tentación es grande al buscar el bien jurídico categorial en la misma autoridad del Estado, tal como se ha destacado en el debate parlamentario y apoyado por la doctrina ${ }^{331}$. En efecto, estos delitos, como lo afirma SAPIN, demuestran que "uno de los primeros deberes del Estado debe ser de asegurar al ciudadano contra las abusos de la autoridad pública"332, lo que justifica la presencia, en ese grupo, de delitos contra los intereses individuales. "La autoridad del Estado es gravemente lesionada cuando sus representantes faltan a su deber de probidad"333. Tal afirmación, nos llevaría a la concepción según la cual

\footnotetext{
${ }^{329} \mathrm{~A}$ lo largo de este trabajo vemos que los únicos autores que han hecho un estudio bastante profundo sobre el concepto de bien jurídico son J. WALTHER y M. LACAZE en el seno de la doctrina francesa. Sin embargo, aunque sea una señal esperanzadora de la apertura del sistema doctrinal francés hacia el sistema inspirado del modelo alemán, son simplemente estudios generales de macro-comparación cuyo enfoque es la demostración del estado actual del concepto de bien jurídico en el sistema jurídico francés. Por lo cual, carecemos, al redactar este trabajo, de reflexiones doctrinales sobre el tema en estudio, esto es, la Administración pública, a diferencia de las que se pueda encontrar en la doctrina española.

${ }^{330}$ E. DEMETRIO CRESPO, Corrupción..., op. cit., p.70.

331 G. GIUDICELLI-DELAGE, Livre IV..., op. cit., p.505.

332 M. SAPIN, Doc. Ass. Nat. 2083, p.11.

333 M. SAPIN, Doc. Ass. Nat. 2083, p.12.
} 
estos delitos protegen los deberes del cargo que han de cumplir los funcionarios, los deberes de lealtad que han de observar y la dignidad de una Administración Pública concebida como supraentidad compresiva del conjunto de las funciones estatales, la cual hunde sus raíces en concepciones profundamente autoritarias ${ }^{334}$. En este mismo sentido, aunque de un modo más detallado, se ha pronunciado CUGAT MAURI al comparar la construcción del Estado liberal y la perduración de sus valores (protección de la obediencia por parte de los funcionarios, protección de los derechos individuales a lo que obliga la teoría del contrato social, también se debe proteger de modo prioritario al Estado y el Derecho, sin el cual no cabría ni la identificación ni la protección de aqué$\operatorname{llos}^{335}$ ) en las versiones actuales de corte autoritario. Así pues, esta perspectiva está preocupada fundamentalmente en la afirmación del aparato estatal como sujeto de voluntad política suprema y autónoma de otro tipo de poderes. La característica fundamental de este tipo de perspectiva se encuentra en el carácter subjetivista de la protección, puesto que en definitiva lo que se protege directamente es la primacía de una voluntad sobre las otras, y en concreto la de la voluntad del Jefe del Estado o del Estado sobre la de los funcionarios públicos. Tal subjetivismo acaba siendo la otra cara de la moneda del formalismo al que se recurre para encauzar la obediencia a aquella voluntad a través de normas de conducta de carácter lógicamente disciplinario. Ello desemboca en la concreción del ilícito en la infracción de un deber correspondientemente personal y formal, en la medida en que, en definitiva, lo que se exige es la obediencia o fidelidad a aquella voluntad, a través del respeto a unas normas que pueden dar protección a cualquier contenido material en tanto esté sancionado por la voluntad suprema. El subjetivismo se plasma en el bien jurídico, en la referencia a la fidelidad personal a la voluntad estatal y por lo tanto en el cumplimiento de los deberes del cargo ${ }^{336}$.

Añade la misma autora que al respecto cabe decir que, progresivamente, se han ido añadiendo al anterior criterio otros factores que se identifican expresamente con el contenido del bien jurídico, como el buen funcionamiento de la Administración. "A pesar de la introducción de otros factores, esta postura continúa sosteniendo una mirada introspectiva, dirigida más hacia el interior del Estado que hacia el exterior. Es decir, se ve el buen funcionamiento de la Administración más como el resultado de la obligación derivada del cumplimiento de mandatos estatales, que como presupuesto de un servicio público." Dentro de la misma línea, se hace referencia también a otros aspectos derivados de tales subjetividades, como las expectativas estatales o de la comunidad en

\footnotetext{
${ }^{334}$ E. DEMETRIO CRESPO, Corrupción..., op. cit., p.69.

335 S. JOISSAINS, Les options fondamentales..., op. cit., pp. 13 y ss. La autora afirma la inspiración del Libro IV para hacer uso de la protección penal al "contrato social" fuente del ius puniendi del Estado pero que éste último no puede ejercer este poder más que dentro de los límites fijados por las leyes particulares, que son la expresión de la voluntad general.

336 M. CUGAT MAURI, La desviación..., op. cit., pp.63-65.
} 
relación a la fidelidad de los funcionarios o al buen funcionamiento de la Administración, donde indirectamente ya se introducen contenidos de orden material que llevan a posiciones de carácter mixto, pero mantienen el fondo subjetivista. Además, se ha recurrido al argumento de que la Administración del Estado tiene una personalidad jurídica única, que sostiene la idea de Administración-función, para la que la esencia de todos los poderes públicos radica en la misma función de ejercicio del poder político de soberanía. Tal postura coincide pues con un modelo de Administración ampliamente discrecional, que ejerce directamente funciones políticas o de soberanía. Desde este punto de vista ha sido fácil ver a cada funcionario como representante directo de la voluntad estatal suprema, y su acto, como acto "del" Estado, no ya sólo desde el Estado ${ }^{337}$. Tal planteamiento ha sido asumido por un sector mayoritario de la doctrina francesa en la actualidad aun dentro de la reforma del Código penal ${ }^{338}$.

Sin embargo, aunque se ha propuesto la autoridad del Estado como bien jurídico categorial de los delitos contra la Administración Pública, y con las consecuencias que ello puede acarrear en la configuración de las relaciones entre la Administración y sus agentes y entre éstos últimos y los administrados, tal como se acaba de señalar, la nueva presentación de los delitos a partir de la reforma legislativa llama la atención para ver más allá del propio texto. En efecto, sostener la autoridad del Estado como valor digno de protección podría ser defendible con el anterior Código penal que castigaba los delitos del cargo ya que se consideraba que los actos del funcionario son propiamente un acto del Estado y el agente, su representante para cumplir las misiones asignadas por la Constitución. Efectivamente la doctrina entiende que los funcionarios

\footnotetext{
${ }^{337}$ Ibídem, op. cit., pp.65-68. "En consecuencia, esta postura, a la vez que posibilita el control arbitrario del poder, basado en un principio de autoridad incuestionable, puede llevar a la extensión a la Administración de la insindicabilidad que caracteriza a las decisiones políticas del Gobierno, puesto que en este modelo se difuminan las fronteras entre lo político y lo administrativo por la transmisión en cadena desde la alta Administración hacia las esferas inferiores no ya sólo de los contenidos políticos de las decisiones, sino de alguna manera también el carácter político del poder en la medida en que la filosofía de la obediencia jerárquica se complementa con la idea de la representación por parte de cada uno de los órganos respecto de sus superiores.

338 G. GIUDICELLI-DELAGE, Livre IV..., op. cit., p.505 ; C. AMBROISE-CASTÉROT, Droit pénal..., op. cit., p.329. Es de destacar que estos autores precisan el valor protegido antes de abordar el estudio del tipo. La falta de interés de los autores franceses en precisar lo que pretende proteger el legislador con las diferentes incriminaciones nos impide encontrar más reflexiones en este ámbito. La mayoría de los autores a pesar de la clasificación ya hecha en el texto legislativo, ofrece otra manera de clasificar los delitos según el enfoque de la monografía. Es decir la clasificación puede ser diferente si se trata de un estudio de la parte especial del Derecho penal o de Derecho penal de los negocios (Droit pénal des affaires). Además, cada autor determina su propia clasificación de los delitos con lo cual es difícil encontrar consenso significativo respecto a los conceptos entre los autores. Véase P. BONFILS, Droit pénal des affaires, Cours et travaux dirigés, Montchrestien, 2009, p123. Este autor reconoce clasificar de manera subjetiva los delitos del libro IV según su importancia para el estudio del derecho penal de los negocios. Cada clasificación doctrinal obedece a un hilo conductor definido arbitrariamente.
} 
son los últimos en la escala de la representación del Estado después del Gobierno, y que su inferioridad, su carácter instrumental y su subordinación a los órganos políticos garantizan la unidad del poder ejecutivo y, por lo tanto, una parte de la unidad del Estado ${ }^{339}$. A raíz de ello, doctrina y jurisprudencia admiten la falta al deber de lealtad, de obediencia, de probidad, de dignidad ${ }^{340}$ como referencia inmediata lesionada en varios delitos en concreto dentro del grupo ${ }^{341}$. De acuerdo con ASÚA BATARRITA, estas explicaciones que sitúan confusamente la desaprobación en actitudes o tendencias, en calificaciones subjetivizadas que poco dicen de la significación objetiva del hecho para la sociedad, ni de lo que debe constituir el fundamento del reproche jurídico: la nocividad objetiva para las expectativas legítimas de los ciudadanos respecto al funcionamiento de las instituciones bajo el imperio de la Ley. Las referencias a la deslealtad e infidelidad del funcionario para con el Estado o la Administración resultan demasiado ambiguas si no se conectan a lo que constituye la legitimación de las instituciones democráticas. Desde los parámetros actuales, la tradicional apelación al "deber de lealtad" no puede significar otra cosa que la necesaria sumisión del funcionario a la Ley y al Derecho, en el marco del cumplimiento de objetivos de interés general. Quedan descartadas las "lealtades políticas" a quien decidió un nombramiento de confianza o la fidelidad en la ocultación de prácticas intolerables. Las apelaciones a "deberes" de lealtad, evocan épocas pasadas de lenguaje formalista utilizado eufemísticamente desde concepciones autoritarias. Es la Constitución la que debe ofrecer un modelo de Administración y así establecer el programa básico de lo que "debe ser" el funcionamiento institucional, y por ello la pauta de referencia para delimitar lo que pueda ser el objeto de tutela penal ${ }^{342}$.

Por ello, aunque no es un planteamiento que se ha hecho dentro de la doctrina francesa, se puede entender que la reforma legislativa abre una nueva perspectiva de lectura y de interpretación respecto a los delitos contra la Administración Pública. En este sentido es necesario recurrir a la carta constitucional para entresacar los principios básicos y definir el objeto de protección eliminando todos elementos subjetivos y fijando otros objetivos, conforme a las expectativas de los ciudadanos en el hecho de consagrar la Administración como órgano previsto por la Constitución. Es de destacar también que en esta operación de resaltar los parámetros constitucionales relacionados al grupo de delitos en cuestión, y a diferencia de la Constitución española (a partir de ahora y, en adelante, $C E$ ) en la que se ha detallado la creación, la organización y

\footnotetext{
339 G. DUPUIS, comentando..., op. cit., p.366. El autor adhiere a la tesis según la cual la democratización de las instituciones políticas ha modificado de manera singular el alcance de la subordinación: el Parlamento está sometido al sufragio universal; el Gobierno al Parlamento; de manera que, por los intermediarios inevitables, los funcionarios están subordinados al país.

340 Cons. Ét. 4-11-1965, Vialle, Actualité Juridique Droit Administratif, 1966, p.373; Cons. Ét. 13-12-1969, Gomard, Recueil des décisions, p.652.

341 M. FORGES, Droit de la fonction publique, op. cit., pp.257-259 ; J. CHEVALLIER, L'administration subordonnée? op. cit., p.89.

${ }^{342}$ A. ASUA BATARRITA, La tutela penal..., op. cit., p.20
} 
el modo de actuación de la Administración ${ }^{343}$, la Constitución francesa (a partir de ahora y, en adelante, CF) no contiene referencias detallados sobre la Administración Pública y apenas la ha mencionado al consagrar su subordinación al Gobierno ${ }^{344}$. Sin embargo, y asumiendo la naturaleza "vicaria" del poder que la Administración ejerce en nombre del Estado, podemos encontrar elementos que forman valores constitucionales cuya puesta en marcha incumbe a ésa y por lo tanto son susceptibles de amparo por medio del Derecho penal a riesgo de implicar "agresiones de mayor alcance contra el corazón del modelo"345.

En primer lugar, el artículo 2 de la norma fundamental abre un marco de principio a todo debate sobre la actuación del Estado, al declarar que, entre otros, su carácter democrático y social ${ }^{346}$. La doctrina comenta que este carácter democrático no hace más que corroborar la formula de A. LINCOLN consagrada constitucionalmente en el mismo artículo: "gobierno del pueblo, por el pueblo y para el pueblo" e implica el sufragio universal, la soberanía del pueblo ejercida por medio de sus representantes y la posibilidad de pronunciar por vía de referéndum. En efecto, el principio democrático permite la participación de todos los ciudadanos en la vida política y social y por ello se ha reconocido el pluralismo político en el artículo 4347 , como señal de la democracia liberal. Eso alude al principio de igualdad, que también tiene valor constitucional. Este principio sugiere la idea de no-discriminación como sustrato subyacente. Ahora bien, es evidente que la ley no puede ser idéntica para todos, tiene en cuenta las diversidades de situaciones. Pero, por un lado, la Ley no debe contener ninguna discriminación subjetiva, de otro lado, la Ley, una vez adoptada, debe ser aplicada, de igual manera a las personas concernidas. Lo que es más difícil, afirma MAESTRE, es la delimitación del concepto de "democracia social". Según el mismo autor, la fórmula traduce la voluntad de no limitar la democracia en el campo político sino extenderla en el campo social. Evoca la solicitud de la Nación ante algunos de sus miembros que son más vulnerables y más desafortunados. Para realizar cierta justicia social, la solidariedad nacional

\footnotetext{
343 Artículo 103, CE: "1) La Administración pública sirve con objetividad los intereses generales y actúa de acuerdo con los principios de eficacia, jerarquía, descentralización, desconcentración y coordinación, con sometimiento pleno a la ley y al Derecho. 2) Los órganos de la Administración del Estado son creados, regidos y coordinados de acuerdo con la ley. 3) La ley regulará el estatuto de los funcionarios públicos, el acceso a la función pública de acuerdo con los principios de mérito y capacidad, las peculiaridades del ejercicio de su derecho a sindicación, el sistema de incompatibilidades y las garantías para la imparcialidad en el ejercicio de sus funciones."

${ }^{344}$ Artículo 20, CF: "[el Gobierno] Dispone de la Administración y de las fuerzas armadas."

${ }^{345}$ A. ASUA BATARRITA, La tutela penal..., op. cit., p.21.

346 Artículo 2, CF: "Francia es una república indivisible, laica, democrática y social. Garantiza la igualdad ante la ley de todos los ciudadanos sin distinción por razones de su origen, raza o religión. Respeta todas las creencias."

${ }^{347}$ Artículo 4, CF: "1) Los partidos y las corporaciones políticas concurren a las elecciones. 2) Se forman y ejercen su actividad libremente. Deben respetar los principios de la soberanía nacional y de la democracia."
} 
debe jugar su papel ${ }^{348}$. En efecto el Estado democrático y social no es sólo el que garantiza la participación de los ciudadanos en los diferentes aspectos de la vida comunitaria, sino también el que garantiza su desarrollo para favorecer esta participación.

Destacar estos caracteres del Estado en sí no garantiza que la actuación concreta de la Administración considere estos principios. Es cierto que es un marco ya hecho para determinar el límite del poder punitivo del Estado. Por su falta de claridad, todavía no es suficiente para enfocar la política criminal hacia la protección de la relación prestacional entre los administrados y la Administración y, así, objetivizar la tutela penal en este ámbito. Para ello debemos buscar no sólo en la propia Constitución francesa los parámetros necesarios sino en el bloque de constitucionalidad reconocido por la misma ${ }^{349}$. En este sentido llama significativamente la atención las obligaciones previstas por el Preámbulo de la Constitución francesa de 1946. Entre los derechos que se reconocen en favor de los administrados, la línea 10 proclama que "la Nación proporciona al individuo y a la familia las condiciones necesarias para su desarrollo." Entiende la doctrina francesa que el Preámbulo de la Constitución se ha vuelto una disposición jurídica fundamental, ya que limita la actividad de todos los órganos del Estado incluso el legislador; estos límites son dados no por la primera línea del Preámbulo de la CF de 1958, sino por los textos a los que se refiere directa o indirectamente el texto constitucional, esto es, la declaración de 1789, el Preámbulo de la CF de 1946 y los principios fundamentales reconocidos por las leyes de la República ${ }^{350}$. En efecto, como ya se ha señalado, la Nación tiene como componente principal el Estado con todos sus órganos, incluso la Administración. La lectura del nuevo Código penal debe ser hecha a la luz de esta disposición constitucional en la que no sólo podemos encontrar el límite de poder del Estado incluyendo el de punir, sino también un enfoque político criminal que orienta al legislador a la protección y la promoción de estos derechos a partir del amparo no de la institución administrativa como órgano sino de su misión de asegurar las condiciones necesarias para el desarrollo de los administrados. Lo que necesita protección no es el poder de la Administración, tampoco su prestigio, que le podrá privar de su credibilidad o la confianza de los ciudadanos en ella, sino su forma de actuación conforme a sus fines y en el so-

\footnotetext{
348 J-C. MAESTRE, comentando el artículo 2, $\mathrm{CF}$, en La constitution de la république française, dir. F. LUCHAIRE et G. CONAC, op. cit., pp.85, 86.

${ }^{349}$ Preámbulo, CF: "El pueblo francés proclama solemnemente su adhesión a los derechos humanos y a los principios de la soberanía nacional tal y como fueron definidos por la declaración de 1789, confirmada y completada por el preámbulo de la Constitución de 1946". ARÁNGUEZ SÁNCHEZ y ALARCÓN NAVÍO señalan que estos dos textos comparten ese mismo rango constitucional, situándose en la cúspide del Ordenamiento jurídico. Debe recordarse que la Declaración de 1789 se centraba exclusivamente de derechos individuales, mientras que la Constitución de 1946 suponía la consagración, por primera vez, de un amplio grupo de derechos colectivos, situados en un mismo nivel que las libertades individuales (C. ARÁNGUEZ SÁNCHEZ y E. ALARCóN NAVÍO, El código penal francés, op. cit., p.277).

${ }^{350}$ F. LUCHAIRE, comentando el Preámbulo, CF, en La constitution de la république française, dir. F. LUCHAIRE et G. CONAC, op. cit., p.38.
} 
metimiento a aquellos principios que informan el procedimiento en la adopción de decisiones de su competencia ${ }^{351}$. Sería interesante saber lo que puede contener la expresión "condiciones necesarias para su desarrollo". La doctrina entiende que se trata de tanta generalidad que es imposible extraer de ella reglas jurídicas precisas. Los beneficiarios son tanto los individuos que viven solos como los que vivan en familia, lo que prohíbe la restricción de su alcance a las familias legítimas. Lo que se proporciona son las condiciones de desarrollo lo que puede incluir: alojamiento, espacios verdes, equipamientos culturales y deportivos, tranquilidad, higiene, seguridad, etc. ${ }^{352}$.

Aunque no aparece de manera clara en el texto constitucional, se entiende a partir de estos principios los fines a los que tendrán que someterse las actividades de la Administración. Los criterios de su actuación son la legalidad y la igualdad. Considerando estos criterios y principios que deben guiar la Administración Pública en la misión a ella asignada, se puede defender que el bien jurídico digno de protección en el grupo de delitos en cuestión es su correcto y recto funcionamiento, si bien debe precisarse en cada caso, según el campo de decisión o actividad que se contempla en la descripción de cada delito, el aspecto concreto de tutela. Haciendo nuestra la postura de ASÚA BATARRITA, sostiene la autora que la tutela de la Administración en sus características de actividad, no significa proteger los entes en sí mismos, sino precisamente preservar sus funciones y sus cometidos valiosos para la organización social articulada conforme a la Constitución democrática. La Administración se convierte en un ente necesitado de protección no por constituir parte de uno de los poderes del Estado, sino por constituir instrumento necesario, presupuesto de acceso de los ciudadanos a los servicios públicos en condiciones de igualdad, transparencia, objetividad, conforme a Derecho, etc. Los titulares de ese bien jurídico ahora genéricamente formulado como "comportamiento correcto de la Administración" son los ciudadanos, cuyas legítimas expectativas frente a la Administración son las que se ven perjudicadas cuando se altera la función que ésta debe cumplir en el sistema de organización social dado ${ }^{353}$.

\section{III-La protección penal de la Administración en el Dere- cho malgache}

\section{A-REPASO DE LA EVOLUCIÓN DE LA PROTECCIÓN PENAL DES- DE UNA PERSPECTIVA HISTÓRICA}

\footnotetext{
${ }^{351}$ A. ASUA BATARRITA, La tutela penal..., op. cit., p.21

${ }^{352}$ F. LUCHAIRE, comentando..., op. cit., p.43.

353 A. ASUA BATARRITA, La tutela penal..., op. cit., p.22; M. CUGAT MAURI, La desviación..., op. cit., pp.76 y ss.; E. DEMETRIO CRESPO, Corrupción..., op. cit., p.70.
} 


\section{PARTE I: APROXIMACIÓN AXIOLÓGICA Y ESTRUCTURAL...}

\section{1-La Administración del reino merina ${ }^{354}$}

Haciendo abstracción de las administraciones territoriales de los reinos vecinos, la Administración merina, bajo el reinado de ANDRIANAMPOINIMERINA se caracterizó por la participación activa de los administrados por medio del fokonolona ${ }^{355}$ y de las agrupaciones de casas. Cada comunidad era responsable de la vida social ya que la toma de decisión se hacía entre sus miembros directamente para instaurar una disciplina social en instancias suficientemente democráticas. Con este sistema de gestión directa y de proximidad, los funcionarios que representan el poder real casi no tuvieron que intervenir. Esta situación daba a las comunidades el sentimiento real de sus responsabilidades así como una singular fuerza de cohesión a los diversos grupos que la componían. Eso habría tenido como efecto el crecimiento de los lazos de solidariedad y la facilidad en la vigilancia y la administración en el conjunto. La vigilancia mutual y la tolerancia nula en materia de prevaricaciones de los detentores del poder favorecían la cultura de la integridad. El valor protegido en las incriminaciones que el rey enunciaba en aquel momento era la equidad ${ }^{356}$.

Después de esta época brillante de participación directa de los administrados en los asuntos de la comunidad, se nota después de 1810 un cambio de sistema de administración al denegar poderes al fokonolona para la centralización de los poderes administrativo y judicial entre las manos de funcionarios depredadores, llamados Sakaizambohitra ${ }^{357}$. En las provincias y los feudos, la falta de control y de vigilancia popular, la confusión de las funciones administrativa y judicial se traducía por un poder casi absoluto de los funcionarios reales ${ }^{358}$. Esta situación alarmó al primer ministro, RAINILAIARIVONY quien decidió crear 8 ministerios cuyo origen se veía en la promulgación del Código de los 305 artícu$\operatorname{los}^{359}$. Sustituyendo a los antiguos sakaizambohitra por nuevos funcionarios llamados antily, este último tiene como misión socavar, a favor

354 Este adjetivo se refiere al Reino d' Imerina, la región central de Madagascar, cuya historia ha sido objeto de investigaciones por los historiadores europeos, por lo tanto, se puede tener algunos datos sobre la historia del derecho del país.

355 La palabra fokonolona designaría el conjunto de los miembros de una comunidad. Es la célula base de la administración.

356 P. RAFOLISY, La protection juridique..., op. cit., p.78.

357 Literalmente significa los amigos de los pueblos.

358 Ibídem, op. cit., p.80. Se sostenía observa el autor que es el mal comportamiento de los administradores merina en las provincias, así como de los magistrados, el que habría facilitado la colonia francesa hacia la conquista de Antananarivo. RAMBELOARISON nota, sin embargo, que la confusión entre autoridades administrativa y judicial no era incompatible con el control jurisdiccional de la Administración ya que la función jurisdiccional al ser materialmente distinta de la función administrativa podía ser ejercida por la propia Administración con motivo de un contencioso que la implicaba (J. RAMBELOARISON, Le contrôle juridictionnel de l'Administration à Madagascar, Doctorat d' État de Droit public, dir. G. CONAC, Université de Paris 1, 1984, pp.32 y 33).

359 Sobre la estructura del Gobierno y de la Administración, vid J. RAMBELOARISON, Le contrôle..., op. cit., pp.23 y ss. 
del déspota plebeyo, la influencia de los señores feudales, y cuya misión manifiesta era reprimir los abusos.

El articulo 173 del Código, (título: Antily) es un fiel eco de las preocupaciones que estos inspiraban: "Si un Antily se ha dejado ganar por dones de dinero, (RAINILAIARIVONY sabía bien que la corrupción de sus funcionarios o la de los jefes "menakely360" no eran vanas fórmulas) o que bajo la influencia del miedo, por arreglo para con los que tienen un vínculo"361. Efectivamente, algunas señales de mejora se notaron al volver a dar al fokonolona la autonomía de gestión de las colectividades designando ellos mismos sus jefes por persona de probidad probada y por el serio de los Antily vigilados por los raiamandreny ${ }^{362}$ controladores de los actos de sus gobernadores ${ }^{363}$. RAFOLISY sugiere que el valor categorial de las incriminaciones previstas por los Códigos de ley para proteger tanto el sistema administrativo como la administración real es el fihavanana. Es un concepto bastante difícil de delimitar porque conlleva en él un conjunto de valores, tales como el respeto a los demás, la solidariedad, y la equidad ${ }^{364}$.

La evolución jurídica del pueblo malagasy comenzó en 1828, el Código de RANAVALONA 1a , 48 títulos y artículos. El segundo pareció en 1862 es el Código de RADAMA II con 50 artículos. El tercer texto dató de 1863 y fue llamado Código de RASOHERINA con 68 artículos. Estos tres monumentos legislativos, con el Código de los 101 artículos de RANAVALONA II en 1868 y con el Reglamento de los sakaizambohitra forman con el Código de los 305 artículos de $1881^{365}$ los grandes pasos en materia de Derecho escrito en Derecho malgache.

RAFOLISY, al estudiar las incriminaciones en los diversos Códigos, destaca que durante el reinado de ANDRIANAMPOINIMERINA, los bienes protegidos se han precisado de manera clara en su kabary366: las finanzas del Estado y la equidad, que correspondían a los delitos de la dilapidación de los ingresos del Reino y la aceptación de dones para actuar en contra de la equidad. Sin embargo, con la influencia de los misioneros europeos, los redactores de los subsecuentes Códigos ${ }^{367}$, no obedecían a

360 Ibídem, op. cit., pp.93, 92. Eran los señores feudales y no eran agentes públicos del reino. Sin embargo, son detentores de poder de regalía efectivo sobre su feudo al percibir los impuestos, operación que puede llevar a abuso de autoridad, con lo cual asimilable a funcionarios reales a efectos penales según el Código de los 305 artículos.

361 G. BORREL, Le Code des 305 Articles de Madagascar, Thèse de droit, Université de Paris, Ed. Domat -Montchrestien, 1931, pp.23, 24. R. ATULLY, Le droit pénal de Madagascar, Thèse de droit, Université de Paris, Ed. LMDJ, 1924, pp.95, 96.

362 Que significa los ancianos de la comunidad.

363 Ibídem, op. cit., p.80.

364 Ibídem, op. cit., p.82.

365 G. BORREL, Le Code des 305 Articles de Madagascar, op., cit., p.36 ; R. ATULLY, Le droit pénal de Madagascar, op. cit., pp.41,42.

366 Significa discurso. En efecto, el rey era titular del poder legislativo y la proclamación de su voluntad por medio de discursos (Kabary) valía promulgación de la ley.

367 Es de observar que estos códigos no eran exclusivamente textos incriminatorios sino que con las disposiciones de naturaleza penal, también se contemplaban otras 
ninguna lógica sistemática al simplemente catalogar conductas prohibidas ocultando así el bien jurídico 368 , lo que llevó al autor a buscar el bien jurídico categorial, esto es, el fihavanana que abarca todas las figuras susceptibles de proteger la Administración. Entre los tipos previstos en los Códigos se pueden citar: el soborno, la percepción indebida, los regalos prohibidos ${ }^{369}$.

\section{penal colonial \\ 2- La protección de la función pública en el Derecho}

La colonización trajo sus consecuencias en el ordenamiento jurídico del país colonizado. Para ir adaptando la importación legislativa europea, se ha notado durante cierto momento la coexistencia de dos legislaciones. En efecto, se presentaron dificultades al modernizar la organización judicial ya que principios occidentales tales como la presunción de inocencia, el secreto de la información, el respeto de los derechos de la defensa, etc. no tuvieron equivalencia en el Código procesal precolonial. Provocó una seria dificultad también la confusión de la función administrativa y judicial de las autoridades locales coloniales cuya independencia respecto al gobierno hasta la reforma de 1946 dejaba que desear, para luego volver a poner en su sitio el principio de la separación de poderes. La justicia colonial no inspiraba confianza ante los indígenas, por lo cual el acceso a la protección judicial había sido muy limitado. Conscientes de lo difícil que podía ser gobernar sin la adhesión de los indígenas, la organización administrativa preveía dos tipos de administración: la francesa y la indígena. Esta última tomaba en consideración el concepto de fokonolona para los niveles más cercanos de los autóctonos guardando la gestión de los grandes niveles a funcionarios coloniales ${ }^{370}$.

La dualidad del sistema de valores era el corolario de una dualidad jurídica. La sociedad indígena se había visto obligada a aceptar nuevos valores que emanaban del sistema europeo y habían sido declarados como universales. Efectivamente, los valores europeos se orientan más hacia la protección del individuo y son totalmente desconocidos de la población local. Este esfuerzo de transposición dio su resultado al enfrentar la reticencia de los colonizados. En cuanto a la protección de la Administración colonial, el Código penal francés de 1810 proveía todas las herramientas necesarias a este fin. Efectivamente, este Código contenía figuras más numerosas, detalladas en comparación con los Códigos reales. Los delitos desconocidos por el Derecho penal indígena: la "fofaiture", la malversación, la confusión indeseable de intereses, el tra-

necesarias para la relación social en aquél momento. Vid R. ATULLY, Le droit pénal de Madagascar, op. cit., pp.49-53. El autor señala la confusión del Derecho penal y del Derecho civil y destaca la posibilidad de sancionar con penas más graves ilícitos civiles que los penales.

368 P. RAFOLISY, La protection juridique..., op. cit., p.84.

369 Ibídem op. cit., pp.86-92.

370 J. RAMBELOARISON, Le contrôle..., op. cit., pp. 11 ss. Revela el autor la evolución del uso del tema "Fokonolona" en las diferentes épocas de la historia política del país. 
fico de influencias pasivo, la corrupción y tráfico de influencias activo. RAFOLISY nota que el valor protegido en estas figuras delictivas tal como presentan el Código penal francés de 1810, al comenzar por el delito de "forfaiture" no puede ser el deber general de integridad sino la credibilidad de la función pública y su imagen ${ }^{371}$.

\section{B-DE LA “FORFAITURE” Y DE LOS CRÍMENES Y DELITOS DE LOS FUNCIONARIOS EN EL EJERCICIO DE SUS CARGOS}

Este título es el de la sección II capítulo III "Crímenes y delitos contra la paz pública" del actual Código penal malgache (a partir de ahora y, en adelante, CPM). Se trata aquí de destacar la configuración de esta sección a fin de intentar identificar el objeto de tutela. Es de reconocer la casi inexistencia de doctrina en la materia por lo tanto la utilización de la doctrina francesa ayudaría a entender unos conceptos, ya que el sistema francés sirve de inspiración al legislador malgache.

\section{1- Sistemática de la sección II}

La sección II empieza con la definición de la "forfaiture", que es una incriminación general y subsidiaria. Reza el artículo 166 que se trata de "todo crimen cometido por el funcionario público en el ejercicio de sus cargos". Y ese crimen, si la ley no ha previsto penas más graves, será castigado por la degradación cívica (artículo167). Pero los simples delitos no llevan a los funcionarios en estado de "forfaiture" (artículo 168). Estás disposiciones marcan la voluntad del legislador para dar una protección severa de la Administración desde dentro. Una protección del deber de probidad y de integridad de parte de los funcionarios para mantener la confianza de los administrados para con los órganos administrativos. En el fondo, se necesita luchar contra la puesta en peligro y la desconsideración de la función administrativa ${ }^{372}$ para garantizar la paz pública. Sin embargo, estas disposiciones son completamente inútiles, porque ningún precepto en el Código ha previsto crimen cometido por un funcionario sin indicar al mismo tiempo la pena aplicable. Además, el principio de legalidad criminal prohíbe a los jueces crear una incriminación que podrían sancionar luego con la pena de la "forfaiture"373.

\footnotetext{
371 Ibídem, op. cit., pp.98-132. La "forfaiture" consiste en todo crimen (delito grave) cometido por un funcionario en el ejercicio de su funciones y aparece como una incriminación de segundo grado, esto es, accesorio a los crímenes que los funcionarios públicos podían haber cometido en el ejercicio de sus funciones. Se necesita entonces la calificación de criminal del acto que se traduce luego en "forfaiture". En cambio, la sanción tiene un carácter suplente de manera que si la sanción prevista normalmente para el crimen es menos severa que la degradación, entonces ésta debe ser pronunciado por el juez.

${ }^{372}$ A. VITU, Traité..., op. cit., pp.207.

${ }^{373}$ Ibídem, op. cit., pp.212, 213. No es sorprendente que la última reforma del código penal francés dejó este antiguo precepto.
} 
Por otro lado, los delitos enunciados en la sección deberían tener como exclusivo sujeto activo a los funcionarios públicos. Efectivamente la mayoría de ellos son delitos especiales. En la línea 1 se tipifican las malversaciones cometidas por los depositarios públicos; en la línea 2, las concusiones cometidas por los funcionarios; la tercera, los delitos de injerencia y negocios incompatibles con la cualidad de funcionarios, la cuarta incrimina la corrupción de los funcionarios y de los empleados de las empresas privadas; la quinta, los abusos de autoridad; la sexta, los delitos sobre la conservación del registro civil y finalmente la séptima, el ejercicio de la autoridad pública ilegalmente anticipado o prolongado.

Considerando esta sistemática seguida por el legislador malgache, se constata que no sigue ningún principio director y eso está acentuado por la falta de identificación del bien jurídico que podría ayudar al legislador de 2004 para renovar la clasificación de estos delitos. Si lo que se pretende es proteger la función administrativa de los actos de sus agentes en el ejercicio de sus funciones, estarían mal ubicados los delitos cuyos sujetos activos no son titulares de misión de servicio público y por lo tanto no son funcionario como en los delitos de corrupción activa interna e internacional y el tráfico de influencias activo (artículos 177.1, 177.2). Sostener el deber de integridad en el cumplimiento de las funciones públicas, como lo hace RAFOLISY, no es defendible porque este tipo de deber no se puede pedir a los particulares, los cuales no tienen vinculación especial con la Administración. Si el bien jurídico que se quiere proteger es un bien jurídico institucional o supraindividual, entonces tampoco es acertada la ubicación de los delitos de abusos de autoridades contra los particulares de los artículos 184 a 187 en la sección en cuestión. Habría sido mejor colocarlos en el Título III que lleva por rúbrica "Crímenes y delitos contra los particulares".

Pero lo que más refuerza el rechazo a la clasificación del legislador es el hecho de introducir en la misma sección la corrupción privada del artículo 178. En efecto, dicho precepto castiga a todo directivo o accionario de una empresa privada que ha solicitado o aceptado, directamente o no, algunas ventajas o promesas de ventajas para hacer o abstenerse de un acto en el ejercicio de su función. La segunda parte de este artículo señala la misma conducta pero de parte de los empleados y siempre dentro de una empresa privada. Aunque es cierto que la corrupción privada puede tener proyección en el ámbito público, el bien jurídico que se pretende proteger aquí no puede ser la función administrativa, ni tampoco el deber de integridad de los funcionarios y ni mucho menos la imagen de la Administración. Por lo tanto, este precepto no puede tener cabida en esta sección.

\section{2- Algunas aportaciones de la reforma legislativa de 2004 en la sección II}


A pesar de estas críticas, podemos también destacar los puntos positivos que trajo la reforma del Código penal del año 2004374. Uno de ellos es la definición simplificada de los posibles sujetos activos de estos delitos. El legislador ha preferido usar expresiones más amplias: depositarios de la autoridad pública, encargado de una misión de servicio público e investidos de un mandato público, pero no ha abandonado la especificación de ciertas categorías profesionales sobre todo en el ámbito de la corrupción privada ${ }^{375}$. Las nuevas incriminaciones surgidas en ocasión de esta reforme son: la falta de declaración de conflicto de intereses (artículo 182), los regalos (artículo 183), la falta de declaración de patrimonio (artículo 183.2), el favoritismo (artículo 175.2), el enriquecimiento injustificado (artículo 183.1), el abuso de funciones (artículo 179.1)376. La modernización del arsenal jurídico contra la corrupción llevó al legislador a "diseñar" nuevos tipos penales y ajustar los ya existentes. Sin embargo, es de lamentar que el Código no haya sido modificado en su presentación y en su forma, guardando la misma configuración que tenía el Código penal francés desde $1810^{377}$. Aunque el legislador francés era consciente de la necesidad de reformar su presentación, el legislador malgache no ha seguido su paso y dejó de inspirarse sobre su homólogo.

\section{C- DIFÍCIL IDENTIFICACIÓN DEL BIEN JURÍDICO}

\section{1- La protección de la integridad o de la probidad}

Después de un estudio sobre los conceptos de valores protegidos y su jerarquía para determinar el bien jurídico que el legislador debe proteger ${ }^{378}$, RAFOLISY defiende que el fenómeno de la corrupción en general

\footnotetext{
${ }^{374}$ Ley n ${ }^{\circ} 2004-030$ del 9 septiembre de 2004 sobre la lucha contra la corrupción 375 P. RAFOLISY, La protection juridique..., op. cit., pp.226 ss. En efecto, el código penal malgache no tiene algún precepto para definir lo que se entiende por funcionarios públicos a efectos penales.

376 Ibídem, op. cit., pp.240-329.

377 Es de observar que después de la independencia el primer Gobierno tomó la Ordenanza del 31 de agosto de 1960 relativa a la aplicación de las disposiciones del Código penal francés para intentar tapar todo posible vacío legal que se podía encontrar hasta que el país se dotara de su propio Código penal. Sin embargo, nota PROVOST que aunque transponer todo el Código penal francés parecía ser una solución de facilidad e iba a cambiar toda la legislación aplicable, sus efectos han sido muy limitados. El autor critica la inflación legislativa entre estas dos fechas ya que pensado para fortalecer el nuevo poder ejecutivo post-colonial, finalmente el hecho de legislar con abundancia pone desorden en la actividad del juez y fomenta la inseguridad jurídica de los justiciables en virtud del principio "Nemo censetur ignorare legem" (M. PROVOST en L'évolution du Droit et de la Justice dans les matières pénales à Madagascar d'octobre 1958 à octobre 1960, Thèse de Droit, Université d'Aix-Marseille, 1963, pp.26, 27, 205 y Ss.).

378 P. RAFOLISY, La protection juridique..., op. cit., pp.48-68. Es de precisar que es el primer autor (y hasta el momento el único) malgache que presenta este tipo de planteamiento en cuanto a los estudios del concepto de valor protegido y de bien jurídico aunque con enfoque más del sistema del common law. Aunque su análisis pone el acento sobre el valor de integridad, el planteamiento teórico en general es un avance importante para la doctrina malgache.
} 
tiene como blanco preferido la integridad y, en cambio, la existencia de integridad no daría cabida a la corrupción. La visión reducida sobre el sector público tiende a considerar más la probidad como valor fundamental que proteger mientras que una visión más amplia que consiste en hacer que todos los agentes o si no, todos los ciudadanos sean iguales ante los deberes de integridad pone en una situación necesaria la toma en consideración de ésa última, en cuanto objeto de protección penal, para preservar a la sociedad de la corrupción ${ }^{379}$. El mismo autor lamenta la falta de consideración de la integridad como objeto jurídicamente protegido en los instrumentos internacionales hasta el año 2003 con el Convenio de las Naciones Unidas ${ }^{380}$. En cuanto a su valoración del contexto nacional, la integridad y la probidad han recibido consagración dentro de la estrategia nacional de la lucha contra la corrupción en julio de 2004; sin embargo, la ley 2004-030 sobre la lucha contra la corrupción no menciona la integridad más que en la exposición de los motivos y en la parte del texto que se refería a la prevención. La reforma no ha modificado el título de la sección correspondiente del Código penal que conserva todavía como interés protegido la buena conducta de los funcionarios públicos. Por otra parte, el objetivo es sectorial porque el principio de integridad parece no concernir más que los aspectos de la vida pública y de manera particular a los servidores del Estado $^{381}$.

A nuestro parecer, aunque sea meritorio buscar la integridad en todos los ámbitos de las relaciones sociales tanto públicas como privadas, la integridad es un concepto que refleja un tinte moral demasiado amplio para hacer intervenir una respuesta penal en esos ámbitos. Efectivamente, el problema de un valor amplio puede ser la confusión de las distintas respuestas que el ordenamiento jurídico puede dar en función de la gravedad de la lesión. Por lo tanto, la integridad es un valor social a promover en general pero ha sido recuperado por el legislador para convertir en bien jurídico digno de protección en la Ley Anticorrupción, ya que la lesión de este tipo acarearía una alteración en el funcionamiento del sistema administrativo.

Por otro lado, es comprensible que RAFOLISY constate que el bien jurídico tutelado en la configuración actual de estos delitos es la buena conducta de los agentes públicos. Una modificación del título de la sección correspondiente habría abierto una nueva perspectiva en cuanto a la lectura de estos delitos a fin de ajustarla a principios constitucionales ${ }^{382}$. Otra vez más se entra aquí en el deber del cargo del agente hacia

\footnotetext{
379 Ibídem, op. cit., p.69.

380 Artículo 5 del Convenio de las Naciones Unidas sobre la lucha contra la corrupción.

381 P. RAFOLISY, La protection juridique..., op. cit., pp.70, 71.

382 Se entiende y como ya se ha señalado que tanto en la doctrina francesa como en la malgache no se ha estudiado con profundidad el concepto de bien jurídico. Los autores al señalar los intereses dignos de protección penal en los delitos o grupo de delitos no hacen ninguna referencia a principios constitucionales, sin entender de esta manera que la Constitución debe proveer al legislador los objetos que proteger o si no, por
} 
la Administración. Las críticas sobre ello abundan. Según OCTAVIO DE TOLEDO, sostener el deber del cargo como objeto de protección de los "delitos de funcionarios" implica una concepción política incompartible, una visión formalista y abstracta del bien jurídico reñida con la necesidad de determinación, y una función del bien jurídico exactamente contraria a la función limitadora que éste debe cumplir383. Añade que por ello, el deber del cargo ha de estar siempre en función de la protección de un interés valioso, nunca puede considerarse como bien jurídico, sino muy distintamente, como concepto que existe en función de la protección de un bien jurídico, en definitiva, el deber verdaderamente relevante para el Derecho penal en relación con el bien jurídico de estos delitos es el que tiene la Administración pública, y, por tanto las personas físicas que la componen, de servir a los que administran ${ }^{384}$.

En este mismo sentido se ha pronunciado DE LA MATA BARRANCO, al insistir en la insuficiencia de la tesis del incumplimiento de deberes para explicar el contenido del injusto penal en los delitos del Título XIX del Código penal español (equivalente de la sección II, capítulo III del Código penal malgache), independientemente de cualquier otra consideración sobre su particular objeto de protección, por su incapacidad por ello. En la concepción del "deber del cargo" para definir el injusto de los delitos de funcionarios, se observa una visión autoritaria de la actividad administrativa incompatible con un Estado social y democrático de Derecho, que obliga a una reformulación de dicha concepción en una línea de materialización de carácter institucional. Matiza el mismo autor que, no se sostiene que la "infracción de deber" que compete al funcionario haya de ignorarse para explicar el significado de estos delitos, pero se ha de rechazar a la hora de concretar el objeto de tutela penal. En este sentido, el deber del funcionario - la correcta ejecución del mismo - no es un interés penal per se, sino un presupuesto instrumental de protección de verdadero interés jurídico-penal: la función que desarrolla el funcionario en beneficio de los administrados 385 . Concluye el autor que el contenido material de antijuridicidad que se exige para la intervención del Derecho penal no se satisface en la mera infracción de un deber del cargo, sino que es necesario que esa infracción comporte una cierta entidad para afectar al correcto funcionamiento de la Administración, que incluso sin ulterior especificación constituye una referencia dema-

\footnotetext{
lo menos debe constituir un límite en la identificación de los valores protegidos por parte del legislador.

383 E. OCTAVIO DE TOLEDO Y UBIETO, La prevaricación..., op. cit., p.261.

${ }^{384}$ Ibídem, op. cit., pp. 243, 244, 246, 248, 261.

385 N. J. DE LA MATA BARRANCO, La respuesta a la corrupción pública, tratamiento penal de la conducta de los particulares que contribuyen a ella, Comares, Granada, 2004 , pp. 58, 60, 61. Añade que parece acertado, por ello, seguir en principio las posturas que oponiéndose a una visión del funcionario que actúa solamente en interés del Estado pretenden objetivar su deber, negando que el injusto descanse en la lesión de la relación funcionarial y cifrándolo en el correcto ejercicio de la función pública, siempre desde la perspectiva de los ciudadanos, frente a los cuales el deber de la Administración y de sus órganos operativos físicos - los funcionarios - cobra auténtica relevancia penal.
} 
siado general e insuficiente en sí misma para determinar la necesidad de tutela penal. Por ello, sólo pasa a ser objeto de dicha tutela cuando su afección se acompaña de una lesión a intereses que pueda cifrarse de forma específica ${ }^{386}$.

Si está claro que la infracción del deber del cargo no puede ser bien jurídico sino que necesita ser conectada con un concepto material, del cual será presupuesto instrumental ¿podemos identificar, como en el sistema español, el correcto funcionamiento como bien jurídico tutelado en la Sección II del Capítulo III del Código penal malgache conforme a los principios constitucionales que presidan el funcionamiento de la Administración?

\section{tración}

\section{2- Los parámetros constitucionales sobre la Adminis-}

A diferencia de la Constitución francesa, tal como se ha estudiado, la de Madagascar conlleva más detalles sobre la misión, la actuación y el funcionamiento de la Administración. En primer lugar, el preámbulo de la Constitución de la Tercera República revisada en 2007387 (de ahora en adelante CTRR 2007) proclama que entre las condiciones para la realización de la personalidad y de la identidad de todo ciudadano malagasy son la instauración de un Estado de derecho, el buen gobierno y la transparencia en la dirección de los asuntos públicos. La nueva Constitución de la Cuarta República ${ }^{388}$ (de ahora en adelante Constitución Malgache o $\mathrm{CM}$ ) retoma los mismos términos en su preámbulo pero con la diferencia de que con la dirección transparente de los asuntos públicos se proclama la responsabilización de todos los detentores de los poderes públicos. El artículo primero de la CTRR 2007 precisa que "la democracia constituye el fundamento de la República" de Madagascar. El mismo artículo primero de la CM añade otra cosa más al rezar de la siguiente manera: "La democracia y el principio del Estado de Derecho constituyen el fundamento de la República". Considerando todo lo que se acaba de citar hasta aquí, tenemos un cuadro claro de las bases sobre las que el Estado fundamenta su existencia y eventualmente sus actuaciones. Se trata ni más ni menos de un Estado democrático y de Derecho cuya misión, entre otras, consiste en "organizar el ejercicio de los derechos que garantizan para el individuo la integridad y la dignidad de su persona, su plena realización física, intelectual y moral"389. La CM da otra formulación al asignar al Estado la misión de "proteger y garantizar el ejercicio" de estos mismos derechos ${ }^{390}$.

\footnotetext{
386 Ibídem, op. cit., p.62.

387 Disponible en http://www.pnae.mg/ee/ref/txt nat/constitution revisee.pdf

388 Disponible en http://www.madagascar-presidency.gov.mg/.

389 Artículo 17 de la Constitución de la Tercera República revisada en 2007 (CTRR 2007)

${ }^{390}$ Artículo 17 de la Constitución Malgache (CM)
} 
En cuanto a la Administración, los dos textos reconocen que está a disposición del Gobierno, lo que confirma su posición vicaria respecto de los poderes políticos, sobre todo del poder ejecutivo ${ }^{391}$. Sobre su actuación, el artículo 40 de la CTRR 2007 precisa que "el Estado garantiza la neutralidad política de la administración, las fuerzas armadas, la justicia, la enseñanza y la educación". Algo añade el artículo 39 de la CM así redactado: "el Estado garantiza la neutralidad política de la Administración, las Fuerzas Armadas, la Policía, la Enseñanza y la Educación”392. La primera línea de este precepto precisa que "El Estado organiza la Administración a fin de evitar todo acto de despilfarro y de malversación de fondos públicos con fines personales o políticos". Llama la atención esta expresión "neutralidad política" y es de preguntar en que podría consistir su contenido. Se observa, en primer lugar, que este precepto entra en conflicto con los artículos 62 de la CTRR 2007 y 63 de la CM. En efecto, si el Gobierno dispone de la Administración, significa que hay una subordinación no sólo material y técnica de la segunda al primero sino también en personal. Se habla entonces de subordinación política en dos aspectos. Si el Presidente de la República y el jefe del Gobierno, considerado como jefe de la Administración del Estado ${ }^{393}$, tienen la facultad de nombrar a los altos cargos del Estado y a los cargos civiles y militares de los organismos del Estado, la práctica política ha demostrado que son cargos estratégicamente políticos, con lo cual se tiende a nombrar a personalidades que se adhieren al proyecto de sociedad de los dirigentes políticos. Afirma CHEVALLIER, en este sentido, que los gobernantes siempre entienden que los cargos de dirección administrativa sean confiados a responsables con quienes pueden contar ${ }^{394}$. En segundo lugar, aunque los textos constitucionales afirman que el acceso a la función pública no tiene otras condiciones que las de capacidad y aptitudes, lo que implica la noción de profesionalidad, y que la única flexibilidad que se prevé por el contingente por circunscripción administrativa durante un tiempo determinado ${ }^{395}$, una vez introducido en la máquina administrativa, el funcionario tiene que desempeñar tareas secundarias y de naturaleza subordinada, según los artículos 62 de la CTRR 2007 y 63 de la CM. Por lo tanto, esta subordinación a los gober-

\footnotetext{
${ }^{391}$ Artículo 62 CTRR 2007, artículo 63 CM.

${ }^{392} \mathrm{Al}$ añadir la institución de la Policía y poniendo en mayúscula el inicio de cada institución el constituyente quiso diferenciar Fuerzas armadas y Policía aunque ambas forman las fuerzas de seguridad del Estado y resaltar que la neutralidad política en la Policía favorecería el respeto al Estado de derecho sobre todo en el contexto político en el que se ha redactado el proyecto; en cuanto a las mayúsculas, nos parece acertado en el sentido de que se deja de considerar estas instituciones como meros sectores de actividad del Estado o de la Administración y que por lo tanto merecen una relevancia constitucional para garantizar y proteger su neutralidad política.

${ }^{393}$ Artículos 54. 4, 64.12 y 13 de la CTRR 2007 y artículos 55. 4 y 65. 11 de la CM,

394 J. CHEVALLIER, L'administration subordonnée? op. cit., pp. 91, 92. El autor nota de manera gráfica que la búsqueda de un "Estado imparcial" en el que sólo se nombre en altos cargos a personas conforme a su competencia es pura demagogia con motivo de promesas electorales.

395 Artículo 27 CTRR 2007 y CM.
} 


\section{PARTE I: APROXIMACIÓN AXIOLÓGICA Y ESTRUCTURAL...}

nantes implica de parte de los funcionarios una lealtad sin reserva, una obediencia sin fallo y una estricta disciplina ${ }^{396}$.

Por otra parte, la neutralidad política puede ser entendida como la actitud que se puede pedir a los funcionarios, según FORGES, de evitación de propaganda política sea en el ejercicio de sus cargos, sea fuera de la administración pero siempre utilizando la autoridad y el crédito acarreados por su cualidad de funcionario para preservar la independencia del funcionario y la buena reputación de la Administración ${ }^{397}$.

A nuestro parecer, si es cierto que es imposible técnicamente separar lo político y lo administrativo, y ello se explica por la configuración que los textos constitucionales han dado a la Administración, lo que pretendía el constituyente no es despolitizar la Administración sino garantizar su misión como instrumento del Estado en función de los intereses que los ciudadanos tienen reconocidos en la norma fundamental y de la expectativa que ellos podrían tener de la actuación de aquélla. La neutralidad política sería la evitación de parte de los gobernantes, quienes se hallan en la dirección política de la Administración, de todos intentos con el fin de desviarla de sus cometidos propios tales como han sido definidos en la carta magna para proseguir fines particulares diferentes, haciendo abstracción a otros principios fundamentales como la igualdad, el pluralismo, etc. En efecto, lo que se garantiza aquí es no hacer uso para ventajas individuales o sectoriales del instrumento político que es la Administración, esto es, un uso partidista con fines más partisanos y electoralistas, despojando así el fundamento constitucional del Estado y de la Administración. En este sentido se puede acudir a la expresión de GARRIDO FALLA de "eficacia indiferente" que se puede sacar al poner en relación los principios de objetividad, y de imparcialidad con la profesionalización de la función pública conforme al modo de acceso a ella ${ }^{398}$. El autor sostiene que esta "eficacia indiferente" viene del principio de la neutralidad política de la Administración y la neutralidad administrativa del Gobierno ${ }^{399}$. Explica que es una terminología convencional con la que, ante todo, debe aludirse al "talante" que la Administración, como institución y los funcionarios, como titulares de los órganos administra-

\footnotetext{
396 J. CHEVALLIER, L'administration subordonnée? op. cit., p.89.

397 M. FORGES, Droit de la fonction publique, op. cit., pp.258, 286, 287. Esta neutralidad política es importante no obstante la libertad de expresión y de opinión reconocida por la ley con la flexibilidad que la ley debe aportar para mantener el equilibrio entre los deberes funcionariales de reserva y su libertad y derechos cívicos como todo ciudadano.

398 Comparte esta opinión F. ROVERSI MÓNACO en "Breves consideraciones sobre el Gobierno y la Administración", en La Constitución española de 1978, dir. A. PEDRIERI y E. GARCÍA DE ENTERRÍA, Madrid, Civitas, 1980, pp.594, 595. Matiza el autor que objetividad no puede confundirse con una inalcanzable neutralidad plena de la Administración.

399 F. GARRIDO FALLA, L. M. CAZORLA, R. ETRENA y otros, Comentarios a la Constitución Española, Madrid, Civitas, 1985, (2ª ed.), p. 1425. El autor se pregunta: “ise puede admitir la primacía de la actividad política que significa el ejercicio del gobierno y al mismo tiempo defender la conveniencia de que sea una institución la Administración Pública?"
} 
tivos, deben tener en el ejercicio de sus funciones para la consecución de sus fines. Éste debe ser un talante de eficacia, pero no cualquiera, sino eficacia indiferente, en el sentido de que se debe ser eficaz tanto si se perjudica como si se favorece la política del Gobierno que está en el poder. La única forma de que el funcionario profesional sea en ese sentido y también a título individual una institución es operando así. Cuando el gobernante sabe que los funcionarios que tiene inmediatamente a sus órdenes actúan para conseguir los típicos fines del servicio público, ajenos a cualquier idea de satisfacer los programas políticos del partido que él representa o, al contrario, de sabotearlos, entonces es cuando el funcionario es un autentico funcionario profesional ${ }^{400}$.

Comentando el principio de objetividad, SÁNCHEZ MORÓN indica que la Administración es una institución, una organización abocada a un fin, y que este fin, que fundamenta la existencia de la Administración y que la legitima, es precisamente el servicio a los intereses generales. La Administración es una institución servicial o vicarial ya que, jurídicamente hablando, no tiene intereses propios. El servicio a los intereses generales define la esencia de la Administración Pública y debe determinar totalmente su estructura y su actividad. Desde un punto de vista funcional no puede perseguir legítimamente intereses particulares o privados, sino sólo los de carácter general con la peculiaridad de que esa función de servicio ha de realizarse con objetividad, es decir, sin acepción de personas ni interferencias partidistas, sin favoritismos ni discriminaciones ${ }^{401}$. Precisa el mismo autor que la diferencia fundamental entre el Gobierno y la Administración es el carácter representativo de que la segunda carece ${ }^{402}$ y que la actuación de los órganos gubernativos puede regirse lícitamente por concepciones ideológicos y de partido ${ }^{403}$. Concluye, sin embargo que lo que importa destacar es que el Gobierno, titular de una legitimidad democrática propia, es al mismo tiempo cabeza de la Administración, a la que transmite el impulso y la orientación política que en cada caso han preferido los electores. La Administración pública, por su parte, cumple las directrices e instrucciones del Gobierno correspondiente, con el que todos los empleados públicos tienen un deber de obediencia y de fidelidad institucional. De ahí se deriva su propia legitimidad en el Estado democrático. Pero importa subrayar que la subordinación de las Administraciones Públicas a los órganos de gobierno tiene sus límites, ya que no significa que estos puedan disponer del aparato administrativo a su arbitrio ni que la Administración sea patrimonio (y menos aún botín) del Gobierno y de los partidos políticos que la sostienen. La función de dirección administrativa de los Go-

\footnotetext{
${ }^{400}$ Ibídem, op. cit., p.1426.

401 M. SÁNCHEZ MORÓN, en Comentarios a la Constitución Española, dir. M. E. CASAS BAAMONDE, M. RODRÍGUEZ-PIÑERO Y BRAVO-FERRER, Fundación Wolters Kluwer, Madrid, 2009, pp.1682, 1683.

402 En el sistema español el Gobierno recibe sus poderes del cuerpo electoral, a través de las Cámaras representativas y es, por ello, un órgano político. En el sistema malgache el Gobierno los recibe o bien del Presidente de la República, elegido al sufragio universal (artículo 53 CTRR 2007) o bien de la Asamblea Nacional (artículo 54 CM).

${ }^{403}$ M. SÁNCHEZ MORÓN, en Comentarios..., op. cit., p.1684.
} 
biernos ha de respetar la legalidad y la objetividad o imparcialidad de la acción administrativa, que son características institucionales de ésta última. Ningún gobernante puede condenar a un funcionario a infringir las leyes ni obligarle a actuar en infracción de su deber de imparcialidad, de manera que cualquier desviación partidista de la organización administrativa hacia fines particulares es ilícita, pues el hecho de que la Administración sea dirigida por el Gobierno y deba apoyar su gestión no quiere decir que esté "al servicio" del Gobierno, ya que está solo al servicio de los ciudadanos o de los intereses generales. El sometimiento de la Administración a orientaciones políticas se ciñe a los objetivos y directrices que, de manera transparente y sujeta al control político, señala el Gobierno. En todo lo demás, la política de partido debe quedar al margen de la Administración, que sólo puede regirse por criterios de legalidad y eficacia ${ }^{404}$.

Aunque ni el CTRR 2007 ni la CM contienen el principio de la objetividad, el principio de la neutralidad política constituye un parámetro constitucional importante que traduce la misma idea. En cuanto a la eficacia, se puede deducir de la primera línea del artículo 39 de la CM "El Estado organiza la Administración a fin de evitar todo acto de despilfarro y de malversación de fondos públicos con fines personales o políticos". Se trata aquí de una gestión desviada a los fines institucionales de la Administración. Esta debe actuar con eficacia. Según SÁNCHEZ MORÓN, la eficacia administrativa requiere adecuar los medios a los fines y una permanente atención a las condiciones en que se desenvuelve la acción administrativa y la labor de sus agentes. En algunos casos, de ello derivan o deberían derivar reformas normativas, ya sean del procedimiento de adopción de las decisiones para incrementar la agilidad y la fiabilidad, del régimen jurídico de los funcionarios para favorecer su capacidad, su responsabilidad y su productividad, de los compromisos de prestación de los servicios públicos. Pero en realidad la eficacia administrativa depende sobre todo de los recursos disponibles, de la capacidad y dedicación de los dirigentes, en definitiva, de la buena organización interna. En todo caso concluye el mismo autor que está claro que el principio de eficacia administrativa no puede oponerse al principio de legalidad 405 . Explica CUGAT MAURI, en esta línea de idea, que la racionalidad ${ }^{406} \mathrm{de}$ la eficacia no puede sostenerse sin la legitimidad que le confiere la legalidad (en sentido amplio) o los intereses generales, de los que se ha dicho que depende. El necesario equilibrio en-

\footnotetext{
${ }^{404}$ Ibídem, op. cit., p.1685.

${ }^{405}$ Ibídem, op. cit., p.1686

406 M. CUGAT MAURI, La desviación..., op. cit., p.79. La autora sugiere que la Administración racional lleva al funcionario a una obligación de dar cuenta de su respeto por la ley y por lo tanto debe fundamentar sus decisiones. Añade que lo único exigible jurídica y humanamente al funcionario es un tipo de racionalidad objetivizada en la decisión, es decir, de argumentación y fundamentación coherente de la decisión. El mencionado control de objetividad es el único que puede constituir el objeto del control judicial y no el proceso decisorio subjetivo del funcionario, que podría llevar a procesos absurdos de indagación de los motivos internos de actuación, más propio de un modelo inquisitorial preocupado por el descubrimiento de la «verdad» sustancial.
} 
tre los dos pares de factores se puede romper por la preeminencia de la eficacia por encima de la legalidad; en otras palabras, por la pérdida de vista de los intereses generales legalmente reconocidos. La mencionada descompensación de criterios en la actuación administrativa es la que se encuentra en la base de la mayoría de casos de "corrupción», que intentan justificarse consecuentemente en la prevalencia de una idea de eficacia convenientemente sacada de contexto ${ }^{407}$. A nuestro parecer, la preocupación de la CM mencionar los términos "despilfarro" y "malversación", no era sólo alcanzar un nivel de eficacia en la Administración sino también una eficiencia, la cual, según CUGAT MAURI, no se trata sólo de que la medida consiga los fines, sino de que lo haga de forma óptima, evidentemente dentro de las correspondientes limitaciones por razón del sujeto y de la circunstancia. Así, la obtención de los fines exige la aplicación del medio más idóneo al fin concreto y al menor coste ${ }^{408}$.

La exposición de motivos de la ley 2004-030 sobre la lucha contra la corrupción retoma valores constitucionales y principios que han llevado al legislador a reforzar la protección penal de la Administración frente a esta "plaga" social. Con una cierta jerarquización, se mencionan de un lado los valores constitucionales como "buen gobierno", "Estado de Derecho", y de otro lado principios con finalidad preventiva, "integridad, objetividad, transparencia y honestidad" en la vida pública. En efecto, a partir de todo lo que se ha considerado en este apartado y a pesar de una ausencia de criterio sistemático basado en un bien jurídico en la presentación de los delitos, la perspectiva ofrecida por la CM y la exposición de motivos de la ley Anticorrupción nos lleva a deducir que el bien jurídico protegido en la sección II del Capítulo III del Código penal malgache no puede ser más que el correcto funcionamiento de la Administración dentro de un marco constitucional que es un Estado democrático y de Derecho cuya misión será de proteger y garantizar el ejercicio de los derechos que aseguran al individuo su integridad y la dignidad de su persona, su pleno desarrollo físico, intelectual y moral. Estos cometidos los llevará a cabo la Administración, la cual debe ser protegida en su funcionamiento, esto es, en su relación con los administrados como titulares de estos derechos constitucionalmente reconocidos. Se puede proponer en este sentido el cambio del Título de la Sección II del Capítulo III, que según esta perspectiva dejará el enfoque de la relación de deber entre la institución administrativa y sus agentes

\footnotetext{
${ }^{407}$ Ibídem, op. cit., p.91

408 Ibídem, op. cit., p.94. Matiza la autora que a pesar de la concreción de la eficacia en eficiencia, cabe subrayar que este criterio no puede ser de carácter meramente económico, puesto que los valores económicos no son el objetivo último de la función administrativa. Aparte de que determinadas unidades de ella no tienen fines evaluables económicamente. En definitiva, la aplicación de este criterio implica la realización de una valoración de beneficios y costes de la decisión, tomando en consideración los valores reconocidos por el ordenamiento, que valga la reiteración, no son sólo económicos. Por ello, cuando se justifica la corrupción, es decir el alejamiento de las instituciones públicas de la defensa de determinados intereses públicos en base a la funcionalidad de tal postura, se parte de una acepción parcial de funcionalidad, es decir, generalmente la funcionalidad económica.
} 
para desplazarlo en su relación con los administrados. Se sugiere la rubrica "delitos contra la Administración Pública" para la sección II al separar en otro párrafo dentro de la misma sección "Los delitos contra la Administración de Justicia" marcando de esta manera las especiales condiciones de su actividad, en vez de simplemente señalar la condición de pertenecer a la función judicial como circunstancias agravantes (artículo 181) en delitos de "corrupción". Se necesitará una reflexión profunda de parte de la doctrina y del legislador para tipificar otros delitos en el ámbito judicial (como por ejemplo la figura de la prevaricación judicial, el encubrimiento, la acusación y denuncias falsas y la simulación de delitos, etc. que no existen en el Derecho penal malgache). Se podría cambiar el título del capítulo III de "crímenes y delitos contra la paz pública" por "delitos contra las funciones públicas" abarcando de esta manera todos los tipos que puedan lesionar todas las actividades del Estado sin consideración de los sujetos activos y garantizando de manera general una protección en su conjunto, no obstante, las particularidades de cada una de ellas ${ }^{409}$.

\section{Sección 3-El bien jurídico protegido en los delitos de cohecho y de corrupción}

El estudio del bien jurídico en el marco de estos delitos no se ha tratado de manera igual en los sistemas en comparación. El sistema español, sobre todo la doctrina, ha profundizado en el tema, hasta el punto de encontrarse con una profusión de propuestas aunque se pueda destacar una tendencia cada vez más mayoritaria ${ }^{410}$. En cuanto a los sistemas francés y malgache no se ha notado ninguna evolución notable en las reflexiones doctrinales y jurisprudenciales ${ }^{411}$. Quizá se pueda hablar de

\footnotetext{
${ }^{409}$ M… J. RODRÍGUEZ PUERTA, El delito de cohecho..., op. cit., pp. 40, 41.

${ }^{410}$ Es de observar la existencia en la doctrina española de monografías dedicadas especialmente al estudio del delito de cohecho entre ellas; Ma. J. RODRÍGUEZ PUERTA, El delito de cohecho: Problemática jurídico-penal del soborno de funcionarios, Arazandi, Pamplona, 1999; I. VALEIJE ÁLVAREZ, El tratamiento penal de la corrupción del funcionario: el delito de cohecho, Edersa, Madrid, 1996; I. OLAIZOLA NOGALES, El delito de cohecho, Tirant lo blanch, Valencia, 1999; J. VIZUETA FERNÁNDEZ, Delitos contra la administración pública: estudio crítico del delito de cohecho, Comares, 2003 ; N. J. DE LA MATA BARRANCO, La respuesta a la corrupción pública, tratamiento penal de la conducta de los particulares que contribuyen a ella, Comares, Granada, 2004.

${ }^{411}$ Aunque haya unas monografías y estudios sobre la corrupción en la doctrina francesa, entre ellos, E. REURER, Des atteintes à l'administration publique: la corruption passive et le trafic d'influence, Mémoire de DEA de droit pénal et sciences criminelles, dir. G. DI MARINO, Université d'Aix-Marseille, 1993 ; M. VIGNAU, Le délit de corruption, Mémoire de DEA de droit pénal et sciences criminelles, dir. LECUYER, Université de Montesquieu-Bordeaux IV, 1996/1997; B. HENRI, La corruption: un mal endémique, L'Hermès, 2002; D. DOMMEL, Face à la corruption, Karthala, 2003; F. FAROUZCHOPIN, La lutte contre la corruption, Presses universitaires de Perpignan, 2003 ; F. CECCON, Contribution à l'étude de la lutte contre la corruption, Thèse droit privé et sciences criminelles, dir. M-C. SORDINO, Université de Montpellier I, 2005; son estudios generales que no profundizan el tratamiento dogmático de la figura típica de la
} 
un statu quo que debe ser superado a partir de las reformas legislativas recientes en ambos ordenamientos penales.

\section{I-El bien jurídico protegido en el delito de cohecho en el ordenamiento español}

Esta cuestión no es pacífica. Por lo tanto, se nota una discrepancia en el seno de la doctrina para concretarlo ${ }^{412}$. Pero antes de repasar las propuestas doctrinales sobre este tema, sería interesante ver la evolución de la doctrina en la materia.

\section{A- EVOLUCIÓN DOCTRINAL DEL BIEN JURÍDICO EN MATERIA DE COHECHO}

RODRÍGUEZ PUERTA identifica tres etapas en la valoración doctrinal en cuanto al bien jurídico del delito de cohecho. La primera etapa se caracterizó por la exclusiva referencia a la infracción de los deberes del cargo, presentes en las obras de los primeros comentaristas. Según GROIZARD: “(...) El derecho protegido es sólo el interés que tiene el Estado en que todos sus agentes, en su esfera propia, cumplan con los deberes de su respectivo cargo. Por eso la nota característica del delito que tratamos, resulta del tráfico de los actos que constituyen el ejercicio de las públicas funciones $(. . .)^{\prime 4} 413$. Se destacan las formulaciones como fidelidad en el desempeño de las funciones del cargo, lealtad cuando se aluden específicamente a la idea de incorruptibilidad o integridad en la caracterización de los delitos de los funcionarios públicos como delitos de infracción del deber ${ }^{414}$. La misma RODRÍGUEZ PUERTA señala que la justificación de la sanción del particular no planteaba especiales problemas ya que, durante este primer período - tanto en el Código de 1848 como en el de 1870 -, el delito de cohecho merecía la consideración de delito bilateral, permitiendo considerar al corruptor también autor del delito, puesto que con las dádivas inducía directamente al funcionario a infringir sus deberes ${ }^{415}$. Sin embargo, a pesar de que la autora no comparta esta opinión, entiende que la postura defendida por la

corrupción. El trabajo de CECCON, sin embargo, alude al interés protegido en el delito de corrupción y le dedica unos párrafos, lo que ya es algo como punto de partida en el análisis doctrinal.

${ }^{412}$ C. SUÁREZ-MIRA RODRÍGUEZ y OTROS, Manual de derecho penal, parte especial, Tomo II, Thomson-Civitas, 2008, (5 ed.), p.524; B. FEIJÓo SANCHEZ, "Cohecho" en Comentarios al Código penal, dir. G. RODRÍGUEZ MOURULLO y JORGE BARREIRO, A., Civitas, 1997, p.1126, afirma que la determinación del bien jurídico protegido en el delito de cohecho es uno de los aspectos más oscuros que presenta este delito.

${ }^{413}$ A. GROIZARD y GÓMEZ DE LA SERNA: El Código penal de 1870..., op. cit., p.242.

${ }^{414}$ N. J. DE LA MATA BARRANCO, La respuesta..., op. cit., p.55

415 S. VIADA Y VILLASECA, Código penal de 1870, concordado y anotado, t. III, Madrid, 1926, (5ª ed.), p.473. 
doctrina en aquella época gozaba de una cierta coherencia interna, ya que era capaz de ofrecer una explicación tanto para la sanción de la conducta del funcionario como para la del particular ${ }^{416}$.

En la segunda etapa, la doctrina posterior insistió en la caracterización de los delitos de cohecho como incumplimientos de los deberes encomendados por el Estado al funcionario. Esta comprensión del delito los condujo a identificar como interés tutelado el deber de probidad o de no recibir retribución alguna por el ejercicio de funciones públicas ${ }^{417}$. Señala la autora las importantes modificaciones en estos delitos con unas consecuencias incoherentes. En este sentido, se destaca la Reforma de 1944, por la que se introdujo una nueva modalidad comisiva: la "solicitud" u "oferta" de dádivas y de presentes. Esta modificación condujo a la doctrina y la jurisprudencia a otorgar autonomía al delito cometido por el funcionario y al cometido por el particular. Así, a partir de este de momento, el delito dejó de ser bilateral para convertirse en dos formas delictivas autónomas; en las que no se contempla al corruptor como instigador del delito cometido por el funcionario, sino como autor de otro delito de cohecho diverso (en este caso cohecho activo). Esta nueva concepción del delito impedía relacionar la conducta del particular con la infracción de los deberes del cargo. Por otra parte, esta peculiar visión del delito no facilitaba tampoco su interpretación y crítica. Así, no sólo obstaculizaba la graduación de las diferentes modalidades de cohecho, sino que también dificultaba la explicación de la idéntica sanción del funcionario y del particular. Otra consecuencia fue la aparición por primera vez de la referencia a una duplicidad de bienes jurídicos, según se trate de la conducta del funcionario o de la del particu$\operatorname{lar}^{418}$. Los defensores de esta postura distinguían entre el cohecho pasivo, cometido por el funcionario - que suponía la infracción de los deberes y obligaciones propias del cargo - y el activo - cometido por el particular - cuya perpetración suponía la lesión del respeto que éste debe al normal funcionamiento de la Administración ${ }^{419}$. La distinta naturale-

416 Ma . J. RODRÍGUEZ PUERTA, El delito del cohecho..., op. cit., p.42. La autora añade que durante este primer período la reacción penal se articulaba sobre el correcto desempeño de los deberes impuestos al funcionario por el Estado, entre los que se encontraba el respeto de la legalidad y la gratuidad en el ejercicio de sus funciones, cuya infracción afectaba gravemente al prestigio y decoro de la Administración.

${ }^{417}$ Los defensores de esta postura son A. FERRER SAMA, Comentarios al Código penal, t. IV, Madrid, 1956, (1 $1^{\mathrm{a}}$ ed.), pp.159 y 1160; E. CUELLO CALÓN, Derecho penal conforme al Texto Refundido de 1944, t. II, Barcelona, 1952, (8를 ed.), pp.387 y 389; S. TEJERINA, Derecho penal español, t. II, parte especial, los delitos y las faltas en particular y sus penas, obra ajustada al Código penal de 1944, Madrid, 1950, p.214; F. PUIG PEÑA, Derecho penal, parte especial, t. III, Vol. I, Barcelona, 1959, (5 ed.), pp.360 у 366.

${ }^{418}$ A. QUINTANO RIPOLLÉS, Comentarios al Código penal, Revista de Derecho Privado, Madrid, 1966, pp.718 y 719; J. M. RODRÍGUEZ DEVESA, “Cohecho" en Nueva Enciclopedia Jurídica, IV, 1952, pp.358 y 365.

${ }_{419}$ En contra de esta postura E. OCTAVIO DE TOLEDO Y UBIETO, La prevaricación..., op. cit., pp.252 y ss. Para este autor tal deber de respeto al desempeño normal de la actividad estatal no sólo tiene el particular, sino también el funcionario. Indudablemente el funcionario que ataca la integridad de la gestión lo hace infringiendo ese deber de respeto. El ataque al bien jurídico es algo cuantitativamente mayor, pero además es algo cualitativamente distinto, por cuanto no siempre una infracción al 
za de los bienes jurídicos afectados, llevó a algunos de estos autores a criticar el idéntico castigo de ambas formas de corrupción, pues reconocían que la conducta del particular sólo resulta punible en la medida en que inducía al funcionario a infringir sus deberes ${ }^{420}$. En ciertas formas, señala la autora, estos planteamientos, pese a su falta de concreción, representaron un avance sustancial, pues fueron capaces de fundamentar la sanción del cohecho activo, así permitieron realizar un examen crítico de las distintas conductas típicas ${ }^{421}$.

La tercera etapa, según RODRÍGUEZ PUERTA, se corresponde con una nueva visión de los delitos regulados en el Título VII del Código penal de 1973. En esta época, la insuficiencia de la teoría de la infracción de los deberes del cargo para dotar de contenido a estos delitos, así como la necesidad de reinterpretarlos para adecuarlos a las nuevas condiciones políticas del Estado, llevó a la doctrina a situar el bien jurídico protegido en la "función pública" o en "el buen funcionamiento de la Administración conforme a los principios de un Estado Social y Democrático de Derecho". Esta nueva óptica de análisis permitió superar el freno que, para la interpretación de estos ilícitos, había supuesto la teoría de la infracción de los deberes del cargo. A partir de ahí han surgido propuestas para concretar el bien jurídico propio del cohecho ${ }^{422}$. La principal crítica que hace la autora sobre esas propuestas es su falta de con-

deber de respeto al normal funcionamiento de los órganos del Estado implicará un delito de cohecho. Para que esto ocurra es necesario algo más, una grave infracción del deber, y algo distinto, que afecte a un determinado bien jurídico, que será el correcto servicio que la Administración presta a los ciudadanos y que siempre resultará lesionado en el caso de cohecho pasivo, mientras que en el caso del particular no siempre implicará una lesión, sino que en ocasiones la conducta llevará simplemente al peligro de lesión de dicho bien jurídico. Cuando el funcionario solicita algo del particular ya está lesionando el servicio que debía prestarle; no así cuando es el particular quien ofrece o entrega algo al funcionario; aquí la integridad de la gestión puede resultar lesionada, pero en todo caso ya se ha puesto en peligro. Por último, cuando el particular accede a lo que el funcionario ha solicitado, nos hallamos ante una participación en un hecho ejecutado por otro, que fácilmente puede ser impune, pero que en determinados casos el legislador lo ha elevado a la categoría específica de delito. En este sentido también se posiciona J. VIZUETA FERNÁNDEZ, Delitos..., op. cit., p.203. El autor no comparte la idea de que cuando se trata del cohecho cometido por el particular, se atentaría contra el normal desarrollo de las funciones públicas que tiene encomendadas el conjunto general de los órganos estatales. Defiende el autor que este atentado contra el normal desarrollo de las funciones públicas, aparte de su intolerable imprecisión, lejos de ser exclusivo del cohecho cometido por el particular, parece más predicable del realizado por funcionario público, que es quien, en definitiva, participa del ejercicio de funciones públicas y, en su caso, se desvía de ellas a cambio de la dádiva proporcionada por el particular.

420 A. QUINTANO RIPOLLÉS, Comentarios al Código penal, op. cit., p.720; J. M. RODRÍGUEZ DEVESA, “Cohecho”, op. cit., p.365.

421 Ma . J. RODRÍGUEZ PUERTA, El delito del cohecho..., op. cit., pp.43, 44.

422 Ejemplo de ello E. ORTS BERENGUER, “Delitos contra la Administración (y II)", en VIVES, BOIX, CARBONELL y GONZALEZ, Derecho penal, parte especial, Tirant lo Blanch, Valencia, 1996, (2 ${ }^{\mathrm{a}}$ ed. revisada), pp.700 y 701. Este autor identificó como objeto tutelado en este delito, los servicios que los poderes públicos vienen obligados a rendir a los ciudadanos, con sujeción a los principios proclamados en la Constitución, particularmente el de objetividad o imparcialidad. 
creción. Así pese a lograr extraer importantes consecuencias para la interpretación de los tipos, no precisan la forma en que puede quedar conculcado el bien jurídico en cada una de las modalidades de cohecho. Aún así, debe reconocérseles un logro fundamental: el permitir romper con la infructuosa dinámica que había presidido el estudio de esta materia, e iniciar una nueva línea de trabajo, cuyo punto de partida se sitúa en los principios constitucionales básicos para el correcto funcionamiento de la Administración pública ${ }^{423}$.

\section{B- LAS PROPUESTAS DOCTRINALES ACTUALES EN CUANTO AL BIEN JURÍDICO DEL DELITO DE COHECHO}

La doctrina actual entiende que lo que se tutela no es el conjunto orgánico de la Administración ni su dignidad o prestigio, sino la función pública como actividad de prestación a los administrados, de modo que las conductas punibles sean más acordes con lo que en un Estado de Derecho, pero social y democrático debe recibir protección penal. Se trata entonces de proteger su correcto funcionamiento para que pueda servir con eficacia y objetividad ${ }^{424}$ a los intereses generales ${ }^{425}$. Por lo tanto, la idea de una correcta gestión de la función pública como referente común de todos los delitos contra la Administración ha sido asumida por la doctrina sin mayor dificultad. Se entiende entonces que genéricamente se puede optar por considerar bien jurídico protegido del delito de cohecho el buen funcionamiento de la Administración ${ }^{426}$. A partir de esta consideración ya el asunto no es pacífico.

${ }^{423}$ Ma . J. RODRÍGUEZ PUERTA, El delito del cohecho..., op. cit., pp.44, 45. Añade la autora (p.47) que se puede establecer un paralelismo entre evolución doctrinal y jurisprudencial respecto a esta materia. Nota que sólo a partir, aproximadamente, de 1989 se empieza a advertir una evolución en el tratamiento de esta materia ya que antes de esta fecha la jurisprudencia basaba estas infracciones en el quebrantamiento de los deberes inherentes al cargo, con el siguiente desprestigio y deshonra del funcionario y de la función pública (entre otras tantas SSTS 26-02-1930 [RJ 1930, 168], 23-12-1932 [RJ 1932, 2207], etc.). A partir de esa fecha se abandona la referencia al prestigio y deshonra del Estado, y se alude a la necesidad de proteger el buen funcionamiento y la confianza depositada por la sociedad en el correcto proceder del funcionario, conforme a la legalidad (SSTS 24-05-1989 [RJ 1949, 847], 19-05-1989 [RJ 1989, 4228], 4-101990 [RJ 1990, 7650], etc.). No obstante, señala la autora, se sigue vinculando la comisión del delito a la infracción de los deberes profesionales, pese a que éstos sólo adquieren relevancia en la medida en que perjudican el buen funcionamiento de la Administración (p.49).

${ }^{424}$ B. FEIJÓO SANCHEZ, “Cohecho", op. cit., p.1125.

425 N. J. DE LA MATA BARRANCO, La respuesta..., op. cit., pp.66. Añade el autor que no estamos por tanto sólo ante un concepto objetivo y no subjetivo de la Administración, sino ante un concepto prestacional que exige delimitar sus fines y obliga a someterla a los principios que informan el procedimiento en la adopción de decisiones de su competencia, respecto a lo cual el respeto a las previsiones constitucionales es ineludible y por consiguiente, el respeto a los principios de coordinación, eficacia, imparcialidad, jerarquía y objetividad y, por supuesto, como concepto envolvente, legalidad. En este mismo sentido A. ASUA BATARRITA, La tutela penal..., op. cit., p.21; Ma J. RODRÍGUEZ PUERTA, El delito de cohecho..., op. cit., p.133; I. OLAIZOLA NOGALES, El delito de cohecho, op. cit., p.85.

${ }^{426}$ N. J. DE LA MATA BARRANCO, La respuesta..., op. cit., pp.67. 


\section{CAPÍTULO II: EL BIEN JURÍDICO PROTEGIDO}

pública

\section{1- El correcto funcionamiento de la Administración}

Se destaca en este sentido el argumento de OLAIZOLA NOGALES, quien considera que el bien jurídico protegido en el delito de cohecho es el correcto funcionamiento de la Administración Pública ${ }^{427}$. Se trata de un bien jurídico institucional, para cuya protección habrá que acudir a la técnica de los delitos de peligro abstracto. En efecto, un acto aislado de cohecho no afecta el funcionamiento de la Administración Pública, su lesión o concreta puesta en peligro es difícilmente imaginable, por lo que se establecen bienes jurídicos intermedios cuya lesión permitirá afirmar la tipicidad de la conducta sin que sea preciso demostrar la perturbación del bien jurídico inmaterial mediatamente protegido ${ }^{428}$. Estos bienes jurídicos intermedios son las condiciones básicas para el correcto funcionamiento de la Administración, que, según la autora, "serán algunas referidas al ámbito interno de la Administración, es decir, el funcionario debe actuar conforme a determinados deberes de fidelidad y de integridad, porque de lo contrario supondría un mal ejemplo para el resto de funcionarios y un grave peligro de contagio que acabaría perturbando el correcto funcionamiento de la Administración. Otras condiciones vienen referidas al ámbito externo. En este sentido es preciso que los ciudadanos confíen en la Administración porque sin un mínimo de confianza y de docilidad por parte de los ciudadanos, la Administración se paralizaría" 429 .

Señala ASÚA BATARRITA que la tipificación de las distintas formas de ataque a las diversas propiedades que legitiman el funcionamiento de la Administración se traduce en la existencia de preceptos diferenciados que se alimentan de un sustrato común ${ }^{430}$. DE LA MATA BARRANCO añade que si bien es cierto que la doctrina busca un primer marco de referencia como es el correcto ejercicio de la función pública, ésta hacia cuya genérica protección quepa entender parece dirigirse la norma que prevé también el delito de cohecho, no puede tomarse como concepto vago y omnicomprensivo de todas las actividades realizadas por y para el Estado; de ahí que, exclusivamente tomada en la averiguación del objeto de protección como punto de arranque, haya de sustituirse por otros referentes más concretos. Indica el mismo autor que la alusión al correcto funcionamiento de la Administración, bien categorial o finali-

\footnotetext{
427 I. OLAIZOLA NOGALES, El delito de cohecho, op. cit., p.111.

428 Ibídem, op. cit., pp.62, 63, 103 y 110. Su argumentación se refiere a autores como F. LOOS, Zum "Rechtsgut" der Bestechungsdelikte, en: Fs-Hans Welzel, 1974, 874-895 y T. RODRÍGUEZ MONTAÑES, Delitos de peligro, dolo e imprudencia, Ed. Universidad Complutense de Madrid-Centro de Estudios Judiciales, Madrid, 1994, pp.299 y ss.

${ }^{429}$ Ibídem, op. cit., pp.111 y 372. La autora sugiere como criterios de graduación de las distintas formas de ataque a tales condiciones: 1) el carácter de la decisión a tomar por el funcionario, que implicaría a su vez mayor o menor repercusión en la funcionalidad de la Administración; 2) la mayor o menor responsabilidad del funcionario dentro de la organización administrativa. por la posibilidad de influir más o menos en los demás funcionarios; 3) la cuantía de la dádiva (pp.105-107).

${ }^{430}$ A. ASUA BATARRITA, La tutela pena ..., op. cit., p.39
} 
dad tuitiva general según diferentes terminologías, constituye una referencia en exceso amplia y poco indicativa del contenido sustancial del injusto de cada una de las figuras agrupadas en el Título XIX, insuficiente además para determinar la necesidad penal ${ }^{431}$.

Por su parte VIZUETA FERNÁNDEZ nota, en primer lugar, que si se parte de que el bien jurídico protegido en el delito de cohecho es el correcto funcionamiento de la Administración pública, entendido éste como la correcta prestación de servicios por parte de la Administración a los ciudadanos para garantizar el desarrollo y su participación ${ }^{432}$, el autor no ve razón suficiente para descartar de antemano la posibilidad de su lesión concreta o puesta en peligro, y, en consecuencia, configurar el cohecho como un delito de peligro abstracto. El funcionario público que solicita a un particular una cantidad de dinero para realizar un acto propio de su cargo que debería llevarse a cabo de forma gratuita (artículo 425.1 del Código penal español de 1995 y artículo 420 después de la reforma por la LO 5/2010), realiza una incorrecta prestación de su servicio, $y$, en este sentido, lesiona el bien jurídico protegido. Pero es que, además, aun partiendo de la imposibilidad de lesionar o poner en peligro concreto el correcto funcionamiento de la Administración Pública, desde el momento que, para su protección, se establecen bienes jurídicos intermedios, habrá que estar a estos, y no al bien jurídico mediato, para determinar si se trata de un delito de lesión o un delito de peligro, y habría que inclinarse por la primera opción si, como OLAIZOLA NOGALES ${ }^{433}$, se afirma expresamente la lesión del bien jurídico intermedio.

Por otro lado, los preceptos del Título XIX del Código penal, con carácter general, y los del Derecho disciplinario tienen entre sus fines el de contribuir a la mejor organización del servicio público. Se aspira con ellos a que la Administración Pública, en sentido amplio funcione correctamente. Con los preceptos del Derecho penal, debido a su carácter fragmentario y de ultima ratio de éste, no debe buscarse la perfección del funcionamiento, sino que éste alcance unos niveles aceptables de desarrollo. Con los del Derecho disciplinario, valga la expresión, se pretende hilar más fino, un mayor perfeccionamiento en la prestación a la comunidad de los servicios públicos. Todos ellos, insiste el autor, tienen la finalidad de que la Administración funcione correctamente dentro de las coordenadas de un Estado social y democrático de Derecho, convirtiéndose este objetivo en su razón de ser. El correcto funcionamiento de la Administración Pública equivale pues, a la satisfacción de determinadas necesidades e intereses individuales y colectivos, para cuyo logro se articulan una serie de instrumentos, los bienes jurídicos. Una cosa es, por tanto, el bien jurídico protegido, y otra la finalidad de esta protección. El correcto funcionamiento de la Administración pública no puede considerarse por ello, objeto de tutela. Los que así opinan hacen coinci-

${ }^{431}$ N. J. DE LA MATA BARRANCO, La respuesta..., op. cit., pp.71 y 72.

${ }^{432}$ I. OLAIZOLA NOGALES, El delito de cohecho, op. cit., p.111.

433 Ibídem, op. cit., pp.103 y 110. 
dir la finalidad perseguida, con el instrumento para alcanzarla, la ratio legis del precepto, con el bien jurídico que protege, concepción que el autor no comparte 434 .

Por lo demás, la propia OLAIZOLA NOGALES reconoce la amplitud y vaguedad del correcto funcionamiento de la Administración Pública como bien jurídico ${ }^{435}$. No tiene más fortuna, según VIZUETA FERNÁNDEZ, cuando se refiere a los bienes jurídicos intermedios, o, lo que es lo mismo, a las condiciones básicas necesarias para el correcto funcionamiento de la Administración, pues alude a los deberes de fidelidad del funcionario y a la confianza y docilidad de los ciudadanos en y frente a la Administración ${ }^{436}$, criterios que ya han sido desechados, como ya lo hemos señalado antes. Para este mismo autor, se puede llegar a legitimar por esta vía el castigo penal de la mera infracción de deberes, lo cual parece peligroso; bastaría con considerarlos objetos representativos de bienes jurídicos con un marcado déficit de certeza y concreción, o incluso, como en el caso que nos ocupa, de categorías que ni siquiera tengan tal naturaleza 437 .

\section{2-El abuso del cargo en beneficio propio y la prohibi- ción de venalidad o comerciabilidad en el desempeño de la función pública}

Unos autores intentan a menudo formular la definición del bien jurídico protegido en el delito de cohecho como en otros delitos desde la idea del abuso en el ejercicio de la función pública, aludiendo a la confusión de intereses públicos y privados ${ }^{438}$ o, si cabe aún más explícitamente, a

\footnotetext{
${ }^{434}$ Contrarios a la identificación del bien jurídico y ratio legis, M. POLAINO NAVARRETE, El bien jurídico..., pp.159 y ss., 304 y ss.; COBO DEL ROSAL y T.S. VIVES ANTON, Derecho penal..., pp.320, 321

435 I. OLAIZOLA NOGALES, El delito de cohecho, op. cit., p.111.

${ }^{436}$ Ibídem, op. cit., p.372

437 J. VIZUETA FERNÁNDEZ, Delitos..., op. cit., pp.212-214.

438I. OLAIZOLA NOGALES, "Cohecho y amenazas: la relación entre ambos delitos (A propósito de la STS de 17 de marzo de 1992)", en Poder Judicial, 2a época, núm.40, 1995, p.436. Señala que lo que unifica todos los tipos de cohecho es que el funcionario mezcla sus intereses particulares en el ejercicio de la función pública, es decir "comercializa" la función pública. El funcionario "vende" un acto que le corresponde realizar en el ejercicio de su cargo. Si dicho acto no se incluye entre las tareas a él encomendadas no habrá en ningún caso delito de cohecho, independientemente de que el acto sea justo o injusto. También se ha pronunciado en este sentido I. VALEIJE ÁLVAREZ, "Consideraciones sobre el bien jurídico protegido en el delito de cohecho", en Estudios penales y Criminológicos, T.XVIII, 1994-1995, p.353. Para esta autora la redacción de los tipos legales induce a pensar que si el legislador anticipa la consumación al momento de la "solicitud" o "aceptación" de la dádiva es porque lo que de verdad le interesa no es tanto evitar la comisión o abstención de determinados actos - meros ilícitos, salvo en el caso del cohecho pasivo propio del ,hoy, artículo 419 - , sino evitar que entre funcionario y particular se generen connivencias o negociaciones ilegítimas que puedan ser lesivas para el interés general. Cómo, sin embargo, habría que preguntar, según DE LA MATA BARRANCO, y por qué esta lesión solo le interesa cuando surge desde una connivencia económica (N. J. DE LA MATA BARRANCO, La respuesta..., op. cit., p.81).
} 
la utilización del cargo en interés propio ${ }^{439}$. Señala DE LA MATA BARRANCO que estamos ante las tesis que, expresamente vinculadas al delito de cohecho o figuras similares en el ámbito del enriquecimiento ilícito, han acuñado como bien jurídico los conceptos de no venalidad o no susceptibilidad de comercio o de compra del desempeño de la función pública o de la propia función pública o a los de apariencia o impresión de no venalidad o confianza en dicha no venalidad ${ }^{440}$. Tales posturas obviamente, permiten sancionar conductas en las que no existe un peligro concreto para el servicio público como en supuestos de cohecho pasivo impropio respecto de regalos recibidos en atención al cargo incluso regalos de despedida -, conductas de cohecho antecedente o subsiguiente o conductas vinculadas a la realización de actos ilícitos, incluso aunque no se demuestre relación alguna entre la retribución ilícita y la actividad del funcionario. En definitiva, cualquier hipótesis de corrupción. Con ello se dirá que las figuras de cohecho sufren un proceso de transformación que golpea su esencia más característica, pasándose de una dimensión objetiva fundada sobre el hecho a una dimensión subjetiva fundada sobre el autor ${ }^{441}$.

Según OCTAVIO DE TOLEDO, en todas las figuras de cohecho existe, aunque a modo de objeto de referencia, la preocupación de evitar la actuación pública en interés privado o el reflejo del interés privado en la actuación pública, en el marco de la corrección del servicio que los poderes públicos han de prestar a los ciudadanos, estando presente, además ese otro particular interés del funcionario que, acaso, pueda suscitarle la oferta que se le hace o que realmente se muestra cuando la insta o la acoge: el enriquecimiento injusto con que se le tienta o que busca y/o encuentra. Ello parece evidente. Pero la protección, señala el

\footnotetext{
439 I. VALEIJE ÁLVAREZ, “Consideraciones...”, op. cit., p.352, indica de nuevo que no es sólo el aprovechamiento personal del funcionario lo que está llamado a reprimir y castigar el delito de cohecho, sino también el aprovechamiento singular que de la función pública persigue el particular, quien en el caso de conseguir su objetivo ha contribuido a que, en aras de satisfacer un interés personal, la función pública deje de ser ejercida objetivamente en bien del interés general. De nuevo, sin embargo, matiza DE LA MATA BARRANCO que ello sólo cuando se constata este prejuicio y de nuevo habría de insistirse que sólo si el mismo se conduce a través de la prestación económica (N. J. DE LA MATA BARRANCO, La respuesta..., op. cit., p.81).

440 C. MIR PUIG, Los delitos contra la Administración pública en el nuevo Código penal, Bosch, Barcelona, 2000, pp.226 y ss. El autor sugiere que el bien que en concreto tutela el delito de cohecho es distinto, según se trate del delito de cohecho pasivo propio o impropio. En el delito de cohecho propio se trata de preservar la legalidad de los actos administrativos que no tengan por causa la venalidad del funcionario, castigándose, por consiguiente, la ilegalidad de los actos administrativos "por venalidad". Se trata de evitar que los funcionarios públicos realicen actos de su competencia que sean constitutivos de delitos, o sean injustos o bien se abstengan de actuar cuando la ley les ordena actuar, y que además, tengan por causa la venalidad (corrupción). Respecto del cohecho pasivo impropio, el autor se refiere a la sentencia del TS de 25 de setiembre de 1947 que afirma que "el funcionario público ha de dar siempre a sus conciudadanos el máximo ejemplo de austeridad, no bastando ser honrado, justo e imparcial en los actos que realice en el ejercicio de sus funciones de su cargo, sino que también ha de parecerlo".

${ }^{441}$ N. J. DE LA MATA BARRANCO, La respuesta..., op. cit., pp.81-83.
} 
autor, se dirige más bien hacia uno de los factores que con mayor eficacia puede garantizar esa ausencia de interés privado en las actuaciones públicas, la no venalidad del ejercicio de estas funciones. La inexistencia de interés privado en los actos de la función podrá ser la ratio legis, el criterio de agrupación de las figuras delictivas en estudio, el bien jurídico de esta categoría de delitos, que se integra en el más amplio bien jurídico categorial del Título XIX en su conjunto, consistente en el correcto ejercicio de las funciones públicas. Pero es la no venalidad del desempeño de éstas, en cuanto falta de la cualidad de vendible o expuesto a la venta, lo que se constituye en bien jurídico protegido por la incriminación de todas y cada una de las modalidades de cohecho, idea próxima pero no del todo coincidente con la de no comerciabilidad de la Administración. La no venalidad, continuará, no es ni mero ratio legis, ni simple medio para el acceso al autentico bien jurídico, sino el concreto bien jurídico de los preceptos, que se lesionará en los supuestos de recepción o aceptación por el funcionario de lo que se le ofrece, en los de entrega por la otra parte de lo que el funcionario le solicita o en los de acogimiento por esa otra parte de la solicitud misma, poniéndose en peligro en aquellos supuestos en los que el correspondiente tipo no exija, para su consumación, más que el respectivo ofrecimiento. Y en la medida en que la no venalidad abarca la mera exposición a la venta habrá también lesión en aquellos casos en que el delito se consume con la simple solicitud del funcionario ${ }^{442}$.

Ante esta postura, DE LA MATA BARRANCO observa que esta concepción permite legitimar cualquier figura de cohecho. La cuestión es si el Derecho penal es el instrumento adecuado de actuación para tutelar esa cualidad en el ejercicio de la función pública. Desde luego, se acomoda perfectamente a la actual regulación, permitiendo justificar incluso la incriminación de conductas de cohecho activo no sólo propio - siempre desde la idea de peligro - y, aún más, respecto a meras ofertas no aceptadas. Ahora bien, que el correcto funcionamiento de la Administración, en cualquiera de sus facetas, se perjudique con conductas "incorrectas" de recepción de regalos, transcendentes o intranscendentes, pero sin vínculo a la ejecución de acto alguno, es a juicio del autor, cuestionable. Y en tal caso, la proximidad entre la idea de no venalidad - como objeto jurídico realmente protegido, al margen de la ratio legis - y la infracción del deber del cargo o la prohibición de enriquecimiento del funcionario público derivado del ejercicio de su función es difícil de negar. Que con tal perspectiva adquiere consistencia la sustantividad del delito de cohecho es innegable. Y, al mismo tiempo, es difícil de justificar la distinción de conductas entre cohecho propio e impropio y la mayor penalidad de unas frente a otras, salvando puntuales observaciones sobre la idea de pluriofensividad. Por otro lado, indica el mismo autor, aunque el mantenimiento de esta postura obviamente no permitiría fundamentar

${ }^{442}$ E. OCTAVIO DE TOLEDO Y UBIETO, "Derecho penal, poderes públicos y negocios (con especial referencia a los delitos de cohecho)", en El nuevo Código penal: presupuesto y fundamentos. Libro en homenaje al Profesor Doctor Don Ángel Torío López, J. CEREZO MIR y otros, Comares, Granada, 1999, pp.870-873. 
la existencia del delito de cohecho en otros ámbitos ajenos a la Administración, lo que más ha de preocupar es la dificultad de dotar de un contenido realmente sustantivo a esa idea de no venalidad que la aleje del mero reproche por la obtención de un beneficio al que no se tiene derecho derivado del ejercicio del cargo público y la virtualidad de la misma para satisfacer el contenido material del concepto de bien jurídico por la dificultad de aceptar que su quiebra pueda afectar la satisfacción de necesidades personales cuando esa venalidad no se traduce en la adopción de un acuerdo perjudicial para intereses particulares, la omisión de un acto debido, su retraso o un condicionamiento de la índole que sea en la obtención de un servicio público ${ }^{443}$.

\section{funciones públicas \\ 3-El principio de imparcialidad en el ejercicio de las}

A parte de las referencias a los principios de igualdad ${ }^{444}$, legalidad ${ }^{445} \mathrm{y}$ objetividad ${ }^{446}$ que son numerosas en doctrina como bienes jurídicos en el delito de cohecho de manera alternativa o conjunta con otros, hay sin embargo un cierto acuerdo a la hora de entender que el núcleo fundamental del injusto en los diferentes tipos de cohecho reside en la obtención de un acuerdo injusto y en ese momento, se dirá, se conculca el principio de imparcialidad ${ }^{447}$, pues el funcionario se sitúa en una posición parcial respecto a la futura adopción de un acto propio del cargo, tanto si, una vez obtenido el pacto, se posterga la efectiva recepción de la ventaja, como si ésta se entrega al alcanzarse el acuerdo entre funcionario y particular ${ }^{448}$.

VALEIJE ÁLVAREZ, vigente todavía el Código penal español de 1973, destacó del principio de imparcialidad dos facetas distintas: por un lado el deber de la Administración de obrar con una sustancial objetividad o indiferencia respecto de las interferencias de individuos o grupos de presión o fuerzas políticas y muy especialmente respecto a los intereses

${ }^{443}$ N. J. DE LA MATA BARRANCO, La respuesta..., op. cit., pp.84, 85. En opinión del autor, esta dificultad deberá intentar soslayarse por la vía de fundamentar la prohibición de instrumentalización del cargo no por el enriquecimiento en sí que de la misma pueda derivarse - tampoco por su vinculación desde la idea de peligro con ulteriores principios a los que el propio Derecho penal no les conceda relevancia típica - , sino por la quiebra del principio de igualdad que puede deducirse de ella si se entiende que el funcionario, sin perjudicar intereses concretos, afecta a los de todos obteniendo la ventaja económica vetada a quien no está en su situación: pero ya al margen de cualquier explicación del delito en el ámbito del correcto funcionamiento de la Administración y con la problemática que entonces plantearía legitimar del cohecho activo.

${ }^{444}$ I. VALEIJE ÁLVAREZ, El tratamiento..., op. cit., p.36.

${ }^{445}$ C. MIR PUIG, Los delitos..., op. cit., pp.226 y 227; F. MORALES y Ma J. RODRÍGUEZ PUERTA, “Delitos...”, op. cit., p. 1664; Ma J. RODRÍGUEZ PUERTA, El delito de cohecho..., op. cit., p.140.

${ }^{446}$ B. FEIJÓO SANCHEZ, “Cohecho”, op. cit., p.1125; I. VALEIJE ÁLVAREZ, “Consideraciones...", op. cit., p.368.

${ }^{447}$ E. OCTAVIO DE Y UBIETO, "Derecho penal, poderes públicos y negocios", op. cit., p.872. Revela el autor que es el bien jurídico más extendido dentro de la doctrina en la actualidad.

${ }^{448}$ N. J. DE LA MATA BARRANCO, La respuesta..., op. cit., pp.73, 74. 
privados del funcionario; por otro, el deber de la Administración de obrar de tal modo que la utilidad o el sacrificio derivado de la acción administrativa sea equitativamente distribuido en atención a los legítimos intereses de los ciudadanos, sin que surja, se cree o permanezca alguna posición de privilegio apoyada en la actividad de los poderes públicos. La imparcialidad, así entendida, tiene un contenido conceptual preciso y opera como un límite externo al "buen funcionamiento de la Administración", garantizando que el principio de eficacia que debe presidir la actuación administrativa no derive en arbitrariedad, creando graves desigualdades de tratamiento entre los sujetos destinatarios ${ }^{449}$.

En opinión de esta autora, todas las modalidades de cohecho responden a la protección del principio de imparcialidad de la actuación administrativa como medio para alcanzar una satisfacción igual y objetiva de los intereses generales; más concretamente, con el delito de cohecho se protege la primera de las facetas que se acaba de aludir 450 . Desde su punto de vista, el cohecho pasivo propio (artículos 385 al 387 del Código penal de 1973) y el cohecho pasivo impropio, en su modalidad de admitir dádiva o regalo que le fueren ofrecidos al funcionario público para la consecución de un acto no prohibido legalmente (artículo 390), lesionan el principio de imparcialidad de la actuación administrativa. Con la otra forma de cohecho pasivo impropio, esto es, la de admitir dádiva o regalo que le fueren ofrecidos en consideración a su función (artículo 390), se pone en peligro tal bien jurídico, pues, si bien no existe conexión alguna entre el regalo y un acto concreto del cargo que deba realizarse, el funcionario, al admitir una dádiva en consideración a su función, “(...) queda expuesto a no poder volver a mantener una sustancial posición de neutralidad e indiferencia especialmente frente a aquellos de quienes proviene el regalo, quedando expuesto a sufrir por parte de ellos influencias o peticiones que pueden entrar gravemente en colisión con los intereses colectivos" 451 . Ante esta postura, contesta VIZUETA FERNÁNDEZ que la autora estudia el bien jurídico del delito de cohecho como lo hace TAGLIARINI, al circunscribirlo a la actuación administrativa, sin tener en cuenta que también en el ámbito de las funciones jurisdiccional y legislativa ${ }^{452}$ puede cometerse este delito. Por otra parte, si todas las modalidades de cohecho pasivo propio y, dentro del cohecho pasivo impropio, la consistente en admitir dádiva o regalo ofrecidos para la consecución de un acto no prohibido legalmente, lesionan el principio de imparcialidad de la actuación administrativa, falta explicar por qué cada una de tales modalidades recibe un tratamien-

\footnotetext{
${ }^{449}$ I. VALEIJE ÁLVAREZ, El tratamiento..., op. cit., pp.30, 31; la misma, “Consideraciones sobre el bien jurídico protegido en el delito de cohecho", op. cit., pp.359, 360.

450 I. VALEIJE ÁLVAREZ, El tratamiento... op. cit., p.33.

${ }^{451}$ I. VALEIJE ÁLVAREZ “Consideraciones...”, op. cit., pp.362-368; la misma, El tratamiento..., op. cit., pp.31-35.

452 Ibídem, op. cit., pp.194, 195. La misma autora lo reconoce más tarde. En esas páginas al referirse al acto relativo al ejercicio del cargo de la descripción típica que ella considera elemento normativo del tipo, admite que comete cohecho el parlamentario que solicita una cantidad de dinero por votar a favor o en contra de determinada disposición o por presentar un proyecto de ley.
} 
to penológico distinto. De la misma forma, si, como mantiene VALEIJE ÁLVAREZ, el funcionario público que admite dádiva o regalo que le fueren ofrecidos en consideración a su función, pone en peligro el principio de imparcialidad, y aquel que realiza tal admisión para la consecución de un acto prohibido legalmente, lo lesiona, debería explicarse cuál es la razón que condujo al legislador a castigar en el artículo 390 del Código penal anterior con idéntica sanción ambos tipos penales ${ }^{453}$.

Con la entrada en vigor del Código penal de 1995, quien más decididamente y con mayor esfuerzo ha defendido la imparcialidad como bien jurídico protegido en el delito de cohecho ha sido RODRÍGUEZ PUER$\mathrm{TA}^{454}$. En la determinación del bien jurídico protegido en este delito, comienza su análisis desde una perspectiva que ella misma denomina apriorística, desde la cual la imparcialidad, o, más exactamente, el respeto al principio de imparcialidad en el ejercicio de las funciones públicas, se presenta como una hipótesis de trabajo válida para tal determinación ${ }^{455}$. Reconoce sin problemas tal principio en relación con el ejercicio de las actividades administrativa y judicial, que se deduce por lo que respecta a la primera del artículo 103.1 y 3 de la $\mathrm{CE}^{456}$, y en cuanto a la segunda, de su artículo 117, concretamente del principio de independencia, del que se deriva el deber del juez de realizar su actividad eliminando cualquier clase de dependencia exterior, bien de poderes y entidades públicos, bien de entidades privadas o de particulares, aunque en este ámbito, a diferencia de lo que ocurre en la función administrativa, el principio de imparcialidad no viene reclamado por la idea de servicio a los intereses generales, sino por la necesaria y exclusiva dependencia de la ley en el ejercicio de la actividad jurisdiccional ${ }^{457}$. Por el contrario, la actividad parlamentaria, dentro de la que se incluye la función legislativa, y la actividad política del gobierno del Estado, Comunidades Autónomas y Municipios, son, por naturaleza, parciales, por lo que en relación con ellas no puede defenderse que sea el respeto al principio de imparcialidad el interés tutelado, aunque tales actividades se encuentran limitadas, eso sí, por la prohibición de la arbitrariedad (artículo $9.3 \mathrm{CE}$ ), esto es, por la necesaria adecuación de su ejercicio a los fines constitucionales que justifican su existencia ${ }^{458}$. En conclusión, desde esta perspectiva apriorística, en opinión de RODRÍGUEZ PUERTA, "lo que propiamente se configura como objeto de tutela es el respeto al principio de imparcialidad, que vincula de un lado a los poderes públicos, en cuanto principio alumbrador del ejercicio de la actividad administrativa y judicial, y, circunscrita a la desviación del fin, a la actividad legislativa o política. El referido principio es proyectable también a los ciudadanos, en cuanto destinatarios de esa actividad pública, dado que

\footnotetext{
${ }^{453}$ J. VIZUETA FERNÁNDEZ, Delitos..., op. cit., p.221.

${ }^{454} \mathrm{M}^{\mathrm{a}}$. J. RODRÍGUEZ PUERTA, El delito de cohecho..., op. cit., pp. 78 ss. y 131 ss.

455 Ibídem, op. cit., pp.78 y 79.

456 Ibídem, op. cit., pp.68-70, 80; F. MORALES y Mํa J. RODRÍCUEZ PUERTA, “Delitos...", op. cit., p. 1658.

${ }_{457} \mathrm{M}^{\mathrm{a}}$. J. RODRÍGUEZ PUERTA, El delito de cohecho..., op. cit., pp.72, 73, 80 y 81.

458 Ibídem, op. cit., pp.74-77 y 81-83.
} 
la relación con estos últimos viene también limitada por el respeto a la Constitución y los principios en ella consagrados (artículo 9.1 CE)". Y añade que lo anterior no debe significar que la afección al bien jurídico merezca idéntica valoración en uno y otro caso, ya que la imparcialidad sólo puede predicarse de aquellos que deben y pueden adoptar una decisión. Aunque como principio de funcionamiento propio de una institución, su respeto se hace extensivo no sólo a aquellos que forman parte de ella sino también a los que entablan cualquier tipo de relación con ella o sus miembros ${ }^{459}$. Por eso subrayan ya MORALES PRATS y RODRÍGUEZ PUERTA que el cohecho cometido por el funcionario se presenta como un delito de lesión en tanto el cometido por el particular supone una mera puesta en peligro de la posición imparcial que debe presidir la adopción de la decisión pública, justificándose por ello un tratamiento asimétrico que permite excluir o atenuar la responsabilidad de éste en determinados $\operatorname{casos}^{460}$. En acuerdos referidos a actos reglados, la conducta del particular no pone en peligro el principio de imparcialidad, pero tampoco la del funcionario, aunque obtenga un beneficio indebido, que es lo que le puede hacer merecedor de sanción penal por la instrumentalización del cargo. Sí en cambio respecto a acuerdos referidos a actos políticos, discrecionales o injustos, supuesto éste en el cual se afecta asimismo, concluirá, el principio de legalidad ${ }^{461}$.

Criticando esta postura, VIZUETA FERNÁNDEZ señala que ya la perspectiva apriorística con que comienza RODRÍGUEZ PUERTA, que no es sino una propuesta lege ferenda, merece algún reparo. Porque a pesar de que ella misma reconoce en un primer momento que en relación con la actividad parlamentaria y con la actividad política del gobierno del Estado, Comunidades Autónomas y Municipios no puede defenderse como bien jurídico protegido el respeto al principio de imparcialidad, lo cierto es que esta afirmación inicial va diluyéndose progresivamente, hasta caer en el olvido cuando trata de adecuar tal bien jurídico a las diferentes modalidades de cohecho recogidas en el Código penal, donde ya sin tapujos manifiesta que es el principio de imparcialidad el bien jurídico del cohecho ${ }^{462}$. Los parlamentarios, cuando ejercen sus funciones, están sometidos a la disciplina del partido político al que representan, y éste se debe a los intereses del grupo o clase que lo mantiene en el poder o apoya para conseguirlo. Si su actividad parlamentaria es claramente dependiente de los intereses y presiones de determinados grupos, clases o ciudadanos, y el principio de imparcialidad se define, básicamente, como ausencia de interferencias en la toma de decisiones

\footnotetext{
459 Ibídem, op. cit., p.83. Añade que lo anterior no debe significar que la afección al bien jurídico merezca identidad valoración en uno y otro caso, ya que la imparcialidad sólo puede predicarse de aquellos que deben y pueden adoptar una decisión. Aunque como principio de funcionamiento propio de una institución su respeto se hace extensivo no sólo a aquellos que forman parte de ella sino también a los que entablan cualquier tipo de relación con ella o sus miembros.

${ }^{460}$ F. MORALES PRATS y Ma J. RODRÍCUEZ PUERTA, “Delitos...”, op. cit., p. 1660.

${ }^{461}$ Ma. J. RODRÍGUEZ PUERTA, El delito de cohecho..., op. cit., pp. 78 ss., 83 ss., 135 ss. y 190 ss.

462 Ibídem, op. cit., pp.74-77 y 81-83, y 131-43
} 
públicas $^{463}$, es claro que tal principio nada tiene que ver con la esencia misma del ejercicio de esta actividad ${ }^{464}$. Y esto no queda desmentido por el hecho cierto de que al ejercicio de tal actividad también le sea aplicable la interdicción de la arbitrariedad (artículo 9.3 CE), pues ésta, aunque se quiera ver una cierta relación, no coincide con la falta de imparcialidad. Por tanto, una defensa coherente del principio de imparcialidad como bien jurídico protegido en el delito de cohecho, deberá excluir, sin miramientos, de este delito toda solicitud o aceptación de dádivas realizada por parlamentario que tenga como contrapartida un acto inherente de su función. Si no se hace, lo acertado sería esforzarse en inquirir otro objeto de protección. ${ }^{465}$

Además, el mismo autor rechaza la comprobación, operada por RODRÍGUEZ PUERTA, de la adecuación a la vigente regulación del delito del cohecho, del bien jurídico principio de imparcialidad en el ejercicio de las funciones públicas. En efecto se trata de una imposición de este principio como bien jurídico protegido en este delito. Luego de determinar el objeto de protección, no realiza un estudio sobre cuál es realmente el bien o los bienes jurídicos que se deducen de los preceptos que, bajo la rúbrica Del cohecho, forman parte del Capítulo V, Título XIX, del Código penal, sino que impone su propuesta de lege ferenda en la interpretación de los tipos, y así sigue manteniendo como bien jurídico protegido el principio de imparcialidad a costa de negar la condición de modali-

463 Ibídem, op. cit., pp.84, 138, 140 y 270.

464 M. CUGAT MAURI, La desviación..., op. cit., pp.221-225. E. OCTAVIO DE TOLEDO Y UBIETO, “Derecho penal...", op. cit., p.872 ss. Nota este último autor que siendo aplicables también a jueces, fiscales o parlamentarios los preceptos del delito de cohecho, no puede inferirse la exigencia de la imparcialidad de un artículo 103 CE referido exclusivamente a la Administración pública y predicarse con igual extensión y sin matización dicha imparcialidad para unos - jueces, fiscales y funcionarios administrativos - que para otros - parlamentarios -, sin que ni siquiera la imparcialidad exigible a los jueces resulte plenamente coincidente con la demandable a los funcionarios, cuya relación con la legalidad está condicionada, aunque no supeditada, por su inserción en una organización jerarquizada, o con la requerible a los fiscales, concluyendo que aunque la imparcialidad puede verse afectada por determinados comportamientos - no con conductas cuya finalidad o referencia sea la comisión de delitos en los artículos 419 y 425.2 -, lo será en el mismo terreno de consideración jurídica, y probablemente con menor evidencia, que por ejemplo la legalidad (en el artículo 420) o la eficacia (en el artículo 421), también predicables de la actuación administrativa y de la judicial o fiscal, así como de la parlamentaria.

465 J. VIZUETA FERNÁNDEZ, Delitos..., op. cit., pp.225, 226. Indica el autor que la misma RODRÍGUEZ PUERTA excluye de este delito los acuerdos realizados por miembros del poder legislativo dirigidos a obtener financiación para su formación política, "al no resultar lesivos para el principio de imparcialidad". Sin embargo, olvida tal razonamiento cuando incluye en el cohecho aquellos casos en los que el acuerdo se dirige a la obtención de un beneficio personal, con el argumento de que en estos supuestos no existe una adecuación del ejercicio de su función parlamentaria con los fines que justifican su existencia. Y se pregunta el autor: ¿acaso existe tal adecuación cuando un diputado se compromete a votar en un determinado sentido, en una sesión parlamentaria, a cambio de sumas importantes de dinero que irán a para a las arcas de un partido, con las que se pagará aberrantes campañas electorales, abogados defensores de militantes procesados por delitos graves u otros gastos semejantes? (Ma. J. RODRÍGUEZ PUERTA, El delito de cohecho..., op. cit., pp.81 y 82) 
dad de cohecho a los dos supuestos recogidos en el anterior artículo 426, que evidentemente ni lesionan ni ponen en peligro este bien jurídico 466 , y de realizar exégesis -como la del anterior artículo 425 apartado 1, in fine, y apartado 2- de dudosa constitucionalidad. Se pregunta el autor si no será otro, acaso, el bien jurídico realmente protegido ${ }^{467}$.

Por otra parte, no queda claro en el trabajo de RODRÍGUEZ PUERTA, afirma VIZUETA FERNÁNDEZ, el momento de la lesión del principio de imparcialidad. En un primer momento, la lesión o puesta en peligro de este principio parece hacerse depender del sujeto activo del delito, de tal forma que el cohecho cometido por funcionario público, o cohecho pasivo, lesiona tal principio, “(...) ya que el empleado público que actúa de ese modo se coloca, desde el momento en que solicita o recibe la ventaja, en una posición parcial respecto a la persona con la que ha entablado contactos, y también respecto al resto de los ciudadanos", mientras que el cometido por particular (cohecho activo) alcanza meramente a ponerlo en peligro, pues sobre éste “(...) no pesa la obligación de resolver con imparcialidad, sino tan solo la de dirigirse a la Administración para formular sus pretensiones sin interferir en la toma de decisiones, utilizando los cauces lícitos para la obtención de las mismas, entre los que no se encuentra la oferta o entrega de una ventaja" 468 . Posteriormente, por el contrario, es la modalidad de conducta típica lo que se presenta como criterio clave para determinar la lesión o la puesta en peligro del bien jurídico. De este modo, al establecer en el acuerdo de voluntades entre funcionario y particular el momento en que se produce la lesión del principio de imparcialidad, la solicitud de una dádiva o presente por parte del funcionario, como no requiere tal acuerdo, pone en peligro este bien jurídico; en cambio la recepción de dádiva o presente y la aceptación de ofrecimiento o promesa, al demandar la previa o simultánea obtención del acuerdo, supone su lesión ${ }^{469}$. Este criterio, sin embargo, es desatendido cuando RODRÍGUEZ PUERTA explica las relaciones entre los diversos tipos de cohecho con base en el bien jurídico protegido, pues estima que las modalidades agravadas del delito (les anteriores artículos 419, 420 y 421 del Código penal) lesionan todas ellas el principio de imparcialidad, con independencia, esta vez de la concreta acción típica - solicitar, recibir o aceptar - que realiza el sujeto activo $^{470}$. Cree el autor que de seguir la postura de los defensores del principio de imparcialidad como bien jurídico protegido en el delito de cohecho, debería establecerse el momento de su lesión, no en el acuerdo de voluntades entre empleado público y particular, sino en la realización de por parte del funcionario de la conducta contrapartida de la dádiva, pues la CE, en su artículo 103.3 establece que "la ley regulará (...) las garantías para la imparcialidad en el ejercicio de sus funciones", vinculando la imparcialidad, no tanto al proceso mental en la adopción

\footnotetext{
${ }^{466}$ E. OCTAVIO DE TOLEDO Y UBIETO, “Derecho penal...", op. cit., p.872

467J. VIZUETA FERNÁNDEZ, Delitos..., op. cit., pp.226, 227 y 241 ss.

${ }_{468} \mathrm{M} \stackrel{\mathrm{a}}{ }$. J. RODRÍGUEZ PUERTA, El delito de cohecho..., op. cit., p.84

${ }^{469}$ Ibídem, op. cit., pp.108, 134, 175, 177 y 178.

470 Ibídem, op. cit., pp.140 y 141.
} 
de decisiones, sino sobre todo, al momento culminante del mismo, esto es, al ejercicio efectivo de la función ${ }^{471}$.

Finalmente, y otra vez más de parte de VIZUETA FERNÁNDEZ, la afirmación de RODRÍGUEZ PUERTA, según la cual: "siempre que el objeto del acuerdo sea un acto discrecional, el principio de imparcialidad quedará conculcado, con independencia de que éste resulte objetivamente conforme a Derecho o contrario al ordenamiento jurídico"472, lleva a reflexión. En efecto, cuando el objeto del cohecho es un acto de naturaleza reglada no se lesiona ni se pone en peligro, según esta autora, el principio de imparcialidad, pues el proceso de toma de decisión no puede verse alterado por el acuerdo con el particular, debido a que la decisión es obligatoria y su contenido no puede ser configurado libremente por la Administración, sino que ha de limitarse a lo que la propia ley ha previsto de modo preciso y completo ${ }^{473}$. La situación cambia en relación con los actos discrecionales. En ellos, el funcionario tiene la facultad de decidir de entre varias opciones, todas ellas lícitas, aquélla que considere más acorde con los intereses generales. Como esta decisión no depende ya de criterios estrictamente objetivos (constatación del supuesto de hecho y aplicación de la consecuencia jurídica prevista en la ley), sino de un juicio subjetivo de oportunidad, siempre que uno de estos actos sea objeto del delito de cohecho se producirá, en opinión de RODRÍGUEZ PUERTA, la lesión del principio de imparcialidad ${ }^{474}$. Sin embargo, de entre todas las opciones posibles que se presentan ante el funcionario, existe una que, objetivamente considerada, es la más acorde con los intereses generales. Si es ésta, y no otra, la opción elegida por el funcionario, y acepta una dádiva ofrecida por un particular para llevarla a efecto, no se han producido interferencias en la toma de decisiones públicas, y, en consecuencia, no se vería afectado el principio de imparcialidad ${ }^{475}$.

\footnotetext{
${ }^{471}$ J. VIZUETA FERNÁNDEZ, Delitos..., op. cit., pp.227, 228. Precisa el autor que de esta manera, la solicitud o recepción de dádiva o presente y la aceptación de ofrecimiento o promesa para realizar en el ejercicio del cargo una acción o una omisión constitutivas de delito (artículo 419), para ejecutar un acto injusto relativo al ejercicio del cargo que no constituya delito (artículo 420), con el objeto de abstenerse de un acto que practicarse en el ejercicio del cargo (artículo 421) o para realizar un acto propio del cargo (artículo 425.1, primer inciso) no alcanzarían el nivel de lesión. Estos artículos se refieren por supuesto a la legislación anterior a la reforma de 2010.

472 Mạ. J. RODRÍGUEZ PUERTA, El delito de cohecho..., op. cit., p.135.

${ }^{473}$ Ibídem, op. cit., pp.86, 135 y 136.

${ }^{474}$ Ibídem, op. cit., pp.87 y 135.

475J. VIZUETA FERNÁNDEZ, Delitos..., op. cit., pp.228 y 229. Añade que a semejante conclusión podría llegarse en el supuesto en que el funcionario público recibe una dádiva ofrecida por un particular, bien para realizar en el ejercicio de su cargo una acción u omisión constitutivas de delito, bien para ejecutar un acto injusto relativo al ejercicio de su cargo que no constituya delito, o, finalmente, que tenga por objeto la abstención de una acto que debiera practicar en el ejercicio de su cargo, y aquél - el funcionario -, con anterioridad a que el particular le ofreciese la dádiva, ya tenía la intención de realizar ese delito, ejecutar el acto injusto o llevar a cabo la abstención.
} 
Desde otra perspectiva, critica DE LA MATA BARRANCO la postura de los que defienden la imparcialidad como bien jurídico en los delitos de cohecho. Observa que es difícil acertar a comprender en qué medida, por ejemplo, un funcionario vulnera el principio de imparcialidad cuando decide - inducido o no - cometer un delito de falsificación, violación de secreto, uso de información privilegiada o contrabando motivado por la recepción de una dádiva y no en cambio cuando la decisión se toma por la pretensión de obtener un beneficio derivado de la propia comisión delictiva. La dádiva podrá motivar su conducta, facilitar un mayor empeño en su desarrollo o favorecer la creación de estructuras delictivas, pero que desde luego no es la lesividad del principio de imparcialidad lo que se representa el funcionario como elemento a captar por el dolo parece evidente, salvo en su caso en aquellas actuaciones delictivas relacionadas con un delito de prevaricación. Cuando se produzca o se pretenda alguno de tales delitos - en el ámbito del anterior artículo 419 - parece que será la tutela del bien jurídico que se trata con su previsión la que, con independencia de cualquier otra consideración, puede fundamentar la intervención penal ${ }^{476}$ - aunque sea respecto a estadios preparatorios -, pero no la existencia de la dádiva ${ }^{477}$. Concluye el autor que parece que cuando se recurre a la idea de imparcialidad para definir el bien jurídico en las diferentes figuras del cohecho, se piensa más en aquellas modalidades vinculadas a la conclusión de un acuerdo injusto que es el que, en definitiva, puede conllevar su quiebra. Y aun con todo, sólo en aquellos casos en el mismo - no el que da lugar a un delito de contrabando de malversación - se relaciona con la adopción de una decisión no necesariamente constitutiva pero sí en la orbita de lo que trata de tutelar el delito de prevaricación. El carácter fragmen-

476 En este sentido se ha pronunciado VIZUETA FERNÁNDEZ y defiende que no se puede hablar de un único bien jurídico principal protegido por el anterior art.419, sino de tantos como acciones y omisiones constitutivas de delito pueda realizar el funcionario público en el ejercicio de su cargo. La sustantividad material de las diferentes modalidades recogidas en el anterior art.419 queda, con ello, seriamente en entredicho, pues el bien jurídico principal protegido por este precepto depende de la concreta acción u omisión que el funcionario esté dispuesto a realizar a cambio de dádiva (Ibídem, op. cit., pp.274 y ss., 284)

${ }^{477}$ N. J. DE LA MATA BARRANCO, La respuesta..., op. cit., pp.78 y ss. Añade que incluso en aquellas figuras de cohecho propio no vinculadas a la comisión posterior - o incluso anterior - de un delito es difícil tratar de concretar en qué consiste la quiebra o puesta en peligro del principio de imparcialidad a que se alude en la doctrina. Las definiciones o explicaciones que aparecen en ésta, por regla general, se asocian a la toma de decisiones o actuaciones vinculadas con la prevaricación que, sin embargo, no dan lugar a dicho delito bien por no representar resoluciones, no tener éstas un carácter arbitrario o no actuar el funcionario a sabiendas de su injusticia. Pero es precisamente esa actuación que se condiciona a la recepción de la dádiva - aunque la misma no se produce finalmente o no existe desde un principio intención de realizar - la que se tiene en cuenta para aludir a la quiebra de la imparcialidad, sea desde una perspectiva de lesión sea desde la de un peligro más o menos concreto. $Y$ de nuevo en tales casos no parece ser, por tanto, la existencia de precio en sí lo que permite afirmar la vulneración del principio en cuestión. Sin embargo, téngase en cuenta que en tales casos la imparcialidad que se entiende menoscabada o puesta en peligro sólo es objeto de tutela cuando dicho precio exista, porque, en caso contrario, la ejecución de un acto ilícito pero no injusto o la omisión del acto debido o la omisión del acto debido no da lugar a respuesta penal alguna (p.79). 
tario del Derecho penal permite o aconseja restringir el ámbito de aplicación del mismo a comportamientos activos que tengan por objeto resoluciones arbitrarias, pero no puede negarse la vinculación con este delito de las conductas a que se hace referencia en los anteriores artículos 420 y 421, en cuanto ilícitos administrativos. Si cuando la dádiva se orienta a su realización y en tal caso se entiende vulnerado el principio de imparcialidad, desde luego que ello no se debe a la existencia de la misma, sino a la de tales conductas; otra cosa es que éstas no se sancionen penalmente por razones de subsidiariedad o fragmentariedad, pero que la dádiva no aporta un mayor contenido lesivo a la imparcialidad parece evidente. Y si, por otra parte, vinculamos la tutela a la idea de peligro de que se pueda materializar la actuación injusta que, sin embargo, en sí no se sanciona de forma independiente - salvo en los supuestos del anterior artículo 419 -, qué duda cabe que el motivo de la sanción habrá de cifrarse no en el peligro para la imparcialidad - cuya vulneración no le importa al legislador penal desde el momento en que no sanciona la ejecución del acto injusto del anterior artículo 420 o la omisión del anterior artículo 421 -, sino en alguna otra explicación asociada sin duda a la mera idea de la recepción de un precio por parte del funcionario ${ }^{478}$.

\section{II-El bien jurídico protegido en el delito de corrupción en los ordenamientos francés y malgache}

Contrariamente al ordenamiento jurídico español, los sistemas francés y malgache no gozan de una construcción doctrinal, y aún menos debate, en cuanto a la determinación exacta del bien jurídico en el delito de la corrupción. Los autores franceses, en su mayoría se conformaron con el bien jurídico bajo el cual el legislador ha clasificado el delito en estudio. Sin embargo, este conformismo doctrinal parece superado debido a que cada vez más se percibe la plurofensividad del delito de corrupción. En cuanto a la doctrina malgache, la casi inexistencia de estudio en esta materia nos llevará a referirnos al único autor, en la persona de RAFOLISY, que sí reflexionó sobre el bien jurídico del delito de corrupción, con sus propuestas que merecen ser destacadas aquít79.

\footnotetext{
${ }^{478}$ Ibídem, op. cit., p.80.

479 No porque sus conclusiones sean las únicas que hay en la materia sino porque reflejan una novedad en el planteamiento del estudio de los tipos penales. Hasta podemos decir que aquellas adelantan en profundidad las reflexiones de los autores franceses.
} 
A-LOS BIENES JURÍDICOS PROTEGIDOS EN EL DELITO DE CORRUPCIÓN EN EL MARCO DE LA PROTECCIÓN DE LA ADMINISTRACIÓN PÚBLICA

La doctrina francesa entiende que en el delito de corrupción sólo puede haber un bien jurídico protegido ${ }^{480}$. En efecto VITU defiende que se exige de los detentores del poder un deber de probidad cuyo desconocimiento llama la necesaria intervención de la represión penal para preservar "el buen funcionamiento de los servicios públicos, el respeto debido a los intereses patrimoniales del Estado y la confianza que el público debe normalmente manifestar para con los órganos administrativos: tantos bienes jurídicos de los que el Derecho criminal debe asegurar la protección" 481 .

\section{1-El normal funcionamiento de la Administración}

El planteamiento según el cual el normal funcionamiento de la Administración puede ser uno de los bienes jurídicos propuestos en el delito de corrupción, no es nuevo. Sin embargo, se nota que son los autores bastante modernos los que hacen referencia a ello. Su postura no ha sido profundizada, contrariamente a lo que hemos visto en la doctrina española ${ }^{482}$, aunque alguna similitud existe. En efecto, el normal funcionamiento de la Administración es siempre conectado con el deber de probidad que se le exige al agente público. Analiza DREYER que la violación del deber de probidad es una conducta incompatible con el ejercicio normal de la misión que se le ha asignado al funcionario. Añade que el delito de corrupción, junto con el tráfico de influencias, es capaz de minar el sistema tanto político como económico, lesionando el funcionamiento normal del Estado y del mercado ${ }^{483}$. En este mismo sentido se han pronunciado también LUCAS de LEYSSAC y MIHMAN, para quienes lo común entre la corrupción y el tráfico de influencias es que ambos tienden a asegurar el funcionamiento regular de la Administración Pública $^{484}$. En realidad, analizando la postura de esos autores, se puede observar que el normal funcionamiento de la Administración no es un bien jurídico inmediato del delito de corrupción, sino un bien jurídico categorial o grupal de varios tipos penales o también su ratio legis. Sostienen LUCAS de LEYSSAC y MIHMAN que respecto a la corrupción, alcanzar la finalidad del funcionamiento regular de la Administración Pú-

\footnotetext{
480 Lo ideal sería que al clasificar los delitos según el criterio del bien jurídico, a cada incriminación corresponde un bien jurídico único. Algo imposible para los delitos del libro IV y entre ellos el delito de corrupción constata LACAZE (M. LACAZE, Réflexions..., op. cit., pp.223).

${ }^{481}$ A. VITU, Traité..., op. cit., p.269.

482 I. OLAIZOLA NOGALES, El delito de cohecho, op. cit., p.111.

483 E. DREYER, Cours magistral..., op. cit., p.597.

484 M-P. LUCAS de LEYSSAC y A. MIHNAN, Droit pénal des affaires..., op. cit., no 1011. M. E. CARTIER y C. MAURO, La loi relative..., op. cit., p.744. Observan estos últimos autores que el interés protegido por el derecho interno y los convenios europeos es la buena administración pública.
} 


\section{PARTE I: APROXIMACIÓN AXIOLÓGICA Y ESTRUCTURAL...}

blica viene de la exigencia de que el corrompido tiene que ser un agente público lato sensu ${ }^{485}$.

Se puede observar, en primer lugar, que aludir al funcionamiento normal de la Administración como bien jurídico mediato o ratio legis es algo novedoso en los trabajos doctrinales. Lo destacan autores modernos en esta primera década del siglo XXI. La reforma penal del año 1994 trajo algo nuevo en el planteamiento del estudio de los delitos de corrupción y aunque la presentación del nuevo Código penal ha sido criticada, como ya se ha señalado, la influencia de los sistemas jurídicos vecinos ha tenido su impacto aunque sea en menor medida sobre los autores. En segundo lugar, el esfuerzo de dar un contenido objetivo a los delitos no ha sido del todo desarrollado. En efecto, la doctrina se queda arraigada dentro de la infracción de los deberes del funcionario, intentando utilizar un concepto objetivo pero con consideraciones subjetivas, lo cual destaca otra vez más el aspecto de sujeción especial de la Administración y sus agentes y poniendo en segundo plano la relación de ésta con los administrados.

\section{2-El deber de probidad o de integridad}

La mayoría de la doctrina defiende que el interés protegido en el delito es principalmente el deber de probidad. Se habla en este sentido de la moralización de la vida pública ${ }^{486}$, que consiste en sancionar penalmente la falta de lealtad de los agentes públicos abusando de sus cargos para enriquecerse indebidamente ${ }^{487}$. Explica VITU que es importante que los funcionarios ejerzan su cargo persiguiendo el interés de la colectividad pública: sería profundamente chocante e inmoral que al hacer mal uso de sus prerrogativas, buscaran sacar provecho personal del poder del cual son detentores. En otras palabras, se exige de ellos la estricta observación del deber de probidad en el ejercicio de sus funciones ${ }^{488}$. El contenido de este deber no ha sido precisado por la doctrina, sin embargo, se observa la connotación moral que vehicula el concepto. Indica AMBROISE-CASTÉROT que la probidad incluye valores como integridad, honestidad y rectitud ${ }^{489}$. En contra de esta postura moralista, DREYER defiende que la probidad de la que se trata aquí no debe ser confundida con la honestidad, incluso con la moral. Habrá que superar la definición que los moralistas dan de la probidad presentada como una virtud. Poniendo el concepto de probidad en el contexto del CPF, el au-

\footnotetext{
485 M-P. LUCAS de LEYSSAC y A. MIHNAN, Droit pénal des affaires..., op. cit., no 1011. 486 P. MAISTRE DU CHAMBON, A. LAPAGE y R. SALOMON, Droit pénal des affaires, Litec, 2008, pp.140 ; G. GIUDICELLI-DELAGE, Livre IV..., op. cit., p.505.

487 Ibídem, op. cit., p.144; P. BONFILS, Droit pénal des affaires..., p.127, afirma que es una evidencia constatar que la corrupción supone un desvío, un abuso, una perversión de una relación de autoridad independientemente del origen de la solicitación.

488 A. VITU, Traité..., op. cit., p.269 ; H. XIAO-YING, La lutte contre la corruption..., op. cit., p.71; J. LARGUIER, P.CONTE y A.-M LARGUIER, Droit pénal spécial, 14è éd., Dalloz, 2008, p.319; V. MALABAT, Droit pénal spécial, Hyper Cours Dalloz, 2007, (3è éd), p.527 ;

${ }^{489}$ C. AMBROISE-CASTÉROT, Droit pénal..., op. cit., p.329.
} 
tor señala que un deber de probidad se impone, precisamente, a toda persona que actúa para una autoridad y que parece encarnarla a los ojos del público. Destaca entonces que el propósito sería hacer respetar una doble relación de confianza: la lealtad de los agentes para con la autoridad y la confianza del público en esta autoridad para que ésta no se ponga en tela de juicio por las actuaciones de los que la encarnan ${ }^{490}$. Se habla entonces no de "obligación" sino de "deber" de probidad para subrayar que su fundamento no es contractual sino social: ese deber de probidad sólo corresponde a unos pero es oponible a todos, y es la razón por la cual la ley lo ha erigido en valor superior que debe ser puesto en marcha por algunos pero que todos deben respetar. Por otro lado, el incumplimiento de este deber puede acarrear una sanción por sí misma por lo que puede afectar al funcionamiento de la Administración, cuando ello, además, lleva al lucro de los agentes públicos, lamenta el autor que no hay agravación en la represión ya que representa una traición para con la autoridad y el público ${ }^{491}$. Para LUCAS de LEYSSAC y MIHMAN, aunque esta rúbrica "De los incumplimientos al deber de probidad" ${ }^{\prime 92}$ ha sido considerada anticuada o excesiva, encuentra su justificación en la medida en que el deber de probidad de los agentes públicos lato sensu, es un deber esencial de su función que garantiza la igualdad de tratamiento de los ciudadanos. Destacan estos autores que una razón por la que el legislador ha puesto en el mismo precepto los delitos de corrupción y de tráfico de influencias es porque son delitos de venalidad. Esta exigencia de venalidad tiene como consecuencia que estos delitos no pueden constituirse si les falta ésta. A razón de la venalidad que los caracteriza, ambos delitos son generadores de una ruptura de la igualdad de los ciudadanos ante el servicio público lato sensu: los hay quienes tienen los medios para corromper y no dudan en hacerlo y los que no los tienen o se niegan a hacerlo ${ }^{493}$.

\footnotetext{
490 M. DELMAS-MARTY y G. GIUDICELLI-DELAGE, Droit pénal des affaires, PUF, 2000, pp.237, 239, 286. Defienden la deficiencia de clasificar los delitos según sus valores de referencia porque estos valores son criterios insuficientemente precisos y que algunas infracciones pueden lesionar varios valores. La corrupción, por ejemplo, protegería al individuo a través de las nociones de propiedad y de confianza. Se aplica entonces aquí un Derecho penal de protección. De manera más concreta DELMAS-MARTY afirma que en la corrupción pública, la connivencia prohibida afecta un valor protegido específico que es la fe publica al abolir la confianza que hace posible el mecanismo de la representación y ello por medio de un incumplimiento grave al deber de probidad qui incumbe a uno de los protagonistas.

${ }^{491}$ E. DREYER, Cours magistral..., op. cit., pp.557, 558.

492 Es la sección 3a del capítulo II (Delitos contra la función pública cometidos por personas que desempeñen una función pública). Esta sección abarca cinco delitos: la concusión, la corrupción pasiva y el tráfico de influencias, el cobro ilegal de comisiones, la sustracción y la malversación de los bienes. Vid C. ARÁNGUEZ SÁNCHEZ y E. ALARCÓN NAVÍO, El código penal francés, op. cit., pp.205-208. Estos autores han traducido la rúbrica de la sección $3^{3}$ por "De la corrupción pública" lo que a nuestro parecer no respeta el intento del legislador francés de clasificar este grupo de delitos bajo un mismo bien jurídico.

${ }^{493}$ M-P. LUCAS de LEYSSAC y A. MIHNAN, Droit pénal des affaires..., op. cit., no 1004, 1005.
} 
Esta postura de la doctrina mayoritaria se explica en general por la clasificación dada por el legislador en la reforma del CPF. Esta vez el deber de probidad ha sido considerado de manera explícita como valor superior digno de protección penal y ha tenido la consagración de la jurisprudencia ${ }^{494}$. El problema que plantea tal clasificación es que el mismo bien jurídico se encuentra protegido por más de cuatro tipos, poniendo de esta manera complicada la tarea de delimitación de los aspectos del bien que cada tipo debe tutelar. Este tipo de deber se cifra en conceptos demasiado genéricos para ser de alguna utilidad en cuanto no permiten diferenciar los delitos de corrupción de otros delitos contra la Administración Pública ${ }^{495}$. Ya explicó CUGAT MAURI que este tipo de deber del cargo como objeto de protección en los "delitos de funcionarios", no cumple la importante función del límite al ius puniendi estatal que todo bien jurídico tiene atribuida ${ }^{496}$.

A pesar de los últimos intentos de dar un contenido material y objetivo al bien jurídico protegido, la doctrina francesa no se ha deshecho de un discurso subjetivista que no se considera adecuado a los principios constitucionales de dignidad humana y pluralismo político, en la medida en que se exige la adhesión interna y personal a los valores constitucionales. De modo que, a pesar de que en ocasiones el uso terminológico es irreflexivo o producto de la tradición y no implica ningún tipo de adhesión de ideologías de signo autoritario, ni incluso llega a repercutir en la interpretación de los elementos del delito, el recurso a la idea de lealtad, o fidelidad o traición al Estado sugiere una adhesión personal y se considera contraria a principios constitucionales ${ }^{497}$ que pregonan el respeto a la libertad de conciencias y la legalidad originada por las instituciones que encarnan la soberanía nacional ${ }^{498}$.

En el Derecho malgache, RAFOLISY deduce de las infracciones de los funcionarios y sobretodo de las infracciones de corrupción, que el interés jurídicamente protegido no puede ser otra cosa que la buena conducta de los funcionarios. En efecto, la Ley 2004-030 relativa a la lucha contra la corrupción afirma en su Exposición de Motivos que "la corrupción constituye en Madagascar un fenómeno social grave y preocupante que (...) lesiona peligrosamente la imagen de marca de los funcionarios del Estado". Para concretar, el autor indica que justamente en el caso de

\footnotetext{
${ }^{494}$ Nota WALTHER que a diferencia de los jueces alemanes que citan en sus sentencias a los autores que los inspiran, a los jueces franceses no les llegan los trabajos de la doctrina, por lo tanto el debate entre "la isla de la Ciudad y la Universidad" es difícilmente visible. Por otro lado, si es cierto que, en general, las sentencias de la jurisprudencia penal francesa no hacen referencia al interés protegido, en poquísimas ocasiones lo han hecho de manera clara. Ejemplos de ello son las sentencias: cass. crim. 1905-2003 y cass. crim. 20-05-2009 en las que el juez penal consideraba la corrupción como una lesión a los intereses de la administración por un acto contrario al deber de probidad (J. WALTHER, L'antijuridicité... op. cit., p.18).

${ }^{495}$ N. J. DE LA MATA BARRANCO, La respuesta..., op. cit., p.56.

${ }^{496}$ M. CUGAT MAURI, La desviación..., op. cit., pp.68 y 72.

${ }^{497}$ Ibídem, op. cit., p.69.

498 Vid. Artículos 2 y 3, CF.
} 
la corrupción propiamente dicha el valor protegido por el legislador es la integridad ${ }^{499}$. Sin embargo, lamenta que el legislador ha aplicado el principio de doble estándar en virtud del cual se pide a los agentes públicos un estándar de comportamiento más elevado, incluso muy exigente, en comparación al que se exige a los demás ciudadanos. Lo que se propuso el legislador al activar la reforma en 2004 era principalmente erigir la integridad en un principio general en vista de proteger un interés específico que es la vida pública, dejando fuera de la protección penal las relaciones sociales no directamente vinculadas con esa ${ }^{500}$. Efectivamente es la lógica represiva heredada del legislador napoleónico que consiste sólo en pronunciar expresamente contra la corrupción administrativa ${ }^{501}$.

Ante estas críticas sugiere RAFOLISY que lo que habría sido benéfico al proceder a las reformas en 2004 sería que el legislador se hubiera pronunciado abiertamente sobre la integridad como valor social que preservar por cualquier miembro de la sociedad, igual que la protección de la vida, la propiedad y otros valores fundamentales ${ }^{502}$. Al demostrar la

499 P. RAFOLISY, La protection juridique..., op. cit., p.71.

500 Ibídem, op. cit., p.331.

501 Ibídem, op. cit., p.332. Señala que es sólo al definir ampliamente la noción de corrupción por la enumeración de las infracciones que la componen como se puede dar cuenta que el legislador se ha preocupado un poco del sector privado. De esta constatación se puede deducir dos conclusiones: por un lado, el legislador no quería alejarse de la doctrina del doble estándar poniendo la protección apropiada en el sector público o, por otro lado, la cuestión no ha sido lo suficientemente debatida. Si es imposible tener respuesta sobra las intenciones reales del legislador en el momento de los trabajos preparatorios, el autor se inclinaría por la segunda conclusión. Se ha constatado en el calendario de adopción de la ley Anticorrupción que los parlamentarios han dedicado muy poco tiempo para debatir sobre la ley. Concluye y lamenta el autor que ni siquiera había un debate sobre la diferencia entre la corrupción en el sector privado y público y que en materia de gobierno en general no se conoce ni se acepta y ni, mucho menos, se adopta todavía la responsabilidad horizontal. Lo que lo lleva a la constatación de que el Parlamento constituye cámaras de ratificación donde el debate democrático, sobre todo técnico, es somero. Tampoco no hay que descartar el fenómeno de “¿Donde va Vicente? Donde va la gente” en cuanto a las tendencias normativas internacionales y metropolitanas sin tener el costumbre de confrontarlas con los valores sociales malgaches que preservar. Véase A. RAODINA, La production de la loi de politique publique, la loi 2004-030 sur la lutte contre la corruption à Madagascar, Mémoire Master 2 de Sciences politiques, études africaines, dir. R. BANÉGAS, Université Paris 1Panthéon Sorbonne, 2006, pp.51-56, 73, 74, anexo 4.1. Destaca este autor la incapacidad del Estado malgache en tener una política pública propia y convertirla en ley por falta de medios económicos. Las condiciones de "buen gobierno" en las ayudas públicas por las instituciones financieras internacionales favorecieron la producción de esta ley anticorrupción, la cual ha acarreado la problemática de una construcción exógena incapaz de encajar con los problemas reales del país. Esta construcción exógena engendra además la no adhesión incluso la incomprensión de la sociedad sobre lo que está verdaderamente en juego. La imposición de este tipo de construcción, concluye el autor, siembra dudas en cuanto a la eficacia de la estrategia actual de Madagascar contra la corrupción.

502 P. RAFOLISY, La protection juridique..., op. cit., p.331. Se ha demostrado, indica el autor, que la regresión de la integridad en la escala de valores sociales lleva fatalmente a la destrucción de la sociedad por medio del desarrollo de los fenómenos de co- 
inadecuación en la protección de la integridad, el autor concluye que todos los actores institucionales tanto en el sector público como en el sector privado, deben observar, respecto del Derecho penal las mismas reglas de comportamiento para proteger el valor integridad. Sería una lástima para la sociedad tolerar los incumplimientos por el simple hecho de la no pertenencia de sus autores al sector público. En materia de integridad, considerada como base del respeto de todos los valores protegidos, la igualdad de todos ante ella debería ser la regla ${ }^{503}$. Para lograrlo, el autor propone una modificación en la estructura del Código penal malgache (CPM) para expresar y hacer visible la promoción del valor integridad en la escala de los valores sociales penalmente protegidos a fin de que este valor tenga una posición privilegiada en esta misma escala. Por su carácter fundamental, más que la paz pública ${ }^{504}$, la integridad merecería en exclusividad un capítulo que agrupase al menos todas las infracciones contra ella ${ }^{505}$.

A nuestro parecer, el intento del autor de buscar un marco lógico para abarcar los delitos de corrupción bajo un mismo valor social es acertado. En efecto, el CPM necesita, no sólo en los delitos de funcionarios sino en otros ámbitos de las relaciones sociales, una nueva estructuración sobretodo respecto a la escala de valores para que tal escala se conforme a los principios constitucionales vigentes. Parece comprensible también el deseo del autor de promover el valor integridad y por ello, si se da por asumida la participación de las demás herramientas del ordenamiento jurídico, sería preferible, además, que el legislador elevase aquel valor en rango de bien jurídico penal. Sin embargo, la integridad, vista del lado del funcionario, interesa en la medida en que afecte al correcto desempeño de la función que le compete, sin que pueda argumentarse que la consumación de determinadas figuras no exija la realización material de acto alguno por el funcionario, pues tales previsiones, apunta OCTAVIO DE TOLEDO, no responden sino a la voluntad de adelantar las barreras de protección penal, pero sin que con ello deje de ser dicha realización la razón por la que se estimen punibles las conductas descritas ${ }^{506}$. Las alusiones específicas a la idea de integridad, señala DE LA MATA BARRANCO no impiden que se sustraiga al cohecho de esa caracterización que tradicionalmente se ha venido haciendo de todos los delitos cometidos en el ámbito de la actuación de los funcionarios públicos como delitos de infracción de un deber en los que el bien tutelado se cifra precisamente en el correcto y fiel desempeño de las funciones del cargo o en el quebrantamiento o dejación de los deberes que le son propios, en este caso, al funcionario y, en concreto, los de fideli-

rrupción, siendo estos últimos catalizadores de otros vicios que minan las bases de la vida en sociedad.

503 Ibídem, op. cit., p.333.

${ }^{504}$ El capítulo III que abarca la sección II sobre los crímenes y delitos de los funcionarios públicos en el ejercicio de sus funciones, se titula "Crímenes y delitos contre la paz pública"

505 P. RAFOLISY, La protection juridique..., op. cit., p.334.

506 E. OCTAVIO DE TOLEDO Y UBIETO, La prevaricación..., op. cit., p.147. 
dad, lealtad y probidad ${ }^{507}$. Son posturas que cifran el bien jurídico en conceptos demasiado genéricos para ser de alguna utilidad en cuanto no permite diferenciar los delitos de corrupción de otros delitos contra la Administración, además de la dificultad que ofrecen para presentar un objeto de tutela común a las diferentes figuras de cohecho (pasivo y también activo) ${ }^{508}$. Si es cierto que por el cargo que desempeña el funcionario tiene un deber profesional o un especial deber extra penal de integridad, tal deber no existe en la relación entre la Administración y el particular, con lo cual no puede mantenerse que el bien jurídico ofendido sea el mismo en el caso de que la conducta sea cometida por el funcionario o lo sea por el particular. Defiende VALEIJE ÁLVAREZ que es de rechazar buscar el bien jurídico del cohecho activo en el respeto que debe todo ciudadano a los órganos del Estado por el hecho de que estamos ante un deber de acatamiento o de obediencia del ciudadano para con el Estado. Afirmar que el particular al igual que el funcionario, tiene también un específico deber de lealtad o de fidelidad (a qué o a quién) se muestra incompatible con el principio constitucional de libertad. En efecto la configuración del injusto en la ausencia de lealtad y por qué no de integridad) del ciudadano sólo es de recibo en base a la previa admisión de un poder estatal absoluto, donde carece de sentido hablar de derechos subjetivos de los ciudadanos ${ }^{509}$.

Por lo tanto, no compartimos la tesis de RAFOLISY de cifrar el valor integridad como bien jurídico en todas las infracciones de corrupción. El contenido altamente moral e indeterminado de este valor no permite limitar el ius puniendi del Estado. Sería inaceptable respecto del principio del última ratio del Derecho penal la intervención de este último, ya que no toda infracción de los deberes funcionariales (entre ellos, el de integridad) es delictiva; de igual manera no toda falta de integridad de parte del ciudadano amenaza o pone en peligro la convivencia social. La idea de tener una protección penal igualitaria de la integridad y rechazar el principio del doble estándar puede seducir pero no es realista, puesto que el funcionario tiene una posición especial para con el correcto funcionamiento de la Administración. La falta de integridad del particular puede afectar a la Administración y poner en peligro su normal funcionamiento pero, de ninguna manera, puede ser equiparable a la del funcionario. Es comprensible que este valor pueda interesar en también el sector privado, que su generalización sería indispensable para la sociedad ${ }^{510}$ y que su promoción y protección favorecerían las posibilidades de acceso y participación de los ciudadanos en el disfrute de servicios o desarrollo de actividades que las instituciones del Estado deben garantizar ${ }^{511}$, pero justamente es su falta de concreción y su am-

\footnotetext{
507 N. J. DE LA MATA BARRANCO, La respuesta..., op. cit., p.55.

508I. VALEIJE ÁLVAREZ, “Consideraciones...", op. cit., p.328.

${ }^{509}$ Ibídem, op. cit., p.329.

510 P. RAFOLISY, La protection juridique..., op. cit., p.335

${ }^{511}$ A. ASUA BATARRITA, La tutela penal..., op. cit., p.20
} 
plitud 512 lo que impide que sea un objeto tutelado por el Derecho penal. No obstante, desde el punto de vista de los funcionarios, la infracción del deber de comportarse íntegramente, puede justificar, en todo caso, la imposición de una sanción administrativa al funcionario, pero en modo alguna elevarse a la categoría de bien jurídico. Admite VALEIJE ÁLVAREZ que la regulación de la responsabilidad funcionarial no es competencia ni exclusiva ni primaria del Derecho penal ${ }^{513}$ y concluye que en la concepción objetiva de este mismo Derecho, la violación del deber (entre otros, la integridad) sólo puede tener carta de naturaleza, no como fundamento de la responsabilidad, sino como ulterior requisito para determinar la culpabilidad del sujeto, pero siempre en unión a la ofensa de un bien jurídico ${ }^{514}$. Por lo tanto, indica CARLOS MIR PUIG que sería inaceptable la elevación de injustos disciplinarios a la categoría de injustos penales ${ }^{515}$. Si RAFOLISY preconiza la protección igualitaria del valor de integridad y rechaza la discriminación ad personam de una incriminación en materia de delito de corrupción, esta protección debe respetar el principio de igualdad tomando en cuenta las diferencias respecto del vinculo que cada sujeto tiene para con el valor integridad. Es posible concebir una protección jurídica igualitaria de este valor considerando las desigualdades entre los sujetos pero de ninguna manera esta protección pueda ser penal ${ }^{516}$. Se pueden imaginar entonces sanciones de otra rama del ordenamiento jurídico, sobretodo del Derecho administrativo, para ello.

\section{3- La imparcialidad}

El principio de imparcialidad como bien jurídico en el delito de corrupción en la doctrina francesa se encuentra únicamente en un sector minoritario. Ningún planteamiento especial de este principio se ha hecho en la doctrina malgache ${ }^{517}$. Pionera y defensora de la imparcialidad es CECCON, quien en su trabajo destaca su concepción democrática del

512 P. RAFOLISY, La protection juridique..., op. cit., p.337. Reconoce el autor que a la integridad le falta une definición más objetiva.

${ }^{513}$ I. VALEIJE ÁLVAREZ, “Consideraciones...”, op. cit., p.330. Aclara la autora que la exigencias "de la idoneidad del medio" y de la última ratio dirigidas hoy a la pena criminal -al instrumento del Derecho penal protector de bienes jurídicos- se enfrentan hoy en el ámbito de los delitos de funcionarios públicos a la prueba de que la tutela punitiva sea dispensada sin contradicción, sin duplicación y sin perturbación material y valorativo. El objeto de la tutela penal debe, por tanto, contribuir a una nítida distinción entre ambos sectores.

514 Ibídem, op. cit., p.368.

515 C. MIR PUIG, Los delitos..., op. cit., p.226.

516 La exposición de motivos de la ley 2004-030, sobre la lucha contra la corrupción, señala la integridad como uno de los principios generales de prevención de la corrupción. Lo que destaca que para el legislador el principio o el deber de integridad no tiene sentido sin que se le relacione con la vida pública al participar del normal funcionamiento de la administración y la imagen de los funcionarios.

517 P. RAFOLISY, La protection juridique..., op. cit., pp.241 y 264. Se refiere al principio de imparcialidad en otros delitos como el incumplimiento de declaración de conflicto de intereses (artículos 175 y 175.1 CPM) y en materia de favoritismo (artículo 175.2 CPM) al sugerir que la imparcialidad es uno de los valores fundamentales protegidos en estos tipos. 
interés jurídico protegido en el sentido de que la incriminación de la corrupción manifiesta la voluntad de preservar la cosa pública y el ejercicio de las funciones públicas. Para ello se hace hincapié sobre la protección del servicio público y el deber de imparcialidad de los agentes en el ejercicio de sus funciones ${ }^{518}$. Reconoce la autora que el interés protegido está siempre destinado, en materia de corrupción, a proteger la igualdad de los ciudadanos ante la potestad pública ${ }^{519}$ ya que el buen funcionamiento de la Administración está en peligro cada vez que el funcionario confunde los intereses públicos con su interés privado, lo cual, por lo tanto, erosiona la confianza de los ciudadanos en la Administración. Sin embargo, el criterio más amplio de la imparcialidad, según ella, da prueba de más pertinencia ya que presenta la ventaja de ser común a las diferentes formas de corrupción y aplicable a otros sujetos además de a los agentes públicos stricto sensu, que, aunque no tengan la calidad de funcionarios, intervienen en el sector público. Además, la imparcialidad se presenta igualmente como una garantía contra el arbitrario de la Administración y permite que la igualdad entre ciudadanos sea efectiva ${ }^{520}$.

Esta postura nos lleva a formular algunas observaciones. En primer lugar, el planteamiento no ha sido profundizado por la autora, quien resalta dos características esenciales de la imparcialidad: la garantía contra el arbitrario y el medio de alcanzar la igualdad de los ciudadanos, pero no deja de ser novedoso dentro de la doctrina francesa. En efecto, tanto el rechazo a la arbitrariedad como la igualdad, son valores reconocidos por el bloque de constitucionalidad francés ${ }^{521}$, y aunque este bloque no señala nada sobre el principio de imparcialidad, la configuración de la reforma penal desde una perspectiva constitucional permite defender y entender que la imparcialidad aquí referida, constituye un parámetro de valoración de toda la actividad administrativa, pero al mismo tiempo sirve como garantía para los ciudadanos de que las decisiones administrativas no van a ser influidas por intereses económicos o sociales o por cualquier otro tipo de preferencias o discriminación ajenas o contrarias a los intereses generales ${ }^{522}$. Esta postura supone un avance aunque puede pasar desapercibida. Es un paso adelante para dar un contenido más objetivo a los valores protegidos por el Derecho penal alejándose del subjetivismo basado en la conducta y la situación de uno de los sujetos del delito de corrupción. En segundo lugar, el origen de este planteamiento novedoso dentro de la doctrina francesa viene del estudio del Derecho comparado. La autora en su trabajo se ha inspirado de la doctrina y jurisprudencia italianas y alemanas ${ }^{523}$ para llegar a esta conclusión. Lo cual indica una cierta permeabilidad dentro

\footnotetext{
518 F. CECCON, Contribution..., op. cit., p.68.

${ }^{519}$ M-P. LUCAS de LEYSSAC y A. MIHNAN, Droit pénal des affaires..., op. cit., no 1004.

${ }^{520}$ F. CECCON, Contribution..., op. cit., p.69

${ }^{521}$ Apartado 18 del preámbulo de la CF de 1946 y preámbulo, artículos 1, 2 y 3 de la CF de 1958.

522 Mà. J. RODRÍGUEZ PUERTA, El delito de cohecho..., op. cit., p.70.

${ }^{523}$ F. CECCON, Contribution..., op. cit., pp.69, 70.
} 
del sistema por medio de los autores jóvenes y contemporáneos, resaltando así nuevas perspectivas y reflexiones que sólo pueden enriquecer las construcciones teóricas tanto en la parte general como en la parte especial del Derecho penal francés.

En tercer lugar, se puede observar que aun con el intento de objetivar el objeto de tutela en el delito de corrupción, el proceso no se ha llevado a cabo hasta el final. Todavía se quedan las huellas de la construcción basada en la infracción de los deberes del cargo respecto del funcionario en su relación especial con la Administración. En efecto, tanto la igualdad $^{524}$ como la imparcialidad son valores dentro del marco del deber de probidad o de los deberes inherentes al ejercicio del cargo público los cuales mantienen la confianza de los ciudadanos en la administración. CECCON reconoce que tradicionalmente, la incriminación manifiesta la voluntad de proteger la cosa pública y asegurar que los deberes vinculados con el ejercicio de funciones públicas sean respetados. Se ponía énfasis, indica la autora, en la protección del servicio público, respecto del prestigio que debe beneficiar y en el deber de imparcialidad, de lealtad o de fidelidad de los agentes públicos en el ejercicio de sus cargos. La autora no contradice en ninguna parte esta postura tradicional y ello encuentra su explicación en el movimiento de moralización de la vida pública 525 . Está claro que la imparcialidad se entiende como deber del cargo y no como principio objetivo, por tanto, tiene más un aspecto subjetivo que objetivo. Como deber del cargo, ésta concierne más al funcionario que a los que no tienen esta condición, con lo cual se ha contradicho la autora al presentar la imparcialidad como criterio más amplio y pertinente para abarcar las diferentes formas de corrupción. Es de preguntar, además, si es papel del Derecho penal moderno moralizar la vida pública. Eso nos lleva a aclarar la relación entre moral y Derecho penal. Suscribimos, con el pensamiento liberal y moderno, la idea de que el Derecho penal debe limitarse a tutelar el mínimum ético de una sociedad. En realidad lo que acontece es que en un sistema social pluralista como el que reclama la CF en sus artículos $1^{526}$ y 4527 , el problema de definir lo punible no tiene que ver con el orden moral. El fundamento del poder punitivo del Estado y de la definición de los delitos e imposición de penas debe encontrarse en la dañosidad social de las conductas caracterizadas legalmente como delito, en su condición de resultar de los intereses básicos de la sociedad y de los individuos. La renuncia a la instancia del orden moral para fundamentar el poder punitivo del Estado no quiere decir que el legislador o los ciudadanos renuncien a sus principios éticos, sino tan sólo que los principios éticos por sí solos no

${ }^{524}$ M-P. LUCAS de LEYSSAC y A. MIHNAN, Droit pénal des affaires..., op. cit., no 1004 ; F. CECCON, Contribution..., op. cit., p.69.

525 F. CECCON, Contribution..., op. cit., p.68.

526 Artículo $1 \mathrm{CF}$ "Francia es una república indivisible, laica, democrática y social. Garantiza la igualdad ante la ley de todos los ciudadanos sin distinción por razones de su origen, raza o religión. Respeta todas las creencias."

${ }^{527}$ Artículo 4 CF "Los partidos y las corporaciones políticas concurren a las elecciones. Se forman y ejercen su actividad libremente. Deben respetar los principios de la soberanía nacional y de la democracia." 


\section{CAPÍTULO II: EL BIEN JURÍDICO PROTEGIDO}

deben ser impuestos coercitivamente a todos los individuos y grupos sociales $^{528}$.

En el Derecho malgache el principio de imparcialidad se puede defender como objeto tutelado en el delito de corrupción. Este principio significa que la actividad administrativa no debería permitir la influencia de intereses como, por ejemplo, el lucro económico privado que puede operar no sólo en beneficio personal del funcionario, sino también en beneficio de un grupo de clase. Al mismo tiempo, este principio ha servido como clave para la interpretación de las relaciones entre Administración y Gobierno. La declaración constitucional en su artículo 39 refuerza la idea de servicio a los intereses generales y no al Gobierno. De esta forma garantiza "la neutralidad política de la Administración" que determina una forma típica de actuar, un "talante" que la Administración y los funcionarios deben tener en cuenta en el ejercicio de sus funciones para la consecución de sus fines ${ }^{529}$. La misma declaración constitucional aclara de manera explícita lo que pretende proteger y evitar que se ocurra: el despilfarro y la malversación de los fondos públicos para fines personales o políticos. La neutralidad no es incompatible con los principios de eficiencia y de legalidad. Sin embargo la eficiencia que implica no sólo que la medida tomada por la Administración consiga sus fines sino que se aplique el medio más idóneo al fin concreto y al menor coste, puede ser desviada por razón de una valoración de beneficios y costes de la decisión alejándose de la defensa de determinados intereses públicos ${ }^{530}$. En cuanto a la legalidad, este principio puede correr peligro con la discrecionalidad que habilita la ley a ciertas decisiones administrativas ${ }^{531}$. A nuestro parecer, el principio de imparcialidad tal

528 I. BERDUGO DE LA TORRE y otros, Curso de Derecho Penal, op. cit., pp.3-5. Añaden los autores que esta proclamación de independencia respectiva del Derecho y la moral responde, en las circunstancias de nuestro momento histórico, a las exigencias de una sociedad pluralista y abierta como la que hemos tomado como punto de partida, y es consecuencia directa del proceso encaminado a dar explicaciones racionales a los puntos fundamentales del Derecho penal. Los fines a afrontar por un Estado social y democrática (igual que la república francesa, artículo $1 \mathrm{CF}$ ) se orientan a posibilitar el alcance de un modelo de sociedad libre e igualitaria; solo en función de esta meta ha de ser considerado el Derecho en general y el derecho penal en particular. Es decir, el Derecho penal ha de afrontar como misión el hacer posible la vida en comunidad teniendo presente sólo la dañosidad social de las conductas que se quieren evitar $\mathrm{y}$, de este modo, asegurar el funcionamiento y desarrollo del sistema social. El que al materializar tal función se coincida con planteamientos que corresponden a un orden ético ha de ser interpretado como coincidencia, no como fundamento. Y concluyen que las relaciones del Derecho penal con la ética en una sociedad pluralista y democrática consisten, por tanto, no en tutelar las valoraciones éticas mayoritarias, sino, por el contrario, en mantener las condiciones que posibiliten la existencia de un marco social dentro del cual tengan cabida una pluralidad de órdenes éticos. De donde las valoraciones morales existentes en una sociedad pueden llegar a constituir un principio crítico para la determinación de la validez del ordenamiento jurídico penal, pero en ningún caso pueden ser utilizadas como fundamentación del mismo.

529 F. GARRIDO FALLA, L. M. CAZORLA, R. ETRENA y otros, Comentarios..., op. cit., p. 1425

530 M. CUGAT MAURI, La desviación..., op. cit., pp.91, 94, 95.

${ }^{531}$ Ibídem, op. cit., p.93. Indica la autora que queriendo, el abuso del Derecho se puede conseguir tanto con recurso a leyes discrecionales como a las leyes absolutamente 
como lo destaca la Constitución malgache (CM) no debe ser considerado como uno de los deberes de los funcionarios públicos en el ejercicio de su cargo como lo hace CECCON 532 , ni tampoco como uno de los valores que pueden componer y proteger la integridad, como lo hace RAFOLISY533. Por lo tanto, y haciendo nuestra la postura de RODRÍGUEZ PUERTA, lo que propiamente se configura como objeto de tutela es el respeto al principio de imparcialidad, que vincula de un lado a los poderes públicos, en cuanto principio alumbrador del ejercicio de la actividad administrativa y judicial, y, circunscrita a la desviación del fin, a la actividad legislativa o política ${ }^{534}$. El referido principio es proyectable también a los ciudadanos, en cuanto destinatarios de esa actividad pública, dado que la relación con estos últimos viene también limita por el respeto a la Constitución y los principios en ella consagrados (Preámbulo de la $\mathrm{CM}^{535}$ ). Por otra parte, lo anterior no debe significar que la afección al bien jurídico merezca idéntica valoración en uno y otro caso, ya que la imparcialidad sólo puede predicarse de aquellos que deben y pueden adoptar una decisión ${ }^{536}$. Aunque como principio de funcionamiento propio de una institución su respeto se hace extensivo no sólo a aquellos que forman parte de ella sino también a los entablan cualquier de relación con ella o sus miembros ${ }^{537}$.

estrictas en la descripción de sus presupuestos y consecuencias. Más aún, la rigidez normativa ha llegado a considerarse un factor de corrupción, en la medida en que una legislación absurdamente hipertrofiada puede llevar a su general deslegitimación y su aplicación selectiva y arbitraria como instrumento de poder (de aplicación o no aplicación). En definitiva pues, aunque determinadas técnicas legales, como la habilitación legal a la discrecionalidad administrativa pueden encubrir más facciones arbitrarias, el abuso de la ley depende en definitiva de la conducta arbitraria del sujeto encargado de su aplicación. Lo que se prohíbe es la arbitrariedad, no la discrecionalidad.

532F. CECCON, Contribution..., op. cit., p.68.

${ }^{533}$ P. RAFOLISY, La protection juridique..., op. cit., pp.241 y 264

${ }^{534} \mathrm{M}^{\mathrm{a}}$. J. RODRÍGUEZ PUERTA, El delito de cohecho..., op. cit., pp.80-83. La autora verifica si el principio de imparcialidad puede predicarse de todas y cada una de las funciones públicas, administrar, juzgar y legislar. Si las primeras dos no plantean dificultad, el problema se suscita respecto a las funcionas propias del poder legislativo cuya actividad es política y parcial. La intervención penal, en el ámbito político por medio de los Tribunales tan sólo puede alcanzar -de forma-limitad el control de la adecuación entre la decisión y el fin que la motivó, pero nunca su oportunidad.

535 El preámbulo de la CM considera que "el desarrollo de la personalidad y de la identidad de todo Malagasy es el factor esencial del desarrollo duradero e integrado cuyas condiciones son: (...), la instauración del Estado de derecho en virtud del cual los gobernantes y los gobernados están sometidos a las mismas normas jurídicas, bajo el control de una Justicia independiente".

${ }^{536}$ M. CUGAT MAURI, La desviación..., op. cit., p.99. Compara la autora la objetividad y la imparcialidad (art.103 CE) e indica que el principio de objetividad hace referencia a la actuación en general de la Administración pública, mientras que el de imparcialidad alude más en concreto a garantías en la actuación de los funcionarios públicos. Si bien ambos principios están relacionados por su oposición a la subjetividad o politicidad, la imparcialidad mantiene vínculo directo con la conducta personal. En este sentido la imparcialidad se puede considerar como la condición personal de cumplimiento de la objetividad. Por este motivo, aunque la corrección de la función pública dependa del respeto de los dos principios, el segundo es el más adecuado para integrar un concepto jurídico penal como el de bien jurídico en base al principio de personalidad del Derecho penal.

${ }^{537} \mathrm{M}^{\mathrm{a}}$. J. RODRÍGUEZ PUERTA, El delito de cohecho..., op. cit., p.83 


\section{B- LA TENDENCIA HACIA UNA CONCEPCIÓN ECONOMISTA DEL INTERÉS JURÍDICO PROTEGIDO}

Tanto en la doctrina francesa como en la malgache, se entiende que la incriminación de la corrupción no pretende simplemente proteger el funcionamiento de los servicios públicos, sino también hacer que las relaciones entre individuos sobre todo las comerciales favorezcan el sistema económico.

\section{tor privado}

\section{1-Cambio de enfoque: del sector público hacia el sec-}

No se trata aquí de estudiar el objeto tutelado en los diferentes tipos de corrupción en el sector privado, sino de destacar que existe un trasfondo común que vincula la corrupción pública y la privada. Este trasfondo puede convertirse en objeto tutelado si su afectación puede causar una lesión grave para la sociedad o un daño social que impide el desarrollo del individuo y su participación en la vida de la comunidad. La nueva $\mathrm{CM}$ en su preámbulo considera sin ambigüedad que "el desarrollo de la personalidad y de la identidad de todo Malagasy es el factor esencial del desarrollo duradero e integrado cuyas condiciones son, particularmente: (...) la eliminación de toda forma de injusticia, de corrupción, de desigualdad y de discriminación". Este trasfondo común puede ser el desarrollo duradero considerado no como un fin en sí sino proceso dinámico, según RAFOLISY, y cuya significación de durabilidad sería la continuidad a través del tiempo y ello en un contexto que asocia intereses económicos, ecológicos y sociales ${ }^{538}$. El problema se sitúa en el hecho de que las relaciones económicas entre particulares pueden comprometer el proceso hacia el desarrollo duradero. Y por este motivo, RAFOLISY, pidiendo la eliminación del principio de doble estándar en la formulación de las incriminaciones de corrupción, defiende que algunas conductas cometidas en el sector privado perjudican intereses privados (los de los accionistas, socios de empresas, etc.) y que una respuesta penal debería imponerse a parte de las sanciones disciplinarias. Con la necesidad de una protección igualitaria de la integridad, la lesión de esos intereses privados se repercute también sobre los elementos del desarrollo duradero. La finalidad de toda empresa es contribuir, por lo menos, al crecimiento económico de su entorno y sin la cual está condenada al fracaso ${ }^{539}$. Por su parte, CECCON explica que el interés jurídico protegido deja de ser exclusivamente público cuando el sector privado se vuelve idóneo a la protección penal. Pero semejante extensión de la incriminación de corrupción al sector privado parece ser más reveladora de la conciencia de la necesidad para el sector privado de estar sometido a la protección del Derecho penal y de la influencia del sistemismo económico que la de la igual protección de los sectores privado y público de ser lesionados por la corrupción. En la actualidad, revela la misma autora, la misma incriminación de corrupción concierne todas

538 P. RAFOLISY, La protection juridique..., op. cit., p.11

${ }^{539}$ Ibídem, op. cit., pp.335, 336. 
las relaciones en las que es necesario hacer respetar cierta equidad entre socios, es decir, las relaciones comerciales. Pero la ampliación del interés jurídico no se limita a las relaciones comerciales nacionales, se extiende más allá de los intereses estrictamente nacionales. La ampliación del campo del interés jurídico protegido al sector privado encuentra una extensión en la incriminación de la corrupción de los agentes públicos extranjeros o internacionales en el marco de las actividades comerciales internacionales, en aplicación del Convenio de la OCDE, cuando esta corrupción apunta a la obtención de un mercado u otra ventaja indebida ${ }^{540}$. En este punto se ha pronunciado la doctrina española desde otro enfoque, como FABIÁN CAPARRÓS, al comentar sobre la corrupción dicha privada, quien entiende que la consolidación como delito del uso desviado del poder de decisión en el ámbito de las relaciones económicas entre particulares, ha sido defendida desde diferentes sectores, no fundándose tanto en argumentos basados en la lesividad de la conducta o en la necesidad subsidiaria de criminalizar, como en las dificultades que a veces se manifiestan para distinguir lo público de lo particular, sino en la indisoluble correspondencia que existe entre ambos ámbitos de la vida social. De hecho, se ha destacado que, en el marco de la progresiva internacionalización económica a la que asistimos, el soborno de los funcionarios extranjeros puede ser medio para facilitar un negocio entre empresas privadas de diferentes países ${ }^{541}$. Sin embargo, considera el mismo autor que la entrada del Derecho penal en este ámbito se aleja de los principios limitadores que deben caracterizar la política criminal de ordenamientos constitucionales como el español. Conductas como éstas, por ilícitas y lesivas que sean, no justifican la entrada en juego del ius puniendi, que se extendería peligrosamente sobre un área cuya tutela debe estar esencialmente encomendada a otras instancias jurídicas de control ${ }^{542}$.

\section{2-Protección de la economía de mercado}

A través de la protección otorgada a las relaciones privadas y comerciales, se pretende proteger un interés puramente económico. Según CECCON, dentro de los sistemas jurídicos que han recibido la influencia de los instrumentos internacionales, el interés jurídico protegido participa

\footnotetext{
${ }^{540}$ F. CECCON, Contribution..., op. cit., pp.72, 73.

${ }^{541}$ E. A. FABIÁN CAPARRÓS, La corrupción..., op. cit., p.25.

542 Ibídem, op. cit., p.26. Añade el autor que, valorada la cuestión desde el prisma de los contenidos, no parece correcto someter estas conductas a la misma denominación asignada a ciertos delitos contra la Administración pública, con los que nada tienen que ver, y siempre sin perjuicio de que constituyan alguna otra clase de conducta delictiva basada en un lesividad diferente (ya lo hemos comentado que en el Código penal malgache ha puesto en el mismo apartado todas las incriminaciones de corrupción sin hacer ninguna distinción en su clasificación). No cree el autor que el legislador cuya actividad debería estar guiada por el rigor técnico- deba dejarse arrastrar por la inflación semántica, creando cierta confusión al emplear el mismo vocabulario para definir fenómenos muy diversos entre sí. Aunque estamos de acuerdo con el autor, no podemos más que lamentar la situación del legislador malgache en el momento del proceso de la elaboración de la ley 2004-030. Véase A. RAODINA, La production..., op. cit., pp.69-74; M. CUGAT MAURI, La desviación..., op. cit., pp.91, 92.
} 
de una concepción más liberal y menos democrática. El interés que se quiere tutelar al incriminar los actos de corrupción cometidos para la obtención o la conservación de un contrato o de toda otra ventaja en el marco de las actividades económicas, es la libre competencia ${ }^{543}$. En este sentido se han pronunciado LUCAS de LEYSSAC y MIHMAN, para quienes la corrupción no sólo desestabiliza el Estado de Derecho, sino que también falsea la libre competencia en las operaciones de negocios ${ }^{544}$. En palabras de DREYER, la corrupción mina el sistema tanto político como económico, al lesionar el funcionamiento normal del Estado y del mercado. Por lo tanto no es sólo el funcionamiento regular de la Administración el que está amenazado sino también el libre juego de la competencia ${ }^{545}$. Esta tendencia de la doctrina francesa se puede explicar por le hecho que ya en los trabajos parlamentarios sobre esta parte del CPF, subraya GIUDICELLI-DELAGE, que había que conciliar la necesaria moralización de la función pública y las realidades económicas. El Gobierno deseaba sobretodo moralizar mientras que el Parlamento era más sensible a las realidades económicas ${ }^{546}$.

Además, señala CECCON, hay divergencias según si el interés a proteger es el de la empresa o del mercado. Si se opta por el primer caso, se pone énfasis en la relación de confianza que debe existir en el seno de la empresa. Cuando se trata de proteger el mercado que debe beneficiar de una competencia leal y efectiva, y también de un desarrollo libre y armonioso de la economía liberal, entonces se pone énfasis en el deber de lealtad en los negocios. Sin embargo, esta distinción merece ser minimizada, ya que sólo se trata de diferencia de grado, de "maduración", entre los intereses jurídicos protegidos ${ }^{547}$. Ya hemos señalado que la nueva CM declara explícitamente, en su preámbulo, su adhesión al concepto de desarrollo duradero cuyo factor para alcanzarlo sería el desarrollo de la personalidad y de la identidad de todo Malagasy. Los elementos económicos de este concepto nos llevan a decir que los redactores de la nueva Ley Fundamental, han entendido que al referirse al desarrollo duradero se alude, entre otras cosas, al desarrollo económico. Por lo tanto, de manera clara han declarado que la corrupción debe ser eliminada en todas sus formas. Estamos en presencia de un valor reconocido constitucionalmente que debe ser destacado como digno de protección del conjunto del ordenamiento jurídico, entre ello la rama penal, aunque, como lo indica RAFOLISY, el legislador del 2004 se ha centrado más en la protección de la función pública que en el prejuicio que puede causar la corrupción en el sector privado hacia el desarrollo económi$\mathrm{co}^{548}$.

${ }^{543}$ F. CECCON, Contribution..., op. cit., p.74 ; M. E. CARTIER y C. MAURO, La loi relative..., op. cit., p.744 ;

${ }^{544}$ M-P. LUCAS de LEYSSAC y A. MIHNAN, Droit pénal des affaires..., op. cit., no1005.

545 E. DREYER, Cours magistral..., op. cit., pp.597, 598 ; H. XIAO-YING, La lutte contre la corruption..., op. cit., p.305.

546 G. GIUDICELLI-DELAGE, Livre IV..., op. cit., p.505.

547 F. CECCON, Contribution ..., op. cit., p.74.

548 P. RAFOLISY, La protection juridique..., op. cit., pp.71, 335 y 336. En efecto, el autor no plantea una argumentación desde una perspectiva constitucional sino que conside- 
Para concluir este apartado, notamos la coexistencia entre diversos intereses jurídicos protegidos en el delito de corrupción. Lo cual afirma otra vez más el carácter pluriofensivo del delito en estudio. Estos intereses jurídicos no se excluyen, al contrario, coexisten. Según CECCON, semejante conciliación de intereses jurídicos - uno apunta a la protección del mercado, otro se enmarca en la defensa de los derechos humanos - demuestra la necesaria unión entre respeto de las reglas democráticas y adopción de medidas eficaces en la lucha contra la corrupción. La autorregulación resultante de la apertura a las reglas del mercado es ilusoria, y el fenómeno de la corrupción debe ser combatido, no a coste de una guerra sin piedad, sino en el respeto de los principios democráticos. Eso pide la edificación de una verdadera estrategia que considere la defensa del mercado, pero también la del Estado de Derecho. Por lo tanto, es necesario velar por la coexistencia de los intereses jurídicos puesto que eso constituye la garantía de la armonía entre democracia y economía ${ }^{549}$. La conexión y la interdependencia tanto del sector público y privado, como del ámbito nacional e internacional, hacen que el campo de protección del delito de corrupción no pueda más que ampliarse, con la condición de que esta extensión respete los principios del Estado democrático y de Derecho. Dicho esto, el presente trabajo se centrará en la vertiente del bien jurídico que protege la función pública ya que ésta es la que más ha privilegiado el legislador y que, a nuestro parecer, goza de más interés tanto teórico como práctico desde la perspectiva del Derecho comparado.

ra que la integridad ha sido excesivamente considerada en la tipificación de los delitos cuya finalidad es la protección penal de la función pública, dejando en un segundo plano el sector privado. Entiende el autor que el crecimiento económico en general es producto de la participación de todas las empresas en un entorno económico en el que la competencia es equitativa.

${ }^{549}$ F. CECCON, Contribution..., op. cit., pp.75 y 76. Observa la autora que los derechos nacionales cumplen de manera efectiva la exigencia de la diversificación de la política criminal en materia de lucha contra la corrupción. La coexistencia entre por un lado la protección de los principios democráticos y del Estado de derecho, y por otro lado, la protección del mercado, ha sido aceptada y adoptados por muchos sistemas jurídicos. Sin embargo, la hegemonía del sistema económico peligra este frágil equilibrio, ya que las normas internacionales ya han sucumbido. Véase. E. A. FABIÁN CAPARRÓS, La corrupción..., op. cit., pp.79-81. El autor explica que el artículo 445 bis del CPE es una figura socio socioeconómica que tiende a proteger la posición de los competidores frente a quienes se valen de la corrupción para abusar de una posición dominante en el ámbito internacional. Por lo tanto, se trata de una realidad nueva que va más allá de los intereses meramente domésticos. 


\section{CAPÍTULO III: LA ESTRUCTURA DE LOS TIPOS DE COHECHO Y DE CORRUPCIÓN PASIVA}

La estructura del delito de corrupción recibe un enfoque diferente en el Derecho francés y malgache, de una parte, y el Derecho penal español de otra parte. Conviene recordar la importancia de estudiar la estructura de un tipo. De acuerdo con RODRÍGUEZ PUERTA, resulta evidente que el legislador no decide de forma arbitraria la estructura que van a adoptar los distintos delitos, sino que toma en consideración para ello, entre otras cuestiones, la naturaleza del bien jurídico a tutelar y el alcance que pretende otorgar a dicha tutela ${ }^{1}$. Si la doctrina española, al analizar la técnica utilizada por el legislador hace hincapié en los sujetos que participan del delito en estudio, la doctrina francesa destaca además las modalidades de la acción.

\section{Sección 1-Naturaleza jurídica del delito de cohecho según el número de sujetos partici- pantes}

\section{I-El delito de cohecho como delito bilateral}

Es la concepción tradicional que se defendió por la doctrina y la jurisprudencia española hasta el Código penal de 1928. La doctrina de aquel momento era unánime al considerar necesaria la presencia de al menos dos personas para que cupiera la posibilidad de aplicar el delito. Es importante tener en cuenta que, hasta el Código penal de 1944 la conducta típica consistía en la recepción o aceptación por parte del funcionario de dádivas, presentes, ofrecimientos o promesas presentadas por el particular. Se entendía el delito de cohecho como una compra-venta de un acto oficial por parte del funcionario, como un contrato sinalagmático, en el que era imprescindible por tanto la presencia de dos partes ${ }^{2}$. GROIZARD señalaba que el cohecho pertenece al género de los delitos para cuya perpetración se exige la concurrencia, por lo menos, de dos personas, siendo necesario para que un funcionario sea corrompido, que haya quien procure su corrupción, encontrándonos ante un delito

\footnotetext{
${ }^{1}$ Ma. J. RODRÍGUEZ PUERTA, El delito de cohecho..., op. cit., p.99.

2 T. M. VIZMANOS y C. ÁLVAREZ MARTINÉZ, Comentarios al código penal, Tomo II, Madrid, 1848, p.293, defendían que la prevaricación es un delito que comete el juez o el empleado sin la necesidad de otras personas, mientras que el cohecho han de ser necesariamente dos delincuentes: el que da o propone dar y el que recibe o acepta la promesa. El corruptor y el que se deja corromper; J. F. PACHECO, El código penal concordado y comentado, Tomo II, Madrid, 1848, pp.497 y ss.
} 


\section{PARTE I: APROXIMACIÓN AXIOLÓGICA Y ESTRUCTURAL...}

que no existiría sin la excitación ajena a faltar a los deberes funcionariales por estímulo de lucro ${ }^{3}$.

En 1928 comienzan en España las primeras discrepancias en este tema y empieza a aceptarse, siguiendo la doctrina jurisprudencial, la posibilidad de que la iniciativa partiera del funcionario. No obstante se sigue observando como imprescindible el convenio, el acuerdo entre ambas partes y por lo tanto el carácter bilateral del delito. Sin embargo desde el punto de vista de la corrupción activa, se tipifica como delito consumado el intento de corrupción por parte del sobornante. Ello supone no sólo un importante adelantamiento de las barreras de protección penal, sino que además es la primera vez que se regula clara y expresamente como conducta típica una actuación unilateral ${ }^{4}$. Esta conducta desaparece de nuevo en el Código penal de 1932 que supone una vuelta total al Código penal de $1870^{5}$.

La doctrina francesa considera esta concepción bilateral del delito de cohecho como el aspecto liberal de la corrupción ${ }^{6}$. Nota VITU que en este aspecto hace falta el acuerdo del corruptor y del corrompido para llevar a cabo la corrupción: el punto esencial de la infracción sería el "contrato" ilícito, por el cual se vende el acto de la función. Desde este punto de vista, se puede discrepar en cuanto a las consecuencias prácticas. En primer lugar, se puede considerar que en esta colaboración delictiva, el culpable principal es el corrompido que viola los deberes de probidad, de fidelidad y de imparcialidad que le impone su cargo: el corrompido es, entonces, el autor principal de la infracción; el corruptor, extraño a la función, un cómplice. Señala el mismo autor que en Derecho penal francés, esta concepción presentaría un defecto grave nacido del principio de la complicidad-criminalidad ficticia: el corruptor que intentaría sin éxito comprar a un funcionario escaparía de la represión ya que la tentativa de complicidad es impune; además, se podría dudar si se puede reprimir al cómplice del corruptor porque el problema es controvertido, en Francia, en cuanto a la represión de la complicidad de complicidad. Para evitar estos problemas, se podría decir que el corruptor y el corrompido son coautores de la infracción: ésta sería plenamente consumada en cuanto haya acuerdo formado entre los sujetos, y sólo habría

\footnotetext{
3 A. GROIZARD Y GÓMEZ DE LA SERNA, El código penal de 1870..., op. cit., p.251; J. F. PACHECO, El código penal..., op. cit., p.502. Este autor subraya que verdaderamente si no hubiese sobornantes, nunca tendríamos caso de soborno.

${ }^{4}$ Artículo 473, 1ํ CPE de 1928: "El que con dádivas, presentes, ofrecimientos o promesas, intentare corromper a un funcionario público, será castigado con las mismas penas, menos la de inhabilitación que, en el caso de que el funcionario de que se trate aceptare el soborno, corresponderían a éste."

5 I. OLAIZOLA NOGALES, El delito de cohecho, op. cit., pp.216, 217.

${ }^{6}$ R. GARRAUD, Traité théorique et pratique du droit pénal français, Tome III, Larose et Forcel, Paris, 1889, p.383. El autor llamaba esta concepción de «infracción compleja » por lo que supone el concurso necesario de dos personas, culpables y punibles de igual manera. El corruptor sería coautor o cómplice, con el funcionario corrompido, de una única y misma infracción, y habría solamente tentativa de corrupción, si la oferta no había sido aceptada o si las dádivas o presentes no habían sido recibidos.
} 
tentativa cuando la oferta, hecha por uno al otro, no diera resultado7. Sin embargo, este sistema erra en la asimilación del corruptor al corrompido, aunque el segundo es ciertamente más culpable que el primero, ya que trafica con su cargo y viola los deberes impuestos a él por ello ${ }^{8}$. Este planteamiento había sido defendido por RAUTER, bajo el CPF revisado en 1832, quien concluía que el corruptor y el corrompido eran cómplices en el delito de corrupción, razón por la cual el legislador preveía la misma pena para ambos. Además, defendía el mismo autor, si se estipulaba la confiscación de las dádivas y presentes, objeto del acuerdo de corrupción era porque la ley declaraba el corruptor como cómplice y era natural que la confiscación afectara el objeto en cuestión, porque éste se debía a un cuerpo de delito común entre el corruptor y el corrompido 9 .

El Derecho penal colonial de Madagascar heredó esa corriente ya del Derecho penal francés de aquel momento, es decir, de las revisiones y reformas del CPF hasta194510 que ya consideró ambos delitos como autónomos, sin embargo, nota RAFOLISY que la presencia de más de un protagonista sigue siendo todavía un criterio útil dado que un acto preparatorio que pone en condición la comisión del delito de corrupción no podría ser calificado de fenómenos corruptivos ${ }^{11}$.

\section{II-El delito de cohecho como delito unilateral}

En España tras la reforma de 1944, por la que el delito de cohecho sufre unos pequeños cambios en su fórmula típica, un sector de la doctrina penal española empieza a cuestionarse la validez de las denominaciones de cohecho pasivo y activo. La razón obedece, según VALEIJE ÁLVAREZ, a que a partir de la aludida reforma del CPE, las anteriores denominaciones carecen de apoyatura legal, por cuanto mediante ella se parifica en orden a la penalidad en el cohecho pasivo propio a la conducta del funcionario público que recibe o acepta dádivas la del que las solicita, y en el cohecho activo a la conducta del particular que corrompe al funcionario la del que "intenta corromper" o "acepta sus solicitudes". Lo que implica que al elevar a conductas típicas tanto la solicitud del funcionario como la oferta del particular, desaparece la exigencia del acuerdo o convenio entre ambos sujetos para que se perfeccione el delito. Otra consecuencia de esta reforma, se halla en el debate doctrinal. Surge en un sector de la ciencia penal española el debate sobre la naturaleza jurídica del cohecho, dividiéndose las opiniones entre quienes aprecian la existencia de dos delitos independientes, esto es, el cometido por el funcionario y el cometido por el particular, y entre quienes, por el contrario, aprecian la existencia de un solo delito de carácter bila-

\footnotetext{
7 Ibídem, op. cit., p.385.

${ }^{8}$ A. VITU, Traité..., op. cit., pp.284, 285.

${ }^{9}$ M. RAUTER, Traité théorique et pratique du droit criminel français ou Cours de législation criminelle, Tome I, Charles Hingray, Paris, 1836, pp.492 y 493.

${ }^{10}$ A. VITU, Traité..., op. cit., p.285.

${ }^{11}$ P. RAFOLISY, La protection juridique..., op. cit., p.170.
} 
teral12. En el marco de esta reforma, los defensores de la bilateralidad del cohecho insisten en que no es obstáculo alguno a tal respecto que la conducta de cada uno sea castigada en artículos separados e independientes entre sí. Además entienden que estas conductas unilaterales, como son la solicitud en el cohecho pasivo y el intento de corrupción en el cohecho activo, son equiparables a la corrupción a los únicos efectos de penalidad, sin que ello sea óbice para seguir considerando el convenio entre ambas partes como la esencia del delito de cohecho ${ }^{13}$.

Sin embargo, en la actualidad, frente a esta postura tradicional, la doctrina y la jurisprudencia ${ }^{14}$ más modernas se muestran mayoritariamente partidaria del carácter unilateral del delito de cohecho, y considera al cohecho activo y pasivo como delitos autónomos e independientes. No faltan los argumentos para defender esta postura. En primer lugar, se ha sostenido que el cohecho pasivo y el cohecho activo quebrantan bienes jurídicos distintos. Mientras que el cohecho pasivo es un delito contra la integridad en la gestión administrativa, el delito de cohecho activo es un delito contra el respeto que se debe al normal funcionamiento de los órganos del Estado ${ }^{15}$. Otro sector de la doctrina, a pesar de considerar que el cohecho activo y el cohecho pasivo protegen el mismo bien jurídico, abogan por su naturaleza de delitos independientes y autónomos debido a la especial posición del funcionario respecto de la Administración ${ }^{16}$. En segundo lugar, si son dos delitos independientes entre sí, su consumación respectiva no sólo puede producirse separadamente en ambos tipos sino también no exige el convenio entre funcionario y particular ${ }^{17}$. En este sentido se ha cambiado la opinión de la jurisprudencia, la cual ha dejado de considerar necesario el pacto entre las partes ${ }^{18}$. En tercer lugar se puesto de manifiesto que la modalidad típica de

12 I. VALEIJE ÁLVAREZ, El tratamiento..., op. cit., pp.38, 39; I. OLAIZOLA NOGALES, El delito de cohecho, op. cit., p. 217

13 T. JASO ROLDÁN, en J. ANTÓN ONECA, J. A. RODRÍGUEZ MUÑOZ, Derecho penal. Parte especial, tomo II, Madrid, 1949, pp.213, 214 y 217.

14 STS 30-06-1982: "Frente a otras legislaciones que siguen sistemas distintos, la española se caracteriza por el abandono de la teoría de la bilateralidad y porque el cohecho cometido por funcionarios públicos y del perpetrado por particulares se hacen dos títulos de imputación diferentes, aunque se les subordine a un mismo nomen iuris".

15 E. CASAS BARQUERO, "Observaciones técnico-jurídicas sobre la incriminación del cohecho en el Código Penal Español", Documentación Jurídica, julio-septiembre, 1978, pp.871 y 872; E. OCTAVIO DE TOLEDO Y UBIETO, La prevaricación..., op. cit., pp.147 y 148; J. M. RODRÍGUEZ DEVESA y A. SERRANO GÓMEZ, Derecho penal español, Parte especial, op. cit., p.1170.

16 J. BUSTOS RAMÍREZ, Manual de derecho penal, Parte especial, Barcelona, 1991, (2 $2^{\text {a }}$ ed.), pp.374 y ss.

17 I. OLAIZOLA NOGALES, El delito de cohecho, op. cit., p.408; F. MUÑOZ CONDE, Derecho penal, Parte especial, 2009, op. cit., p.935.

18 STS 14-4-1952 (Jur. Crim. 184): "El sólo intento de corrupción configura el delito que no cabrá estimarse como tentativa"; STS 15-3-1961 (Jur. Crim. 310): "El artículo 391, después de la reforma de 1944 no deja lugar para castigar este delito en grado de frustración o de tentativa, pues el simple hecho de intentar corromper a un funcionario público consuma el delito"; STS 30-4-1985 (A 2152); STS 7-10-1985 (A 4849); STS 18-1-1993 (A 126): "El delito de cohecho es un delito en el que intervienen normal- 
cohecho pasivo constituye un delito especial propio de funcionarios, en tanto que el activo puede ser realizado por cualquier persona, sin exigencia de calificación profesional alguna. En último lugar, está el hecho de que las conductas de cohecho activo y cohecho pasivo se encuadran en artículos diferentes, constituyendo una serie de traba contra el carácter bilateral de delito de cohecho ${ }^{19}$.

En la actualidad, no hay discrepancia en la doctrina francesa al reconocer la teoría de la unilateralidad de los delitos de corrupción pasiva y corrupción activa. Recuerda VITU la indecisión del legislador francés al elegir entre el concepto liberal o unilateral del tipo de corrupción hasta las reformas de los artículos 177 y siguientes por la Ley del 16 de marzo de 1943 y la Ordenanza del 8 de febrero de 1945 que instauró el sistema de dos incriminaciones distintas (corrupción pasiva, artículo 177; corrupción activa, artículo 179 ${ }^{20}$. La explicación de DREYER, que es muy representativa de la postura mayoritaria de la doctrina penal francesa, indica que la corrupción propiamente dicha no es una infracción. Es una situación de hecho con ocasión de la cual dos conductas deben tenerse en cuenta: la conducta del corruptor y la del corrompido. Ambos personajes son igual de culpables: participan de un mismo acuerdo fraudulento. Cada uno comete una infracción; el Derecho penal los sitúa en el mismo nivel. En esta hipótesis, no hay un autor principal y su cómplice sino dos autores principales. La "criminalidad" de uno no está subordinada a la del otro. Se puede haber infracción de un lado y no del otro. Este es el caso en que uno de ellos haya rechazado la propuesta del otro. El "pacto de corrupción" no se ha concluido pero no es una condición de la represión: el autor de la propuesta puede ser declarado culpable de la infracción que le es propia ${ }^{21}$. Por otro lado, tampoco hay

mente dos o más personas, pero no es necesario que exista un acuerdo de voluntades. El bien jurídico es único, la confianza que los ciudadanos tienen en la correcta Administración de acuerdo con los principios de un Estado de Derecho".

19 E. CASAS BARQUERO, "Observaciones...",op. cit., p.868 y ss. Añade el autor que el Título VII debiera estar compuesto de dos capítulos, relativo uno a los delitos de los funcionarios públicos, y otro a los delitos de los particulares contra la Administración pública. De esta forma, el cohecho pasivo estaría ubicado en el primer capítulo y el cohecho activo en el segundo; Vid. I. VALEIJE ÁLVAREZ, El tratamiento..., op. cit., p.50.

${ }^{20}$ A. VITU, Traité..., op. cit., p. 285. Nota el autor que la corrupción se confundía con la concusión en derecho romano y en el antiguo derecho francés pero conquistó su autonomía en el Código penal de 1791 y en el Código napoleónico.

${ }^{21}$ E. DREYER, Cours magistral..., op. cit., pp.597, 598 ; F. GOYET, Droit pénal spécial, Sirey, 1972, (8è éd.), pp.91,92 ; M-P. LUCAS de LEYSSAC y A. MIHNAN, Droit pénal des affaires..., op. cit., no1014. Afirman que la concepción dualista (o, como lo llamamos, unilateral) supera el problema de la complicidad que genera la concepción unitaria (o bilateral), ya que permite al legislador que reprima sólo un lado de la corrupción; C. AMBROISE-CASTÉROT, Droit pénal..., op. cit., p.360; W. JEANDIDIER, Du délit de corruption et des défauts qui l'affectent, JCP, G, no39, 25 septembre 2002, p.1668; P. BONFILS, «La corruption en droit pénal», op. cit., p.238. Aunque este autor defiende la existencia de dos infracciones distintas de corrupción pasiva y activa, también sostiene que hay un hilo conductor que une la noción de corrupción y hace la unidad de la infracción de corrupción: 1) la relación de autoridad, la corrupción exige la intervención sujetos públicos o considerados así como autor de los hechos (corrupción pasiva) o como destinatarios de los mismos (corrupción activa). Esta relación de autoridad 
reticencia dentro de la doctrina al aceptar que aunque se trata de dos infracciones distintas, ambas protegen los mismos intereses jurídicos ${ }^{22}$.

La doctrina malgache se ha alineado en la postura de la doctrina francesa al precisar que ya se ha superado la definición clásica que se basaba en el criterio del pacto corruptor el cual suponía la presencia de, por lo menos, dos protagonistas. En la actualidad, aunque la presencia de más de un protagonista puede ser útil, el criterio convencional ya no es determinante cuando los aspectos activo y pasivo de las incriminaciones de la corrupción se volvieron delitos autónomos ${ }^{23}$. En el marco de la última reforma, RAFOLISY afirma que la nueva ley ha decantado por la autonomía de la corrupción activa de la corrupción pasiva ${ }^{24}$. Lo que supone la voluntad del legislador de dar el mismo desvalor a los actos de los dos autores. En este caso la tentativa ya no tiene cabida puesto que estas infracciones ya están caracterizadas en cuanto haya solicitación o propuesta ${ }^{25}$. El debate sobre el número de bienes jurídicos protegidos en el delito de corrupción no existe ya que para el autor sólo existe uno: la integridad como valor social digno de protección jurídica (entre otra la jurídico-penal) ${ }^{26}$.

\section{III-El delito de cohecho como delito pluripersonal}

permite aprehender las dos facetas de la corrupción, activa y pasiva, según el ángulo por el que se examina esta relación. Además, es esta relación la que permite distinguir la corrupción del tráfico de influencia. 2) El desvío de esta relación de autoridad, la finalidad de este desvío es igualmente un criterio esencial de la corrupción. Sólo hay corrupción si el desvío de autoridad persigue un interés personal o una finalidad interesada. Por lo tanto se amplia la finalidad de los actos. Pues, del lado del corrompido se prevén ofertas, promesas, dádivas, presentes o cualquier beneficio. Del lado del corruptor, la ventaja esperada se entiende de manera amplia porque se habla de toda decisión favorable. A nuestro parecer, lo que une estos dos aspectos de la corrupción no es un elemento característico del entorno de las conductas sino un interés jurídico que el legislador pretende proteger a saber la imparcialidad para garantizar el correcto funcionamiento de la Administración pública. Además, al afirmar el autor que la corrupción supone un desvío independientemente del origen de la solicitación, se ha olvidado precisar el momento exacto en que ocurre el desvío. Este no se produce hasta que el funcionario reciba los presentes y dádivas para actuar de la manera esperada por el corruptor o acepte la propuesta de este último. Lo que significa que no habría desvío si la solicitación del funcionario y la propuesta del particular no habían sido atendidas por su destinatario respectivo. La concepción dualista de la corrupción exige que se consuma el delito antes de que se produzca el desvío de autoridad.

${ }^{22}$ H. XIAO-YING, La lutte contre la corruption..., op. cit., p.305 ; P. MAISTRE DU CHAMBON, A. LAPAGE y R. SALOMON, Droit pénal des affaires, op. cit., p.144.

${ }^{23}$ P. RAFOLISY, La protection juridique..., op. cit., p.170.

${ }^{24}$ Ibídem, op. cit., p.234.

25 Ibídem, op. cit., p.237.

${ }^{26} \mathrm{Al}$ reclamar el rechazo al principio de doble estándar entre los funcionarios y los que no lo son en virtud del cual se puede pedir más obligación para con los primeros, el autor reclama una protección equitativa del bien jurídico, que es la integridad (no sólo de los funcionarios sino de todos ciudadanos). Sin embargo, a nuestro parecer, esta protección equitativa si teóricamente suena bien, no debe deshacer de las consideraciones del principio de igualdad entre diferentes sujetos en situaciones jurídicas desiguales, aunque por razón de política criminal el legislador ha adoptado la teoría de la unilateralidad de ambos delitos concediendo el mismo desvalor tanto a la lesión como la puesta en peligro del bien jurídico tutelado. 
Aunque la tesis de la bilateralidad del delito de cohecho ha sido abandonada desde 1944, como ya hemos señalado, un sector de la doctrina española la ha retomado en los últimos años desde propuestas matizadas ${ }^{27}$. Reconoce RODRÍGUEZ PUERTA que pese a la escasa literatura que se ha ocupado en España de los denominados "delitos pluripersonales" o "con pluralidad de sujetos activos", se ha logrado, en general identificar con bastante acierto los requisitos y características propias de estas categorías ${ }^{28}$. En efecto, autores como COBO DEL ROSAL ${ }^{29}$, BARBERO SANTOS ${ }^{30}$ y más recientemente CARRASCO ANDRINO ${ }^{31}$ son de referencia en esta materia. Plantea esta última autora que existen algunos delitos que están configurados de tal forma que, para su realización, requieren necesariamente la intervención de varios sujetos, sin que, a diferencia de lo que ocurre con las restantes figuras delictivas, sea posible cometer el hecho delictivo aisladamente por un solo individuo $^{32}$. La síntesis de las características de este tipo de delito, hecho por COBO DEL ROSAL y retomado por la doctrina ${ }^{33}$, considera que se podrá hablar de delito pluripersonal cuando se den las siguientes notas:

a) Que sean varias las conductas que componen el tipo, para cuya realización se necesite la inevitable contribución de dos o más personas.

b) Que se trate de una única figura delictiva y de un mismo bien jurídico protegido que solamente una vez se vea lesionado, es decir, que sea, desde el punto de vista de lesión que se verifica, un único delito.

c) Distinción entre el plano típico lesivo y el desvalor personal que implica el delito. Son pues, varios y no equivalentes los preceptos que se dirigen a los diversos partícipes y, por tanto, existe una neta diferencia entre la dimensión personal del injusto y la dimensión típica y lesiva del mismo, siendo la primera autónoma e independiente, pues afecta tan sólo a cada uno de los sujetos en particular. En consecuencia, carecerá de sentido cualquier alusión a la punibilidad (abstracto o concreta) en orden a la presente delimitación ${ }^{34}$.

${ }^{27}$ N. J. DE LA MATA BARRANCO, La respuesta..., op. cit., p.120. Nos parece interesante $y$, por lo tanto retomaremos el repaso que el autor hace de las grandes líneas de los argumentos que demuestran el carácter pluripersonal del delito de cohecho dentro de la doctrina española (pp.120-130).

${ }^{28}$ Ma. J. RODRÍGUEZ PUERTA, El delito de cohecho..., op. cit., p.102.

29 M. COBO DEL ROSAL, "Sobre la naturaleza pluripersonal del delito de adulterio (art.449 del Código penal)", A.D.P.C.P., 1967, pp.147-167.

30 M. BARBEROS SANTOS, “El bandolerismo en la legislación vigente”, A.D.P.C.P., 1970, pp. 255-286.

31 Ma. D. M. CARRASCO ANDRINO, Los delitos plurisubjetivos y la participación necesaria, Comares, Granada, 2002.

${ }^{32}$ Ibídem, op. cit., p.2.

33I. OLAIZOLA NOGALES en El delito de cohecho, op. cit., p. 224; Mạ. J. RODRÍGUEZ PUERTA, El delito de cohecho..., op. cit., p.102; I. VALEIJE ÁLVAREZ, El tratamiento..., op. cit., pp. 42 y 43.

${ }^{34}$ M. COBO DEL ROSAL, "Sobre la naturaleza pluripersonal...", op. cit., pp.155, 156; Con matiz, la postura de BARBEROS SANTOS, “El bandolerismo..." op.cit., p.257 y ss., clasificada por OLAIZOLA NOGALES como concepción restringida, destaca que hay que par- 
El siguiente paso tratará de averiguar si el delito de cohecho puede ser considerado como delito pluripersonal ${ }^{35}$. Así, defiende VALEIJE ÁLVAREZ el carácter pluripersonal del cohecho, entendiendo que cada modalidad delictiva reclama en su estructura típica la concurrencia de varias acciones de diferentes personas; faltando una de las cuales el tipo penal no se verifica, pero sin estar de acuerdo con la postura tradicional que justifica la bilateralidad en base a la idea de un acuerdo o convenio -que ciertamente no se exige llegue a producirse -, y aun cuando señale el cohecho consiste en un trato o pacto o un intento de llevarlo a cabo entre funcionario y particular que tiene por objeto el ejercicio de una función pública dispuesta al servicio de intereses particulares que pueden entre gravemente en colisión con los intereses públicos ${ }^{36}$.

En cuanto al cohecho activo, entiende que si se quiere saber cuál es la intención del particular, la razón por la que corrompe o intenta corromper, debemos poner en relación el artículo 391 con los artículos 385, 386 y 387 - del viejo CPE, al que todavía se refiere todavía -, sin que captase el significado de esa figura, sin acudir a lo dispuesto en los tipos correspondientes de cohecho pasivo, porque, en su ausencia, el cohecho activo resultaría un tipo legal sin límite y, por lo tanto, cualquier conducta que fuera dirigida a trastocar o alterar el ánimo o la voluntad del funcionario - intento de cualquier clase - caería dentro del ámbito de dicho artículo 391. Pero recuerda que el éxito o fracaso del asunto perseguido por el particular depende de la aquiescencia o del rechazo del funcionario, ya que sólo él es quien puede realizar el acto pretendido a cambio de la dádiva. La intención del particular al ejecutar la acción típica se completa con la persecución de un resultado exterior que ha de producirse sin su intervención y sí mediante la del funcionario, con posterioridad al hecho típico. Por ello señala que es inevitable la concurrencia de dos actividades en sentido amplio y, consecuentemente, la necesaria y material participación del particular, aunque no cualquiera, sino única y exclusivamente, por propia exigencia de los tipos de cohecho, aquélla que se concreta en dar o prometer, convirtiéndose quien participa de esta concreta y específica forma en sujeto activo del cohecho activo, por imperativo del artículo 391, y sin que para nada sean empleadas las normas de la parte general del Código ${ }^{37}$.

tir de la descripción de la figura delictiva para determinar si es está frente a un delito con sujeto activo individual o pluripersonal. El último existe cuando en la descripción de la figura del delito se exija que dos o más personas actúen de una forma determinada para que la conducta típica pueda verificarse, con independencia de la punibilidad en concreto. Será esencial, por tanto, para la sustantividad de la figura delictiva, la intervención de dos o más sujetos. En estos delitos todos los sujetos físicos son punibles en abstracto como autores del delito. No hace falta sin embargo, su punibilidad en concreto (I. OLAIZOLA NOGALES en El delito de cohecho, op. cit., p. 223). Esta postura restringida ha sido rechazada por CARRASCO ANDRINO y RODRÍGUEZ PUERTA. (Ma D. M. CARRASCO ANDRINO, Los delitos plurisubjetivos..., op. cit., p.51 y Ma. J. RODRÍGUEZ PUERTA en El delito de cohecho..., op. cit., pp.93 y ss.)

${ }^{35}$ Se seguirá el repaso propuesto por N. J. DE LA MATA BARRANCO en La respuesta..., op. cit., pp.120-130.

${ }^{36}$ I. VALEIJE ÁLVAREZ, El tratamiento..., op. cit., pp. 42 y 47.

37 Ibídem, op. cit., pp.46 y ss. 
El hecho de que particular y funcionario respondan cada uno en base a la aplicación de un artículo diferente depende a su juicio, en gran medida, de que el cohecho pasivo es un delito especial, razón por la cual el particular, al no reunir las condiciones requeridas por el tipo, no podrá ser coautor del delito ejecutado por el funcionario, con lo que su contribución debería ser valorada a lo sumo como partícipe. Sin embargo, señala que, posiblemente, al observar el legislador que el particular contribuye conjuntamente con el funcionario a la ejecución de los hechos no ha dudado ni por un instante en extender a aquél la responsabilidad prevista para éste, tipificando un comportamiento que acompaña siempre y necesariamente al del funcionario y que de no haberse tipificado y no responder el particular nunca como coautor - debido a esa caracterización como delito especial -, sin perjuicio de que en ocasiones pudieran aplicarse las reglas de participación, quedaría impune en la mayoría de los supuestos ${ }^{38}$. Por eso la equiparación de pena - corolario de su condición de autores afirmará de forma cuestionable - no es más que la consecuencia de la posición homóloga que ambos ocupan en el plano del desvalor ofensivo tratando de obtener ventajas a costa del ejercicio de la función pública ${ }^{39}$.

En referencia al cohecho pasivo, en cuanto a la solicitud, que abre la puerta a su consumación unilateral, coincide con la doctrina mayoritaria en que se trata de una modalidad monosubjetiva de cohecho, aunque entiende que esto es sólo potencialmente cierto, ya que la misma puede conducir a un estructura plurisubjetiva cuando se atienda la mis$\mathrm{ma}^{40}$.

Para OLAIZOLA NOGALES, no es necesario aludir a la diferenciación de bienes jurídicos del cohecho pasivo y activo en la fundamentación del carácter unilateral de la figura del delito de cohecho, aunque sí es relevante cómo lesionan o ponen en peligro el funcionario y el particular el interés que se protege ${ }^{41}$. En su opinión, las actividades de recibir y aceptar ofrecimiento o promesa del cohecho pasivo tienen carácter pluripersonal, lo que convierte en un delito bilateral en cuanto estamos ante conductas de encuentro que requieren por su naturaleza dos actividades contrapuestas dirigidas todas ellas al mismo fin; en cambio la conducta de solicitar tiene carácter unilateral. Y lo mismo entiende ocurre en el cohecho activo, donde las conductas de corromper y de aceptar la solicitud del funcionario implican una actividad por parte de éste de modo tal que el delito adquiere naturaleza pluripersonal, en tanto el intentar corromper es una conducta del particular que no requiere más que su sola actividad. En ambos casos, concluye, la regulación actual implica una equiparación entre conductas de carácter bilateral y unila-

\footnotetext{
${ }^{38}$ Ibídem, op. cit., p.50. En contra de esta opinión N. J. DE LA MATA BARRANCO, La respuesta..., op. cit., p.122.

${ }^{39}$ I. VALEIJE ÁLVAREZ, El tratamiento..., op. cit., p.51.

${ }^{40}$ Ibídem, op. cit., p.48.

${ }^{41}$ I. OLAIZOLA NOGALES, El delito de cohecho, op. cit., p.93.
} 
teral, que adelantan el momento de consumación, anticipando de forma importante las barreras de protección penal ${ }^{42}$.

Según RODRÍGUEZ PUERTA, la tendencia de la doctrina y de la jurisprudencia a otorgar autonomía a los delitos de funcionario y particular, después de 1944, se basa en argumentos que incurren en el insalvable defecto de prescindir de la necesaria situación interactiva que debe mediar entre los dos sujetos que intervienen en el delito de cohecho, siendo la tipificación en preceptos distintos un dato accidental que responde a la necesidad de individualizar con claridad los distintos comportamientos, sin que ello afecte a la unidad delictiva. Pero tampoco le parece determinante el argumento de la posibilidad de consumación del delito por parte de uno solo de los sujetos, pues se confunden dos planos distintos, en cuanto que estructuras bilaterales considera que la tentativa requiere que todos den inicio a la ejecución del delito, pero, como ocurre en el delito de cohecho, en ocasiones resulta insatisfactoria la exclusión de estos comportamientos unilaterales del ámbito de conductas punibles, reclamando la eficaz salvaguardia del bien jurídico la sanción de conductas que sin lesionarlo lo ponen en peligro de forma significativa, aunque sin que de ello deba deducirse que el cohecho consiste, por ejemplo, en intentar corromper en vez de en corromper ${ }^{43}$.

Ella define el cohecho como tipo de encuentro - representando el anterior artículo 423, el reverso de los anteriores artículos 419, 420 y 421 -, delito único del que responden particular y funcionario, ambos como autores del mismo, pero diferenciando aquellos supuestos en los que se intenta el acuerdo sin éxito - tentativas unilaterales de cohecho -, en los que únicamente responderá quien formuló la propuesta corruptora, tipos de participación necesaria, de aquellos otros en que sí logró dicho acuerdo y que, siendo de participación necesaria, serán además pluripersonales, calificación que se señala encuentra refrendo tanto a partir del examen de la propia descripción típica como desde del bien jurídico tutelado ${ }^{44}$.

Como ya señala, junto con MORALES, la lesión del principio de imparcialidad se constata tanto desde la perspectiva de la actuación del funcionario como la del particular, cuyas conductas resultan imprescindibles, exigiendo asimismo los verbos empleados en los anteriores artículos 419 y siguientes del Código, la presencia de más de un sujeto, de cuya sanción va a depender la calificación de pluripersonal de la concreta modalidad de cohecho de que se trate ${ }^{45}$.

La justificación de la impunidad del destinatario de la acción corruptora cuando no se alcanza el pacto responde a su juicio a la falta de relevancia de su conducta desde la perspectiva del bien jurídico tutelado, aun-

\footnotetext{
42 Ibídem, op. cit., p.228.

${ }^{43}$ Mà. J. RODRÍGUEZ PUERTA, El delito de cohecho..., op. cit., pp.111 y 112.

${ }^{44}$ Ibídem, op. cit., pp.144 y 201.

${ }^{45}$ F. MORALES PRATS y Mํㅡㄹ. RODRÍGUEZ PUERTA, “Delitos...”, op. cit., p. 1662.
} 
que entiende que la perfección de la modalidad delictiva sí exige la intervención de ambos, pues es imprescindible que la oferta o solicitud lleguen a ser conocidas por su destinatario. Y entiende que ha sido esta equiparación legal entre conductas que suponen una puesta en peligro del interés tutelado con aquéllas que suponen una autentica lesión del mismo la que ha conducido a un sector doctrina a negar en bloque el carácter pluripersonal de todas las formas de cohecho, confundiendo sin embargo dos cuestiones diversas, pues la equiparación implica simplemente construir el delito de cohecho como tipo de emprendimiento, con finalidad de agravar la reacción penal otorgando a las dos secuencias lógicas de peligro y lesión un idéntico desvalor al situar la consumación en un momento anterior al de la plena afección del bien jurídico. En cuanto a los anteriores artículos 425 y 426 entiende la autora que el particular no actúa movido por la intención de conseguir una ventaja, pues el acto es debido, lo que justifica la decisión de sancionar únicamente al funcionario en dos tipos que se definen entonces de participación necesaria ${ }^{46}$.

Fundamenta su posición argumentando que tanto cuando se obtiene el acuerdo de voluntades como cuando se intenta sin éxito el mismo delito de cohecho que se comete es único en la medida en que se afecta una sola vez el respeto del principio de imparcialidad que debe presidir la adopción de las decisiones públicas, interés tutelado en el delito, que se lesiona en un caso por funcionario y particular, de forma conjunta, o se pone en peligro en otro, pero ahora ya sólo por uno de ellos. Y tanto en uno como en otro supuesto se requiere la intervención de ambas partes, al fundamentarse el injusto en el acuerdo de voluntades y necesitarse para ello la presencia cuando menos de dos sujetos ${ }^{47}$. El anterior artículo 423 cumplirá entonces, a su juicio, únicamente la función de determinar la pena que corresponde al particular, puesto que su contribución al hecho delictivo ya se encuentra implícitamente prevista en los tipos que contienen la que corresponde al funcionario, pudiendo variar la técnica concreta de tipificación sin que ello incida sobre la caracterización del tipo como de participación necesaria o pluripersonal ${ }^{48}$.

Ante este debate sobre el carácter pluripersonal del delito, DE LA MATA BARRANCO indica otra alternativa ${ }^{49}$ y recurre a autores como CRESPO BARQUER0 50 y RUEDA MARTÍN ${ }^{51}$. El primero plantea la posibilidad de entender que no estamos ante dos delitos distintos o ante la tipificación desdoblada de un delito plurisubjetivo, sino ante la tipificación expresa

\footnotetext{
${ }^{46}$ Ma. J. RODRÍGUEZ PUERTA, El delito de cohecho..., op. cit., pp.143 ss. y 201.

${ }^{47}$ Ibídem, op. cit., pp.154, 190 ss. y 285.

48 Ibídem, op. cit., pp.150 y ss.

${ }^{49}$ N. J. DE LA MATA BARRANCO, La respuesta..., op. cit., p.128.

50 P. CRESPO BARQUERO, "Corrupción y tráfico de influencias" en El nuevo Código penal y su aplicación a empresas y profesionales. Manuel teórico y práctico (III), Recoletos, Madrid, 1996, pp.483-525.

51 Mà. A. RUEDA MARTIN, "Reflexiones sobre la participación de extraños en los delitos contra la Administración Pública", en Revista de Derecho Penal y Criminología, núm 8, 2ae época, 2001, pp.128-164.
} 
de la participación de un sujeto común en un mismo delito especial ${ }^{52}$. La segunda señala que "el acceso al dominio social típico por parte del particular está efectivamente determinado por el funcionario público"53. Por consiguiente, afirma DE LA MATA BARRANCO que el hecho de que el legislador opte por contemplar la conducta del particular en un artículo propio o incluso que acuerde sancionar el intento de corrupción no justifican la perspectiva unilateral, por cuanto el contenido de antijuridicidad material de cohecho activo sólo se entiende desde la previsión legal de los artículos que, dedicados al cohecho pasivo, delimitan la misma, siendo incierto por otra parte que en las conductas denominadas tentativas unilaterales se requiera únicamente la intervención de una de las partes, pues incluso ellas sólo se entienden desde la perspectiva interactiva que exige, al menos, la capacidad para recibir la oferta o la solicitud de corrupción ${ }^{54}$. Lo que matiza el autor es que si el delito de cohecho es un delito pluripersonal cabe incluir conductas, equiparables, de autoría, lo que es inaceptable porque la relevancia de una o de otra conducta es absolutamente dispar. Sí se trata de conductas complementarias, salvo que se mantenga que el núcleo de lo injusto reside en el intercambio paritario de prestaciones y que la lesividad de las mismas no debiera cifrarse en el enriquecimiento del funcionario y la correlativa ventaja del particular, sino en el desvalor que se produce con la actuación a realizar, se lleve a cabo o no, que depende - en exclusiva - del funcionario. Por eso, concluye el mismo autor, el debate no se ha de plantear en torno a la naturaleza bilateral o no de los preceptos, porque además las conclusiones que se obtienen del mismo - teniendo en cuenta las previsiones expresas del legislador - no difieren en las propuestas de los diferentes autores. Sí deberá rechazarse el concepto de bilateralidad si de él pretende deducirse la imposibilidad de sancionar únicamente al funcionario y no al particular, o viceversa, la necesidad de conclusión de un acuerdo que muchos tipos no exigen o la equiparación en cuanto al desvalor material y/o a la pena que se prevea - de ambas conductas. Pero también la tesis de la unilateralidad si de ella pretenden extraerse consecuencias en el ámbito de la ejecución delictiva, la participación criminal o la teoría del concurso que, por defender una estricta autonomía de ambas figuras, no tengan en cuenta el componente lesivo de la conducta del particular por su necesaria dependencia de una actuación ajena y su vinculación a ésta desde el prisma de la participación -autónoma - en la actuación en el ejercicio del cargo del funcionario ${ }^{55}$.

\footnotetext{
52 P. CRESPO BARQUERO, “Corrupción...”, op.cit., p.513.

${ }^{53}$ Ma. A. RUEDA MARTIN, "Reflexiones...", op. cit., pp. 152 y ss.

${ }^{54}$ N. J. DE LA MATA BARRANCO, La respuesta..., op. cit., p129. Añade que la vulneración del bien jurídico, a la que contribuye el particular, se explica únicamente desde la actuación en el ejercicio del cargo que, en caso de que no se produzca, no necesariamente debe impedir la sanción de dicha contribución, por el teórico peligro - aun de remota o imposible concreción - que pueda conllevar, sin que ello sea propio de estos delitos ni, en general, obligue a predicar la unilateralidad de la misma, si por tal concepto se entiende ausencia de vinculación con la conducta principal idónea para generar aquella lesividad.

${ }^{55}$ Ibídem, op. cit. p.130.
} 
Por otro lado, indica CERINA lo difícil de conciliar la plurisubjetividad del delito de cohecho con la tesis según la cual, mientras que el bien jurídico protegido se vería lesionado por la conducta del sujeto público, tan sólo podría ser puesto en peligro por el particular ${ }^{56}$. En efecto, si por un lado se afirma que es característica de los delitos pluripersonales, en primer lugar la necesidad de que exista un bien jurídico tutelado, para cuya lesión o puesta en peligro sea imprescindible la conducta de varias personas llevadas a cabo por sujetos distintos y que la lesión, pese a la concurrencia de varios comportamientos sea una sola, parece difícil luego compatibilizar que, en el cohecho activo y pasivo, existe un único bien jurídico tutelado, para cuya lesión es necesaria la concurrencia de varias conductas y sujetos, con el hecho de que el extraneus pone en peligro un bien jurídico a la vez que el intraneus lo lesiona. Ni parece poderse afirmar que "esta circunstancia (...) no es un obstáculo para defender el carácter pluripersonal del delito de cohecho (...)" ya que "en todo caso podría conducir (...) a establecer una pena distinta para cada uno de los intervinientes o a limitar la sanción del particular"57. En primer lugar, es cierto que la pluripersonalidad no conlleva la identidad de sanción para todos los autores, pero no es menos cierto que, una vez afirmada la unicidad del ataque al bien jurídico, la diferencia de pena podrá fundamentarse sobre diversos motivos político-criminales, pero nunca en la diferente afectación del bien jurídico protegido. Según el mismo autor el equívoco deriva de una recepción parcial de aquella idea del ilícito penal como ilícito de modalidad de lesión. Cuando se habla de afectación del bien jurídico protegido, nos referimos no ya a la genérica relación entre sujetos activos e interés tutelado, sino más bien a la concreta modalidad de ataque al bien jurídico considerada por la norma. Es indiferente, en otras palabras, que el intraneus mantenga deberes especiales en virtud de su relación con la Administración que el particular no tendría. Concluye el autor que si, como corolario de la plurisubjetividad, se postula que cohecho activo y pasivo producen una única lesión del bien jurídico (lo que demostraría que nos encontramos frente a un único delito), debemos, de igual manera, postular un único ataque al mismo. Ahora bien, un solo "ataque" podrá representar una (sola) lesión o bien una (sola) puesta en peligro para el interés tutelado pero no al mismo tiempo, una lesión $y$ una puesta en peligro: si así fuera, deberíamos hablar ya no de un único ataque sino de dos. Así las cosas, si consideramos que, en el cohecho, la afectación al bien jurídico procede del acuerdo entre dos sujetos ${ }^{58}$, este acuerdo o bien lesiona o bien pone en peligro el bien jurídico y tertium non datur 59 .

No se encuentra este tipo de debate dentro de la doctrina francesa y malgache. Los autores asumen plena y simplemente la unilateralidad de

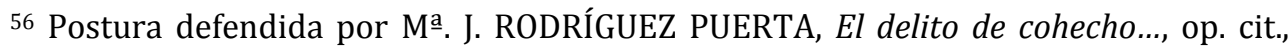
p.84; I. OLAIZOLA NOGALES, El delito de cohecho, op. cit., p.140.

${ }^{57}$ Mํ. J. RODRÍGUEZ PUERTA, El delito de cohecho..., op. cit., p.107.

${ }^{58}$ Ibídem, op. cit. p.108.

${ }^{59}$ Salva la posibilidad que ni lesione ni afecte precisa CERINA (G. D. M. CERINA, La lucha contra la corrupción, op.cit., pp.636-638).
} 
los delitos de corrupción pasiva y activa basándose en el hecho de caracterizar el delito por una conducta unilateral sin llegar a cualquier acuerdo de voluntades y la equiparación del desvalor de las conductas activa y pasiva, dedicando el legislador a cada una de ellas un precepto diferente. Los defensores de la pluripersonalidad del delito en estudio verán una confusión de dos planos distintos: la dimensión personal y la dimensión típica y lesiva ${ }^{60}$, pero la reflexión doctrinal no va más allá de lo que acabamos de indicar. El presente trabajo pretende sembrar la semilla de este debate desconocido dentro de la doctrina francesa y malgache para contribuir a enriquecer la reflexión científica en el estudio del delito de corrupción. Nos parece singular la postura de XIAOYING quien admite que se trata de dos delitos autónomos pero cuando un tercero ha tomado la iniciativa, la cual encuentra la aceptación del beneficiario de la oferta pues aparecen la el aspecto bilateral de la corrupción y la noción de pacto de corrupción que se realiza a través de una solicitación (o de aceptación), el cumplimiento o la abstención de un acto de la función del corrompido y una relación de causa-efecto entre el cumplimiento o la abstención del acto de la función y la solicitación 61 .

\section{Sección 2-Naturaleza del delito de cohecho según las modalidades de acción}

El párrafo en estudio intentará destacar las propuestas doctrinales sobre la estructura del cohecho o de la corrupción al considerar elementos objetivos del tipo, tales como el resultado y su momento consumativo.

\section{I-El delito de cohecho como delito formal o de mera acti- vidad}

Existe unanimidad en la doctrina francesa al considerar el delito de corrupción como delito formal. En efecto, ella entiende que la corrupción pasiva tiene una naturaleza formal que no necesita tentativa porque la infracción se consume independientemente del resultado, lo que equivale a sancionar, como infracción autónoma, conductas que, en la tenta-

${ }^{60} \mathrm{M}^{\mathrm{a}}$. J. RODRÍGUEZ PUERTA, El delito de cohecho..., op. cit., pp.103 y 111.

${ }^{61} \mathrm{H}$. XIAO-YING, La lutte contre la corruption..., op. cit., p.51. Esta postura nos parece más cerca de la de OLAIZOLA NOGALES quien reconoce el carácter pluripersonal del delito de cohecho pasivo en las modalidades de "aceptar" y "recibir" y del cohecho activo en sus modalidades de "corromper" y de aceptar", sin embargo se tratará de delito unipersonal y por consiguiente de delitos autónomos e independientes en la modalidad de "solicitar" para el cohecho pasivo y en la de "intentar corromper" en cuanto al cohecho activo. Postura que compartimos en el marco de este trabajo (I. OLAIZOLA NOGALES, El delito de cohecho, op. cit., p.228). 
tiva, serían analizadas como comienzo de ejecución ${ }^{62}$. En cuanto a la corrupción activa, su naturaleza formal no implica que la oferta haya sido aceptada por su destinatario ${ }^{63}$. El acuerdo entre el corrompido en respuesta a la invitación del corruptor influye en la determinación del momento de la consumación del delito. Subraya XIAO-YING que poco importa que la contrapartida solicitada no haya sido proporcionada porque la mera solicitación basta para caracterizar la acción del sujeto. En otras palabras, según el mismo autor, estamos ante un delito formal e instantáneo ${ }^{64}$. Precisan DELMAS-MARTY y GIUDICELLI-DELAGE que la solicitación, que supone que el agente público haya tomado la iniciativa del acto, consume el delito aunque no ha sido aceptada por la persona solicitada. La respuesta de esta última no atenúa ni refuerza la culpa ${ }^{65}$ del solicitante. Por lo tanto, la corrupción pasiva por solicitación es un delito formal caracterizado independientemente del efecto producido - lo que significa que la colusión es eventual en la hipótesis de la solicitación, mientras que es efectiva en caso de aceptación. En cuanto a la corrupción activa, para la consumación delictiva no importa que la oferta haya sido aceptada o no y que a fortiori, haya producido efecto o no. Por lo tanto, la tentativa no está incriminada ${ }^{66}$. En esta misma línea se ha posicionado la doctrina malgache ${ }^{67}$.

La doctrina española, al cifrar el núcleo del injusto en la conclusión del acuerdo entre funcionario y particular, considera el delito de cohecho como de mera actividad - con relación a su estructura típica y con independencia de cómo se defina desde la perspectiva del bien jurídico - en cuanto las diferentes modalidades requieren la realización de una actividad, sea la emisión de una declaración de voluntad, sea la entrega o recepción de una dádiva, pero no la obtención de un resultado, sin que pueda considerarse como tal el acuerdo, dado que no se trata de un efecto exterior separable espacio-temporalmente de la acción ${ }^{68}$. La consumación del delito se produce desde ese mismo momento, además sin necesidad de realización de acto alguno derivado del mismo ${ }^{69}$. DE LA MATA BARRANCO destaca que la caracterización de un tipo como de mera actividad no afecta necesariamente a su consideración como delito de peligro o de lesión, dependiendo evidentemente la postura que se adopte del modo en que se entienda el concepto de resultado jurídico;

62 ; P. MAISTRE DU CHAMBON, A. LAPAGE y R. SALOMON, Droit pénal des affaires, op. cit., p.148

${ }^{63}$ Ibídem, op. cit. p.141. Para apoyar su postura citan Cass. crim., 16-10-1985, Gaz. Pal. 1986, jurispr. p.152; en el caso, la jurisprudencia no dudó en condenar a un estudiante que, creyéndose gracioso, aunque era simplemente deshonesto, le había propuesto, sin éxito, un cheque de 10000 Francos a un examinador, éste encima sin fondos, colmo de la grosería.

${ }^{64} \mathrm{H}$. XIAO-YING, La lutte contre la corruption..., op. cit., p.51.

${ }^{65}$ Podemos sustituir por el término "desvalor" ya que la palabra "culpa" tiene otro sentido en la doctrina penal española.

${ }_{66}$ M. DELMAS-MARTY y G. GIUDICELLI-DELAGE, Droit pénal des affaires, op. cit., pp.288, 290, 291 y 294.

${ }^{67}$ P. RAFOLISY, La protection juridique..., op. cit., p.237.

${ }^{68} \mathrm{M}$ a. J. RODRÍGUEZ PUERTA, El delito del cohecho..., op. cit., p.181.

${ }^{69}$ N. J. DE LA MATA BARRANCO, La respuesta..., op. cit., p.104. 
pero si éste, en cuanto afección al bien jurídico protegido, se define al margen del resultado estructural que dominantemente se viene aceptando no concurre en los delitos de mera actividad, ningún problema existirá en aceptar que un delito de mera actividad ni predetermina la configuración del injusto típico ni impide, en consecuencia, afirmar que estemos ante un delito de lesión. El resultado delimita la configuración típica del precepto y el desvalor de resultado afecta a la antijuridicidad material de la conducta. En este sentido su definición como delito de mera actividad sólo afecta a la determinación del momento de la consumación que, además, en estos supuestos aparece expresamente concretado por las distintas previsiones del legislador. Ninguna otra conclusión debe obtenerse de tal caracterización de la estructura típica de la figura, de cara a la concreción de lo injusto y a las consecuencias que pueden desplegar hechos posteriores al momento de la consumación ${ }^{70}$. Por otro lado, una consecuencia de asumir el carácter de mera actividad del cohecho es la imposibilidad de su construcción en comisión por omisión ya que es necesario, para cometer el delito de cohecho que el funcionario realice una conducta positiva, que ponga de manifiesto su intención de recibir o hacer suyo el objeto poseído como retribución por un acto propio del cargo ${ }^{71}$. El segundo argumento que provee RODRÍGUEZ PUERTA para justificar la imposibilidad de cometer el delito de cohecho por omisión de la calificación como delito de mera actividad de las distintas formas de cohecho, se encuentra en las acciones descritas en los tipos de cohecho que tienen un carácter eminentemente activo -solicitar, recibir o aceptar - de modo que su equiparación a la omisión podría desbordar el marco del sentido literal posible. Esta conclusión, indica la autora, deja, sin embargo, imprejuzgados aquellos supuestos en los que la aceptación o la recepción de la dádiva, o incluso, su solicitud se hacen de modo tácito o encubierto ${ }^{72}$.

A nuestro parecer, lo que hace la diferencia entre el delito de cohecho como delito de mera actividad y el delito de corrupción como delito formal se sitúa en que en éste último el resultado penal parece cifrarse en lograr el acuerdo corrupto entre el agente público y el particular. En efecto, el asumir tal acuerdo como núcleo del injusto y a la vez resultado penal, nos llevará a la conclusión de que sólo son delitos formales las modalidades en las que las conductas han sido tipificadas sin exigir que se llegue a un pacto de corrupción. Las que alcanzan un acuerdo no se-

\footnotetext{
${ }^{70}$ Ibídem, op. cit. pp.104 y 105.

${ }^{71}$ I. VALEIJE ÁLVAREZ, El tratamiento..., op. cit., pp.113-116. La autora niega el carácter delictivo de la conducta del funcionario que no se pronuncia sobre la oferta hecha por un particular, o no rechaza el dinero que éste deposita en su mesa de trabajo. En ambos casos, siempre que el funcionario no lleve a cabo una mínima actividad positiva tendente a disfrutar del objeto, a incorporarlo a su patrimonio o sacar rendimiento, no podrá ser condenado por el delito de cohecho. Por el contrario, cuando, sin existir una declaración expresa, el funcionario lleva a cabo cualquiera de los actos antes indicados, éstos serán suficientes para considerar que acepta o recibe la dádiva o presente, y por tanto para apreciar el delito de cohecho. Véase I. OLAIZOLA NOGALES, El delito de cohecho, op. cit., pp. 258, 259.

72 Mà. J. RODRÍGUEZ PUERTA, El delito de cohecho..., op. cit., pp.182 y 183.
} 
rían delitos formales sino delitos de resultado. La doctrina española rechaza el acuerdo como resultado de la infracción, ya que no se trata de un efecto exterior separable espacio-temporalmente de la acción. Con lo cual todas las modalidades del cohecho son de mera actividad aunque reconoce OLAIZOLA NOGALES la dificultad al plantearse si la recepción de la dádiva o presente en el sentido de la incorporación real al patrimonio del funcionario es resultado o si forma parte de la propia actividad de recibir ${ }^{73}$. Sería interesante que la doctrina penal francesa y malgache pudiera desarrollar el concepto de resultado penal o resultado de la infracción. Pero mientras tanto, la doctrina francesa propone otra estructura del delito de corrupción, la de delito sucesivo.

\section{II-El delito de corrupción como delito sucesivo.}

El carácter sucesivo o de ejecución sucesiva del delito de corrupción se debe a que la ejecución material del pacto de corrupción da a luz a un nuevo delito, el cual es repetido si el acto codiciado por el corruptor no ha sido cumplido por el corrompido hasta después de que éste haya recibido el pago que le había sido propuesto ${ }^{74}$. La doctrina francesa considera que la corrupción es una infracción instantánea, es decir el delito es consumado desde la solicitación o bien desde la aceptación en esta última hipótesis, desde la conclusión del pacto -. En este último supuesto, la corrupción es un delito sucesivo cuando el pacto da lugar a varios actos de ejecución ${ }^{75}$. Precisa XIAO-YING que todos estos momentos (solicitación, aceptación de la oferta, recepción de las dádivas) son, a menudo, escalonados en el tiempo, caracterizan el cumplimiento de la corrupción y forman tantos delitos sucesivos mientras dura el acuerdo fraudulento ${ }^{76}$. La jurisprudencia afirma esta postura al enunciar que "si el delito de corrupción es una infracción instantánea, consumada desde la conclusión del pacto entre el corruptor y el corrompido, el mismo delito se renueva con cada acto de ejecución del dicho pacto"77. Se podría preguntar el interés de esta estructura identificada por la doctrina y la jurisprudencia. Ambas son unánimes en acordarse que el último de los actos de ejecución marcará el punto de partida de la prescripción de la acción pública, el cual se retrasará por la dificultad de probar el momento del nacimiento del pacto corrupto ${ }^{78}$.

La figura del delito sucesivo tal como se ha aplicado en el delito de corrupción por la doctrina y la jurisprudencia francesa recuerda, por la equivalencia funcional, al delito continuado en el Derecho español. Indican MUÑOZ CONDE y GARCÍA ARÁN la dificultad de establecer el con-

\footnotetext{
${ }^{73}$ I. OLAIZOLA NOGALES, El delito de cohecho, op. cit., p. 259

${ }^{74}$ M-P. LUCAS de LEYSSAC y A. MIHNAN, Droit pénal des affaires..., op. cit., no1015.

75 M. DELMAS-MARTY y G. GIUDICELLI-DELAGE, Droit pénal des affaires, op. cit., p.294.

${ }^{76} \mathrm{H}$. XIAO-YING, La lutte contre la corruption..., op. cit., p.51.

77 Cass. crim. 27-10-1997, affaire Carignon, JCP, 1998, II, 10017.

78 M. DELMAS-MARTY y G. GIUDICELLI-DELAGE, Droit pénal des affaires, op. cit., p.294 ; H. XIAO-YING, La lutte contre la corruption..., op. cit., p.51 ; M. VIGNAU, Le délit de corruption, op. cit., p.55.
} 
cepto de unidad de acción hace que, muchas veces, se llegue a admitir un concurso de delitos allí donde realmente, con una valoración global de lo acaecido, sólo hay un delito, aunque cometido en diversos momentos y a través de la realización de distintas acciones perfectamente separables de unos a otros. Surge así el problema de la existencia de pluralidad de acciones constitutivas de un solo delito ${ }^{79}$. En palabras de MIR PUIG $^{80}$, la estructura del delito continuado es una construcción de la doctrina y de la jurisprudencia, acogida en el CPE de 1983, para evitar tener que admitir la concurrencia de varios hechos típicos constitutivos de otros tantos delitos cuando existe una unidad objetiva y / o subjetiva que permite ver a distintos actos, por sí solos delictivos y no producidos en forma de "unidad natural de acción", como parte de un proceso continuado unitario. Se habla en este caso de una "unidad jurídica de acción". El delito continuado, según la definición propuesta por MUÑOZ CONDE y GARCÍA ARÁN, consiste en dos o más acciones homogéneas realizadas en distinto tiempo, pero en análogas ocasiones, que infringen la misma norma jurídica o normas de igual o semejante naturaleza. El delito continuado se caracteriza porque cada una de las acciones que lo constituyen representa ya de por sí un delito consumado o intentado, pero todas ellas se valoran conjuntamente como un solo delito. El delito de cohecho cumple esta definición del tipo continuado. Desde la solicitación hasta la recepción de promesas y dádivas pueden sucederse varios actos, con los cuales cada uno de ellos es susceptible de consumar el delito. Lo mismo ocurre con el aspecto activo, el que intenta corromper y luego consigue corromper o el que atiende a la solicitud del agente público y lo corrompe, no comete varios delitos sino uno. Si asumimos que las dos facetas del cohecho afectan al mismo bien jurídico, y que su modo de comisión tiene que venir de una de las actividades descritas por el tipo al establecer una conexión entre el momento y el lugar de los actos que puedan consumar del delito de cohecho, entonces se cumplen los elementos objetivos de la estructura del delito continuado. Y si ello fuera insuficiente podríamos acudir a los elementos subjetivos que exigen la presencia de un dolo conjunto o designio criminal común a las diversas acciones realizadas ${ }^{81}$. En efecto, para VALEIJE ÁLVAREZ, en cuanto al dolo del cohecho pasivo propio, es necesario que el funcionario se represente todas las circunstancias esenciales del hecho típico constitutivo del delito. A estos efectos es ineludible que acepte la dádiva entregada o prometida como retribución por un acto contrario al cargo $^{82}$. El funcionario debe ser consciente del carácter y finalidad de la misma y debe querer actuar pese a todo. En el caso concreto de las conductas de "aceptar" y "recibir" el particular atribuirá a la dádiva entregada o prometida el mismo significado. En cuanto a los actos propios del cargo que los sujetos intervinientes en la relación delictiva pretenden perseguir, con la realización de la acción típica -solicitar, ofrecer,

\footnotetext{
${ }^{79}$ F. MUÑOZ CONDE y M. GARCÍA ARÁN, Derecho penal..., op. cit., pp.468 y 469.

${ }^{80}$ S. MIR PUIG, Derecho penal..., op.cit., p.636, no 15.

${ }^{81}$ F. MUÑOZ CONDE y M. GARCÍA ARÁN, Derecho penal..., op. cit., p.469.

82 I. VALEIJE ÁLVAREZ, El tratamiento..., op. cit., pp. 228 y 229.
} 
etc. - por tanto, ellos han de actuar con esta intención ${ }^{83}$. Para las demás modalidades como (los anteriores artículos 425, 426 y actuales artículos 421 y $422 \mathrm{CPE}$ ), bastará con que el elemento intelectual del dolo del autor comprenda, en primer lugar, su condición de funcionario y además la acción típica, esto es, la admisión de una dádiva y regalo, y que éstos sean ofrecidos en consideración a la función que desempeña o del acto ya realizado, es decir, debe conocer el funcionario la conexión causal existente entre el regalo que se le ofrece y la función pública que ejerce ${ }^{84}$.

El interés de este delito se encuentra originariamente en que beneficia al reo, al excluir sus diversas acciones delictivas de las reglas del concurso real, valorándolas como una sola o por lo menos como un solo delito. Sin embargo, se recurrió también a la figura del delito continuado cuando existen dificultades para probar las diversas acciones aisladas, y por otras razones procesales, que no siempre beneficia al reo ${ }^{85}$.

\section{III-El delito de corrupción como delito de emprendimien- to}

En la doctrina española surge un nuevo debate sobre la pregunta si el delito de cohecho encaja en el tipo de emprendimiento. Parece interesante señalar el origen de esta estructura y su régimen jurídico, aunque sea brevemente, antes de responder a esta pregunta. La categoría ha sido elaborada en Alemania y la misma palabra "emprendimiento" pretende traducir literalmente el término alemán "unternehmen". El Código penal alemán, en efecto, en su capítulo 11 numeral 6, establece que "emprender un hecho es su tentativa y su consumación"86. Reconoce RODRÍGUEZ PUERTA que el escaso interés que han despertado en la doctrina española los delitos de emprendimiento probablemente tiene mucho que ver con el reducido número de preceptos que adoptan esta estructura ${ }^{87}$. Se pregunta CERINA que puesto que en el CPE no se utili$\mathrm{za}$, ni en la parte general ni en la parte especial, la palabra "emprendimiento", si es realmente correcto y necesario utilizar semejante terminología ${ }^{88}$. Aunque las premisas sobre las que se asienta esta denomina-

\footnotetext{
${ }^{83}$ Mà. J. RODRÍGUEZ PUERTA, El delito de cohecho..., op. cit., p.251.

${ }^{84}$ J. VIZUETA FERNÁNDEZ, Delitos..., op. cit., p.236.

85 F. MUÑOZ CONDE y M. GARCÍA ARÁN, Derecho penal..., op. cit., p.469; Vid S. MIR PUIG, Derecho penal..., pp.637-639; otra opinión Véase J. VIZUETA FERNÁNDEZ, Delitos..., op. cit., p.247. Este autor propone la estructura de tipo mixto alternativo para tratar la realización de los subtipos que se encuentran en el anterior artículo $425 \mathrm{CPE}$ para conservar la unidad delictiva.

${ }^{86} \mathrm{M}^{\mathrm{a}}$. J. RODRÍGUEZ PUERTA, El delito de cohecho..., op. cit., p.118. Añade la autora que esta especial cláusula definitoria cumple así dos funciones: la primera, declarar punible la tentativa en los tipos en los que se utiliza esta locución -requisito éste necesario a la vista del sistema de numerus clausus que adopta la tentativa en este ordenamiento -, y la segunda, excluir, en esos casos, la aplicación de la atenuación en el capítulo 23. II, de este cuerpo legal, para el delito intentado.

${ }^{87}$ Ibídem, op. cit. p.118.

${ }^{88}$ G. D. M. CERINA, La lucha contra la corrupción, op cit., p.652.
} 
ción en Alemania no se corresponde con las que acoge el CPE, ambas realidades presentan una estructura similar. La doctrina española ofrece alternativas para designar los delitos que equiparan la tentativa y la comisión: "delito de tentativa", "delitos de atentado", o la genérica, "delito de consumación anticipada"89. Si la diferenciación terminológica no es pacífica, tampoco lo es en cuanto a la definición de lo que se entiende por delito de emprendimiento. Una parte de la doctrina entiende que este tipo de delito se caracterizaría "por realizar una equiparación típica entre lo que desde la perspectiva de la acción sería una tentativa y la consumación" 90 , debiéndose excluir de la categoría "aquellos delitos en los que se establecen reglas excepcionales destinadas a equiparar, únicamente a efectos de pena la tentativa o la consumación, o a incriminar autónomamente tentativas cualificadas" 91 . Otra parte de la doctrina defiende que serían "delitos sui generis" aquellos en los que "existen supuestos de acciones que materialmente constituyen una tentativa o una preparación, pero que el legislador ha tratado como delitos sui generis" 92 , mientras que serían delitos de emprendimiento aquellos en los cuales "el legislador se limita a equiparar la tentativa a la pena de la consumación estableciendo en estos casos una excepción a la regla general"93. Por lo tanto, estas dos posturas pretenden diferenciar, por un lado, aquellos casos en los que una norma de parte especial tipifica como delito consumado una conducta de tentativa de aquellas otras en las cuales la tentativa es equiparada por una norma de parte especial a la consumación sólo en cuanto a la pena ${ }^{94}$. Una de las cuestiones normalmente planteadas en este marco es la aplicabilidad de los límites de relevancia previstos por el CPE en materia de tentativa: toda vez que el Código penal sanciona, en una parte especial, a quien "intenta" hacer algo, ¿deben considerarse punibles incluso todos (o parte) de los actos preparatorios o la referencia ha de retenerse limitada a los ejecutivos? Indica CERINA que se retiene comúnmente que el límite establecido por el artículo 16.1 CPE debe considerarse aplicable tanto a los casos en los que una norma de parte especial sanciona autónomamente la tentativa de delito como en el caso en el cual la equipare quoad poenam a la hipótesis de delito consumado ${ }^{95}$.

La respuesta de los autores parece unívoca: para aquellos delitos en los cuales el legislador, en la parte especial, se limita a cambiar la pena a la tentativa, tipificándola autónomamente con la única finalidad de sancionarle mayormente, "no será posible apreciar una tentativa, un inicio de ejecución de un inicio de ejecución"96 ya que el supuesto sigue siendo de "tentativa", de tal manera que como tentativa ha de ser tratado ${ }^{97}$.

\footnotetext{
${ }^{89}$ Mà. J. RODRÍGUEZ PUERTA, El delito de cohecho..., op. cit., p.121.

${ }^{90}$ Ibídem, op. cit. p.121.

${ }^{91}$ Ibídem, op. cit. p.123.

92 E. FARRÉ TREPAT, La tentativa del delito, Bosch, Barcelona, 1986, pp.496 y 467.

${ }^{93}$ Ibídem, op. cit. p.498.

${ }^{94}$ G. D. M. CERINA, La lucha contra la corrupción, op cit., p.653.

${ }_{95} \mathrm{M}^{\mathrm{a}}$. J. RODRÍGUEZ PUERTA, El delito de cohecho..., op. cit., p.124

${ }^{96}$ Ibídem, op. cit. p.124.

${ }^{97}$ Ibídem, op. cit. p.124.
} 
Además, si "no es posible apreciar una tentativa de tentativa en un delito previsto en la parte Especial como consumado, tampoco lo será en estos supuestos, pues en ambos casos, el peligro para el bien jurídico que estas conductas revelan es insignificante" ${ }^{\prime \prime 8}$. En cambio, la solución para aquellos delitos previstos en la parte especial en los cuales la tentativa aparecería "transformada" en consumación: en estos casos, "a pesar de considerarse perfectamente posible la construcción de una tentativa (...) quizás su punición no resulte siempre adecuada", de tal manera que "es necesario plantearse, tal como ha hecho la doctrina, la impunidad de la tentativa en algunos o en todos los casos en base a fundamentaciones de carácter material, pues, si bien es cierto que en estos casos formal y técnicamente existe una consumación, desde el punto de vista material la acción no ha perdido su carácter de tentativa o de preparación y, por consiguiente, un nuevo adelanto de la punición más allá de lo que el legislador ha previsto puede aparecer innecesario"99. Considera CERINA que la doctrina que plantea la posibilidad de una tentativa de tentativa ahí donde "las necesidades y las características de cada supuesto" lo aconsejan ${ }^{100}$, no proporciona ejemplo ninguno, el mismo autor adhiere a la opinión según la cual, incluso en los casos en los que el supuesto de delito intentado se ve conmutado en delito consumado por una norma de parte especial, en ausencia de una norma expresa en sentido contrario, debe excluirse la posibilidad de sancionar la tentativa de este delito ${ }^{101}$.

Al terminar este breve repaso sobre el concepto de delito de emprendimiento, suscribimos la opinión de CERINA, según la cual la solución a todos los interrogantes planteados vale indistintamente tanto para los así llamados delitos de emprendimiento como para todos aquellos otros en los cuales el legislador, al tipificarlos en la parte especial, considera como delitos consumados lo que, en realidad, representa un principio de ejecución de la acción encaminada a lesionar al bien jurídico protegido. De tal manera que, pretender distinguir aquellos casos en los que la tentativa se convierte en delito consumado de aquellos otros en los cuales la misma sigue siendo tentativa porque el legislador tan sólo

\footnotetext{
${ }^{98}$ Ibídem, op. cit. p.124; E. FARRÉ TREPAT, La tentativa del delito, op. cit., p.498.

${ }_{99} \mathrm{M}$ a . J. RODRÍGUEZ PUERTA, El delito de cohecho..., op. cit., p.123; E. FARRÉ TREPAT, La tentativa del delito, op. cit., p.499.

${ }^{100}$ E. FARRÉ TREPAT, La tentativa del delito, op. cit., p.499.

101 G. D. M. CERINA, La lucha contra la corrupción, op cit., pp.655 y 656. Concluye el autor que la distinción entre delito de atentado, delitos de emprendimiento o delitos sui generis parece ser, desde un punto de vista práctico, de muy escasa utilidad. En ambos casos, el legislador sanciona en normas de parte especial supuestos en los cuales el bien jurídico protegido no resulta lesionado, sino sólo puesto en peligro. Sancionar la tentativa en estos supuestos (y la tentativa no es otra cosa sino un delito consumado de peligro para el bien jurídico) equivaldría a sancionar el peligro de un peligro para el bien jurídico, cosa que a su opinión, choca de frente con el principio de lesividad: sin una indicación expresa del legislador en sentido contrario (que sería, de todas maneras, cuestionable incluso constitucionalmente) debe considerarse preferible no alargar ulteriormente en vía interpretativa el espectro de punibilidad, recordando que el artículo $16.1 \mathrm{CPE}$ exige un principio de ejecución típica, portadora de un peligro para el bien jurídico, insertable en la órbita del tipo.
} 
habría querido, con su mención expresa, aumentar su pena, parece no del todo justificado: incluso en aquellos delitos en los cuales el legislador ha sancionado sólo un principio de ejecución de la acción lesiva del bien jurídico protegido, es siempre posible pensar en la lesión del mismo; de tal manera que el principio de ejecución, a pesar de ser sancionado autónomamente por un precepto de parte especial, sigue siendo un principio de ejecución. Cuando se afirma, por la doctrina, que, en algunos supuestos, el legislador habría llevado a cabo una "equiparación típica entre lo que desde la perspectiva de la acción sería una tentativa y la consumación", se dice cosa exacta. Lo que parece desaconsejable es luego sustituir la palabra "equiparar" con "transformar": un acto que configura un "principio de ejecución" de la acción que lleva a la lesión del bien jurídico ${ }^{102}$, por mucho que sea "equiparado" a la consumación, materialmente sigue siendo un "principio de ejecución" aunque jurídicamente se considera como delito consumado. De la misma manera, cuando se equipara sólo a efectos de pena la tentativa con la relativa hipótesis consumada, la primera sigue siendo materialmente un "principio de ejecución" aunque jurídicamente (quoad poenam) se le trate como un delito consumado. De ahí que, o bien es posible sancionar un "principio de ejecución de un principio de ejecución" siempre o no lo es nunca ${ }^{103}$.

Llegados a este punto, se podría decir que estamos en condiciones de determinar si el delito de cohecho es un delito de emprendimiento, recordando que éste se caracteriza por realizar una equiparación típica entre tentativa y consumación ${ }^{104}$. Para RODRÍGUEZ PUERTA, la mención expresa de la solicitud o la oferta de una ventaja junto a las conductas que desde la perspectiva del bien jurídico suponen la plena conculcación, equivale a construirlo como delito de emprendimiento. De este modo, siempre que para describir la conducta típica se equiparen, en sede normativa, el intento de alcanzar un acuerdo y su efectiva obtención, el tipo será de emprendimiento. En ese caso la conducta típica se habrá previsto en términos de tentativa, siendo indiferente para la consumación del delito la efectiva producción del evento lesivo, el acuerdo de voluntades. Por lo tanto, así planteado el tema, en estos supuestos no nos encontraríamos frente a una tentativa cualificada, ni tampoco ante una mera equiparación, a efectos de pena entre tentativa y consumación, sino ante una particular construcción unitaria de la tentativa y la consumación ${ }^{105}$. En respuesta a este planteamiento, CERINA enfoca su crítica en los casos en que la solicitud o la oferta de una ventaja no llevan a la conclusión de un acuerdo "por causas independientes de su voluntad". Responde el autor que de no ser sancionados por una norma

102Ibídem, op. cit. p.657. Nota el autor que así debe interpretarse el término "resultado" utilizado por el artículo $16.1 \mathrm{CPE}$, so pena de convertir en inoperativa la disposición para los delitos de mera actividad.

${ }^{103}$ Ibídem, op. cit. pp.656-658.

104 Mà. J. RODRÍGUEZ PUERTA, El delito de cohecho..., op. cit., p.125. Precisa la autora que se trata de una particular construcción unitaria de la tentativa y la consumación, en la que se equiparen conductas que desde la óptica del bien jurídico son distintas.

105 Ibídem, op. cit. p.126. 
de parte especial, estos casos lo serían en virtud de la aplicación del artículo 16 CPE. La mención de estas conductas debe explicarse con la intención del legislador de agravar la respuesta sancionadora que la disciplina general habría determinado para sus autores. Lo que hizo el legislador aquí es una equiparación de pena entre la situación para los sujetos en situación de búsqueda de acuerdo, que este se alcance o no ${ }^{106}$.

Para defender su posición, RODRÍGUEZ PUERTA argumenta que lo fundamental para caracterizarlo como delito de emprendimiento es la unificación bajo un mismo precepto del intento de corromper y la corrupción. Una vez confirmado este extremo, será desde esta perspectiva desde la que deberá abordarse la cuestión sobre la posibilidad de construir una tentativa del cohecho. De hecho, en general se defendió, admite la autora, como los delitos de emprendimiento, sería posible conceptualmente apreciar el delito de cohecho en grado de tentativa. En efecto, algunos autores han defendido la calificación de tentativa de la conducta, por ejemplo, del funcionario que solicita por carta, y ésta es interceptada antes de haber sido conocido por el particular al que iba dirigida, o también, aquellos supuestos en los que la conducta del funcionario o del particular consiste en ofrecer o solicitar una ventaja por la realización del acto injusto, cuando éste en realidad resulta ser, desde una perspectiva objetiva, conforme a Derecho - justo -. En general, según la misma autora, podría decirse que en el delito de cohecho resulta difícil un inicio de la ejecución distinto de las acciones unilaterales de los dos autores del delito (solicitar para el funcionario y ofrecer para el particular). Sin embargo, estas conductas consuman el delito, por lo que perderían su condición de tentativas. Así, la posibilidad de apreciar el delito en grado de tentativa va a depender de la interpretación que se haga de los términos "solicitar" y "ofrecer". La respuesta a esta cuestión estará supeditada, en último término, a la exigencia de que la oferta o la solicitud lleguen a ser conocidas por su destinatario ${ }^{107}$.

Replica CERINA, en cuanto a la posibilidad de sancionar una tentativa del cohecho fuera de las hipótesis expresamente consideradas por las normas de la parte especial, que cabe duda que el legislador pueda, previendo su sanción en una norma de parte especial, convertir una tenta-

\footnotetext{
106 Defiende el autor que en ausencia de una regla clara recogida en la parte general del Código, es totalmente arbitrario pensar si el legislador ha optado por equipara la pena de la tentativa con la consumación o que este ha convertido la tentativa en delito consumado: ¿con apoyo en qué criterio, en efecto, debería sostenerse una u otra perspectiva? Mientras que el legislador alemán en una norma de parte general establece un criterio para distinguir los supuestos de emprendimiento, en España, en ausencia de indicaciones legislativas al respecto, de aceptarse que la pertenencia a la categoría implica diferencias de disciplina, se terminaría convirtiendo al intérprete en legislador. Al mismo autor, no le resulta del todo justificado el intento de la doctrina de aplicar al derecho vigente una figura que el mismo derecho no contempla Si se estima conveniente distinguir los delitos sui generis de los delitos de emprendimiento, habrá que plantear una reforma legislativa al respecto (G. D. M. CERINA, La lucha contra la corrupción, op cit., p.658).

107 Mํ. J. RODRÍGUEZ PUERTA, El delito de cohecho..., op. cit., pp.126 y 127.
} 
tiva de delito en un delito consumado. Responder afirmativamente determinará la aplicación al supuesto de parte especial de la disciplina prevista en materia de delito consumado, y del artículo $16.1 \mathrm{CPE}^{108}$. Y en este sentido la doctrina española está de acuerdo con que hay solicitud u ofrecimiento cuando éstas lleguen a ser conocidas por su destinatario, u otra forma de realización imperfecta (la intercepción por la policía, por ejemplo, de la carta de oferta del particular en el bolsillo del funcionario) ${ }^{109}$. Sin embargo, el autor está en contra de la punibilidad de una tentativa de cohecho fuera de los casos expresamente previstos por el legislador. En efecto la solicitud y el ofrecimiento no aceptados configuran hipótesis delictivas en las que se sanciona con una pena más grave un principio de ejecución de la acción lesiva del bien jurídico protegido, que, en este supuesto, no resulta lesionado, sino tan sólo puesto en peligro: admitir la sanción de una tentativa de solicitar (o de ofrecer o prometer), significaría admitir la sanción de una tentativa de la tentativa, lo que parece difícilmente conciliable con una interpretación respetuosa del principio de lesividad. Por otro lado, la tipificación al lado de la hipótesis de delito intentado, de aquélla de delito consumado, impide que, por el sólo hecho de haber sido mencionada por una norma de parte especial, la solicitud o el ofrecimiento no aceptados puedan considerarse equivalentes a las hipótesis en los que el acuerdo realmente se produce (ya que éstas últimas solas representan efectivas lesiones del bien jurídico protegido) ${ }^{110}$. El ilícito se realiza sólo en el caso en que el destinatario de ofrecimiento o promesa acepte (si hubiera aceptación, ya no hablaríamos de solicitar u ofrecer, sino, respectivamente de "aceptar el ofrecimiento o promesa" y de "prometer"), de tal manera que será necesario (al igual que en la tentativa) que el resultadoaceptación no se produzca: así las cosas, parece difícil, según el autor, afirmar que el ilícito está completo de todos sus elementos.

En la doctrina francesa y malgache no se ha planteado este debate. Pero parece interesante recordar el régimen jurídico de la tentativa en ambos sistemas. El artículo 124-4 CPF estipula que es autor de la infracción quien: en primer lugar comete el hecho penado por la ley, y en segundo lugar, intenta cometer un delito grave o, en los casos expresamente previstos por la ley, un delito menos grave. El CPM en su artículo

\footnotetext{
108 G. D. M. CERINA, La lucha contra la corrupción, op cit., p.659.

${ }^{109}$ Ibídem, op. cit. p.660.

110 Ibídem, op. cit. p.661. A menos de querer retener que la tentativa del delito también es una hipótesis de delito consumado. La discusión (querelle), nota el autor, es sólo nominal: así, podríamos decir que, en un caso, se trata de delito consumado, mientras que en el otro, se trata de delito intentado consumado. Como ya ha afirmado, no puede discutirse que quien "solicita" consuma el delito de cohecho. Lo que ocurre es que es preferible decir que consuma un delito de cohecho intentado que, por voluntad del legislador expresada en una norme de parte especial, merece la misma sanción a aplicarse al delito consumado. Vid. I. OLAIZOLA NOGALES, El delito de cohecho, op. cit., p. 408. Para esta jurista la solicitud del funcionario y el intento de corrupción se sancionan como delito consumado pero que este intento de corromper no puede verse como un delito de emprendimiento puro, sino que habrá que interpretarlo como una declaración de voluntad de parte del particular dirigida a un funcionario concreto en la que se realiza la oferta de algo a cambio de un acto.
} 
3 dispone que las tentativas de delitos menos graves no son considerados como delitos salvo en los casos determinados por una disposición especial de la ley. Entiende la doctrina francesa que la ley puede incriminar una etapa más o menos precoz del iter criminis y su elección depende de la política criminal del legislador ${ }^{111}$. Recuerda GARRAUD, que desde los actos preparatorios, la ley puede incriminarlos aunque se encuentran bastante distantes de la tentativa propiamente dicha y aún más de la consumación del delito. Cuando los hechos, por su naturaleza o por la condición de sus autores, tienden a preparar, facilitar u ocasionar ciertos delitos y cuyo carácter, eventualmente peligroso, está suficientemente caracterizado para ser objeto de una previsión penal, la ley incrimina estos hechos como delitos sui generis ${ }^{112}$. En el Derecho penal francés se estipula en el artículo 121-5 que "hay tentativa cuando, habiendo dado comienzo la ejecución del hecho, ha sido suspendido o no ha causado el resultado por circunstancias ajenas a la voluntad de su autor". Nos parece importante subrayar la clasificación que hace la doctrina francesa sobre lo que llama la tentativa simple y la tentativa acabada o delito inacabado. El primer caso sucede cuando se ha detenido al sujeto, a pesar de él, durante la ejecución del delito. El segundo caso ocurre cuando el sujeto ha hecho todo lo que podía y ha ejecutado completamente los actos necesarios para cumplir sus propósitos pero el resultado no ha sido alcanzado. Ambas formas de tentativa se han previsto y se sancionarán bajo ese artículo del CPF. Es de observar que el CPM no prevé el caso de desistimiento voluntario en materia de tentativa en los delitos menos graves como el delito de corrupción. Por lo tanto sería conveniente que el legislador malgache hiciera una reforma de la parte general del CPM y extendiera el privilegio del desistimiento voluntario a los delitos menos graves, evitando así la consumación de estos delitos y favoreciendo la disuasión de los sujetos activos en su proyecto delictivo aun cuando estuvieran en una etapa avanzada del iter criminis ${ }^{113}$.

Volviendo al delito en estudio, se trata de saber si el delito de corrupción en Derecho francés y malgache puede ser clasificado como delito de emprendimiento. Conviene señalar de antemano que no hay precisión exacta de la intención de ambos legisladores si, al equiparar la tentativa a la consumación del delito de corrupción, lo han hecho desde la

\footnotetext{
111 J.-H. ROBERT, Droit pénal général, op.cit., pp. 239.

112 R. GARRAUD, Précis de droit criminel, Sirey , 1934, (15ª éd.), pp. 194 y ss. El autor precisa que el delito sui generis es la incriminación de hechos constitutivos de los actos preparatorios y no la incriminación de las tentativas del delito,

113 Ibídem, op. cit., pp.194 y ss. Argumenta el autor que la ley promete la impunidad, sea cual sea el grado ejecución y mientras el delito no ha sido consumada, al sujeto activo quien, pudiendo llevarlo a cabo, se ha detenido o se ha desistido de su proyecto criminal. Añade que la sociedad, ciertamente, tiene más interés en hacer la vista gorda sobre los actos que no han consumado el delito para prevenir el mal que hacer, que en castigar el mal ya hecho: al declarar punible, en todos los casos, el principio de ejecución, la sociedad llevaría al malhechor a la ejecución completa del delito. Esta amnistía, concedida de antemano para toda tentativa voluntariamente interrumpida hace parte de la misión preventiva del derecho penal.
} 
perspectiva de la acción típica o desde la perspectiva de la pena ${ }^{114}$. Asumir que el delito de corrupción es un tipo de emprendimiento, esto es, una equiparación desde la perspectiva de la acción, conlleva problemas técnicos. En primer lugar, como ya se ha señalado, tal asunción nos llevaría a aceptar la configuración de la tentativa del delito en cuestión. Sin embargo, tanto la doctrina francesa como malgache está de acuerdo en considerar que es imposible contemplar la tentativa en materia de corrupción. Las acciones típicas de "solicitar" o de "proponer" son una forma de tentativa prevista por el legislador y son consideradas como momento anticipado de consumación del delito de corrupción. La técnica utilizada no permite aquí admitir otra forma de tentativa ${ }^{115}$ ya que se trata de un principio de ejecución ${ }^{116}$. Por lo tanto, no se puede contemplar la tentativa de solicitar o de proponer. En segundo lugar, ya que se rechaza la tentativa de una tentativa, la doctrina francesa no admite otra precisión más. Sabemos que, en la doctrina española, se plantea el supuesto en el que la solicitud o la oferta, han sido formuladas pero no han llegado al conocimiento de su destinatario y que se ha propuesto como una figura de tentativa, como ya lo hemos señalado anteriormente. Este planteamiento no es de recibo para la doctrina francesa. En efecto, para que haya represión de la corrupción por solicitación del funcionario o por proposición del particular, hace falta que el acto unilateral venga de la iniciativa de uno de ellos y como delito formal, sea cual sea el resultado posterior, lo que importa es el acto $^{117}$ de proponer o de solicitar ${ }^{118}$. La otra condición sería que independientemente de las formas utilizadas para solicitar o proponer, sería esencial que, en su formulación, no pudiera caber duda en cuanto a la intención del autor de la iniciativa unilateral. A partir de ahí, y cumplidas esas dos condiciones, resulta de poca relevancia si la proposición o la solicitación, ha sido interceptada en el camino o no ha llegado a su destinatario por cualquier motivo o si éste último la ha rechazado. Observamos que, según el análisis de la doctrina francesa que acabamos de hacer, el legislador aquí no diferencia el régimen jurídico de la tentativa simple, la tentativa inacabada y la consumación del delito de corrupción. Nota VITU que como la tentativa es imposible en el delito en cuestión, el desistimiento voluntario del sujeto activo no tendría efecto, aunque se

\footnotetext{
${ }^{114}$ A. VITU, Traité..., op. cit., p. 25. Advierte el autor que "el intérprete no puede ignorar la construcción del conjunto del derecho penal especial. La determinación del alcance de un tipo penal es parcialmente guiada por el lugar y el papel que el legislador le ha asignado en el conjunto del sistema penal. (...) La búsqueda de las intenciones legislativas no es siempre fácil cuando las disposiciones del CP no están coordenadas en un todo coherente y lógico" (p.26).

115 P. RAFOLISY, La protection juridique..., op. cit., p.237 ; A. VITU, Traité..., op. cit., p. 294; C. AMBROISE-CASTÉROT, Droit pénal..., op. cit., p.366 ; M-P. LUCAS de LEYSSAC y A. MIHNAN, Droit pénal des affaires..., op. cit., no1015, 1024 ; M. DELMAS-MARTY y G. GIUDICELLI-DELAGE, Droit pénal des affaires, op. cit., p.290.

116 P. MAISTRE DU CHAMBON, A. LAPAGE y R. SALOMON, Droit pénal des affaires, op. cit., p.148

117 La cursiva es nuestra.

118; M. DELMAS-MARTY y G. GIUDICELLI-DELAGE, Droit pénal des affaires, op. cit., p.288 ; C. AMBROISE-CASTÉROT, Droit pénal..., op. cit., p.366.
} 
produzca antes de la conclusión del pacto prohibido ${ }^{119}$. Tal interpretación encaja también en la lógica del Derecho penal malgache, ya que la interpretación literal de los artículos 2 y 3 del CPM, no deja otra alternativa que conceder el beneficio del desistimiento voluntario para los autores de delitos graves, lo cual no es el caso del delito de corrupción, clasificado como delito menos grave.

Así las cosas, no podemos más que expresar nuestro rechazo respecto del castigo de la solicitación o proposición sin que una de ellas llegue a su destinatario. Si el destinatario consigue conocer la iniciativa del sujeto activo, entendemos que desde la perspectiva del bien jurídico se trataría de una puesta en peligro mientras no hay aceptación de aquél, lo que supondría la lesión del mismo. Por lo tanto, la solicitación o proposición no recibida por su destinatario sería una mera puesta en peligro del peligro al bien jurídico que no se puede sancionar como si fuera una lesión al objeto de tutela. Debería ser considerado como una forma imperfecta de la tentativa con las consecuencias que eso conlleva en el plano sancionador. En efecto, si castigar un principio de ejecución como solicitar o proponer, con la condición de que el destinatario logre conocerlo, supone castigar con la misma pena la mera puesta en peligro y la lesión del bien jurídico ya es criticable en virtud del principio de lesividad $^{120}$, sería aún más inaceptable el hecho de castigar el acto de solicitar o de proponer, sin más.

A parte de ello, como ya se ha señalado, el bien jurídico del delito de corrupción tanto en el Derecho penal francés como el malgasy se cifra en el deber de probidad o de integridad. En este caso, haciendo nuestra la posición de VALEIJE ÁLVAREZ para quien la conducta de corromper debe ser entendida en relación a la voluntad del funcionario y a la conquista de su posible connivencia; rechaza toda posible vinculación con sus cualidades morales o subjetivas. De este modo, la acción "corromper o intentar corromper" ha de ir dirigida a alterar o trastocar la voluntad del funcionario para que consienta en actuar en el ejercicio del cargo de manera distinta ${ }^{121}$. Desde este punto de vista, la manera efectiva de lograr que se trastoque la voluntad del funcionario es llegar a un acuerdo con él corrompiéndolo o, por lo menos intentarlo. Trasladando la idea en el Derecho penal francés y malgache, para que el funcionario con-

\footnotetext{
${ }^{119}$ A. VITU, Traité..., op. cit., p. 294.

120 M. POLAINO NAVARRETE, "Delitos...", op. cit., p. 336. Afirma el autor que "como quiera que tanto la conducta de solicitar como la de recibir hacen expresa referencia a un común objeto, representando por una "dádiva o presente", la aceptación por la autoridad o funcionario de la efectiva entrega de una contraprestación económica debiera tener mayor significancia de pena que la mera solicitud de entrega del mismo objeto". 121 I. VALEIJE ÁLVAREZ, El tratamiento..., op. cit., pp. 45-47. Para la autora, el significado de "corromper o intentar corromper" parece apuntar a la acción del particular dirigida a alterar o trastocar la voluntad del funcionario mediante dinero u otra ventaja, para que a cambio de la compensación obre en el ejercicio de su cargo de manera distinta a la debida, o, lo que es lo mismo, para que por medio de un beneficio económico haga dejación de la obligación de imparcialidad y objetividad que tiene contraída en razón de la función pública que desempeña.
} 
sienta en actuar de manera distinta en el ejercicio del cargo, tiene que haber una aceptación a la oferta que viene del particular, lo que supondría una lesión al objeto tutelado, o por lo menos, que el funcionario conozca o llegue a conocer la intención del particular, sin que su respuesta pueda implicar más de dos opciones: la aceptación, lo que supone la consumación del delito de corrupción pasiva y activa, o su rechazo, lo que supone la consumación del delito de corrupción activa y una puesta en peligro del bien jurídico. Ahora bien, el caso de la oferta que no llegue al conocimiento del funcionario no puede ser tratado como una puesta en peligro del interés protegido, ya que no llega a trastocar ni a alterar la voluntad del funcionario, lo que significa que su capacidad para afectar el bien jurídico es de dudar. Por lo tanto, si no tiene real capacidad lesiva, deberíamos optar por su impunidad o por motivo de política criminal, una pena inferior y nunca una pena igual que la consumación del delito. Otra cosa diferente sería en cuanto a la solicitud, que no llega al conocimiento del particular, y cuya iniciativa es del funcionario, pero incluso en este caso el tratamiento penal no debería tener la misma consecuencia sancionadora que el grado de consumación. Otra vez más, no estamos de acuerdo con RAFOLISY para suprimir el principio de doble estándar con la idea de que la integridad como valor social y jurídico debe ser protegida de igual manera respecto a todos los ciudadanos, sin ninguna discriminación de la situación jurídica de la persona ${ }^{122}$. Si el funcionario no ha recibido la oferta del particular, en nada sería afectada la integridad del primero y el correcto funcionamiento de la Administración. Por lo tanto, abogaríamos por una pena menor por motivo de política criminal si dicha oferta ha sido interceptada. Sería inaceptable justificar la sanción del particular quien es autor de una oferta de corrupción sin que ésta haya llegado a su destinatario por lesión de su integridad moral personal, la cual parece ser un interés fundamental para el desarrollo duradero del sistema social. Insistimos, rechazar semejante postura se justifica porque no es función del Derecho penal moderno intervenir en la convicción moral de cada ciudadano. Por último, estamos de acuerdo con CERINA en afirmar que mientras que el acuerdo implica una lesión del bien jurídico, la solicitud no recibida o el intento de corrupción que no tiene éxito suponen su mera puesta en peligro, su equiparación desde un punto de vista sancionador, es dudosamente compatible con el principio de proporcionalidad y, por ende, de dudosa constitucionalidad ${ }^{123}$.

Después de este análisis, difícilmente se puede considerar el delito de corrupción en Derecho penal malgache y francés como un tipo de emprendimiento.

122 P. RAFOLISY, La protection juridique..., op. cit., pp.335 y 336.

123 G. D. M. CERINA, La lucha contra la corrupción, op cit., p.661. 


PARTE II: ESTUDIOS DE LOS ELEMENTOS TÍPICOS DEL DELITO DE COHECHO 

A lo largo de este apartado, señalamos que para enfocar nuestro trabajo en lo que se refiere al delito de "los gobernantes", se propone que el aspecto pasivo de la corrupción recibirá un estudio más profundizado, acudiendo al aspecto activo sólo en caso de necesidad para la aclaración del análisis aquí aportado. Se tratará entonces de identificar quién puede ser autor del delito de corrupción pasiva (Capítulo III). Además, deberíamos precisar los comportamientos susceptibles de llevar a la consumación del delito en estudio (Capítulo IV). Tras estudiar el acto ejecutado objeto del delito (Capítulo V) podríamos delimitar el contenido del objeto de la corrupción (Capítulo VI). El análisis del tipo subjetivo cerrará esta parte (Capítulo VII).

\section{CAPÍTULO IV: TIPO OBJETIVO (I). LOS SUJETOS ACTIVOS}

Se destacan en nuestra aproximación comparativa dos técnicas, aparentemente diferentes, de legislar por el legislador francés y malgache de un lado y el legislador español del otro. En efecto éste último utiliza la estructura de "delito especial" en la tipificación del delito de cohecho. En la variedad de este tipo de delito, propio o impropio, entendemos que el legislador español ha optado por el tipo de "delito especial propio"1. En cuanto a los primeros, la utilización de la expresión "toda persona" nos puede inducir a pensar que podría tratarse de un delito común, sin embargo, inmediatamente, el precepto precisa las características que debe tener "toda persona" susceptible de ser sujeto activo del delito de corrupción pasiva. Por lo tanto, estamos ante la misma configuración del tipo en ambos sistemas, lo que varía es la formulación de la letra. No obstante, el CPE ha previsto otro elemento, que ni el CPF ni el CPM han estipulado, se trata del concepto de autoridad y funcionario a efectos penales. Si el concepto de autoridad no ha suscitado un debate especial

\footnotetext{
${ }^{1}$ Entre muchos, I. BERDUGO y otros, Curso de Derecho Penal, op. cit., p.208. Precisan estos autores que los delitos especiales sólo los pueden realizar algunos sujeto en comparación con los delitos comunes que pueden ser cometidos por cualquier sujeto. Haciendo una distinción interna entre delitos especiales propios y delitos especiales impropios, mientras en los primeros el tipo prevé sólo como posibles sujetos activos a personas especialmente cualificadas, de forma que esa conducta realizada por otra persona nunca les convertirá en autores del delito (por ejemplo, el delito de prevaricación del artículo 446 sólo puede cometerlo el Juez o Magistrado que dicte una sentencia injusta, quedando impune esta conducta si es realizada por persona que no reúne esta condición) , en los segundos, a diferencias de los anteriores, tienen correspondencia con un delito común, pero su realización por sujeto cualificados hace que éste se convierta en un tipo autónomo distinto. CERINA propone que el delito de cohecho es delito especial propio sui generis: la peculiaridad consistiría en que tratándose de ilícito a realización plurisubjetiva (en las hipótesis consumadas), se requiere que, de sus autores, por lo menos uno reúne determinadas cualidades (G. D. M. CERINA, $L a$ lucha contra la corrupción, op cit., p.665; Véase también I. OLAIZOLA NOGALES El delito de cohecho, op. cit., p. 113).
} 
dentro de la doctrina española, el de funcionario ha sido objeto de una discrepancia entre los autores españoles. Aunque tal previsión no puede más que afianzar, garantizar y delimitar el alcance del precepto en estudio, como veremos, no es una tarea del todo fácil ni mucho menos, pacífica.

\section{Sección 1-El concepto de funcionario a efec- tos penales en Derecho penal español}

\section{I- Los criterios del artículo 24 CPE}

Dispone el artículo 24 CPE en su primer inciso que "a los efectos penales se reputará autoridad al que por sí solo o como miembro de alguna corporación, tribunal u órgano colegiado tenga mando o ejerza jurisdicción propia. En todo caso, tendrán la consideración de autoridad los miembros del Congreso de los Diputados, del Senado, de las Asambleas Legislativas de las Comunidades Autónomas y del Parlamento Europeo. Se reputará también autoridad a los funcionarios del Ministerio fiscal". En su segundo inciso el mismo artículo estipula que "se considerará funcionario público todo el que por disposición inmediata de la Ley o por elección o por nombramiento de autoridad competente participe en el ejercicio de funciones publicas". Antes de plantear los puntos de debate respecto a la interpretación de este precepto, conviene también repasar los puntos de acuerdo entre la doctrina y la jurisprudencia. En primer lugar hay acuerdo sobre la autonomía del concepto de funcionario público a efectos penales. Se trata de un concepto amplio respecto de aquél proporcionado por otra rama del ordenamiento jurídico, sobretodo el administrativo ${ }^{2}$. En segundo lugar, se acuerda pacíficamente que toda autoridad es también funcionario público, mientras no necesariamente es correcto afirmar lo contrario. De ello, según CERINA, se deduce que siendo, en todas las hipótesis de cohecho, sujeto cualificado un "funcionario público o autoridad", no previendo el CPE diferencia de

2 I. OLAIZOLA NOGALES, El delito de cohecho, op. cit., p. 168. Explica que al comparar los requisitos para ser considerado funcionario a efectos penales y a efectos administrativos se puede ver que el primero es un concepto más restringido por un lado y más amplio por otro que el concepto administrativo lo que puede llevar a afirmar que el concepto penal es un concepto autónomo y propio. Es más restringido porque el derecho penal le van a interesar únicamente las conductas de determinados sujetos no por ser funcionarios, sino porque actúan en el ejercicio de una determinada función, la función pública y pueden con su actuación perturbar el correcto funcionamiento de la Administración en el sentido de afectar a la imparcialidad, objetividad y legalidad con que ésta debe actuar frente a los ciudadanos. Y por otro lado es un concepto más amplio, porque se exige únicamente en el artículo 24. 2 del CPE que por disposición inmediata de la ley, nombramiento de autoridad competente o por elección, el sujeto participe en el ejercicio de funciones públicas. I. VALEIJE ÁLVAREZ, El tratamiento..., op. cit., p.72 y 73. Entre otras sentencias SSTS 15-01-1966, 12-02-1979, 12-04-1934 (Ar. 669), 28-01-1966 (Ar. 280), 1-02-1964 (Ar. 570), 7-4-1993 (Ar. 3048), 19-121994 (Ar.10231), 4-12-2007 (Ar. 1030), 10-10-2000 (Ar.1292), 23-05-2005 (Ar. 663). 


\section{CAPÍTULO IV: TIPO OBJETIVO (I). LOS SUJETOS ACTIVOS}

sanción ninguna entre funcionarios y autoridades, se puede concluir que será sujeto activo de cohecho pasivo el funcionario público, así definido por el artículo 24.2 del $\mathrm{CPE}^{3}$. Y, por último, de acuerdo con el precepto de este artículo, la condición de funcionario público se adquiere por la concurrencia de dos requisitos distintos: uno de índole subjetiva, relativo a la existencia de un título o cualidad jurídica en la persona, y otro de índole objetiva que vendrá constituido por una efectiva participación en la función pública ${ }^{4}$. Más allá de estos puntos de acuerdo, la discrepancia se sitúa primero en la interpretación de la parte del precepto "por disposición inmediata de la Ley o por elección o por nombramiento de autoridad competente" y segundo en la delimitación de los que participan en el ejercicio de funciones públicas ${ }^{5}$.

\section{A- PARTICIPACIÓN EN EL EJERCICIO DE FUNCIONES PÚBLICAS}

Como ya hemos señalado, es funcionario público a efectos penales quien participa de una función pública. Con independencia de que esta participación puede ser excepcional o singular para poder atribuir la cualidad de funcionario, se desprende que la noción de funcionario se define mediante el reenvío al concepto de función pública, transformando la tarea hermenéutica en una tautología o en un mero juego de intercambio de palabras ${ }^{6}$. Por lo tanto se necesitará preguntarse ¿qué es función pública?

\section{1- Las propuestas de la doctrina española respecto al concepto de funciones públicas}

Se destacan entre la doctrina española tres principales corrientes de interpretación al respecto.

La primera corriente se basa en un criterio formal según el cual son funciones públicas las que se realizan mediante actos de Derecho público. Es decir si la actividad de un ente público está sometida a Derecho público, serán funciones públicas y si la actividad esta sometida a Derecho privado, serán funciones privadas. Por consiguiente, quienes presten sus servicios a una entidad sometida a Derecho público serán funcionarios públicos a efectos penales independientemente de que su ré-

\footnotetext{
${ }^{3}$ G. D. M. CERINA, La lucha contra la corrupción, op cit., pp.711 y 712.

4 I. VALEIJE ÁLVAREZ, El tratamiento..., op. cit., p.54; J. M. RODRÍGUEZ DEVESA y A. SERRANO GÓMEZ, Derecho penal español, Parte especial, op. cit., pp.1125 y 1126; E. OCTAVIO DE TOLEDO Y UBIETO, La prevaricación..., op. cit., pp.139 y 142 ss.

${ }^{5}$ I. VALEIJE ÁLVAREZ, El tratamiento..., op. cit., p.57. Habla de la interpretación doctrinal, que goza de un gran número de partidarios y prescinde de entrar a considerar el tipo de relación subjetiva que existe entre el sujeto y la Administración, poniendo en cambio, el acento en la efectiva participación de funciones públicas, núcleo en torno al cual gira para ellos todo el concepto penal. G. D. M. CERINA, La lucha contra la corrupción, op cit., p.713. Para este autor se trata de la individualización del límite "externo" entre sujetos "públicos" y "privados", es decir, la acotación de la expresión "participación en el ejercicio de una función pública".

${ }^{6}$ I. VALEIJE ÁLVAREZ, El tratamiento..., op. cit., p.57.
} 
gimen estatutario personal no sea público ${ }^{7}$. Esta postura ha sido criticada por VALEIJE ÁLVAREZ por ser artificial y harto insegura para diferenciar el carácter público o privado de la función, puesto que la Administración, cada vez más sujeta sus intervenciones de fomento y desarrollo económico tanto al Derecho público como al privado. Así, si por una parte, la Administración confía cada vez más la ejecución de servicios públicos de carácter técnico a empresarios privados - a través de la concesión, el concierto o de arrendamientos de servicios - a los que estima mejor equipados para cumplirlos de manera satisfactoria, de otro, al lado de esta personas privadas que ejecuten tareas de interés general existen órganos fácticamente privados, que en realidad son organismos públicos, cuyo carácter privado sólo es una fachada jurídica, y en el fondo no constituyen más que prolongaciones disimuladas de la Administración ${ }^{8}$.

La segunda corriente, de criterio teleológico, define las funciones públicas atendiendo a los fines que se debe perseguir con dichas actividades que constituyen a la par los fines inherentes a la existencia del Estado. Bajo este criterio se consideran públicas aquellas funciones que tienden al bien común, interés colectivo o social o que satisfacen necesidades colectivas 9 . En contra de esta postura se ha defendido que ningún fin es inherente a la esencia del Estado y la identificación del Estado con un fin específico, supone una restricción inadmisible de su concepto, ya que el Estado constituye un medio para la realización de todos los fines posibles. Además, el recurso a un criterio que incida en el fin público que persigue la actividad, debido, fundamentalmente, a su naturaleza coyuntural, impide la construcción de un concepto ahistórico y estable de funciones públicas (y correlativamente de funcionario público) de tal manera que el criterio sería incompatible con los principios de rigor y taxatividad que deben presidir la interpretación de los tipos penales, ya que la concreción de un elemento como es, en concreto, el término función pública no puede depender de las orientaciones que suministre cada vez la experiencia histórica, política o social de un Estado en concreto $^{10}$. A estas objeciones contesta OLAIZOLA NOGALES que no habría problema ninguno en admitir un concepto coyuntural "de finalidad pública", admitiendo a la vez que el mismo no debe necesariamente postularse como inestable ya que no tendría por qué variar según qué partido ostente el poder: en un Estado social y democrático de Derecho existen objetivos básicos y sociales que se deben cubrir, como la sanidad, la justicia, la educación, etc., por lo que siempre mantendrá un concepto general de función pública, variando a lo largo del tiempo, únicamente su contenido específico ${ }^{11}$.

7 J. QUERALT JIMÉNEZ, "El concepto penal de funcionario público", en Cuadernos de Política Criminal, no 27, 1985, pp.482 ss.

${ }^{8}$ I. VALEIJE ÁLVAREZ, El tratamiento..., op. cit., pp.61 y 62.

${ }^{9}$ E. CASAS BARQUERO, “Observaciones...", op. cit., p.876 y 877.

${ }^{10}$ I. VALEIJE ÁLVAREZ, El tratamiento..., op. cit., p.61.

${ }^{11}$ I. OLAIZOLA NOGALES El delito de cohecho, op. cit., pp. 133 y 134. 


\section{CAPÍTULO IV: TIPO OBJETIVO (I). LOS SUJETOS ACTIVOS}

La tercera corriente, de criterio formal-subjetivo, sostiene que la función pública es aquella actividad realizada por un ente público. La formulación de este criterio se apoya en las críticas formuladas a las dos anteriores y ha sido propuesta por VALEIJE ÁLVAREZ para quien "difícilmente se puede reconocer la función pública a una noción formal, esto es caracterizada por criterios objetivos", debe admitirse que "en la mayoría de las ocasiones, de una función pública se puede hablar solamente en un sentido orgánico-subjetivo, equivalente a actividad desarrollada por la propia Administración, ya sea ésta de ámbito estatal, autonómico o local"12. Después de proponer un listado más o menos completo de órganos que integrarían una Administración Pública entendida en sentido amplio"13, afirma la autora que "función pública es toda aquella actividad material o jurídica que directa o indirectamente (...) es imputable (al Estado). Lo esencial, pues es la titularidad de la actividad o la función, siendo por el contrario un dato accidental la forma concreta de gestión a través de la cual éste se desempeñe"14. De esta propuesta parecen quedar excluidos aquellos particulares que, al margen de cualquier tipo de relación con la Administración, desempeñan, a todas luces, funciones públicas: estas actividades no parecen poderse decir de ninguna manera imputables a la Administración. Por otra parte, si se abandona la adopción de un criterio teórico estricto, tampoco existe mayor problema en englobar a estos sujetos en el listado de personas que participan en el ejercicio de una función pública. La propia autora admite que "bajo la expresión «ejercicio privado de funciones públicas» se designan ciertas actividades que gozan de una especial eficacia reconocida por el Derecho o que se ejercitan haciendo uso de potestades que, en principio, sólo corresponden a la Administración (por ejemplo, dar fe con presunción de verdad, ejercer autoridad, imponer

\footnotetext{
12 I. VALEIJE ÁLVAREZ, "Reflexiones sobre los conceptos penales de funcionario público, función pública y "personas que desempeñan una función pública»", Cuadernos de Política Criminal, 1997, p.473. Sobre esta postura observa CERINA que la idea entraña un matiz tautológico ya que no hace sino desplazar la pregunta: en el complicadísimo contexto actual, ¿qué debemos de entender por "actividad desarrollada por la propia Administración”? ¿Cuál es el exacto alcance de la expresión "ente público”? Contestar a estas preguntas de forma teóricamente satisfactoria, parece implicar la utilización de aquellos criterios ya criticados (G. D. M. CERINA, en La lucha contra la corrupción, op cit., p.716).

13 I. VALEIJE ÁLVAREZ, “Reflexiones...”, op. cit., pp.471 y 472. Según la autora serían entes públicos los entes públicos "de mano pública" y los entes privados "de mano pública”. El primer conjunto incluiría los "organismos -estatales, autonómicos o municipales - estructurados en órganos - dependientes o autónomos -, que se rigen por reglas presupuestarias y que, generalmente, son gestionados por personas de empleo estable. En el segundo conjunto de órganos se colocarían las "Entidades de Derecho público que por ley han de ajustar sus actividades al ordenamiento jurídico privado (...)" cuya característica común sería la de ser "fundados con el asentimiento del legislador para controlar algún sector de productividad de interés estratégico o para estar presentes en un determinado sector de servicios (transportes, abastecimiento de hidrocarburos, suministro de aguas)" o el "haber sido creados por otro organismo estatal (normalmente un Ministerio, una comunidad autónoma o un municipio) con el cual subsiste una relación de sujeción especial".

14 Ibídem, op. cit., p.473.
} 
correctivos o sanciones, ejercer la potestad arbitral, contribuir a la formación oficial de precios de contratación, etc.)"15.

La mayoría de la doctrina española ha preferido emplear estos criterios de forma simultánea o combinándolos todos o dos de ellos. Se ha llegado entonces a una propuesta de definición de la función pública en la que deben concurrir tres elementos: 1) un elemento subjetivo: la función pública es la llevada a cabo por un ente público; 2) un elemento objetivo: función pública es la realizada mediante actos sometidos al Derecho público; 3) un elemento teleológico: función pública es aquélla en la que se persiguen fines públicos ${ }^{16}$. A este criterio ecléctico se ha adherido la jurisprudencia española ${ }^{17}$ que entiende, en una de sus numerosas sentencias, que la función pública "se determinará por el interés servido, por la tendencia y finalidad de los actos realizados para conseguir actividades públicas y no privadas, dirigidas al bien común y desde dentro de un órgano oficial, estatal, provincial o corporativo de igual condición pública..."18. Y recientemente la sentencia 1030/2007 de 4 de diciembre afirma que "en cuanto al concepto de función pública, la doctrina ha utilizado diversos criterios para su identificación. Desde un punto de vista formal se ha entendido que se calificarán como funciones públicas las actividades de la Administración sujetas al Derecho público; teniendo en cuenta las finalidades con las que se ejecuta la actividad, se ha sostenido también que serán funciones públicas las orientadas al interés colectivo o al bien común, realizadas por órganos públi$\cos ^{\prime \prime} 19$.

\footnotetext{
${ }^{15}$ Ibídem, op. cit., p.472. Esta postura ha sido criticada por CERINA para quien se pregunta si la tesis de VALEIJE ÁLVAREZ es de tipo objetivo o subjetivo: si la naturaleza pública o privada de la actividad de un sujeto se hace depender de la calificación de "público" o "privado" del órgano en cuyo marco dicha actividad se lleva a cabo, diremos que la tesis es subjetiva, mientras que diremos que se trata de una tesis objetiva toda vez que la calificación de la actividad dependa de notas inherentes al objeto de la misma. Por lo tanto, discrepa el autor respecto de la parte en la que se incluyen en el abanico de personas que desempeñan una función pública a los particulares "que no están integrados dentro de la organización burocrática del Estado", aquí VALEIJE ÁLVAREZ asume una postura objetiva: las actividades desempeñadas por estos sujetos según la autora pueden calificarse de función pública toda vez que "gozan de una especial eficacia reconocida por el Derecho o que se ejercitan haciendo uso de potestades que, en principio, sólo corresponden a la Administración". Y efectivamente, no podría ser de otra forma: si se quiere calificar de pública una actividad que se desarrolla fuera del marco de un organismo latu sensu público, no queda sino adoptar un criterio objetivo que prescinda de la naturaleza del órgano (G. D. M. CERINA, La lucha contra la corrupción, op cit., pp.724 y 725).

${ }^{16}$ Entre otros I. OLAIZOLA NOGALES, El delito de cohecho, op. cit., p.132; E. CASAS BARQUERO, “Observaciones...", op. cit., p.876.

${ }^{17}$ Severamente critica CERINA a la jurisprudencia por su actuación inspirada a dudosos criterios de justicia sustancial cuya aplicación no parece ser incumbencia constitucionalmente confiada al poder judicial (G. D. M. CERINA, La lucha contra la corrupción, op cit., p.718).

${ }_{18}$ STS 23-4-1973 (Ar. 1772); Vid I. OLAIZOLA NOGALES, El delito de cohecho, op. cit., pp.131 y 132 para un análisis de otras sentencias.

${ }^{19}$ También G. D. M. CERINA, La lucha contra la corrupción, op cit., pp.719-722, analiza la jurisprudencia al respecto.
} 


\section{CAPÍTULO IV: TIPO OBJETIVO (I). LOS SUJETOS ACTIVOS}

\section{2- Observaciones y toma de postura}

Para la doctrina española la dificultad se encuentra en delimitar lo que se entiende por "función pública" ya que puede ser sujeto activo de los delitos de cohecho de los nuevos artículos 419, 420, 421, 422 incluso "cualesquiera personas que participan en el ejercicio de la función pública”, precisa el nuevo artículo 423 CPE. Tal situación, con el precepto del artículo 24.2 CPE, ha dejado a la interpretación un espacio más amplio $^{20}$.

En primer lugar, antes de enfocarnos en la expresión "función pública", sería interesante resaltar el modo de vinculación del funcionario a efectos penales con la función pública a partir del verbo "participar", el cual ha sido objeto de interpretación a partir de la expresión "ejercicio del cargo"21. Para QUERALT JIMÉNEZ, ejercer el cargo y participar en el ejercicio de las funciones públicas es lo mismo a efectos penales ya que por una pura cuestión terminológica, "la coloquialidad de las expresiones del Código penal en este contexto no permite efectuar preciosismos dialécticos con su terminología". Además conforme a la ratio de la ley penal "no parece convincente el limitar la consideración de funcionario público a efectos penales únicamente a quien lo es desde el punto de vista de otros sectores del Derecho público, máxime si se tiene en cuenta la polémica que en torno a tal concepto se respira en Derecho administrativo. Por ello, junto a los que desempeñan funciones públicas en el sentido del Derecho Público, el CP incluye otros individuos en la categoría de funcionarios, por vía de título de incorporación, los cuales de otro modo, no lo serían. Todo ello, concluye el autor, permite la equiparación terminológica aquí sostenida"22.

En contra de esta propuesta se posiciona COBO DEL ROSAL quien entiende que se ha de evitar el uso indistinto de participación del ejercicio de la función pública y ejercicio del cargo, ya que se puede participar en la función pública sin ejercer y sin tener un cargo. Para este autor la rúbrica del Título del CP (se trata del CPE 1944/1973) "de los delitos de los funcionarios en el ejercicio de sus cargos", resulta redundante y repetitiva. Señala que "es indudable que el ejercicio del cargo supone precisamente la participación del ejercicio de la función. Por tanto, siempre que se cite en el CP el término funcionario público es porque participa del ejercicio de la función, del cargo público. En consecuencia carece de sentido decir "en el ejercicio de sus cargos", porque es justamente lo que le da rango de funcionario, ya que fuera del mismo se carece de dicho carácter. Si el CP hubiera sido coherente, le habría bastado con decir en el título VII del libro II del CP «De los delitos de los funcionarios públicos», evitando una inútil repetición”. Por otro lado, el mismo autor considera que el legislador habría tenido que agrupar bajo esa rúbrica todos aquellos delitos en los el sujeto activo es funcionario público y, en

\footnotetext{
20 Ibídem, op. cit., p.722.

21 I. OLAIZOLA NOGALES, El delito de cohecho, op. cit., pp.135 y ss.

22 J. QUERALT JIMÉNEZ, “El concepto penal...”, op. cit., p.484.
} 
consecuencia, todos aquellos delitos que se cometen en la participación del ejercicio de la función pública ${ }^{23}$.

Esta postura de COBO DEL ROSAL ha sido criticada por OCTAVIO DE TOLEDO quien ve un pequeño vicio de planteamiento en su argumentación, lo cual oscurece todo el desarrollo posterior. El planteamiento de que el ejercicio del cargo supone precisamente la participación del ejercicio en la función pública es engañoso, porque ejercer el cargo supone más que participar del ejercicio de la función pública, implica ejercer dicha función; por ello el inicial planteamiento no se puede invertir, es decir, la participación en el ejercicio de la función pública no implica el ejercicio del cargo; en cambio, el ejercicio de tal función sí supone el ejercicio del cargo ${ }^{24}$. Defiende el autor que "el legislador persigue un propósito concreto al introducir la puntualización de que las conductas han de realizarse ejerciendo el cargo. Al legislador no le interesa agrupar en este título todos los delitos de los empleados públicos (de los que desempeñan un cargo público), sino únicamente aquéllos que son cometidos por estos precisamente cuando ejercen el cargo y no en otras ocasiones en las que un empleado público (del que se puede predicar tal cualidad porque desempeña un cargo público) realiza acciones consideradas delictivas, fuera del ejercicio del cargo que desempeña, o bien, realizándolas dentro del mismo, cuando con ellas conculca no sólo la función pública, sino también a otros bienes jurídicos, pero el legislador estima prevalente en estos casos a efectos de sistematización el primero respecto a los segundos" 25 . Por lo tanto, la fórmula "en el ejercicio del cargo" debe ser entendida en sentido penal, en sentido amplio. Al legislador le interesa agrupar las conductas de los funcionarios públicos (funcionarios en sentido penal) que, atentando contra la función pública, se llevan a cabo precisamente por realizar esa participación en el ejercicio de tal función; no le interesan ni las que atacando dicho bien jurídico, se realizan fuera de esa actividad (por ejemplo las de los particulares que ni siquiera participan en el ejercicio de la función pública), ni las que realizadas dentro de esa actividad atacan además del bien jurídico señalado otro considerado prevalente, lo que motiva su ubicación en otros lugares del CP, ni mucho menos las que realizadas por quienes tienen la cualidad de funcionarios públicos, no atacan el bien jurídico motivo de la agrupación (las conductas de los funcionarios cuando actúan fuera de su esfera profesional) ${ }^{26}$. Añade OCTAVIO DE TOLEDO que el ejercicio del cargo, por tanto, no debe ser tomado en

\footnotetext{
${ }^{23}$ M. COBO DEL ROSAL, "Examen crítico...", op. cit., pp.254 y ss. Precisa el autor que lo que no puede decirse es que los tipos previstos en el título VII sean los únicos que recogen esta nota de especialidad, por cuanto siempre se hable en el CP de funcionario público habrá que tener en cuenta la definición del párrafo 3o del art.119 del CP, esto es, la participación en el ejercicio de la función pública. No todos los delitos que se cometen con ocasión de la función se encuentran en el título VII, lo que afirma más la impropiedad de la rúbrica y de la eficacia de la participación del ejercicio de funciones públicas siempre que el ordenamiento penal trata del "funcionario".

${ }^{24}$ E. OCTAVIO DE TOLEDO Y UBIETO, La prevaricación..., op. cit., p.139.

25 Ibídem, op. cit., pp.140 y 141.

${ }^{26}$ Ibídem, op. cit., p.142.
} 


\section{CAPÍTULO IV: TIPO OBJETIVO (I). LOS SUJETOS ACTIVOS}

sentido estricto o técnico, sino con un carácter ampliatorio. Ello supone abarcar la mera participación en el ejercicio de la función pública. En este sentido la rúbrica desglosada diría lo siguiente: "de los delitos de los que participan del ejercicio de funciones públicas, en la participación de dichas funciones". Bajo este prisma no se excluirán de la agrupación aquellas conductas de los particulares que, participando del ejercicio de funciones públicas (siendo funcionarios a efectos penales) no ejercen cargo alguno, entendiendo este término en su acepción administrativa ${ }^{27}$.

Consideramos más convincente la propuesta de OCTAVIO DE TOLEDO, y compartiendo la postura de OLAIZOLA NOGALES 28 , creemos que al legislador no le interesa tanto recoger en el título VII los delitos cometidos por los funcionarios públicos, sino los delitos que dichos funcionarios públicos (sujetos que en virtud de la ley, nombramiento o elección participan en el ejercicio de funciones públicas) cometen cuando precisamente están ejerciendo dicha función. No basta, por tanto para que un sujeto cometa un delito de los tipificados en el título VII que sea funcionario, (que participe en el ejercicio de las funciones públicas en virtud de disposición inmediata de la ley, elección o nombramiento), sino que realice la conducta como funcionario público, esto es en el ejercicio de su cargo (se trata de conductas que perturban bienes jurídicos directamente relacionados con tal ejercicio). Desde esta perspectiva, estamos de acuerdo con OCTAVIO DE TOLEDO cuando dice que la fórmula en "el ejercicio del cargo" debe ser entendida en sentido amplio y no en sentido estricto administrativo, porque, además, no tendría sentido que se entendiera el concepto de funcionario público a efectos penales como un concepto más amplio que el concepto administrativo y se limitase la posibilidad de cometer los delitos del título VII CP 1944/1973 (traspasable al título XIX CP 1995) a los que ejercieran un cargo en sentido administrativo, ya que ello llevaría a que sólo los funcionarios en sentido administrativo, es decir aquellos que ejercen un cargo estricto, pudiesen ser autores de los delitos tipificados en el título VII. Por lo tanto, aceptando el concepto amplio de cargo, se pueden considerar sinónimos el ejercicio del cargo y la participación en la función.

Volviendo ahora al intento de delimitar el concepto de función pública por la doctrina española, hemos señalado los límites de cada una de las

\footnotetext{
${ }^{27}$ Ibídem, op. cit., pp.142 y 143. Concluye el autor que "estamos ante un título que recoge los delitos contra la función pública cometidos por aquéllos que pueden atacarla desde dentro (quienes participan de su ejercicio), precisamente cuando actúan desde el interior (cuando realizan esa participación). No estamos ante todos los delitos cometidos por los funcionarios públicos, tampoco ante todos los delitos que atacan la función pública, ni ante los delitos que no atacan dicho bien jurídico aunque el sujeto activo reúna la condición de funcionario público a efectos penales, precisamente porque no es actuando en dicha cualidad cuando los comete; ni tampoco por último, ante delitos que atacando tal valor son cometidos por quienes ni siquiera participan del ejercicio de funciones públicas ( no son funcionarios públicos a efectos penales, sino llanamente particulares)".

${ }^{28}$ I. OLAIZOLA NOGALES, El delito de cohecho, op. cit., p.139.
} 
tres propuestas. Estos límites afectarán al criterio ecléctico adoptado por la jurisprudencia y la mayoría de la doctrina. Combinar dos o tres criterios a la vez puede ser tentador pero no consigue garantizar una aproximación del todo aceptable respecto por ejemplo al principio de taxatividad y sobre todo, cuando la jurisprudencia ha llegado a interpretaciones amplias con "dudosos criterios de justicia sustancial cuya aplicación no parece ser incumbencia constitucionalmente confiada al poder judicial" ${ }^{29}$. En efecto, además de lo que se ha dicho sobre el criterio teleológico que ha sido criticado por la cuestión inherente a los fines del Estado y por la de la finalidad pública que sería "coyuntural" y nunca "ahistórico", totalmente incompatible con el principio de taxativi$\operatorname{dad}^{30}$, y aunque compartimos también la postura de OLAIZOLA NOGALES quien afirma que el propio Derecho penal es producto de la voluntad política y por ende, coyuntural ${ }^{31}$, nos parece pertinente y contundente la consideración de VALEIJE ÁLVAREZ según la cual decir que es función pública la actividad instrumental a la realización del interés social, bien común, necesidades colectivas... no resuelve sino desplaza el problema: la discusión ya no gira alrededor de la pregunta ¿qué es función?, sino que exige una respuesta a otra cuestión no menos compleja: ¿qué es "interés social"? ¿Qué es el "bien común"? ¿Cuáles son las "necesidades colectivas"? 32 En cuanto al criterio formal, es planteado por QUERALT JIMÉNEZ, para quien "lo decisivo a la hora de dictaminar el carácter público o privado de la función será el régimen jurídico al que se encuentra sometida. Públicas son las funciones sometidas a Derecho público; privadas las que se rigen por el Derecho privado". Pero afirma el autor que "quienes presten su servicio a una entidad sometida a Derecho público serán funcionarios públicos a efectos penales, independientemente de que su régimen estatutario de persona no sea públi-

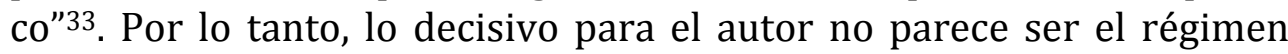
jurídico de la actividad sino el marco normativo en el cual actúa el órgano en el que el sujeto la desempeña. De acuerdo con CERINA, consecuencia de ello, es, inevitablemente que la misma actividad deberá calificarse de pública toda vez que se preste "en una entidad sometida a Derecho público", mientras que, a contrario, será privada si se desempeña en una entidad sometida a Derecho privado ${ }^{34}$. Aunque la crítica que se ha hecho a este criterio sostiene que "existen órganos fácticamente privados, que en realidad son organismos públicos"35, tal obje-

\footnotetext{
${ }^{29}$ G. D. M. CERINA, La lucha contra la corrupción, op cit., pp.718 y 719. El autor destaca la oscilación del Tribunal entre interpretaciones restrictivas (STS 1122/2007, 10-122007) el concepto de función pública hasta llegar a otras sumamente amplias de la misma (STS 1544/2004, 23-12-2004).

${ }^{30}$ I. VALEIJE ÁLVAREZ, El tratamiento..., op. cit., p.61.

${ }^{31}$ I. OLAIZOLA NOGALES, El delito de cohecho, op. cit., pp.133 y 134.

32 I. VALEIJE ÁLVAREZ, "Reflexiones...", p.466.

33 J. QUERALT JIMÉNEZ, “El concepto penal...", op. cit., p.483.

${ }^{34}$ G. D. M. CERINA, La lucha contra la corrupción, op cit., pp.718. Para el autor la tesis no puede calificarse de objetiva, sino que es, una vez más, subjetiva, en tanto en cuanto se apoya no ya en la "publicidad" de la concreta actividad prestada, sino en el tipo de órgano en cuyo marco el sujeto la desempeña.

35 I. VALEIJE ÁLVAREZ, El tratamiento..., op. cit., p.62.
} 


\section{CAPÍTULO IV: TIPO OBJETIVO (I). LOS SUJETOS ACTIVOS}

ción debe ser matizada. En efecto no siempre es fácil determinar si un ente u órgano que actúa utilizando formas jurídicas sustancialmente privadas se encuentra, por sí sólo, fuera del ámbito de aplicación del Derecho público y no está ni mucho menos claro que sea suficiente que la Administración elija para un órgano o ente una forma jurídicoprivada (por ejemplo una sociedad anónima) para concluir que, a dicho ente u órgano, no le sea aplicable de ninguna manera y en ninguna medida una disciplina de Derecho público ${ }^{36}$. Se puede hablar entonces de una deriva subjetivista que debilita el criterio formal-subjetivo a pesar de que se han defendido las limitaciones de criterios objetivos ${ }^{37}$.

Así las cosas, consideramos adecuado y hacemos nuestro el planteamiento que propone CERINA quien aboga por un criterio objetivo. De acuerdo con el autor, para ser sujeto activo del delito de cohecho pasivo, es necesario desempeñar cierta función que se caracteriza por ser pública. Por consiguiente, el punto de partida de la reflexión debe ser que, una vez individualizadas aquellas funciones que son públicas, todo sujeto que las desempeña, con independencia de para quien, en nombre de quien, por cuenta de quien lo haga, es sujeto activo del delito de cohecho pasivo ${ }^{38}$. Por lo tanto, el criterio a tenerse en cuenta debe ser por un lado, objetivo (que distingue según el tipo de actividad y no sobre el órgano o ente en cuyo marco se lleva a cabo) y, por otro, formal (ya que el criterio basado sobre el contenido de la actividad es de demasiado difícil acotación, no queda sino centrarse en las formas en las cuales

${ }^{36}$ G. D. M. CERINA, La lucha contra la corrupción, op cit., pp.726-728.

37 I. VALEIJE ÁLVAREZ, El tratamiento..., op. cit., pp.61 y 62. Véase I. OLAIZOLA NOGALES, El delito de cohecho, op. cit., p.133, quien se pregunta si cualquier actividad realizada por un funcionario será función pública, porque si no lo es habrá que volver de nuevo a plantearse qué es función pública y qué no lo es, y habremos vuelto al inicio de la discusión.

${ }^{38}$ G. D. M. CERINA, La lucha contra la corrupción, op. cit., pp.713. El autor toma el ejemplo de la educación universitaria, en el caso de que afirmáramos que es una función pública, de acuerdo con la normativa en vigor, nos veríamos obligados a concluir que todo profesor universitario, en el momento en el que desempeñe su actividad de educar en la universidad, participa de una función pública, siendo totalmente irrelevante que eduque en el marco de una universidad de derecho público o de derecho privado. Lo mismo ocurre con la azafata. Si concluyéramos que la azafata, a la hora de servir comida en un vuelo intercontinental no participa de una función pública, deberemos concluir que ninguna azafata de ninguna compañía aérea (no importa el régimen jurídico de la empresa) puede ser sujeto activo de la vertiente pasiva del delito de cohecho propio. De la misma manera, si consideráramos que la misma azafata, a la hora de colaborar en la coordinación de la evacuación de un avión en llamas, sí desempeña una función pública, si queremos ser consiguientes con las premisas de las que partimos, diremos que toda azafata - con independencia de la naturaleza pública de la aerolínea en la que presta sus servicios - participa de una función pública a la hora de colaborar en la evacuación de la aeronave. Y finalmente - lo que quizás sea lo más importante de cara a los planteamientos de la doctrina española - de estimar certeras ambas las últimas dos afirmaciones (la azafata no participa de una función pública cuando sirve la comida, pero sí cuando colabora en la coordinación de la evacuación de la aeronave), diremos que la misma persona, empleada por la misma empresa, cuando desempeña la segunda actividad mencionada, puede ser sujeto activo de cohecho pasivo propio antecedente, mientras que no lo podrá ser relación a la primera. 


\section{PARTE II: ESTUDIOS DE LOS ELEMENTOS TÍPICOS...}

dicha actividad se realiza). Será entonces función pública la actividad disciplinada por normas de Derecho público y por determinados actos administrativos ${ }^{39}$.

\section{B- NECESIDAD DE UN TÍTULO DE HABILITACIÓN}

Según el precepto del artículo 24.2 CPE para ser considerado como funcionario a efectos penales no basta con participar en el ejercicio de las funciones públicas sino que se exige uno de los tres títulos que el mismo ha previsto, a saber: la disposición inmediata de la ley, la elección o el nombramiento de autoridad competente. La doctrina mayoritaria considera necesarios estos títulos ${ }^{40}$. A este respecto, QUERALT JIMÉNEZ no considera funcionarios públicos a los meros colaboradores de la Administración, porque lo que hace básicamente este colaborador es cumplimentar su deber, por ejemplo, de denunciar un delito o ejercer un derecho, por ejemplo el de detener a un delincuente in fraganti. "Pero tales conductas, si bien constituyen participación en funciones públicas, no integran per se la noción de funcionario a efectos penales. Para llegar a serlo es requisito indispensable estar habilitado para ejercer tal participación y estar en condiciones de poderse incorporar al puesto correspondiente" 41 . Frente a esta postura, COBO DEL ROSAL, aunque admite la necesidad de un título habilitador para adquirir la condición de funcionario a efectos penales, sostiene que el mero hecho de participar en funciones públicas es causa bastante en el Derecho penal para que un sujeto sea considerado funcionario público. Para el autor, aludiendo al artículo 119, párrafo 3 del anterior CPE, el precepto de este artículo "no requiere una incorporación, sino la mera participación en la función pública. Así, por ejemplo, el colaborador de la Administración sería funcionario a efectos penales desde el momento en que legalmente participa en la función pública, careciendo de esa calidad a efectos administrativos" 42 . Sin mayor especificación de este autor respecto al título con

\footnotetext{
${ }^{39}$ Ibídem, op. cit., p.738. Precisa el autor que habrá que tener en cuenta el ámbito de aplicación del derecho público, según la doctrina administrativista, en todo caso, no refleja acríticamente la distinción comúnmente aceptada entre instituciones "de derecho privado" e instituciones "de derecho público" (distinción más relacionada con la forma jurídica del órgano que con el régimen jurídico de su actividad), sino que va más allá de ello, cualquiera que sea el criterio que se adopte para delimitar su extensión. Se ha pronunciado en este sentido VALEIJE ÁLVAREZ para quien funciones públicas o actos estatales son aquellas acciones que son consideradas como actos del Estado, que son imputadas al Estado (y, viceversa, acto estatal es todo y cuanto el Estado atiende) y, un acto sólo puede ser considerado como desarrollo de una función pública - $\mathrm{y}$, por tanto, acto coactivo o estatal - cuando una normativa de Derecho público lo ha calificado previamente como tal (I. VALEIJE ÁLVAREZ, en El tratamiento..., op. cit., p.63). Apoya esta postura Mà. J. RODRÍGUEZ PUERTA, El delito de cohecho..., op. cit., p.164.

40 Entre otros A. DEL TORO MARZAL, "Comentario al artículo 119", en J. CÓRDOBA RODA y otros, Comentarios al Código penal, Tomo II, Ariel, Barcelona, 1972, p.734; VALEIJE ÁLVAREZ, en El tratamiento..., op. cit., p.64; J. M. RODRÍGUEZ DEVESA y A. SERRANO GÓMEZ, Derecho penal español, Parte especial, op. cit., p. 1126.

${ }^{41}$ J. QUERALT JIMÉNEZ, “El concepto penal...”, op. cit., p.485.

${ }^{42}$ M. COBO DEL ROSAL, "Examen crítico...", op. cit., p.237. Señalará el mismo autor más tarde que si por un lado la participación en el ejercicio de funciones públicas sigue
} 


\section{CAPÍTULO IV: TIPO OBJETIVO (I). LOS SUJETOS ACTIVOS}

que un individuo colabora con la Administración ya que sólo con un contrato laboral se lo podrá considerar funcionarios a efectos penales, el hecho de colaborar sin ninguna vinculación con ella impide la misma consideración.

Por lo tanto, estamos de acuerdo en rechazar toda interpretación según la cual se ha afirmado, más o menos claramente, que basta con participar en el ejercicio de una función pública para ser considerado funcionario público a efectos penales. Esta postura supone una interpretación contra legem y por lo tanto inaceptable ${ }^{43}$.

\section{1- La disposición inmediata de la ley}

La interpretación de este primer elemento no es unánime en la doctrina penal española. En efecto, se trata de resolver dos interrogantes: en primer lugar, el significado jurídico-penal del término ley y, en segundo lugar, si con la citada expresión se trata de configurar una modalidad amplia de acceso al ejercicio de la función pública, o bien se refiere a la relación estatutaria que une determinados sujetos con el Estado ${ }^{44}$.

En cuanto al primer interrogante, un sector doctrinal defiende una interpretación restringida de la palabra "ley", no bastando un reglamento o cualquier otra disposición con rango inferior a la ley ya que ello llevaría a extender la responsabilidad criminal en prejuicio del reo y más allá la letra del Código, o a un trato más severo ${ }^{45}$. Incluso algún autor apunta que "a lo más que se puede llegar es equiparar Ley a normas con fuerza de de Ley, es decir, Ley formal y Ley material, estatal, autonómica, tal como hace la Constitución. Pero, no se olvide, que el Código penal tiene rango de Ley orgánica"46. Otro sector doctrinal sostiene que la expre-

siendo "la esencia del concepto penal de funcionario público", debe tenerse en cuenta "la matización (...) atinente al título habilitante"; M. COBO DEL ROSAL y M. QUINTANAR DÍEZ, "Comentario al artículo 24 del Código Penal Español", en Comentarios al Código Penal (Dir. M. COBO DEL ROSAL), Tomo III, Edersa, 2000, pp.46 y 47.

${ }^{43}$ G. D. M. CERINA, en La lucha contra la corrupción, op cit., p.741; I. OLAIZOLA NOGALES, El delito de cohecho, op. cit., pp.145 y 149. Añade esta autora que el CPE al exigir que esa participación en las funciones públicas se realice en virtud de unos títulos de incorporación quiere proteger el correcto ejercicio de esas funciones por parte de sujetos que de alguna manera se encuentran ligados a la Administración. Ello, desde el punto de vista de la autora no es incorrecta, porque lo contrario supone una ampliación excesiva de la protección de la protección penal, siempre y cuando esos títulos de incorporación sean lo suficientemente amplios para que se pueda seguir defendiendo que la diferencia entre el Derecho penal y el Derecho administrativo, es que el primero fundamenta su protección en el correcto desarrollo de esas funciones, necesarias para el libre desarrollo de la sociedad.

${ }^{44}$ M. COBO DEL ROSAL y M. QUINTANAR DíEZ, “Comentario al artículo 24...”, op. cit., p.51; I. OLAIZOLA NOGALES, El delito de cohecho, op. cit., pp.151 y 152. Notará la autora que es probable que en toda discusión se estén entremezclando dos cuestiones distintas que no tiene por qué considerarse contrarias entre sí, sino que responden a dos problemas distintos.

45 J. M. RODRÍGUEZ DEVESA y A. SERRANO GÓMEZ, Derecho penal español, Parte especial, op. cit., p. 1126.

${ }^{46}$ J. QUERALT JIMÉNEZ, “El concepto penal...”, op. cit., p.487. 
sión Ley no puede entenderse en sentido estricto, por lo excepcional de que una ley de este tipo se adscriba a una persona concreta, a una función determinada, entendiéndose así que la expresión Ley comprendería reglamentos o disposiciones inferiores ${ }^{47}$. En este sentido, se ha pronunciado VALEIJE ÁLVAREZ, apelando a la unidad sistemática del Texto penal, y para quien "el artículo 24 permite acceder al status de funcionario por nombramiento de una autoridad competente", interrogándose por qué no por un decreto u otra disposición, "máxime si se tiene en cuenta que la Autoridad puede ser competente para emanar tales disposiciones" ${ }^{\prime \prime 8}$. En otras palabras, puesto que el artículo $24.2 \mathrm{CPE}$ considera como suficiente el "nombramiento de la autoridad competente", sería contradictorio no admitir que pueden constituir títulos idóneos para asumir la cualidad de funcionario a efectos penales también fuentes normativas jerárquicamente superiores al "nombramiento", aunque sean inferiores a la ley ${ }^{49}$. Concluye la misma autora que si bien en Derecho penal sólo tienen la cualidad de Ley las leyes formales, emanadas por el órgano legislativo, el Tribunal Constitucional ha manifestado en diversas sentencias, que la vigencia del principio de legalidad en el ámbito penal, no es impedimento para que la ley remita a disposiciones de rango inferior a los solos efectos de desarrollarla, siempre y cuando en aquélla queden suficientemente detallados determinados elementos de la conducta jurídica. Y, en nuestro caso, la expresión "disposición inmediata de la Ley" no es más que uno de los elementos normativos que conforman la definición penal de funcionario, y que sólo interviene en relación a uno de los modos o formas de adquirir dicha cualidad, por lo que, una interpretación del término "Ley" no conculcaría la vigencia del principio de legalidad 50 .

Respecto al segundo interrogante, un sector de la doctrina española reconoce la dificultad de atribuir a la expresión "disposición inmediata de la ley" el específico carácter de título de conexión o incorporación por lo excepcional de que una ley adscriba a una concreta persona con una función. Por lo tanto, ante esta dificultad fundamental la expresión "por disposición inmediata de la ley" no constituye un requisito independiente, sino que sirve para legitimar los dos restantes títulos - elección y nombramiento - aunque esta postura contradice, sin duda, la estructura gramatical del artículo $24 \mathrm{CPE}^{51}$. Con una postura similar se ha pronunciado MUÑOZ CONDE, para quien las tres fuentes de incorporación pueden reducirse a una: a la disposición inmediata de la ley, por cuanto la elección o el nombramiento tienen que basarse en una ley que las determine ${ }^{52}$. En contra de esta postura se posiciona OLAIZOLA NOGALES y afirma que la Ley de Presupuestos Generales del Estado señala una serie de límites que la oferta de empleo pública de cada ministerio

\footnotetext{
47 A. DEL TORO MARZAL, “Comentario al artículo 119”, op. cit., pp.734 y 735.

48 I. VALEIJE ÁLVAREZ, “Reflexiones...”, p.453.

${ }^{49}$ G. D. M. CERINA, La lucha contra la corrupción, op cit., p.742.

${ }^{50}$ I. VALEIJE ÁLVAREZ, “Reflexiones...”, p.455.

${ }^{51}$ A. DEL TORO MARZAL, "Comentario al artículo 119”, op. cit., pp.735 y 736.

${ }^{52}$ F. MUÑOZ CONDE, Derecho penal, Parte especial, 2009, op. cit., p. 903.
} 


\section{CAPÍTULO IV: TIPO OBJETIVO (I). LOS SUJETOS ACTIVOS}

no podrá sobrepasar. Por tanto, en este sentido, la Ley puede de forma inmediata disponer una plaza concreta. Es decir, la Ley puede ser un título habilitador autónomo de la condición de funcionario, cuando de forma inmediata prevea la creación de una plaza y a la vez funcione como medio de legitimar un nombramiento o una elección, en el sentido de que va a ser siempre una ley la que indique quién es competente para realizar un nombramiento ${ }^{53}$.

A nuestro parecer, sería más acorde con una interpretación restrictiva de ley penal asumir el sentido estricto de la palabra "Ley" y ello con la razón expuesta anteriormente por RODRÍGUEZ DEVESA y SERRANO GÓMEZ, según la cual interpretarla de forma amplia supondría hacer una interpretación ampliatoria contra reo ${ }^{54}$. Sin embargo, al aceptar este planteamiento nos enfrentamos ante otra exigencia legal que es la inmediatez, en sentido estricto también, de la disposición legal como fuente habilitadora autónoma. Por otro lado, no estamos de acuerdo con reducir los tres títulos, según la formula legal, habilitadores independientes entre ellos en uno, "lo cual parece chocar con la interpretación que se propone y en virtud del cual, la ley, por sí sola, no habilitaría inmediatamente absolutamente nada 55 .

Quizá sea preferible una postura intermedia tal como ha sido propuesta por VALEIJE ÁLVAREZ ante las objeciones de las propuestas anteriormente expuestas. Según la autora, "la expresión «disposición inmediata de la ley» (...) está haciendo referencia descriptiva al acto de nombramiento de los funcionarios de carrera (...) es una fórmula jurídica formal - hoy en día reducida a una fictio iuris - que contempla cómo un funcionario constituye su relación con el Ente al que se incorpora. La citada expresión se refiere a la resolución u orden ministerial que se publica en el B.O.E. indicativa de un nombramiento legal"56. Con esta visión orgánico-subjetiva de la función pública, si, por un lado, resulta coherente con las soluciones interpretativas anteriormente apuntadas y

53 I. OLAIZOLA NOGALES, El delito de cohecho, op. cit., pp.151 y 152. Señala la propia autora la objeción fundamental de su postura " y es que en el ejemplo (...) propuesto la Ley dispone de forma inmediata la creación de plazas, pero no las personas concretas que deben ocupar dichas plazas, sin embargo, considero (según la autora) que ésta es la única interpretación posible si no se quiere dejar vacío el contenido de este título de incorporación, porque no existen supuestos en los que una ley indique ya directamente el nombre de la persona que deba desempeñar un cargo".

54 J. M. RODRÍGUEZ DEVESA y A. SERRANO GÓMEZ, Derecho penal español, Parte especial, op. cit., p. 1126.

55 G. D. M. CERINA, La lucha contra la corrupción, op cit., p.743; J. QUERALT JIMÉNEZ, “El concepto penal...", op. cit., p.487, el autor reconoce la dificultad de individualizar a personas que adquieren la calidad de funcionario público (a efectos penales) en virtud de una "disposición inmediata de la ley"; A. DEL TORO MARZAL, "Comentario al artículo 119”, op. cit., p.735. Observa este autor que es también admisible, de manera más hipotética, que se optase por la enumeración independiente de los tres títulos para no hacer demasiado patente aquella desconfianza o preocupación (se refiere el autor al preocupación del legislador de 1870 sobre posibles irregularidades en el nombramiento en la elección) concluyendo que "en cualquier caso la enumeración no es afortunada".

56 I. VALEIJE ÁLVAREZ, “Reflexiones...”, p.456. 
absolutamente mayoritarias en España, por otro y de compartirse las observaciones formuladas, podría quizás admitirse una interpretación distinta del inciso "por disposición inmediata de la ley".

La exégesis propuesta por VALEIJE ÁLVAREZ parece suponer que "participar en el ejercicio de la función pública", implica que se incorpore ${ }^{57}$ a un Ente público. Esta incorporación o adscripción, evidentemente, nunca o casi nunca es expresamente prevista inmediatamente por una ley. De ahí la interpretación de la autora y de la doctrina mayoritaria ${ }^{58}$. Por lo tanto, nos parece pertinente y recibe nuestra adhesión la propuesta de CERINA, quien observa que el artículo 24.2 CPE "no configura títulos de "adscripción" a la función pública, sino títulos de "participación en el ejercicio de funciones públicas". Y si "participar en el ejercicio de una función pública" no presupone la incorporación a un Ente público (admitiendo que pueda llevarse a cabo una diferenciación estricta entre Entes públicos y Entes privados), sino desempeñar una actividad disciplinada por normas de Derecho público y/o determinados actos administrativos, debe concluirse que es funcionario público quien en virtud de una disposición inmediata de ley, desempeña una actividad disciplinada por normas de Derecho público y/o determinados actos administrati$\operatorname{vos}^{59}$.

\section{2- La elección}

La elección consiste generalmente en el nombramiento hecho por votos para desempeñar un cargo o comisión ${ }^{60}$. La doctrina penal española destaca la supresión del adjetivo "popular" desde la reforma del CPE de 1944, lo que significa que hasta esa fecha, el funcionario lo era proveniente del ejercicio de un derecho fundamental de los ciudadanos como es el sufragio. El contexto democrático actual deberá requerir el sufragio universal. Sin embargo, existen una serie de funcionarios a efectos penales que gozan del carácter de autoridad sin ser elegidos directa-

${ }^{57}$ F. MUÑOZ CONDE, Derecho penal, Parte especial, 2009, op. cit., p. 905; A. DEL TORO MARZAL, “Comentario al artículo 119", op. cit., p.735.

${ }^{58}$ G. D. M. CERINA, La lucha contra la corrupción, op cit., pp.743 y 744.

${ }^{59}$ Ibídem, op. cit., p.744. En esta misma línea argumentativa se han pronunciado COBO DEL ROSAL y QUINTANAR DÍEZ para quienes "la expresión "disposición inmediata de la Ley" expresa más que una relación estatutaria interna entre determinados sujetos que una a determinados sujetos con el Estado, encerraría una fórmula amplia que, a efectos penales, permitiría la consideración de funcionario público a quien, en rigor, administrativamente, no lo es, bien por la interinidad de su relación con la Administración, bien por el carácter no profesional de la misma"( M. COBO DEL ROSAL y M. QUINTANAR DÍEZ, “Comentario al artículo 24...", op. cit., pp.52 y 53); T.S. VIVES ANTÓN, La detención: delitos cometidos por los funcionarios públicos contra el ejercicio de los derechos de la persona reconocidos por las leyes: detenciones ilegales, Bosch, Barcelona, 1977, p.49, afirma el autor que "no resulta absolutamente raro que la Ley atribuya determinada participación en el ejercicio de funciones públicas a quien técnicamente, desde el punto de vista del derecho administrativo, no posee la condición de funcionario; y ello, sin que tal atribución, por ser regularmente genérica, implique elección ni nombramiento".

${ }^{60}$ I. VALEIJE ÁLVAREZ, El tratamiento..., op. cit., p.67. Añade la autora que la elección es un medio al servicio de la representación política. 
mente por los ciudadanos ${ }^{61}$. Según QUERALT JIMÉNEZ, lo cierto es que ante determinados sistemas electorales, al ejercer el derecho al voto, si la ley lo prevé y así lo estipula, está poniendo en marcha un complejo sistema de elecciones indirectas que, en puridad, en nada empecen a otorgarles plena naturaleza democrática. En su virtud, la supresión del adjetivo "popular" relativo a las elecciones permite, sin tener que forzar en nada la letra de la ley, la inclusión de aquellos funcionarios que lo son por elección, aunque ésta sea secundaria o incluso terciaria. En definitiva, se está contraponiendo con claridad el acceso al cargo por nombramiento - o designación - al acceso al cargo por voluntad popular - elección -62. Por lo tanto, si después de la elección se necesita nombramiento, habrá que tener en cuenta el primer título de habilitación, ya que el segundo será relevante cuando no se ha previsto elección previa ${ }^{63}$.

\section{3- El nombramiento por la autoridad competente}

Este tercer título de habilitación ha sido puesto en relación con el primero (la disposición inmediata de la ley), de una o de otra manera por la doctrina española. En efecto, cuando una disposición legal prevé la participación en el ejercicio de la función pública, la misma disposición suele necesitar que intervenga un acto administrativo concreto que lo habilite para ello. Este acto se llama "nombramiento"64. El debate se plantea en la fuente normativa que legitima la autoridad que nombra y su nombramiento. Para QUERALT JIMÉNEZ, desde la perspectiva del respeto al principio de legalidad, esta disposición afecta de lleno a los agentes de autoridad que reciben tal calificación en virtud de disposiciones reglamentarias, vulnerando el principio de legalidad si el sujeto no es, previa o simultáneamente, ya funcionario público a efectos penales ${ }^{65}$. En coherencia con lo sostenido respecto de la expresión, "disposi-

\footnotetext{
${ }^{61}$ J. QUERALT JIMÉNEZ, “El concepto penal...", op. cit., p.488, el autor cita los ejemplos de los alcaldes, diputados provinciales, los presidentes de las corporaciones provinciales y los senadores representantes de las Cámaras legislativas autónomas.

62 Ibídem, op. cit., p.488. Se ha surgido la polémica, dentro de la doctrina publicista, para saber si los sujetos que desempeñan funciones legislativas pueden ser considerados funcionarios públicos a efectos penales a la luz de los principios de naturaleza política directamente derivados de la idea representativa, así como a la luz de la inmunidad parlamentaria recogida en el artículo 71.1 de la CE, Vid, I. VALEIJE ÁLVAREZ, "Reflexiones...", pp. 457 y 460; M. COBO DEL ROSAL y M. QUINTANAR DÍEZ, en “Comentario al artículo 24 ...", op. cit., p.55.

${ }^{63}$ I. OLAIZOLA NOGALES, El delito de cohecho, op. cit., p.154.

${ }^{64}$ Ibídem, op. cit., p. 154. La autor toma el ejemplo de aquellos supuestos en los que la ley no dispone de forma inmediata la provisión de plazas, sino que se remite a otras disposiciones que la complementan o la desarrollan, o también aquellos casos en los que no venga precedida de una elección.

65 J. QUERALT JIMÉNEZ, "El concepto penal...", op. cit., p.489. Observa el autor que "al no especificar el CP (analiza en marco del CPE 1944/1973) qué es lo que se entiende por agente de la autoridad y pese a ello, el Texto legal los considera expresamente sujetos pasivos de determinados delitos (...) si su consideración les viene vía reglamento, se está ampliando en perjuicio del reo, y de forma ilegítima, el ámbito de lo punible, puesto que la determinación última de lo que se considere punible, esta en manos de una disposición normativa de menor rango legal".
} 
ción inmediata de la ley", defiende el autor que si la condición de funcionario a efectos penales, encuentra su fundamento en una disposición con rango de Ley que, tras la entrada en vigor de la Constitución española deberá ser orgánica, mal puede ser una Ley ordinaria, y menos aún un reglamento, fuente de punición, pues ello vulneraría los principios de jerarquía normativa y de legalidad ${ }^{66}$. Siguiendo el mismo autor la postura de RODRÍGUEZ DEVESA y SERRANO GÓMEZ ${ }^{67}$, la cual afirma que "no debe ser concedida la categoría de funcionario público a efectos penales a quien no es nombrado mediatamente en virtud de una ley, sino disposición de inferior rango normativo, o cuando se señala que es la ley el origen de la habilitación para conferir el título de incorporación por parte de la autoridad. En consecuencia, no será funcionario público a efectos penales quien sea nombrado por autoridad competente, sólo en base a una disposición reglamentaria". En definitiva "sin habilitación, en suma, no existe funcionario a efectos penales"68.

Frente a esta postura, si bien, por un lado, reconoce OLAIZOLA NOGALES la exigibilidad de que la potestad para realizar un nombramiento venga otorgada a través de ley, esto es, cualquier disposición legal, dicho nombramiento puede ser consecuencia de la disposición de plazas que se realiza de forma inmediata por una ley, por lo que se puede decir que el título de incorporación es por ley, o bien, y esos serán los casos de incorporación por nombramiento cuando la ley no indica directamente las plazas, sino señala quién es la autoridad competente para decidir ${ }^{69}$; por otro lado, defiende sin embargo la misma autora que desde esta perspectiva pierde importancia a su vez la cuestión de si por ley debe entenderse o no ley en sentido estricto. De optarse por la primera opción, más restrictiva, cabría decir que la incorporación por decreto u orden ministerial constituye una forma por autoridad competente ${ }^{70}$ porque si se considera como único título habilitador la ley en sentido estricto, se reduciría de forma extrema la posibilidad de adquirir la condición de funcionario público a efectos penales ${ }^{71}$. Para COBO DEL ROSAL y QUINTANAR DÍEZ, la vulneración del principio de legalidad, no se produce, según el propio Tribunal Constitucional ha subrayado cuando la ley orgánica remite a disposiciones de rango inferior que la desarrollan, si quedan suficientemente detallados determinados elementos esenciales de la conducta antijurídica, siendo la expresión "por nombramiento de autoridad competente", simplemente, uno de los modos de adquirir la cualidad de funcionario público a efectos penales, extremo éste que no se puede regular, por su amplitud, siempre por ley orgánica, máxime cuando el elemento objetivo de participación en el

\footnotetext{
${ }^{66}$ Ibídem, op. cit., p.489.

${ }^{67}$ J. M. RODRÍGUEZ DEVESA y A. SERRANO GÓMEZ, Derecho penal español, Parte especial, op. cit., p. 1129.

${ }^{68}$ J. QUERALT JIMÉNEZ, “El concepto penal...”, op. cit., p.490.

${ }^{69}$ I. OLAIZOLA NOGALES, El delito de cohecho, op. cit., p.155.

70 I. VALEIJE ÁLVAREZ, “Reflexiones...”, p.453.

${ }^{71}$ I. OLAIZOLA NOGALES, El delito de cohecho, op. cit., p.154; A. DEL TORO MARZAL,

“Comentario al artículo 119", op. cit., p.736.
} 


\section{CAPÍTULO IV: TIPO OBJETIVO (I). LOS SUJETOS ACTIVOS}

"ejercicio de la función pública" sí queda perfectamente descrito por la ley penal ${ }^{72}$.

Nos parece pertinente, entre todas las propuestas la de VALEIJE ÁLVAREZ para quien el nombramiento, a efectos del artículo 24, consiste en designar o señalar a alguien para un cargo o función. Esta designación ha de ser realizada por una Autoridad competente, esto es, un sujeto que aparte de ser Autoridad (o sea, aparte de gozar mando y jurisdicción) tiene competencia o atribución legítima para adscribir un sujeto al concreto empleo público y para crear una relación jurídica válida. Respecto a la relación entre la existencia de una disposición legal y un posterior nombramiento de la autoridad competente, defiende la autora que el artículo 24 no está haciendo referencia a los requisitos administrativos exigidos para la condición de funcionario, sino que está describiendo los títulos o modos jurídicos que facilitan el acceso a la misma. Así, en un principio, esta modalidad nació con la vocación de conferir la cualidad de funcionario público a efectos penales a los sujetos que eventualmente participaban en tareas públicas en razón de la libre designación o aquellos que actualmente se dan en llamar personal de confianza política cuyo sueldo, en ocasiones, no deriva directamente del Presupuesto general del Estado ${ }^{73}$. En la actualidad, bajo esta fórmula, se comprenden los funcionarios de empleo (que tampoco son funcionarios en la acepción técnica de la palabra puesto que no tienen derecho a plaza) englobando este último concepto a los funcionarios interinos, los contratados administrativos y el personal laboral temporal. Todos ellos entran en la categoría penal de funcionario público por nombramiento de Autoridad competente (pudiendo adoptar el acto de designación bien la forma de resolución o de un documento contractual que supone el título-nombramiento mismo ${ }^{74}$. Por otro lado, abogamos también por

72 M. COBO DEL ROSAL y M. QUINTANAR DíEZ, “Comentario al artículo 24...”, op. cit., p.54.

${ }^{73}$ I. OLAIZOLA NOGALES, El delito de cohecho, op. cit., p.155. Habla la autora de funcionarios eventuales o de confianza política que constituyen personal de nombramiento y cese discrecional para desempeñar cargos de asesoramiento o confianza no reservados a funcionarios de carrera.

${ }^{74}$ I. VALEIJE ÁLVAREZ, "Reflexiones...", pp.457 y 458. Recientemente plantea CERINA si se puede equiparar al nombramiento un acto administrativo por medio del cual la administración delega tareas que le son propias a un sujeto particular. Toma el ejemplo, de una concesión o autorización administrativa y se pregunta si puede decirse que el concesionario o autorizado participan de una función pública en virtud de un nombramiento de la autoridad competente. Según el autor, la terminología legislativa (nombramiento) parece hacer referencia a determinados actos administrativos distintos a la concesión (por ejemplo, como se ha dicho, a los cargos de libre designación y cese). Sin embargo, la inclusión del personal laboral de la Administración en el abanico de sujetos que el CPE considera funcionarios públicos, parece abrir el camino a interpretación amplia del inciso "nombramiento de la autoridad competente". Y a quienes objetaran que se defendería así una interpretación analógica in malam partem, cabe responder que, equiparar la contratación de personal laboral al nombramiento no es muy distinto. Una vez admitido que cuando la Administración contrata, nombra, el autor no cree que existan argumentos jurídicamente aceptables para excluir del ámbito de aplicación de esta norma toda persona que recaiga en el ámbito de 
un retoque sustancial que ponga esta norma en condición de desempeñar una función interpretativa concreta y auténtica, teniendo en cuenta la complejidad que, a comienzos de la segunda década del siglo XXI, ha venido asumiendo la relación entre Administración en sentido tradicional, entes administrativos económicos y también particulares ${ }^{75}$.

\section{II- La extensión del artículo 423 CPE76}

La doctrina española no se ha interesado mucho en el análisis de este punto $^{77}$ aunque, como veremos más adelante, la interpretación puede plantear no pocos problemas, sobre todo en el marco de la regulación anterior a la reforma penal de 2010. Uno de los pocos autores que han estudiado la materia, considera que se trata de "una asimilación ${ }^{78}$ en orden al tratamiento punitivo correspondiente de determinadas personas no funcionarias a quienes legalmente lo son a efectos penales" con la pretensión de "amparar aquellos sujetos que están a medio camino entre la función pública stricto sensu y el mero particular colaborador de la Administración"79. Subraya VALEIJE ÁLVAREZ que "en el Derecho penal actual, la exigencia de responsabilidad a particulares que participan en el ejercicio de funciones públicas no es sino la respuesta del legislador penal a la necesidad de romper la rígida distinción entre el funcionario y el particular colaborador de la función pública para dar cabida a supuestos intermedios en los que el interés público exige, por un lado, la incorporación de elementos profesionales con sus propias características, pero de otro, exige también su sometimiento a un orden general y al control penal cuando su actuación sea lesiva de aquel interés"80. En otras palabras, por medio de este precepto, el legislador penal español ha pretendido proporcionar su propia respuesta frente a la complejidad del panorama administrativo, con la finalidad de extender

\footnotetext{
aplicación de la ley 30/2007 de 30 de octubre de Contratos del Sector público, es decir, "contratada" por la Administración en régimen de derecho público, siempre y cuando participe en el ejercicio de una función pública. Ni qué decir tiene que una persona que trabaja para una empresa concesionaria de un servicio público, ejerciendo actividades regladas por normas de derecho público, participa del ejercicio de una función pública en virtud de la concesión administrativa (G. D. M. CERINA, La lucha contra la corrupción, op cit., p.746 y ss.).

75 G. D. M. CERINA, La lucha contra la corrupción, op cit., p.748.

76 Dispone actualmente este artículo que "lo dispuesto en los artículos precedentes serán también aplicable a los jurados, árbitros, peritos, administradores o interventores designados judicialmente, o cualesquiera personas que participen en el ejercicio de la función pública".

77 Ibídem, op. cit., p.748.

${ }^{78} \mathrm{M}$ a. J. RODRÍGUEZ PUERTA, El delito de cohecho..., op. cit., p.168, no habla de asimilación sino de una "posición próxima a la del funcionario público, aunque desde luego no idéntica".

${ }^{79}$ I. VALEIJE ÁLVAREZ, El tratamiento..., op. cit., p.70; Ma a J. RODRÍGUEZ PUERTA, El delito de cohecho..., op. cit., p.168. Para esta autora la ampliación de los sujetos activos del cohecho de funcionarios públicos se encuentra plenamente justificada, pues también estos sujetos están obligados a decidir imparcialmente cuando participan en el ejercicio de funciones públicas.

${ }^{80}$ I. VALEIJE ÁLVAREZ, El tratamiento..., op. cit., p.71.
} 


\section{CAPÍTULO IV: TIPO OBJETIVO (I). LOS SUJETOS ACTIVOS}

la aplicabilidad del delito de cohecho a aquellas "zonas grises" entre público y privado ${ }^{81}$.

Las dificultades planteadas por la doctrina se encuentran en la relación entre los artículos 423 (anterior artículo 422) y 24.2 del CPE y las consecuencias que ha podido generar la ubicación del anterior artículo 422 para la interpretación sistemática. Estas consecuencias han llevado al legislador penal de 2010 a colocar de otra manera el mismo contenido en el nuevo artículo 423.

A- RELACIÓN ENTRE LOS ARTÍCULOS 423 (ANTERIOR ARTÍCULO 422) Y 24.2 DEL CPE

CERINA destaca, en el marco de la anterior regulación que la diferencia entre sujetos que "participan en el ejercicio de una función pública" y aquellos en virtud de lo dispuesto por el artículo 24.2 CPE, son funcionarios públicos a efectos penales, se cifra en la ausencia, en los primeros, de un título habilitador ${ }^{82}$. Por lo tanto, para determinar el alcance del artículo 422 CPE 1995, habrá que proponer una interpretación restrictiva al artículo 24.2 y así podrá otorgársele un mayor espacio. Sostiene RODRÍGUEZ PUERTA, también dentro del marco de la regulación anterior a la reforma de 2010, que no todo aquél que participa en el ejercicio de funciones públicas puede ser considerado funcionario en el sentido del artículo $24 \mathrm{CPE}$. Por el contrario para adquirir tal condición, a los efectos penales, es necesario además de la participación en el ejercicio de funciones públicas, un título que habilite para ello, es decir, la constatación de una relación jurídica entre el sujeto y la organización estatal. En consecuencia, esta interpretación restrictiva del concepto de funcionario público del artículo 24 CPE permite excluir de la órbita de este precepto a aquellos particulares que carecían de un título habilitante para participar en el ejercicio de funciones públicas ${ }^{83}$. Razona la misma autora que de no compartirse esta interpretación del artículo 24 CPE, el precepto del artículo 422 CPE resultaría redundante. "Así, los peritos, árbitros, los miembros del jurado o los particulares encargados accidentalmente del despacho o custodia de documentos de la Administración, por poner ejemplos, fueran, en todo caso, funcionarios a efectos penales no sería necesaria su mención expresa en los preceptos señalados"84.

\footnotetext{
81 G. D. M. CERINA, La lucha contra la corrupción, op cit., p.749.

82 Ibídem, op. cit., p.750; Una posición matizada tiene I. VALEIJE ÁLVAREZ, El tratamiento..., op. cit., p.70. Para la autora se trata de "sujetos que participan en el ejercicio de una función pública no sin que media una relación jurídica, sino que ésta no se establece con arreglo alguno de los que describe el párrafo 3o del artículo 119 del CP" ( o, en la actualidad el párrafo $2^{\circ}$ del artículo $24 \mathrm{CPE}$ ).

83 Mà. J. RODRÍGUEZ PUERTA, El delito de cohecho..., op. cit., p.167.

${ }^{84}$ Ibídem, op. cit., p.167. La autora hace referencia también a los artículos 416, 435, 440 y 459 CPE.
} 


\section{PARTE II: ESTUDIOS DE LOS ELEMENTOS TÍPICOS...}

Así las cosas, quedarán incluidos en la cláusula del anterior artículo 422 CPE y por lo tanto pueden ser sujetos activos de los delitos de cohecho de los anteriores artículos 419, 420 y 421, entre otros:

1) Los profesionales privados que ejercen actividades que han sido asumidas por el Estado, como por ejemplo, los concesionarios de servicios públicos ${ }^{85}$.

2) Aquellos otros profesionales que desempeñan también una actividad privada pero que se sirven para ello de potestades administrativas, tales como el ejercicio de autoridad o fe pública. Como ejemplos de esta clase de sujetos encontramos los notarios, comandantes de aeronave, vigilantes privados, comandantes de buque, profesores de academias privadas que extienden calificaciones con valor público, médicos que deben responder del valor probatorio de los certificados de nacimiento o defunción que emitan, etc. ${ }^{86}$.

3) Por último, son reconducibles también a esta categoría los profesionales que son llamados por la autoridad judicial o por un organismo administrativo para encargarse de realizar alguna actividad concreta como por ejemplos, los peritos, árbitros, jurados o sujetos que contratan con la Administración para realizar por ejemplo una obra o prestar un servicio ${ }^{87}$.

Efectivamente tal interpretación "salva" de alguna manera la coherencia en la sistemática del código, pero, como lo nota CERINA, esta construcción presenta algunos perfiles de incompatibilidad con la litera legis ${ }^{88}$.

En primer lugar, respecto a los profesionales en el numeral 2 del listado anterior y cuya actividad se caracterizaría por implicar el ejercicio de potestades típicas de la Administración, observa el mismo autor que la atribución de estos "poderes", como ha reconocido inclusive quien ha defendido la anterior partición entre funcionarios y personas que participan en el ejercicio de una función pública, sólo "puede producirse por «Ley» (...) o en base a una Ley cuando se realiza mediante un acto administrativo discrecional o mediante un contrato de Derecho público"89. De ahí se puede preguntar: si es funcionario público quien participa del ejercicio de una función pública por disposición inmediata de la ley ¿por qué no deberían serlo sujetos que tienen atribuida una función pública con apoyo en una ley? El ejemplo de la figura notario es el más evidente. Son sujetos que, según la doctrina expuesta anteriormente, participarían en el ejercicio de una función pública (dar fe) sin ser - a efectos penales - funcionario público (sin habilitación ni por ley, ni por elección y

${ }^{85}$ I. VALEIJE ÁLVAREZ, El tratamiento..., op. cit., p.70.

${ }^{86}$ Ibídem, op. cit., pp.70 y 71; Ma. J. RODRÍGUEZ PUERTA, El delito de cohecho..., op. cit., p.168.

87 I. VALEIJE ÁLVAREZ, El tratamiento..., op. cit., p.71; Ma. J. RODRÍGUEZ PUERTA, El delito de cohecho..., op. cit., p.168.

${ }^{88}$ G. D. M. CERINA, La lucha contra la corrupción, op cit., p.751.

${ }^{89}$ I. VALEIJE ÁLVAREZ, El tratamiento..., op. cit., p.71 
ni por nombramiento). Sin embargo, dispone el artículo 1 de la ley de 28 de mayo de 1892 del Notariado que "El Notario es el funcionario público autorizado para dar fe, conforme a las leyes, de los contratos y demás actos extrajudiciales" y que "Habrá en todo el Reino una sola clase de estos funcionarios". ¿Se puede realmente decir que los notarios desempeñan una función pública sin que para ello los habilite una disposición inmediata de la ley? La respuesta sería la negativa. Pero además, el artículo 11 de la misma ley dispone que: "Los Notarios serán de nombramiento Real". De ahí hay otra pregunta: ¿participan los notarios de una función pública sin ser nombrados por una autoridad competente? La contestación debe ser, de nuevo, negativa. Concluye CERINA que los notarios deben considerarse funcionarios públicos a efectos penales. La misma conclusión, si se quiere mantener cierta coherencia argumentativa, debe extenderse a todas aquellas personas que participen en el ejercicio de una función pública (actuando con poderes típicos de la Administración) que les hayan sido otorgados con apoyo en una disposición inmediata de la ley, una elección o un nombramiento de la autoridad competente ${ }^{90}$.

En segundo lugar, en cuanto a los sujetos incluidos en el primer punto del listado (los concesionarios de servicios públicos), parece problemático, como también se ha sostenido anteriormente, reconocer la calidad de funcionarios a efectos penales al personal contratado de la Administración y no al personal empleado en un ente concesionario de un servicio público que desempeña una actividad reglada por normas de Derecho público. Si se considera que el contrato laboral es equiparable "al nombramiento de la autoridad competente", debe considerarse que la concesión administrativa o una autorización, a fortiori, también son nombramientos de una autoridad competente ${ }^{91}$.

Por último, el tercer punto del listado parece plantear más dificultad ya que el anterior artículo 422 CPE expresamente se refiere a: árbitros, jurados y peritos. Dicha norma parecería presuponer que no se trata de funcionarios públicos ni de autoridades a efectos penales: de lo contrario, sonaría pleonástica e inútil su mención expresa. Según CERINA, ello no obstante, este argumento, por sí solo, no es decisivo para excluir $a b$ origine que jurados, árbitros o peritos puedan considerarse incluidos en el abanico de sujetos considerados por el artículo 24, primero y segundo párrafo del $\mathrm{CPE}^{92}$. El problema es particularmente evidente en el caso de los jurados, sujetos que, según parte la doctrina, no sólo son a efectos penales, funcionarios públicos, sino que deban considerarse

\footnotetext{
${ }^{90}$ G. D. M. CERINA, La lucha contra la corrupción, op cit., pp.751 y 752.

91 Ibídem, op. cit., pp.752 y 753. Nota el autor que como correctivo a una interpretación amplia en exceso, debe hacerse hincapié en que, para que una actividad pueda rotularse de función pública, no es suficiente que la misma se realice en virtud de una concesión o de una autorización, sino que es necesario que sea, además, disciplinada por normas de derecho público.

${ }_{92}$ Ibídem, op. cit., p.753
} 
como autoridades ${ }^{93}$. Y, en efecto, admitido que el jurado ejerce una potestad jurisdiccional ${ }^{94}$, no puede razonablemente excluirse que los miembros del jurado deban considerarse autoridades a efectos penales. Algo más complejo es el discurso alrededor de los peritos, mientras que difícilmente podrán considerarse funcionarios públicos a efectos penales los árbitros. De todas maneras y para zanjar la cuestión, se debe admitir que, si se considera que sus funciones son "públicas" (cualquiera que sea el criterio adoptado), debe reconocerse que el hecho de ser nombrados (designados) por un juez es requisito suficiente para considerar a sendos sujetos como funcionarios públicos a efectos penales. Por lo tanto, concluye CERINA que de aceptarse la interpretación propuesta, debe retenerse que la norma del artículo $422 \mathrm{CPE}$ es pleonástica e inútil ya que estos sujetos, en el ejercicio de sus funciones, son autoridades (jurados) y funcionarios (peritos y árbitros) a efectos penales $\mathrm{y}$, por lo tanto, serían sujetos activos del delito de cohecho pasivo antecedente inclusive en ausencia de una norma ad hoc que así lo establecie$\mathrm{ra}^{95}$.

Con la reforma legislativa de 2010, el nuevo artículo 423 ha añadido a su listado a los administradores o interventores designados judicialmente. Sin embargo, los autores reconocen que tal ampliación no represente una novedad sustancial ${ }^{96}$ y que permanecen actuales la mayoría de las observaciones formuladas al respecto dentro del marco de la regulación anterior ${ }^{97}$.

B- LAS CONSECUENCIAS DE LA UBICACIÓN DEL ANTERIOR ARTÍCULO 422 CPE PARA LAS FIGURAS DEL DELITO DE COHECHO ANTES DE LA REFORMA PENAL DE 2010

Antes de dicha reforma, se destacan unos problemas respecto a los posibles autores de cohecho pasivo antecedente, la ubicación de la norma en estudio, su formulación en la medida en que influye sobre la interpretación de los preceptos que la preceden y la siguen.

En primer lugar, el anterior artículo 422 no equipara de ninguna manera los sujetos que menciona con autoridades y funcionarios públicos. Dispone simplemente que "lo dispuesto en los artículos precedentes, será también aplicable" a estos sujetos. Por lo tanto se excluye que

\footnotetext{
${ }^{93}$ J. PAVÍA CARDELL, Responsabilidad penal en el ejercicio de la función pública de jurado, Comares, Granada, 2004, pp.130 y ss.

${ }_{94}$ Ibídem, op. cit., pp. 137 y ss. "Resulta indiscutible que los ciudadanos ejercen desde el mismo instante en que toman asiento en los estrados del Tribunal, aunque tal ejercicio no alcanza su verdadera significación hasta el momento en que se emite el veredicto, expresión máxima de la jurisdicción privativa del Jurado" (p.139).

95 G. D. M. CERINA, La lucha contra la corrupción, op cit., p.754.

96 C. RAMOS RUBIO, Del delito de cohecho: mano "más" dura "todavía" contra la corrupción nacional e internacional (arts. 419, 420, 421, 422, 423, 424, 425, 426, 427, 428, 429, 430, 439 y 445) en G. QUINTERO OLIVARES (Dir.) La Reforma Penal de 2010: Analisis y Comentarios, Arazandi, Pamplona, 2010, p.343.

97 G. D. M. CERINA, La lucha contra la corrupción, op cit., p.1192
} 
quienes participan en el ejercicio de una función pública sin ser funcionarios públicos a efectos penales, puedan ser autores de cohecho subsiguiente (propio e impropio) y de cohecho antecedente impropio. Opina CERINA que, con ello, se debía excluir también la punibilidad del cohecho activo propio antecedente: si el destinatario de la conducta de corromper o intentar corromper es un sujeto mencionado por el artículo 422 que no sea a la vez funcionario público o autoridad, el corruptor ha de quedar impune. El autor evoca dos razones. La primera es que la punibilidad del extraneus se dispone en el anterior artículo $423 \mathrm{CPE}$, es decir, en una norma no precedente, sino sucesiva al anterior artículo $422 \mathrm{CPE}$. El segundo motivo de dicha exclusión, se apoya en la formulación del anterior artículo 423 CPE que conmina una sanción a "los que con dádivas...corrompieren e intentaren corromper a las autoridades $o$ funcionarios públicos". Defender la aplicación de este último precepto a conductas que tienen como destinatarios a sujetos que no son autoridades o funcionarios públicos a efectos penales, significaría, por lo tanto, obrar una inaceptable analogía in malam partem ${ }^{98}$.

En segundo lugar, se plantea la punibilidad de los sujetos mencionados por el anterior artículo $422 \mathrm{CPE}$ que son, a la vez, funcionarios públicos o autoridades a efectos penales (por ejemplo, el jurado). En efecto, su mención expresa por parte de este artículo dejaría entender que, fuera de los casos contemplados por esta norma, a los sujetos ahí mencionados no debe atribuírseles punición. 0 sea, si los jurados se sancionan en los casos disciplinados por los anteriores artículos 419, 420, $421 \mathrm{CPE}$, a contrario, deberían considerarse impunes en los demás hipótesis de corrupción (cohecho subsiguiente e impropio antecedente). Ello, por otra parte, chocaría con el tenor literal de los anteriores artículos 423 y siguientes que mencionan a todos los funcionarios y autoridades ${ }^{99}$.

Sin embargo, explica CERINA que el problema es simplemente aparente. En efecto, el anterior artículo 422 CPE no dice que "lo dispuesto en los artículos precedentes será también aplicables a jurados, árbitros y peritos no obstante estos sujetos no sean funcionarios públicos a efectos penales o cualesquiera personas que participe en el ejercicio de una función pública sin ser funcionarios a efectos penales". Esta lectura del precepto se ve contradicha por una interpretación aceptable del artículo 24, primero y segundo párrafo. De tal manera que se podrá concluir que el anterior artículo $422 \mathrm{CPE}$ es norma pleonástica e innecesaria en la parte en la cual menciona o se refiere a sujetos que ya serían punibles por ser funcionarios públicos a tenor de lo dispuesto por el artículo 24 CPE. Por consiguiente, los sujetos ahí mencionados (con específica referencia a los jurados), en tanto en cuanto puedan considerarse, a efectos penales, autoridades o funcionarios públicos, serán posibles sujetos activos de todas y cada una de las vertientes pasivas del cohecho y será punible el extraneus que los corrompa o intente corromper ${ }^{100}$.

${ }^{98}$ Ibídem, op. cit., p.755.

${ }^{99}$ Ibídem, op. cit., pp.755 y 756.

100 Ibídem, op. cit., p.756. 
Por nuestra parte, estamos a favor de una interpretación extensiva del artículo $24 \mathrm{CPE}$, y por consiguiente, restrictiva por lo que respecta al ámbito de aplicación exclusivo del anterior artículo 422 y actual artículo 423 CPE. En este sentido, proponemos, en el marco de una urgente revisión de estas normas ${ }^{101}$, considerando las discusiones hasta aquí expuestas, la eliminación de este último precepto para sustituirlo por una fórmula ampliatoria que no debe recogerse de manera aislada en la parte especial y en relación a un delito especial, sino que debe estudiarse la posibilidad y viabilidad de que en la Parte general del Código figure, junto al de funcionario, un concepto de encargado de servicio público o de una función pública ${ }^{102}$.

\section{C- ESTADO DE LA CUESTIÓN CON LA REFORMA PENAL DE 2010}

Al parecer la doctrina, en su mayoría, ha recibido de manera positiva la nueva ubicación del precepto en cuestión. En efecto, la novedad aportada por la reforma es la ubicación sistemática del artículo 423 CPE tras todos los preceptos relativos al cohecho pasivo, lo que incluye también el relativo al cohecho pasivo subsiguiente e impropio antecedente (actuales artículos 421 y $422 \mathrm{CPE})^{103}$. Se puede concluir que la intención del legislador de 2010 es sancionar el cohecho en el cual esté involucrada cualquier persona que participe en el ejercicio de una función pública sin ser funcionario, con independencia de la vertiente del delito en el que estuviera involucrada ${ }^{104}$, lo cual mejora la seguridad jurídica y la técnica legislativa ${ }^{105}$. Sin embargo, otro sector de la doctrina se muestra crítico respecto a esta cláusula extensiva de penalidad. Defiende POLAINO NAVARRETE que acaso con excepción de los jurados, a los que

\footnotetext{
101 Ibídem, op. cit., p.757

102 I. VALEIJE ÁLVAREZ, El tratamiento..., op. cit., pp.71, 72. Señala la autora que "sólo así se logrará evitar en la medida de lo posible no sólo la amplia interpretación que habitualmente se realiza del concepto penal de funcionario, sino también las fuertes lagunas de punibilidad que afloran actualmente debido a una gestión defectuosa o ilícita de una función pública privatizada y que, en ocasiones, traen causa de la confusión que hoy en día existe sobre el carácter público o privado de la persona que las gestiona".

${ }_{103}$ C. RAMOS RUBIO, Del delito de cohecho... op. cit., p.343; C. MIR PUIG, El delito de cohecho en la reforma del Código penal (I), Iuris, febrero de 2011, p.50; J. QUERALT JIMÉNEZ, Derecho penal español, Parte especial, Atelier, 2010, p.1168.

104 G. D. M. CERINA, La lucha contra la corrupción, op cit., p.1193.

105 C. MIR PUIG, El delito de cohecho en la reforma...op. cit., p.50. Añade CERINA, por una parte, que si ese era el resultado que se perseguía, quizás hubiera sido más oportuno decirlo abiertamente: así, los nuevos artículos 419, 420, 422, en lugar de empezar diciendo "la autoridad o funcionario público", bien hubiesen podido decir "cualquier persona que participe en el ejercicio de una función pública" (ya que, como se sabe, tanto la autoridad como el funcionario público "participan en el ejercicio de una función pública"). El hecho que se haya procedido de otra forma, por otra parte, no está exento de inconvenientes: así, por ejemplo, deberá concluirse que lo dispuesto por los artículos 424.3 y 426 será aplicable sólo en el caso en el cual el sobornado sea una autoridad o un funcionario público, sin posibilidad de entender relevantes los hechos realizados por una persona que participe en el ejercicio de una función pública y que no sea, a la vez, funcionario público (G. D. M. CERINA, La lucha contra la corrupción, op cit., p.1193).
} 
ahora habría que añadir los administradores o interventores judiciales, la nominación de los demás sujetos mencionados (árbitros, peritos y cualesquiera personas que sin ser funcionarios participen en el ejercicio de la función) implica una desorbitada extensión legal de sujetos activos posibles del cohecho propio del funcionario público. El concepto de funcionario no debe desvirtuarse extensivamente, por una pretendida proyección de funcionalidad pragmática, a toda persona que, por cualquier concepto y en cualquier situación, de algún modo tome parte en el desempeño de una actividad correspondiente al ejercicio de la causa pública. Añade el mismo autor que en el medida en que no puedan ser reconducidos al concepto de autoría quienes formal y materialmente se equiparan con fundamentos legitimadores de la legalidad de su intervención al servidor de la causa pública, se atentará contra los principios de certeza y seguridad jurídica y quedará comprometida la constitucionalidad del precepto incriminador en los extremos indicados ${ }^{106}$.

\section{Sección 2- Ausencia de la noción de funcio- nario público en materia penal en Derecho francés y malgache}

A diferencia del Derecho penal español, no existen ni en el CPF ni en el CPM disposiciones equivalentes a los artículos 24 y 423 CPE. Resulta llamativo, en este sentido, que el capítulo II del CPF se titula "De los delitos contra la Administración Pública cometidos por las personas que desempeñen una función pública" frente a su antecesor, la sección II del título I del Libro III del anterior CPF, que tiene como rúbrica "La "Forfaiture" y los delitos graves y menos graves de los funcionarios públicos en el ejercicio de sus cargos". Así el artículo 177.1 del antiguo CPF daba un listado enriquecido por varias reformas sucesivas y citaba como posibles autores del delito de corrupción pasiva: las personas investidas de un mandato electivo, los funcionarios públicos del orden administrativo y judicial, los agentes y encargados de una Administración Pública o de una Administración bajo tutela de la potestad pública, los militares y asimilados, los ciudadanos encargados de un ministerio de servicio público, los árbitros, los peritos, y, por último, los miembros de las profesiones médicas. Sin embargo, al situar en otras disposiciones la corrupción pasiva de los magistrados y los miembros de los profesiones médicas o, más generalmente, las personas que, en el ejercicio de su profesión, redactarían certificados inexactos, los redactores del nuevo Código penal han limitado el ámbito de aplicación del artículo 432-11 CPF a las personas que ejercen una función pública, es decir, el precepto sólo se refiere a las personas depositarias de la autoridad pública, las personas encargadas de una misión de servicio público y, en última instancia, las

\footnotetext{
${ }^{106}$ M. POLAINO NAVARRETE, "Cohecho. Tráfico de influencias. Malversación de caudales públicos." en M. POLAINO NAVARRETE (dir.) Lecciones de Derecho penal, Parte especial, Tomo II, Tecnos, 2011, p.329.
} 
que ostentan un mandato electivo público ${ }^{107}$. En efecto en comparación con el listado del artículo 177.1 del antiguo CPF el criterio previsto por el actual Código en su artículo 432-11 parece haber limitado los posibles sujetos activos del delito en estudio. Sin embargo, podemos notar la utilización de la expresión "los funcionarios públicos en el ejercicio de sus cargos" en el primer precepto y la de "las personas que desempeñen una función pública" en el segundo. A nuestro parecer, el antiguo Código penal francés al elaborar un listado bastante amplio respecto a aquellos sujetos respetaba la mínima coherencia por haber asimilado como funcionario público al ciudadano encargado de un ministerio de servicio público, utilizando un criterio teleológico, los agentes y encargados de una Administración pública o una Administración bajo tutela de la potestad pública, utilizando aquí un criterio subjetivo y los árbitros, peritos y profesiones médicas a través de un criterio formal. Ahora bien, como no había y todavía no hay concepto de funcionario a efectos penales, por lo menos a efectos de la aplicación del artículo 177.1 del antiguo $\mathrm{CPF}$, estos sujetos son considerados, entre otros, como funcionarios públicos. La amplitud del concepto se encuentra en que, a parte de los funcionarios públicos en el sentido del Derecho administrativo, otros sujetos que no lo reconocen como tal la rama administrativa del ordenamiento jurídico, pueden ser considerados funcionarios públicos a través de cualquier de los tres criterios, lo cual extendía de una manera irrazonable el alcance el precepto ${ }^{108}$.

En cuanto al nuevo CPF, se nota la intención de modernizar, simplificar y crear ${ }^{109}$ por parte del legislador penal francés, sin embargo, cuando el título del capítulo II prevé que su contenido verse sobre "los delitos contra la Administración Pública cometidos por las personas que desempeñen una función pública" y el artículo 432-11 precisa que se trata de "toda persona" en una situación determinada, difícilmente se puede sacar algún concepto de funcionario ni a efectos penales ni a efectos del precepto en estudio. Por lo tanto, no compartimos la postura simplista de un sector de la doctrina francesa que ve a los autores del delito corrupción pasiva como funcionario ${ }^{110}$ o agente público ${ }^{111}$. Por consiguiente, nos parece acertada y más respetuosa a la letra de la ley la postura doctrinal que precisa que el autor del delito de corrupción puede

\footnotetext{
${ }^{107}$ A. VITU, Corruption passive et trafic d'influence commis par des personnes exerçant une fonction publique, en Juris-Classeur, Droit pénal, 2004, art.432-11, fasc.10, p.10 ; F. CECCON, Contribution..., op. cit., p.34.

${ }^{108}$ Postura diferente a la nuestra, E. REURER, Des atteintes..., op. cit., p.89. Para la autora la larga enumeración que existía en el artículo 177 parecía abarcar a un gran número de personas por las categorías que preveía, pero estas categorías eran tan precisas que era difícil de asimilar a alguien que no pertenecía expresamente a una de ellas.

109 G. GIUDICELLI-DELAGE, Livre IV..., op. cit., p.503.

110 Ibídem, op. cit., p.503. En su valoración sobre capítulo II del Libro IV del CPF, la autora habla de "funcionarios" como autores de los delitos contra la Administración pública. Según ella, se entiende por la palabra "funcionario" la persona depositaria de la autoridad pública o encargada de una misión de servicio público y la que ostente un mandato electivo público.

${ }^{111}$ E. DREYER, Cours magistral..., op. cit., p.599.
} 


\section{CAPÍTULO IV: TIPO OBJETIVO (I). LOS SUJETOS ACTIVOS}

ser un funcionario (en el sentido estricto del término o sea, conforme a la previsión del Derecho administrativo) o una persona que tiene vinculación con el servicio público ${ }^{112}$.

En definitiva, los delitos agrupados en el capítulo II del libro IV del CPF ya no son delitos de los funcionarios contra la Administración sino los de los que desempeñan una función pública. En efecto, el desempeñar una función pública no convierte necesariamente a una persona en funcionario, sino en autor de uno de estos delitos. Se podría preguntar, entonces, el sentido del verbo "desempeñar" desde la perspectiva del delito de corrupción pasiva. El verbo "desempeñar" o "ejercer" una función pública excluye la idea de mera participación o colaboración. Ejercer implica más que participar, implica continuar ejerciendo dicha función ${ }^{113}$. Tal ejercicio no puede ser posible sin tener una condición jurídica que habilite para ello. Para el artículo 432-11 CPF, la habilitación se posee por ser la persona depositaria de la autoridad pública o encargada de una misión de servicio público o por ostentar un mandato electivo público.

Respecto al Derecho penal malgache, se puede notar que el antiguo artículo 177 CPM, esto es, antes de la reforma penal de 2004, refleja un contenido idéntico a su equivalente francés en cuanto a los sujetos ahí enumerados. Es de lamentar que tal reforma no ha mejorado la sistemática de los diversos apartados sino que se ha enfocado en modificar el contenido de algunos artículos de la Sección II del Capítulo III del Título I del Libro III. Curiosamente, los redactores de la reforma del CPM se han inspirado en el nuevo Código penal francés y han ajustado su trabajo conforme a éste sin llevarlo hasta sus últimas consecuencias, esto es, sin dar una presentación más coherente de los artículos y agruparlos con principios directores que puedan ayudar al intérprete ${ }^{114}$. Respecto a los posibles autores del delito de corrupción pasiva, ya hemos señalado la flagrante falta de rigor del trabajo legislativo sobre el contenido de la sección II "crímenes y delitos de los funcionarios públicos en el ejercicio de sus funciones" que abarca delitos cuyos autores no son ni funcionarios públicos ni tienen vinculación alguna con la función pública. La misma dificultad persiste en el párrafo IV de la misma sección. Dicho párrafo tiene como rúbrica "De la corrupción de los funcionarios públicos y de los empleados de las empresas privadas". La novedad introdu-

\footnotetext{
112 H. XIAO-YING, La lutte contre la corruption..., op. cit., p.77.

113 E. OCTAVIO DE TOLEDO Y UBIETO, La prevaricación..., op. cit., p.139.

114 M. DELMAS-MARTY, Avant-propos, op. cit., pp.441 y 442. La autora considera el nuevo CPF no como arcaico sino como incapaz de anticipar ya que al preocuparse por atender las expectativas inmediatas de la opinión pública y anclarse en el presente, el código no puede ser un acto fundador de un derecho penal del futuro (p.443). Por nuestra parte, se puede decir que el CPM es verdaderamente anticuado, todavía mantiene la inspiración, el espíritu hasta las formas del antiguo CPF de 1810 (Vid P. RAFOLISY, La protection juridique..., op. cit., p.134). Por lo tanto, creemos que es razonable que si han pasado dos siglos, habrá que hacer una reforma profunda del CPM en vez de contentarse con modificar algunos artículos, lo que no hace más que dificultar su interpretación.
} 
cida por la reforma de 2004 consistió en cada artículo una rúbrica antes de desarrollar su contenido. El artículo 177 del CPM trata de "la corrupción pasiva de las personas que ejercen una función pública". Resaltamos que este precepto no señala en su letra que los autores de este delito tienen que ser funcionarios públicos sino personas que ejercen una función pública. En efecto, si es cierto que todos los funcionarios desempeñan una función pública, en cambio, no todos los que ejercen una función pública tienen que ser funcionarios públicos. Por lo tanto, en ausencia de un concepto penal de funcionario público, rechazamos todo atajo que pueda llevar a interpretar que funcionario público es toda persona que ejerce la función pública. La razón es obvia: el legislador identifica a los sujetos activos del delito de corrupción con la condición de ser la persona depositaria de autoridad pública, encargada de una misión de servicio público o que ostente un mandato electivo público ${ }^{115}$. Cada una de estas tres categorías de personas puede incluir en su ámbito de aplicación a personas que no son funcionarios públicos, en el sentido estricto, es decir, del Derecho administrativo ${ }^{116}$. Lo más importante, a nuestro parecer, es destacar, que para ser sujeto activo del delito de corrupción pasiva, no hace falta ser funcionario público sino ejercer una función pública y para ello no basta con participar ni colaborar sino cumplir una de las tres condiciones jurídicas que demuestran dicho ejercicio: ser depositario de la autoridad pública, ser encargado de una misión de servicio público y ostentar un mandato electivo público ${ }^{117}$.

\section{I-. Los criterios de identificación de la persona que des- empeña una función pública según los artículos 432-11 CPF y 177 CPM}

\section{A- LA PERSONA DEPOSITARIA DE AUTORIDAD PÚBLICA ${ }^{118}$}

\footnotetext{
115 Visto el contenido del párrafo IV, se puede proponer el cambio de la rúbrica en "De la corrupción cometida por personas que ejercen la función pública, los particulares y los empleados de las empresas privadas". Aun así nuestra propuesta no es del todo satisfactoria ya que en el párrafo en cuestión se encuentran otros delitos que no corresponden al tipo de corrupción sino delitos "vecinos", por lo tanto, siempre la mejor opción sería categorizar los delitos conforme a un valor protegido determinado y de fácil identificación.

116 P. RAFOLISY, La protection juridique..., op. cit., p.227

117 Se notará que como el CPM no conlleva delitos contra la Administración de justicia, el legislador ha previsto como circunstancia agravante el supuesto de la corrupción pasiva cuyo autor es un magistrado que se pronuncia en una causa criminal, o sea, de delito grave. También es circunstancia agravante la corrupción pasiva cometida por un magistrado o toda persona que pertenece a una formación jurisdiccional, un administrador, un árbitro o un perito (artículo 181 CPM).

118 No compartimos el cambio de traducción operado por ARÁNGUEZ SÁNCHEZ y ALARCÓN NAVÍO, de la expresión francesa "le fait, par une personne dépositaire de l'autorité publique". Unas veces la traducen por "todo aquel que siendo depositario de la autoridad pública", otras por "toda persona constituida en autoridad pública" (C. ARÁNGUEZ SÁNCHEZ y E. ALARCÓN NAVÍO, El código penal francés, op. cit., pp.203210,). A nuestro parecer, la segunda opción no expresa de manera satisfactoria la idea original de "depositario". En efecto, la diferencia estriba en el hecho de que "ser depositario de algo" en francés alude a una persona a quien se le ha confiado o dado algo y lo guarda hasta que se lo retire y "ser constituido en algo" se refiere a asignar o dotar a
} 
Es de reconocer que la doctrina penal francesa, y también malgache, no ha hecho un estudio profundo acerca de esta categoría de persona. El punto de partida se basa en que no se puede corromper a cualquier persona: la persona a corromper tiene que pertenecer a ciertas esferas del poder119. La doctrina entiende por "persona depositaria de la autoridad pública" a aquéla persona que es titular de un poder de decisión y de coacción sobre los individuos y las cosas, poder que manifiesta en el ejercicio de sus funciones, permanentes o temporales, y del que ha sido investida por delegación de la potestad pública ${ }^{120}$. Sin más precisión, la misma doctrina reconoce la amplitud de esta definición, que puede abarcar a los representantes del Estado, de las colectividades territoriales, los funcionarios del orden administrativo y especialmente los representantes de la fuerza pública, los profesionales privados que actúan con la utilización de las potestades administrativas y diversas personas que, sin tener la cualidad de funcionario, ejercen funciones de autoridad. Por lo tanto, bajo la categoría de los representantes del Estado y de las colectividades territoriales se pueden citar el Presidente de la República, los miembros del gobierno ${ }^{121}$, los prefectos y subprefectos, les representantes ante los diversos organismos internacionales o ante países extranjeros (embajadores, cónsules, etc.) ${ }^{122}$. Respecto de los funcionarios del orden administrativo, se trata de "todos los miembros de la Administración, independientemente de su rango en la jerarquía, en cuanto ejercen, bajo el impulso y la vigilancia de sus superiores, atribuciones de potestad pública en el orden administrativo"123. En esta categoría, se clasifica a los miembros de la enseñanza ${ }^{124}$, las administraciones fiscales ${ }^{125}$, los funcionarios de los servicios de la policía y gendarmería ${ }^{126}$, y otros funcionarios como los de Correos ${ }^{127}$, del ministerio de

alguien de una nueva posición o situación. Pero lo más relevante se halla en la duración de la situación: si el depositario de algo tiene una situación que se puede acabar o limitar en el tiempo, en cambio, la situación del que se ha constituido en algo es fija, esto es, no se puede cambiar o variar una vez adquirida.

${ }^{119}$ C. AMBROISE-CASTÉROT, Droit pénal..., op. cit., p.361. En efecto, esta aserción es particularmente cierta para esta primera categoría. Sin embargo, la autora advierte que la corrupción no se sitúa sólo en el sector público, y se puede hacer falsa deducción al pensar que sólo se trata de los altos cargos del Estado o de la administración local, sino también en el sector privado.

120 A. VITU, Corruption passive..., op. cit., p.10 ; M. VIGNAU, Le délit de corruption, op. cit., p.19 ; E. DREYER, Cours magistral..., op. cit., p.599 ; F. CECCON, Contribution..., op. cit., p.35 ; H. XIAO-YING, La lutte contre la corruption..., op. cit., p.77 ; P. RAFOLISY, La protection juridique..., op. cit., p.227.

${ }^{121}$ Cass. crim. 24- 02-1894, Bull. crim. no-49.

${ }^{122}$ A. VITU, Corruption passive..., op. cit., p.11 ; F. CECCON, Contribution..., op. cit., p.35

${ }_{123}$ R. GARRAUD, Traité théorique et pratique du droit pénal français, Tome IV, Sirey, 1922, (3르 ed.), no 1522.

124 Cass. crim., 16-10-1985, no 84-92.832, Gaz. Pal. 1986, 1, jur., p.152. Se trata en el caso de un estudiante que había intentado, en vano, corromper a un profesor de la Facultad de derecho para obtener de él una nota satisfactoria en un examen.

125 Cass. crim., 6-01-1922, Bull. crim. no 7.

${ }^{126}$ Cass. crim., 10-06-1948, D. 1949, jur., p.15, nota H. Carteret.

127 Cass. crim., 28-01-1909, Bull. crim. no55. 


\section{PARTE II: ESTUDIOS DE LOS ELEMENTOS TÍPICOS...}

trabajo $^{128}$, de la Administración penitenciaria ${ }^{129}$, de las prefecturas ${ }^{130}$, de los ayuntamientos ${ }^{131}$, de las fuerzas armadas ${ }^{132}$ y de los colectividades territoriales ${ }^{133}$. En cuanto a los profesionales privados que ejercen su función con la potestad administrativa llamados en francés "Officiers publics et ministeriels", son sujetos que han sido instituidos como intermediarios o mandatarios de los particulares, y se benefician de un monopolio para cumplir, en beneficio de estos, actos oficiales ${ }^{134}$. Se trata de los notarios y los notarios de diligencias ("huissier") 135 .

\section{PÚBLICO \\ B-LAS PERSONAS QUE OSTENTEN UN MANDATO ELECTIVO}

La doctrina penal francesa y malgache moderna no se ha detenido sobre esta segunda categoría de sujeto susceptible de ser autor del delito de corrupción pasiva. Para VITU los componentes de esta categoría no son otros que personas depositarias de la autoridad pública ${ }^{136}$. Sin embargo, es de constatar que se ha producido una evolución por parte de la jurisprudencia al aceptar que las personas elegidas puedan ser sujeto activo del delito de corrupción en un momento en que un sector de la doctrina defendió lo contrario ${ }^{137}$. No dudaron los tribunales en aplicar el artículo 177 del antiguo CPF a los elegidos, tales como: un concejal del Consejo municipal de París ${ }^{138}$, miembros del Senado y de la Cámara de los diputados ${ }^{139}$, un alcalde ${ }^{140}$, un consejero general ${ }^{141}$ (equivalente a diputado a nivel provincial en España).

La expresión "persona que ostenta un mandato electivo público" utilizada por el artículo 432-11 CPF, muy parecido a la utilizada por el CPF de 1945 ("persona que ostenta un mandato electivo"), designa no sólo a

\footnotetext{
${ }^{128}$ Cass. crim., 19-02-1953, Bull. crim. n5․

129 T. corr. Le Mans, 5-07-1946, JCP G 1946, I, no3362.

130 Cass. crim., 3-06-1997, Droit pénal 1997, no150, p.8.

${ }^{131}$ CA Grenoble, 17-11-1972, Gaz. Pal. 1973, 1, p.155.

132 Cass. crim., 18-07-1889, Bull. crim. no260.

133 Cass. crim. 12-05-1998, no96-83-366.

134 A. VITU, Corruption passive..., op. cit., p.12.

135 Cass. crim., 8-07-1813, S. 1813, 1, p.391.

136 A. VITU, Corruption passive..., op. cit., p.10

137 R. GARRAUD, Traité..., Tome IV, op. cit., no 1522. Exponía el autor que las razones para tal rechazo eran que: esta categoría de personas no eran funcionarios públicos del orden administrativo o judicial, y, además, es difícil admitir que las gestiones o recomendaciones hechas por un miembro de una asamblea deliberante o de un consejo elegido pudieran constituir, un acto de la función o del cargo. GARÇON contesta esta postura y defiende que se trata de una confusión entre el tráfico de influencia con la corrupción propiamente dicha que es el trafico de la función. Es manifiesto que el miembro de un órgano elegido que acepta regalos, no para hacer gestiones sino para votar en tal o cual sentido, o apoyar tal o cual proyecto, trafica su función y no su influencia, con lo cual no hay razón para exceptuarlos del rigor de la ley (E. GARÇON, Code pénal annoté, Tome I, Recueil Sirey, 1952, no 22, p.693).

138 Cass. crim., 29-05-1886, Bull. crim. no199.

139 Cass. crim., 24-02-1893, Bull. crim. no49.

140 Cass. crim., 19-04-1894, Bull. crim. nำ101.

141 Cass. crim., 03-11-1933, Bull. crim. nํ200.
} 


\section{CAPÍTULO IV: TIPO OBJETIVO (I). LOS SUJETOS ACTIVOS}

los miembros de los grandes cuerpos nacionales (Senado, Asamblea Nacional), sino también a las personas que forman parte de las asambleas regionales, departamentales, y municipales. Lo mismo se predica para los ciudadanos franceses que son miembros elegidos del Parlamento europeo. Por otra parte, señala VITU ${ }^{142}$ que se podría aplicar el precepto en estudio a los presidentes y miembros elegidos de ciertos establecimientos públicos administrativos tales como las Cámaras de comercio y de industria ${ }^{143}$, Cámaras de agricultura y Cámaras de los gremios $^{144}$.

\section{C- LAS PERSONAS ENCARGADAS DE UN SERVICIO PÚBLICO}

La doctrina considera que una persona forma parte de esta categoría cuando resulta de su estatuto legal o reglamentario que, a pesar de que no disponga de poderes que le hayan sido conferidos en virtud de una delegación de la potestad pública, es encargada, de manera permanente o temporal, de ejercer una función o cumplir actos que tienen por finalidad la satisfacción de un interés general145. El concepto de servicio público supone que se cumplen dos condiciones: una vinculación orgánica directa o indirecta con una persona pública y el ejercicio de la actividad con vistas a un interés general. Este interés es de mayor servicio, es decir, que los interesados deben satisfacer el interés de los administrados, y del mayor provecho, es decir, que satisfarán el interés propio, a menudo financiero, del organismo al que pertenecen ${ }^{146}$. Sin más precisiones, la jurisprudencia francesa ha considerado que entran en esta categoría: los administradores judiciales para las empresas en dificultad ${ }^{147}$; un inspector principal de la RATP (empresa de transporte público en París) que intervino en la concesión de trabajos a empresas ${ }^{148}$; las personas que trabajan en los hospitales ${ }^{149}$, universidades, Cámara de comercio e industria, Cámaras de agriculturas y de gremios, etc. 150 ; los miembros de ciertas comisiones instituidas con objeto de dar recomen-

142 A. VITU, Corruption passive..., op. cit., p.11. En este mismo sentido también, M-P. LUCAS de LEYSSAC y A. MIHNAN, Droit pénal des affaires..., op. cit., no1022.

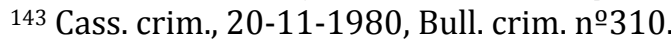

144 Cass. crim., 08-03-1965, Bull. crim. no83.

145 A. VITU, Corruption passive..., op. cit., p.13 ; , M-P. LUCAS de LEYSSAC y A. MIHNAN, Droit pénal des affaires..., op. cit., no1021 ; F. CECCON, Contribution..., op. cit., p.36. Según XIAO-YING las personas que forman de parte de esta categoría ejercen funciones de autoridad pero no tienen la calidad de funcionario (H. XIAO-YING, La lutte contre la corruption..., op. cit., p.79).

${ }^{146}$ F. CECCON, Contribution..., op. cit., p.36.

147 Cass. crim., 23-01-1973, Bull. crim. no29

148 Cass. crim., 2-04-1998, Bull. crim. no127.

${ }^{149}$ Cass. crim., 29-09-1998, no97-84.164

150 A. VITU, Corruption passive..., op. cit., pp.13 y 14. Explica el autor que aquí se trata de administraciones que no son en sí públicas, en el sentido del derecho administrativo, sino organismos que benefician de una autonomía de gestión más o menos marcada, y que toman cuerpo en el seno de personas jurídicas diferentes del Estado, departamentos y municipios. Estas administraciones incluyen sobre todo los organismos públicos de formas variadas, las concesiones de servicios públicos o también los servicios asegurados por vía de gestión delegada. Sobre todos estos organismos, el Estado ejerce una vigilancia más o menos estrecha y directa. 
daciones a las autoridades públicas o decidir sobre demandas, expedientes, proyectos que necesitan autorizaciones, aceptaciones o habilitaciones oficiales ${ }^{151}$.

\section{II- Observaciones y toma de postura}

Como ya lo hemos señalado anteriormente la escasa producción científica o quizá la falta de preocupación doctrinal en la materia, ha llevado a la jurisprudencia francesa a dar interpretaciones amplias, y a veces injustificadamente contradictorias, de los términos de la ley. En efecto, sin otra precisión en la parte general del Código penal francés o malgache sobre los conceptos de "depositario de autoridad pública", de "persona encargada de una misión de servicio público" y de "persona que ostente un mandato electivo público", la única fuente de referencia del intérprete es la jurisprudencia, aunque lo ideal no es que el trabajo de interpretación en esta materia se deje entre las únicas manos de los tribunales. Por consiguiente, nos vemos obligados a formular unas observaciones para proveer un poco de precisión en el manejo de los conceptos y, todo ello, desde las aportaciones del Derecho comparado.

En primer lugar, constatamos la necesidad de una definición del concepto de autoridad pública. Como ya se ha señalado la opinión de la doctrina francesa al respecto, se trata de un poder de decisión y de coerción sobre los individuos y las cosas. Varias preguntas pueden surgir a partir de esta propuesta de definición: ¿qué tipo de decisión?, ¿qué tipo de coerción? Evidentemente, todo ello se halla bajo el transfondo de la potestad pública. La intervención del legislador es más que necesaria aquí para concretar el alcance de este concepto. Respecto al poder de decidir, se podría tratar de la potestad de resolver los asuntos sometidos al titular del poder que implique la aplicación del Derecho objetivo $^{152}$. Poco importa que se trate de juzgar, legislar (ya que en la actualidad se reconoce que el poder legislativo no se dedica únicamente a legislar sino a ejercer control político sobre el gobierno) o administrar y también que el titular de este poder tenga competencia propia o delegada $^{153}$. El poder de decidir no sólo se manifiesta cuando se le someten

151 Ibídem, op. cit., p.13. Se pueden citar los ejemplos de los miembros de las comisiones departamentales y de la comisión nacional de equipamiento comercial (CA Toulouse, 18-05-2000, no536/2000), los miembros de las comisiones regionales y de la comisión nacional de las instituciones sociales y médico-sociales y los miembros de las comisiones que juegan un papel central en materia de bolsa y de banco.

152 Ello nos hace pensar al concepto de "jurisdicción propia" en derecho penal español, Vid J. QUERALT JIMÉNEZ, “El concepto penal...”, op. cit., pp.498 y ss.; A. DEL TORO MARZAL, "Comentario al artículo 119”, op. cit., p.739; I. OLAIZOLA NOGALES, El delito de cohecho, op. cit., p.171.

${ }^{153}$ La doctrina francesa y malgache considera que este poder de decisión viene por la delegación de la potestad pública, lo que significa que su titular ostenta sus funciones como imputables a un ente público delegante. Lo que contrasta con la noción "jurisdicción propia" en derecho español que excluye la jurisdicción delegada ya que la delegación es siempre revocable y como jurisdicción derivada, no puede delegarse sucesivamente, hay que hacer constar en las resoluciones que se adoptan que son por delegación y se consideran tales resoluciones como dictadas por la autoridad delegan- 


\section{CAPÍTULO IV: TIPO OBJETIVO (I). LOS SUJETOS ACTIVOS}

al titular unos asuntos que resolver por medio del Derecho objetivo sino también puede por iniciativa propia tomar decisiones que afectan a los individuos y las cosas. Lo más relevante, a nuestro parecer, es que el titular del poder de decisión tenga competencia para tomar actos jurídicos que permiten incidir unilateralmente en la situación jurídicosubjetiva de los ciudadanos ${ }^{154}$ y las cosas.

En cuanto al poder de coerción, se podría interpretar como la imposición al particular de una determinada conducta que puede consistir en acciones u omisiones ${ }^{155}$. Sin embargo, destaca QUERALT JIMÉNEZ que aunque a la autoridad por el hecho de serlo, le es implícita la potestad de ordenar, de mandar, ello no implica per se la existencia de la coerción, al menos en sentido físico. Así lo demuestra el hecho de que la desatención de los mandatos emanados de la autoridad por parte de los funcionarios o de los particulares engendre el delito de desobediencia, que no es reprimido por la propia autoridad, sino que ésta debe ponerlo en conocimiento de la autoridad judicial correspondiente. Por tanto, la autoridad está dotada de mando, pero éste no implica la coerción física por el hecho mismo de la desobediencia. Se trata de una coerción jurídica, fruto de una premisa previa que es la potestad de reclamar obediencia $^{156}$. Por lo tanto, suscribimos la idea de que la coacción es una consecuencia que tiene su origen en el incumplimiento de la decisión del titular o del depositario de la autoridad, es decir, en la desobediencia a él. Con lo cual, la coacción es un efecto fundamentado en la desobediencia, no una característica consustancial al concepto de autoridad. En consecuencia, podemos decir que la coerción ha de entenderse como coerción jurídica que implica la potestad de reclamar la obediencia ${ }^{157}$.

Dicho todo esto, habrá que averiguar entre los ejemplos que la doctrina ha recogido de los casos jurisprudenciales, quién no puede pertenecer a esta categoría de personas depositarias de la autoridad pública. Pues, a nuestro parecer, salta a la vista que los profesionales "privados" que ejercen sus funciones por delegación de la potestad pública no pueden formar parte de esta categoría. Además, el mismo VITU explica en qué

te. Vid. J. QUERALT JIMÉNEZ, “El concepto penal...", op. cit., pp.498-500; I. OLAIZOLA NOGALES, El delito de cohecho, op. cit., p.172.

154 I. VALEIJE ÁLVAREZ, El tratamiento..., op. cit., p.63.

155 M. COBO DEL ROSAL, "Examen crítico...", op. cit., p.244.

156 . J. QUERALT JIMÉNEZ, "El concepto penal...", op. cit., p.495. Añade el autor que la coerción física presupone necesariamente la jurídica, ya que de lo contrario estaríamos ante una vía de hecho, y tal coerción física es difícilmente ejercitable por la autoridad como tal. A. DEL TORO MARZAL, "Comentario al artículo 119", op. cit., pp.746 y ss. Afirma este autor que toda actividad coactiva de la autoridad o de sus agentes implica virtudes persuasivas, esto es, que la obediencia se produzca de modo espontáneo o natural. De no suceder así, el acto de mando debe disuadir de la previsible situación de desobediencia. Si, pese a ello, la desobediencia se presenta, o la resistencia en su caso, el acto de autoridad puede contener, de manera proporcional y progresiva, la agresión lícita contra los desobedientes y resistentes o, lo que es igual, el empleo de la violencia.

157 J. QUERALT JIMÉNEZ, “El concepto penal...", op. cit., p.495; I. OLAIZOLA NOGALES, El delito de cohecho, op. cit., p.171. 
consiste su función: estos profesionales han sido instituidos como intermediarios o mandatarios de los particulares, y se benefician de un monopolio para cumplir, en beneficio de éstos, actos oficiales ${ }^{158}$. Es el caso de los notarios y los notarios de diligencias ("huissier"). No vemos en qué sentido estos profesionales pueden acumular a la vez un poder de decisión y de coerción sobre los individuos y las cosas si su función es más bien de representar y actuar por cuenta del que los ha contrata$\mathrm{do}^{159}$.

En segundo lugar, un sector de la doctrina francesa defiende que la categoría de "las personas que ostentan un mandato electivo público" es simplemente un subcategoría de "las personas depositarias de la autoridad pública"160. Según JEANDIDIER, se trata de un duplicado de ésta última categoría, con lo cual, se pone en evidencia un defecto en la redacción del artículo 432-11 CPF. So pretexto de precisiones, el legislador diluye en una prosa enrevesada un concepto que se podría decir en unas palabras: una persona, nombrada o elegida, que ejerce una función pública ${ }^{161}$. Por otro lado, la reforma legislativa de 1994 del CPF ha añadido el adjetivo "público" detrás de la expresión "un mandato electivo" prevista también por el artículo 177 del anterior Código. La misma observación vale respecto de la reforma del CPM de 2004. Para REURER, esta aportación se habría justificado si la jurisprudencia hubiera tenido que conocer antes de un caso en el que un "elegido" privado habría sido implicado en un asunto de corrupción que se habría calificado de "pasiva". Sin embargo, según la misma autora, no se halla ninguna publicación de semejante problema. Por lo tanto, el legislador ha demostrado un celo de precisión para evitar toda dificultad futura ${ }^{162}$.

A nuestro parecer, si hay que ser coherente con la definición de lo que se tiene que entender por "persona depositaria de la autoridad pública", destacando el poder de decisión y de coerción (dos elementos necesarios y suficientes para ser considerado como tal una persona de esta

\footnotetext{
${ }^{158}$ A. VITU, Corruption passive..., op. cit., p.12.

${ }^{159} \mathrm{Si}$ el notario de diligencias tiene la potestad de ejecutar una sentencia judicial en nombre de una parte en un proceso (civil o penal), está claro que la sentencia no viene de él. Por lo tanto, si bien puede reclamar la obediencia a un acto judicial, no es autor de éste. (Artículo 1 de la Ordenanza 45-2592 del 2 noviembre de 1945 sobre el estatuto de los notarios de diligencias, modificado por la Ley 2006-728 del 23 de junio de 2006 - art. 35). En cuanto a los notarios, son profesionales privados que han recibido de la potestad pública la misión de recibir todos los actos y contratos a los cuales las partes deben o quieren dar el carácter de autenticidad atribuido a los actos de la autoridad pública, asegurarles la fecha de dichos actos y conservarlos a fin de expedir un extracto (Artículo 1 de la Ordenanza 45-2590 del 2 noviembre de 1945 sobre el estatuto del notariado). En consecuencia, no vemos en qué sentido el notario puede tener poder de decisión y ni mucho menos de coerción, si la mayor parte de su función es dar fe a los actos a él confiados por las partes y conservarlos.

160 A. VITU, Corruption passive..., op. cit., p.12. Para el autor se trata, sin duda, de una precisión más al artículo 432-11; H. XIAO-YING, en La lutte contre la corruption..., op. cit., p.77; C. AMBROISE-CASTÉROT, Droit pénal..., op. cit., p.361.

${ }^{161}$ W. JEANDIDIER, Du délit de corruption..., op. cit., p.1669.

162 E. REURER, Des atteintes..., op. cit., pp.90 y 91.
} 


\section{CAPÍTULO IV: TIPO OBJETIVO (I). LOS SUJETOS ACTIVOS}

categoría), cabe preguntarse si todos los sujetos que ostenten un mandato electivo público pueden pertenecer a la categoría de depositarios de la autoridad pública. La respuesta es sencilla. Ésta debe ser afirmativa con la condición de que las elecciones públicas lleven como consecuencia la ostentación de un poder de decisión y de coerción. Ahora bien, cuando se repasa el listado que la doctrina propone sobre los sujetos miembros de esta categoría, vemos que efectivamente hay sujetos elegidos que son titulares del poder de decisión y de coerción. Sin embargo, no lo son todos. En efecto, los miembros elegidos de los órganos deliberantes de los grandes cuerpos nacionales (Senado y Asamblea Nacional o el Parlamento europeo) y de las colectividades territoriales no tienen personalmente la potestad de reclamar la obediencia de lo que se ha decidido o deliberado. Con lo cual, nos parece acertada la postura de DREYER quien describe los sujetos susceptibles de pertenecer a esta categoría como los elegidos en el sentido amplio y que pueden disponer o no de un poder de coerción ${ }^{163}$. En este sentido vemos justificada la postura del legislador francés y malgache que han querido incluir en una clasificación diferente a estos sujetos que acabamos de describir. Por lo tanto, no se trata de un mero duplicado de los sujetos depositarios de la autoridad pública. Por otro lado, dicho listado incluye también a los presidentes y los miembros elegidos de ciertos organismos públicos administrativos como las Cámaras de comercio y de industria, Cámaras de agricultura y Cámara de gremios. Si bien es cierto que son elegidos, no tienen poder de resolver asuntos que implican la aplicación del Derecho objetivo ni el poder de reclamar la obediencia de los ciudadanos. Lo más llamativo, respecto del caso de estos últimos es el contraste de su modo de elección con el adjetivo "público". Recordemos que se trata de la categoría de sujetos que ostenten un mandato electivo "público". El alcance de este adjetivo no ha sido considerado por la doctrina penal francesa y malgache. En efecto para que un mandato electivo sea "público" se debería tratar de una elección en la que el ciudadano puede participar de manera directa o no. Se hablaría entonces de un sufragio directo o también indirecto ${ }^{164}$. Cosa que no sucede en la elección de los presidentes y los miembros elegidos de las varias cámaras anteriormente citadas ${ }^{165}$. Si se hubiera mantenido la expresión del artículo 177 del antiguo CPF y anterior a la reforma de 2004 respecto del

\footnotetext{
163 E. DREYER, Cours magistral..., op. cit., p.599.

164 I. OLAIZOLA NOGALES, El delito de cohecho, op. cit., p.153. Para la autora, con el adjetivo "popular" junto con la palabra "elección" tal como se ha previsto por el artículo 410 del CPE/1932, se trata del ejercicio de un derecho fundamental de los ciudadanos como es el sufragio. I. VALEIJE ÁLVAREZ, "Reflexiones...", p.458: "La elección consiste generalmente en el nombramiento por votos para desempeñar un cargo o comisión. Se trata de cargos electos de representación política como consecuencia del ejercicio de la soberanía popular y del derecho de sufragio activo y pasivo."

${ }^{165}$ A pesar de que el funcionamiento de este tipo de organismo público sea establecido por un decreto del Gobierno, es de constatar que su finalidad mayormente es de servir el interés público al incentivar y favorecer las iniciativas empresariales. Sin embargo, los dirigentes de estás cámaras deben ser empresarios elegidos por sus pares entre ellos (ejemplo de ello podemos ver el artículo L710-1 del Código de comercio respecto a las cámaras de comercio y de industria). Por lo tanto, no vemos en que sentido este tipo de elección puede ser "pública".
} 
CPM, "mandato electivo", la pertenencia de estos sujetos a esta categoría habría sido justificada, pero al añadir el adjetivo "público" en los artículos 432-11 CPF y 177 CPM se debería quitar del listado de la categoría en estudio estos sujetos y ponerlos en otro sitio. A nuestro parecer, los presidentes y miembros elegidos de estos organismos públicos encajan perfectamente en la categoría de las personas encargadas de una misión de servicio público. Desgraciadamente, no encontramos una postura similar a la nuestra dentro de la doctrina francesa y malgache ${ }^{166}$.

En último lugar, constatamos que respecto de las personas encargadas de una misión de servicio público, la doctrina en la materia destaca dos criterios: uno teleológico y otro subjetivo. Por un lado, VITU define esta categoría de personas como aquéllas "encargadas de cumplir actos o ejercer una función cuya finalidad es satisfacer a un interés general"167. Por otro lado, CECCON considera que esta definición no es suficiente porque habrá que delimitar el concepto de servicio público. Para ello, la autora señala que la noción de servicio público supone la reunión de dos condiciones: la vinculación directa o indirecta a una persona pública y el ejercicio de la actividad cuya finalidad es la satisfacción del interés general ${ }^{168}$. Los ejemplos de los sujetos que pertenecen a esta categoría, anteriormente citados, vienen todos de la aplicación jurisprudencial. En efecto, el Alto Tribunal utiliza cualquiera de estos criterios indistintamente a fin de demostrar la vinculación del sujeto con el servicio público. Sin embargo, la doctrina francesa ${ }^{169}$ ha revelado que la jurisprudencia hacía una doble aplicación de la expresión "personas encargadas de una misión de servicio público": si el tipo penal "no exige de estas personas que dispongan de un poder de decisión en el nombre de la potestad pública" entonces pueden ser autores de los delitos de corrupción pasiva, de tráfico de influencias, de cobro de comisión ilegal, etc. Sin embargo, estas mismas personas no pueden valer de tal condición para pretender la protección penal en el marco de los delitos previstos en los artículos 31 de la ley del 19 de julio 1881 (difamación), 433-3 (amenazas y actos intimidatorios) y 433-5 (desacato) del CPF por la razón de que se exige que los sujetos tengan "prerrogativas de potestad pública" 170 .

\footnotetext{
166 Consideramos que la elección de los presidentes y miembros de estas cámaras no es del todo pública. Es pública en el sentido de que la potestad pública la reconoce como tal. Por lo tanto, no estamos de acuerdo con REURER cuando dice que al añadir el adjetivo "público" el legislador ha manifestado un celo de precisión puesto que el caso de corrupción pasiva de un sujeto que ostente un mandato por medio de una elección corporativa y "privada”, como el caso de estas cámaras, sí que ocurrió (Cass. Crim., 8-03-1965, Bull. crim. $\mathrm{n}$-83). Por lo tanto, una interpretación diferente de la que aquí propuesta entraría en conflicto con la letra de la ley.

167 A. VITU, Corruption passive..., op. cit., pp.10 y 13 ; E. DREYER, Cours magistral..., op. cit., p.599.

168 F. CECCON, Contribution..., op. cit., p.36.

169 J-P. DELMAS SAINT-HILAIRE, Chroniques, Revue de science criminelle et de droit pénal comparé (RSC), 2004, pp.91-94.

170 El primer caso se refiere a los síndicos (Cass. crim. 26-09-2001, Bull. crim. nํ193), y el segundo a dos periodistas free lance de la estación local de la cadena de televisión
} 


\section{CAPÍTULO IV: TIPO OBJETIVO (I). LOS SUJETOS ACTIVOS}

Así las cosas, independientemente de los motivos que se pueden presentar para explicar la actuación de la jurisprudencia, se resalta la necesidad de un criterio claro para delimitar la noción penal de "persona encargada de una misión de servicio público". Nos parece inaceptable, en virtud del principio de interpretación estricta de la norma penal, que el mismo concepto pueda tener dos contenidos diferentes si en realidad se trata de unos sujetos que pertenecen a la misma categoría. Una reforma legislativa en este sentido sería más que necesaria porque sólo el legislador tiene la capacidad de delimitar un concepto penal garantizando así la seguridad jurídica de los destinatarios de la norma penal. Resulta peligroso que haya dentro de las decisiones jurisprudenciales sentencias, que sin fundamentos claros, denieguen la condición de "persona encargada de una misión de servicio público" a los mismos sujetos que en otras ocasiones sí se había considerado como tal siguiendo los mismos criterios ${ }^{171}$. Por otro lado nos parece insuficiente que la mayoría de la doctrina se enfoque en la finalidad de la actividad desempeñada para calificarla de servicio público. Enriquecería el debate doctrinal francés y malgache la aportación de la doctrina española en la materia, que se puede resumir de la siguiente manera: aunque desde la perspectiva de los fines del Estado, la finalidad pública sería "coyuntural" y nunca "ahistórica" lo cual sería incompatible con el principio de taxati$\operatorname{vidad}^{172}$, hay que reconocer que el Derecho penal es un producto de la voluntad política y, por lo tanto, coyuntural ${ }^{173}$. Si es cierto que la discrecionalidad del legislador, a la hora de tejer el entramado de normas penales, se ve limitada por toda una serie de principios básicos del Estado de Derecho, no lo es menos que la propia Constitución, en materia de individualización de aquellos que son los "intereses generales" marca unas pautas mínimas más allá de las cuales ningún partido político puede llegar ${ }^{174}$. Respecto del criterio subjetivo defendido por CECCON que exige en su propuesta de noción de servicio público la vinculación orgánica directa o indirecta a una persona pública, cabe contestar que hoy

FR3 (Cass. crim., 19-03-2003, Bull. crim., no73). Destaca DELMAS SAINT-HILAIRE que lo que se puede sacar de estos casos es que cuando la aplicación de una ley penal está subordinada al reconocimiento de la calidad de "persona encargada de una misión de servicio público", el hecho para el interesado de tener una actividad de interés general sería sin duda, una condición necesaria a la puesta en marcha de las medidas correspondientes, pero no sería siempre una condición suficiente: en ciertos casos habría que ser titular de prerrogativas de potestad pública. Pero ¿cuáles son estos casos? La exigencia de prerrogativas de potestad pública referida por la jurisprudencia no está inscrito en ninguno de los tipos aplicables a estos supuestos: la afirmación de su existencia es puramente pretoriana y, por lo tanto, difícilmente admisible por cuanto estamos en materia penal (J-P. DELMAS SAINT-HILAIRE, Chroniques, op. cit., p.92).

171 Cass. crim., 13-07-1966, Bull. crim. nํ201. Se trata en el caso del presidente de una sociedad anónima de crédito inmobiliario, que el Alto Tribunal había rechazado la tutela de la potestad pública ignorando el decreto del 26 de julio de 1954 sobre el Código urbanístico. Cass. crim., 07-04-1986, Bull. crim., no115, es el caso de un empleado de un banco nacionalizado, es decir bajo la tutela de la potestad pública, a quien la Corte de Casación le denegó la calidad de "persona encargada de una misión de servicio público".

172 I. VALEIJE ÁLVAREZ, “Reflexiones...”, p.467.

173 I. OLAIZOLA NOGALES, El delito de cohecho, op. cit., pp.133 y 134.

174 G. D. M. CERINA, La lucha contra la corrupción, op cit., pp.730 y 731. 
en día es un criterio artificial y harto inseguro para diferenciar el carácter público o privado de la función, puesto que la Administración encuentra cada vez más sujetas sus intervenciones de fomento y desarrollo económico, tanto al Derecho público como al privado. Existen órganos fácticamente privados, que en realidad son organismos públicos, cuyo carácter privado sólo es una fachada jurídica y, en el fondo, no constituyen más que prolongaciones disimuladas de la Administración ${ }^{175}$. Aun así, no es del todo cierto que a un órgano o ente con una forma jurídico-privada, no le sea aplicable de ninguna manera y en grado alguno una disciplina de Derecho público ${ }^{176}$.

A nuestro parecer, sería preferible que el legislador definiera lo que se entiende por "persona encargada de una misión de servicio público" en la parte general del Código penal, a fin de guiar a los intérpretes en cuanto a su posible ámbito de aplicación. A falta de ello, se podrá pedir al legislador que se pronuncie sobre la noción de funciones públicas a efectos de los delitos tipificados en la parte especial del Código penal. Para ello, sugerimos una aproximación formal-objetiva: se trata de individualizar las funciones que se caracterizan por ser públicas para que todo sujeto que las desempeña, con independencia de para quién, en nombre de quién, por cuento de quién lo haga, sea sujeto activo de todos los delitos que implican tal noción. La función considerada como pública será, entonces, la actividad disciplinada por normas de Derecho público y/o por determinados actos administrativos ${ }^{177}$.

\footnotetext{
175 I. VALEIJE ÁLVAREZ, “Reflexiones...”, p.467.

176 G. D. M. CERINA, La lucha contra la corrupción, op. cit., pp.727 y ss.

177 Ibídem, op. cit., pp.723 y 738. Se justifica el criterio objetivo porque distingue según el tipo de actividad y no sobre el órgano o ente en cuyo marco se lleva a cabo y el criterio formal porque el criterio basado sobre el contenido de la actividad es de difícil acotación, no queda sino centrarse en las formas en las cuales dicha actividad se realiza.
} 


\section{CAPÍTULO V: TIPO OBJETIVO (II). LAS CON- DUCTAS TÍPICAS}

El CPE, para referirse a las acciones que pueden dar lugar a la apreciación de las modalidades de cohecho tipificados en los artículos 419, 420, 421 y 422 emplea los verbos: solicitar, recibir, aceptar y admitir. En lo que se refiere al verbo "admitir", para que se pueda "admitir" dádiva o regalo, deberán darse ofrecerse o prometerse dádiva o regalo, al igual que el "aceptar una promesa" necesita que alguien prometa y "aceptar un ofrecimiento" necesita que alguien ofrezca. Por lo tanto, concluye la doctrina española que hay una equivalencia entre los verbos "admitir" y "aceptar"1 o sea que se puede afirmar que "admitir" es, en español sinónimo de "aceptar"2.

El CPF y el CPM tipifican las únicas conductas de "solicitar" y de "aceptar". Es de observar que el tipo de corrupción pasiva en ambos ordenamientos sólo se ha concentrado en los artículos 432-11 del CPF y 177 del CPM, excluyendo toda posibilidad de categorizar el delito en cuestión. A diferencia de la doctrina española, que clasifica el delito de cohecho pasivo en propio e impropio ${ }^{3}$, tal clasificación no es posible en el Derecho penal malgache y francés y tampoco tiene equivalencia a efectos de comparación. Por tanto, si sólo hay un tipo de corrupción pasiva, la reflexión doctrinal en la materia se ha conformado con precisiones totalmente sumarias respecto a las conductas típicas.

${ }^{1}$ E. OCTAVIO DE TOLEDO Y UBIETO, “Derecho penal...”, op. cit., p.875.

2 Ma. J. RODRÍGUEZ PUERTA, El delito de cohecho..., op. cit., p.254; G. D. M. CERINA, La lucha contra la corrupción, op. cit., pp.821 y 822; E. OCTAVIO DE TOLEDO Y UBIETO, "Derecho penal...", op. cit., p.875; con matiz sobre este punto E. CASAS BARQUERO, "Observaciones...", op. cit., p.898.

${ }^{3} \mathrm{M}^{\mathrm{a}}$. J. RODRÍGUEZ PUERTA, El delito de cohecho..., op. cit., pp. 155 y ss. Prefiere la autora clasificar los delitos de los anteriores artículos 419, 420 y 421del CPE bajo la rúbrica "las modalidades agravadas de cohecho de funcionario público" y los anteriores artículos 425 y 426 del CPE como "las modalidades básicas de cohecho para el funcionario". Considera la autora que "la denominación que tradicionalmente ha servido para distinguir estos supuestos no resulta la más adecuada. En primer lugar, porque no aporta nada nuevo respecto a la consideración del cohecho impropio como tipo básico y del cohecho propio como modalidad agravada. Por el contrario, la utilización de términos distintos para designar la modalidad básica y las modalidades agravadas únicamente puede llevar a confusiones, además de suponer, en el nuevo contexto que plantea el Código penal de 1995, una inversión valorativa. Así, de mantenerse la distinción entre cohecho propio e impropio pudiera parecer que el cohecho propio es en realidad el "auténtico" cohecho, mientras que el impropio integra una modalidad sui generis, cuando ésta no es la relación que se infiere de la actual tipificación del delito de cohecho". Al llegar la reforma de 2010, parece que la autora se une a la doctrina mayoritaria en cuanto a la clasificación del delito de cohecho pasivo en propio e impropio (Mạ. J. RODRÍGUEZ PUERTA, "Modificaciones en materia de cohecho", en F. ÁLVAREZ GARCÍA y J. GONZÁLEZ CUSSAC (Dirs.), Comentarios a la Reforma penal de 2010, Tirant Lo Blanch, Valencia, 2010, pp.468, 469). 
Por otro lado, encontramos un punto de acuerdo entre la doctrina española y la francesa ${ }^{4}$ al calificar los tipos penales que dan vida al delito de cohecho pasivo propio como de "tipos alternativos mixtos"s y el delito de corrupción pasiva como de delito de ejecución sucesiva ${ }^{6}$. En efecto, observa VALEIJE ÁLVAREZ que la ley castiga distintas modalidades de conducta (solicitar, recibir, aceptar); todas ellas son fungibles entre sí, resultando indiferente a efectos de punibilidad que el sujeto realice una $\mathrm{u}$ otra conducta, o incluso todas a la vez (por ejemplo, el funcionario que solicita una cantidad de dinero recibiendo una parte y aceptando la promesa de recuperar posteriormente el resto, una vez que ha realizado el acto), ya que, aun en este último supuesto, el delito cometido por el funcionario es único. La consumación del cohecho pasivo resulta cumplimentada por la ejecución de cualquiera de las formas alternativamente descritas en sus artículos respectivos, sin que la ejecución de varias de ellas, en el supuesto concreto, suponga una multiplicidad de delitos ${ }^{7}$. En cuanto al delito de corrupción pasiva como tipo de ejecución sucesiva, los momentos de solicitación, aceptación y en su caso recepción son, a menudo escalonados en el tiempo pero caracterizan el cumplimiento de la corrupción y forman cuantos delitos sucesivos se den mientras dure el concierto fraudulento ${ }^{8}$. Lo que significa que un pacto de corrupción puede dar lugar a varios actos de ejecución ${ }^{9}$ y cada uno de estos actos renueva el pacto ${ }^{10}$, y por lo tanto, se trata del mismo delito sin que sea relevante el número de actos de ejecución que pueda conllevar. El interés consiste para la doctrina francesa en determinar el último acto para marcar el punto de partida del plazo de la prescripción de la acción pública ${ }^{11}$.

También se puede notar que la conducta punible pivota sobre acciones de signo opuesto, ya que la primera -solicitar- implica una actitad activa por parte del funcionario frente a las otras dos -recibir y aceptar -,

\footnotetext{
${ }^{4}$ No hemos hallado una toma de postura semejante en la doctrina malgache. ${ }^{5}$ I. VALEIJE ÁLVAREZ, El tratamiento..., op. cit., p.76; Ma. J. RODRÍGUEZ PUERTA, El delito de cohecho..., op. cit., pp. 174.

${ }^{6}$ M-P. LUCAS de LEYSSAC y A. MIHNAN, Droit pénal des affaires..., op. cit., no1015 ; M. DELMAS-MARTY y G. GIUDICELLI-DELAGE, Droit pénal des affaires, op. cit., p.294 ; H. XIAO-YING, La lutte contre la corruption..., op. cit., p.51.

${ }^{7}$ I. VALEIJE ÁLVAREZ, El tratamiento..., op. cit., p.76.

${ }^{8}$ H. XIAO-YING, La lutte contre la corruption..., op. cit., p.51.

${ }^{9}$ M. DELMAS-MARTY y G. GIUDICELLI-DELAGE, Droit pénal des affaires, op. cit., p.294 .

${ }^{10}$ Cass. crim. 27-10-1997, Affaire Carignon, Bull. crim. no352; M-P. LUCAS de LEYSSAC y A. MIHNAN, Droit pénal des affaires..., op. cit., ํㅜ1015. Para estos autores la consecuencia de cada ejecución material del pacto de corrupción es el nacimiento de un nuevo delito, lo cual no nos parece bien planteado ya que es el cumplimiento del pacto que puede dar lugar a varias ejecuciones pero todas ellas se desarrollan dentro del mismo marco del pacto inicial que constituye el núcleo del tipo. Con lo cual cada acto de ejecución no supone el nacimiento de un nuevo delito sino una renovación de la vigencia del pacto, la cual retrasa el plazo de prescripción de la acción pública.

11 M. DELMAS-MARTY y G. GIUDICELLI-DELAGE, Droit pénal des affaires, op. cit., p.294 ; J. LARGUIER, P.CONTE y A.-M LARGUIER, Droit pénal spécial, op. cit., p.320.
} 
que suponen una actitud pasiva o mejor dicho, una actitud expectante por parte de éste ${ }^{12}$.

\section{Sección 1 - "Solicitar"}

\section{I-Significado}

\section{A-FUNDAMENTO}

El verbo "solicitar" fue introducido por primera vez en el CPE con la reforma de 1944. El legislador español, consecuente con su idea de que el cohecho era un pacto ilícito sobre la función pública y entendiendo que este pacto podía ser iniciado tanto por el funcionario como por el particular, tipificó por primera vez en los artículos 385, 386 y 387 del CPE/1944 "la solicitud de dádivas por parte del funcionario" equiparándola plenamente al hecho de recibirlas o aceptarlas. Paralelamente, en el artículo 391 del mismo texto legal, junto con el "intento de corromper al funcionario" se castigó también como cohecho activo la "aceptación" de las mismas por parte del particular ${ }^{13}$. Destaca VALEIJE ÁLVAREZ los dos motivos por los que legislador español introdujo esta modalidad típica en la figura del cohecho en el momento de la reforma penal.

El primer y fundamental motivo de la reforma obedece a la necesidad de llenar un vacío legal para aquellos supuestos en los que es el propio funcionario público quien da los pasos necesarios para llegar a un acuerdo con el particular, ya que esta conducta, dada la estructura estrictamente bilateral del delito de cohecho, permanecía hasta aquel momento impune ${ }^{14}$. Un segundo objetivo que se persigue tipificando "la

\footnotetext{
12 I. VALEIJE ÁLVAREZ, El tratamiento..., op. cit., p.76. En la doctrina francesa abunda este tipo de observación para matizar que tanto en la corrupción pasiva como en la corrupción activa el autor puede tener actitud a la vez pasiva y activa, con lo cual, la esencia de la diferencia se encuentra en la calidad de los sujetos activos de los delitos respectivos. Véase. P. MAISTRE DU CHAMBON, A. LAPAGE y R. SALOMON, Droit pénal des affaires, op. cit., p.139; J. LARGUIER, P.CONTE y A.-M LARGUIER, Droit pénal spécial, op. cit., p.320 ; C. AMBROISE-CASTÉROT, Droit pénal..., op. cit., p.361; V. MALABAT, Droit pénal spécial, op. cit. p.527.

13 I. VALEIJE ÁLVAREZ, El tratamiento..., op. cit., p.77. Nota la misma autora, en las páginas siguientes, la reticencia por parte de la doctrina penal respecto a esta reforma en su momento.

${ }^{14}$ Ibídem, op. cit., pp. 79-81. Señala la autora que el Tribunal Supremo se venía pronunciando en el sentido de considerar la solicitud no aceptada del funcionario una tentativa de cohecho. Sin embargo esta conducta nuca podría ser considerada como tentativa, porque en lo que atañe al delito de cohecho pasivo propio antes de la reforma, el tipo se limitaba a sancionar conductas de recibir o aceptar; mal se podía mantener que la conducta de "solicitar" constituía un acto intentado de otra conducta de "recibir" o "aceptar" ya que no se podría sostener que aquella conducta fuera un acto encaminado a ejecutar la acción típica de "recibir" o "aceptar". Todo lo más, la solicitud constituía un acto preparatorio encaminado a crear una relación necesaria entre dos sujetos, es decir una propuesta delictiva que debía permanecer impune. Por lo tanto, concluye la autora que la tipificación de la "solicitud" del funcionario desempe-
} 
solicitud de dádivas por parte del funcionario público", al igual que "el intento de corromper" a éste por parte del particular, es que el delito se consume anticipadamente al logro del acuerdo, es decir, a su consumición fáctica. De este modo, el legislador, tipificando un acto preparatorio, otorga una mayor protección al bien jurídico. Este adelantamiento de las barreras de defensa de la ley obedece a consideraciones de política criminal del todo lógicas, como era tratar de romper el vínculo de solidaridad criminal que hasta entonces, en vista de la común impunidad, se venía formando entre corruptor y corrompido ${ }^{15}$.

En la doctrina francesa, el debate se sitúa en la bilateralidad del delito de corrupción, la cual se entiende porque la consumación de la infracción reside en el "acuerdo" ilícito concluido entre corruptor y corrompido y por el cual éste segundo trafica su función o su cargo. La ventaja de la bilateralidad reside en la posibilidad de distinguir el delito de corrupción del delito de concusión. Pero, nota VITU que se han dado diferentes soluciones todas ellas criticables. Una de ellas es considerar al corrompido como autor de la infracción, aunque no ha tomado la iniciativa y se ha conformado con aceptar los ofrecimientos del tercero, y el corruptor sólo debería ser considerado como un cómplice. Tal solución, sin embargo, choca contra la concepción francesa de la complicidad. Tanto en el antiguo como en el nuevo CPF, el cómplice "extrae" su criminalidad del hecho cumplido por el autor principal, con lo cual, habría que concluir que escaparía totalmente a la represión el particular que intentaría, sin lograrlo, corromper a un funcionario puesto que la tentativa de complicidad es impune ${ }^{16}$. La solución propuesta por GARRAUD para superar este problema era considerar a las dos partes como coautores del mismo delito ${ }^{17}$. Desde esta óptica, el delito sería plenamente realizado cuando se alcanzó el acuerdo entre ambos delincuentes y habría tentativa si el ofrecimiento, hecho por uno de ellos al otro, no resultaba concluido. En este análisis, el corruptor no queda impune aunque el funcionario no ha aceptado los avances del primero. Esta solución no está exenta de crítica. Defiende VITU que esta propuesta tiene el defecto de no distinguir de manera adecuada el grado de implicación de los dos personajes. En efecto, el funcionario viola las obligaciones que constituyen el fundamento de la confianza que la potestad pública ha puesto en él y que, desde luego, lo vinculan sólo a él. Sin duda el corruptor se aprovecha de la debilidad del corrompido, pero no es él, a

\footnotetext{
ña un papel que con las normas de Parte General relativas a la tentativa no se podía lograr.

${ }^{15}$ Ibídem, op. cit., p.81. Añade que para conseguir el mencionado objetivo, el legislador deja abierta la puerta a una consumación unilateral, facilitando al particular la denuncia de los "avances" del funcionario y viceversa, sin que a su vez corran el riesgo de verse implicados en un eventual delito de cohecho. A partir de la reforma comentada, si cualquiera de ellos no quiera llevar a cabo el acuerdo (es decir, aceptar el ofrecimiento de la otra parte), sólo tiene que rechazarlo o denunciarlo en su caso; de lo contrario puede que ambos estén completamente de acuerdo con las proposiciones respectivamente recibidas.

${ }^{16}$ A. VITU, Corruption passive..., op. cit., p.6.

${ }^{17}$ R. GARRAUD, Traité..., Tome IV, op. cit., no 1520.
} 
título principal, el que trafica la función. Ahora bien, el mirarlos a los dos como coautores de una única infracción y amenazarlos de una pena idéntica sería desconocer, desde un punto de vista legislativo, la diferencia de las situaciones que separan a los dos culpables ${ }^{18}$. La evolución legislativa en la materia nota que el CPF de 1810 mantenía todavía el aspecto "bilateral" del delito de corrupción pero distinguía dos delitos en vez de uno (un delito para el funcionario y otro para el particular) y habría que esperar la ley del 16 de marzo de 1943 y la ordenanza del 8 de febrero de 1945, que reforman los artículos 177 y siguientes del antiguo CPF, para atenuar el aspecto "bilateral" de la corrupción al mantener la existencia de dos infracciones distintas y optar por la consumación del delito no sólo por la aceptación de dádivas y promesas sino también por la simple solicitación o el mero ofrecimiento, con vistas a traficar la función. El nuevo CPF de 1994 ha hecho suya esta postura ${ }^{19}$.

Encontramos también otro punto de convergencia entre el sistema jurídico español de un lado y el francés y malgache de otro al considerar la modalidad delictiva de solicitar como un delito de mera actividad o delito formal. En efecto, desde el punto de vista de la acción, cualquiera de los tres tipos penales que describen el delito de cohecho pasivo propio e impropio del CPE se satisfacen con un único comportamiento, esto es, una manifestación externa de voluntad, sin que sea necesario que además se produzcan ciertas consecuencias externas separables ontológica y cronológicamente de ella ${ }^{20}$. La doctrina francesa y malgache apunta en el mismo sentido al afirmar que poco importa si la contrapartida de la solicitación sea entregada o no, y tampoco importa el resultado de la misma, la mera solicitación basta para caracterizar la acción del sujeto $^{21}$.

\section{B-PROPUESTAS DE DEFINICIÓN}

La doctrina española define la acción de "solicitar" como la emisión de una declaración de voluntad dirigida a un tercero, por la que se manifiesta la disposición a recibir una dádiva o presente a cambio de la realización de un acto del cargo ${ }^{22}$. Añade VALEIJE ÁLVAREZ que el injusto del delito de cohecho pasivo no se satisface con la existencia de cualquier manifestación de voluntad, es decir, con la mera subsunción formal de la petición de un funcionario en alguna de las descripciones típicas, sino que es necesario que esta "declaración" sea portadora de un

\footnotetext{
${ }^{18}$ A. VITU, Corruption passive..., op. cit., p.7.

${ }^{19}$ Ibídem, op. cit., p.7.

${ }^{20}$ I. VALEIJE ÁLVAREZ, El tratamiento..., op. cit., p.94; M. POLAINO NAVARRETE, “Delitos...", op. cit., p. 367; E. CASAS BARQUERO, "Observaciones...", op. cit., p.874.

${ }^{21}$ H. XIAO-YING, La lutte contre la corruption..., op. cit., p.51 ; M. DELMAS-MARTY y G. GIUDICELLI-DELAGE, Droit pénal des affaires, op. cit., pp.288 y 289 ; P. RAFOLISY, La protection juridique..., op. cit., p.237.

${ }^{22}$ Mà. J. RODRÍGUEZ PUERTA, El delito de cohecho..., op. cit., p.174; I. VALEIJE ÁLVAREZ, El tratamiento..., op. cit., p.96; I. OLAIZOLA NOGALES, El delito de cohecho, op. cit., p. 231.
} 


\section{PARTE II: ESTUDIOS DE LOS ELEMENTOS TÍPICOS...}

mínimo de objetividad para causar o poner en peligro el bien jurídico protegido por este delito ${ }^{23}$.

La doctrina francesa entiende que la solicitación implica una conducta, con la iniciativa del interesado, que invita a su interlocutor, de manera directa o indirecta, a comprender que debe "pagar" para obtener el cumplimiento o no de un acto de la función ${ }^{24}$. En efecto, se trata de una iniciativa unilateral del funcionario con la finalidad de hacer una propuesta de pacto fraudulento explicando al particular que podría actuar o no en su favor a cambio de ciertas ventajas ${ }^{25}$.

Por lo tanto, a nuestro juicio, se trata de una petición o una demanda seria y concreta de una contraprestación que el funcionario hace al particular a cambio de la aceptación de la ejecución de un acto, que puede ser contrario a los deberes inherentes de su cargo o propio al mismo, en el marco de su función. ${ }^{26 .}$

\section{II-Alcance de la conducta}

\section{A-LAS FORMAS DE "SOLICITAR”}

Como se ha señalado antes, el rechazo inicial de la doctrina penal española en cuanto a la equiparación punitiva entre la "solicitud de dádivas por parte del funcionario" y la "aceptación de éstas por parte del particular" se basa en el argumento según el cual, las solicitudes de dádivas provenientes de los funcionarios públicos constituyen, casi siempre extorsiones para los particulares que las aceptan. Ahora bien, señala VALEIJE ÁLVAREZ, la razón por la que, para la doctrina, estas solicitudes constituyen extorsiones o chantajes está en el hecho de que el particular que ha aceptado el ofrecimiento del funcionario, al no poder de-

${ }^{23}$ I. VALEIJE ÁLVAREZ, El tratamiento..., op. cit., p.95. Para la autora el bien jurídico protegido es el principio de imparcialidad de la función pública. Por consiguiente, sólo aquellas "solicitudes de dádivas o presentes" que sean susceptibles de poner en peligro la imparcialidad de la función pública, o, lo que es lo mismo, aquellas peticiones del funcionario que sean susceptibles de generar compromisos o connivencias entre los órganos de la Administración pública y los intereses privados del ciudadanos ajenos a ella y, por lo tanto, puedan dar lugar a indebidas injerencias en la imparcial actuación de los poderes públicos pueden ser calificadas como delito de cohecho pasivo; I. OLAIZOLA NOGALES, El delito de cohecho, op. cit., p. 232. Basta, según la autora, con que la solicitud sea reconocible objetivamente para que pueda afectar el bien jurídico identificado en aquellas condiciones básicas de funcionamiento desde un punto de vista interno como externo que hacen que la Administración sirva a los ciudadanos conforme a criterios de objetividad e imparcialidad.

${ }^{24}$ A. VITU, Corruption passive..., op. cit., p.14 ; H. XIAO-YING, La lutte contre la corruption..., op. cit., p.50.

${ }^{25}$ M. VÉRON, Droit pénal spécial, Sirey, 2010, (13ae ed..), p.388 ; M. DELMAS-MARTY y G. GIUDICELLI-DELAGE, Droit pénal des affaires, op. cit., p.288 ; E. DREYER, Cours magistral..., op. cit., p.602 ; F. CECCON, Contribution..., op. cit., p.38 ; W. JEANDIDIER, Du délit de corruption..., op. cit., p.1669.

${ }^{26}$ V. MALABAT, Droit pénal spécial, op. cit. p.528; E. ORTS BERENGUER, “Delitos...”, op. cit., p.702; M. POLAINO NAVARRETE, “Delitos...”, op. cit., p. 364; E. CASAS BARQUERO, "Observaciones...", op. cit., p.874. 
nunciar lo sucedido, por temor a sufrir la misma pena que el funcionario del que partió la iniciativa, termina siendo, además de la primera víctima de la corrupción, su forzoso encubridor ${ }^{27}$. Según la misma autora, este tipo de argumento viene de la confusión que hacía la doctrina penal española del delito de cohecho con el delito de concusión. Y que tal confusión se deba por parte a la escasa atención que se ha prestado en España al delito de concusión ${ }^{28}$. Se ha acudido al artículo 317 del Código penal italiano ${ }^{29}$ para llevar a cabo la comparación entre ambas figuras delictivas. Sin entrar en la rica polémica que ha generado este asunto en la doctrina italiana, nos referimos a CERINA para destacar que la diferencia entre el delito tipificado con arreglo al artículo 317 del Código penal italiano y el delito de corrupción se cifra en que, en el primero, la lesividad tiene un elemento ulterior respecto al segundo: así, en la concusión (y no en la corrupción o cohecho), amén de la imparcialidad de la Administración Pública (o su buen funcionamiento...), resulta menoscabada la libre determinación del particular (que actúa con metus). De ahí que, por un lado, amén de recibir un beneficio a cambio de una actuación de su oficio, se exige que el funcionario público haga algo (abuso) para interferir en la libre determinación del particular: por ello, se le aplica a este sujeto una mayor sanción respecto a la que le correspondería como autor de cohecho; por otra parte, el particular constreñido o inducido a dar mediante abuso, no se considera merecedor de sanción ninguna ${ }^{30}$.

Sin embargo, no existe el delito de concusión en la regulación española, lo que ha llevado a la doctrina a buscar preceptos que permiten suplir esta ausencia con figuras como el delito de exacción ilegal ${ }^{31}$ (artículo $437 \mathrm{CPE}$ ) o de amenazas 32 (artículos 169 y $171 \mathrm{CPE}$ ). Sin querer rebasar el marco de este trabajo ya que hacer la comparación entre estos delitos con la concusión y destacar las similitudes de estos con el cohecho necesitan precisiones técnicas muy complejas, nos contentaremos con señalar que, por un lado, el fondo común de todos estos delitos se basa en el acto de "solicitar" y de la manera como se lleva cabo conforme a parámetros legales bien distintos; por otro lado, el ámbito de aplicación

\footnotetext{
${ }^{27}$ I. VALEIJE ÁLVAREZ, El tratamiento..., op. cit., p.82.

${ }^{28}$ Ibídem, op. cit., p.83.

${ }^{29}$ Este precepto reza de la siguiente manera: "el funcionario público o el encargado de un servicio público que, abusando de su cualidad o de sus poderes constriñe o induce a alguien para que le de o promete indebidamente, para él o para un tercero, dinero u otra utilidad, es penado con la reclusión de cuatro a doce años".

${ }^{30}$ G. D. M. CERINA, La lucha contra la corrupción, op. cit., p.826; I. VALEIJE ÁLVAREZ, El tratamiento..., op. cit., p.93. En palabras de esta autora, la diferencia entre ambas infracciones estriba en que en el cohecho el particular entrega la dádiva libre y espontáneamente, mientras que en la concusión lo hace para causa del miedo o del temor que le ha infligido el funcionario. A efectos prácticos esta diferencia se traduce en que, si se trata de cohecho, el particular que acepta las solicitudes del funcionario responde por el correspondiente delito de cohecho activo, mientras que, si se trata de concusión, el particular quedará exento de pena.

${ }^{31}$ I. VALEIJE ÁLVAREZ, "Aspectos problemáticos del delito de concusión (diferencias con el cohecho)", Revista general de derecho, 1994, pp.6517 y ss.

32 I. OLAIZOLA NOGALES, Cohecho y amenazas..., op. cit., pp.453 y ss.
} 
del delito de exacciones ilegales y del de amenazas pueden coincidir o también concurrir en algunos casos con otros delitos: como el delito de estafa (artículo $248 \mathrm{CPE}$ ) o el delito de extorsión (artículo $243 \mathrm{CPE}$ ). Después de haber repasado estas figuras, señala CERINA, y volviendo a la comparación entre la corrupción y la concusión, de la existencia de una zona gris que se compone de casos caracterizados por una inducción que no es ni amenaza explicita, ni coacción, ni mucho menos violencia y en los que, sin embargo, se aprecia cierto miedo al poder público (metus pubblicae potestatis) ${ }^{33}$. Concluye el autor que la solución adoptada por el legislador español se presenta como "cohechoabsorbente": fuera de los casos de exacciones ilegales, amenazas, coacción, extorsión, por un lado, y estado de necesidad y medio insuperable por otro (es decir, casos en los que resulta particularmente evidente la conculcación de la libertad de autodeterminarse del particular), el legislador español no ha considerado apreciable un metus pubblicae potestatis relevante para incidir sobre la responsabilidad penal de corrupto y corruptor. Por consiguiente, la zona gris a la que hacíamos referencia anteriormente, debe seguramente considerarse comprendida en el espectro de aplicación del delito de cohecho ${ }^{34}$.

\section{B-LA EXPRESIÓN “SIN TENER DERECHO A ELLO” EN EL DERE- CHO FRANCÉS Y MALGACHE}

No se encuentra en la doctrina francesa un análisis profundizado de esta expresión nueva que salió por primera vez en la reforma del CPF en 1994 y del CPM en 2004. No obstante, podemos encontrar algunas observaciones concisas que pueden aclaran al intérprete sobre el alcance y la pertinencia de la misma. En efecto, decir "sin tener derecho a ello" deja suponer que, en ciertos casos, las personas designadas pueden tener derecho de solicitar o aceptar ventajas. Afirma XIAO-YING que tal situación no se puede admitir dentro de la función pública ${ }^{35}$. REURER señala que la expresión "sin tener derecho a ello" plantea la legitimidad del acto del cargo puesto que dicha expresión es la equivalencia de otra prevista antes de la reforma: "hacer o abstenerse de hacer un acto de sus funciones, justo o no, pero no sujeto a sueldo", lo que significaba, según la autora, que el funcionario había sido pagado para cumplir o abstenerse de este acto y, por consiguiente, se volvería delictivo el hecho de que percibiera un segundo pago para ello ${ }^{36}$.

\footnotetext{
${ }^{33}$ G. D. M. CERINA, La lucha contra la corrupción, op. cit., p.836.

${ }^{34}$ Ibídem, op. cit., p.837.

${ }^{35}$ H. XIAO-YING, La lutte contre la corruption..., op. cit., p.50 ; A. VITU, Corruption passive..., op. cit., p.15.

36 E. REURER, Des atteintes..., op. cit., p.94 . A nuestro parecer, lo que se plantea en la redacción del nuevo precepto sobre el delito de corrupción pasiva, no es la legitimidad de un acto del cargo si se lo paga una o dos veces, ni de su justicia ni de su remuneración ni que el funcionario tenga o no derecho de hacerlo, sino la legitimidad de la solicitación para cumplir o no un acto de la función. Por lo tanto, si el régimen jurídico del acto no le legitima al funcionario a solicitar pago para hacer o abstener de hacerlo, pues ir en contra de la configuración legal de dicho acto caracterizaría el tipo de corrupción pasiva.
} 
A pesar de estos diferentes intentos, hay un acuerdo dentro de la doctrina francesa en afirmar que la razón de ser de esta expresión es poder distinguir la corrupción pasiva de la concusión ${ }^{37}$. El criterio de distinción entre ambos delitos reside en el título al que el funcionario recibe la remuneración delictiva. Si recibe, solicita o exige dicha remuneración como el precio de un acto que se compromete cumplir, retrasar o no cumplir y que entra en el ámbito de su función o es facilitado por ésta, entonces comete un delito de corrupción. Si al contrario el funcionario ha recibido fondos como algo supuestamente debido a título de impuesto, entonces hay concusión. Poco importa que el concusionario haya exigido o simplemente aceptado la cuantía recibida ${ }^{38}$. En efecto, en el marco de la concusión, todo sucede como si la persona a la que se ha reclamado el pago indebido tuviera la obligación de pagar. En cambio, en el marco de la corrupción, hay libertad de aceptar o rechazar el ingreso de la ventaja que solicita el agente público para el cumplimiento de un acto de su función ${ }^{39}$. La consecuencia es evidente: si el cumplimiento de un acto de la función es legalmente sometido a pago, el hecho de exigirlo no puede constituir delito. Inversamente, si se solicitan fondos para el cumplimiento de un acto de la función que no es sometido legalmente a pago, entonces se trata de una solicitación de fondos sin derecho, independientemente de su móvil. La segunda consecuencia es que en la concusión el funcionario es autor de la infracción y el particular su víctima, mientras que en la corrupción, corruptor y corrompido son sujetos activos ${ }^{40}$.

Es de observar que la concusión en el Derecho penal francés (artículo 432-10 CPF) y malgache (artículo $174 \mathrm{CPM}$ ) se define de la manera siguiente: "toda persona constituida en autoridad pública o encargada de una misión de servicio público que reciba, exija u ordene el cobro en concepto de derechos o contribuciones, de tasas o impuestos públicos, (añade, el artículo 174 CPM, "de salarios o pagos") de una cantidad a sabiendas de que no se debe, o que exceda la cuantía de que se debe, será castigada con la pena de cinco años de prisión y $500.000 \mathrm{~F}$ de multa ( en el CPM, "de dos a diez años de prisión y de 1000000 a 2000000 Ariary de multa)". La configuración de este delito ha llevado a los traductores al castellano del CPF a traducirlo no como concusión sino como exacciones ilegales ${ }^{41}$, lo cual nos parece justificado desde el punto de vista del contenido del injusto. La única diferencia entre la concusión del CPF y del CPM y las exacciones ilegales en el CPE se halla en que en la primera se contempla no sólo la actitud positiva de "exigir" u "orde-

\footnotetext{
37 Ibídem, op. cit., p.95; M-P. LUCAS de LEYSSAC y A. MIHNAN, Droit pénal des affaires..., op. cit., no1026.

${ }^{38}$ A. VITU, Corruption passive..., op. cit., p.6 ; V. MALABAT, Droit pénal spécial, op. cit. p.529.

${ }^{39}$ M-P. LUCAS de LEYSSAC y A. MIHNAN, Droit pénal des affaires..., op. cit., no1026; P. RAFOLISY, La protection juridique..., op. cit., p.236.

${ }^{40}$ M-P. LUCAS de LEYSSAC y A. MIHNAN, Droit pénal des affaires..., op. cit., no1026.

${ }^{41}$ C. ARÁNGUEZ SÁNCHEZ y E. ALARCÓN NAVÍO, El código penal francés, op. cit., p.205. No obstante, nos parece preferible traducirlo por "concusión" que es más fiel a la cultura y a la sensibilidad francesa y, por lo tanto, al espíritu del legislador francés.
} 
nar" sino también una actitud pasiva de "recibir", la cual no ha sido prevista por el legislador español. Esta situación, esto es, la utilización únicamente del verbo "exigir" ha llevado a la doctrina española a apuntar algunas similitudes entre el delito de exacciones ilegales y la concusión del Código penal italiano ${ }^{42}$. La doctrina francesa y malgache no pretende equiparar la concusión de su respectivo Código penal con la concusión italiana. Así mismo no se ha encontrado el mismo interés tal como hay en la doctrina española.

A nuestro parecer, es de preguntar si con el verbo "recibir" previsto en el delito de concusión del CPF y CPM se atenta también a la libre determinación del particular como se infiere de los verbos "exigir" y "ordenar". Materialmente, el ámbito de aplicación de esta modalidad encajaría en los supuestos en los que el funcionario recibe una contraprestación después de haberla exigido u ordenado, con lo cual este verbo se quedaría pleonástico o bien, el particular piensa tener que pagar algunos impuestos o tasas y ofreció la cuantía al funcionario sin que éste se la rechazara o se la devolviera. Efectivamente, la equivocación del particular es favorecida por el silencio del funcionario. Por lo tanto, lo determinante para diferenciar la concusión y la corrupción pasiva no es tanto la legitimidad y la cuantía de la remuneración sino la pretensión de legalidad con la que el funcionario hace creer al particular al recibir o exigir de éste la cuantía que pagar y de esa forma consigue condicionar su libre determinación ${ }^{43}$. Es de lamentar la muy leve sanción prevista para el funcionario que comete concusión, sobre todo en su modalidad de "exigir" y "ordenar", ya que parece singular la elección de un legislador que sanciona menos intensamente a quien lesiona dos bien jurídicos (la imparcialidad de la Administración Pública y la libre capacidad de determinación del sujeto pasivo), respecto de quien, con su conducta, afecta sólo al primero de ellos (la imparcialidad de la Administración Pública) ${ }^{44}$. La frontera entre esta situación de pretensión de legalidad y el engaño parece muy sutil. Sin embargo, el engaño no entraña el menoscabo de la libre determinación y nos lleva a pensar más bien en un delito de estafa ${ }^{45}$.

Por otro lado, el debate quizás más cercano, en cuanto al inciso "sin tener derecho a ello" contenido en el CPF y el CPM, ha sido destacado por CERINA, cuando señala la falta de precisión sobre el carácter indebido de la dádiva o del presente en el delito previsto por el legislador español. En efecto, el CPE se muestra reticente a establecer el carácter indebido de la dádiva o del presente que se solicita. Así, si es naturalmente siempre "indebida" la dádiva que se solicita, ofrece... a cambio de un acto injusto (o acto contrario a los deberes inherentes al cargo), lo mis-

\footnotetext{
42 G. D. M. CERINA, La lucha contra la corrupción, op. cit., p.827 y 828.

43 J. LARGUIER, P.CONTE y A.-M LARGUIER, Droit pénal spécial, op. cit., p.319; M. VÉRON, Droit pénal spécial, op. cit., p.386.

${ }^{44}$ G. D. M. CERINA, La lucha contra la corrupción, op. cit., p.829.

45 Para apreciar la diferencia entre el delito de corrupción pasiva y los delitos de estafa y de chantaje, Véase A. VITU, Corruption passive..., op. cit., pp. 4 y 5
} 
mo no se puede afirmar toda vez que el acto no está prohibido legalmente (o acto propio del cargo): el tenor literal des la normas españolas, en este sentido, obligaría a calificar como cohecho el caso de un profesor universitario que recibe una remuneración para dar una conferencia. Y también sería constitutivo de delito del mismo caso, toda vez que, gracias a un sponsor, la Facultad o la Universidad respectiva ingrese dinero. En sentido contrario, defiende el mismo autor, la doctrina española ha argumentado que el término "dádiva" ha de ser entendido como "mejora del funcionario a la que éste no tiene derecho y en este sentido, indebida" ${ }^{46}$. Por lo tanto, si la interpretación gramatical y literal lleva a entender que el término "dádiva" es "cualquier cosa que se da" 47 , el autor añade que cuando se pretende incluir en el lema de este término el adjetivo "indebida", se realiza una operación de sentido común dudosamente permitida en el ámbito penal. Una modificación legislativa es necesaria para ajustar el precepto legal con los distintos convenios internacionales ratificados por España que, por lo general, precisan el carácter indebido de la dádiva o presente. Concluye CERINA que debe retenerse que, en materia de corrupción impropia, la dádiva o el presente, han de resultar "indebidos", esto es, para que su conducta sea penalmente relevante, el particular no debe de estar ni facultado ni mucho menos, obligado para otorgarlos, ofrecerlos o prometerlos al funcionario público ${ }^{48}$. Lamenta el autor que el legislador ha desaprovechado la reforma legislativa de 2010 y sigue sin precisar el carácter indebido de la dádiva, regalo o retribución en el caso de cohecho impropio ${ }^{49}$.

\section{III-Los presupuestos objetivos de la "solicitud"}

El intento de definición que hemos hecho en apartados anteriores, nos lleva a verificar el sentido literal del verbo "solicitar". La variedad de significados que se le puede dar en ambos idiomas obliga a hacer una elección entre ellos a fin de abarcar todas las consecuencias que dicha elección puede implicar. Conforme con lo que los legisladores penales español, francés y malgache han configurado con los delitos de cohecho pasivo y de corrupción pasiva, no sería de recibo el sentido de "instar, urgir a alguien a cumplir rápidamente" lo cual quiere decir que "el funcionario pide con insistencia al particular una contraprestación no debida" sin correr el riesgo de exigir del funcionario público, a los fines de la punibilidad, una conducta afectada de menor incisividad y desvalor respecto a la cometida por el particular (el cual debe ofrecer o prometer cualquier cosa a fin de corromper el funcionario ${ }^{50}$. En cambio, es de recibo entender el verbo solicitar en el sentido de "pretender o pedir para obtener algo" ya que al contraponer las figuras de cohecho pasivo y de corrupción pasiva con la figura de cohecho activo y de corrupción

\footnotetext{
46 I. OLAIZOLA NOGALES, El delito de cohecho, op. cit., p. 358; E. CASAS BARQUERO, "Observaciones...", op. cit., p.890.

47 G. D. M. CERINA, La lucha contra la corrupción, op. cit., p.883.

${ }^{48}$ Ibídem, op. cit., pp.950, 951.

${ }^{49}$ Ibídem, op. cit., p.1199.

${ }^{50}$ I. VALEIJE ÁLVAREZ, El tratamiento..., op. cit., p.96.
} 
activa nos encontramos con que el funcionario solicita la entrega de la dádiva o presente por cumplir un acto contrario ${ }^{51}$, propio o, como en Derecho francés y malgache, facilitado por el cargo. Por lo tanto, si el objetivo perseguido por el funcionario es obtener una contraprestación por el acto a realizar, esta finalidad implica de antemano, respecto a la "solicitud", una serie de consecuencias que serán estudiadas una por una.

\section{A-LA SOLICITUD COMO DECLARACIÓN DE VOLUNTAD RECEP- TICIA}

Un sector de la doctrina española considera que la solicitud, como acto de comunicación que es, debe llegar a conocimiento de la otra parte ${ }^{52}$. La intervención de otro sujeto distinto al funcionario es necesaria, dado que la consumación del delito de cohecho requiere que la solicitud de la dádiva o presente llegue a ser conocida por el destinatario de la mis$\mathrm{ma}^{53}$. Explica VALEIJE ÁLVAREZ que no es concebible una solicitud de "algo" que no esté dirigida a obtener la cosa solicitada, ya que de no existir esta intención en el solicitante se puede decir que no estamos ante una auténtica "solicitud", sino ante la expresión de un deseo ilícito. No basta, pues, que el funcionario emita una declaración de voluntad, es menester que se desprenda de ella y la dirija al particular, esto es, a la persona que ha de hacer la entrega o la promesa ${ }^{54}$. Por consiguiente, defiende la misma autora que aunque desde el punto de vista formal la solicitud típica se perfecciona con un único comportamiento desde el punto de vista material puede decirse que este comportamiento se halla formado por dos fases o momentos diferenciados: uno que viene dado por el momento de la emisión de la declaración y el otro por el de la recepción de esa declaración. Sólo cuando se han dado estas dos fases o momentos ejecutivos podemos decir que el comportamiento se ha verificado. Este fraccionamiento tiene importantes consecuencias, por ejemplo respecto a la consumación. Ya que la ley no pide resultados materiales sino actos de voluntad, la coincidencia espacio-temporal entre la formulación de la petición y la presencia del particular para recibirla llevará una consumación instantánea el delito. Sin embargo, en el caso de que esta coincidencia no se de, esto es, exista una distancia considerable entre el uno y el otro, para que se consume el delito de cohecho pasivo es necesario que transcurra un cierto espacio de tiempo, el suficiente para que la declaración llegue a conocimiento del destinatario, ya que sólo cuando aquélla es conocida por el particular podemos decir que el delito de cohecho pasivo se ha verificado. En este supuesto,

\footnotetext{
51 Ibídem, op. cit., p.96.

52 I. OLAIZOLA NOGALES, El delito de cohecho, op. cit., p. 231.

53 Ma. J. RODRÍGUEZ PUERTA, El delito de cohecho..., op. cit., p.175.

54 I. VALEIJE ÁLVAREZ, El tratamiento..., op. cit., p.97. Para la autora, sólo cuando la declaración de voluntad del funcionario, en el sentido de solicitar el soborno - esto es, cuando ha exteriorizado su intención de traficar con el cargo -, llega a conocimiento del particular se verifica la lesión al bien jurídico protegido por el delito de cohecho: el principio de imparcialidad. Antes de ese momento se está en el ámbito de una nuda cogitativo o lo más en el de una posible tentativa de cohecho pasivo.
} 


\section{CAPÍTULO V: TIPO OBJETIVO (II). LAS CONDUCTAS TÍPICAS}

cuando la consumación no es instantánea, es cuando cabe admitir la existencia de formas imperfectas de ejecución, en concreto la posibilidad de tentativa ${ }^{55}$.

Otro sector de la doctrina española considera que, si es cierto que el funcionario se dirige a alguien en solicitud de la dádiva para que el delito se consume, independientemente de que se acepte o no, a juicio de MUÑOZ CONDE, es suficiente con que la solicitud haya sido hecha formalmente y, así, existe ya consumación y ésta es la fase que hay que estimar cuando, por ejemplo, la solicitud es interceptada por la policía y no existe otra forma de ejecución imperfecta ${ }^{56}$. Más clara es la afirmación de ORTS BERENGUER para quien no es necesaria la aceptación de la solicitud, pues tan pronto ésta se formula, el delito se consuma para el funcionario ${ }^{57}$.

Ésta última postura ha sido la adoptada por la doctrina francesa. Subraya XIAO-YING que poco importa que la contrapartida solicitada no haya sido proporcionada porque la única solicitación basta para considerar punible la acción del sujeto. En otras palabras, según el mismo autor, estamos ante un delito formal e instantáne $0^{58}$. En efecto, para que haya represión de la corrupción por solicitación del funcionario hace falta que el acto unilateral venga de la iniciativa del funcionario y como delito formal, sea cual sea el resultado posterior, lo que importa es el acto de solicitar ${ }^{59}$. Más explícita es la afirmación de VITU para quien la simple solicitación de cualquier ventaja basta para entender que el delito de corrupción pasiva que está consumado desde la emisión de la solicitación ${ }^{60}$. La consecuencia más importante de esta postura en Derecho francés y malgache es la imposibilidad de concebir otra forma de ejecución imperfecta ya que la solicitación ha sido considerada como una tentativa61.

\footnotetext{
55 Ibídem, op. cit., pp.98 y 99.

56 F. MUÑOZ CONDE, Derecho penal, Parte especial, 2009, op. cit., p. 905.

57 E. ORTS BERENGUER, “Delitos...”, op. cit., p.702. En este mismo sentido se han pronunciado también M. POLAINO NAVARRETE, “Cohecho...”, op. cit., p. 322; E. CASAS BARQUERO, “Observaciones...”, op. cit., p.874; L. MORILLAS CUEVA, “Delitos contra la administración pública (V). Cohecho", en Sistema de Derecho Penal español, Parte Especial, Dykinson, Madrid, 2011, p.957; J. CARDONA TORRES, Derecho Penal, Parte Especial, Bosch, 2010, p.502

${ }^{58}$ H. XIAO-YING, La lutte contre la corruption ..., op. cit., p.51.

59 M. DELMAS-MARTY y G. GIUDICELLI-DELAGE, Droit pénal des affaires, op. cit., pp.288 y 294 ; C. AMBROISE-CASTÉROT, Droit pénal..., op. cit., pp.365 y 366 ; V. MALABAT, Droit pénal spécial, op. cit. p.528.

${ }^{60}$ A. VITU, Corruption passive..., op. cit., p.14.

61 M. DELMAS-MARTY y G. GIUDICELLI-DELAGE, Droit pénal des affaires, op. cit., p.290 ; C. AMBROISE-CASTÉROT, Droit pénal..., op. cit., p.370 ; M. VÉRON, Droit pénal spécial, op. cit., p.389 ; P. RAFOLISY, La protection juridique..., op. cit., p.237. A nuestro parecer, semejante postura de la doctrina francesa y malgache es la razón por la cual no se ha podido desarrollar el debate sobre la posibilidad de entender el delito de corrupción como delito pluripersonal o como delito de emprendimiento.
} 
A nuestro modo de ver, entender el verbo "solicitar" por "pretender o pedir para obtener algo" supone lógicamente que esta petición se dirige a un destinatario. No obstante, no parece claro que tal petición tenga que llegar al conocimiento del destinatario para que haya consumación de la modalidad típica de "solicitar". La sola formulación de esta petición ya pone en peligro el principio de imparcialidad, ya que el funcionario se encuentra predispuesto a actuar de una manera diferente de lo que debiera. Hacer depender la punibilidad del acto del funcionario de un evento tal como el conocimiento del destinatario de la solicitación del contenido de la misma, añade otra condición que supera la letra de ley. Por lo tanto, suscribimos la idea de MUÑOZ CONDE y de la postura de la doctrina francesa, según la cual no puede haber forma imperfecta de ejecución en este delito ya que con la solicitación existe la consumación.

\section{B-EL DESTINATARIO DE LA SOLICITUD}

Según VALEIJE ÁLVAREZ, si se interpreta el término "solicitud" como "una pretensión o petición de algo" se está afirmando implícitamente que dicha solicitud consiste en una "proposición concreta y dirigida personalmente a un sujeto o sujetos determinados". Por lo tanto, eso lleva unas consecuencias sobre el destinatario de la misma. Defiende la autora que la persona o las personas a quien se dirige la petición han de ser de ciertas y determinadas y deberán reunir, además, las cualidades suficientes para que, en caso de aceptar, puedan ser capaces de desempeñar el papel de sujeto activo del delito de cohecho activo ${ }^{62}$. En primer lugar, asumiendo que no tiene que ser siempre negativa la respuesta del particular, el destinatario de la solicitud ha de ser una persona física determinada y ha de tener capacidad de acción. La ausencia de esta capacidad excluirá la calificación de cohecho pasivo propio cuando la solicitud de dádivas vaya dirigida a una persona jurídica o cuando, aun siendo física, la persona se encuentra en estado que le impide actuar y manifestar su voluntad63. Por otro lado, no es válida la oferta del funcionario al público, esto es, la que va dirigida a un círculo de personas indeterminadas ${ }^{64}$.

A nuestro juicio, el planteamiento de VALEIJE ÁLVAREZ es lógico para la postura según la cual la solicitud no es típica hasta que la declaración de voluntad del funcionario llegue a conocimiento de su destinatario, lo cual nos lleva a averiguar el significado y el alcance de dicha expresión

\footnotetext{
${ }^{62}$ I. VALEIJE ÁLVAREZ, El tratamiento..., op. cit., p.99.

${ }^{63}$ Ibídem, op. cit., p.100. La autora habla de estado de sueño profundo, delirios de fiebre o plena paralización de sus facultades derivada, por ejemplo, del uso de estupefacientes.

${ }^{64}$ Ibídem, op. cit., p.100 y 101. Demuestra la autora que en el delito de cohecho lo que se hace es no una provocación que exige que la incitación se proyecte sobre una colectividad de personas sino una proposición delictiva que implica una invitación ejecutiva dirigida al particular para cometer el delito en cuestión.
} 
"llegar a conocer"65. Y es cierto que al formular su solicitud y al pensar cómo procesar el camino de la misma, efectivamente, el funcionario ya tiene que haber determinado e individualizado a quien se va a dirigir, $y$ de acuerdo con POLAINO NAVARRETE, el particular es mero destinatario de la solicitud y está llamado a desempeñar la función de "corruptor hipotético"; no real, pues la autoridad o funcionario acreditan ya ser corrupto al efectuar la descrita solicitud de enriquecimiento ilícito ${ }^{66}$. Añade el mismo autor que el particular a quien la autoridad o funcionario solicita tan reprochable contraprestación económica, a su vez, obviamente puede ser un individuo corrupto y, en su caso, eventualmente también un corruptor empedernido. Quizá por ello tal autoridad o funcionario dirigen precisamente a él su interesada solicitud. Pero tales extremos carecen de relevancia para la ejecución de la conducta típica. Es indiferente en esta modalidad típica que el particular, destinatario de la solicitud funcionarial, sea o no corruptor o corrupto. La acción conminada se circunscribe a la mera solicitud funcionarial de tan ilegal contraprestación ${ }^{67}$. Por lo tanto, al defender que la consumación de la modalidad de "solicitar" se caracteriza al instante cuando el funcionario emite su declaración de voluntad y se desprende de ella, no vemos otro motivo para condicionar su tipicidad con la capacidad de acción del destinatario puesto que basta con que este último sea identificado o determinado. Por otro lado, tanto el artículo 424.2 CPE como el artículo 433-1 CPF y el artículo 177-1 CPM prevén la posibilidad de que el particular pueda "atender" las solicitudes de las autoridades o funcionarios o "ceder" ante éstas, pero son presupuestos del tipo de cohecho activo y de corrupción activa, y que desde luego, sería imprescindible en esta modalidad valorar la capacidad de acción del particular antes de pronunciarse sobre estas conductas. Sin embargo, de ningún modo la potencialidad delictiva del particular puede supeditar la tipicidad de la "solicitud" por parte del funcionario.

\section{C-OTROS CARACTERES DE LA SOLICITUD}

Como se ha señalado anteriormente, dentro de la doctrina española no hay acuerdo al considerar que la solicitud de dádivas o favor debe llegar a conocimiento del sujeto, que en caso de aceptar debe realizar la entrega o la promesa. Sin embargo, hay convergencia en el momento de afirmar que no importa de qué forma y en qué modo sea formulada la solicitud, ya que carecen de transcendencia los términos en los que se produzca la petición pudiendo ser realizada directamente por el funcionario o indirectamente a través de un tercero, oralmente o por escrito, de forma expresa o tácita e incluso de forma figurativa ${ }^{68}$. Cabe decir

65 I. OLAIZOLA NOGALES, El delito de cohecho, op. cit., pp. 231 y 232. Se plantea la autor la duda de si el destinatario de la solicitud debe comprender su significado en el sentido de captar la relación entre la solicitud y el acto oficial. Según la autora, la respuesta positiva o negativa depende de razones relativas al bien jurídico protegido.

66 M. POLAINO NAVARRETE, “Delitos...”, op. cit., p. 365.

${ }^{67}$ Ibídem, op. cit., p.366.

${ }^{68}$ I. VALEIJE ÁLVAREZ, El tratamiento..., op. cit., p.101. Añade la autora que la solicitud no tiene necesariamente que ser efectuada con una declaración explícita; al contrario 
que en orden a la forma que debe revestir la solicitud, la única exigencia es que el medio adoptado sea idóneo para hacer llegar el contenido de la misma a conocimiento del particular. Por otra parte, señala VALEIJE ÁLVAREZ, la solicitud debe ser seria y ha de realizarse de modo convincente, preciso y persuasivo, de tal forma que pueda influir en la voluntad del particular a entregar la dádiva solicitada. Ha de ser, por tanto, una declaración de voluntad real y concreta, y no vaga e imposible. Ha de constituir una conducta de la que se desprenda claramente la voluntad de realizar un pacto ${ }^{69}$.

En la doctrina francesa y malgache no se encuentran observaciones de las formas o los caracteres de la modalidad típica de "solicitar". Sin embargo, llama la atención la precisión del legislador francés al introducir los adverbios "directo o indirectamente". Un sector doctrinal entiende que se trata de la persona quien va a ejecutar el acto típico. Si la ejecución es "directa", eso significa que es el mismo funcionario quien va a emitir su petición sin necesidad de ningún intermediario entre él y el destinatario de la solicitud. En el supuesto de que ésta se ejecute de manera "indirecta", implicaría la intervención de una persona interpuesta entre el autor de la petición y su destinatario final ${ }^{70}$. A nuestra manera de entender, estos adverbios pueden también referir no sólo a las modalidades de solicitación, sino también a las formas de la misma. Se puede compartir la postura de VITU, para quien la solicitación implica una iniciativa del interesado que invita a su interlocutor de manera directa o con medios indirectos a entender su pretensión ${ }^{71}$. El mismo autor dedica otro apartado para analizar la cuestión de la persona interpuesta en el delito en cuestión ${ }^{72}$, dejando claro en el principio de su análisis que poco importa la forma en que se ha formulado la petición. En este mismo sentido se han pronunciado LUCAS de LEYSSAC y MIH-

en el delito de cohecho normalmente las solicitudes de dádivas o aceptación de éstas se hacen entender con frases o conductas que son de por sí ambiguas y que sólo adquieren inequivocidad en relación a una situación concreta; Mạ. J. RODRÍGUEZ PUERTA, El delito de cohecho..., op. cit., pp.174 y 175; E. CASAS BARQUERO, "Observaciones...", op. cit., p.874; P. RODRÍGUEZ LÓPEZ y A. I. SOBRINO MARTÍNEZ, Delitos..., op. cit., p.236.

69 I. VALEIJE ÁLVAREZ, El tratamiento..., op. cit. p.102. Para la autora no son suficientes ofrecimientos del funcionario hechos por broma o jactancia o que revelan de inmediato al particular la falta de un propósito firme y decidido de llevar a efecto el acto prometido. La declaración de voluntad falta de seriedad y hecha en condiciones que permitan reconocer dicha falta de seriedad es nula. Por otro lado, la solicitud no debe tener ninguna connotación de coacción o amenaza para el particular, ya que, consecuentemente con el concepto de cohecho manejado, toda presión psicológica del funcionario sobre el particular para que acepte su petición rompería la relación perfecta igualdad - entre funcionario y particular - que caracteriza el acuerdo ilícito, típico del delito de cohecho. Matiza la autora que sin embargo, ello no es óbice para que la solicitud del funcionario pueda ser en algún momento pronunciado en un tono "amenazante o coactivo" o que, al menos, al particular así la interprete (p.103); M. POLAINO NAVARRETE, “Delitos...”, op. cit., p. 366.

${ }^{70}$ H. XIAO-YING, La lutte contre la corruption..., op. cit., p.56 ; M-P. LUCAS de LEYSSAC y A. MIHNAN, Droit pénal des affaires..., op. cit., n-1024.

${ }^{71}$ A. VITU, Corruption passive..., op. cit., p.14.

${ }^{72}$ Ibídem, op. cit., p.14. 
MAN, que defienden que la forma de la solicitación es indiferente porque la ilicitud de la práctica tiene como consecuencia que las propuestas con finalidad corruptiva no se hacen por escrito. Es decir, son orales y confidenciales, lo que suscitará dificultades respecto a las pruebas del delito. Sucede, rara vez, que la solicitud sea escrita. Por lo tanto, no hace falta que sea formulada expresamente en cuanto no deje lugar a dudas $^{73}$. MALABAT entiende la solicitud como una petición, sin importar su formulación en cuanto sea explícita ${ }^{74}$. En efecto, el punto de convergencia entre estas interpretaciones doctrinales, tanto española como francesa, es la aceptación de que la formulación de la solicitud es indiferente a partir del momento en que la petición, aun codificada, delata la seria voluntad de su autor de llegar a un pacto.

\section{D-LA IDONEIDAD DE LA SOLICITUD}

Como se ha señalado anteriormente, el carácter formal del delito de cohecho implica que su punibilidad es independiente del resultado obtenido, pero ello no impide la exigencia relativa a la idoneidad de la petición. Por eso, no se cabe deducir en absoluto que es indiferente que la solicitud del funcionario sea idónea o no para poder "potencialmente" causar aquel resultado. La finalidad perseguida por el legislador al tipificar la modalidad típica de "solicitar" obedece a la necesidad de anticipar la protección del bien jurídico desde el momento que surgiera una iniciativa del funcionario susceptible de ponerlo en peligro; este objetivo ya impone que la "solicitud" haya de ser capaz, idónea y apta para que aquel juicio pueda formularse ${ }^{75}$. Según VALEIJE ÁLVAREZ, aun cuando es necesario para apreciar la existencia de un delito de cohecho pasivo que la solicitud del funcionario sea aceptada por el particular (es decir, no es necesario que el funcionario alcance el resultado proyectado), sí es imprescindible que la "solicitud" en sí misma considerada sea susceptible de poder serlo. La actuación del funcionario ha de ser seria, idónea y efectiva para causar el peligro de una probable aceptación por parte del particular, o sea, ha de ser potencialmente capaz de generar un vínculo o una connivencia entre un órgano de la Administración Pública y un sujeto (o un grupo de ellos) portador de un interés particular ajeno al que debe presidir la actuación de aquélla ${ }^{76}$. De la constatación de la existencia de este peligro para el bien jurídico depende la existencia del delito. En el supuesto de que la solicitud carezca de seriedad o idoneidad para ser aceptada por el particular, estaremos en presencia de una conducta atípica o, todo lo más, ante una tentativa inidónea ${ }^{77}$.

Si bien es cierto que la solicitud debe tener los caracteres de seriedad y de idoneidad para que sea típica, en Derecho penal francés y malgache, puede plantear duda la atipicidad de la solicitud inidónea. Como ya

\footnotetext{
${ }^{73}$ M-P. LUCAS de LEYSSAC y A. MIHNAN, Droit pénal des affaires..., op. cit., no1024.

${ }^{74}$ V. MALABAT, Droit pénal spécial, op. cit. p.528.

${ }^{75}$ I. VALEIJE ÁLVAREZ, El tratamiento..., op. cit. p.104.

${ }^{76}$ Ibídem, op. cit., p.104.

${ }^{77}$ Ibídem, op. cit., pp.104 y 105.
} 
hemos señalado anteriormente, la teoría francesa de la infracción no ha profundizado en la antijuridicidad material del delito, por lo tanto, la punibilidad de una conducta no depende de la lesión ni de la puesta en peligro de un bien jurídico. La concepción del delito se basa en la violación de la ley, con lo cual no se admite ninguna gradación conceptual del injusto entre la tentativa y la infracción consumada ${ }^{78}$. Volviendo a la solicitud inidónea para lograr decidir a su destinatario, desde esta perspectiva, la doctrina penal francesa la interpretará como una tentativa acabada cuya represión no se difiere de la tentativa simple, la cual tendrá la misma pena que la infracción consumada. La base de este análisis se encuentra en la realidad de la intención del autor de la solicitud y en la materialidad de los hechos, en el sentido de que los medios utilizados tienen que ser capaces de llegar a cumplir su resultado. La tentativa inidónea se castigará como las demás tentativas al igual que en el supuesto de un delito imposible, que lamentablemente es punible ${ }^{79}$ por la realidad de la intención criminal del autor, a pesar de que la infracción no pueda ser consumada o bien porque el proyecto criminal no se podía alcanzar ${ }^{80}$ o bien porque los medios utilizados no permitían que la comisión del delito resultara ${ }^{81}$.

A nuestro juicio, nos parece excesivo el hecho de asimilar todas las tentativas entre ellas y las tentativas con la consumación. No se puede reprimir de manera igual una solicitud idónea que otra inidónea, so pretexto que la intención criminal ya existe y el proyecto delictivo toma forma a partir del acto de comunicación y de petición emitido por el autor, aun cuando dicho acto no era idóneo para poder potencialmente causar el resultado pretendido. El juicio sobre la probabilidad de que surja la aceptación del particular a las propuestas del funcionario deberá realizarse retrotrayéndose al momento en que el funcionario realizó la conducta típica (ex ante) y tomando en cuenta todas las circunstancias que concurrieron en el caso concreto ${ }^{82}$. En función de esta probabilidad el juez decidirá la punibilidad del autor y sería deseable, en virtud del principio de proporcionalidad, que, si decide reprimir la solicitud inidónea, no aplicara la misma pena que el autor de una solicitud idónea.

\section{E-EL CONTENIDO DE LA SOLICITUD}

\footnotetext{
${ }^{78}$ M. LACAZE, Réflexions..., op. cit., pp.122 y ss.

${ }^{79}$ J.-H. ROBERT, Droit pénal général, op. cit., p.245

${ }^{80}$ Cass. crim. 16-01-1986, Revue Dalloz, 1986, 265.

${ }^{81}$ CA. Nanterre, 4-05-1979, Gazette du Palais, 1979, 2, 567.

82 I. VALEIJE ÁLVAREZ, El tratamiento..., op. cit. p.105. Se tratará de valorar, según la autora, el lugar y el momento en que la solicitud fue efectuada, la personalidad del destinatario, sus condiciones económicas, la posibilidad o no de que el funcionario realice el acto, etc. Sólo la valoración de todas estas circunstancias permitirá al juez o al intérprete establecer la aptitud, capacidad e idoneidad del comportamiento del funcionario para causar un determinado efecto (la aceptación del particular), ya que es en esta "aptitud, capacidad e idoneidad" de la solicitud donde radica la probabilidad (y no mera posibilidad) del peligro para el bien jurídico, el cual subsiste aunque no se haya producido el resultado esperado por funcionario.
} 
Si la solicitud del funcionario puede dar lugar al nacimiento de un delito de cohecho activo, se impone, en consecuencia, que la declaración o la oferta del funcionario deba contener todos los elementos aptos para determinar la consumación de aquel delito; esto es, debe hacer referencia a cuál es el objeto y la finalidad de dicha solicitud. Adquieren especial protagonismo en este sentido la cantidad solicitada (o, en su caso, el valor pecuniario del objeto que la represente) y el acto ofrecido por el funcionario. Respecto al objeto de la solicitud, el funcionario pide, por cumplir un acto contrario, propio o facilitado por el cargo, una dádiva o un presente que tienen o no un carácter retributivo e ilegítimo. Conviene precisar que la dádiva, dinero, presente o favor solicitado o el ofrecimiento o promesa aceptados operan como una "remuneración" o "contraprestación" del acto a realizar por el funcionario. Y esta característica de "retribución" o "contraprestación" de la dádiva está también presente aun cuando el acuerdo no haya sido alcanzado ${ }^{83}$.

En efecto, la ausencia o la presencia del objeto y de la finalidad en la solicitud caracterizan su tipicidad, por lo que sin ellos o sin uno de ellos no habrá solicitud ${ }^{84}$.

\section{IV-El papel de la persona interpuesta}

Como se ha señalado anteriormente, la consumación del delito de cohecho pasivo no necesita una relación personal y directa entre el funcionario y el particular. Dentro de la acción típica, se ha previsto el papel de la acción de la persona intermedia quien realiza la actividad mediadora entre el funcionario y el particular, o, lo que es lo mismo, "la encargada de trasladar la declaración de voluntad desde su emisario hasta su receptor"85. Este elemento personal intermedio es un partícipe necesario que puede desempeñar funciones de mero transmisor ${ }^{86} \mathrm{o}$ incluso un negociador con el particular para fijar las condiciones del soborno y las características del acto a realizar ${ }^{87}$. El intermediario puede realizar el sustrato material, pero ello no significa que pueda ejecutar la totalidad del injusto, ya que el funcionario deberá dirigir y planear la comisión del delito. En el supuesto de que el intermediario actúe por cuenta propia, faltando el conocimiento y el consentimiento del funcionario obligado a realizar el acto, ya no estaríamos ante un delito de cohecho pasivo sino ante otros delitos como tráfico de influencias o estafa, según el $\operatorname{caso}^{88}$. A los efectos del cohecho, la persona mediadora (que puede

\footnotetext{
${ }^{83}$ Ibídem, op. cit., pp.105 y 106; Ma. J. RODRÍGUEZ PUERTA, El delito de cohecho..., op. cit., pp.178 y 179.Para esta autora, el objeto del pacto (es decir, la proposición si se trata de la tentativa unilateral) debe quedar mínimamente determinado, o cuanto menos, debe ser determinable. Esta exigencia resulta predicable tanto de las dádivas o presentes como del acto propio del cargo contrapartida de las mismas.

${ }^{84}$ E. DREYER, Cours magistral..., op. cit., p.602.

85 I. VALEIJE ÁLVAREZ, El tratamiento..., op. cit. p.106.

${ }^{86}$ E. ORTS BERENGUER, “Delitos...”, op. cit., p.702.

${ }^{87}$ C. SUÁREZ-MIRA RODRÍGUEZ y otros, Manual..., Tomo II, op. cit., p.526.

${ }^{88}$ I. VALEIJE ÁLVAREZ, El tratamiento..., op. cit. p.107; E. CASAS BARQUERO, “Observaciones...", op. cit., p.886.
} 
ser a su vez otro funcionario público o un particular) ha de actuar no en su propio beneficio, sino en el del funcionario, lo que no obsta para que aquél reciba una comisión por su participación en el delito. Hay acuerdo en la doctrina española en aplicar las reglas generales sobre participación a la persona intermedia ${ }^{89}$. Por otro lado, la cantidad solicitada debe significar una retribución para el funcionario. Esto no implica que la cantidad solicitada deba estar destinada a ser disfrutada directamente por él, pudiendo serlo por un tercero (por ejemplo, un automóvil para un hijo, una subvención para su partido político, etc.); lo que sí es requisito indispensable es que la prestación solicitada debe redundar, siquiera sea indirectamente, como una ventaja a su favor, a fin de que exista la relación contraprestación con el acto solicitado ${ }^{90}$.

En la doctrina francesa la cuestión de la persona intermedia se plantea a partir de los adverbios "directa o indirectamente". Ya hemos señalado que estos adverbios también se interpretaban como la manera de formular la solicitación. Sin embargo, hay un acuerdo entre los autores franceses en considerar que dichos adverbios se refieren a que el autor de la solicitud podía cumplir él mismo los pasos necesarios para alcanzar al destinatario o acudir a la intermediación de un tercero ${ }^{91}$ que puede ser miembro de su familia ${ }^{92}$. En Derecho penal malgache, el legislador de 2004 precisó que la solicitación se podrá hacer "directamente o por persona interpuesta", lo cual, gramaticalmente no plantea problema en cuanto a su sentido. La persona intermedia ha sido considerada como una persona que no actúa por cuenta propia, sino por cuenta del autor de la solicitud. En este caso, el tercero actuará como cómplice por ayuda o asistencia ${ }^{93}$. Sin embargo, reconoce VITU que la apreciación de la interposición plantea delicados problemas, ya que no existe presunción de ley de interposición de persona en esta materia. En efecto, hay que establecer el papel delictivo, aunque sea indirecto, jugado por el funcionario; no bastaría con demostrar que, por ejemplo, la mujer, o el hijo, del funcionario han solicitado dádivas o promesas, sino habría que probar que el mismo funcionario ha querido la actuación del tercero, o al enterarse de la misma ha manifestado su aprobación ${ }^{94}$.

\footnotetext{
${ }^{99}$ C. BLANCO LOZANO, Tratado de Derecho Penal Español, Tomo II, Volumen 2, Bosch, 2005, p.507; E. CASAS BARQUERO, “Observaciones...", op. cit., p.886; I. VALEIJE ÁLVAREZ, El tratamiento..., op. cit. p.107. Nota la autor que si persona intermedia fuere funcionario público, sólo podría estimarse que ambos actúan en régimen de autoría si concurren dos clases de presupuestos: uno objetivo - coejecución - y otro subjetivo el acuerdo de voluntades -. Caso contrario, es decir, cuando falten estos dos elementos, aunque el tercero sea funcionario público, su contribución será a lo sumo de partícipe.

90 I. VALEIJE ÁLVAREZ, El tratamiento..., op. cit. p.107.

${ }^{91}$ H. XIAO-YING, La lutte contre la corruption..., op. cit., p.56 ; F. CECCON, Contribution..., op. cit., p.38; M-P. LUCAS de LEYSSAC y A. MIHNAN, Droit pénal des affaires..., op. cit., no1024.

${ }^{92}$ H. XIAO-YING, La lutte contre la corruption..., op. cit., p.56 ; A. VITU, Corruption passive..., op. cit., p.15.

${ }^{93}$ F. CECCON, Contribution..., op. cit., p.38; M-P. LUCAS de LEYSSAC y A. MIHNAN, Droit pénal des affaires..., op. cit., no 1024.

${ }^{94}$ A. VITU, Corruption passive..., op. cit., p.15.
} 
A nuestro parecer, y aunque la reflexión de la doctrina francesa y malgache no lo ha considerado, el hecho de que la persona interpuesta actúe en su propio beneficio implica que ya no estamos en el campo del delito de corrupción pasiva. También es de notar que la reforma penal en Francia, por medio de la ley de 13 noviembre de 2007, introdujo en el artículo 432-11 CPF las expresiones "pour elle-même ou pour autrui", lo que tendría su equivalencia en los artículos 419, 420 y 422 CPE con las expresiones "en provecho propio o de un tercero". Antes de esa fecha la jurisprudencia francesa consideraba que la solicitud típica era la que tenía como contraparte un acto de la función y que el beneficiario de la contraprestación no tenía que ser directamente el mismo solicitante, sino también su familia o una organización o un partido político95. Por lo tanto, la contraprestación debía redundar como una ventaja a su favor, aunque fuera indirectamente. De lege ferenda, la introducción de esta expresión en el artículo 177 CPM añadiría más precisión al ámbito de aplicación de este precepto, sobre todo a la hora de determinar la relación entre el acto de la función con el beneficio que pretendía sacar aunque sea indirectamente. En efecto, cabe dudar de la tipicidad de una solicitud que no refleja la idea de sacar provecho. En este supuesto dicha solicitud estará desprovista de finalidad, por lo tanto debería ser atípica.

\section{Sección 2 - "Recibir"}

Esta modalidad típica ha sido prevista por los artículos 419, 420 y 421 del CPE y con cierta similitud en su significado con la modalidad típica del artículo 422 del mismo Código, al utilizar el verbo "admitir". Al contrario, los CPF y CPM no han configurado de manera directa el delito de corrupción pasiva con esta conducta. Sin embargo, la doctrina especializada en la materia ha contemplado esta modalidad en la interpretación de los artículos 432-11 CPF y 177 CPM.

\section{I-Significado}

Recibir consiste, según RODRÍGUEZ PUERTA, en la efectiva admisión de la dádiva o presente por parte del funcionario con la voluntad de hacerla suya ${ }^{96}$. Esta acción presupone un acto de acogida, no de demanda ni de sustracción, que se corresponde exactamente con correlativo acto de entregar por persona ajena ${ }^{97}$. Pero OLAIZOLA NOGALES va más allá de la mera acción de admitir, y defiende que la recepción de la dádiva o el presente se produce cuando el funcionario la incorpora a su propio patrimonio, es decir cuando actúa respecto a ella como dueño. Es, en este sentido, un acto de apropiación del funcionario ${ }^{98}$. En la misma línea ar-

${ }^{95}$ Cass. crim. 30-06-1999, Bull. crim. no168.

96 Ma. J. RODRÍGUEZ PUERTA, El delito de cohecho..., op. cit., p.176; P. RODRÍGUEZ LÓPEZ y A. I. SOBRINO MARTÍNEZ, Delitos..., op. cit., p.236.

${ }^{97}$ M. POLAINO NAVARRETE, “Delitos...”, op. cit., p. 366.

98 I. OLAIZOLA NOGALES, El delito de cohecho, op. cit., p.255; E. ORTS BERENGUER,

"Delitos...", op. cit., p.702. 
gumentativa se ha pronunciado VALEIJE ÁLVAREZ y explica que la acción de "recibir" es indicativa de un acto de apoderamiento de la cosa que le dan a uno o envían. Para que exista "apoderamiento" previamente ha de existir el desplazamiento físico de una cosa mueble - en este caso de la dádiva o el presente - del patrimonio del particular al del funcionario. En el cohecho, el desplazamiento de la cosa de un patrimonio al otro no tiene lugar mediante la actividad física del funcionario, sino que ocurre en virtud de un acto de disposición realizado por el particular o por la persona que le represente; por lo que en consecuencia, la recepción de dádivas o presentes ha de ser entendida exclusivamente como un alejamiento de las mismas del espacio sobre el que se proyecta el poder patrimonial del particular para incorporarse al de funcionario. Dicho apoderamiento no requiere, en cambio, un contacto manual del sujeto activo con la dádiva o presente, es decir, una acción de "coger"; semejante conducta puede llevarse a cabo por cualquier clase de instrumentos, sean documentales, mecánicos o humanos ${ }^{99}$.

En la doctrina francesa y malgache, no encontramos una definición tal como se ha expuesto en la doctrina española. Como ni el CPF ni el CPM han estipulado esta modalidad, no se puede esperar un desarrollo doctrinal en esta materia. Apenas la palabra "recibir" se utiliza como un variante de la conducta típica "aceptar"100. De las escasas, casi inexistentes veces que se ha utilizado este verbo, se desprende de las observaciones doctrinales que en efecto se trata de una actitud pasiva de parte del funcionario a quien se entregan cosas materiales 101 . Por lo tanto, un sector de la doctrina, el que contempla esta conducta, utiliza este verbo en función de la materialidad de lo que se ofrece y se entrega ${ }^{102}$. En efecto, cabe pensar que "recibir" sin otra precisión más se reduciría a un simple acto de "coger", lo cual tiene el riesgo de extender el ámbito de aplicación de este verbo. Por lo tanto, cabe limitarlo, siquiera de forma mínima, al considerar la recepción como una situación que se puede realizar en virtud de un acto de disposición por parte del particular que permite al funcionario o a un tercero de su elección el disfrute del objeto de dicho acto de disposición ya que no es obligatorio que el traslado por parte del particular beneficie directamente el patrimonio del funcionario.

\footnotetext{
${ }^{99}$ I. VALEIJE ÁLVAREZ, El tratamiento..., op. cit. p.108. Añade la autora que la acción típica de "recibir" consiste en la actividad de un sujeto que da fin a otra conducta de traslado. Tal forma de actuar es, desde luego correlativa a otra conducta de "dar" (conducta constitutiva del delito de cohecho activo), lo que indica que el comportamiento del funcionario lleva implícito el comportamiento correspondiente del particular. En la base de esta modalidad delictiva existe un acuerdo mediante el cual el funcionario recibe una dádiva o presente como contraprestación o retribución convenida y satisfecha por realizar o abstener de realizar un acto contrario al cargo, comprando por su parte el particular "la parcialidad" del funcionario gracias a la dádiva o presente aceptado.

${ }^{100}$ H. XIAO-YING, La lutte contre la corruption ..., op. cit., p.51.

${ }^{101}$ Ibídem, op. cit. p.51; W. JEANDIDIER, Du délit de corruption..., op. cit., p.1669.

102 A. VITU, Corruption passive..., op. cit., p.15.
} 


\section{II-Presupuestos objetivos y subjetivos de la recepción típica}

Como se ha señalado, el funcionario no "recibe" si no hay alguien que "da"; el comportamiento de cada uno de los sujetos manifiesta, por tanto, el carácter pluripersonal del delito de cohecho. El encuentro de sus respectivas manifestaciones volitivas produce el efecto de constituir la conducta típica objeto de previsión: el traslado efectivo de la dádiva o presente que viene descrito en el texto penal desde el punto de vista de cada uno de los sujetos. En este sentido, según VALEIJE ÁLVAREZ, conviene precisar que en el cohecho es preciso que la relación objetiva que media entre los dos comportamientos esté también sujeta a un correlativo elemento intencional, compresivo de la actitud psicológica que liga a cada uno de los sujetos intervinientes con el hecho delictivo completo ${ }^{103}$. Por consiguiente, para que exista recepción típica no es suficiente el acto material de tomar o apoderarse de la dádiva o el presente; es también necesario que el funcionario haya advertido o tenga conocimiento de que ésta es fruto de otra contraprestación. El funcionario público que se apodera de un cantidad de dinero desconociendo el motivo de la entrega no responde de cohecho pasivo ${ }^{104}$. La misma autora defiende que la necesidad de que el funcionario advirtiera tanto la entrega como su finalidad tiene también su importancia en el terreno del cohecho activo. Si la entrega ha sido hecha de tal forma que éste no puede en algún modo reconocer la intención del soborno, estaremos ante un delito imposible de cohecho activo. Por consiguiente, desde el punto de vista subjetivo, el conocimiento de cuál es la finalidad de la dádiva debe ser recíproco. En aquellos supuestos en que dicha entrega del particular no se hace voluntaria o espontáneamente, aunque exista recepción y dolo de corrupción por parte del funcionario, no existe cohecho pasivo ni activo. Concluye la autora que el conocimiento de la finalidad de la que está teñida la entrega impregna de tal forma la noción de "recibir" que, en el caso de su ausencia, aunque su falta afecte a uno solo de los sujetos intervinientes, la conducta realizada es impune, al menos como cohecho, no porque falte el dolo, sino sencillamente porque desaparece el sustrato del delito (el elemento subjetivo del injusto), siendo, por tanto, atípica ${ }^{105}$.

Estamos de acuerdo con VALEIJE ÁLVAREZ al afirmar que bajo las conductas "dar" y "recibir" tiene que haber un transfondo psicólogico común que es el conocimiento de la finalidad de la dádiva ofrecida por el

\footnotetext{
103 I. VALEIJE ÁLVAREZ, El tratamiento..., op. cit. p.110.

${ }^{104}$ Ibídem, op. cit., p.111. Explica la autora que entender lo contrario, esto es, que colman las exigencias de tipicidad con el solo conocimiento de la entrega material, lleva a una ampliación desmedida - con los peligros que ello comporta en orden a la determinación de la figura legal - de la esfera de aplicación del delito en cuestión. El primero de ellos es el riesgo de equiparar conductas ilícitas (se piensa, por ejemplo, en la recepción de un regalo de autor desconocido y del que, en consecuencia, se ignoran los motivos concretos que han inducido a entregarlo).

105 Ibídem, op. cit., p.112.
} 
particular, la cual va a ser la contraprestación de un acto que se espera del funcionario. En efecto, si este conocimiento falta en el momento de recibir, según la autora, pues no se puede hablar de delito de cohecho ni pasivo ni activo. Sin embargo, a nuestra manera de entender, la recepción no puede ser típica sin la voluntad de ambas partes de llegar a un pacto o un acuerdo ilícito. Por lo tanto, sería importante que antes de la recepción, el funcionario no sólo conozca la finalidad y la pretensión del particular, sino también asuma las consecuencias de tal conocimiento. Esta asunción no tiene otro significado en este contexto que el verbo "aceptar". Es la razón por la que, a nuestro juicio, el legislador francés y malgache no ha previsto la modalidad típica "recibir", porque realmente lo que se reprime no es una incorporación patrimonial o un acto de apoderamiento en sí sino actos de voluntad. Por eso, cabe concluir que no puede haber recepción típica si no hay aceptación típica. En otras palabras, no basta con que el funcionario tenga conocimiento de la finalidad de la dádiva como contraprestación de algo que el particular espera de él, sino que, al recibir dicha contraprestación, "acepte" su entrega a cambio de actuar a favor de aquél, y así dar forma al pacto de corrupción ${ }^{106}$.

Por lo tanto, cabe preguntar si puede haber delito de cohecho o de corrupción si el conocimiento de la finalidad y de los compromisos de cada parte no es recíproco. Aunque VALEIJE ÁLVAREZ contesta de manera negativa a esta interrogación, consideramos que no debe ser así. En realidad, para que haya delitos de cohecho pasivo o de corrupción pasiva y de cohecho activo o de corrupción activa, se necesita la reciprocidad del conocimiento de la finalidad y de los compromisos para llegar a un pacto de corrupción. Sin embargo, en un momento determinado del iter criminis del delito de cohecho o de corrupción, una de las partes comienza a tomar la decisión de manera unilateral para alcanzar, no un resultado, sino un acuerdo. En la modalidad de recepción, que es una actitud pasiva del funcionario ${ }^{107}$, el que tiene que tomar la iniciativa de manera unilateral es el particular ${ }^{108}$. Por lo tanto, si el funcionario llega a conocer la finalidad de la dádiva pero no se adhiere a ella, aunque ya se ha finalizado la entrega, la recepción no puede ser típica. En cuanto al particular, sí se considerará típica su acción de "dar" por medio del artículo 424.1 CPE al "ofrecer entregar" al funcionario o de los artículos 433-1 CPF y 177.1 CPM al "proponer" dádiva a este último. En este caso, la recepción no puede ser típica bajo los preceptos de cohecho pasivo o corrupción pasiva, ya que antes de "recibir" se necesita la aceptación

\footnotetext{
${ }_{106}$ Ma . J. RODRÍGUEZ PUERTA, El delito de cohecho..., op. cit., p.177. Señala esta autora que "a diferencia de la acción de solicitar, la recepción demanda la previa o la simultanea obtención del acuerdo entre funcionario y particular, momento en el cual se produce la conculcación del principio de imparcialidad". Creemos que materialmente la recepción para que sea típica debe ser precedida de un acuerdo aunque el consentimiento del funcionario se concrete inmediatamente por el acto de apoderamiento de la dádiva entregada.

107 I. VALEIJE ÁLVAREZ, El tratamiento..., op. cit., p.109; M. POLAINO NAVARRETE, "Delitos...", op. cit., p. 366; I. OLAIZOLA NOGALES, El delito de cohecho, op. cit., p.254.

${ }^{108}$ I. OLAIZOLA NOGALES, El delito de cohecho, op. cit., p.254.
} 


\section{CAPÍTULO V: TIPO OBJETIVO (II). LAS CONDUCTAS TÍPICAS}

para concluir un pacto. La recepción subsiguiente a la aceptación es típica en el sentido de que el delito de cohecho se perfecciona con la efectiva admisión de la dádiva ${ }^{109}$.

\section{III-Las formas de recibir}

La doctrina española especializada defiende que el cohecho es siempre un delito de comisión activa110. Por tanto, es necesaria una conducta positiva del funcionario que tenga como consecuencia que la dádiva ingrese en su patrimonio. Ahora bien, esta conducta puede ser efectuada de cualquier modo, ya que los tipos penales de cohecho no reclaman ninguna forma de entrega determinada. Siendo así que la recepción puede tener lugar tanto de modo directo como indirecto (mediante un tercero intermediario), explícita o implícitamente. Lo importante en el delito de cohecho es el provecho o ventaja económica que el funcionario recibe, más que el medio mismo por el que se efectúa el traslado ${ }^{111}$. Esta misma doctrina revela el debate sobre la posibilidad de realizar la recepción de la dádiva no sólo mediante el traslado sino incluso mediante la retención de cosas u objetos que ya estaban en poder del funcionario $^{112}$. En ambos casos, indica OLAIZOLA NOGALES, para que se pueda hablar de delito de cohecho debe haber un acuerdo de voluntades entre el particular y el funcionario ${ }^{113}$. La polémica gira en torno a si el delito de cohecho puede ser cometido por omisión ${ }^{114}$. Aunque el debate ha surgido en Italia, la doctrina española especializada en esta materia niega la posibilidad de cometer el delito de cohecho en comisión por omisión. Así, VALEIJE ÁLVAREZ, articula su postura a partir de la calificación del delito de cohecho como delito de mera actividad ${ }^{115}$, lo que im-

${ }^{109}$ Ma . J. RODRÍGUEZ PUERTA, El delito de cohecho..., op. cit., p.181. Creemos que "admisión" aquí se entiende por "recepción" ya que la "aceptación" no perfecciona sino da origen al delito.

110 I. VALEIJE ÁLVAREZ, El tratamiento..., op. cit., p.112; I. OLAIZOLA NOGALES, El delito de cohecho, op. cit., p.255.

111 I. VALEIJE ÁLVAREZ, El tratamiento..., op. cit., pp.112 y 113.

112 Ibídem, op. cit., p.113, según la autora, se puede "recibir" aceptando como un regalo un objeto que el funcionario poseía de antemano, o sencillamente aceptando la utilización del mismo más allá del tiempo pactado inicialmente. En estos casos el funcionario ejecuta su voluntad de "recibir", ya sea adquiriendo la propiedad del objeto, ya sea con su disfrute por un tiempo determinado; I. OLAIZOLA NOGALES, El delito de cohecho, op. cit., p.255, esta autor califica esta modalidad de "conducta pasiva".

113 I. OLAIZOLA NOGALES, El delito de cohecho, op. cit., p.255.

114 I. VALEIJE ÁLVAREZ, El tratamiento..., op. cit., p.113. “Desde el punto de vista del cohecho pasivo, se ha pensado que puede darse esta posibilidad en relación al caso en que el funcionario obtiene como regalo el objeto ya poseído anteriormente, y desde el punto de vista del cohecho activo, al del particular que con conocimiento de esta situación consiente en la retención del objeto por parte del funcionario".

115 Ibídem, op. cit., p.109. Parte la autora, al calificar la modalidad típica de "recibir" como delito de mera actividad, del principio que el concepto de resultado, en sentido estricto, implicaba que el tipo exigiese la producción de ciertas consecuencias separables ontológica y cronológicamente de la manifestación de voluntad. Desde este punto de vista, puede afirmarse que la recepción de las dádivas o presentes no es una acción independiente de la manifestación de voluntad del particular, sino que son y representan una misma cosa; el desplazamiento de la dádiva o del presente del patrimonio del 
pide ya, su construcción en comisión por omisión. En este sentido, el ejemplo paradigmático del que se sirve la doctrina italiana para confirmar tal posibilidad - aquellos supuestos en los que la dádiva o presente es poseída legítimamente por el funcionario - no integrarían auténticos supuestos comisivos. Respecto a esta hipótesis es también necesario, para cometer el delito de cohecho, que el funcionario realice una conducta positiva, que ponga de manifiesto su intención de recibir o hacer suyo el objeto poseído como retribución por un acto del cargo. Así, la autora niega el carácter delictivo de la conducta del funcionario que no se pronuncia sobre la oferta hecha por un particular, o no rechaza el dinero que éste deposita en su mesa de trabajo. En ambos supuestos, siempre que el funcionario no lleve a cabo una mínima actividad positiva tendente a disfrutar del objeto, a incorporarlo a su patrimonio o a sacar rendimiento, no podrá ser condenado por el delito de cohecho. Por el contrario, cuando, sin existir una declaración expresa, el funcionario lleva a cabo cualquiera de los actos antes indicados, éstos serán suficientes para considerar que acepta o recibe la dádiva o presente, y por tanto para apreciar el delito de cohecho ${ }^{116}$.

Como la conducta típica de "recibir" no figura en el delito de corrupción pasiva previsto por el CPF y el CPM, a nuestro parecer, las consideraciones sobre las formas de recibir estudiadas desde la doctrina española son perfectamente trasladables en la interpretación que pueden hacer la doctrina francesa y malgache. En efecto el modo de recibir y de entregar puede ser directo o indirecto, explícito o implícito, ya que lo importante para el legislador penal es la evitación de la formación de un acuerdo de voluntades entre el funcionario y el particular, el cual lesionaría el bien jurídico, y no la forma del traslado entre dos patrimonios. En cuanto a la posibilidad de plantear una comisión por omisión del delito de corrupción, en el caso de que la dádiva o el presente ya estén entre las manos del funcionario, ya se ha destacado anteriormente, que el delito en cuestión ha sido considerado por la doctrina francesa y mal-

particular al del funcionario simboliza la declaración de voluntad del particular de corromper al funcionario y, en el supuesto que sea admitida, la perfección del acuerdo de voluntades. Por lo tanto, la acción típica de recibir es también un delito de mera actividad, ya que basta la existencia del comportamiento corporal externo de "recibir" para afirmar que el delito de cohecho pasivo propio se ha verificado; Ma . J. RODRÍGUEZ PUERTA, El delito de cohecho..., op. cit., p.181; I. OLAIZOLA NOGALES, El delito de cohecho, op. cit., p.259.

116 I. VALEIJE ÁLVAREZ, El tratamiento..., op. cit., pp.114 -116; I. OLAIZOLA NOGALES, El delito de cohecho, op. cit., p.256. Sostiene esta autora que no está de acuerdo en que la conducta de "no devolver" una dádiva o presente que ya estuviera en poder del funcionario constituya una omisión. Es una conducta pasiva pero no omisiva, sino comisiva. Cuando el funcionario, de acuerdo con el particular, no devuelve la dádiva, desde luego deja de hacer algo que debería hacer, devolverla, pero lo realiza por medio de un acto comisivo de apropiación, al incorporar la dádiva a su patrimonio, es en ese momento cuando se produce la recepción, aunque lo lógico es que previamente lo que sí haya producido ya sea la aceptación. Mạ. J. RODRÍGUEZ PUERTA, El delito de cohecho..., op. cit., p.182. La autora esgrime un segundo argumento según el cual las acciones descritas en los tipos de cohecho tienen un carácter eminentemente activo solicitar, recibir o aceptar - de modo que su equiparación a la omisión podría desbordar el marco del sentido literal posible. 
gache como un delito formal, por tanto, no necesita la producción de ningún resultado. También se admite en Derecho penal francés y malgache que una infracción de comisión por omisión se caracteriza por la no evitación de un resultado alcanzado por una actitud pasiva. Pues, cabe concluir que si el delito de corrupción pasiva (y también la corrupción activa) es un delito formal cuya caracterización no depende de la existencia de un resultado, no se puede contemplar su comisión por omisión. Y como ya lo hemos señalado, la recepción, en la mayoría de los casos, viene de una aceptación previa o simultánea, por tanto, la mera formación del acuerdo de voluntades basta para consumir el delito de corrupción independientemente de que la dádiva esté o no en poder del funcionario ${ }^{117}$. Si el funcionario da indicios de un comienzo de disfrute del objeto, se considerará que se ha alcanzado un acuerdo. Mientras no manifiesta esos indicios, todavía no se puede hablar de corrupción pasiva. Este tipo de planteamiento no se encuentra ni en la doctrina francesa ni en la malgache. Su reflexión se ha conformado con constatar que el delito de corrupción es un delito formal e instantáneo. La razón es evidentemente porque si el resultado no se pide en este tipo de delito, es imposible o incluso innecesario, plantear una posibilidad de comisión por omisión. Sin embargo, como ya hemos señalado anteriormente también, la doctrina penal francesa y malgache no ha precisado el concepto de resultado penal. No se sabe exactamente a qué alude la doctrina en cuestión al utilizar este término "resultado": o se refiere a la efectiva lesión del bien jurídico, lo cual en este caso se refiere al acuerdo de voluntades entre el funcionario y el particular, o se refiere a la ejecución del pacto al tomar el funcionario el acto propio de su cargo y al incorporar en su patrimonio la dádiva ${ }^{118}$, o algún resultado que implica la exigencia de la producción de ciertas consecuencias separables ontológica y cronológicamente de la manifestación de voluntad ${ }^{119}$. La lectura detenida de la doctrina francesa nos lleva a deducir que ésta entiende por resultado el cumplimento de la promesa por parte del funcionario, tomando un acto propio de su cargo o el cumplimiento del ofrecimiento de dádiva por parte del particular ${ }^{120}$.En definitiva, independientemente del concepto de resultado que se opte, tanto alcanzar un acuerdo como incorporar al patrimonio la dádiva o simplemente dar indicios de disfrute exigen un comportamiento positivo aunque éste puede tomar la forma de conducta pasiva. La importancia práctica de la precisión aquí propuesta se encuentra en la complejidad de las formas en que el delito de corrupción pueda presentarse.

\footnotetext{
117 I. OLAIZOLA NOGALES, El delito de cohecho, op. cit., p.259.

118 M. POLAINO NAVARRETE, "Delitos...", op. cit., p. 367; E. CASAS BARQUERO, “Observaciones...", op. cit., p.875.

119 Mà. J. RODRÍGUEZ PUERTA, El delito de cohecho..., op. cit., p.181; I. VALEIJE ÁLVAREZ, El tratamiento..., op. cit., p.109.

${ }^{120}$ H. XIAO-YING, La lutte contre la corruption..., op. cit., p.50; M. DELMAS-MARTY y G. GIUDICELLI-DELAGE, Droit pénal des affaires, op. cit., p.289; P. MAISTRE DU CHAMBON, A. LAPAGE y R. SALOMON, Droit pénal des affaires, op. cit., pp.141 y 147; E. DREYER, Cours magistral..., op. cit., p.603; M-P. LUCAS de LEYSSAC y A. MIHNAN, Droit pénal des affaires..., op. cit., no1015.
} 


\section{IV-La intervención de la persona interpuesta}

Se han planteado en la doctrina penal española las cuestiones que pueden aparecer con la intervención de una persona interpuesta en los delitos especiales como lo es el delito de cohecho pasivo y su posible responsabilidad ${ }^{121}$. Los artículos 419,420 y 421 CPE se refieren a la posibilidad de que se solicite, se reciba o se admite la dádiva, el favor o el regalo en provecho propio o de un tercero y por sí o por persona interpues$t a^{122}$. La lectura detenida de estos preceptos lleva a dos hipótesis: aquellas en las que un tercero interviene en el delito, como intermediario o interlocutor entre funcionario y particular, y, una segunda constelación de supuestos, en los que el tercero se limita a recibir la dádiva o presente o a beneficiarse de ella. En ambos casos, el sujeto responderá gene-

121 I. OLAIZOLA NOGALES, El delito de cohecho, op. cit., pp. 197 y ss. La autora evoca en primer lugar la situación de la "utilización" de un extraneus por parte de un intraneus. Se trata de los casos en los que un intraneus induce a un extraneus que obra con plena libertad y de manera dolosa a la realización de la conducta propia de un delito especial propio. En estos casos el extraneus que actúa de modo inmediato no puede ser autor del delito especial, porque le falta la característica personal exigida por el tipo, resultando su conducta en principio atípica; el inductor intraneus no podrá responder como inductor, en virtud del principio de accesoriedad limitada de la participación, que hace atípica la participación en un hecho no típicamente antijurídico. Para evitar esta laguna de punición se ha propuesto acudir a la figura de la autoría mediata por utilización de un instrumento doloso o cualificado: el intraneus sería autor mediato del hecho y el extraneus un partícipe en el mismo, que sería calificado normalmente como cooperación necesario. Sugiere la autora que el quid de la cuestión estará en el estudio de cada caso para ver si lo relevante es que la conducta venga realizada por el propio funcionario o no. Es decir, si desde del punto de vista de la protección del bien jurídico es o no importante el que la conducta se realice directamente por el funcionario. A partir de ahí se podrá formular críticas a aquellas redacciones formales que impidan la realización del tipo por un particular cuando el bien jurídico se perturbe de la misma forma independientemente de que sea el funcionario el que realice la conducta directamente o la realice a través de un tercero. En segundo lugar, la autora plantea el caso de utilización de un intraneus por parte de un extraneus. En este caso sí que se produce una auténtica utilización, porque de no ser así, si el funcionario actúa libremente y con plena consciencia, se estará ante un caso de participación de un extraneus en un delito especial, que es perfectamente posible y punible. El supuesto que se estudia es el del extraneus que, sirviéndose de alguno de los medios que normalmente fundamentan la autoría mediata, consigue que el intraneus realice la conducta propia del delito especial. El problema se plantea cuando el intraneus actúa en un supuesto de falta de acción, de modo justificado o meramente imprudente en tipos en los que sólo es punible la comisión dolosa. En estos casos el intraneus no realiza una acción típicamente antijurídica, por lo que en virtud del principio de accesoriedad limitada de la participación, el extraneus no puede ser castigado como inductor, pero tampoco, al faltarle la cualidad personal necesaria en un delito especial, podrá responder como autor ni mediato ni inmediato de ese delito.

122 Ibídem, op. cit., pp.203 y 204. Según la autora, y bajo la vigencia de la anterior redacción, en el delito de cohecho están solucionados, por la propia redacción del delito, los problemas relativos a la utilización de un extraneus por un intraneus. En la redacción del delito de cohecho pasivo se establece la posibilidad de que el funcionario solicite o reciba la dádiva a través de una persona interpuesta. Dado que el funcionario no precisa para realizar la conducta típica realizar él mismo la solicitud o recibir directamente la dádiva, sino que puede hacerlo a través de otra persona, entonces, en estos casos, el funcionario seguirá siendo autor inmediato y la persona intermediaria sería partícipe del delito. 


\section{CAPÍTULO V: TIPO OBJETIVO (II). LAS CONDUCTAS TÍPICAS}

ralmente como cooperador necesario, no obstante conviene diferenciar unos casos de otros ${ }^{123}$.

\section{A-CUANDO EL SUJETO REALIZA LABORES DE MEDIACIÓN EN- TRE EL FUNCIONARIO ENTRE EL FUNCIONARIO Y EL PARTICULAR}

En estos supuestos, habrá que determinar si con su conducta auxilió a uno u otro de los sujetos implicados en el delito de cohecho. Sin duda, si la conducta desarrollada por el tercero se dirige a facilitar al particular corruptor la obtención del acto, en este caso, no habrá dificultad para considerarlo autor del delito de cohecho o si su participación en el hecho delictivo consistió en entablar relaciones con el funcionario y entregarle o prometerle la dádiva. Como indica VALEIJE ÁLVAREZ, en esas hipótesis será autor del delito y no partícipe, pues es indiferente que el acto propio del cargo a cambio del cual entrega la ventaja le beneficie a él o a un tercero, así como también resulta intranscendente que la ventaja, por ejemplo, no le pertenezca124. Nota RODRÍGUEZ PUERTA que no obstante, en el ejemplo propuesto, el particular a favor de quien actúa el tercero podrá responder como inductor o cooperador necesario dependiendo de cuál haya sido su concreta aportación ${ }^{125}$. Por otro lado, se plantean de forma distinta los casos en los que el intermediario auxilia con su conducta al funcionario y es él, precisamente, el que entabla relaciones con el particular, e incluso el que recibe en su nombre la dádiva o presente. En estos supuestos, la cláusula legal ofrece cobertura jurídica para sancionar también al funcionario que no interviene directamente en el hecho delictivo, así como permitir calificar de cohecho los hechos, pues el particular ni es funcionario ni tampoco, obviamente, es competente para realizar el acto propio del cargo. De este modo, el legislador posibilita la autoría mediata, también en este delito especial. Aun así, la expresa mención de estos supuestos permite excluir cualquier duda sobre la responsabilidad a título de autor del funcionario - si conocía efectivamente lo que el tercero está realizando - y la

123 Mạ. J. RODRÍGUEZ PUERTA, El delito de cohecho..., op. cit., p.263; I. VALEIJE ÁLVAREZ, El tratamiento..., op. cit., p.117. Esta autora distingue dos interpretaciones o supuestos en los que el tercero es "intermediario en la actuación" y en los que el mismo es "intermediario en el interés o beneficio".

124 I. VALEIJE ÁLVAREZ, El tratamiento..., op. cit., pp.118 y 119. Opina la autora que la persona que actúa como intermediaria entre el cohechante y el cohechado para hacer llegar a éste la retribución es directa y personalmente el agente corruptor, es decir, es un directo protagonista del delito de cohecho activo.

125 Ma . J. RODRÍGUEZ PUERTA, El delito de cohecho..., op. cit., p.263. Nota la autora que el particular que emplea a un intermediario para obtener un acto propio del cargo de un funcionario al que ofrece, entrega o promete una ventaja - a través de un tercero podrá responder como inductor de un delito de cohecho o bien como cooperador necesario si él mismo proporciona por ejemplo, la cantidad de dinero necesaria para corromper al funcionario. De mantenerse una interpretación amplia de la modalidad de tráfico de influencias tipificada en el artículo 430 CPE también, en función de cuál fuera el modo comisivo, podría responder el particular por este delito. 
responsabilidad, a su vez, a título de cooperador necesario del intermediario ${ }^{126}$.

\section{B-CUANDO EL TERCERO SE LIMITA A RECIBIR LAS DÁDIVAS, SIN PARTICIPAR DE NINGÚN OTRO MODO EN LA REALIZACIÓN DE LAS DIVERSAS CONDUCTAS TÍPICAS}

Para estos supuestos el CPE de 1995, y aun con la reforma de 2010, ha previsto que la posibilidad de que la dádiva o presente que solicita o recibe el funcionario pueda aprovechar a un tercero. En estos casos, cabe a su vez distinguir dos hipótesis, aquéllas en las que la ventaja es recibida directamente por el tercero - que la utiliza en su provecho - $y$, aquellas otras, en las que la dádiva tiene como destinatario directo al funcionario; si bien éste únicamente actúa como intermediario, pues posteriormente dirige las ventajas a un tercero. En ambos supuestos resulta complejo calificar la conducta del tercero receptor y/o beneficiario de la dádiva de cooperación necesaria, dado que éste únicamente se beneficia del delito; incluso tampoco resultaría pertinente tal calificación cuando ello haya sido pactado de antemano con el funcionario o con el particular corruptor ${ }^{127}$. En esos casos, la sanción como partícipe en un delito de cohecho del sujeto a quien aprovecha la dádiva va a depender de varias circunstancias. En primer lugar, será en todo caso necesario que el tercero que recibió directamente la dádiva con el objetivo de disfrutar de ella ${ }^{128}$, conozca que a cambio de ella el funcionario se ha comprometido a adoptar un acto propio del cargo; así como será también imprescindible que el funcionario conozca que está dispuesto a adoptar un acto propio del cargo a cambio de una dádiva, un presente o un favor que directa o indirectamente aprovecha a un tercero ${ }^{129}$. Además, considera RODRÍGUEZ PUERTA imprescindible para que responda el funcionario competente para adoptar el acto objeto de cohecho que obtenga, aunque sea indirectamente, algún beneficio o ventaja de su actuación, sobre todo cuando no intervino en el trato con el particular que fue llevado a cabo por el tercero a quien aprovechará la dádiva - o

126 Ibídem, op. cit., p.264; I. OLAIZOLA NOGALES, El delito de cohecho, op. cit., p.204; I. VALEIJE ÁLVAREZ, El tratamiento..., op. cit., pp.244 y 245.

127 I. OLAIZOLA NOGALES, El delito de cohecho, op. cit., pp.205 y 206.

128 Cosa muy diferente es los casos en los que el tercero recibe la dádiva para ocultar el verdadero destinatario y beneficiario de la misma. Así, como indica VALEIJE ÁLVAREZ cuando se utiliza un "testaferro" o incluso "empresas pantalla" para ocultar la verdadera titularidad de las dádivas, el responsable del delito de cohecho será sin duda el funcionario (I. VALEIJE ÁLVAREZ, El tratamiento..., op. cit., pp.120 y 121). Pero entendemos con RODRÍGUEZ PUERTA que también responderán penalmente las empresas o particulares que auxiliaron al empleado público, como mínimo por el delito de encubrimiento o receptación (.Ma ${ }^{\mathrm{a}}$. J. RODRÍGUEZ PUERTA, El delito de cohecho..., op. cit., p.265).

${ }^{129}$ I. OLAIZOLA NOGALES, El delito de cohecho, op. cit., p.206. Advierte la autora que en estos supuestos se parte de que el funcionario y el intermediario actúan consciente y libremente. Si el intermediario actúa por su cuenta sin saberlo el funcionario, no se cumplirá el delito de cohecho, al faltar en el intermediario la cualidad personal necesaria. Si el intermediario "utiliza" al funcionario como instrumento se trataría de utilización de un intraneus por un extraneus, cosa que es de difícil solución. 


\section{CAPÍTULO V: TIPO OBJETIVO (II). LAS CONDUCTAS TÍPICAS}

cuando la dádiva fue entregada o prometida directamente al tercero a quien beneficia ${ }^{130}$. Para la autora, el examen de estos supuestos debe realizarse distinguiendo dos planos de análisis.

Por un lado, han de determinarse las condiciones que van a permitir considerar como autor del delito de cohecho al funcionario cuando éste no se aprovecha de las dádivas, presentes o favores contrapartida del acto propio del cargo. Así, en todo caso será cuanto menos necesario que éste conozca que las dádivas o presentes benefician a un tercero persona física o jurídica -. No obstante, en aquellos supuestos en los que él no intervino directamente en la negociación con el particular y además la ventaja fue directamente entregada al tercero, a quien aprovecha, únicamente podrá responder el funcionario como autor de delito de cohecho si, como antes se indicó, conocía la negociación o trato entre el beneficiario y el particular corruptor, y sabía que las dádivas se entregaban o prometían a cambio de que él adoptara un acto propio del cargo, en un sentido determinado. Ahora bien, en estos supuestos, en los que el funcionario ni solicita ni recibe nada, será necesario, además, para calificar de cohecho su comportamiento, que la ventaja, al menos de forma indirecta, le reporte un beneficio ${ }^{131}$. De no ser así, se estaría haciendo responder del delito de cohecho a un sujeto que no ha llevado a cabo ninguna de las acciones típicas, incluso es posible que ni siquiera adopte el acto propio del cargo o haya voluntad de hacerlo ${ }^{132}$. En estos supuestos, el que negoció en nombre del funcionario podrá responder por delito de estafa - si nunca existió la intención o la posibilidad de llevar a cabo el acto prometido - o también, sería posible que respondiera por la modalidad de tráfico de influencias tipificada en el artículo $430 \mathrm{CPE}^{133}$.

\footnotetext{
130 Ma . J. RODRÍGUEZ PUERTA, El delito de cohecho..., op. cit., pp.264 y 265.

131 Ibídem, op. cit., p.266. La autora toma el ejemplo en el que el funcionario negoció la transacción con el particular corruptor a través de un miembro de su familia, y este último fue el que acabó recibiendo directamente la ventaja; podrá responder como autor del delito de cohecho el funcionario siempre que mejore asimismo su situación. Esto también puede ocurrir cuando el funcionario utiliza una empresa, de la que accionista o en la que tiene participación, de modo que se beneficie indirectamente de la dádiva. Se plantea el problema de la calificación cuando la ventaja revierte en el partido político sin que el funcionario hay intervenido ni en la negociación ni en la recepción de la dádiva. Es necesario que el funcionario se beneficie aunque sea de forma indirecta de la ventaja recibida por su partido (nombramiento en algún cargo del partido, favorecerlo en las listas electorales, etc.).

132 I. OLAIZOLA NOGALES, El delito de cohecho, op. cit., p.202.

133 Ma . J. RODRÍGUEZ PUERTA, El delito de cohecho..., op. cit., p.266. Así, por ejemplo, si el acuerdo con el particular lo llevó a cabo un miembro del partido político al que pertenece el funcionario solicitando o recibiendo dádivas a cambio de utilizar sobre el funcionario competente su influencia para satisfacer así las pretensiones del particular - o empresa - que promete o entrega la gratificación al partido político. Esta misma solución resultaría, según la autora, también aplicable cuando el beneficiario de la dádiva fuera un particular. En estas hipótesis no parece lógico hacer responder al funcionario del delito de cohecho cuando éste no llevó a cabo conducta alguna, ni siquiera en aquellos supuestos en los que conocía la maniobra realizada por su partido político o por otro particular; I. OLAIZOLA NOGALES, El delito de cohecho, op. cit., p.206.
} 
Por otro lado, es necesario esclarecer cuál es la responsabilidad del tercero beneficiario. La respuesta a esta cuestión dependerá, obviamente, de cuál haya sido la conducta llevada a cabo por el sujeto. Así, si éste realizó labores de intermediario - solicitando por ejemplo la dádiva en nombre del funcionario - además de aprovecharse de la misma, no habrá inconveniente en calificar su aportación delictiva como una cooperación necesaria. Si por el contrario, se limitó a aprovecharse de las dádivas o presentes solicitados o recibidos por el funcionario, difícilmente podrá calificarse su conducta de cooperación simple o necesaria, pues su contribución al hecho delictivo se verifica una vez éste se ha consumado ${ }^{134}$. Las hipótesis pueden ser muy variadas. Así, en no pocas ocasiones el beneficiario de la dádiva habrá sido precisamente el que hizo nacer la voluntad criminal en el funcionario: de este modo podrá responder del delito de cohecho cometido por el funcionario como inductor. Por último, cuando el tercero, en provecho del cual se entrega la dádiva, la recibió él directamente - tanto si ésta fue negociada por el funcionario, como si él hizo de intermediario - será posible calificar de cooperación necesaria su conducta, aunque no puede descartarse ni la inducción ni la posible responsabilidad por un delito de receptación o blanqueo de dinero ${ }^{135}$.

Por lo que se refiere al Derecho penal francés y malgache, la cuestión de la persona interpuesta se plantea, generalmente, de la misma manera que en el español. Como ya hemos señalado, la modalidad de recepción no ha sido prevista en ambos ordenamientos, con lo cual el debate sobre la posibilidad de que esta modalidad pudiera existir es fruto de la interpretación de parte de la doctrina penal. La recepción típica se entiende como otra forma de manifestar la modalidad típica de "aceptar". Es decir, al recibir la dádiva o presente, el funcionario manifiesta de manera expresa y simultánea que acepta el ofrecimiento del particular, entiende su pretensión y se ha alcanzado un acuerdo entre ellos. Esta aclaración es importante cuando se analiza el papel de la persona interpuesta. La doctrina francesa sostiene que ante la dificultad de apreciar los respectivos papeles del intermediario y del autor, habrá que demostrar que éste último ha aprobado o tiene algo que ver con la actuación del primero ${ }^{136}$. Por lo tanto, desde esta perspectiva de la vertiente pasiva de la corrupción en el ordenamiento penal francés y malgache, los intermediarios no pueden negociar ni actuar sin que el funcionario lo sepa y lo apruebe, aunque sea a posteriori ${ }^{137}$.

\footnotetext{
${ }^{134} \mathrm{M}^{\mathrm{a}}$. J. RODRÍGUEZ PUERTA, El delito de cohecho..., op. cit., p.267; I. VALEIJE ÁLVAREZ en El tratamiento..., op. cit., pp.244 y 245; I. OLAIZOLA NOGALES, El delito de cohecho, op. cit., pp.206 y 210.

${ }_{135} \mathrm{M}^{\mathrm{a}}$. J. RODRÍGUEZ PUERTA, El delito de cohecho..., op. cit., pp.267 y 268; I. VALEIJE ÁLVAREZ en El tratamiento..., op. cit., p.246.

${ }^{136}$ A. VITU, Corruption passive..., op. cit., p.15.

${ }^{137}$ H. XIAO-YING, La lutte contre la corruption..., op. cit., p.56. Aclara el autor que habrá que traer la prueba de que el tercero ha solicitado o ha actuado en nombre del funcionario o que éste ha manifestado su aprobación.
} 


\section{CAPÍTULO V: TIPO OBJETIVO (II). LAS CONDUCTAS TÍPICAS}

No hay debate en la doctrina francesa y malgache, como el que se ha visto en España, sobre la consecuencia de considerar un delito como tipo especial y la posibilidad de acudir a la figura de la autoría mediata por utilización de un instrumento doloso no cualificado ${ }^{138}$. Sin embargo, la ausencia de este debate no impide a la doctrina entender que hay infracciones en las que una persona no puede ser el autor principal sino solamente el partícipe. La previsión legal en materia de corrupción pasiva admite que las modalidades típicas puedan ser llevadas a cabo por una persona intermediaria. Por tanto, el funcionario sería autor del delito y la persona intermedia su cómplice ${ }^{139}$.

También hay que notar que, a diferencia del Derecho penal español, la participación en Derecho penal francés y malgache se reduce a la complicidad. En efecto, ambos sistemas jurídicos incluyen en el concepto de cómplice tanto los cooperadores como los inductores ${ }^{140}$. Se trata de un concepto muy amplio de complicidad en el que no se matiza ni la cooperación ni la inducción ${ }^{141}$. No es de extrañarse, por tanto, que los autores franceses, cuando se refieren a la participación de una persona interpuesta en el delito en estudio, sólo hablen de complicidad ${ }^{142}$.

En el supuesto en el que la persona interpuesta actúa como mediador y facilita al particular la obtención del acto propio del cargo del funcionario, entregando a éste la dádiva o presente, se ha señalado antes que desde la perspectiva del Derecho penal español el mediador puede ser considerado como autor del delito de cohecho activo ${ }^{143}$, aunque, de to-

\footnotetext{
${ }^{138}$ A nuestro parecer, la ausencia de tal debate viene de la manera en que se han clasificado los delitos en ambos sistemas jurídicos. La doctrina española por ejemplo clasifica los delitos a partir del tipo objetivo (por el bien jurídico) y subjetivo, las modalidades de la acción y los sujetos (Vid. I. BERDUGO DE LA TORRE y otros, Curso de Derecho Penal, op. cit., pp.152-158). La teoría de la infracción francesa procede, de manera general, con otra forma de clasificación y conforme a los elementos que componen dicha teoría: legal, material y moral (Vid. G. STEFANI, G. LEVASSEUR y B. BOULOC, Droit pénal général, Dalloz, 1984, (12ª ed.), pp.147-261).

139 Cass. crim. 9-11-1995, Bull. Crim., no346.

140 Dispone el artículo 121-6 CPF que "serán castigados como autores los cómplices de la infracción, en el sentido del artículo 121-7". Y el artículo 121-7 CPF precisa que "son cómplices de un delito grave o menos grave, los que, conscientemente, con su ayuda o cooperación, hayan facilitado su preparación o ejecución. También son cómplices quienes, por medio de la dádiva, promesa, amenaza, orden, o bien abuso de autoridad o de poder, hayan inducido a otro o le hayan dado instrucciones para que se cometa la infracción". Con términos parecidos reza el artículo 60 del CPM: "serán castigados como cómplices de una acción calificada de delito grave o menos grave quienes por medio de dádiva, promesa, amenaza, abuso de autoridad o de poder, maquinación o artificio culpable hayan provocado dicha acción o dado instrucciones para cometerla; quienes hayan facilitado armas o instrumentos o cualquier otro medio que haya servido para la acción, sabiendo que estos servirían para ello; quienes hayan ayudado o asistido, a sabiendas, al autor o los autores de la acción, en los hechos que la hayan preparado o facilitado, o en los que la hayan consumado (...)".

141 C. ARÁNGUEZ SÁNCHEZ y E. ALARCÓN NAVÍO, El código penal francés, op. cit., p.43.

142 F. CECCON, Contribution..., op. cit., p.38 ; M-P. LUCAS de LEYSSAC y A. MIHNAN, Droit pénal des affaires..., op. cit., no 1024 .

143 Mà. J. RODRÍGUEZ PUERTA, El delito de cohecho..., op. cit., p.263; I. VALEIJE ÁLVAREZ en El tratamiento..., op. cit., pp.118 y 119.
} 
dos modos, todo depende de su grado de participación. Dentro de la doctrina francesa y malgache no se plantea el problema de matizar si este tercero puede ser autor, ya que su participación será castigada con la misma pena que el particular considerado como verdadero autor del delito de corrupción activa. Sin embargo, en su esfuerzo de diferenciar el autor del cómplice de un delito, la doctrina defiende que el autor es el que reúne en su persona todos los elementos (material y moral) de la infracción; es el que ha cumplido personalmente los actos materiales constitutivos del delito. En cambio, el que no realiza en su persona los elementos de la infracción - y que ha cooperado simplemente en la comisión de ésta por un acto material (distinto del elemento material de la infracción) pero con intención - es sólo un cómplice ${ }^{144}$. En el supuesto que nos interesa, si el tercero entabla las relaciones y las negociaciones con el funcionario y le entrega la dádiva o regalo, es evidente que el tercero ha cumplido personalmente los actos materiales constitutivos de la infracción y el elemento moral que ello implica. Por lo tanto, no hay razón para considerarlo como simple cómplice sino es verdadero coautor del delito de corrupción activa ${ }^{145}$.

En el supuesto en el que el tercero auxilia al funcionario y entabla relaciones con el particular y recibe de éste la dádiva en su nombre, no hay duda de que se trata de un caso de autoría mediata, según el vocablo de la doctrina española, en el que el autor es el funcionario y el tercero es cómplice. Efectivamente, la doctrina francesa entiende que hay infracción cuyo autor no puede ser cualquier persona; en consecuencia, otro participante no puede ser coautor sino simplemente cómplice ${ }^{146}$. Es el caso de la corrupción pasiva cuyos autores deben tener las características definidas por la letra de la ley. En este sentido, ha acertado la doctrina penal francesa y malgache al considerar al tercero intermediario como cómplice ${ }^{147}$.

En el supuesto en el que el tercero es un receptor y/ o beneficiario de la dádiva, hay que reconocer la dificultad de considerarlo como cómplice y habrá que ver si el autor principal puede tener algún beneficio del delito. En todo caso, el tercero beneficiario de la dádiva quien entabló las relaciones con el particular es cómplice del delito de corrupción pasiva

\footnotetext{
144 G. STEFANI, G. LEVASSEUR y B. BOULOC, Droit pénal général, op. cit., p.277.

${ }^{145} \mathrm{El}$ interés de la distinción sería en la consideración de que la punibilidad de la complicidad depende de la tipicidad del hecho principal del autor. Si la conducta del autor principal todavía no alcanza el umbral de la puesta en peligro del bien jurídico y el cómplice ya manifiesta su intención de adelantar este límite y actúa en consecuencia, no sería lógico no considerar al tercero como coautor si el autor principal conoce y aprueba su actuación. (Véase G. STEFANI, G. LEVASSEUR y B. BOULOC, Droit pénal général, op. cit., pp.279 y 280).

146 G. STEFANI, G. LEVASSEUR y B. BOULOC, Droit pénal général, op. cit., p.280.

147 En efecto, todo depende de cada caso. Si el tercero no reúne las condiciones legales para ser autor de corrupción pasiva puede ser cómplice del mismo delito. En el caso de que el tercero tenga las mismas características que el autor principal, su actuación se podría subsumir o en el delito de corrupción pasiva por acto facilitado por su competencia o en el delito de tráfico de influencias si personalmente no es competente para tomar el acto propio del cargo.
} 


\section{CAPÍTULO V: TIPO OBJETIVO (II). LAS CONDUCTAS TÍPICAS}

si el funcionario puede tener algún beneficio, aunque sea de manera indirecta, del hecho de que el tercero sea beneficiario de la dádiva. En el caso de que el funcionario no tenga ningún provecho y tampoco manifieste intención concreta de tomar un acto de su cargo, estamos de acuerdo en considerar que el beneficiario receptor podría cometer un delito de estafa ${ }^{148}$ o de tráfico de influencias ${ }^{149}$. Sin embargo, si éste último sólo disfruta de la dádiva posteriormente al acuerdo de voluntades alcanzado por el funcionario y el particular, será difícil, desde la perspectiva del Derecho penal francés y malgache, considerarlo como cómplice ya que su actuación interviene después de la consumación del delito. Por lo tanto, no puede ser cómplice de del delito de corrupción pasiva. De hecho, la doctrina francesa defiende que los actos posteriores a la comisión de la infracción no pueden en principio ser considerados como actos de complicidad. Pero eso no quiere decir que todos los actos posteriores escapen a la represión. Pueden dar lugar a otros delitos autónomos como el de receptación ${ }^{150}$. Estamos de acuerdo en considerar que, en esta hipótesis, el tercero beneficiario que interviene posteriormente a la consumación del delito de corrupción pasiva no puede ser cómplice del mismo, pero puede ser autor del delito de receptación o de blanqueo de dinero. Por último, si un tercero intermediario ha inducido al funcionario a cometer el delito de corrupción pasiva, el CPF no deja sin castigo a la persona interpuesta por faltarle la cualidad personal necesaria. Toda inducción que sea por medio de dádiva, promesa, amenaza, orden, o bien abuso de autoridad o de poder es un acto de participación que, aunque no hace a la persona interpuesta coautor, sí que lo hace cómplice, que tiene la misma pena que el autor principal. Quizá es

\footnotetext{
148 Dispone el artículo 313-1 CPF que "la estafa es el hecho de engañar a una persona física o jurídica, bien mediante uso de un nombre falso o de una cualidad falsa, bien mediante abuso de una cualidad verdadera, o bien mediante empleo de maniobras fraudulentas, determinándola así, en perjuicio propio o ajeno, a entregar fondos, valores o bienes cualesquiera, a proporcionar un servicio, o a consentir un acto que le suponga una obligación o carga". En el derecho penal malgache el delito de estafa se da, según el artículo 405 CPM, cuando "el que, o haciendo uso de falsos apellidos o falsas calidades, o utilizando maniobras fraudulentas para persuadir la existencia de falsas empresas, de un poder o de un crédito imaginario, o para originar la esperanza de un logro, de un accidente o de todo evento quimérico, haya recibido o haya intentado recibir fondos, muebles o obligaciones, disposiciones, billetes, promesas, recibos, y haya, a través de uno de estos medios, estafado o intentado estafar la totalidad o parte de la fortuna ajena (...)".

${ }_{149}$ Tanto para el CPF en su artículo 432-11 inciso segundo como para el CPM en su artículo 177.1 tercer inciso, el trafico de influencias consiste en el hecho de que toda persona constituida en autoridad pública, encargada de una misión de servicio público o que ostente un mandato público electivo solicite o acepte sin tener derecho a ello, en cualquier momento, directa o indirectamente, ( el derecho penal malgache habla de recibir propuesta "sin tener derecho a ello, directamente o por persona interpuesta") ofertas, promesas dádivas, regalos u otros beneficios cualesquiera "para que abuse de su influencia real o supuesta con vista a conseguir de una autoridad o de una administración pública condecoraciones, empleos, contratas 0 cualquier otra decisión favorable". (Vid. C. ARÁNGUEZ SÁNCHEZ y E. ALARCÓN NAVÍO, El código penal francés, op. cit., pp.205 y 206).

150 J.-H. ROBERT, Droit pénal général, op. cit., p.367; G. STEFANI, G. LEVASSEUR y B. BOULOC, Droit pénal général., op. cit., pp.289 y 290.
} 
la razón por la que este debate no se plantea en la doctrina penal francesa $^{151}$ ni malgache ${ }^{152}$.

\section{Sección 3- "Aceptar"}

\section{I-Significado}

De manera general "aceptar" es admitir voluntariamente lo que se ofrece. A diferencia de la modalidad "recibir", estudiada anteriormente, con la que se destaca la entrega de una dádiva y su incorporación en el patrimonio del funcionario, la modalidad "aceptar" una promesa o un ofrecimiento supone posponer por un tiempo la entrega de la dádiva, una vez cerrado el compromiso ${ }^{153}$. La mayoría de la doctrina española especializada en la materia, se centra en un punto de vista temporal. Así, para POLAINO NAVARRETE, la aceptación lleva a cabo la efectiva percepción de algo que es constituido por un mero ofrecimiento o promesa, un futurible de contraprestación patrimonial, no una tangible traslación de un bien económico ${ }^{154}$. En este mismo sentido se ha pronunciado RODRÍGUEZ PUERTA, para quien la aceptación es una conducta del funcionario que significa la aprobación futura de dádiva o presente ${ }^{155}$. Con matices, pero desde la perspectiva temporal, entiende OLAIZOLA NOGALES que la aceptación del ofrecimiento o la promesa es el estadio temporal anterior al de la recepción de la dádiva o el presente ${ }^{156}$. En cambio, VALEIJE ÁLVAREZ enfatiza sobre lo que se recibe y señala que, mientras que en la modalidad típica "recibir" el funcionario obtiene una prestación de carácter material que simboliza el acuerdo de voluntades entre ambas partes, en la modalidad de "aceptar" el funcio-

151 G. STEFANI, G. LEVASSEUR y B. BOULOC, Droit pénal général, op. cit., pp.272 y ss. Denuncian estos autores de la excesiva extensión que hacen la ley y la jurisprudencia al no respetar conceptualmente la distinción entre autor principal y cómplice. J.-H. ROBERT, Droit pénal général, op. cit., p.393, habla de « un deseo empírico de represión » que inspira la jurisprudencia al no respetar la criterio teórico de distinción entre coacción y complicidad.

152 El artículo 60 del CPM no habla de inducción sino de provocación. Este precepto inspirado por el antiguo CPF nos lleva a considerar la doctrina francesa al respecto. En efecto, el provocador que es realidad el autor moral de la infracción cometida después de su provocación, no puede ser considerada como autor o coautor, sino simplemente como cómplice del que ha ejecutado materialmente la infracción. Pero hace falta que la provocación haya sido directa es decir que la idea de infracción haya sido netamente expresada por el provocador y que haya sido individual, es decir dirigida personalmente a quien se quiere convencer para cometer la infracción. Por último, es necesario que la provocación haya tenido efecto, o sea el delito grave o menos grave haya sido consumado o por lo menos intentado por el que había sido provocado. (Véase G. STEFANI, G. LEVASSEUR y B. BOULOC, Droit pénal général, op. cit., pp.285 y 286). Esta teoría de la provocación es más cerca de la proposición que es más adecuada a la consumación del delito de cohecho pasivo según VALEIJE ÁLVAREZ (Véase I. VALEIJE ÁLVAREZ El tratamiento..., op. cit., pp.100 y 101).

153 E. ORTS BERENGUER, “Delitos...”, op. cit., p.702.

154 M. POLAINO NAVARRETE, “Delitos...”, op. cit., p. 367.

155 Ma. J. RODRÍGUEZ PUERTA, El delito de cohecho..., op. cit., p.177; E. CASAS BARQUERO, “Observaciones...”, op. cit., p.898.

156 I. OLAIZOLA NOGALES, El delito de cohecho, op. cit., p.257. 
nario obtiene o recibe una prestación de carácter inmaterial. Esto es, recibe del particular una declaración de voluntad mediante la cual éste se compromete a dar, hacer o decir algo a favor del funcionario ${ }^{157}$. La misma autora traslada su razonamiento aún más lejos y defiende que en la modalidad típica de aceptar, el funcionario no sólo recibe compromiso de obtener una ganancia en el futuro a cambio de la ejecución del acto contrario al cargo, sino que también puede obtener en el acto una retribución de carácter inmaterial, esto es, prestaciones que no son susceptibles de transferencia material. Por lo tanto, son objeto de la acción típica de aceptar todos los elementos incorporales, esto es, manifestaciones de voluntad que comprenden tanto el compromiso de entregar en el futuro un retribución (cualquier sea su naturaleza) como el compromiso de entregar aquellas prestaciones que por carecer de corporeidad no son susceptibles de traslado y aprehensión ${ }^{158}$. Critica esta postura OLAIZOLA NOGALES para quien de esta forma se restringen los objetos susceptibles de la conducta de recibir a aquéllos susceptibles de ser trasladados. Recibir debe entenderse como un apoderamiento en sentido amplio, esto es como la incorporación efectiva de una ventaja al patrimonio del funcionario. No es lo mismo que al funcionario le sea ofrecido un descuento importante en la compra de un objeto que se le haga realmente el descuento. En el primer caso se trataría de un ofrecimiento que el funcionario acepta en tanto que en el segundo caso se trataría de una entrega que el funcionario recibe. La diferencia fundamental no estriba, según la misma autora, en el carácter corpóreo o no del objeto, sino fundamentalmente en el carácter presente o futuro del hecho. No obstante, reconoce que lo normal sí que va a ser que la recepción sea de cosas materiales susceptibles de traslado ${ }^{159}$.

Por otro lado, hay acuerdo dentro de la doctrina penal española para afirmar que la modalidad típica de aceptar refleja el carácter pluripersonal del delito en cuestión, ya que la aceptación del ofrecimiento o promesa requiere una previa y simultánea oferta de dádivas o presentes por el sujeto interesado en la obtención de un acto propio del cargo ${ }^{160}$. En efecto, nadie "acepta" si en principio no hay alguien que "prometa" (lo contrario no es del todo cierto, ya que se puede "prometer u ofrecer" sin que nadie "acepte") ${ }^{161}$.

En el Derecho penal francés y malgache, la modalidad típica de "aceptar" es la única que manifiesta la conducta pasiva del funcionario. Según la doctrina francesa que ha estudiado el tema, se trata aquí para el funcionario de aceptar una oferta de corrupción ${ }^{162}$. Hay acuerdo entre los autores franceses en entender que este tipo de oferta o promesa es una

\footnotetext{
${ }^{157}$ I. VALEIJE ÁLVAREZ, El tratamiento..., op. cit., p.121.

158 Ibídem, op. cit., pp.121 y 122.

159 I. OLAIZOLA NOGALES, El delito de cohecho, op. cit., p.258.

${ }_{160}$ M‥ J. RODRÍGUEZ PUERTA, El delito de cohecho..., op. cit., p.177.

${ }^{161}$ I. VALEIJE ÁLVAREZ, El tratamiento..., op. cit., p.122.

162 V. MALABAT, Droit pénal spécial, op. cit. p.528 ; J. PRADEL y M. DANTI-JUAN, Droit pénal spécial, Cujas, 2010, (5a ed.), p.671.
} 
propuesta con la que el particular toma la iniciativa de sacarle al funcionario un acuerdo ${ }^{163}$. Por lo tanto, el enfoque de la doctrina francesa en la materia se centra en el hecho de que en la modalidad típica de aceptar se haya llegado a un acuerdo de voluntades entre el particular y el funcionario. Dicho acuerdo, señalan DELMAS-MARTY y GIUDICELLIDELAGE, consuma la infracción en cuanto la aceptación se haya concedido ${ }^{164}$. Es la razón por la cual la doctrina francesa y malgache considera que la corrupción pasiva es un delito formal ya que basta con alcanzar el pacto de corrupción para que se consuma, independientemente de lo que viene a continuación que se haga entrega de dádiva prometida o cumplimiento o no del acto del cargo o facilitado por éste. A nuestro parecer, con semejante perspectiva, ambos legisladores no han considerado necesario tipificar la modalidad de "recibir" por revelarse innecesaria aunque un sector de la doctrina francesa intenta dar una interpretación que incluye esta modalidad en estudio con la de "recibir". En este sentido, autores como VITU o XIAO-YING sostienen que "la palabra "aceptación" indica tanto la aceptación, por el corrompido, de las ofertas que le son hechas como la recepción de las dádivas o presentes prometidos, en ejecución del acuerdo de voluntades que se ha formado entre el corruptor y el corrompido"165. Según esta afirmación, la palabra recepción se utiliza cuando el particular corruptor cumple su parte del pacto al entregar materialmente las "cosas"166 ya prometidas anteriormente. Si éste es el supuesto en el que estos autores permiten la utilización de esta modalidad, entonces se puede entender la razón por la cual los legisladores francés y malgache han omitido el verbo "recibir" en el precepto. En efecto, si el hecho de recibir resulta de una entrega de algo prometido, este acto no influye en nada en la formación del delito puesto que éste se ha consumado en el momento en que se ha aceptado la promesa ${ }^{167}$. Ya GARÇON, bajo la vigencia de la ordenanza del 8 de enero de 1945, la cual previó la modalidad típica de "recibir" dádivas y presentes, minimizó su importancia y consideró que "el delito es constituido no por el pago de las ofertas corruptoras (lo que significa "entregar" desde la perspectiva de la corrupción activa y "recibir" desde la corrupción pasiva), sino por la simple adhesión dada por el corrompido a las

\footnotetext{
163 P. MAISTRE DU CHAMBON, A. LAPAGE y R. SALOMON, Droit pénal des affaires, op. cit., p.146; E. DREYER, Cours magistral..., op. cit., p.602; F. CECCON, Contribution..., op. cit., p.38 ; C. AMBROISE-CASTÉROT, Droit pénal..., op. cit., p.365.

164 M. DELMAS-MARTY y G. GIUDICELLI-DELAGE, Droit pénal des affaires, op. cit., p.289; V. MALABAT, Droit pénal spécial, op. cit. p.528.

165 A. VITU, Corruption passive..., op. cit., p.15 ; H. XIAO-YING, La lutte contre la corruption..., op. cit., p.51.

${ }^{166}$ H. XIAO-YING, La lutte contre la corruption..., op. cit., p.51. Precisa este autor que estas « cosas» pueden ser materiales o intelectuales. Este planteamiento nos hace pensar a la distinción, que hace VALEIJE ÁLVAREZ, sobre la corporeidad de lo que se ofrece al funcionario para elegir entre "aceptar" o "recibir".

167 Mà. J. RODRÍGUEZ PUERTA, El delito de cohecho..., op. cit., p.177. Indica la autora que la entrega o la recepción de dádiva, si con anterioridad se alcanzó el acuerdo, no supone más que el agotamiento del delito ya consumado.
} 
ofertas o promesas que le hace el corruptor"168. Pero más llamativa aún resulta la afirmación de GARRAUD para quien "tanto en la corrupción activa como en la corrupción pasiva, el delito se consuma en cuanto el tráfico ilícito ha sido concluido entre el individuo corrompido y el agente corruptor, es decir en cuanto las dádivas hayan sido aceptadas ("dons acceptés") o las promesas aceptadas ("promesses agréées")"169. Se puede concluir que el legislador francés de 1994 y el legislador malgache de 2004 no han hecho más que seguir la trayectoria de una antigua interpretación doctrinal ${ }^{170}$ que destacaba lo superfluo de la modalidad "recibir"171. Por lo tanto, en Derecho penal francés y malgache, importan poco la corporeidad o la temporalidad de la contraparte del acto propio o facilitado por el cargo del funcionario: se aceptan tanto ofertas o promesas como dádivas o regalos o, incluso, otros beneficios cualesquiera.

\section{II-Requisitos objetivos y subjetivos de la aceptación}

Al igual que la modalidad de "recibir", atendiendo a la naturaleza pluripersonal del delito de cohecho, para que exista aceptación típica es necesario que junto con el comportamiento material que representa la exteriorización de la voluntad exista un elemento psicológico que permita establecer una relación entre el "aceptar" del funcionario con el "prometer" (u "ofrecer" conforme con la actual redacción del CPE) del particular172. Explica VALEIJE ÁLVAREZ que para que exista aceptación típica, no basta cualquier asentimiento del funcionario a la propuesta del particular relativo a la entrega de una ganancia futura u otro tipo de ventaja, sino que es necesario que, respectivamente, el funcionario reconozca la propuesta en su sentido de promesa, es decir, debe reconocer en la conducta del particular una declaración de voluntad que le asegure una ventaja económica aunque sea en el futuro, como contraprestación de un acto realizado en el ejercicio del cargo y que el particular promete u ofrece esperando la contraprestación del funcionario. Lo mismo puede decirse de la propuesta del particular: no basta una oferta vaga y confusa o simplemente que realice el acto material de ofrecer o prometer; es necesario que sea consciente de que el funcionario ha advertido y comprende el alcance del aludido ofrecimiento ${ }^{173}$. En palabras

\footnotetext{
168 E. GARÇON, Code pénal annoté, Tome I, op. cit., no 83, p.697. Añade este autor que la culpabilidad del funcionario reside enteramente en la adhesión que da a las propuestas que le son hechas.

${ }^{169}$ R. GARRAUD, Traité..., Tome IV, op. cit., no 1519.

170 La primera edición de los tratados de GARRAUD data por ejemplo de 1888-1891 y bajo la vigencia del Código penal francés de 1810.

${ }^{171}$ En Francia, a pesar de que el GRECO recomendó expresamente a las autoridades que precisaran todos los elementos materiales o conductas típicas previstas por el Convenio Penal sobre la corrupción (STE 173) en los delitos de corrupción pasiva y de tráfico de influencia, al preveer de manera expresa la modalidad típica de "recibir", las autoridades francesas han replicado que tal previsión no es necesaria ya que la noción de "recibir" está necesariamente incluida en el concepto de la modalidad de "aceptar" ("agréer").Ver: http://www.coe.int

172 I. VALEIJE ÁLVAREZ, El tratamiento..., op. cit., p.122.

173 Ibídem op. cit., pp.122 y 123 . Advierte la autora que si el ofrecimiento ha sido realizado de tal forma que el funcionario no se ha percatado del contenido del acuerdo,
} 
de OLAIZOLA NOGALES, para que se dé el delito, es preciso que el funcionario, al recibir la dádiva, sepa que es como contraprestación a un acto del ejercicio del cargo, ya que, si no es consciente de tal relación, no se dará el delito de cohecho pasivo ${ }^{174}$.

En cuanto a la forma en que deben revestir las respectivas declaraciones de voluntad (es decir el ofrecimiento de la promesa y la correlativa aceptación), pueden éstas ser expresas o tácitas ${ }^{175}$. Por tanto, puede producirse una aceptación expresa o bien una aceptación simplemente tácita, llevada a cabo por medio de actos concluyentes ${ }^{176}$.

Ya que el delito de cohecho es un delito de mera actividad, por lo cual no se admite su comisión por formas omisivas, VALEIJE ÁLVAREZ plantea que la falta de un rechazo explícito a las propuestas del particular puede ser sólo un comportamiento omisivo en apariencia, ya que en ocasiones el silencio puede constituir una conducta positiva si por las circunstancias concretas en que ha sido formulada la promesa, el silencio es una verdadera y auténtica aceptación tácita177.

La doctrina penal francesa y malgache no plantea el mismo debate como la doctrina española. En efecto, también en la letra de la ley de ambos ordenamientos "aceptar" tiene que tener un objeto: ofertas, promesas, dádivas, regalos u otros beneficios. Por lo tanto, no se trata aquí de cualquier manifestación unilateral de voluntad sino un encuentro entre dos voluntades, el cual origina una relación de compromiso ${ }^{178}$. Es decir, no basta con que ambas partes exterioricen su respectiva voluntad, se comuniquenn y se escuchen ${ }^{179}$ sino que hace falta que lleguen a un compromiso común cuyo objetivo sería beneficiarse de la aportación de cada parte ${ }^{180}$. La conciencia de este objetivo por parte del funcionario originará el delito de corrupción pasiva y lo mismo de parte del particular dará como resultado la corrupción activa. Si esta conciencia conjunta del objetivo no se da, habrá que determinar la responsabilidad de cada parte valorando su respectiva pretensión. A nuestro parecer, lo que importa en esta modalidad no es tanto que las partes lleguen a un pacto como la verificación de hechos y actitudes que permitan inferir la voluntad inequívoca de adherirse a la oferta o a la promesa. Aunque no hay debate en la doctrina penal francesa y malgache sobre la cuestión de "aceptar" con un comportamiento omisivo tal como la falta de recha-

\footnotetext{
aunque existe previamente una promesa, no puede haber aceptación típica. Estaremos entonces ante una hipótesis de tentativa inidónea de cohecho, o ante una hipótesis de tentativa absolutamente inidónea si al funcionario le era materialmente imposible comprender el mensaje.

174 I. OLAIZOLA NOGALES, El delito de cohecho, op. cit., p.258.

175 Ma. J. RODRÍGUEZ PUERTA, El delito de cohecho..., op. cit., p.181.

176 I. VALEIJE ÁLVAREZ, El tratamiento..., op. cit., p.123.

177 Ibídem op. cit., p.123.

${ }^{178}$ H. XIAO-YING, La lutte contre la corruption..., op. cit., p.51. El autor ve en esta modalidad de "aceptar" la aparición del aspecto bilateral del delito de corrupción.

179 E. GARÇON, Code pénal annoté, Tome I, op. cit., no 85, p.697.

180 E. DREYER, Cours magistral..., op. cit., p.602.
} 
zo o el silencio, en principio el silencio del destinatario no puede interpretarse como aceptación tácita de la oferta y aún menos en el ámbito penal. No obstante, habrá que valorar las circunstancias concretas en que se ha hecho la promesa para poder concluir que el silencio equivale a una aceptación tácita ${ }^{181}$. De todos modos, para que haya aceptación típica, generalmente, habrá que verificar algún indicio del asentimiento del funcionario sobre el contenido de la oferta. Tal asentimiento debe tener un carácter eminentemente activo, por ser delito formal o de mera actividad, para no desbordar el marco de la letra de la ley ${ }^{182}$.

Otros problemas plantea VALEIJE ÁLVAREZ cuando indica que las declaraciones de voluntad del funcionario y del particular deben mostrar su conformidad con el acto y con el precio. En el supuesto de que no llegaran a un acuerdo sobre cada uno de los extremos, y el desarrollo del pacto necesitara de la prestación de nuevos consentimientos sobre los puntos no desenvueltos, el problema en rigor consistiría en decidir si estamos ante un delito de cohecho pasivo consumado o solamente ante un delito de cohecho activo o ante ninguno de los dos delitos. A juicio de la autora, al bastar el mero acuerdo de voluntades y, por lo tanto, no ser necesario ni el cumplimiento del acto ni la materialización efectiva de la promesa para estimar perfeccionado el delito, la conducta delictiva queda excesivamente subjetivizada y falta del apoyo informativo que pueden aportar los datos del tipo objetivo (como, por ejemplo, la cosa mueble a los efectos de la recepción típica). Podría decirse, según la misma autora, que se trata de un proceso que versa sobre las motivaciones del funcionario y el particular ${ }^{183}$. Desde la perspectiva de la doctrina penal francesa, como ya se ha señalado anteriormente, el delito de corrupción es un delito de ejecución sucesiva, lo cual significa que todos los momentos incluidos dentro de un pacto son escalonados en el tiempo y caracterizan el cumplimiento de la corrupción y forman tantos delitos sucesivos mientras dura el concierto fraudulento ${ }^{184}$. Por lo tanto, lo que importa para el legislador no es que el acuerdo alcanzado llegue a fijar todos lo extremos, basta con que el funcionario manifiesta su adhesión a la oferta inicial para que se caracterice el delito. De acuerdo con RODRÍGUEZ PUERTA, cuando se produce un acuerdo de voluntades, el objeto del pacto debe quedar mínimamente determinado, o cuanto menos, debe ser determinable ${ }^{185}$. Si esto debe ser así, la doctrina francesa señala que los culpables, si tienen algo de habilidad, tra-

\footnotetext{
${ }^{181}$ Se puede tomar el ejemplo de una oferta en la que el particular corruptor determina un plazo para recibir una respuesta negativa de parte del funcionario. Pasado dicho plazo la falta de rechazo o el silencio de éste se considerará como aceptación tácita. Se puede interpretar que aunque el comportamiento es omisivo, el silencio aquí es una conducta activa por dejar que con el agotamiento de este plazo se permita la realización de una promesa y la incorporación en su patrimonio (o en el patrimonio de un tercero pero que de alguna manera tenga beneficio) del objeto de la oferta.

182 Ma . J. RODRÍGUEZ PUERTA, El delito de cohecho..., op. cit., p.182.

${ }^{183}$ I. VALEIJE ÁLVAREZ, El tratamiento..., op. cit., p.124.

${ }^{184}$ H. XIAO-YING, La lutte contre la corruption..., op. cit., p.51 ; M-P. LUCAS de LEYSSAC y A. MIHNAN, Droit pénal des affaires..., op. cit., no1015.

${ }_{185}$ Mà. J. RODRÍGUEZ PUERTA, El delito de cohecho..., op. cit., p.178.
} 
tarán de en tomar el máximo cuidado de no dejar ninguna pista de la oferta y de la aceptación ${ }^{186}$. Así, la dificultad de determinar estos elementos, nos lleva a suscribir también la postura de VALEIJE ÁLVAREZ en lo que refiere a la excesiva subjetivización de esta modalidad. Advierte, en este sentido, GARÇON que el juez debe ser muy prudente, exigir la prueba del acuerdo alcanzado, y no olvidar que la duda debe interpretarse siempre a favor del reo ${ }^{187}$.

\section{III-La necesaria idoneidad de la promesa o del ofreci- miento}

Si la promesa, entendida desde la perspectiva del delito en estudio, es toda declaración de voluntad que tenga por objeto una prestación futura capaz de servir como retribución al funcionario público, hay un acuerdo dentro de la doctrina al considerar que puede ser hecha de cualquier forma. El problema se sitúa en la validez de la promesa en el sentido de que posea ciertas probabilidades de ser cumplida y en la voluntad de no cumplir la promesa reconocida por el funcionario ${ }^{188}$. Para VALEIJE ÁLVAREZ, la promesa desprovista de toda posibilidad de ser cumplida no vincula penalmente al funcionario ni al particular. A juicio de la autora, para el cumplimiento del injusto típico del delito de cohecho pasivo no vale cualquier promesa, sino que ésta ha de estar dotada de cierta objetividad, entidad e idoneidad para poder colmar las exigencias típicas de aquel delito. Es necesario que la promesa en sí misma considerada esté dotada de un valor económico innegable y, consiguientemente, tenga cierta objetividad e incluso credibilidad, ya que sólo de la promesa que cumpla estos requisitos podrá decirse que, de acuerdo a las máximas de la experiencia, en las circunstancias concretas y con respecto a un acto determinado, será susceptible de poder funcionar como contrapartida económica por el acto. Para valorar la objetividad y la idoneidad de la promesa es necesario separar dos cuestiones distintas, como son, de un lado, la voluntad de querer cumplir la promesa y, de otro, la capacidad que la promesa tiene para ser cumplida. En lo que se refiere a la posibilidad que tiene la promesa de ser cumplida, la autora defiende que hay que tener en cuenta que se está ante un delito imposible cuando por inidoneidad de los medios o por inexistencia del objeto, es imposible que se verifique la puesta en peligro o el resultado lesivo para el bien jurídico ${ }^{189}$.

Este debate sobre la idoneidad de la promesa no se ha planteado en la doctrina penal francesa ni malgache. Como ya se ha explicado, desde la perspectiva de una teoría general de la infracción que no se basa en la consideración de que el delito es la lesión o la puesta en peligro de un bien jurídico, sino en la violación a la ley, tanto la tentativa inidónea como el delito imposible no se quedan impunes. A nuestro parecer, se

\footnotetext{
186 E. GARÇON, Code pénal annoté, Tome I, op. cit., nº 83, p.697.

187 Ibídem, op. cit., no 85, p.697.

188 I. VALEIJE ÁLVAREZ, El tratamiento..., op. cit., pp.125 y 126.

189 Ibídem, op. cit., pp.126-128.
} 
deberá considerar caso por caso las circunstancias que permiten valorar la idoneidad o no de la promesa. Si la idoneidad es sólo aparente y que más tarde se descubre que no es el caso o no existe el objeto de la promesa, consideramos que se han consumado tanto el delito de corrupción pasiva como el de corrupción activa. Más complicado sería el supuesto en el que la inidoneidad de la promesa es obvia y el funcionario la ha aceptado, porque si el delito imposible se castiga como delito tentado, y en materia de corrupción la tentativa no existe porque se trata de un delito formal, el cumplimiento de la conducta típica supone consumación del delito. En este caso, sin perjuicio de las circunstancias concretas de caso, habría delito de corrupción pasiva por haber aceptado la promesa, aunque ésta sea inidónea y delito de corrupción activa. En cuanto a la voluntad del particular de no cumplir la promesa después de haber alcanzado un pacto, a nuestro juicio, tal situación no es revelante ante la teoría francesa de la infracción, ya que es un hecho posterior a la voluntad exteriorizada de llegar a un acuerdo con el funcionario. En este sentido se ha pronunciado la doctrina penal francesa al considerar la poca importancia de que se cumpla o no la promesa, o sea de que el particular quiera o no cumplirla una vez que haya adquirido el asentimiento del funcionario ${ }^{190}$.

\section{Sección 4 -.0bservaciones y toma de postura}

\section{I-Observaciones sobre la técnica legislativa en materia de cohecho pasivo}

No parece estar exenta de objeciones la mención expresa de la "aceptación" o "recepción" del ofrecimiento y de la promesa. Un sector de la doctrina discrepa de las afirmaciones hechas por la doctrina española especializada en materia de cohecho. Por un lado, este mismo sector no está de acuerdo con la tesis que defiende ésta de que el momento en el que se realiza la aceptación debe entenderse como siempre precedente a aquel en el cual se "recibe"191. Por otro lado, se rechaza la tesis de VALEIJE ÁLVAREZ quien sostiene que en la modalidad típica de aceptar, el funcionario no sólo recibe el compromiso de obtener una ganancia en el futuro a cambio de la ejecución del acto contrario al cargo, sino que también puede obtener en el acto una retribución de carácter inmaterial, esto es, prestaciones que no son susceptibles de una transferencia material ${ }^{192}$. Por último, tampoco al mismo sector doctrinal le parece de recibo la idea de que si el instrumento del delito se entrega directamente, se llamará "dádiva o presente", mientras que si no se entrega en el acto, ofrecimiento o promesa ${ }^{193}$.

\footnotetext{
${ }^{190}$ Entre otros M-P. LUCAS de LEYSSAC y A. MIHNAN, Droit pénal des affaires..., op. cit., no1015; M. DELMAS-MARTY y G. GIUDICELLI-DELAGE, Droit pénal des affaires, op. cit., p.289.

${ }^{191}$ E. CASAS BARQUERO, “Observaciones...”, op. cit., p.874.

192 I. VALEIJE ÁLVAREZ, El tratamiento..., op. cit., p.121

193 E. CASAS BARQUERO, “Observaciones...", op. cit., p.887; M. POLAINO NAVARRETE, "Delitos...", op. cit., p. 367.
} 
En efecto, siendo el español lengua neo-latina, el significado de las palabras "ofrecer" y "prometer" no cambia. Quien ofrece, pone algo a disposición de alguien ${ }^{194}$, mientras quien promete se obliga a hacer, decir o dar algo (en el futuro). De tal manera que lo prometido difícilmente podría recibirse, sino tan sólo aceptarse, mientras que aceptar lo ofrecido equivaldría a recibirlo ${ }^{195}$.

Por lo tanto, al compartir estas observaciones, deberá concluirse que "quien acepta (o admite) un ofrecimiento", en realidad, "recibe" cuanto es ofrecido. De ahí que una vez sancionado el funcionario público que "recibe dádiva o presente" deviene pleonástico penarle también por "aceptar el ofrecimiento"196.

También se puede criticar la congruencia de la intervención de la persona interpuesta en los delitos de cohecho pasivo. En efecto, se refiere, en los artículos 419 y $420 \mathrm{CPE}$, al funcionario público que actúa "en provecho propio o de un tercero" y "por sí o por una persona interpuesta". Pero, mientras que aquel provecho propio o ajeno lo conecta con o todos los comportamientos de cohecho que recoge (esto es, lo mismo con el de solicitar o recibir dádiva, favor o retribución, que con el de aceptar ofrecimiento o promesa), vincula la actuación personal o con intermediario exclusivamente a la primera de las modalidades de comportamiento que describe (es decir, a la que solicitar o recibir dádiva, favor o retribución). De donde se deduce que la aceptación del ofrecimiento o promesa ha de hacerla el funcionario personalmente o, dicho al contrario, que la aceptación mediante tercero no es típica a los efectos de estos artículos ${ }^{197}$. También parece injustificada la falta de simetría en el caso del cohecho subsiguiente del artículo 421 al sólo prever las modalidades de recibir y solicitar sin alusión alguna a la modalidad

\footnotetext{
${ }^{194}$ Es decir, según la Real Academia Española, "presentar y dar algo voluntariamente". Sin embargo como primer significado del mismo término "ofrecer" el mismo diccionario propone "comprometerse a dar, hacer o decir algo". Si se entendiera así, "ofrecer" resultaría sinónimo de "prometer" de tal manera que su mención expresa sería inútil y pleonástica.

195 G. D. M. CERINA, La lucha contra la corrupción, op. cit., pp.823 y 824.

${ }^{196}$ En el mismo sentido y con más detalle se ha pronunciado E. OCTAVIO DE TOLEDO Y UBIETO, “Derecho penal...", op. cit., p.875. Señala el autor, bajo la vigencia de la anterior redacción, que en el artículo 425.1 CPE se da la misma identificación entre la "dádiva" y el "presente", habiéndose de igualar la conducta de admitir el ofrecimiento o la promesa con la de aceptarlos del artículo 419, por que estos verbos debieran reducirse a uno, siendo preferible el de "aceptar". Por otro lado, el artículo 426 del mismo código se refiere al funcionario que "admitiere dádiva o regalo que le fueren ofrecidos". Si "dádiva" y "regalo" son una misma cosa y "ofrecidos" distinto de "prometidos" entonces "admitir" equivale, a un tiempo, a "aceptar" y a "recibir"; por lo que, en definitiva, estamos ante el funcionario que acepta un ofrecimiento que se materialice en el acto (pues siguiendo la argumentación anterior, pues se trata aquí de "recibir"); pero no, al contrario, ante el comportamiento del funcionario que acepta un ofrecimiento de ulterior realización o promesa de más lejana materialización, conducta que, por tanto, ha de estimarse atípica, lo mismo que la del funcionario que solicita dádiva, ofrecimiento o promesa.

197 Defiende una opinión contraria M. POLAINO NAVARRETE, "Delitos...", op. cit., p. 368.
} 
de aceptar ofrecimiento o promesa. Daría a entender que esta modalidad es atípica en este tipo de cohecho.

Parece criticable que se utilice el verbo "admitir", en el artículo 422 $\mathrm{CPE}$, en lugar de que "recibir" (o "aceptar") para describir la conducta típica del funcionario público y se sigue echando en falta una mención expresa de la solicitud del funcionario público no aceptada por la contraparte ${ }^{198}$.

Algo sin duda, incongruente. Por último, en el artículo 421 se omite tanto que la actuación se practique por el funcionario "en provecho propio o de un tercero", cuanto que la efectúe "por sí o por persona interpuesta". Con lo cual, y a la vista de los criterios existentes al respecto entre los artículos 419 y 420, no es posible considerar que ambos requisitos o alguno de ellos se encuentren implícitamente formulados en el artículo $421 \mathrm{CPE}$; ello implica que se impone la interpretación literal estricta en este último precepto, conforme a la que en las modalidades de cohecho incluidas en él resulta admisible la actuación del funcionario en provecho propio y personalmente (sin mediador). Conclusión que resulta político-criminalmente discutible ${ }^{199}$.

Aunque la exegesis que se ha propuesto desde algún sector doctrinal permite superar parte de los problemas que derivan de la técnica legislativa utilizada, cuanto menos opinable, y a pesar de la mejora destacable demostrada por el legislador penal de 2010, compartimos la afirmación de OCTAVIO DE TOLEDO en el marco de la redacción anterior, quien ha subrayado que "esta desigual verbosidad plantea (...) dudas, de nuevo innecesariamente y de nuevo contrarias a la deseable seguridad jurídica $200 "$. Dicho en palabras de CERINA, las incongruencias terminológicas denunciadas, parecen absolutamente censurables 201.

\section{II-Observaciones sobre la técnica legislativa francesa y malgache}

En primer lugar, valoramos como positiva la ausencia (o incluso se puede decir la exclusión) en ambos ordenamientos de la modalidad típica de "recibir". En efecto, debemos averiguar el significado de lo que puede ser aceptado para entender la pertinencia de esta postura. Entre la palabra "oferta" y "promesa" puede haber una confusión en el sentido de que ambas palabras tienen un significado que proyectan hacia el futuro ${ }^{202}$. Tanto la idea de proponer algo a alguien como la de prometer

198 G. D. M. CERINA, La lucha contra la corrupción, op. cit., pp.1210 y 1211.

199 En este mismo sentido, aunque bajo la vigencia del redacción de 1995, ver E. OCTAVIO DE TOLEDO Y UBIETO, “Derecho penal...”, op. cit., pp.875 y 876.

200 Ibídem, op. cit., p.874.

201 G. D. M. CERINA, La lucha contra la corrupción, op. cit., p.825.

202 El diccionario Larousse define la palabra "offre" (oferta) como la acción de proponer algo o la acción de proponer a otra persona la conclusión de un contrato; mientras la palabra "promesse" (promesa) es la acción de prometer o el compromiso que se toma al prometer algo. (Véase www.larousse.fr) 
algo o de comprometerse al prometer algo, se pueden utilizar sin ningún problema con la modalidad típica de solicitar y de aceptar. Si lo futuro no se puede entregar o materializar de inmediato, entonces el verbo "aceptar" es adecuado para expresar la idea. Cuando la palabra "oferta" supone, ya no algo que se puede materializar en el futuro, sino una entrega material ${ }^{203}$, se le puede confundir con la palabra "presente" que supone una oferta con objeto 204 , con lo cual la terminología empleada puede resultar pleonástica. Aceptar un objeto que se entrega o se ofrece materialmente no puede significar más que "recibir", por lo tanto, la exclusión de este verbo se puede justificar. Además, entre las palabras "don" (dádiva) y "présent" (presente) no hay prácticamente diferencia alguna ${ }^{205}$ y con una de ellas podría haber sido suficiente.

En segundo lugar, se puede cuestionar la utilidad de la expresión "sin tener derecho a ello". Como ya hemos señalado, según una parte de la doctrina francesa, esta expresión sirve para distinguir la figura de la corrupción pasiva de la concusión ${ }^{206}$. Sin embargo, nos parece pertinente la postura de otra parte de la misma doctrina, al sostener que es evidente que la aceptación o la solicitación de cualquier beneficio para cumplir un acto de la función de parte de una persona que responde a las características del sujeto activo de la corrupción pasiva, es ilícita por naturaleza, por tanto, esta expresión al parecer no tiene ningún sentido. Creyendo innovar en buena manera con esta precisión, el legislador ha cometido una torpeza ${ }^{207}$. VITU indica que habría sido más acertado no hacer mención de una solicitación formulada "sin tener derecho a ello"208. En efecto, la falta de este derecho de no sólo de solicitar, sino también de aceptar beneficio alguno caracteriza el de delito de corrupción pasiva. El hecho de que el funcionario pretenda tener un derecho que no tiene lo expone a otro de tipo de delito y depende de cómo presenta esta pretensión falsa si la expresión "sin tener derecho a ello" vale para distinguir la corrupción pasiva de la concusión. Por lo tanto, se puede concluir el carácter pleonástico de la expresión en cuestión, puesto que lo que justamente fundamenta la corrupción es la autoretribución que el mismo funcionario decida a cambio de un acto de su función o acto facilitado por la misma.

Aun así, se entiende la preocupación del legislador por dar más precisión en la letra de la ley ya que, como hemos visto, no hay ninguna clasi-

\footnotetext{
${ }^{203}$ El segundo sentido de "offre" es la acción de ofrecer algo; lo que ha sido ofrecido. Se da a entender que aquí se trata de "dar" algo más concreto que una propuesta, esto es objeto material.

${ }^{204}$ El mismo diccionario defina la palabra "présent" como el objeto que se ofrece, regalo.

205 En este sentido, E. OCTAVIO DE TOLEDO Y UBIETO, "Derecho penal...", op. cit., p.874; la palabra francesa "don", según el diccionario Larousse significa "cosa o suma de dinero dada, regalo".

${ }^{206}$ Entre otros, M-P. LUCAS de LEYSSAC y A. MIHNAN, Droit pénal des affaires..., op. cit., no1026.

${ }^{207}$ W. JEANDIDIER, Du délit de corruption..., op. cit., p.1670.

${ }^{208}$ A. VITU, Corruption passive..., op. cit., p.15.
} 
ficación del delito de corrupción pasiva en propio e impropio. Lo que significa que la expresión "sin tener derecho a ello" sirve simplemente para dar relevancia penal a la conducta cada vez que el acto entra en el marco de la función del sujeto activo. En efecto, sin esta expresión estamos obligados a calificar como corrupción el caso de un profesor de universidad que recibe una remuneración para dar una conferencia, así como en el supuesto en el que gracias a un sponsor, la Facultad o Universidad respectiva ingrese dinero ${ }^{209}$.

Por último, puede preguntarse también el alcance de la expresión "provecho propio o ajeno" añadida en el CPF a partir de la reforma penal de 2007. ¿Era necesario que el legislador francés introdujera esta precisión? El legislador malgache, durante la reforma penal del año 2004, no previó tal precisión. Comparando el artículo 432-11 del CPF con el 177 del CPM $i$ se puede decir que el primero tiene algún plus respecto al segundo? A nuestro parecer, la respuesta es negativa. Para defender nuestra postura hacemos nuestra la reflexión que hizo VALEIJE ÁLVAREZ quien observa que "al CP no le interesa si el funcionario recibe o disfruta directamente la retribución o si al sujeto que la entrega le mueve el interés propio o ajeno ${ }^{210}$ ". En efecto, tanto en el CPF como en el CPM, la figura de la corrupción pasiva alude a "cualquier beneficio", con lo cual ambos legisladores determinan que la existencia de este delito se basa en la idea de ventaja y lo que ello puede implicar. Por lo tanto, si el legislador malgache no ha precisado sobre el destinatario del beneficio es simplemente porque no era típicamente relevante. Ya antes del año 2007 la jurisprudencia francesa admitía el provecho ajeno para caracterizar el delito en estudio ${ }^{211}$. Cabe concluir que el inciso "en provecho propio o ajeno" no era tan necesario en el Derecho penal francés ${ }^{212}$. Quizá lo positivo de este inciso sería aclarar o confirmar a la jurisprudencia el alcance del precepto y, de esta manera, agotar todas las posibilidades. Por otro lado, es de lamentar que al introducir de este inciso en el artículo 432-11 CPF, el legislador francés no persigue ni fines político-criminales ni dogmáticos, sino una simple y formal "preocupación por la harmonización con las nuevas infracciones"213.

${ }^{209}$ G. D. M. CERINA, La lucha contra la corrupción, op. cit., p.950.

${ }^{210}$ I. VALEIJE ÁLVAREZ, El tratamiento..., op. cit., p.119. Entiende la misma autora que el Código lo único que pretende reprimir es, desde el punto de vista del cohecho pasivo, que el funcionario no obtenga ninguna retribución ilegítima a través del ejercicio del cargo y desde el punto de vista del cohecho activo, que un ciudadano no compre la actuación del funcionario, y ello en razón de las gravísimas consecuencias que la corrupción conlleva para el interés público.

${ }^{211}$ Cass. crim. 30-06-1999, Bull. Crim. n.o 168. En este caso se ha condenado a un elegido quien solicitó fondos destinados a la financiación de actividades políticas.

212 Y, según CERINA, tal inciso es innecesario en el marco de la reforma de 1995 del CPE. El autor afirma su carácter pleonástico y demanda una revisión urgente de las normas. (Vid. G. D. M. CERINA, La lucha contra la corrupción, op. cit., pp.951-954).

${ }^{213}$ Se puede ver la Exposición de los motivos de la ley 2007- 1598 del 13 de noviembre de 2007 sobre la lucha contra la corrupción en: http://www.legifrance.gouv.fr/ 



\section{CAPÍTULO VI: TIPO OBJETIVO (III). EL ACTO OBJETO DE ACUERDO}

Antes de examinar los diferentes actos previstos por los tres Códigos penales en estudio, sería necesario hacer unas precisiones previas tales como el vínculo que debe existir entre el acto y la dádiva, la competencia del sujeto activo y la delimitación del propio término "acto". Luego, nos detendremos en la importancia del momento de la ejecución del acto por parte del funcionario.

\section{Sección 1-Consideraciones previas}

\section{I- Vínculo entre el acto y la dádiva}

\section{A- LA NECESARIA RELACIÓN ENTRE EL ACTO Y LA DÁDIVA}

La dádiva, el favor o la retribución deben solicitarse o prometerse a cambio de la realización, por parte del funcionario, de un acto en el ejercicio de su cargo. La característica del delito de cohecho o de corrupción consiste en un acuerdo entre el funcionario y el particular, dirigido a transaccionar las funciones públicas. Se trata, así, de un intercambio mutuo de prestaciones, en el que el funcionario aporta al "pacto" el acto propio del cargo y el particular se encarga de facilitar el beneficio o la ventaja. De este modo, una y otra contraprestación se encuentran estrechamente relacionadas y vinculadas entre sí1. Según MUÑOZ CONDE debe existir una conexión causal entre la dádiva y el acto a realizar ${ }^{2}$. La doctrina francesa admite también la exigencia de una relación de causalidad entre los ofrecimientos y los actos realizados u omitidos ${ }^{3}$. Aunque la doctrina malgache no se ha pronunciado de manera explícita en el marco del delito de corrupción pasiva, no vemos ninguna razón para rechazar la exigencia de esta relación de causalidad entre las ventajas y los actos a realizar en Derecho penal malgache, puesto que el artículo 177 CPM tiene la misma configuración que el artículo 432-11 del CPF4.

\footnotetext{
${ }^{1}$ Mà. J. RODRÍGUEZ PUERTA, El delito de cohecho..., op. cit., pp.201 y 202

2 F. MUÑOZ CONDE, Derecho penal, Parte especial, Tirant lo Blanch, Valencia, 2010, (18 ${ }^{\mathrm{a}}$ ed.), p.1022. Entiende el mismo autor que es indiferente que la dádiva se perciba antes o después de realizado el hecho, siempre que haya sido pactada o solicitada con anterioridad a su realización.

3 J.-H. ROBERT y H. MATSOPOULOU, Traité de droit pénal des affaires, PUF, 2004, p.180 ; M. VIGNAU, Le délit de corruption, op. cit., p.42; H. XIAO-YING, La lutte contre la corruption..., op. cit., p.70 ; M. VÉRON, Droit pénal spécial, op. cit., p.389 ; A. VITU, Corruption passive..., op. cit., p.17.

${ }^{4}$ El CPM da un tratamiento penal particular al asunto del regalo y consagra el artículo 183 para este efecto. Según RAFOLISY para que un regalo sea prohibido en una administración que no cuenta con un código de deontología, tiene que tener una relación
} 


\section{PARTE II: ESTUDIOS DE LOS ELEMENTOS TÍPICOS...}

Sin embargo, no es necesario, para la consumación del delito, que ninguna de ellas se realice efectivamente, basta con manifestar la intención de entregar la dádiva - para el particular - o de realizar el acto propio del cargo -para funcionario -5 .

Esta necesaria relación remuneratoria - o retributiva - que media entre el acto propio del cargo y la dádiva o el favor se deduce del propio tenor literal de los preceptos en examen. Así, los artículos 419 y 420 CPE requieren que las ventajas se soliciten, reciban o acepten para realizar en el ejercicio del cargo un acto (contrario a los deberes inherentes al mismo o propio del cargo). Tanto el CPF como el CPM exigen que la solicitación o la aceptación del funcionario de la contrapartida ofrecida, entregada o prometida por el particular sean para [...] que realice o deje de realizar [...] un acto de su competencia, o facilitado por su competencia ${ }^{6}$. Por consiguiente, el motivo o finalidad por la que el funcionario se muestra dispuesto a adoptar, en el ejercicio de sus funciones, uno de los actos mencionados debe situarse en la recompensa que por ello solicita, recibe o acepta $^{7}$. No es de extrañar que el legislador español de 2010 introduzca por primera vez la palabra "retribución" para destacar el carácter de esta relación. Por su parte, el legislador francés y el malgache hablan de "beneficios" o "ventajas" para caracterizar la misma relación.

Para VALEIJE ÁLVAREZ, la exigencia típica de que el funcionario ordene su comportamiento para conseguir o producir la meta prevista en la ley, es el elemento determinante para la fundamentación de la antijuridicidad típica del cohecho. Añade la misma autora que, a su parecer, el cohecho es un delito doblemente subjetivado: por una parte, en virtud de las exigencias sustanciales del contexto típico (relativas a la finalidad de ejecutar un acto contrario al cargo) y, por otro lado, y aun cuando no conste en la estructura típica con inequívoca precisión, por la concurrencia de otro momento de índole subjetiva cifrado en la finalidad lucrativa que se pretende obtener como contrapartida de la ejecución del acto funcionarial ilícito ${ }^{8}$. Desde la perspectiva del principio de imparcia-

de causalidad con el ejercicio del cargo (P. RAFOLISY, La protection juridique..., op. cit., p.252). Más adelante podemos ver la utilidad de este precepto a efectos de comparación con el Derecho penal español.

${ }^{5} \mathrm{M}$ a . J. RODRÍGUEZ PUERTA, El delito de cohecho..., op. cit., p.202; M. DELMAS-MARTY y G. GIUDICELLI-DELAGE, Droit pénal des affaires, op. cit., p.290.

${ }^{6}$ C. ARÁNGUEZ SÁNCHEZ y E. ALARCÓN NAVÍO, El código penal francés, op. cit., p.206. La traducción propuesta por estos autores facilita la comprensión para el lector hispanohablante. Sin embargo la reforma legislativa operada en mayo de 2011 cambiará la manera de traducir de este precepto en español.

7 Ma. J. RODRÍGUEZ PUERTA, El delito de cohecho..., op. cit., p.202; G. D. M. CERINA, La lucha contra la corrupción, op. cit., p.991.

8 I. VALEIJE ÁLVAREZ, El tratamiento..., op. cit., p.170. Explica la misma autora que la primera función que desempeña el propósito de realizar el acto, en tanto que indica la presencia de un elemento subjetivo del injusto en la descripción objetiva, es la de impedir en principio la posibilidad de cometer imprudentemente un delito de cohecho. Además, su presencia es necesaria para deshacer la equivocidad a que puede dar lugar el aspecto objetivo de la conducta, cuya sola dimensión externa puede hacer pasar por una conducta ilícita lo que en realidad es ajustado a Derecho. Por tanto, no basta el 
lidad, como bien jurídico protegido en el delito de cohecho, indica RODRÍGUEZ PUERTA que la lesión o la puesta en peligro del dicho principio, que debe presidir la adopción de decisiones públicas, requiere en todo caso que el funcionario adopte o deba adoptar, en el ejercicio de su cargo, un acto determinado o determinable, respecto del cual se muestre dispuesto a actuar de forma "parcial" a cambio de una remuneración. Así, de no quedar probada esta circunstancia, esto es, de aceptar el funcionario la ventaja sin mediar entre ésta y el acto del cargo una relación de retribución, la conducta no podría subsumirse en ninguna de las modalidades de cohecho. De no requerirse esta relación, se estaría sancionando el mero incumplimiento de los deberes del cargo, o incluso la falta de honestidad o decoro del funcionario, pero no el debido respeto del principio de imparcialidad 9 .

Si en la doctrina española no hay desacuerdo en considerar esta necesaria relación entre el acto y las ventajas como elemento subjetivo del injusto, se puede preguntar si el acto en sí es elemento objetivo del tipo u objeto del dolo.

B- ¿ACTO OBJETO DEL ACUERDO COMO ELEMENTO OBJETIVO DEL TIPO U OBJETO DEL DOLO?

Aunque en la doctrina española la mayoría de los autores trata el acto objeto del acuerdo entre los elementos objetivos del tipo, es VALEIJE ÁLVAREZ la que se ha pronunciado de forma explícita sobre esta cuestión y señala que el acto, en su objetividad futura o actual, constituye un elemento objetivo del tipo de injusto y es el que, a la postre, discrimina entre dos figuras igualmente delictivas (cohecho propio/impropio) ${ }^{10}$. Sin embargo, CERINA, sin rechazar del todo esta postura, prefiere distinguir según se trate de corrupción subsiguiente o antecedente. Para este autor, en el primer caso parece problemático afirmar que el acto es parte del elemento objetivo del tipo de injusto: la conducta típica, en el caso del cohecho subsiguiente, no incluye la realización de acto ninguno, sino que se desarrolla a partir de la previa existencia de un acto del cargo (que podrá ser conforme o contrario a los deberes del funcionario). Si se acepta la categoría, por tanto, deberá concluirse que, en los supuestos de cohecho subsiguiente, el acto que remunera debe encuadrarse dentro de aquellos presupuestos necesarios para que pueda

\footnotetext{
que sea comprobable, por un lado, la intención de realizar el acto y, por el otro, la solicitud o aceptación de una ventaja patrimonial, sino que en virtud de la presencia de dicho elemento subjetivo en la estructura de los tipos penales deberá exigirse en todo momento que ésta (aceptación o solicitud) se haya llegado como concreción de aquélla (intención). La presencia o ausencia de la finalidad, en tanto que elemento anímico incardinado en el tipo de injusto, determina en muchos casos la exclusión de la antijuridicidad o la calificación del comportamiento funcionarial con arreglo a otro tipo delictivo. En tercer lugar, la finalidad o la clase de acto perseguido por el funcionario en tanto que elemento subjetivo del delito permite diferenciar entre los tipos de cohecho pasivo propio y el impropio.

${ }^{9} \mathrm{M}$ a. J. RODRÍGUEZ PUERTA, El delito de cohecho..., op. cit., p.203.

10 I. VALEIJE ÁLVAREZ, El tratamiento..., op. cit., p.204.
} 
producirse el injusto típico (tanto objetivo como subjetivo). De ahí que, al igual que la presencia de las cualidades que permiten calificar a uno de los dos sujetos activos como "funcionario público", debe retenerse que el acto objeto del acuerdo es presupuesto fáctico del tipo del injusto objetivo y que tiene que ser objeto de representación por parte de ambos los sujetos activos.

En el supuesto de cohecho antecedente, por otra parte, es igualmente evidente que el acto objeto del acuerdo no precisa producirse para que se den por realizados todos los elementos objetivos del injusto típico. De ahí que, en esta vertiente del delito, no puede sostenerse que la realización del acto objeto del pacto es parte del elemento objetivo del tipo de injusto. Además, el legislador español condiciona la perfección del delito (tanto intentado como consumado) a la presencia de una finalidad de realización del acto. De ahí que, para que exista delito de cohecho antecedente punible, es preciso que ambos sujetos activos se representen la futura existencia de un acto del cargo.

Concluye el autor que en el caso del cohecho subsiguiente, el acto recompensado es presupuesto objetivo del tipo de injusto, mientras que, en el cohecho antecedente, el acto renumerado es externo al elemento objetivo del injusto típico ${ }^{11}$.

La mayoría de los autores españoles no se han planteado este tipo de pregunta quizá, a nuestro modo de ver, porque la solución no lleva consecuencia significativa a la hora de aplicar el tipo. Por esta última razón, entendemos que, tanto en la doctrina francesa como en la malgache, no se encuentra así mismo este tipo de debate. Pero podemos añadir otros motivos a ello. En primer lugar, la inexistencia de este debate se debe a la configuración de la misma teoría francesa de la infracción. En efecto, al aplicar esta teoría, el acto objeto del delito de corrupción forma parte de los elementos materiales ${ }^{12}$. La doctrina francesa entiende que el punto central del delito es el pacto corruptor ${ }^{13}$ al que llegan el funcionario y el particular. Todo intento para alcanzar este punto, sea por medio de la solicitación de parte del primero sea por propuesta de parte del segundo, ha sido considerado por el legislador francés, y también malgache, como delito consumado. Sin embargo, se enfatiza que a pesar de que el

\footnotetext{
${ }^{11}$ G. D. M. CERINA, La lucha contra la corrupción, op. cit., pp.989 y 990. Añade el autor en su conclusión que el acto objeto del acuerdo remuneratorio, en la vertiente antecedente del cohecho, viene en consideración como un dolo específico (que existe cada vez que la ley subordine el reproche a la representación de un elemento ulterior que no tiene por qué producirse y que, por ende, no se encuentra integrado en el elemento objetivo del tipo de injusto ni, por supuesto, en el presupuesto fáctico del mismo), mientras que, en el cohecho subsiguiente, como objeto de un dolo genérico (que requiere del sujeto activo la representación de todos los elementos del tipo de injusto objetivo, junto, en su caso, con los presupuestos objetivos del mismo).

12 E. DREYER, Cours magistral..., op. cit., pp.602 y ss ; M. DELMAS-MARTY y G. GIUDICELLI-DELAGE, Droit pénal des affaires, op. cit., pp.288 y ss.

${ }^{13}$ Entre todos, M-P. LUCAS de LEYSSAC y A. MIHNAN, Droit pénal des affaires..., op. cit., nำ1030.
} 
acto objeto del delito no llegue a realizarse, el solo hecho de que el funcionario tenga en su posesión "algo" (competencia para cumplir un acto determinado o que lo facilita) que le permite iniciar la búsqueda de un pacto corruptor hace que ese "algo" si llegara a concretarse no formara parte del elemento moral del delito puesto que es una condición objetiva previa para que se forme el delito de corrupción. De otra manera estaríamos en el campo de otros delitos tales como el tráfico de influencias o también la estafa. En el elemento moral del delito en estudio, los autores franceses sólo estudian la intención culpable que anima al sujeto activo para llegar a un acuerdo de corrupción.

En segundo lugar, como destaca CERINA, para que exista delito de cohecho antecedente punible, es preciso que ambos sujetos activos se representen la futura existencia de un acto del cargo, justo o injusto ${ }^{14}$. Eso significa que el acto representado por ambos discrimina entre dos figuras del delito de cohecho: propio e impropio ${ }^{15}$. Y ya hemos señalado que esta clasificación no existe ni en el CPF ni en el CPM, por lo tanto la representación del acto objeto de la corrupción no tiene ningún efecto discriminatorio en ambos ordenamientos, y su realización no forma parte del elemento moral del delito porque basta con que la intención de cumplirlo sea evidente por medio del pacto corruptor. En el caso de la corrupción pasiva subsiguiente, ya que se trata de un acto del cargo ya realizado, no hay ningún problema en considerar que no puede ser parte del elemento moral del delito en estudio.

\section{I- La competencia del sujeto activo}

\section{A-LA RELACIÓN ENTRE EL ACTO Y LA ACTIVIDAD DESEMPE- ÑADA}

Para que exista delito de cohecho pasivo no es suficiente con que el funcionario solicite o reciba una dádiva o acepte un ofrecimiento o promesa, sino que es preciso que tal conducta se produzca como contraprestación a una acción u omisión determinadas que correspondan al ejercicio del cargo. Por tanto no cualquier acto que el funcionario se comprometa realizar va a dar lugar al delito de cohecho, sino únicamente aquél que esté relacionado con su cargo. Por ello es importante determinar qué actos son los que tienen capacidad de integrar el delito de cohecho. De esta premisa surge la pregunta sobre la competencia del funcionario ${ }^{16}$. El acto no sólo tiene que estar en conexión de tiempo y lugar con el cargo, sino que debe patentarse como tal.

La cuestión a dilucidar es si las conductas deberán corresponder a las específicas competencias legales o si, por el contrario, pueden consistir

\footnotetext{
${ }^{14}$ G. D. M. CERINA, La lucha contra la corrupción, op. cit., p.990.

15 I. VALEIJE ÁLVAREZ, El tratamiento..., op. cit., p.204.

${ }^{16}$ I. OLAIZOLA NOGALES, El delito de cohecho, op. cit., p.258.
} 


\section{PARTE II: ESTUDIOS DE LOS ELEMENTOS TÍPICOS...}

en meros poderes fácticos derivados de la posición funcional del agente ${ }^{17}$.

Existen dos orientaciones opuestas al resolver esta pregunta. De una parte están los autores que exigen, para hablar de cohecho pasivo, que la actividad solicitada por el soborno se encuentre comprendida entre las atribuciones o en la competencia específica del concreto funcionario que se comprometió a realizarla. Fuera del campo de la infracción quedaría, pues, aparte de la conducta de un particular que haciéndose pasar por funcionario público se beneficiase así de un soborno, el propio funcionario que se arrogue competencias por practicar un acto que no cae dentro de sus específicas atribuciones y, en contrapartida, aceptase una retribución. Cualquiera de los casos que se presentasen serían subsumibles en otra figura legal (estafa o usurpación de funciones públicas si el acto llegara a ejecutarse), pero no dentro del cohecho pasivo ${ }^{18}$.

Otros autores prescinden del hecho de que la conducta prometida o efectuada por el funcionario pertenezca a la esfera de sus atribuciones o competencia específica, bastando con la circunstancia de que la actividad solicitada se encuentre en una relación funcional inmediata con el desempeño del cargo ${ }^{19}$. Es decir, no se trata de cualesquiera posibilidades "fácticas" - que también un particular puede poseer -, sino de aquéllas que, a pesar de significar una extralimitación de sus tareas, son proporcionadas por el cumplimiento normal de sus atribuciones legales. Desde esta perspectiva, cuando el funcionario corrompido no participa de la aludida "relación funcional inmediata" se presenta como extraño al servicio, y por tanto, en una posición equiparable al particular, con lo que su conducta no puede ser encuadrada en el delito de referencia. Explica VALEIJE ÁLVAREZ que la competencia limita la idoneidad y aptitud de un órgano estatal participante de la función pública en cuanto a su posibilidad de resolver asuntos o llevar a cabo actividades correspondientes a aquella función estatal. La individualización de las competencias de un funcionario es un terreno bastante controvertido. Puesto que hay que atender no sólo a los principios generales que rigen en materia de organización administrativa (por lo que siempre cabe la posibilidad que funcionarios de órganos diversos tengan las mismas competencias), sino también a específicas disposiciones estatutarias, a los criterios de delegación y a otros procedimientos relacionados con los criterios de división de trabajo del ente de que se trate. Al hacer referencia al cohecho pasivo propio, la misma autora indica que la ley nunca confiere competencia para la realización de injustos o ilícitos (o, según la redacción legal de la reforma penal de 2010, acto contrario a los deberes inherentes al cargo), por lo que cabe colegir que la posibili-

${ }^{17}$ I. VALEIJE ÁLVAREZ, El tratamiento..., op. cit., p.197.

18 J. BUSTOS RAMÍREZ, Manual... Parte especial, op. cit., p.375; R. GARRAUD, Traité..., Tome IV, op. cit., pp.387-388, 399; E. CASAS BARQUERO, "Observaciones...", op. cit., p.886

19 T.S. VIVES ANTÓN, La detención...op. cit., p.54; J. M. RODRÍGUEZ DEVESA y A. SERRANO GÓMEZ, Derecho penal español, Parte especial, op. cit., pp.1175 y ss. 
dad de ejecución no se debe a la "competencia", sino única y exclusivamente a los poderes fácticos derivados de la "relación funcionarial inmediata" del agente con el cargo al que se encuentra adscrito. Esto es, el funcionario realiza el acto en virtud de las facilidades u oportunidades que se derivan de la situación subjetiva de la que es titular ${ }^{20}$. En palabras de RODRÍGUEZ PUERTA, no es en ningún caso imprescindible que sea competente específicamente para realizar la actividad a cambio de la cual solicita o recibe la dádiva, únicamente se exige que el acto objeto del delito de cohecho no resulte completamente ajeno al ámbito de atribuciones del funcionario o que, cuando menos, la acción presente una relación directa con el círculo o ámbitos de competencias del funcionario o de la oficina o entidad donde éste presta sus servicios ${ }^{21}$.

En conclusión, para la doctrina española mayoritaria ${ }^{22}$, deben considerarse "actos realizados en el ejercicio del cargo" en el sentido de delito de cohecho, tanto aquellos para los que el funcionario es objetiva, territorial y materialmente competente, como aquellos otros que, sin ser específicamente competente para adoptarlos, no son totalmente ajenos a la órbita de sus competencias, de modo que de facto puede llevarlos a cabo bien porque estos resultan facilitados por su posición en la Administración, bien porque su ejecución corresponde al órgano o entidad de la Administración donde él presta sus servicios, siempre y cuando, en este último caso, pueda establecerse alguna relación entre el acto objeto del cohecho y las genéricas funciones desempeñadas por el funcionario ${ }^{23}$.

Esta postura de la doctrina mayoritaria española es la que defiende también la mayoría de los autores franceses. En efecto, ya la letra del precepto en estudio es bastante clara a este respecto. Tanto el artículo 432-11 CPF como el 177 CPM han previsto que el intercambio de contraprestaciones tendrá como objeto un acto de la competencia del funcionario o facilitado por su competencia ${ }^{24}$. Al tomar la letra de la ley en su versión original, el legislador explicita que se trata de un acto de la función, de la misión o del mandato del sujeto activo o acto facilitado por los mismos. Por lo tanto, la doctrina francesa, en primer lugar, entiende que se trata de acto que forma parte de la prerrogativa del agente público ${ }^{25}$. Sin embargo, hay acuerdo mayoritario dentro de la doctrina francesa según el cual no se habla sólo aquí de la competencia exclusiva y personal del agente público sino también de acto que tiene relación con la misma. Por si acaso la amplitud de esta concepción pudiera

\footnotetext{
20 I. VALEIJE ÁLVAREZ, El tratamiento..., op. cit., p.201.

${ }^{21}$ Mà. J. RODRÍGUEZ PUERTA, El delito de cohecho..., op. cit., p.205

22 Entre otros E. ORTS BERENGUER, "Delitos...", op. cit., p.701; I. OLAIZOLA NOGALES,

El delito de cohecho, op. cit., pp.273 y 274; I. VALEIJE ÁLVAREZ, El tratamiento..., op. cit., p.201.

${ }^{23}$ Ma. J. RODRÍGUEZ PUERTA, El delito de cohecho..., op. cit., p.206.

${ }^{24}$ C. ARÁNGUEZ SÁNCHEZ y E. ALARCÓN NAVÍO, El código penal francés, op. cit., p.206.

${ }^{25}$ V. MALABAT, Droit pénal spécial, op. cit. pp.528 y 529 ; E. DREYER, Cours magistral..., op. cit., p.602.
} 
dar lugar a dudas, como ya veremos más adelante y en detalle su alcance, el legislador ha utilizado la expresión "acto facilitado" que indica un acto cuya posibilidad de realizarse depende del vínculo que existe entre las atribuciones del agente y el acto en cuestión ${ }^{26}$.

A pesar de este acuerdo mayoritario en la doctrina española en cuanto a la competencia, VALEIJE ÁLVAREZ plantea la única duda que consiste en saber si las situaciones en las que el pago del soborno corresponde al ejercicio de actividades materiales se reconducen siempre a casos de corrupción propia y nunca a la impropia, una vez que el acto obtenido a través de la gratificación se puede presentar irregular desde el punto de vista administrativo porque está viciado de incompetencia. Es decir, si el vicio de incompetencia es válido para la inclusión de la conducta en el cohecho pasivo propio, en detrimento siempre del impropio, o si por el contrario, la ilicitud a la que aquélla se refiere afecta únicamente al fondo y a la sustancia de la conducta del funcionario sobornado ${ }^{27}$.

\section{B- EL PROBLEMA DE LA INCOMPETENCIA}

El problema de la incompetencia se ha debatido dentro de la doctrina española cuando en el marco de las redacciones anteriores a la reforma de 2010, se clasificaba el cohecho pasivo como propio o impropio según si se trata, por un lado, de un acto delictivo o sólo injusto y por otro lado, de acto propio del cargo o de acto no prohibido legalmente ${ }^{28}$. Con la mencionada reforma, el legislador penal español de 2010 ya dejó de utilizar el adjetivo "injusto" o "delictivo" y prefirió la expresión "acto contrario a los deberes inherentes" al cargo. Al debatir lo que haría que un acto fuera injusto, CERINA, inspirándose de la doctrina italiana, concluye que el término "injusto" utilizado por los anteriores artículos 420 y 421 CPE es sinónimo de "contrario al deber del oficio" empleado por el legislador italiano ${ }^{29}$. Tal expresión no se aleja del significado que ha utilizado el legislador español en la última reforma del CPE.

Para el mismo autor, aunque para unos autores el acto objeto del acuerdo deber ser tomado dentro del ámbito competencial específico del sujeto, el Derecho administrativo español prevé una diferencia entre incompetencia genérica e incompetencia específica y según la incompetencia de la que se trate, un acto administrativo puede ser anulable o puede ser nulo. De ahí que cualquier funcionario pueda realizar actos anulables (o injustos, según el debate doctrinal bajo la vigencia de la

\footnotetext{
${ }^{26}$ M. VIGNAU, Le délit de corruption, op. cit., pp.42 y ss; H. XIAO-YING, La lutte contre la corruption..., op. cit., pp.70 y ss ; M. VÉRON, Droit pénal spécial, op. cit., p.389 ; F. CECCON, Contribution..., op. cit., pp.41 y ss ; A. VITU, Corruption passive..., op. cit., pp.17 y ss ; M-P. LUCAS de LEYSSAC y A. MIHNAN, Droit pénal des affaires..., op. cit., no1028 y ss ; J.-H. ROBERT y H. MATSOPOULOU, Traité... pp.181 y 182.

27 I. VALEIJE ÁLVAREZ, El tratamiento..., op. cit., pp.201 y 202.

${ }^{28}$ Mà. J. RODRÍGUEZ PUERTA, El delito de cohecho..., op. cit., pp. 211 y ss.; I. OLAIZOLA NOGALES, El delito de cohecho, op. cit., pp. 275 y ss.; J. VIZUETA FERNÁNDEZ, Delitos..., op. cit., pp. 250 y ss.

${ }^{29}$ G. D. M. CERINA, La lucha contra la corrupción, op. cit., p.1043.
} 
anterior redacción) de los cuales es competente. Por otra parte, observa que con la dicción "relación funcional inmediata" se pretende alargar el espectro de conductas calificables como cohechos punibles haciendo entrar por la ventana lo que se había echado por la puerta, entonces debe objetarse, recordando que los actos cometidos "en ocasión de la función" o sólo "facilitados por la función" no podrán subsumirse como cohecho pasivo propio sino como impropio ${ }^{30}$.

Si para VALEIJE ÁLVAREZ "la competencia, en tanto que es la medida de la atribución, no es más que un criterio de imputación del acto a su autor, por que debe ser referida al aspecto subjetivo de la conducta y no al contenido material"31, eso significa para CERINA que la incompetencia podrá relevar para excluir la relevancia penal del comportamiento (ya que impediría imputar el acto al funcionario corrupto) pero en ningún caso, por sí sola, determina la injusticia del acto: incluso el acto realizado por el funcionario incompetente, si resulta realizado en el marco de una "relación funcional inmediata", puede ser tanto justo (si no contradice el ordenamiento jurídico-administrativo) como injusto (si lo contradice), lo cual constituye una solución de la que debe discrepar. Razona este último autor que puesto que las normas sobre competencia implican un deber jurídico de no actuar (si el funcionario A es incompetente para dictar el acto $\mathrm{X}$, tiene el deber jurídico de no dictar el acto $X$ ) lo correcto es considerar que el acto viciado por incompetencia, en tanto en cuanto contrario a una norma específica de Derecho positivo, es injusto $y$, por tanto, si es objeto de un pacto corrupto, integra siempre una hipótesis de cohecho propio y no impropio ${ }^{32}$.

Nos parece acertada la postura de CERINA, sobre todo en el marco de la reforma penal de 2010. En efecto, la regulación anterior ha sido objeto de críticas, esencialmente por razón de la complejidad de la clasificación de las conductas delictivas y por eso, el legislador ha optado por la simplificación y la reorganización de esta normativa y ha decidido reformular estos delitos, de manera que ahora la clasificación se realiza tomando como punto de referencia si el acto (u omisión) es contrario o no a los deberes del cargo ${ }^{33}$. Por lo tanto, a nuestro juicio, a la luz de la vigente redacción, el acto viciado de incompetencia relativa (y anulable), realizado en el ejercicio del cargo debe integrar los supuestos de cohecho propio por ser un acto contrario a los deberes inherentes al mismo. Si la incompetencia es absoluta porque el acto es totalmente ajeno al ámbito competencial del funcionario entonces no habrá delito de cohecho.

Este debate no se plantea en la doctrina francesa y malgache ya que los legisladores penales de ambos países no consideran como relevante si

\footnotetext{
${ }^{30}$ Ibídem, op. cit., pp.1043 y 1044.

${ }^{31}$ I. VALEIJE ÁLVAREZ, El tratamiento..., op. cit., pp.215 y 216.

32 G. D. M. CERINA, La lucha contra la corrupción, op. cit., pp.1044 y 1045.

${ }^{33}$ I. BLANCO CORDERO, La reforma de los delitos de corrupción mediante la Ley Orgánica 5/2010: nuevos delitos y aumento de penas, La Ley, 12/2010, p.24.
} 
el acto objeto del acuerdo corrupto es justo o no ${ }^{34}$. Y, como ya lo hemos visto, ello implica la inexistencia de la clasificación de la corrupción pasiva en propia o impropia. En última instancia, la doctrina francesa precisa que el acto que no integraría en el tipo de corrupción pasiva es aquél que, por su naturaleza, escaparía totalmente a las atribuciones del agente público ${ }^{35}$. Es decir, mientras un acto viciado por incompetencia tiene algún vínculo o cierta proximidad con su competencia personal, dicho acto puede integrar una hipótesis de corrupción pasiva; de lo contrario, sugiere la doctrina francesa subsumirlo bajo otra calificación y no dejarlo sin represión ${ }^{36}$.

A estas alturas del debate, el concepto de acto da a pensar en alguna resolución o decisión formal que el agente público puede tomar según el marco de sus atribuciones. Sin embargo, a efectos del delito de cohecho, la noción de acto va más allá de lo que es un acto administrativo.

\section{III-El acto administrativo y el acto en el ejercicio del car- go}

La doctrina especializada admite que la noción de acto no debe ser valorada según los criterios propios del Derecho administrativo sino en consonancia con las exigencias del Derecho penal ${ }^{37}$. Varias razones justifican esta postura.

\section{A- LA FUNCIONALIDAD DEL “ACTO ADMINISTRATIVO"}

La expresión "acto administrativo" hace referencia a un acto dictado por la Administración u otro poder público en el ejercicio de potestades administrativas y mediante el cual imponen su voluntad sobre derechos, libertades o intereses a otros sujetos públicos o privados y que están sometidos a la jurisdicción contencioso-administrativa. La funcionalidad del concepto "acto administrativo" es delimitar la materia contencioso-administrativa a efectos de su impugnación ante los tribunales de ese orden. No es cometido del Derecho penal si o cómo un acto de la Administración pública puede ser impugnado ante la jurisdicción contenciosa. La ciencia penal sólo pretende establecer cuáles los requisitos mínimos para someter a sanción penal a la persona física que realiza una conducta contraria a los deberes que su cargo le impone ${ }^{38}$.

\footnotetext{
${ }^{34}$ M. VIGNAU, Le délit de corruption, op. cit., p.45 ; A. VITU, Corruption passive..., op. cit., p.17.

${ }^{35}$ H. XIAO-YING, La lutte contre la corruption..., op. cit., p.72 ; A. VITU, Corruption passive..., op. cit., p.19 ; M-P. LUCAS de LEYSSAC y A. MIHNAN, Droit pénal des affaires..., op. cit., no1029 ; M. VIGNAU, Le délit de corruption, op. cit., p.45.

${ }^{36}$ A. VITU, Corruption passive..., op. cit., p.20.

37 Mà. J. RODRÍGUEZ PUERTA, El delito de cohecho..., op. cit., pp. 207 y 208; I. VALEIJE ÁLVAREZ, El tratamiento..., op. cit., pp.191 y ss.; I. OLAIZOLA NOGALES, El delito de cohecho, op. cit., pp. 274 y ss.

38 I. VALEIJE ÁLVAREZ, El tratamiento..., op. cit., pp.192 y 193; I. OLAIZOLA NOGALES,

El delito de cohecho, op. cit., p.274.
} 


\section{B-LA INOPERABILIDAD DEL CONCEPTO DE "ACTO ADMINITRA- TIVO" A EFECTOS DEL DELITO DE COHECHO PASIVO}

El primer motivo por el que se niega la identidad entre el acto propio del cargo al que se refieren los tipos de cohecho y el acto administrativo, se encuentra en la incoherencia que esta interpretación generaría, pues sujetos activos de este delito - desde la perspectiva del funcionario - pueden serlo tanto aquellos funcionarios que desempeñan una actividad administrativa, stricto sensu, como aquellos otros que desarrollan actividades jurisdiccionales o legislativas. De este modo, restringir el alcance del término "acto" únicamente al "acto administrativo" supondría excluir la posibilidad de cometer este delito por funcionarios que desempeñaran funciones distintas a la administrativa, así como aquellos sujetos a los que se refiere el artículo $423 \mathrm{CPE}$. En este último caso, ni los peritos ni los árbitros ni los jurados ni los administradores o interventores designados judicialmente podrían cometer el delito de cohecho, pues su participación en el ejercicio de funciones públicas en ningún caso alcanza a la emisión de actos administrativos ${ }^{39}$. De igual manera, quedan fuera de tal noción, los actos que no conllevan una posibilidad de recurso o de impugnación, sino una responsabilidad política (como los actos de gobierno) o una sujeción a la regulación del Derecho privado ${ }^{40}$.

Junto a este argumento, también debe alegarse en favor de la interpretación amplia del término "acto" la contradicción a la que conduciría la exclusión del ámbito del delito de cohecho de aquella actividad desempeñada por el funcionario administrativo no fiscalizable por la jurisdicción contencioso-administrativa. Así, no existe razón para excluir del ámbito del delito de cohecho que pueda desarrollar un funcionario: tanto los actos de trámite, los informes, las resoluciones de alcance general, las leyes, los reglamentos y ordenanzas e incluso cualquier tipo de actividad material o mecánica, como, por ejemplo, poner orden a los expedientes para su resolución por la persona competente, etc. Esta interpretación amplia resulta así plausible porque el CPE no emplea el término "resolución" sino que utiliza un término más amplio y polivalente "acto" que, fuera de la interpretación estrictamente administrativa - no aplicable por los motivos expuestos -, permite, en su acepción literal, incluir en su seno toda la actividad desplegada por el funcionario ${ }^{41}$ aun

\footnotetext{
${ }^{39}$ Mạ. J. RODRÍGUEZ PUERTA, El delito de cohecho..., op. cit., p. 207; I. VALEIJE ÁLVAREZ, El tratamiento..., op. cit., p.192; I. OLAIZOLA NOGALES, El delito de cohecho, op. cit., p.274.

${ }^{40}$ I. OLAIZOLA NOGALES, El delito de cohecho, op. cit., p.274; I. VALEIJE ÁLVAREZ, El tratamiento..., op. cit., p.192.

${ }^{41}$ F. MORALES PRATS y Mạ. J. RODRÍGUEZ PUERTA, "Delitos contra la Administración Pública" en G. QUINTERO OLIVARES (dir.), Comentarios al Código Penal Español, Thomson/Arazandi, 2011; (6 $6^{\underline{a}}$ ed.), p. 1223. Estos autores hablan de comportamiento (no sólo resoluciones) comprendido entre las competencias del funcionario, cuando menos, de hecho.
} 
cuando ésta no consiste en la emisión de resoluciones de carácter definitivo, siempre que esa actividad se realice en el ejercicio del cargo ${ }^{42}$.

En la doctrina francesa no se encuentra este tipo de precisión. En efecto, la misma doctrina incluye en la noción de "acto de la competencia" no sólo actos jurídicos específicos conforme a las atribuciones del sujeto activo, sino actividades materiales tales como: la participación de un voto o de una preparación de un informe, maniobras utilizadas para no cumplir los deberes inherentes al cargo, etc. Pero la letra de los artículos 432-11 CPF y 177 CPM habla de "acto facilitado por la competencia" del agente público. Un acto facilitado por la competencia no puede ser un acto jurídico, ni mucho menos administrativo, puesto que se trata de un acto que no se puede vincular al ejercicio normal de las atribuciones del agente público ${ }^{43}$. Por lo tanto, la interpretación amplia del término "acto" se admite en la doctrina francesa y no vemos ninguna razón para rechazarla respecto al artículo 177 del CPM.

\section{Sección 2- Momento de la ejecución del acto objeto del delito de cohecho}

\section{I-El principio de la anterioridad}

\section{A-LA RELACIÓN REMUNERATORIA ENTRE EL ACTO DEL OBJE- TO DEL ACUERDO Y LA DÁDIVA}

Cabe señalar la multiplicidad de consecuencias que de las expresiones empleadas en los artículos 419 y $420 \mathrm{CPE}$-"para realizar", "para no realizar" o "para retrasar"- se derivan para la interpretación de estas modalidades delictivas. Así, en primer lugar, como ya se ha indicado, del empleo de estos términos se infiere que entre la dádiva y el acto objeto del delito de cohecho debe mediar una relación remuneratoria ${ }^{44}$. En segundo lugar, como veremos más adelante, también de estas expresiones típicas cabe deducir la presencia de un elemento subjetivo del injusto, integrado por la intención, por parte del funcionario, de ejecutar el acto al que se comprometió. Así, en el supuesto de no concurrir el citado propósito el delito de cohecho quedaría excluido ${ }^{45}$. Y, por último, tam-

\footnotetext{
42 I. VALEIJE ÁLVAREZ, El tratamiento..., op. cit., pp. 192, 193 y 195. En palabras de esta autora, la consideración de "acto del cargo" se extiende no sólo a los actos jurídicos (reglamentos, actos administrativos, contratos, etc.), sino también a todas las actividades materiales y técnicas que realiza el funcionario y que no implican ninguna modificación de situaciones jurídicas específicas ligadas a su sola emanación. Estas últimas actividades no consisten en producir actos jurídicos, sino en gestionar, en actuar con arreglo a las regulae artis y no a los postulados jurídicos. Mํ. J. RODRÍGUEZ PUERTA, El delito de cohecho..., op. cit., pp. 207 y 208.

${ }^{43}$ Entre otros, E. DREYER, Cours magistral..., op. cit., p.602.

${ }^{44}$ Entre otros E. CASAS BARQUERO, “Observaciones...", op. cit., pp.865 y ss.; J. M. RODRÍGUEZ DEVESA, “Cohecho", op. cit., pp.362 y ss.

45 Explica OLAIZOLA NOGALES, al repasar la interpretación de los artículos 385 y ss. CPE 1944/1973 y a nuestra manera de entender tal observación sigue teniendo validez en el marco del actual CPE, que el funcionario recibía y solicitaba la dádiva con
} 
bién de las expresiones reseñadas se deduce la necesidad de que las acciones típicas - la solicitud, la recepción o la aceptación - se realicen con anterioridad a la ejecución del acto propio del cargo ${ }^{46}$. Es más, la efectiva realización del acto por el funcionario no afecta a la consumación del delito: por el contrario, éste se habrá consumado aun cuando el funcionario ni siquiera dé inicio a la ejecución del acto prometido. La duda se suscita en relación a la posibilidad de considerar también incluidos en estas modalidades de cohecho los supuestos en los que el funcionario ya adoptó el acto propio del cargo a cambio del cual, $a$ posteriori, solicita del particular una dádiva o presente ${ }^{47}$.

\section{B-VIGENCIA DEL PRINCIPIO DE ANTERIORIDAD DEL PACTO CORRUPTOR EN EL DERECHO PENAL FRANCÉS Y MALGACHE}

El tratamiento de esta cuestión no difiere mucho con lo que se ha visto en la doctrina española. Tanto el CPF como el CPM estipulan las expresiones "para que realice" o "para que deje de realizar" para resaltar la finalidad retributiva perseguida por el agente público. La doctrina francesa enfatiza que la presencia del término "para" exige que las dádivas, ofertas y promesas hayan sido solicitadas, aceptadas o, por lo menos, hayan sido objeto de un acuerdo entre ambas partes antes de la realización del acto o de la abstención por parte del agente corrupto 48 . En efecto, antes de la reforma penal de 2000, el principio de la anterioridad del pacto corrupto ha sido una regla clásica del Derecho penal francés a diferencia de los sistemas jurídicos vecinos como el alemán o el italia$\mathrm{no}^{49}$. Sin embargo, según VITU, la formulación legal, tanto la anterior a la reforma del año 2000 como la actual, indicaba bien que debía haber

una finalidad concreta: la realización o abstención de un acto propio de su cargo. Se podría tratar, por tanto, de elemento subjetivo del injusto de los que configuran los delitos de intención, también denominados "delitos de tendencia interna trascendente"; en los que se requiere obrar con ánimo, finalidad o intención adicional de lograr un ulterior resultado (delitos cortados de resultado) o una ulterior actividad (delitos mutilados de dos actos). En estos casos se anticipa la consumación a la realización de la actividad típica unida a la intención de causar un resultado o efectuar una segunda actividad, pero sin necesidad de que se produzca el ulterior resultado o actividad. Por ello, en el delito de cohecho tampoco va a ser necesario para su consumación que el acto llegue a realizarse (I. OLAIZOLA NOGALES, El delito de cohecho, op. cit., p.262). Ver también en este sentido I. VALEIJE ÁLVAREZ, El tratamiento..., op. cit., p.170.

46 Se puede entender aquí acto propio del cargo como el conjunto de los actos contrarios o no al deber del oficio. La redacción anterior a la reforma de 2010 creó confusiones terminológicas y clasificaciones no del todo claras dentro de la doctrina. Ver en este sentido G. D. M. CERINA, La lucha contra la corrupción, op. cit., pp.993-996.

${ }^{47}$ Ma . J. RODRÍGUEZ PUERTA, El delito de cohecho..., op. cit., p.209.

48 M-P. LUCAS de LEYSSAC y A. MIHNAN, Droit pénal des affaires..., op. cit., no1032. Añaden estos autores, comentando la situación legal antes de la reforma legislativa de 2000, que de la anterioridad del pacto corrupto procedía la necesaria relación de causalidad que existe entre las ofertas del corruptor y el acto o la abstención del corrompido. De esta manera, se podía decir que se estaba ante una esquema acabada de delito de corrupción. Véase también E. DREYER, Cours magistral..., op. cit., p.605 ; F. CECCON, Contribution..., op. cit., p.39.

${ }^{49}$ A. VITU, Corruption passive..., op. cit., p.16. 
una sucesión de hechos cuyo orden había sido previsto por el legislador: primero la solicitación y luego el acto a realizar, y no al revés ${ }^{50}$.

A nuestro modo de ver, el principio de anterioridad del pacto corruptor sigue estando vigente en el Derecho penal francés a pesar de las últimas reformas que han afectado expresamente al artículo 432-11 del CPF51. En cuanto al Derecho penal malgache, el mismo principio no sólo está vigente, sino que sigue siendo fundamental ya que la reforma penal de 2004 no ha previsto en su formulación ninguna excepción para flexibilizarlo.

Si bien la doctrina española estaba de acuerdo en que la dádiva debía tener por objeto la ejecución o la abstención de un acto del ejercicio del cargo del funcionario, se planteaba la duda sobre si dicha relación finalística implicaba que el acto por el que se solicitaba o aceptaba la dádiva debía ser un acto futuro, o si por el contrario cabía que la dádiva solicitada o recibida fuera por un acto ya realizado ${ }^{52}$. Tal planteamiento ha llevado a los legisladores europeos a proceder a unas reformas para contemplar la modalidad subsiguiente del delito de corrupción. Sin embargo, el legislador malgache ha optado por resolver el asunto de forma diferente.

\section{II-La modalidad subsiguiente del cohecho pasivo}

\section{A-DERECHO ESPAÑOL}

Se puede repasar la evolución legislativa del cohecho subsiguiente en 3 períodos.

\section{1-Situación con el CPE 1944/1973.}

La doctrina española denomina cohecho subsiguiente a aquellos casos en los que el funcionario solicita o recibe una dádiva o presente, $\mathrm{o}$ acepta un ofrecimiento o promesa por un acto del ejercicio de su cargo ya realizado o por haberse abstenido de realizarlo. Naturalmente, la recompensa por el acto ya realizado no ha de haber sido solicitada, aceptada o pactada antes de la realización del acto, pues en tal caso se trataría de una de las modalidades de cohecho pasivo antecedente. Se planteaba la cuestión de si esta conducta podía ser castigada como delito de cohecho con el CPE 1944/1973, y se distinguían tres posturas doctrinales al respecto ${ }^{53}$. La postura mayoritaria era partidaria de no considerar

\footnotetext{
50 Ibídem, op. cit., p.17; C. AMBROISE-CASTÉROT, Droit pénal..., op. cit., p.368.

${ }^{51}$ Según el informe del GRECO, la legislación francesa con sus aplicaciones jurisprudenciales en materia de corrupción siguen necesitando un pacto, el cual ya no hace falta con la modalidad de "solicitar" y, a pesar de las últimas reformas, se sigue buscando la anterioridad del mismo. El órgano de valoración se ha mostrado insatisfecho y pide a las autoridades francesas que hagan más esfuerzo para suavizar la exigencia de anterioridad. Ver: http://www.coe.int (pp.3 y 4).

52 I. OLAIZOLA NOGALES, El delito de cohecho, op. cit., p.262.

${ }^{53}$ Ibídem, op. cit., pp.263 y ss.
} 
incluido el cohecho subsiguiente en el cohecho pasivo propio al entender la preposición "por" como sinónimo de "para", "con el fin de" con un claro significado de un acto futuro. Sin embargo, estos mismos autores entendían que los casos de cohecho subsiguiente debían ser incluidos en el cohecho pasivo impropio del artículo 390 CPE 1944/1973, en la modalidad típica de admisión de dádivas o regalos "en consideración a su función". En este supuesto se incluían aquellos casos en los que el funcionario recibe la dádiva o el presente o acepta el ofrecimiento o promesa por un acto ya realizado por él, siendo indiferente que el acto realizado fuera ilícito y contrario a los deberes del cargo o lícito y justo, si bien se admitía como crítica el que si se trataba de una actuación ilícita lo que motivaba la entrega de la dádiva o el presente, no se castigara con mayor severidad que si se trataba de un acto ilícito o justo ${ }^{54}$.Frente a esta postura, otros consideran incluido el cohecho subsiguiente en el delito de cohecho pasivo propio. Según estos autores la consideración de la finalidad del precepto ponía de relieve que tanto se atacaba el bien jurídico si se solicitaba, recibía, etc. una dádiva a cambio de ejecutar un acto futuro, como si después de cometido, el funcionario solicitaba, recibía, etc., una dádiva en pago del acto ejecutado. La expresión "por" para ellos no indicaba una sucesión temporal, sino una relación que indicaba que el funcionario era capaz de corromperse y con ello perturbar el correcto funcionamiento de la Administración ${ }^{55}$. La tercera postura doctrinal es aquella que excluye el delito de cohecho subsiguiente del delito de cohecho pasivo propio, pero tampoco considera incluido en el delito de cohecho pasivo impropio ${ }^{56}$.

54 J. M. RODRÍGUEZ DEVESA, "Cohecho", op. cit., pp.362 y ss.; E. CASAS BARQUERO, "Observaciones...", op. cit., pp.899 y ss.

55 E. CUELLO CALÓN, Derecho penal... (10 ${ }^{\mathrm{a}}$ ed.) op. cit., p.367; J. BUSTOS RAMÍREZ, Manual... Parte especial, op. cit., p.375.

${ }^{56}$ I. VALEIJE ÁLVAREZ, El tratamiento..., op. cit., pp.170 y ss. La autora niega que pueda integrarse el cohecho subsiguiente en el cohecho pasivo propio por cuatro razones. 1) En primera lugar afirma esta autora, que interpretar que una misma expresión, por ejemplo "por ejecutar un acto" puede hacer referencia tanto a un acto futuro como a un acto pasado ya realizado, es contradictorio y por tanto atenta contra la seguridad jurídica y la certeza que debe presidir en materia penal. 2) en segundo lugar apela esta autora al tenor literal de los preceptos, especialmente en lo que se refiere al "aceptar ofrecimientos o promesas", porque no parece posible perseguir penalmente, sin crear un cierto margen de inseguridad jurídica, a los funcionarios que acepten ofrecimientos o promesas "por cumplir actos" que ya están cumplidos. 3) La tercera razón es la propia naturaleza jurídico-penal de los términos típicos "por ejecutar un acto". Según la autora se trata de un elemento subjetivo del injusto y de admitir la posibilidad del cohecho subsiguiente, el papel dogmático-jurídico desempeñado por la voluntad de "ejecutar un acto contrario al cargo" ya no sería el de constituir un elemento subjetivo del injusto, sino que entraría a formar parte o a constituir objeto del dolo. Ello llevaría a que si bien en el cohecho antecedente el "acto contrario al cargo" constituye el objeto de una finalidad que no es preciso que efectivamente se produzca para la consumación del delito, en el cohecho subsiguiente "el acto contrario al cargo" pasa a ser objeto del dolo, y puesto que el dolo reclama que todos los elementos a los cuales se dirige la voluntad y el conocimiento estén efectivamente presentes en el mundo externo, la conclusión será que el "acto contrario al cargo" debe estar efectivamente realizado. 4) La cuarta razón es de corte teleológico. Según la autora, es difícil sostener que se ha vulnerado la imparcialidad de la Administración si no ha intervenido antes de la ejecución de acto ninguna promesa o retribución y, por lo tanto, no hay ninguna interfe- 


\section{2-Situación a partir del CPE 1995}

Con la entrada en vigor del CPE 199557, no resultan válidos los argumentos esgrimidos por aquel sector de la doctrina que consideraba incluidos en los artículos 385, 386 y 387 CPE 1944/1973 tanto los actos futuros a los que el funcionario se comprometía a cambio de una ventaja, como aquellos que fueron ejecutados previamente al intento de establecer un acuerdo entre funcionario y particular. La nueva modalidad de cohecho tipificada en el segundo inciso del artículo 425 CPE 1995 lo impide dado que contempla precisamente esos supuestos - cohecho subsiguiente -. Así, la segunda de las modalidades típicas previstas en el precepto señalado sanciona al funcionario que solicita o admite dádivas o presentes o promesas de ellas como recompensa por un acto propio del cargo ya realizado. De este modo, indica RODRÍGUEZ PUERTA, una interpretación sistemática de las distintas modalidades de cohecho tipificadas en el CPE cierra la posibilidad de incluir doblemente una misma modalidad delictiva, más aún cuando las penas previstas para supuestos idénticos resultan completamente distintas. No obstante, la exclusión de las hipótesis en las que el funcionario adoptó previamente el acto propio del cargo se infiere del propio tenor literal de los artículos 419, 420 y 421 CPE 1995, no sólo porque estos emplean, para describir la conducta típica, las conjunciones "por" y "para", sino también porque a continuación se emplea el verbo que describe la acción en infinitivo, para indicar una acción de presente o de futuro ${ }^{58}$.

A pesar de estas aclaraciones aportadas por la reforma legal de 1995, la doctrina española especializada destaca lagunas importantes y plantea algunas dudas no sólo respecto a la técnica legislativa sino también al fundamento de la tipificación del cohecho subsiguiente.

rencia o preferencia en la actuación de la Administración. Por otra parte, VALEIJE ÁLVAREZ niega también la posibilidad de que se aplique el artículo $390 \mathrm{CPE}$ 1944/1973, cohecho pasivo impropio, en aquellos casos de cohecho subsiguiente. Un respeto al tenor literal del precepto sólo da lugar a pensar que a través de esta modalidad delictiva se pretende reprimir los obsequios hechos al funcionario público, no como premio explícito a un acto anterior al cargo, sino en general como forma de captar su favor para predisponer su ánimo a favor del donante en el ejercicio futuro de su profesión. Lo contrario implicaría convertir el artículo 390 en un cajón de sastre en el que se incluyen conductas para los cuales no ha sido concebido. La autora llega a la conclusión de la impunidad de los casos de cohecho subsiguiente y proponía una reforma legislativa para tratar de esta modalidad tal como se hace en el Derecho comparado. Ver la crítica de esta postura por I. OLAIZOLA NOGALES, El delito de cohecho, op. cit., pp.265-267.

57 Reza el artículo 425 CPE 1995: “1º La autoridad o funcionario público que solicitare dádiva o presente o admitiere ofrecimiento o promesa para realizar un acto propio de su cargo o como recompensa de ya realizado, incurrirá en la pena de multa del tanto al triple del valor de la dádiva y suspensión de empleo o cargo público por tiempo de seis meses a tres años. 2o En el caso de recompensa por el acto ya realizado, si éste fuera constitutivo de delito se impondrá, además, la pena de prisión de uno a tres años, multa de seis a diez meses e inhabilitación especial para empleo o cargo público por tiempo de diez a quince años".

58 Mà. J. RODRÍGUEZ PUERTA, El delito de cohecho..., op. cit., p.210. 
El legislador español de 1995, de forma algo precipitada ha sancionado la solicitud, recepción o aceptación de una dádiva como recompensa por un acto ya realizado, con independencia de que éste - el acto público objeto del delito de cohecho - se haya adoptado conforme o contrariamente al ordenamiento jurídico ${ }^{59}$. En efecto, se recogen aquellos supuestos en los que el funcionario solicita o recibe una dádiva o presente o acepta ofrecimiento o promesa por un acto de su cargo ya realizado (artículo 425, 10 CPE 1995), o como recompensa de un acto ya realizado si éste fuera constitutivo de delito (artículo 425, 2 CPE 1995). Se plantea la duda de qué ocurre cuando el acto realizado no sea constitutivo de delito, pero sí constituya un acto injusto, o cuando la recompensa sea por haberse abstenido el funcionario de realizar un acto que debiera haber ejecutado. Señala OLAIZOLA NOGALES que no tiene sentido afirmar que en estos casos no cabe el cohecho subsiguiente, porque no hay razones materiales que pudieran hacer pensar que fuera lógico que sí hubiera para los casos en que se trate de un acto justo y de un acto constitutivo de delito y no para los otros dos casos. Explica la misma autora que parece que no habrá más remedio que incluir los casos en los que el acto realizado constituya un acto injusto en el artículo 425, 1ㅇ CPE 1995, por ser a la vez acto propio del cargo del funcionario. No obstante ello no deja de ser insatisfactorio, al no tener en cuenta esa mayor gravedad que supone la injusticia del acto a la hora de valorar la pena ${ }^{60}$. Respecto a la abstención, de igual modo podría interpretarse que cuando el 425, 10 habla de "acto" se refiere a acto en sentido amplio, es decir tanto acción como omisión, pero se trataría de una interpretación un tanto forzada puesto que el precepto dice "acto realizado" y difícilmente se puede realizar una omisión. Además, aunque el verbo "realizar" no constituyera un obstáculo insalvable, el problema para aplicar el cohecho subsiguiente en los supuestos de abstención podría venir del diferente tenor literal del artículo 421 CPE 1995: "Cuando la dádiva tenga

\footnotetext{
${ }^{59}$ Ibídem, op. cit., p.281. Precisa la autora que la situación varía substancialmente en uno y otro supuesto. Si se trataba de un acto conforme a Derecho la solicitud del empleado público debería ser el resultado de un engaño. Al contrario si el acto es injusto, es posible que tanto el funcionario como el particular estén interesados en alcanzar un acuerdo, pues ambos obtienen indebidamente una ventaja. (p.282).

60 I. OLAIZOLA NOGALES, El delito de cohecho, op. cit., p.268. Observa la autora que quizás pudiera pensarse que lo importante no es si el acto realizado es justo o injusto, sino que lo relevante es que el funcionario reciba dinero por un acto propio de su cargo, y mezcle así sus propios intereses con los intereses públicos, y esto podría ser verdad pero entonces tampoco tiene sentido que se incremente la pena cuando el acto realizado constituya delito, pues no hay que olvidar que por ese delito el funcionario recibirá la pena que el corresponda al mismo, y finalmente, tampoco tendría sentido que sí se valore la diferencia cuando el acto sea un acto que se ha de realizar en un futuro (cohecho antecedente). Concluye la autora que se trata de un defecto de técnica legislativa. También en términos parecidos G. D. M. CERINA, La lucha contra la corrupción, op. cit., p.1102. Propone otra opción J. VIZUETA FERNÁNDEZ, Delitos..., op. cit., pp.243-245.
} 
por objeto que el funcionario público se abstenga de un acto que debiera practicar"61.

Por otra parte, observa CERINA que la solución normativa prevista en el precepto en estudio resulta difícilmente conciliable con el principio de proporcionalidad. En efecto, la elección del legislador de no diferenciar quoad poenam entre el soborno solicitado o admitido en recompensa de un acto justo y el cohecho subsiguiente por acto injusto no delictivo desentona visiblemente en la sistemática del capítulo V del título XIX del CPE $1995^{62}$. También se pregunta el autor respecto al artículo 425, 2o CPE 1995: ¿qué necesidad hay de agravar la pena explícitamente en un precepto del capítulo $V$ cuando el mismo efecto se conseguiría en aplicación de los principios generales previstos en materia de concurso de delitos? En el supuesto de cohecho subsiguiente, en efecto, la agravación de la pena por la naturaleza delictiva del acto recompensado es absolutamente inútil, ya que aquí, a diferencia de lo que acontece en el cohecho antecedente propio, el acto delictivo remunerado ha de ser necesariamente realizado (por lo menos en estadio de tentativa) para que haya cohecho punible ${ }^{63}$. El mismo autor nota que la equiparación de las penas, en el CPE 1995, no está limitada a supuestos de cohecho impropio (en los que el autor de la vertiente antecedente de la corrupción recibe la misma pena que el autor de la subsiguiente), sino que se extiende al cohecho subsiguiente propio (en el cual el acto objeto del acuerdo no es constitutivo de delito). Es decir, lo verdaderamente incomprensible es que el cohecho subsiguiente propio (recompensa por un acto injusto pero no constitutivo de delito) no se haya equiparado quoad poenam al cohecho antecedente propio (tipificado con arreglo al artículo 420 y 421 CPE 1995), sino que se haya considerado este supuesto merecedor de la misma sanción prevista para el cohecho subsiguiente impropio y al antecedente impropio. En este mismo orden de ideas, representa sin dudas una vistosa incongruencia que en el supuesto más grave (cohecho subsiguiente por un acto delictivo) la equiparación de penas con el relativo caso de cohecho antecedente (tipificado

${ }^{61}$ I. OLAIZOLA NOGALES, El delito de cohecho, op. cit., p.269; J. VIZUETA FERNÁNDEZ, Delitos..., op. cit., pp.243-249.Este autor sugiere, con la dificultad que supone este escollo, la aplicación del artículo 426 CPE 1995, inciso primero, porque, con todo, ofrecer a un funcionario una dádiva como recompensa de una omisión relativa al ejercicio de su función supone que tal ofrecimiento se haga en consideración a su función con la condición de que la acción consiste en admitir, y no en solicitar, ofrecimiento o promesa. En contra de esta postura se manifiesta G. D. M. CERINA, La lucha contra la corrupción, op. cit., pp.1096 y 1097.

62 G. D. M. CERINA, La lucha contra la corrupción, op. cit., pp.1101 y 1102

${ }^{63}$ Ibídem, op. cit., p.1102. Añade el mismo autor que el artículo 425, 2 CPE 1995 presenta una diferencia respecto del 419 CPE 1995: en el cohecho subsiguiente por acto delictivo, el legislador (ha omitido el inciso "sin prejuicio de la pena". De ahí que, para evitar peligrosas contradicciones con el principio de ne bis in idem en vía interpretativa, podrá aquí considerarse aplicable lo dispuesto por el artículo $8 \mathrm{CPE}$, por lo menos, toda vez que el delito cometido con anterioridad respecto al cohecho, ofenda exclusivamente el bien jurídico "legalidad de la actuación de la administración" o la imparcialidad de la misma. En los demás casos, lo normal es que, entre el delito presupuesto y el cohecho, exista un concurso real de delitos. 
con arreglo al artículo 419 CPE 1995) sencillamente no se haya llevado a cabo ${ }^{64}$.

En cuanto al fundamento de la tipificación del cohecho subsiguiente, la doctrina especializada está dividida. Para RODRÍGUEZ PUERTA, la incorporación expresa de esta forma de cohecho no responde a la tutela del principio de imparcialidad en el ejercicio de las funciones públicas, pues difícilmente se habrá producido, en tales casos, una interferencia en el proceso de toma de decisión, cuando el acuerdo entre funcionario y particular se lleva a cabo una vez adoptado el acto, siendo imposible influir sobre él65. Defiende la autora que si el acto por el que el empleado público solicita una dádiva se ha adoptado injustamente, con la finalidad de que ambas partes obtengan indebidamente una ventaja, su sanción no encuentra su fundamento en la conculcación del principio de imparcialidad, sino en la instrumentalización de las funciones para obtener un beneficio. En esta medida, resulta cuestionable la mención independiente de estos supuestos que podrían resolverse a través del delito de prevaricación o incluso aplicando el delito de exacciones ilegales. Concluye la misma autora que la única forma de dotar de un significado propio a esta forma delictiva es incluir, en la esfera típica del artículo 425 CPE 1995 (segundo inciso), aquellos supuestos en los que, pese a haberse producido un acuerdo entre funcionario y particular previo a la ejecución del acto, sólo ha quedado acreditada la entrega de la dádiva o presente con posterioridad a la ejecución del acto contrapartida de la misma. Así, la tipificación de estas conductas puede haber respondido a la necesidad de superar los problemas probatorios que suscitan los supuestos en los que sólo se conoce que se produjo un pago posterior, aunque se sospeche que el acuerdo, origen del acto público adoptado fue previo. En consecuencia, la sanción de este proceder estaría dirigida a evitar posibles problemas probatorios ${ }^{66}$.

Ante esta postura, OLAIZOLA NOGALES manifiesta su desacuerdo y defiende que no hay duda que, de esta forma se podrán penar aquellos casos en los que, habiendo un pacto previo a la realización del acto, éste no se puede demostrar, y si ésta fuera la única razón por la que se tipificara el cohecho subsiguiente no estaría justificada su punición. Cree la autora que se perturba el bien jurídico, cifrado en el correcto funciona-

\footnotetext{
${ }^{64}$ Ibídem, op. cit., p.1105. Para el autor todo ello parece demostrar una vez más que la redacción del artículo $425 \mathrm{CPE}$, más que a un diseño político-criminal predeterminado, se debe a un clamoroso despiste del legislador de 1995.

${ }^{65}$ En términos similares se ha pronunciado I. VALEIJE ÁLVAREZ, El tratamiento..., op. cit., p.180.

${ }^{66}$ Ma. J. RODRÍGUEZ PUERTA, El delito de cohecho..., op. cit., pp.281- 283. Sugiere la autora que hubiera resultado más coherente político-criminalmente prever esta modalidad de cohecho junto a la forma antecedente. Es decir, incriminar estos supuestos en relación al cohecho que tiene por objeto un acto injusto (artículo 420 CPE 1995) o delictivo (artículo 419 CPE 1995), para evitar así la impunidad de conductas gravemente atentatorias contre el bien jurídico. Parece que el legislador español de 2010 ha optado por la autonomización de esta modalidad de cohecho mientras el legislador francés de 2011 ha seguido la propuesta de la autora inspirada del Derecho penal italiano y alemán.
} 
miento de la Administración ${ }^{67}$, en estos casos y que ésta es la razón por la que se deben castigar estos hechos ${ }^{68}$.

También VIZUETA FERNÁNDEZ critica a RODRÍGUEZ PUERTA por convertir el cohecho subsiguiente, en virtud de una interpretación teleológicamente orientada ${ }^{69}$, en una modalidad de cohecho antecedente. De esta manera, el principio de imparcialidad ya queda cercenado como consecuencia del convenio previo ${ }^{70}$.El empeño en defender a todo trance el principio de imparcialidad en el ejercicio de funciones públicas como bien jurídico en el delito de cohecho, lleva a RODRÍGUEZ PUERTA a una interpretación del artículo 425 CPE 1995 altamente cuestionable. Hace girar el precepto en torno al principio de imparcialidad, y para que éste pueda verse afectado, presume la existencia de un acuerdo entre funcionario y particular previo a la ejecución del acto contrapartida de la dádiva, pues sólo así es posible interferir en el proceso de toma de decisión del mismo. De esta forma, se exige únicamente que quede probada la entrega de la dádiva con posterioridad a la ejecución del acto contrapartida de la misma; sin embargo, el acuerdo previo entre funcionario y particular, que es precisamente de lo que depende el ataque al bien jurídico, tan sólo se presume. En definitiva, se pretende proteger el principio de imparcialidad, y se castigan conductas donde solamente se sospecha su afectación. Para el autor, RODRÍGUEZ PUERTA interpreta el artículo 425 CPE 1995 como un delito de sospecha, en el que se presume un elemento del tipo a partir de la concurrencia de los demás. Se viola, con ello, el derecho a la presunción de inocencia, pues se castiga a un funcionario por la lesión del principio de imparcialidad, lesión que tiene lugar con el acuerdo entre funcionario y particular previo a la ejecución del acto contrapartida de la dádiva, acuerdo, sin embargo, que no queda probado, únicamente se presume. Debido a que el derecho a la presunción de inocencia se recoge en el artículo 24.2 de la Constitución Española (CE), la exégesis que la autora hace de este precepto es abiertamente contraria a la norma fundamental71. Concluye el autor que lo que se pretende proteger en esta modalidad es la honradez o integridad de la condición de funcionario, por lo tanto aboga por la despenaliza-

\footnotetext{
${ }^{67}$ I. OLAIZOLA NOGALES, El delito de cohecho, op. cit., pp.265 y 266. Explica la autora que si se considera que el bien jurídico protegido en el delito de cohecho son aquellas condiciones básicas que la Administración precisa para poder servir a los ciudadanos en el sentido de que mantengan la expectativa de poder acceder a la Administración para satisfacer derechos en condiciones de igualdad., el contacto entre el funcionario y el particular, mediante el cual el particular paga u ofrece pagar al funcionario por un acto ya ejecutado puede perturbar la confianza que la generalidad debe tener en el correcto funcionamiento de la Administración, confianza que es una de las condiciones básicas de funcionamiento de la Administración, porque es necesario un mínimo de "docilidad" de los ciudadanos para que la Administración funcione, ya que la solicitud o la aceptación de dicho pago muestra el peligro de que el funcionario en un futuro no atienda exclusivamente a la hora de de acatar a los principios de objetividad, imparcialidad, e igualdad con que debe actuar.

${ }^{68}$ Ibídem, op. cit., p.269.

${ }^{69}$ Mํ. J. RODRÍGUEZ PUERTA, El delito de cohecho..., op. cit., p.283.

${ }^{70}$ J. VIZUETA FERNÁNDEZ, Delitos..., op. cit., p.242.

${ }^{71}$ Ibídem, op. cit., p.243.
} 
ción de todas las modalidades de cohecho subsiguiente - sea el acto realizado contrapartida de la dádiva lícito o ilícito - por proteger un bien jurídico no merecedor de tutela penal, y, además, ser ésta innecesaria $^{72}$.

Opina CERINA, para quien el bien jurídico protegido en el delito de cohecho se cifra en la imparcialidad procedimental73, que se debe convenir que, en la corrupción subsiguiente, lo que se sanciona no es sino el peligro (abstracto) de que haya lugar, en el futuro, corrupción antecedente (propia e impropia). En otras palabras, la penalización de la aceptación (o del otorgamiento) de una recompensa por un acto ya realizado encontraría su ratio en el peligro de que la misma denote, en el futuro, una incapacidad por parte del funcionario público de desarrollar de forma imparcial el proceso de toma de decisión ${ }^{74}$.

Según el autor, frente a quien sugiere que, con la tipificación de la corrupción subsiguiente no se hace sino exonerar al órgano jurisdiccional del deber de probar la relación cronológica existente entre el acto y el pacto, debe contestarse, de forma tajante que, de iure condito, esta tesis no puede sostenerse. En efecto, el tenor literal de las normas penales del CPE1995 no exime en ningún caso de dicho deber probatorio, puesto que el legislador sigue diferenciando (aunque no siempre en cuanto a pena) entre acto-causa-del-pacto y acto-fin-del-pacto. Y a los que afirman que, en el cohecho subsiguiente, se pretende presumir que, toda vez que haya lugar una recompensa de un acto, siempre ha existido un pacto previo y esto último puede haber sido imposible de demostrar, debe contestarse que, en el proceso penal, lo que no se puede probar es tamquam non esset ${ }^{75}$. Por lo tanto el autor no comparte la tesis con apo-

72 Ibídem, op. cit., pp.249 y 250.

${ }^{73}$ G. D. M. CERINA, La lucha contra la corrupción, op. cit., pp.536-544. El autor propone cifrar la lesión del bien jurídico en la alteración del proceso de toma de decisión del funcionario público que inclinándose hacia exigencias "particulares", procede alejándose de aquella imparcialidad que la CE quiere subyacente a toda la actividad administrativa.

${ }^{74}$ Ibídem, op. cit., p.553. Precisa el autor que desde un punto de vista político-criminal, el sujeto público A que acepta de $\mathrm{B}$ una recompensa por el acto $\mathrm{X}$ ya realizado, toda vez que tenga que volver a intervenir en un proceso de decisión en el cual esté involucrando el mismo B, se encontrará expuesto al riesgo de verse condicionado por la recompensa a la hora de decidir como actuar. El legislador, con la criminalización de esta hipótesis de corrupción, ha considerado este riesgo como no tolerable: en sede de la aplicación del tipo penal, de todas formas, el juez deberá interrogarse acerca de la efectiva idoneidad del acuerdo para perjudicar la imparcialidad en el desarrollo de futuros procesos de toma de decisiones.

${ }^{75}$ Ibídem, op. cit., p.554. Refiriéndose al artículo al artículo 425 1을 1995, observa el autor que el tenor literal de la norma impone el deber de probar si se versa en una u en otra situación (es decir, si se trata de dádiva o presente, ofrecimiento o promesa para realizar un acto propio del cargo o bien recompensa del ya realizado). El legislador, en otras palabras, no se contenta con considerar delictiva la recepción de un beneficio por parte del intraneus, sino que sigue exigiendo que exista una relación de causa-efecto entre acto y pacto, relación que en todo caso, habrá que probar para poder calificar el hecho o bien de cohecho antecedente o subsiguiente. Máxime en el caso del segundo inciso del mismo precepto, es decir en el caso de cohecho propio, deberá, 
yo en la cual la corrupción subsiguiente oculta, en realidad, una hipótesis de corrupción antecedente en la cual no se consigue probar el acuerdo anterior al pacto, pero sí la dádiva posterior al mismo. Con ello, no se pretende minimizar las dificultades que entraña proporcionar la prueba de un acuerdo que no se sustancia en una trasferencia de algo tangible ${ }^{76}$.

Concluye el autor que cuando se quiere resolver una cuestión de prueba modificando normas sustantivas, se termina suportando un coste en términos de presunción de no culpabilidad que resulta absolutamente inaceptable para quien defiende un Derecho penal respetuoso de los principios garantizadores básicos que han de considerarse irrenunciables en todo Estado de Derecho ${ }^{77}$.

\section{3-Situación a partir de la reforma penal de 2010}

La reforma de 2010 respecto a esta modalidad, ha sido valorada positivamente por la doctrina especializada ${ }^{78}$. De un lado se ha previsto esta modalidad de cohecho de forma autónoma, y de otro, se ha vinculado su sanción al tipo del acto objeto de corrupción ${ }^{79}$. De este modo, la pena que se impondrá al funcionario dependerá de la naturaleza del acto recompensado ${ }^{80}$. En efecto, el legislador de 2010 respecto de la disciplina de 1995, ha creído oportuno aumentar considerablemente las sanciones previstas para el funcionario público autor de esta vertiente de la corrupción. De acuerdo con el artículo 421 del texto reformado ${ }^{81}$, a los supuestos de cohecho subsiguiente propio, les resultarán aplicables las mismas sanciones previstas para el cohecho antecedente propio; de la misma manera, las penas previstas por el artículo 420 (cohecho antecedente impropio) resultarán aplicables al relativo caso de cohecho subsiguiente impropio ${ }^{82}$. Por otra parte, se debe reconocer al legislador de 2010 una mayor coherencia respecto al CPE 1995: remitiendo, en efecto, el nuevo artículo 421 a los supuestos de cohecho antecedente tipifi-

en todo caso, exigirse prueba de la relación temporal entre pacto y acto. Si no fuera posible demostrar que el segundo es anterior al primero, deberá aportarse prueba de que el mismo es posterior. En ausencia tanto de la una como de la otra, el imputado deberá ser sencillamente absuelto (p.1100). En estos términos, también M. DÍAZ Y GARCÍA CONLLEDO, "El delito de cohecho", en A. ASUA BATARRITA (dir.), Delitos contra la Administración Pública, IVAP, 1997, p.167

${ }^{76}$ Ibídem, op. cit., p.555.

77 Ibídem, op. cit., p.1105.

78 Ma. J. RODRÍGUEZ PUERTA, “Modificaciones...” op. cit., p.469; G. D. M. CERINA, La lucha contra la corrupción, op. cit., p.1208.

79 En contra de esta postura M. POLAINO NAVARRETE, “Cohecho...”, op. cit., p. 326.

${ }^{80}$ Ma․ J. RODRÍGUEZ PUERTA, “Modificaciones...” op. cit., p.469.

81 Reza el artículo 421 del CPE 2010: "Las penas señaladas en los artículos precedentes se impondrán también cuando la dádiva, favor o retribución se recibiere o solicitare por la autoridad o funcionario público, en sus respectivos casos, como recompensa por la conducta descrita en dichos artículos."

82 I. BLANCO CORDERO, La reforma..., op.cit., p.24; G. D. M. CERINA, La lucha contra la corrupción, op. cit., p.1208; C. MIR PUIG, El delito de cohecho en la reforma...op. cit., p.48. 
cados con arreglo a los nuevos artículos 419 y 420 se cancela la equiparación de penas prevista por la anterior redacción entre cohecho subsiguiente por acto justo y cohecho subsiguiente por acto injusto no constitutivo de delito. De igual manera, desaparece la distinción de penas entre cohecho subsiguiente propio por acto no delictivo y cohecho subsiguiente propio por acto delictivo, distinción que no tiene razón de ser, ya que, de forma más coherente y sin quebrantar el principio de ne bis in idem sustancial, el mismo resultado puede lograrse mediante la aplicación de las normales reglas establecidas en materia de concurso de leyes y de delitos ${ }^{83}$.

A pesar de estas mejoras, hemos destacado anteriormente la postura de la mayoría de la doctrina española abogando por la despenalización del cohecho subsiguiente debido sustancialmente a la falta de una lesividad suficiente. Según el bien jurídico protegido defendido por cada sector doctrinal, se llega a la conclusión de que se debería destipificar el cohecho subsiguiente, por no afectar al bien jurídico protegido ${ }^{84}$. Amén de ello, también se ha subrayado que no existen instrumentos jurídicos internacionales que obliguen a mantener dicha tipificación y que el Informe de evaluación del GRECO señala que en la tipificación de los cohechos subsiguientes "el Código Penal español va más allá de lo exigido por el Convenio." 85 La mayoría de la doctrina española entiende que realmente el artículo 421 CPE 2010 aparenta ser un precepto cuyo objeto es facilitar la prueba del cohecho en los casos en los que se acredita que el funcionario dispone de dádivas y que ha realizado un acto propio de su cargo (lícito o ilícito), no siendo necesario probar la solicitud o aceptación previas a dicho acto, es decir, el acuerdo previo entre funcionario y particular, que parece presumirse ${ }^{86}$.

${ }^{83}$ G. D. M. CERINA, La lucha contra la corrupción, op. cit., p.1209. Defiende una postura contraria M. POLAINO NAVARRETE, “Cohecho...", op. cit., p. 326.

${ }^{84}$ J. VIZUETA FERNÁNDEZ, Delitos..., op. cit., pp.249 y 250; Ma. J. RODRÍGUEZ PUERTA, El delito de cohecho..., op. cit., pp.281- 283; G. D. M. CERINA, La lucha contra la corrupción, op. cit., pp.552 y ss.; M. POLAINO NAVARRETE, “Cohecho...”, op. cit., pp. 326 y 327. Este último autor precisa que no se pueden desvalorar penalmente predisposiciones que pongan en peligro el correcto ejercicio de la función pública, referidas exclusivamente a actuaciones funcionariales históricas, anteriores a la admisión de contraprestaciones económicas ajenas y carentes de significación en el desempeño actual y futuro de la función pública. No se debe proteger bien alguno frente a un ataque ficticio, pero no real, ni frente a un ataque histórico, pero no actual, contra el "buen desarrollo" de la "gestión pública". La admisión de recompensa a posteriori del ejercicio de actividad funcionarial, por su extemporaneidad, no permite apreciar incidencia sobre el objeto de protección del tipo de cohecho, a no ser que la recompensa por hechos anteriores implique ex ante un precio de soborno de acciones futuras.

85 C. MIR PUIG, El delito de cohecho en la reforma...op. cit., p.48; G. D. M. CERINA, La lucha contra la corrupción, op. cit., p.1208; C. RAMOS RUBIO, Del delito de cohecho... op. cit., p.347.

86 I. BLANCO CORDERO, La reforma..., op.cit., p.24; C. MIR PUIG, El delito de cohecho en la reforma...op. cit., p.48; F. MORALES PRATS y Ma . J. RODRÍGUEZ PUERTA, "Delitos...", 2011, op. cit., p. 1236; F. MUÑOZ CONDE, Derecho penal, Parte especial,...2010, op.cit., p.1022; Mạ. J. RODRÍGUEZ PUERTA, “Modificaciones..." op. cit., p.469. Esta última autora defiende que en realidad lo que parece haber querido evitar el legislador al mantener el cohecho subsiguiente es la impunidad, o la imposición de una sanción poco 
Por otro lado, la equiparación de las penas del delito de cohecho subsiguiente a las del cohecho antecedente, considerada como una mejora de técnica legislativa, refuerza, según BLANCO CORDERO, la idea de que el legislador presume que ha habido acuerdo previo, lo que puede constituir una presunción difícilmente admisible en Derecho penal ${ }^{87}$. De acuerdo con CERINA, la elección del legislador español pone de manifiesto el papel meramente instrumental (desde un punto de vista probatorio) del delito de corrupción subsiguiente (cuya utilidad quedaría limitada a aquellos casos en los que, siendo imposible probar la existencia de un acuerdo anterior al acto del cargo, tan sólo puede hallarse suficiente de la entrega posterior al mismo). Y como el mismo autor ha observado, convertir una cuestión probatoria en cuestión de Derecho sustantivo tiene efectos colaterales: en este caso, parece avalarse legalmente una presumptio iuris et de iure contra reo (toda vez que hay una entrega posterior al acto, se presume que haya habido acuerdo antes del mismo, sin posibilidad de prueba contraria ${ }^{88}$ ) absolutamente incompatible con un Derecho penal del hecho respetuoso del principio de presunción de inocencia ${ }^{89}$.

Por lo tanto estamos de acuerdo en que se debe por ello evitar una interpretación en este sentido. A nuestra manera de entender, y con ello compartimos la postura de CERINA, el legislador no ha eximido la exigencia de la prueba de la relación temporal entre pacto y acto. Si no fuera posible demostrar que el segundo es anterior al primero, deberá aportarse prueba de que el mismo es posterior. En ausencia tanto de la una como de la otra, el imputado deberá ser sencillamente absuelto90.

La redacción imperfecta del artículo 421 CPE 2010, denunciada en su día en relación al Anteproyecto 2008 por el Consejo Fiscal, no contempla si el delito puede cometerse por sí o por persona interpuesta., y si se producirá tanto si lo es en provecho propio como en el de un tercero, y si la pena correspondiente dejará a salvo, conforme a las reglas del concurso, la del acto realizado si fuere constitutivo de delito, pero se debe entender que la remisión a los artículos anteriores (ínsita en la expre-

grave, en aquellos casos en lo que no logra probarse que hubo un acuerdo previo, pero sí que el funcionario recibió una ventaja después de la efectiva adopción del acto (justo o injusto).

87 I. BLANCO CORDERO, La reforma..., op.cit., p. 24.

88 En este sentido se ha pronunciado también VALEIJE ÁLVAREZ, ya en su momento, quien destaca la dificultad que conlleva imponer una sanción penal al funcionario que, una vez realizado el acto injusto, bien sea por error o por negligencia, pasado un tiempo acepta del particular beneficiado por dicha actuación una promesa de dinero en atención al acto perpetrado (o conforme a la letra del actual artículo $421 \mathrm{CPE}$, recibe una dádiva de parte del mismo particular). En principio, afirma la autora, no parece posible perseguir penalmente sin crear un cierto margen de inseguridad jurídica a los funcionarios que acepten promesas $u$ ofrecimientos por cumplir actos ya cumplidos (o reciben dádiva, favor o retribución como recompensa de un acto contrario o no a los deberes de su cargo, según la letra actual del precepto en estudio) (I. VALEIJE ÁLVAREZ, El tratamiento..., op. cit., p.178).

${ }^{89}$ G. D. M. CERINA, La lucha contra la corrupción, op. cit., p.1209.

${ }^{90}$ Ibídem, op. cit., p.1100. 
sión "en sus respectivos casos") no puede entenderse sin asumir tales precisiones ${ }^{91}$.

Por último, no entiende la doctrina española la razón por la que no se castiga en el artículo $424 \mathrm{CPE}$ al particular que paga al funcionario para recompensarle por el acto realizado, esto es, cohecho activo subsiguiente. Se trata de una laguna de punibilidad merecedora de crítica $^{92}$. Opina CERINA que o bien se justifica dicha impunidad en razón de la menor gravedad del supuesto o bien en motivos de carácter político-criminal. El primer argumento, sin embargo, se ve irremediablemente contradicho por la importancia de la sanción conminada al sujeto público autor de cohecho subsiguiente. Quedaría, por tanto, la segunda razón que, por sí sola, sin embargo, no parece poder justificar dicha exención de responsabilidad en el supuesto subsiguiente, máxime cuando, en la vertiente antecedente del delito, al particular se le conminan las mismas severas penas previstas para el funcionario ${ }^{93}$.

\section{B-DERECHO FRANCÉS}

\section{0}

\section{1-Situación antes de la reforma penal de junio de}

Antes de junio de 2000, la anterioridad del pacto corruptor ha sido una exigencia legal, es decir el convenio (o su intento) entre el corruptor y el corrupto debe ser anterior al acto o a la abstención. Como ya hemos señalado, la letra del artículo 432-11 CPF antes de junio de 2000 establecía una secuencia de las diferentes etapas de la corrupción ${ }^{94}$. La ley penal francesa reprimía solamente las maniobras que tenían la finalidad de "comerciar" el cargo, pero dejaba sin castigo las remuneraciones ofrecidas a posteriori. Estas últimas podían ser constitutivas de una falta disciplinaria pero no podían ser objeto de reproche penal ${ }^{95}$. Sin embargo, la doctrina francesa señalaba la dificultad al exigir la anterioridad del pacto de corrupción y era DELMAS-SAINT-HILAIRE el que des-

91 C. RAMOS RUBIO, Del delito de cohecho... op. cit., p.347; C. MIR PUIG, El delito de cohecho en la reforma...op. cit., p.48; M. POLAINO NAVARRETE, “Cohecho...”, op. cit., p. 326. Este autor se muestra más crítico respecto al precepto en estudio y nota que una interpretación correctora de la ley creador de un precepto legal contra reo que entiéndese que se cometieron las conductas tipificadas en los artículos 419 y $420 \mathrm{CPE}$ sin la concurrencia de las características relativas a la exigencia de una contraprestación económica, indefectiblemente, quebrantaría el principio de legalidad penal, pues elemento esencial del tipo es la realización de la "conducta descrita en dichos artículos".

92 I. BLANCO CORDERO, La reforma ..., op.cit., p.24; A. NIETO MARTÍN, “Corrupción y abuso de poder" en C. GÓMEZ RIVERO (coord.), Nociones fundamentales de Derecho penal. Parte Especial, Tecnos, Madrid, 2010, pp.763-764. Para este autor se trata de un "olvido" del legislador.

93 G. D. M. CERINA, La lucha contra la corrupción, op. cit., pp.1209 y 1210.

${ }^{94}$ H. XIAO-YING, La lutte contre la corruption..., op. cit., p.60 ; E. DREYER, Cours magistral..., op. cit., p.605 ; C. AMBROISE-CASTÉROT, Droit pénal..., op. cit., p.368.

95 A. VITU, Corruption passive..., op. cit., p.16 ; H. XIAO-YING, La lutte contre la corruption..., op. cit., p.60. 
tacaba sus consecuencias paradójicas: el funcionario que solicita una retribución, pero que finalmente desiste de realizar un acto de su competencia era penalmente condenable, mientras que si comienza a realizar el mismo acto o deja de realizarlo y luego reclama o acepta una retribución, escapará de la represión penal ${ }^{96}$.

Para la doctrina francesa la mayor dificultad reside en la producción de la prueba de esta anterioridad ${ }^{97}$ y ésta dependía del momento de la entrega de la retribución respecto del acto de la competencia. En efecto, la jurisprudencia y la doctrina francesa admitían que si las retribuciones debían ser objeto de convenio antes del acto o de la abstención del funcionario, podían ser entregadas o bien antes o en el momento del acto o de la abstención o bien después ${ }^{98}$. Afirman LUCAS de LEYSSAC y MIHNAN que como los delitos de corrupción, en principio, no dan lugar a escritos y no suceden ante testigos "peligrosos", las posibilidades de prueba que incumben a la acusación dependían del momento en que las retribuciones corruptoras se habían entregado. Si habían sido entregadas antes o en el momento del acto o de la abstención del funcionario, se podía deducir (prueba por presunción judicial) de esta cronología que las exigencias relativas a la anterioridad del pacto y a la relación de causalidad estaban satisfechas. En caso de que la entrega hubiera sido efectuada después del acto o de la abstención del funcionario, no había manera para probar la anterioridad del pacto, y la relación de causalidad que postula dicha anterioridad podía ser contestada luego al destacar que se trataba de regalos de agradecimiento o de manifestaciones de gratitud a posteriori. Como la acusación no dispone generalmente de indicios o de elementos para combatir esta tesis (aunque había pacto de corrupción), numerosas puestas en libertad, a menudo por el beneficio de la duda, han sido pronunciadas a favor de imputados que habían construido su defensa sobre la base del argumento del agradecimiento ${ }^{99}$.

Para remediar esta dificultad y corregir estas imperfecciones que provocan impunidades escandalosas, la jurisprudencia francesa flexibilizó la exigencia de la anterioridad del pacto. En efecto, para la Corte de Casación francesa la anterioridad se ponía de manifiesto cuando la ventaja consentida al funcionario después de la realización del acto de competencia (o de la abstención) no era sino la realización de una promesa hecha anteriormente ${ }^{100}$. Por otra parte, el Alto Tribunal francés ha tenido la oportunidad de conocer de casos en los que la persona que ejerce o participa de la función pública ha sido remunerada de manera frecuente, por un corruptor, con el fin de realizar actos sucesivos y repeti-

\footnotetext{
${ }^{96}$ Cass. crim. 14-05-1986, Bull. crim. no163; Revue de science criminelle et droit pénal comparé, 1987, p.685, obs. J-P DELMAS-SAINT-HILAIRE.

${ }^{97}$ F. CECCON, Contribution..., op. cit., p.39.

${ }^{98}$ A. VITU, Traité..., op. cit., pp. 290 y 291.

${ }^{99}$ M-P. LUCAS de LEYSSAC y A. MIHNAN, Droit pénal des affaires..., op. cit., no1032 ; H. XIAO-YING, La lutte contre la corruption..., op. cit., pp.61 y 62.

100 Cass. crim 16-12-1997, Bull. Crim. no428.
} 
dos de su competencia. En tal hipótesis, la jurisprudencia francesa ha considerado que las remuneraciones entregadas, contrapartida de actos ya realizados tienen una doble finalidad. De un lado, retribuir las ventajas obtenidas y por otro lado, asegurar que estas ventajas se mantendrán en el tiempo y se podrían incluso reproducir en el futuro101. En este tipo de situación, se ha verificado que la anterioridad del pacto de corrupción, y la relación de causalidad que ello implica está suficientemente establecida por la repetición de las artimañas ${ }^{102}$ del corrupto y del corruptor ${ }^{103}$. Esta reacción jurisprudencial sólo se refiere a corrupciones repetidas del mismo agente público y ello lleva como consecuencia el hecho de dejar sin resolver el problema de la casi imposibilidad de obtención de prueba que enfrentaba la acusación cuando la corrupción consistía en un acto aislado que no daba lugar más que a una remuneración a posteriori ${ }^{104}$. Para DREYER, en ausencia de actos reiterados, existía un ángulo muerto de la represión y además, le parecía chocante que en ausencia de algún pacto, el delito se hubiera constituido sobre la base de la única propuesta de remuneración hecha por el agente público ${ }^{105}$.

Analizando la postura de la jurisprudencia francesa, DELMAS-SAINTHILAIRE nota que la incriminación de la corrupción reviste claramente un aspecto preventivo cuya finalidad es impedir actos corruptos futuros presagiados por los actos delictivos ya perpetrados ${ }^{106}$.

Sólo podemos valorar negativamente el intento de corregir la laguna de impunidad, emprendido por la jurisprudencia francesa antes de la reforma penal de 2000. En primer lugar, de lege lata el legislador francés exigía la anterioridad del pacto corruptor antes de la realización del acto de la competencia por parte del agente público. Ya hemos destacado el orden secuencial de las conductas descrito por el CPF. No hay ninguna otra posibilidad de interpretación para poner las remuneraciones a posteriori dentro del ámbito de aplicación del entonces artículo 432$11 \mathrm{CPF}$. Efectivamente la misma jurisprudencia ha reconocido que se trata de otro tipo de falta y no de un delito107. Por lo tanto, por muy escandalosa que sea la cantidad de una retribución a posteriori, el legislador penal no ha tipificado este tipo de conducta. Por otra parte, aunque la dificultad en materia de prueba era "irritante" según algunos autores

\footnotetext{
${ }^{101}$ Cass. crim. 06-02-1968, Bull. Crim. no37.

102 Para VITU se trata de un tejido de relaciones entablado entre el funcionario y el particular, que provee un contexto sospechoso de series de regalos, los cuales le imprimen un carácter delictivo. (A. VITU, Corruption passive..., op. cit., p.17).

103 Cass. crim. 29-09-1993, Bull. Crim. no271.

104 M-P. LUCAS de LEYSSAC y A. MIHNAN, Droit pénal des affaires..., op. cit., ㄲo1032.

105 E. DREYER, Cours magistral..., op. cit., p.605. El autor se refería a la sentencia del 14-05-86 que destaca la propuesta de remuneración de parte de un inspector de Hacienda después de haber asesorado a un contribuyente.

106 Cass. crim. 28-01-1987, Bull. crim. no47, Revue de science criminelle et droit pénal comparé, 1987, p.685, obs. J-P DELMAS-SAINT-HILAIRE..

107 CA Nancy, 27-07-1979, JCP G 1950, IV, p.30; Cass. crim. 31-07-1926, DH 1926, p.482.
} 
franceses ${ }^{108}$, no nos parece justificable que la entrega de alguna dádiva o regalo antes de la realización de un acto o de una abstención por parte del funcionario pueda constituir alguna prueba por "presunción" de la existencia del delito de corrupción ${ }^{109}$. Habría que probar la relación de causalidad entre la entrega (averiguando si se ha alcanzado un pacto o no) y el acto realizado. También era criticable la postura de la jurisprudencia francesa que consideró que los actos del cargo repetidos y cada vez remunerados a posteriori bastaban para establecer la anterioridad del pacto corruptor. Es comprensible el deseo de los tribunales de alcanzar ese tipo de comportamiento que pone en duda la probidad (el bien jurídico protegido según el legislador francés) de los agentes públicos, sin embargo, el legislador francés no ha eximido a la acusación de la obligación de probar la relación de causalidad entre estos actos y sus remuneraciones posteriores. Si no se demuestra que existe algún pacto que fundamenta estos futuros intercambios, entonces los tribunales han forzado la letra de la ley, violando de esta manera el principio de legalidad en materia penal y la presunción de no culpabilidad. En este sentido, estamos de acuerdo con VITU, quien considera que aunque el sistema francés, en materia de tipificación de la corrupción pasiva, haya sido imperfecto, le correspondía al legislador corregir esta imperfección persistente y no a los tribunales ${ }^{110}$.

\section{2-Situación a partir de la reforma de junio de 2000}

Para remediar estas situaciones complicadas en las que la jurisprudencia francesa tenía que corregir o superar las imperfecciones de la letra del artículo 432-11 CPF, el legislador francés intervino por medio de la Ley 2000-595 del 30 de junio de 2000 que modifica el Código Penal y la Ley de Enjuiciamiento Criminal y relativa a la lucha contra la corrupción, al introducir los términos "en cualquier momento". Con esta adjunción, el legislador francés ha pretendido suprimir la exigencia de anterioridad y, así, reprimir las solicitaciones que tienden a la obtención de dádivas como agradecimiento por actos del cargo realizados anteriormente ${ }^{111}$. La mayoría de la doctrina francesa ha acogido favorablemente esta reforma. El argumento principal defendido es la facilidad de probar el delito de corrupción cuando la prueba de la anterioridad de un pacto corrupto parece imposible de demostrar ${ }^{112}$. Afirma DREYER

\footnotetext{
108 M-P. LUCAS de LEYSSAC y A. MIHNAN, Droit pénal des affaires..., op. cit., no1032.

109 Ibídem, op. cit., no1032.

110 A. VITU, Corruption passive..., op. cit., p.17.

111 Los trabajos preparatorios de esta ley destaca que con los términos "en cualquier momento" el legislador ha modificado la definición del delito de corrupción a fin de precisar que la infracción está constituida aunque la oferta de corrupción es posterior al acto o a la abstención del corrompido (Rapport parlementaire no201, 8-12-1999, presentado ante la Asamblea Nacional por la Comisión de leyes).

112 M. VÉRON, Droit pénal spécial, op. cit., p.388 ; C. AMBROISE-CASTÉROT, Droit pénal..., op. cit., p.368 ; F. CECCON, Contribution..., op. cit., p.40. Precisa esta autora que no se trata de suprimir la exigencia de todo pacto corruptor, sino suprimir simplemente la de un acto corruptor concluido anteriormente a la realización del primero de los actos incriminados. En este mismo sentido se ha pronunciado XIAO-YING para quien supeditar la culpabilidad a una anterioridad del pacto no es jurídicamente lógi-
} 
que intelectualmente, la solución aportada por la reforma legislativa de 2000 parece más satisfactoria y facilita prácticamente la tarea del Ministerio público ${ }^{113}$.

Sin embargo, otro sector de la doctrina opina que a pesar del intento del legislador de 2000 de suprimir la exigencia de la anterioridad del pacto corruptor añadiendo los términos "en cualquier momento", hay una ambigüedad que persiste, puesto que la forma sintáctica del resto del artículo supone la anterioridad ${ }^{114}$. En efecto, esta supresión de la exigencia de la anterioridad del pacto de la corrupción, no se refleja en el texto de la ley debido al término "para" que todavía es parte del mismo, lo que no significa que los términos "en cualquier momento" estén desprovistos de consecuencias. Explica JEANDIDIER que es cierto que la solicitación o la aceptación pueden intervenir "en cualquier momento" pero lamentablemente el legislador francés de 2000 no estimó necesario - o más bien no fue consciente que era necesario - modificar en consecuencia la redacción del resto del texto. Éste último precisa que la solicitación o la aceptación de ventajas tengan lugar en cualquier momento para realizar o dejar de realizar un acto de la competencia del agente público. Defiende el autor que por mucho que otro sector de la doctrina intente interpretar que con la reforma ha desaparecido la exigencia de la anterioridad del pacto, la letra de la ley sigue diciendo lo contrario. La solicitación después de la realización del acto de la competencia no puede ser considerada como hecha para realizar un acto que ya ha sido realizado ${ }^{115}$.

Para conciliar la exigencia de la anterioridad del pacto corruptor, reflejada en la letra de ley y las consecuencias de la introducción de los términos "en cualquier momento" en el precepto en estudio, LUCAS de LEYSSAC y MIHNAN sugieren que en el estado de la redacción del artículo 432-11 CPF 2000/2007, los términos "en cualquier momento" no pueden tener más que une incidencia sobre la prueba. En efecto, debido a esos términos, el hecho de que el agente haya recibido dádivas, presentes, etc. después de la realización (o la abstención) del acto del cargo, puede "bastar" para fundamentar una prueba por presunción judicial de la relación de causalidad que debe unir el acto (o la abstención)

co, sobre todo si hay repeticiones de las conductas tipificadas (H. XIAO-YING, La lutte contre la corruption..., op. cit., p.64).

${ }^{113}$ E. DREYER, Cours magistral..., op. cit., p.605.

114 C. AMBROISE-CASTÉROT, Droit pénal..., op. cit., p.368.

115 W. JEANDIDIER, Du délit de corruption..., op. cit., p.1670 ; P. CONTE, «L'art de légiférer se perd-il ? Réflexions en forme de pamphlet à partir de quelques illustrations de droit pénal », Mélanges Lapoyade-Deschamps, Presses Universitaires de Bordeaux, 2003, pp.307 y ss. Este autor critica la manera en que el legislador francés ha pretendido cambiar la definición del delito de corrupción añadiendo sólo tres palabras ("à tout moment"). Lamenta el mismo autor que al escatimar esfuerzos y recursos en materia de técnica legislativa, el legislador no ha conseguido nada con la reforma (p.313). 
con esas dádivas o presentes ${ }^{116}$. En la práctica, habría que valorar cada caso: si la remuneración a posteriori es módica, se podrá argumentar sobre la base de ofrecimiento de regalo o de detalles de agradecimiento; de lo contrario se podría admitir la hipótesis de un pacto de corrupción previo ${ }^{117}$.

Ante estas críticas, la doctrina pensaba que con la reforma de noviembre de 2007 el legislador francés iba a reaccionar para subsanar estas imperfecciones sobre la persistencia en la exigencia de la anterioridad del pacto de corrupción. Sin embargo, los trabajos preparatorios de la Ley 2007-1598 del 13 de noviembre de 2007 relativa a la lucha contra la corrupción, han revelado que el legislador de 2007 se refería a la intención del legislador de 2000, mientras que el término "para" podía afectar esta intención ${ }^{118}$.

\section{3-Situación a partir del mayo de 2011}

En una situación en la que el legislador francés parece haber cumplido lo que se le pedía y en la que las críticas de la doctrina parecen no tener ninguna oportunidad de ser consideradas, los evaluadores del GRECO instaron a las autoridades francesas desde 2009 que aclararan algunos elementos materiales en la tipificación del delito de corrupción. El órgano evaluador europeo recordó que la constitución de este delito no dependía de la existencia de un pacto, ni mucho menos, que este tiene que ser anterior a la realización del acto de la función ${ }^{119}$. Con estas recomendaciones se promulgó en mayo de 2011 la Ley 2011-525 que añadió unos elementos por medio de su artículo 154 a la letra del artículo 432-11 CPF. Estos nuevos elementos consisten en verbos en tiempo infinitivo pasado introducidos al lado de los verbos con infinitivo presente. Es decir, la solicitación o la aceptación de ventajas de parte del funcionario es "para que realice o por haber realizado, para que deje de realizar o por haber dejado de realizar un acto de su competencia, o facilitado por su competencia."

En efecto, habrá que esperar para recoger la valoración de la doctrina francesa al respecto. Quizá las opiniones emitidas en esta tesis son una de las primeras sobre la modificación de la letra del artículo 432-11 CPF operada por la reforma penal de 2011. En primer lugar, se han tenido

116 M-P. LUCAS de LEYSSAC y A. MIHNAN, Droit pénal des affaires..., op. cit., no1033. Notan estos autores que esta relación de causalidad permitirá inducir la existencia de un pacto anterior.

117 Ibídem, op. cit., nำ1033. La postura de estos autores se inspira del Circular de aplicación del 30 de diciembre de 2001 tomado por el Ministerio de Justicia respecto de la Ley del 30 de junio de 2000. Precisa dicho circular que "independientemente de la interpretación que la jurisprudencia futura dará, al fundamentar sobre todo en la intención explícita del legislador de suprimir la anterioridad del pacto de corrupción (...) la introducción de los términos "en cualquier momento" facilitiará la prueba de la corrupción."

${ }^{118}$ Ibídem, op. cit., no1033.

${ }^{11}$ http://www.coe.int/t/dghl/monitoring/greco/evaluations/round3/GrecoRC3\%28 2011\%291 France FR.pdf (pp.2, 3). 
en cuenta las críticas de la doctrina francesa sobre la difícil conciliación entre los términos "en cualquier momento" y "para". La introducción del infinitivo pasado del mismo verbo que indica el acto o la abstención junto con el infinitivo presente significa, y ahora con más claridad, que no importa el momento donde se coloca el pacto corruptor o su intento en el iter criminis. En materia de técnica legislativa el legislador francés siguió, de cierta manera, el paso del legislador alemán e italiano en este ámbito ${ }^{120}$. Para RODRÍGUEZ PUERTA prever la modalidad de cohecho subsiguiente junto a la forma antecedente es la opción más coherente político-criminalmente ${ }^{121}$, ya que de este modo, se lograría cubrir típicamente los supuestos que presentan una efectiva ofensividad para el bien jurídico ${ }^{122}$.

En segundo lugar, la mejora de la técnica legislativa no impide cuestionarse sobre su posible aplicación e interpretación. No pensamos que con esta reforma se haya suprimido la exigencia de probar la anterioridad del pacto para convertir en prueba por presunción judicial toda recepción de dádivas y ventajas posterior a la realización de un acto del cargo. No estamos de acuerdo con un sector de la doctrina francesa que defiende que el hecho de recibir regalos por un acto ya realizado puede "bastar" para fundamentar una prueba por presunción judicial de la relación de causalidad entre los regalos y el acto (o abstención). Ésta, a su vez, permitirá "inducir" la existencia de un pacto anterior ${ }^{123}$. Lo que se consigue con la reforma de 2011 es simplemente suprimir la exigencia de anterioridad del pacto corruptor pero, de ninguna manera, eliminar la exigencia del mismo ${ }^{124}$. Y aunque la mayoría de la doctrina puede pensar que con la reforma de 2000 se ha facilitado la tarea del Ministerio público ${ }^{125}$, y que la reforma de 2011 no hace más que reforzar esta postura, a nuestro modo de ver, el legislador no exime en ningún caso el deber probatorio para demostrar la relación de causalidad entre el pacto y el acto (o la abstención). En el caso de que resulte imposible demostrar dicha relación, no debe haber ni siquiera proceso penal y si éste llegara a tener lugar no debería haber condena. De lo contrario, se convertiría el delito de corrupción en un delito de sospecha, en el que se presume un elemento del tipo a partir de la concurrencia de los demás. Con ello, se viola el derecho a la presunción de inocencia, pues la constitución del delito de corrupción dependerá no de la prueba de la existencia de un acuerdo o de su intento, sino de la presunción de la existencia de dicho acuerdo a partir de indicios que el legislador no ha contempla-

\footnotetext{
120 La doctrina francesa ha comparado siempre la técnica legislativa francesa con la del legislador alemán e italiano en esta materia (Ver en este sentido, entre otros, A. VITU, Corruption pasiva..., op. cit., p.16). Otro sector de la doctrina ha visto incluso la intención del legislador francés de seguir el paso de estos últimos pero sin llevar su proyecto hasta sus últimas consecuencias (W. JEANDIDIER, Du délit de corruption..., op. cit., p.1670)

${ }^{121} \mathrm{M}^{\mathrm{a}}$. J. RODRÍGUEZ PUERTA, El delito de cohecho..., op. cit., p.283

122 F. MORALES PRATS y Ma. J. RODRÍGUEZ PUERTA, “Delitos...”, 2011, op. cit., p. 1237.

${ }^{123}$ M-P. LUCAS de LEYSSAC y A. MIHNAN, Droit pénal des affaires..., op. cit., no1033.

124 F. CECCON, Contribution..., op. cit., p.40.

125 Entre todos, E. DREYER, Cours magistral..., op. cit., p.605.
} 
do, lo cual va en contra del principio de legalidad en materia penal. Creemos que esta situación puede crear un cierto margen de inseguridad jurídica a los funcionarios que acepten promesas u ofrecimientos por actos ya cumplidos ${ }^{126}$.

Por último, si el bien jurídico protegido en el delito de corrupción pasiva es el deber de probidad en el desempeño de las actividades de servicio público, el legislador francés ha considerado que el delito está consumado a partir del momento en que el agente público solicita o acepta algunas retribuciones de parte del particular. Si bien es cierto que el deber de probidad se lesiona al tomar la decisión de pedir o al alcanzar un acuerdo con el particular respecto a los términos del intercambio corrupto, antes de realizar (o abstenerse) el acto de su competencia, se puede preguntar si este deber funcionarial puede ser lesionado de igual manera cuando el agente público manifiesta la misma conducta después de la realización (o la abstención) del mismo acto. En efecto, cifrar el bien jurídico en el deber del cargo, como ya hemos señalado, tiene el peligro de no poder limitar el ius puniendi del Estado. A nuestro modo de entender, la probidad del funcionario se ve afectada cuando éste último exterioriza su deseo de ser recompensado o de aceptar alguna recompensa, sin tener derecho a ello, posteriormente a la realización del acto de su competencia ${ }^{127}$. Por lo tanto, se puede justificar la equiparación de penas entre la modalidad antecedente y la subsiguiente con la condición de que se pruebe el pacto corruptor, el cual no se presume. No basta la entrega posterior al acto del cargo para establecer ni la relación de causalidad que permite inducir la existencia de un pacto anterior ni la relación de causalidad entre el acto ya realizado y dicha entrega. Así, la idea según la cual esta equiparación manifiesta la elección del legislador de dar un papel meramente instrumental a la corrupción $a$ posteriori al facilitar la obtención de la prueba, a nuestro parecer, no es de recibo.

Si se considera que el bien jurídico protegido se cifra en el principio de imparcialidad, entonces la equiparación de penas entre la modalidad antecedente y la subsiguiente conlleva problemas, tal como se ha des-

\footnotetext{
126 I. VALEIJE ÁLVAREZ, El tratamiento..., op. cit., p.178.

127 Según la postura defendida por VIZUETA FERNÁNDEZ, el bien jurídico protegido en el delito de corrupción subsiguiente es la honradez o la integridad de la condición de funcionario, por lo tanto el autor es partidario de la despenalización de todas las modalidades de cohecho subsiguiente por proteger un bien jurídico no merecedor de tutela penal, y, además, ser ésta innecesaria (J. VIZUETA FERNÁNDEZ, Delitos..., op. cit., p.250). Esta postura tiene su lógica pero desde luego ha sido abandonada por el legislador francés de 2011. Aunque desde la postura de la mayoría de la doctrina penal española contemporánea el deber del cargo no puede convertir por sí solo en un bien jurídico merecedor de protección penal, el legislador francés elevó el deber de probidad al rango de bien jurídico penal. La amplitud de este tipo de bien jurídico tiene la desventaja de no poder limitar el alcance del precepto por lo tanto, a nuestra manera de ver, el papel de la jurisprudencia es fundamental para determinar qué tipo de acto puede ser penalmente relevante. Para LUCAS de LEYSSAC y A. MIHNAN, habrá que estudiar caso por caso la cantidad de la remuneración a posteriori (M-P. LUCAS de LEYSSAC y A. MIHNAN, Droit pénal des affaires..., op. cit., n1033).
} 
crito anteriormente. En efecto, en materia de corrupción pasiva subsiguiente, no se lesiona el principio de imparcialidad ${ }^{128}$ sino se pone en peligro, puesto que la aceptación de una recompensa por un acto ya realizado encontraría su ratio en el peligro de que la misma denote, en el futuro, una incapacidad por parte del funcionario público de desarrollar de forma imparcial su cargo y su toma de decisiones ${ }^{129}$. Por lo tanto, equiparar la sanción de la vertiente subsiguiente del cohecho con la prevista por la respectiva hipótesis antecedente, equivale a proporcionar una misma pena, respectivamente, a la lesión y a la mera puesta en peligro de un mismo bien jurídico, lo cual resulta difícilmente aceptable, y sobre todo, difícilmente compatible con el principio de proporcionali$\operatorname{dad}^{130 .}$

\section{C-DERECHO MALGACHE}

Tanto antes como después de la reforma del CPM de 2004, el legislador malgache ha mantenido la exigencia de la anterioridad del pacto corruptor o de su intento respecto al acto de la competencia o a la abstención por parte del funcionario. La letra del artículo177 CPM no contempla ninguna posibilidad de corrupción pasiva a posteriori. El término "para" marca un orden secuencial que no se puede invertir: la solicitación o la aceptación de ventajas debe tener lugar antes de realizar un acto de la competencia o una abstención relativa a la misma.

Por consiguiente, se debe concluir que en Derecho penal malgache todo pacto alcanzado o todo intento de alcanzarlo después de la realización de un acto del cargo no pueden subsumirse con arreglo al artículo 177 CPM. De lege ferenda parece posible reclamar una reforma del CPM para incluir esta modalidad en la legislación penal de Madagascar. La principal razón para ello estriba en la ratificación por el Estado malgache del Convenio de la Unión Africana relativo a la prevención y la lucha contra la corrupción firmado en Maputo en julio de 2003131. En efecto, aunque la Ley 2004-030 de septiembre de 2004, relativa a la lucha contra la corrupción ha recogido la mayoría de las incriminaciones previstas en el Convenio, de manera inexplicable, el legislador malgache no ha introducido en la reforma del CPM el artículo 4 (c) de la norma internacional que prevé "la realización o la omisión, por parte de un agente pú-

\footnotetext{
${ }^{128}$ Mạ. J. RODRÍGUEZ PUERTA, El delito de cohecho..., op. cit., p.281.

129 G. D. M. CERINA, La lucha contra la corrupción, op. cit., p.553; M. POLAINO NAVARRETE, “Cohecho...", op. cit., p. 326. Este autor defiende que si antes de la actuación no existió promesa ni ofrecimiento aceptados ni entrega de dádiva o presente recibidos, después de realizada la actuación del funcionario no se concreta el tipo de cohecho a no ser que la contraprestación económica solicitada o admitida se proyecto al futuro apreciando la corrupción del titular de la función en orden a su ulterior desempeño del oficio público.

130 G. D. M. CERINA, La lucha contra la corrupción, op. cit., p.556.

${ }^{131}$ Se ha autorizado la ratificación de dicho convenio por medio de la Ley 2004-018 del 19 de agosto de 2004. Su artículo 2 precisa que esta ley de autorización será ejecutada como ley del Estado. Sin embargo, el legislador malgache deberá tomar las normas jurídicas necesarias para introducir el contenido del Convenio en el ordenamiento jurídico nacional.
} 
blico u otra persona asimilada, de un acto de su competencia, a efectos de obtener ventajas ilícitas en provecho propio o de un tercero". La letra de este precepto (el acto del cargo seguido por la búsqueda de retribución) describe precisamente lo que es la corrupción pasiva a posteriori. Desgraciadamente, la organización continental no cuenta con un órgano de evaluación como en Europa para valorar la adecuación de las normas nacionales a un convenio internacional.

Sin embargo, la entrega de un regalo después de la realización de un acto del cargo no se queda impune, según la doctrina malgache. El legislador malgache ha tipificado unas figuras delictivas con aspecto más bien preventivo ${ }^{132}$. Una de estas figuras está prevista en el artículo 183 del CPM y tiene cómo título "De los regalos"133. Para RAFOLISY el punto central del delito es la aceptación, lo cual implica que la recepción material del regalo prohibido no representaría más que una facilidad en materia de prueba. Si este delito exige un acuerdo entre las partes, el autor hace una distinción según el momento de la iniciativa. Si la iniciativa emana del agente público, entonces la figura delictiva en estudio se asemeja a la corrupción pasiva salvo en el caso de que el regalo se haya solicitado sin tener influencia alguna en el acto ya realizado. Pero incluso en esta última hipótesis, aunque la cuestión de la influencia parece que ya no se plantea, el agente debía haber actuado con la esperanza o la finalidad inconfesada de obtener una retribución indebida. En ambos casos, la modalidad típica "aceptar" se ha comprobado134.

Se pregunta el autor sobre el tipo de regalo capaz de influenciar al agente público. Defiende el autor que todo dependerá de la apreciación del juez conforme a las normas de conducta que rigen la función del agente o de la autoridad pública ${ }^{135}$. Además, se deberá probar una relación de causalidad entre el regalo y el ejercicio del cargo. El mismo autor acude al criterio llamado de "anormalidad" para calificar el regalo como típicamente relevante. Este criterio se basaría en el valor de este regalo según lo que el donante pretende obtener en el procedimiento o la transacción ${ }^{136}$. Por otra parte, se debería demostrar la relación de influencia entre el tratamiento del procedimiento y el regalo. Esta relación tiene la función de guiar la toma de decisión del agente público a favor del particular.

Añade el autor otro criterio que se basa en el momento de la aceptación. Los regalos de agradecimiento se entregan a menudo después de la transacción o del procedimiento favorable al donante. Pero eso no ex-

\footnotetext{
132 P. RAFOLISY, La protection juridique..., op. cit., p.240.

133 Reza el artículo 183 CPM: "Será castigado con pena de 6 meses a 2 años de prisión y/o con multa de 100000 a 1000000 Ariary, el agente público o toda autoridad pública que acepte de una persona un regalo o una ventaja indebida susceptible de influenciar o haber influenciado un procedimiento o una transacción relacionada con su cargo."

${ }^{134}$ P. RAFOLISY, La protection juridique..., op. cit., p.251.

135 Ibídem, op. cit., p.251.

136 Ibídem, op. cit., p.252.
} 
cluye que la entrega pueda tener lugar antes de la toma de decisión para influir sobre el agente público quien tomará decisiones satisfactorias para el autor del regalo. En este sentido, el artículo 183 CPM no da importancia particular a la cronología de la aceptación ${ }^{137}$.

A nuestro modo de ver, el autor ha interpretado la figura delictiva de una manera extensiva. En primer lugar, no estamos de acuerdo con la idea según la cual la recepción material es una implicación lógica de la aceptación y puede ser la prueba de ésta. El legislador malgache no ha previsto ninguna presunción ni ha eximido ni ha facilitado la demostración de la prueba de la conexión entre la aceptación del regalo y el tratamiento del procedimiento.

En segundo lugar, cuando el regalo se ha ofrecido y el procedimiento ya ha sido tratado a favor del donante, no es siempre cierto que la decisión tomada haya sido influenciada de alguna manera. Por lo tanto, este tipo entrará en concurso con el delito de corrupción pasiva. Para que un regalo tenga la capacidad de influir sobre la conducta del agente, debe ser ofrecido y aceptado antes de que éste último tome su decisión de proceder según la indicación del ofertante. No vemos en la letra de la ley ninguna indicación de que el momento de aceptación no tenga importancia particular. El único supuesto en el que se puede contemplar la aplicación de este tipo delictivo es cuando se ha formado entre el agente público y el particular una serie de contactos o un tejido de relación en la que se suceden, de manera repetitiva, decisiones favorables y regalos sustanciosos. Pero incluso en este caso, siempre se podrá aplicar también el delito de corrupción pasiva del artículo 177 CPM.

Por último, al utilizar únicamente el verbo "aceptar" la letra de la ley no ha previsto otro tipo de conducta. No se justifica la idea de RAFOLISY según la cual la iniciativa puede emanar del agente público al solicitar una retribución indebida después de haber realizado el acto relativo al procedimiento o a la transacción. A nuestro juicio, si el legislador malgache no ha tipificado la conducta "solicitar", eso significa que la iniciativa debe venir únicamente del particular quien intentará proponer un regalo capaz de influenciar al agente público y obtener su aceptación. Esta conducta "proponer" por parte del particular no se ha tipificado para dar una simetría respecto a la actitud pasiva del agente público estipulada en el artículo 183 CPM. En otras palabras, parece que proponer un regalo capaz de influenciar sobre un procedimiento o una transacción es atípico y en caso de aceptación, sólo se incriminará esta conducta del agente público. A nuestro modo de ver, se aplicará el artículo 177.1 CPM que se refiere a la corrupción activa, puesto que este precepto alcanza a una gran variedad de actos de la competencia del funcionario, y entre ellos se incluyen los procedimientos y las transacciones. En cuanto a la solicitación de regalo por parte de un servidor público, quedará impune cuando se ha hecho después de haber realizado un acto de

137 Ibídem, op. cit., p.253. 
su competencia, y eso incluye tanto el procedimiento como la transacción, ya que el artículo 177 ha definido el orden secuencial de las conductas y el artículo 183 exige la capacidad influenciadora del regalo en la decisión del funcionario, privando a éste último de la iniciativa de solicitarlo.

En definitiva, la corrupción pasiva subsiguiente todavía es atípica según la legislación penal malgache.

\title{
Sección 3-Los diferentes actos en Derecho comparado español, francés y malgache
}

Desde la reforma del CPE de 2010, se han reducido notablemente los comportamientos funcionariales realizados o perseguidos: por un lado, el supuesto más grave es el que tiene como objeto del acuerdo un "acto contrario a los deberes inherentes" al cargo o la no realización o retraso injustificado del acto que debiera practicar (artículo 419 CPE); y, por otro, el que tiene como referencia el "acto propio de su cargo" (artículo 420 CPE) ${ }^{138}$. El Derecho penal francés desde la reforma legislativa de 1994 ha reunido todos los actos susceptibles de ser objeto de un pacto corrupto bajo la formulación "acto de la competencia o facilitado por ella"139. El legislador penal malgache de 2004 hizo suya esta reforma francesa de 1994 y redactó el nuevo artículo 177 CPM casi de la misma forma ${ }^{140}$ que el artículo 432-11 CPF.

\section{I-Acto contrario a los deberes inherentes del cargo y acto de la competencia o facilitado por ella}

\author{
A-OBSERVACIONES GENERALES
}

\section{1-Los cambios introducidos por la reforma legislativa de 2010 en el CPE}

La reforma incluye una notable simplificación en materia de cohecho antecedente propio. Más allá de discusiones no siempre fundadas sobre

\footnotetext{
138 I. BLANCO CORDERO, La reforma..., op.cit., p.24. Se trata de una simplificación que ha sido recibida favorable por la doctrina española. Ver en este sentido, G. D. M. CERINA, La lucha contra la corrupción, op. cit., p.1189; J. QUERALT JIMÉNEZ, Derecho penal..., 2010, op. cit., p.1160.

${ }^{139}$ Se trata de una adaptación a la traducción propuesta por ARÁNGUEZ SÁNCHEZ y ALARCÓN NAVÍO quienes traducen, sin perjuicio de la reforma legislativa de 2011, el primer inciso de la siguiente manera: "bien para que realice o deje de realizar un acto de su competencia, o facilitado por su competencia" (C. ARÁNGUEZ SÁNCHEZ y E. ALARCÓN NAVÍO, El código penal francés, op. cit., p.206).

${ }^{140}$ Es de observar que cuando el legislador penal malgache quiso hacer una reforma en 2004 inspirándose, en cuanto a la redacción del delito de corrupción pasiva, de la reforma francesa de 1994, como ya lo hemos señalado, el legislador francés modificó la redacción del artículo 432-11 en junio de 2000 al añadir dos expresiones "sin tener derecho a ello" y "en cualquier momento". El legislador malgache de 2004 prefirió no añadir estas expresiones en la nueva redacción del artículo 177 CPM.
} 
el carácter dogmáticamente aceptable de las diferenciaciones que propone la disciplina actual ${ }^{141}$, la mayoría de la doctrina española ha puesto de manifiesto que la redacción de los artículos 419-421 del CPE 1995 supone más problemas para el intérprete que ventajas en términos de taxatividad $^{142}$. Si bien hubiera sido posible actuar de forma distinta, dejando intactas las diferenciaciones entre acto injusto delictivo y acto injusto no delictivo, entre acto injusto no ejecutado y acto injusto ejecutado, corrigiendo toda una serie de errores técnicos, el legislador español de 2010 escoge el camino de la simplificación. La elección ha sido acogida favorablemente por la mayoría de la doctrina española ${ }^{143}$. En efecto, el actual artículo 419 CPE engloba todos estos actos en las expresiones "acto contrario a los deberes inherentes" al cargo y no realización o retraso injustificado del acto que debiera practicar. Ahora se castigan con la misma pena tanto los comportamientos activos del funcionario como los omisivos ${ }^{144}$. De este modo, señala RODRÍGUEZ PUERTA, se soslaya un problema que había sido destacado por la doctrina y la jurisprudencia española: la injustificada diferencia a efectos penológicos de supuestos que materialmente presentan un injusto similar, puesto que el objeto de la transacción, entre funcionario y particular, viene integrado en todos los casos por un acto contrario a Derecho' ${ }^{145}$.

Por otra parte, otro sector de la doctrina plantea dudas respecto a la equiparación de pena para las tres modalidades que contiene el artículo 419 CPE. Según MORILLAS CUEVA, no parece de la misma intensidad realizar un acto contrario a los deberes inherentes al cargo o no realizar que retrasar, aunque ciertamente la esencia, al menos a su inicio, de las conductas está en recibir o solicitar la dádiva, regalo, retribución, ofrecimiento o promesa ${ }^{146}$. Más crítica es la postura adoptada por SERRANO GÓMEZ y SERRANO MAÍLLO quienes indican que estamos ante un precepto que conlleva una notable inseguridad jurídica ya que en muchos casos serán cuestionables las situaciones de "no realizarlo" o "retrasar-

\footnotetext{
141 C. RAMOS RUBIO, Del delito de cohecho... op. cit., p.342. El autor señala que la simplificación tiene su causa en las críticas de un autorizado sector de la doctrina que entendía que nada aporta a la protección del bien jurídico ni al desvalor de la conducta el que el acto a realizar por el funcionario (o autoridad) a cambio de la retribución del particular fuere constitutivo de delito o mera ilegalidad administrativa.

142 Entre otros, G. D. M. CERINA, La lucha contra la corrupción, op. cit., pp.1205 y 1206; J. QUERALT JIMÉNEZ, Derecho penal..., 2010, op. cit., pp.1164 y 1165; Ma. J. RODRÍGUEZ PUERTA, “Modificaciones...” op. cit., p.468.

${ }^{143}$ A. NIETO MARTÍN, “Corrupción y abuso...", op. cit., p.754; C. MIR PUIG, El delito de cohecho en la reforma ...op. cit., p.43; G. D. M. CERINA, La lucha contra la corrupción, op. cit., p.1206; J. QUERALT JIMÉNEZ, Derecho penal..., 2010, op. cit., p.1164.

${ }^{144}$ I. BLANCO CORDERO, La reforma..., op.cit., p.24.

145 Ma. J. RODRÍGUEZ PUERTA, “Modificaciones...” op. cit., p.468. En este mismo sentido se ha pronunciado NIETO MARTÍN para quien "no realizar o retrasar injustificadamente el que debiera practicar" no son sino ejemplos del acto contrario a los deberes del cargo (A. NIETO MARTÍN, “Corrupción y abuso...", op. cit., p.759). Comparten la misma postura G. D. M. CERINA, La lucha contra la corrupción, op. cit., p.1206 y J. QUERALT JIMÉNEZ, Derecho penal..., 2010, op. cit., p.1165.

146 L. MORILLAS CUEVA, “Delitos...”, op. cit., p.959.
} 
lo", así como "realizar en el ejercicio de su cargo un acto contrario a los deberes inherentes al mismo". De otra parte lo que se solicita o recibe a veces pueden ser cosas de escaso valor, será muy fácil interponer querellas carentes de fundamento. Defienden que hay que tener en cuenta que la pena privativa de libertad es muy grave y que todo procedimiento penal tiene un margen de inseguridad. En su redacción anterior, estas formas de cohecho ofrecían más seguridad ya que la conducta típica era "para realizar en el ejercicio de su cargo una acción u omisión constitutiva de delito" 147 .

A nuestra manera de entender, esta reforma, lejos de conllevar una inseguridad jurídica, unifica todas las variedades de cohecho propio al sancionarlas con una única pena, simplifica su régimen y facilita el castigo, ya que las subdivisiones aludidas dificultaban notablemente la prueba de los delitos cohecho donde no era fácil, por ejemplo, determinar si un soborno se había solicitado o pagado para cometer una simple irregularidad o una irregularidad de tal calibre que constituyera, por ejemplo, una prevaricación ${ }^{148}$. En cuanto a la duda planteada por MORILLAS CUEVA, creemos que "no hacer algo que se tiene el deber de hacer" equivale desde un punto de vista valorativo, a "hacer algo que no se debe hacer". Cualquier intervención legislativa que no se limita a aclarar sino que pretende dictar, para las actuaciones omisivas una disciplina distinta respecto de la prevista para las activas, resulta criticable desde un punto de vista del respeto del principio de proporcionali$\operatorname{dad}^{149}$.

Por otro lado, a pesar de la modificación introducida por el legislador en la redacción del artículo $419 \mathrm{CPE}$, la doctrina española sigue utilizando el adjetivo "injusto" a la hora referirse a la situación de contrariedad a los deberes inherentes al cargo ${ }^{150}$. Sin entrar en el debate abierto bajo la anterior redacción sobre la determinación de la injusticia de un acto ${ }^{151}$, entendemos que con la nueva dicción contrario a los debe-

\footnotetext{
147 A. SERRANO GÓMEZ y A. SERRANO MAÍlLO, Derecho Penal, Parte Especial, Dykinson, Madrid, 2010, (15 ed.), pp.837 y 838. Concluyen esto autores que si se desconoce el valor de la dádiva no se puede imponer multa. El legislador, para evitar estas situaciones que favorecen al autor del delito, debía de haber fijado una cantidad mínima. ${ }^{148}$ A. NIETO MARTÍN, “Corrupción y abuso...”, op. cit., p.754.

${ }^{149}$ Mà. J. RODRÍGUEZ PUERTA, El delito de cohecho..., op. cit., pp.236 y 237; I. VALEIJE ÁLVAREZ, El tratamiento..., op. cit., pp. 218-221; G. D. M. CERINA, La lucha contra la corrupción, op. cit., p.1072.

${ }^{150}$ F. MORALES PRATS y Mà. J. RODRÍGUEZ PUERTA, “Delitos...”, 2011, op. cit., p. 1225; L. MORILLAS CUEVA, “Delitos...”, op. cit., p.959; Ma. J. RODRÍGUEZ PUERTA, "Modificaciones..." op. cit., p.468; G. D. M. CERINA, La lucha contra la corrupción, op. cit., p.1042. Para este autor el término injusto, a finales de cuentas, es sinónimo de "contrario a los deberes del cargo".

151 Ma. J. RODRÍGUEZ PUERTA, El delito de cohecho..., op. cit., pp. 211 y ss.; G. D. M. CERINA, La lucha contra la corrupción, op. cit., pp.1031 y ss.; I. VALEIJE ÁLVAREZ, El tratamiento..., op. cit., pp.207 y ss.; I. OLAIZOLA NOGALES, El delito de cohecho, op. cit., pp.280 y ss.
} 
res del cargo se rechazan todas aquellas tesis que pretendían anclar la injusticia del acto a razones materiales más que legales ${ }^{152}$.

\section{2-Dificultad en la comparación entre el Derecho penal español y el Derecho penal francés o malgache}

Como ya hemos señalado, la reforma del CPE de 2010 mantiene la clasificación en materia de cohecho pasivo según el acto objeto del acuerdo. En efecto, se aplicará el artículo 419 CPE cuando el pacto corruptor o su intento tiene por objeto un acto contrario a los deberes del cargo, una abstención o un retraso injustificado de un deber que el funcionario debiera practicar. La mayoría de la doctrina española ha denominado el delito tipificado en este precepto cohecho pasivo propio. En cambio, si el mismo pacto tiene como finalidad la realización de un acto propio del cargo tal como se describe en el artículo 420, entonces se trata de cohecho pasivo impropio ${ }^{153}$. La importancia de esta clasificación no es simplemente didáctica. La naturaleza del acto objeto del acuerdo de corrupción determina el precepto que se debe aplicar y la pena que eso implica. Estos artículos reflejan la elección del legislador español en cuanto al desvalor que cada acto merece.

La dificultad reside en la inexistencia de esta clasificación cohecho propio e impropio en el Derecho penal francés y malgache. La amplitud de la expresión "acto de la competencia, o facilitado por ella" da a entender que los actos previstos tanto por el artículo 419 como el artículo 420 del CPE pueden ser abarcados en los artículos 432-11 CPF y 177 CPM, sin otro tipo de consideración. Además, el legislador francés sólo ha establecido el tope máximo de penas dejando a la apreciación de los tribunales la graduación del desvalor del acto objeto del acuerdo de corrupción. Aunque el legislador malgache ha previsto una horquilla de penas, le corresponde al juez valorar cada caso y proponer sus propios

152 En este mismo sentido se ha pronunciado G. D. M. CERINA, La lucha contra la corrupción, op. cit., p.1206.

153 Entre todos, C. MIR PUIG, El delito de cohecho en la reforma...op. cit., pp.45 y 47; G. D. M. CERINA, La lucha contra la corrupción, op. cit., pp. 1186 y ss.; I. ORTIZ DE URBINA GIMENO, "Delitos contra la Administración pública", en J.M. SILVA SÁNCHEZ (dir.); R. RAGUÉS I VALLÉS (coord.), Lecciones de derecho penal. Parte especial, Atelier, Barcelona, 2011, (3 ${ }^{a}$ ed.), pp.336-339. RODRÍGUEZ PUERTA prefiere otra clasificación: "tipo básico" y "tipo agravado", para un mayor respeto al principio de taxatividad respecto de las diferentes modalidades previstas por el legislador penal español de 1995 (Mํ. J. RODRÍGUEZ PUERTA, El delito de cohecho..., op. cit., pp.158 y 159). Sin embargo, la misma autora reconoce la dicotomía "cohecho propio" y "cohecho impropio" en el marco de la nueva redacción introducida por la reforma penal de 2010 (Ma . J. RODRÍGUEZ PUERTA, "Modificaciones..." op. cit., pp.468 y 469). Otra clasificación propone POLAINO NAVARRETE quien considera como "cohecho propio" el cometido por el funcionario público y "cohecho impropio" el cometido por el particular (M. POLAINO NAVARRETE, “Cohecho...”, op. cit., pp. 321 y 330). MUÑ OZ CONDE y MORILLAS CUEVA proponen los mismos términos para clasificar pero en cuanto al contenido, formarán parte del cohecho propio los artículos 419, 420, 421 del CPE. En cambio, el cohecho impropio tiene como único elemento el artículo 422 del mismo Código (F. MUÑOZ CONDE, Derecho penal, Parte especial,...2010, op.cit., pp.1020 y 1024; L. MORILLAS CUEVA, “Delitos...", op. cit., pp.956 y 961). 
criterios para aplicar el precepto en estudio. Nos atrevemos a decir que en materia de corrupción pasiva, estamos ante un Derecho jurisprudencial en el que son los tribunales los que sustituyen al legislador en la finalización del trabajo legislativo. El estudio de la doctrina penal francesa pone de manifiesto que los conceptos manejados para delimitar y explicar la expresión "acto de la competencia, o facilitado por ella" son todos de origen jurisprudencial. Llegamos a la constatación de que, al no respetar el legislador francés el principio de taxatividad 154 , la jurisprudencia se ha visto obligada, por un lado, a delimitar los elementos del tipo, violando el artículo 111-3 del $\mathrm{CPF}^{155} \mathrm{y}$, por otro lado, a dar una interpretación que no se puede calificar de estricta al artículo 432-11 $\mathrm{CPF}$, transgrediendo la exigencia del artículo 111-4 del mismo Código ${ }^{156}$. En consecuencia, esta situación termina irrogando un alto coste en términos de seguridad jurídica.

En este mismo sentido, no podemos sino reclamar una reforma del CPM para introducir en su parte general principios tales como la taxadividad, la reserva de ley en materia penal y la interpretación estricta de la ley penal. De esta manera, siempre se podrán fortalecer las garantías pretendidas al aplicar las normas penales.

En los apartados siguientes sólo podremos comparar los conceptos manejados por la doctrina penal española y francesa para interpretar el significado de las expresiones "acto contrario a los deberes del cargo" y "acto de la competencia o acto facilitado por ella" y su posible contenido, ya que en la doctrina penal malgache no hemos encontrado algún estudio u observación al respecto ${ }^{157}$.

154 Nos parece interesante el debate planteado por MORESO quien indica que el principio de taxatividad exige la formulación en términos precisos de los supuestos de hecho de las normas penales. Esta exigencia suele ser entendida en, al menos, dos sentidos: a) una reducción de la vaguedad de los conceptos usados para determinar los comportamientos penalmente prohibidos y b) una preferencia por el uso de conceptos descriptivos frente al uso de conceptos valorativos. Sin embargo, en la discusión actual hay perfecta consciencia de que la vaguedad de los conceptos, la indeterminación semántica, es un rasgo ineliminable de nuestros conceptos generales (J. J. MORESO, Principio de legalidad y causas de justificación, Cuadernos de Filosofía del Derecho, Universidad de Alicante, disponible en la red: http://publicaciones.ua.es , (pp.8 y 9)

155 Estatuye el artículo 111-3 CPF: "Nadie podrá ser castigado por un delito grave o menos grave cuyos elementos no estén delimitados por la Ley,..."

156 Dispone el artículo 111-4 CPF: "La Ley penal es de interpretación estricta." La Circular de 14 de mayo de 1993, "Comentario de las disposiciones de la parte legislativa del nuevo Código Penal (libros I al IV) y de las disposiciones de la ley de 16 de diciembre de 1992 relativas a su entrada en vigor"- dicha circular ministerial fue elaborada por un grupo de trabajo compuesto por magistrados de distintas jurisdicciones, profesores universitarios, representantes del Colegio de Abogados y de la Policía- considera la interpretación estricta de la Ley un pilar básico del principio del legalidad. Con la consagración de la interpretación estricta se prohíbe la interpretación extensiva y la analógica (C. ARÁNGUEZ SÁNCHEZ y E. ALARCÓN NAVÍO, El código penal francés, op. cit., p.36).

157 RAFOLISY habla de "acto de la competencia o acto facilitado por ella" cinco veces en su trabajo. La única referencia a esta expresión en el marco del artículo 177 CPM no 


\section{B-LOS PRESUPUESTOS DE ACTO CONTRARIO A LOS DEBERES DEL CARGO Y SU EQUIVALENCIA EN EL DERECHO PENAL FRANCÉS}

\section{1-El alcance de la expresión "deberes propios del car-}

go"

Señalan MORALES PRATS y RODRÍGUEZ PUERTA que, lógicamente entre los deberes propios del cargo, se encuentran el de respetar la legalidad y el resto de obligaciones determinadas normativamente. Así, el acto objeto del cohecho en el artículo 419 CPE debe ser injusto en el sentido de contrario a las leyes - .ilegal - o los deberes propios del cargo ${ }^{158}$. El Tribunal Supremo, en una sentencia de 19 de diciembre de 2000 (ponente MARTÍN PALLÍN), ha venido admitiendo la existencia de este tipo de cohecho cuando no se vulnera una ley concreta pero sí se produce una infracción de principios constitucionales ${ }^{159}$.

Para examinar la concurrencia de este elemento, deberá llevarse a cabo un análisis detenido del acto a la luz de la normativa que regula el sector de actividad pública en el que éste se incardina. Esta cuestión no se presenta excesivamente problemática en aquellos casos en los que el funcionario, una vez alcanzado el acuerdo, ejecuta el acto al que se había comprometido. En estos supuestos, será suficiente con someterlo a un juicio de contraste con la legislación que se ocupa del sector de actividad, en particular, con aquellas normas administrativistas que guardan relación directa con el concreto acto ejecutado ${ }^{160}$. Añade MUÑOZ CONDE que en general, la realización de un acto contrario a los deberes del cargo puede ser constitutivo de alguno de los delitos cometidos por los funcionarios en el ejercicio de sus cargos (prevaricación, infidelidad en la custodia de documentos, revelación de secretos, etc.), pero también un mero ilícito administrativo, en cuyo caso queda también subsistente la posibilidad de una sanción disciplinaria. Evidentemente, si el acto es constitutivo de un delito entonces éste entrará en concurso con el cohecho, tal como dispone el último inciso del artículo 419 CPE 161 . Indica NIETO MARTÍN que el acto que ofrece o que se pretende del funcionario en este precepto es objetivamente ilícito, es decir, contrario a una norma jurídica de cualquier rango ${ }^{162}$.

\footnotetext{
da explicación sobre su posible contenido (P. RAFOLISY, La protection juridique..., op. cit., p.191).

158 F. MORALES PRATS y Mà . J. RODRÍGUEZ PUERTA, “Delitos...”, 2011, op. cit., p. 1225.

159 Entre otras sentencias SSTS 21-05-2007 y 2-12-2007 (Sentencias estudiadas y citadas por I. ORTIZ DE URBINA GIMENO, “Delitos...”, pp.337 y 338.

160 F. MORALES PRATS y Ma. J. RODRÍGUEZ PUERTA, “Delitos...”, 2011, op. cit., p. 1225. Añaden estos autores que hasta ahora esta cuestión era interpretada por los tribunales exigiendo que el acto fuera "ilegal"; es decir contrario objetivamente al ordenamiento jurídico y citan unas sentencias al respecto.

${ }^{161}$ F. MUÑOZ CONDE, Derecho penal, Parte especial,...2010, op.cit., p.1023. También se han pronunciado en este sentido L. MORILLAS CUEVA, “Delitos...”, op. cit., p.959; J. CARDONA TORRES, Derecho Penal..., op. cit., p.504.

162 A. NIETO MARTÍ́N, “Corrupción y abuso...”, op. cit., p.759.
} 
Otro sector de la doctrina española sostiene que el modo en que la contrariedad a Derecho se acredita, reside en el propio hecho de que la decisión no se adopta sobre la base de los principios de imparcialidad, objetividad y probidad que deben presidir la función pública, sino que está influida y predeterminada por el aliciente económico ${ }^{163}$.

La postura de la doctrina penal francesa tiende a combinar estas dos tendencias existentes en la doctrina española. Nota VITU que no hay que encerrarse en una concepción demasiado estrecha de la noción de acto de la competencia. El artículo 432-11 CPF debe ser considerado como una disposición general que sanciona penalmente toda violación remunerada de los deberes de obediencia, de probidad, de discreción y de fidelidad que conlleva el cargo del funcionario. Los actos de la competencia, no son sólo los que resultan de las disposiciones legales o reglamentarias que rigen el cargo sino también, y de manera más amplia, los que la disciplina de la función impone, independientemente de que ésta provenga de textos o de una especie de deontología sin formular pero cierta ${ }^{164}$.

A nuestro juicio, el planteamiento que defiende que la contrariedad a Derecho se concretiza cuando la decisión se adopta en contra de los principios de imparcialidad y objetividad o con la falta de honorabilidad, resulta demasiado genérico. En efecto, tanto el cohecho propio como el impropio, son comportamientos ilícitos y en cuanto tales, implican la violación de ciertos "deberes", el primero de ellos es el de no lesionar el bien jurídico protegido realizando la conducta típica; ahora bien, en la vertiente impropia del cohecho, el legislador hace referencia a una conformidad con los deberes del acto pactado, mientras que, en la primera (la propia), se exige explícitamente que exista una contrariedad del mismo acto a dichos deberes. De ello se deduce que el deber jurídico (de no lesionar el bien jurídico protegido) violado en ambos casos es necesariamente diverso de los "deberes del cargo" a los que se refieren ambas normas. Por consiguiente, el quebrantamiento por el funcionario del deber jurídico de no lesionar el bien jurídico protegido, tanto por el precepto sobre el cohecho propio como por la norma sobre cohecho impropio, es inidóneo para discernir el acto que es conforme a los deberes del cargo de aquellos otros contrarios a los mismos ${ }^{165}$.

\footnotetext{
163 J. QUERALT JIMÉNEZ, Derecho penal..., 2010, op. cit., p.1165. El autor fundamenta su postura con unas sentencias, entre otras: SSTS 21-12-1999, 19-12-2000, 7-1-2001, 26-6-2003. En términos parecidos, J. CARDONA TORRES, Derecho Penal..., op. cit., p.504; C. RAMOS RUBIO, Del delito de cohecho... op. cit., p.346.

164 A. VITU, Corruption passive..., op. cit., p.18. El autor da ejemplos de sentencias que consagran esta doctrina, entre ellas: cass. crim., 6-02-1968, Bull. crim. no37, cass. crim., 18-03-1955, Bull. crim. no181, cass. crim., 30-06-1999, Bull. crim. no168, cass. crim., 16-01-2001, Bull crim. no124, cass. crim 28-01-1909, Bull. crim. $\mathrm{n}$-55, etc. En el mismo sentido, M. VIGNAU, Le délit de corruption, op. cit., p.43; H. XIAO-YING, La lutte contre la corruption..., op. cit., p.71; F. CECCON, Contribution..., op. cit., p.41.
}

165 Con el mismo argumento rechaza CERINA las afirmaciones que intentan diferenciar la corrupción propia de la impropia por el quebrantamiento de un deber funcionarial de actuar "de forma correcta" o del deber de fidelidad ya que no es suficiente para 
En cuanto a la postura de la doctrina francesa, no estamos de acuerdo con VITU al considerar el artículo 432-11 CPF como una disposición general que sanciona penalmente toda violación remunerada de los deberes de obediencia, de probidad, de discreción y de fidelidad que conlleva el cargo del funcionario. Este planteamiento nos parece bastante genérico, puesto que la sección tercera del capítulo II (De los delitos contra la Administración Pública cometidos por personas que desempeñen un función pública) del Título III (De los delitos contra la autoridad del Estado) del Libro IV (De los delitos graves y menos graves contra la Nación, el Estado y la paz pública) del CPF, tiene como rúbrica "De los incumplimientos del deber de probidad"166. Por lo tanto, todos los delitos que se encuentran en la misma sección comparten con el delito de corrupción pasiva el quebrantamiento del deber de probidad. En otras palabras, si el legislador francés ha alzado este deber como bien jurídico de los delitos en la sección en estudio, eso significa que su lesión no es suficiente para que se caracterice el delito de corrupción pasiva. Lo mismo sucede con los demás deberes citados por VITU y la mayoría de la doctrina francesa especializada. El repaso de los delitos enumerados en el Capítulo II (De los delitos contra la Administración Pública cometidos por personas que desempeñen un función pública) nos lleva a la constatación de que muchos de ellos comparten con los de la tercera sección el mismo deber de probidad y los otros citados por la doctrina francesa ${ }^{167}$. Podemos concluir que toda violación remunerada de los deberes de obediencia, de probidad, de discreción y de fidelidad que conlleva el cargo del funcionario no implica necesariamente la aplicación del precepto del artículo 432-11 CPF. La misma observación se extiende al Derecho penal malgache, si la integridad es el valor protegido en el delito de corrupción pasiva previsto por el artículo 177 CPM, el incumplimiento de este deber no es decisivo para dar aplicación a este precepto.

Por otra parte, compartimos la propuesta de CERINA según la cual habrá que identificar un quid pluris del cohecho pasivo propio para diferenciarlo del impropio ${ }^{168}$, asumiendo que las dos vertientes de este delito tienen en común el deber jurídico de no lesionar el bien jurídico protegido. A nuestra manera de entender, esta misma operación nos ayudará a determinar los deberes del cargo cuyo incumplimiento impli-

\footnotetext{
establecer la contrariedad del acto a los deberes del caro y, por ende, a diferenciar las dos vertientes de la corrupción (G. D. M. CERINA, La lucha contra la corrupción, op. cit., pp.1000 y 1001).

${ }^{166}$ No estamos de acuerdo con la traducción propuesta por ARÁNGUEZ SÁNCHEZ y ALARCÓN NAVÍO de la rúbrica de esta sección. En efecto, al traducir "Des manquements au devoir de probité" por "De la corrupción pública" estos autores han ignorado el esfuerzo por parte del legislador francés para presentar cierta lógica sistemática (C. ARÁNGUEZ SÁNCHEZ y E. ALARCÓN NAVÍO, El código penal francés, op. cit., p.205).

167 Se puede citar como ejemplos de delitos del Capítulo II que comparten los mismos deberes con los de la tercera sección del mismo capítulo: los abusos de autoridad, los delitos contra la inviolabilidad del domicilio, los delitos contra el secreto de la correspondencia, etc.

168 G. D. M. CERINA, La lucha contra la corrupción, op. cit., p.1003.
} 
ca la aplicación del delito de corrupción pasiva, y no de otro tipo, en los sistemas jurídicos que no cuentan con la clasificación corrupción pasiva propia e impropia. Para individualizar correctamente este quid pluris no se puede circunscribir el cohecho propio a los casos de ilegitimidad del acto administrativo, ya que los actos del cargo pueden consistir en comportamientos materiales cuya esencia es la imposibilidad de ser objeto de una contestación en el ámbito contencioso-administrativo. Tampoco se puede considerar contrario a los deberes del cargo todo tipo de actuación que se opone a los genéricos deberes de fidelidad, de corrección o de imparcialidad. Somos partidarios de la idea según la cual este quid pluris que distingue la hipótesis propia de la impropia, debe cifrarse en el deber específico de uniformar los concretos actos del cargo o de la función a las normas de ley o a las otras directrices de la Administración Pública pero haciendo referencia a toda violación de la ley o de normas emitidas por la Administración Pública (reglamentos, circulares, instrucciones de servicio...y hasta costumbres) ${ }^{169}$.

Por consiguiente, la violación de los así llamados deberes específicos podrá implicar la aplicación del tipo de corrupción pasiva, para los sistemas penales que no contemplan la diferencia entre corrupción pasiva propia e impropia, es decir, los artículos 432-11 CPF y 177 CPM, o de cohecho pasivo propio, esto es, artículo $419 \mathrm{CPE}$, sólo en la medida en que el acto concordado resulte no genéricamente infiel, sobre la base de una evaluación aséptica de la contrariedad al deber, sino concretamente idóneo a producir una ofensa al principio de legalidad de la Administración misma. De tal manera que, por ejemplo, la inversión del orden cronológico en el cual se ha de analizar un expediente, determinará cohecho propio sólo si existe una norma (legal o reglamentaria), o una directriz o una praxis de respetar este orden cronológico. Asimismo, se puede calificar como cohecho propio el caso del enfermero que, mediando un soborno, comunica la muerte de un paciente a una empresa funeraria, permitiendo a esta última aprovechar la noticia poniendo sus servicios a disposición de los familiares, siempre y cuando sea posible indi-

\footnotetext{
169 Ibídem, op. cit., pp. 1004 y 1005. Siguiendo la misma línea argumentativa, el autor opina que esta orientación interpretativa permite, por un lado, apartarse de quienes considera propia la corrupción cuya finalidad se halle en contraste con el genérico deber de fidelidad, corrección o imparcialidad ni tampoco cuando el comportamiento del funcionario se presente como contrario a normas cuyo respeto obliga indistintamente a todos los ciudadanos ya que se mantiene que en tanto en cuanto subsistan los requisitos prescritos por el ordenamiento y el intraneus pacte o acepte una retribución para realizar el acto, tendremos corrupción impropia, mientras los deberes del oficio que resultan violados en el caso de corrupción propia son aquéllos que el incumben al funcionario y que descienden del propio ordenamiento jurídico, es decir, de normas de ley, reglamento, instrucciones relativas al servicio a desempañar. Por otro lado, esta tesis resulta idónea para explicar también la contrariedad/conformidad a los deberes del cargo de aquellos comportamientos materiales de los funcionarios, respecto de los cuales, en todo caso, será posible hablar -si bien no de legitimidad strictu sensu- de adecuación a leyes o reglamentos que disciplinan el desarrollo de la actividad del funcionario o del agente público, o bien de compatibilidad con las instrucciones u órdenes recibidas.
} 
vidualizar una norma (legal o reglamentaria), una orden o una praxis que prohíba a la Administración revelar esa clase de información.

Dicho de otra forma, la noción de acto contrario a los deberes del cargo, ha de interpretarse necesariamente de forma rigurosa, es decir, restrictivamente, refiriéndola a los deberes específicos del todo diversos del deber genérico o general violado por una como por otra vertiente del delito ${ }^{170}$.

\section{2-El alcance de la contrariedad a Derecho}

Defiende un sector de la doctrina española que la contradicción con el derecho del acto, o con los deberes del funcionario, no debe hacerse de modo meramente formal. Así, no procede calificar de injustas, o contrarias a los deberes del cargo, las decisiones en las que el funcionario se sustrae a la aplicación de requisitos formales de menor entidad -como, por ejemplo, la concreta competencia para emitir la resolución, la falta de presentación de documentos acreditativos, etc.-. En cambio, merecen la consideración de contrarias a los deberes del cargo aquellas resoluciones o actos que presentan una contradicción entre su contenido y el ordenamiento jurídico; también aquéllas que omiten formalidades de carácter esencial o siendo accidentales, cuando su concurrencia hubiera variado la decisión sobre el fondo del asunto ${ }^{171 .}$

A nuestro modo de ver, este intento de excluir del ámbito de lo relevante (a efectos de calificar el acto de injusto, o contrario a los deberes del cargo) los meros vicios de forma, formulado en estos términos, no se debe compartir. Hay que diferenciar en primer lugar, entre aquellos vicios de forma, invalidantes del acto (que lo hacen nulo o anulable) y aquellos otros que inclusive el Derecho administrativo considera como irrelevantes ${ }^{172}$. Explica CERINA que a la luz del artículo 63 (citado en la nota anterior) de la Ley 30/1992, de 26 de noviembre, de Régimen Ju-

170 Ibídem, op. cit., pp. 1005 y 1006.

171 F. MORALES PRATS y Ma ${ }^{2}$. J. RODRÍGUEZ PUERTA, “Delitos...”, 2011, op. cit., p. 1225; Mà. J. RODRÍGUEZ PUERTA, El delito de cohecho..., op. cit., pp.220 y 221; I. VALEIJE ÁLVAREZ, El tratamiento..., op. cit., pp. 216 y 217, para quien un acto será reputado o no injusto según las distintas actividades que representan el medio de actuación o que han contribuido a hacer posible el presupuesto de hecho estén o no exentas de irregularidades. Pero no todas las irregularidades del acto deberán ser tenidas en cuenta, sino sólo aquellas que atribuyan a la conducta del funcionario una capacidad lesiva para el bien jurídico tutelado. No podrán ser reputados de injustos aquellos defectos o vicios que en relación al caso concreto se presienten como no significativos por inidóneos para contribuir a la dimensión lesiva del tipo.

172 Obsérvese, por ejemplo, que, de acuerdo con el artículo 63 de la Ley 30/ 1992, de 26 de noviembre, de Régimen Jurídico de las Administraciones Públicas y del Procedimiento Administrativo Común, resultan “...anulables los actos de la Administración que incurran en cualquier infracción del ordenamiento jurídico, incluso la desviación de poder. 2. No obstante, el defecto de forma sólo determinará la anulabilidad cuando el acto carezca de los requisitos formales indispensables para alcanzar su fin o dé lugar a la indefensión de los interesados. 3. La realización de actuaciones administrativas fuera del tiempo establecido para ellas sólo implicará la anulabilidad del acto cuando así lo imponga la naturaleza del término o plazo." 
rídico de las Administraciones Públicas y del Procedimiento Administrativo Común, puede concluirse que se dice cosa exacta cuando se afirma que el acto que presenta un defecto de forma no siempre se convierte por esto mismo en injusto, pero se yerra profundamente cuando no se reconoce que el acto administrativo objeto del acuerdo corrupto será injusto cuando anulable a tenor de lo establecido por el artículo 63 LPC sin necesidad de ulteriores e innecesarios matices (por lo menos, toda vez que el acto objeto del acuerdo sea un acto calificable como acto administrativo). Y, en efecto, si es cierto que no hay Derecho menos formalista que el Derecho administrativo y que el vicio de forma implica invalidez del acto administrativo sólo en los casos en los que el acto carece de los requisitos indispensables para alcanzar su fin, se dicte fuera del plazo previsto, cuando éste tenga carácter esencial o se produzca una situación de indefensión, no se ven razones por las que el juez penal, a la hora de comprobar la injusticia del acto administrativo objeto del acuerdo, deba apartarse de tales indicaciones proporcionadas por el propio legislador ${ }^{173}$.

Llegamos a la conclusión de que lo importante para el Código penal español no es el tipo de vicio que el funcionario consiente al aceptar alguna retribución, en caso de que se trate de un acto administrativo, ni la categoría de acto según su capacidad de lesionar el bien jurídico, sino la consciencia del funcionario de que la finalidad del soborno es un acto que va en contra de sus deberes.

En cuanto a la competencia, aunque ya hemos tenido la oportunidad de ver esta cuestión, un sector de la doctrina española admite que algunos de los actos hacia los cuales el funcionario es "genéricamente competente" configuran un supuesto de cohecho propio, pero no conviene hablar técnicamente de "competencia" ya que, "la ley nunca confiere competencia para la realización de actos injustos o ilícitos"174.

Sin entrar en las complicadas comparaciones de las categorías de incompetencia propuestas por la doctrina penal comparada ${ }^{175}$, lo importante en esta parte del trabajo es saber en qué medida la incompetencia puede ser hipótesis de cohecho propio. Recordemos la postura de un sector de la doctrina española que sostiene que la competencia para emitir una resolución hace parte de estas decisiones en la que el funcionario se sustrae a la aplicación de requisitos formales de menor entidad y por tanto no procede calificarlas de injustas. Ante esta postura, somos partidarios de la tesis según la cual las normas sobre competencia implican un deber jurídico de no actuar (si el funcionario A es incompetente para dictar el acto $\mathrm{X}$, tiene el deber jurídico de no dictar el acto $X$ ) lo correcto es considerar que el acto viciado por incompetencia, en tanto en cuanto contrario a una norma específica de Derecho positivo, es in-

\footnotetext{
173 G. D. M. CERINA, La lucha contra la corrupción, op. cit., p.1040.

174 I. VALEIJE ÁLVAREZ, El tratamiento..., op. cit., p.201; I. OLAIZOLA NOGALES, El delito de cohecho, op. cit., p.274

175 G. D. M. CERINA, La lucha contra la corrupción, op. cit., pp.1043 y 1044.
} 
justo y, por tanto, si es objeto de un pacto corrupto, integra siempre una hipótesis de cohecho propio y no impropio ${ }^{176}$.

Ahora bien, ¿cómo distinguir el acto injusto por estar viciado de incompetencia del acto penalmente atípico a efectos de cohecho?

Nos parece contundente la respuesta de CERINA al respecto. Este autor propone una clasificación inspirada en la doctrina italiana que distingue la incompetencia relativa y la incompetencia absoluta: la primera permite clasificar el acto de anulable y, puesto que, hasta la declaratoria de la nulidad, el mismo produce efectos y después de la misma, ya no los produce, el acto puede considerarse lesivo de la legalidad de la actuación de la Administración Pública. De ahí que, al acto objeto del acuerdo viciado por incompetencia relativa y anulable, se le califica como idóneo para integrar un supuesto de cohecho propio.

En el caso de la incompetencia absoluta, en cambio, el hecho de que el acto tenga que considerarse nulo, parece excluir de raíz que pueda hablarse de acto realizado en el ejercicio del cargo, ya que el intraneus no sólo tiene un deber jurídico de no actuar, sino que el hecho de ser funcionario público no le atribuye ningún poder para hacerlo, de tal manera que su actuación (al igual que aquélla de cualquier particular que los realizara), en principio, no es idónea ni para constituir ni para modificar ni para extinguir situaciones jurídicas subjetivas relevantes para el ordenamiento.

En España, de acuerdo con lo dispuesto por los artículos 62 y 63 de la Ley 30/1992, de 26 de noviembre, de Régimen Jurídico de las Administraciones Públicas y del Procedimiento Administrativo Común, el acto administrativo será nulo de pleno derecho (con todas las consecuencias que ello conlleva) toda vez que la incompetencia por razón de la materia o del territorio, del órgano que lo dicta es manifiesta177. En todos los demás supuestos de incompetencia, el acto mismo resulta anulable.

Por lo tanto, se propone considerar como atípico el pactum sceleris que pretenda la realización, por parte del funcionario, de un acto subsumible en el supuesto del artículo 62.1 letra b) LPC (ya que resulta difícil considerarlo como realizado en el ejercicio del cargo), mientras que podrá sin problemas considerarse como injusto todo acto administrativo (o actuación) hacia el cual el sujeto no resulte directamente competente (y que sea, por ende, anulable) ${ }^{178}$.

\footnotetext{
176 Ibídem, op. cit., p. 1045.

${ }^{177}$ Así establece el artículo 62.1 letra b).

178 G. D. M. CERINA, La lucha contra la corrupción, op. cit., pp.1045 y 1046. Observa el autor que la tesis resiste a la objeción principal que se le plantea: la misma, en efecto, parece idónea para ser aplicada incluso a aquellos "actos" penalmente relevantes que no constituyan actos administrativos recurribles.
} 
A nuestro juicio, el legislador español de 2010 ha precisado los criterios para la aplicación del artículo 419. En primer lugar, el acto objeto del acuerdo tiene que ser realizado "en el ejercicio de su cargo", lo cual significa que todo vicio de incompetencia que lleva a la exclusión del acto pactado del ordenamiento jurídico con la consecuencia de que no puede producir los efectos jurídicos esperados, no puede integrar una hipótesis de cohecho propio, sino de otro delito (por ejemplo, delito de estafa ${ }^{179}$ ). En cambio, si el mismo vicio no afecta a la existencia del acto y sus efectos, entonces, sí, se aplicará el artículo 419. Si bien es cierto que no es cometido del juez penal - compete a los jueces de la jurisdicción contenciosa-administrativa - el tutelar derechos subjetivos o intereses legítimos que lesionan por un acto de la Administración ${ }^{180}$, la existencia de un vicio que afecta a un acto no le impide valorar su alcance y determinar a partir de ello el delito que objetivamente ha cometido el funcionario. Por lo tanto, no estamos de acuerdo con la postura de RODRÍGUEZ PUERTA quien defiende que "serán irrelevantes aquellos vicios de forma o procedimiento que no afecten al fondo del asunto o actividad objeto del cohecho, con independencia de que se trate de vicios que convierten el acto en nulo o anulable"181. Tanto la nulidad como la anulabilidad de un acto influyen en la aplicación o no del artículo 419 CPE, y aunque se trata de vicio de forma o procedimiento que no afecta al fondo del asunto, ese hecho es relevante para el legislador español de 2010 siempre y cuando un deber específico del cargo haya sido violado con una finalidad retributiva.

Para la doctrina francesa, el acto que no integraría en el tipo de corrupción pasiva es aquél que, por su naturaleza, escaparía totalmente a las atribuciones del agente público ${ }^{182}$, ya que la letra del artículo 432-11 CPF habla de "acto propio de su función, de su servicio o de su mandato"183. Esta interpretación de la doctrina francesa ha sido reconocida por la jurisprudencia, después de un período de indecisión, con la sentencia de las Salas reunidas del 31 de marzo de 1827184.

Eso significa que en Derecho penal francés el acto viciado por incompetencia puede integrar una hipótesis del artículo en estudio mientras exista algún vínculo o cierta proximidad entre el acto viciado y la competencia personal del agente público, de lo contrario sugiere la doctrina francesa subsumirlo bajo otra calificación y no dejarlo sin represión ${ }^{185}$.

\footnotetext{
${ }^{179}$ M‥ J. RODRÍGUEZ PUERTA, El delito de cohecho..., op. cit., p.221.

180 I. VALEIJE ÁLVAREZ, El tratamiento..., op. cit., p.216.

181 Mà. J. RODRÍGUEZ PUERTA, El delito de cohecho..., op. cit., p.221. La cursiva es nuestra. I. VALEIJE ÁLVAREZ, El tratamiento..., op. cit., p.217.

${ }^{182}$ H. XIAO-YING, La lutte contre la corruption..., op. cit., p.72; A. VITU, Corruption passive..., op. cit., p.19 ; M-P. LUCAS de LEYSSAC y A. MIHNAN, Droit pénal des affaires..., op. cit., n-1029; M. VIGNAU, Le délit de corruption, op. cit., p.45.

${ }^{183}$ Esta traducción propuesta por RODRÍGUEZ PUERTA nos parece más cercana del texto original (ver Mํ. J. RODRÍGUEZ PUERTA, El delito de cohecho..., op. cit., p.312)

184 A. VITU, Corruption passive..., op. cit., p.20, repasa con más detalles la evolución de la jurisprudencia francesa al respecto.

185 Ibídem, op. cit., p.20.
} 
Aunque no encontramos en el debate la clasificación de incompetencia relativa o absoluta, hay una similitud en el fondo. El acto, viciado por incompetencia, tiene que ser "propio" de la función, del servicio o del mandato, es decir, realizado en el ejercicio de la competencia.

Por otro lado, es de notar que el juez penal francés tiene, en virtud del artículo 111-5 CPF186, amplio poder para "interpretar y valorar la legalidad de todos los actos administrativos con la única condición de que de este examen dependa el resultado del proceso penal"187. A nuestra manera de entender, independientemente de las consecuencias de la valoración de la legalidad del acto objeto del acuerdo de corrupción, sea la nulidad o la anulabilidad, este poder conferido a las jurisdicciones penales es innecesario para establecer la existencia del delito de corrupción pasiva. En efecto, la legalidad de un acto no es determinante para la aplicación del artículo 432-11 $\mathrm{CPF}^{188}$. Un acto puede ser declarado perfectamente legal e integrar un supuesto de delito de corrupción. En materia de vicio por incompetencia, si este elemento lleva al juez penal a declarar anulación del acto salvaguardando algunos de sus efectos, se podría contemplar la existencia del delito de corrupción. En cambio, si con el mismo elemento se pronuncia su nulidad de pleno derecho, entonces el acto será atípico a efectos de corrupción y se subsumirá bajo otra calificación.

\section{3-Los actos discrecionales}

Se recuerda que el acto discrecional es aquél en el que el funcionario puede optar libremente entre varias soluciones igualmente justas, porque la decisión se fundamenta en criterios extrajurídicos (de oportunidad, económicos, etc. ${ }^{189}$. Se plantea el problema de dilucidar cuándo es injusto, si en algún caso lo es, el acto que siendo una de las alternativas correctas, es realizado por el funcionario a cambio de la dádiva recibida. La doctrina española entiende que discrecionalidad no es, de ninguna manera, sinónimo de arbitrariedad ${ }^{190}$ y que, por ende, el poder de elegir

\footnotetext{
186 Dispone el artículo 111-5 CPF: “Los Jueces y Tribunales penales son competentes para interpretar los actos administrativos, reglamentarios o individuales, y para decidir acerca de su legalidad cuando de este examen dependa la decisión del proceso penal que se les somete."

187 Circular de 14 de mayo de 1993 (Lib I, Tit. I, Cap. 1--D) "Comentario de las disposiciones de la parte legislativa del nuevo Código Penal (Libros I al IV) y de las disposiciones de la ley de 16 de diciembre de 1992 relativas a su entrada en vigor" citada por C. ARÁNGUEZ SÁNCHEZ y E. ALARCÓN NAVÍO, El código penal francés, op. cit., p.36. Esta norma añade que "de esta manera, ya no se mantendrá la distinción entre actos individuales y reglamentarios o entre los actos penalmente sancionados y los demás. En efecto, el Parlamento ha decidido que prevalezca sobre cualquier consideración la protección de la libertad individual. que el juez penal debe salvaguardar."

188 Véase, el análisis en este sentido de G. D. M. CERINA, La lucha contra la corrupción, op. cit., pp.1036 y ss.

189 Mà. J. RODRÍGUEZ PUERTA, El delito de cohecho..., op. cit., p.218; I. OLAIZOLA NOGALES, El delito de cohecho, op. cit., p.286.

190 Véase el estudio doctrinal propuesto por I. OLAIZOLA NOGALES, El delito de cohecho, op. cit., pp.289 y ss.
} 
del funcionario ha de desarrollarse de acuerdo con las pautas normativas establecidas para ello. Dicho ello, el ejercicio "abusivo" del poder discrecional se relaciona comúnmente con aquel vicio del acto administrativo que se identifica con la desviación de poder. En este sentido, suele precisarse que el acto discrecional que se emana con finalidades distintas de las que la ley (en sentido amplio) le atribuye, resulta anulable y penalmente injusto ${ }^{191}$.

Explican MORALES PRATS y RODRÍGUEZ PUERTA que, para comprobar la adecuación de un acto discrecional al ordenamiento jurídico, deberá recurrirse a las técnicas de control de la actividad discrecional propias de la disciplina administrativa. Así, para apreciar esta forma grave de cohecho habrá de acreditarse que no se cumplen, por ejemplo, las condiciones legales que autorizan su adopción, pues, de no quedar probada tal circunstancia, la sola motivación de lucro - que pudo llevar al funcionario a adoptar tal decisión - no será suficiente para calificarla de injusta (o contraria a los deberes del cargo) ${ }^{192}$. Añaden estos autores que una solución interpretativa contraria a este planteamiento conduciría a anular las diferencias entre la modalidad de cohecho de los artículos 419 y $420 \mathrm{CPE}$, cuando el acto objeto de la transacción fuera discrecional. La referencia a la contravención de los deberes del cargo no debería anular la diferencia entre actos administrativos conformes a la legalidad y contrarios a ella, sobre todo cuando el acto discrecional se ha ejecutado y es posible enjuiciar su conformidad, en concreto, a Derecho' ${ }^{193}$.

Por otro lado, destaca OLAIZOLA NOGALES que el funcionario que no se inspire en intereses generales o no persiga en el caso específico el objetivo particular concreto en virtud del cual viene atribuido el poder en cuestión, o no respete los preceptos que impone la lógica o la imparcialidad, estará violando las reglas que disciplinan el ejercicio del poder discrecional, y por ello será injusto o delictivo si es resolutivo ${ }^{194}$.

A nuestra manera entender, esta postura se debe rechazar ya que en el delito de cohecho, tanto propio como impropio, el funcionario se inspira siempre en intereses particulares y nunca en intereses generales: si fuera cierto el primer inciso de la frase mencionada (si el funcionario no

\footnotetext{
191 G. D. M. CERINA, La lucha contra la corrupción, op. cit., p.1047

192 En términos diferentes lo plantea NIETO MARTÍN quien defiende que en este grupo de casos, en el que se trata de un comportamiento discrecional, el cohecho propio no deriva de la naturaleza del acto, sino del proceso de adopción del mismo. Por eso debe demostrarse que la contraprestación se solicitaba, ofrecía o se aceptaba con el fin de influir en la decisión (u omisión) del funcionario o autoridad. No es suficiente por tanto la simple prueba de la oferta, aceptación o solicitud. No obstante, cuando la oferta parte del funcionario o autoridad, en términos probatorios es fácil colegir que piensa actuar motivado por la ventaja patrimonial (A. NIETO MARTÍN, “Corrupción y abuso...", op. cit., p.759).

${ }^{193}$ F. MORALES PRATS y Mํ. J. RODRÍGUEZ PUERTA, “Delitos...”, 2011, op. cit., p. 1226. Para más detalles, véase Ma. J. RODRÍGUEZ PUERTA, El delito de cohecho..., op. cit., pp.226 y ss.

${ }^{194}$ I. OLAIZOLA NOGALES, El delito de cohecho, op. cit., p.292.
} 
se inspira en intereses generales, el acto será injusto), obtendremos que el acto discrecional objeto del acuerdo será siempre injusto, lo cual, no es aceptable. El error de perspectiva se encuentra en la elección del sujeto de la oración: en efecto, el juez penal, a la hora de evaluar la contrariedad/conformidad a Derecho del acto discrecional, deberá tener en cuenta no el móvil del funcionario ni sus finalidades personales, sino la valoración de la finalidad del acto. Además, se deberá investigar si el poder discrecional, amén que responder al fin con apoyo en el cual se ha concedido, ha sido ejercido en el respeto de las reglas jurídicas establecidas. En este marco, es incorrecto individualizar las normas de referencia en la "lógica" o en la "imparcialidad": respecto de la primera, no parece representar fuente del ordenamiento jurídico, ni penal ni administrativo; respecto de la segunda, en cambio, vale la pena repetir una vez más que la imparcialidad, en tanto en cuanto resulta lesionada tanto por el cohecho propio como por el impropio, es inidónea para distinguir el acto conforme del contrario a Derecho ${ }^{195}$.

Este tipo de debate no existe en la doctrina o la jurisprudencia francesas, ya que sabemos que el CPF no contempla la clasificación de corrupción pasiva propia e impropia. Sin embargo, nada le impide al juez penal tomar en cuenta las situaciones de desviación de poder y manifestar un mayor desvalor a través de las penas, las cuales deberían ser diferentes si el agente público cumpliera con todas las condiciones legales que conforman los actos discrecionales o si no se probara la existencia de alguna desviación, respetando de esta forma el principio de proporcionalidad.

\section{4-Los actos no realizados}

Analizan MORALES PRATS y RODRÍGUEZ PUERTA, en su comentario al artículo $419 \mathrm{CPE}$, la manera de determinar el carácter contrario a los deberes del cargo, de aquellos actos que no llegaron a ejecutarse. En primer lugar, según estos autores, en estos supuestos será necesario identificar mínimamente cuáles fueron los términos del acuerdo o de su intento, de modo que el acto objeto del cohecho pueda ser determinado, o cuanto menos, determinable. De no ser así, se aplicará el artículo 420 y no el 419 CPE. En estos supuestos - actos objeto de soborno que no llegan efectivamente a practicarse - también se debe distinguir entre actos reglados y actos discrecionales. Para los primeros, deberá recurrirse a parámetros objetivos con el fin de identificar y determinar su "injusticia". Esto es, habrá de comprobarse, en atención a lo pactado, que la finalidad que se pretendía obtener era contraria al ordenamiento jurídico. Si, por el contrario, se trata de actos discrecionales, será necesario probar que el funcionario, cuando aceptó o solicitó la retribución, renunció al correcto uso de sus poderes discrecionales. Así, si sucede, por ejemplo, cuando se acuerda hacer un uso distinto o indebido de los mismos, excluyendo la posibilidad de que otros obtuvieron una obra o

195 G. D. M. CERINA, La lucha contra la corrupción, op. cit., p.1047 
contrato de suministros, evacuando informes para incidir injustificadamente en la voluntad del funcionario que debe decidir, etc. De no probarse que el acuerdo iba dirigido a la adopción de una decisión discrecional que resulta injusta para la concurrencia de alguna de las circunstancias indicadas, sería de aplicación el artículo 420 CPE. Concluyen los mismos autores que esta interpretación en clave material del significado del "acto contrario a los deberes del cargo", se acomoda al fundamento de esta modalidad de cohecho y permite diferenciarlo de los supuestos de cohecho impropio del artículo 420 CPE. En los casos examinados (artículo $419 \mathrm{CPE}$ ), la obtención de un beneficio ilícito resulta claramente facilitada, cuando el funcionario se compromete a adoptar una decisión, favorece injustamente al particular que solicita la dádiva, ya que este último obtendrá una decisión que, de no mediar una remuneración, no hubiera podido obtener, pues sus pretensiones son contrarias al ordenamiento jurídico en sentido amplio ${ }^{196}$.

Aunque en el marco de la redacción anterior la doctrina especializada ha criticado la técnica legislativa utilizada por plantear un problema con el principio de "ne bis in idem"197, a nuestra manera de entender, sigue siendo válida la idea según la cual la ejecución o no del acto injusto no añade mayor contenido de desvalor al injusto propio del delito de cohecho ${ }^{198}$. Por lo tanto, el legislador español de 2010 supo aprovechar la oportunidad de no diferenciar en cuanto a pena en virtud de si se realiza o no el acto injusto.

Por otra parte, en orden a la equiparación entre el acuerdo que tiene como finalidad la realización de un acto delictivo o no delictivo, opina CERINA que el propio juez penal podrá graduar la sanción a imponerse dentro de los límites legales (suficientemente amplios), teniendo en cuenta la naturaleza del acto no realizado ${ }^{199}$.

En la doctrina francesa no hemos encontrado este tipo de planteamiento pues se limita a destacar la importancia del pacto corruptor alcanzado independientemente de que se cumpla o no lo que se ha prometi$\mathrm{do}^{200}$. A nuestro modo de ver, a pesar de que el legislador no haya establecido la diferencia entre cohecho pasivo propio e impropio, nada le impide al juez penal francés y malgache, por un lado, valorar el acto objeto del pacto de corrupción y por otro lado, tener en cuenta la ejecución o no del acto, a efectos de graduar la sanción para el autor de cohecho con las circunstancias concretas, incluyendo la conminación (o no

\footnotetext{
196 F. MORALES PRATS y Ma. J. RODRÍGUEZ PUERTA, “Delitos...”, 2011, op. cit., p. 1226. 197 I. OLAIZOLA NOGALES, El delito de cohecho, op. cit., p.293; G. D. M. CERINA, La lucha contra la corrupción, op. cit., p.1076.

198 I. OLAIZOLA NOGALES, El delito de cohecho, op. cit., p.293.

${ }^{199}$ G. D. M. CERINA, La lucha contra la corrupción, op. cit., p.1207.

${ }^{200}$ Entre todos, M. DELMAS-MARTY y G. GIUDICELLI-DELAGE, Droit pénal des affaires, op. cit., p.290.
} 
conminación) al funcionario de una sanción disciplinaria (o indemnizatoria) ${ }^{201}$.

\section{5-Los casos de "transfuguismo retribuido"}

Defienden MORALES PRATS y RODRÍGUEZ PUERTA que al utilizar los términos "acto contrario a los deberes del cargo", el legislador español de 2010 ha resuelto la problemática que planteaba la inclusión en esta forma grave de cohecho de las decisiones de naturaleza política ${ }^{202}$, lo que se ha denominado el "transfuguismo retribuido". La adopción por el funcionario de un acto de ese tipo (votar a favor o en contra de una moción de censura, de una modificación del plan urbanístico o cambiar de partido, etc.) a cambio de una ventaja, planteaba problemas de subsunción, al referirse los anteriores artículos 419 y 420 CPE a actos injustos. En estos casos, la actividad comprometida vinculada por el funcionario se convertía en injusta precisamente por estar causalmente vinculada a la obtención de una ventaja ${ }^{203}$. Es decir, de llevarse a cabo la misma conducta sin mediar precio (por una modificación en la estrategia del partido u otra finalidad cualquiera), la calificación de la misma no podía merecer la consideración ni de injusta ni de contraria a Derecho.

Los mismos autores explican que la caracterización de estos supuestos como formas de cohecho grave (cohecho propio) será ahora más fácilmente argumentable al no requerir, el artículo $419 \mathrm{CPE}$, que el acto objeto del cohecho sea injusto sino únicamente contrario a los deberes del cargo. Quienes desempeñan esta clase de actividad, gozan de un margen de actuación discrecional mucho más amplio que en el resto de empleados adscritos en la esfera pública. Muestra de ello es la imposibilidad de que estos cometan el delito de prevaricación con relación a la adopción de actos políticos. En relación a este tipo de actividad pública, sea cual fuere el acto adoptado (y su sentido), desde un prisma estrictamente objetivo, éste no podrá ser calificado de injusto. Si la decisión ha venido motivado por intereses privados (por ejemplo, porque se ha recibido una cantidad de dinero), el funcionario habrá actuado movido por fines ajenos o contrarios a los que legalmente justifican sus atribuciones representar los intereses del partido político en nombre de quien actúan y de los electores a los que representan -, pero la resolución no perderá por tal circunstancia su objetiva sujeción a la legalidad. Sin embargo, aunque el acto logrado por esta vía no pueda merecer la consideración de injusto 204 ; no existe inconveniente en calificarlo de contrario a los deberes del cargo por cuanto la decisión se ha desviado del fin que la legitima. Este tipo de decisiones o actos políticos podrán ser calificados de arbitrarios y contrarios a los deberes en el sentido del artículo

${ }^{201}$ En términos parecidos, G. D. M. CERINA, La lucha contra la corrupción, op. cit., p.1076.

202 A. NIETO MARTÍN, “Corrupción y abuso...”, op. cit., p.759.

${ }^{203}$ C. MIR PUIG, El delito de cohecho en la reforma...op. cit., p.46

204 Véase al respecto la STS 11-05-1994 [RJ 1994, 3687] 


\section{PARTE II: ESTUDIOS DE LOS ELEMENTOS TÍPICOS...}

419 CPE, pese a no cercenar el principio de legalidad, ni ponerlo en pe$\operatorname{ligro}^{205}$.

Con una postura matizada, reconoce QUERALT JIMÉNEZ que la compra del voto de miembros de asambleas corporativas (parlamentos y plenos de corporaciones locales) es un tema poliédrico $\mathrm{y}$, por tanto, de difícil solución. Pese a la gravedad del hecho y pese a constituir la muestra evidente del llamado transfuguismo político, es una especie que cae de lleno en este ámbito pero con limitaciones, no presenta siempre un perfil de tipicidad, por más que su inmoralidad resulte evidente. Hay que distinguir cuando las asambleas realizan actos de soberanía de cuando realizan actos de administración, pues sólo estos están incursos entre los delitos que ahora nos ocupan. Así es, quedará fuera del tipo la conducta venal del sobornado cooperando a confeccionar un acto soberano - una ley, un nombramiento, por ejemplo -; en cambio, si la compra del voto es para aplicar la ley, sí resulta típica la corrupción, pues un acto a efectos penales-administrativos: aplicación de la norma, no creación soberana de la misma. La diferencia estriba en la categoría del acto: dictar una ley nunca puede ser delito; en cambio dictar un reglamento $\mathrm{u}$ otra aplicación normativa, sín ${ }^{206}$; de ahí que este delito no lo puedan cometer los diputados, estatales o autonómicos y sí eventualmente, los alcaldes, concejales diputados provinciales cuando votan en el pleno del órgano de la Administración local; por ello, el cambio de voto, por compra, de un concejal o de cualquier otro miembro de una corporación local deberá ser ponderado caso a caso. Cuando efectúe actuaciones políticas (incluida la dimisión), el autor entiende que la compra del voto es impune; en otros supuestos, si se dictan normas que desarrollan otras (ordenanzas) y la resolución de cualquier petición (otorgamiento o denegación de licencias) sí será punible ${ }^{207}$.

A nuestro modo de ver, nos parece más contundente la postura de MORALES PRATS y RODRÍGUEZ PUERTA, ya que se destaca la elección del legislador español de 2010 para intentar alcanzar situaciones que anteriormente planteaban dudas al utilizar términos más genéricos ${ }^{208}$. De esta forma no hay lugar para muchas categorías de acto contrario a los deberes del cargo. No estamos de acuerdo con QUERALT JIMÉNEZ al hacer la distinción entre los actos de las diversas asambleas normativas. En efecto, los actos de soberanía son actos del cargo, y justamente, como ya hemos señalado, el término "acto" no puede ser confundido con "acto administrativo" sino que tiene una concepción bastante más amplia ${ }^{209}$. Y también es cierto que "dictar una ley nunca puede ser delictivo", sin embargo "hacer una ley" sí puede entrañar una conducta delic-

205 F. MORALES PRATS y Ma. J. RODRÍGUEZ PUERTA, “Delitos...”, 2011, op. cit., pp. 1224 y 1225. Véase también la STS 12-12-2008 [RJ 2008, 1559]; Mạ. J. RODRÍGUEZ PUERTA, “Modificaciones..." op. cit., pp.468 y 469.

206 STS 19-12-2000.

${ }^{207}$ J. QUERALT JIMÉNEZ, Derecho penal..., 2010, op. cit., p.1166.

${ }^{208}$ F. MORALES PRATS y Ma. J. RODRÍGUEZ PUERTA, “Delitos...”, 2011, op. cit., p. 1224.

209 I. VALEIJE ÁLVAREZ, El tratamiento..., op. cit., pp.191 y ss.; Ma. J. RODRÍGUEZ PUERTA, El delito de cohecho..., op. cit., pp.204 y ss. 
tiva. En nuestra opinión, nada obsta a que un parlamentario o varios de un grupo puedan solicitar una cantidad de dinero por votar a favor o en contra de determinada disposición o por presentar un proyecto de ley. La inmunidad parlamentaria por los votos u opiniones expresadas en el ejercicio de la función legislativa no excluye la responsabilidad penal por estos hechos ${ }^{210}$. Asimismo, un nombramiento por parte del poder ejecutivo que puede constituir un acto soberano y cuyo control de legalidad no compete a ninguna jurisdicción, puede dar lugar a la comisión de un delito de cohecho. Lo importante para el legislador español de 2010 no es la categoría del sujeto activo ni de los actos jurídicos tomados por él, sino la desviación de los fines que legitiman sus atribuciones.

En la doctrina penal francesa este planteamiento se sustentó desde la vigencia del CPF de 1810. Se debatía si el parlamentario podía cometer el delito de corrupción previsto en el aquel entonces artículo 177 CPF. GARRAUD contestó negativamente y defendió que esta categoría de personas no eran funcionarios públicos del orden administrativo o judicial, y, además, era difícil admitir que las gestiones o recomendaciones hechas por un miembro de una asamblea deliberante o de un consejo elegido pudieran constituir, un acto de la función o del cargo ${ }^{211}$. GARÇON replicó a esta postura y sostuvo que se trataba de una confusión entre el tráfico de influencias con la corrupción propiamente dicha, que es el tráfico de la función. "Es manifiesto que el miembro de un órgano elegido que acepta regalos, no para hacer gestiones sino para votar en tal o cual sentido, o apoyar tal o cual proyecto, trafica su función y no su influencia, con lo cual no hay razón para exceptuarlos del rigor de la ley"212.

En la actualidad, se considera que puede cometer un delito de corrupción pasiva la "persona investida de mandato público electivo" que solicita o admite dádivas para cumplir o abstenerse de cumplir "un acto de su mandato". Los términos "acto de su mandato" se refieren no sólo a actos jurídicos sino también a todas las actividades materiales y técnicas que dicha persona realiza y que no implican modificación de situaciones jurídicas específicas ligadas a su sola emanación. Por lo tanto, estas actividades pueden originar el inicio de un pacto de corrupción o de su intento. Y aunque el acto logrado por esta vía pueda tener validez dentro del ordenamiento jurídico, la prueba de que durante las actividades materiales previas a la toma de decisión, el sujeto, que ostenta un mandato público electivo, ha actuado en contra de los fines que justifican sus atribuciones le permite al juez penal francés ${ }^{213}$, y también malgache, aplicar respectivamente los artículos 432-11 CPF y 177 CPM.

${ }^{210}$ I. VALEIJE ÁLVAREZ, El tratamiento..., op. cit., p.195.

${ }^{211}$ R. GARRAUD, Traité..., Tome IV, op. cit., no 1522.

212 E. GARÇON, Code pénal annoté, Tome I, op. cit., no 22, p.693.

${ }^{213}$ Como ya lo hemos señalado anterioridad, la ampliación de los poderes del juez penal francés, por medio del artículo 111-5 CPF, permite a este último interpretar y valorar la legalidad de los actos administrativos cuando de este examen depende la decisión del proceso penal. Señala la Circular de 14 de mayo de 1993 que "a este respecto conviene precisar que al conferirles a las jurisdicciones penales el derecho de 


\section{6-Abstención y retraso}

Por último, el acto propio del cargo, contrario a los deberes inherentes al mismo, podrá consistir en una acción, o en cualquier clase de comportamiento o conducta del funcionario que debe realizar en el ejercicio de su cargo o en una abstención o retraso. Estas dos últimas modalidades que puede presentar el acto objeto del soborno integran las principales novedades en este terreno. Con la reforma legislativa de 2010, opinan MORALES PRATS y RODRÍGUEZ PUERTA, el Código ha equiparado acertadamente las formas activas y omisivas en el ámbito del cohecho. Así, tras la reforma merecen la misma valoración legal la conducta del funcionario que incumple sus deberes por acción, actuando o emitiendo una resolución ilegal, que la del que los incumple por omisión, es decir, absteniéndose de llevar a cabo un acto debido, al que está legalmente obligado. El Tribunal Supremo ha interpretado este término "abstención" de modo equivalente a "no realización" en el sentido de "diferir un acto propio del cargo". Esto es, el funcionario ha de haber manifestado su disposición a adoptar una posición pasiva respecto al asunto objeto del acuerdo 214 .

Concluyen los mismos autores que el nuevo artículo 419 CPE equipara, a los efectos de esta forma grave de cohecho, también la aceleración o retraso de trámites administrativos. En relación a esta cuestión, el Tribunal Supremo había venido realizando una interpretación tendente a incluir esta clase de proceder del funcionario en los supuestos más graves del anterior artículo $420 \mathrm{CPE}$ y no en la modalidad atenuada dispuesta en el anterior artículo 421 del mismo Código ${ }^{215}$. Ahora la cuestión ha quedado definitivamente aclarada. Ha desaparecido la discutida modalidad de cohecho dirigido a obtener una abstención y en su lugar se han equiparado en términos de sanción todos los supuestos en los que el particular persigue obtener un acto público o situación a la que no tendría derecho de no mediar soborno. En este sentido, resulta injusta o, cuanto menos, contraria a los deberes del cargo la actuación del

dictaminar "la legalidad" de un acto administrativo, el Parlamento no ha pretendido privarlos del derecho de valorar su constitucionalidad". En efecto, no siempre coinciden la injusticia de un acto con su ilegalidad, pero el juez penal francés puede, al constatar la arbitrariedad y la contrariedad a los deberes del cargo, pronunciar la consumación del delito de corrupción pasiva y a la vez anular el acto jurídico que se ha logrado a través de un pacto corruptor. La misma Circular indica el límite de la amplitud del poder de los Tribunales penales en estos términos: "La expresión de control de la legalidad implica la posibilidad de controlar que el Reglamento se ajuste al conjunto de normas jurídicas superiores bajo reserva. de que este control no implique una apreciación de la constitucionalidad de un texto legislativo." A nuestro modo de entender, si bien es cierto que no puede apreciar la constitucionalidad de un acto legislativo, el juez penal francés tiene la posibilidad de apreciar la existencia o no de arbitrariedad o de contrariedad a los deberes del cargo en el proceso de elaboración y de adopción de una ley.

${ }^{214}$ SSTS 06-07-1993 [RJ 1993, 5933], 30-05-1995 [RJ 1995, 4506], 05-12-1997 [RJ 1997, 8810], 06-11-2002 [RJ 2003, 3037].

${ }^{215}$ SSTS 30-05-1995 [RJ 1995, 4506], 06-07-1993 [RJ 1993, 5933], 06-11-2002 [RJ 2003, 3037]. 
funcionario que, a cambio de una ventaja, acelera un expediente, pues en tal caso se provoca, cuanto menos, el retraso de otros asuntos administrativos, que se ven injustamente perjudicados por vía indirecta ${ }^{216}$.

Precisa QUERALT JIMÉNEZ que dado que la diligencia es un deber esencial de los funcionarios, no llevar a cabo la tramitación de los negocios que tengan encomendados, supone una infracción de las obligaciones inherentes a su cargo y, por ello, tales omisiones y retrasos se integran en esta modalidad agravada de cohecho pasivo ${ }^{217}$. Para el autor, entra de lleno en este apartado la cuestión de la no ejecución de lo legalmente establecido. Tanto si la abstención del funcionario corrupto integra un acto presunto, como si es jurídicamente irrelevante en cuanto a sus efectos jurídicos, la omisión integra ahora este tipo ${ }^{218}$.

Ya hemos señalado anteriormente la reticencia de un sector de la doctrina española respecto de la equiparación de pena para las tres formas (realizar, no realizar y retrasar) que contiene el precepto pues, según MORILLAS CUEVA no parece de la misma intensidad realizar un acto contrario a los deberes inherentes al cargo o no realizar que retrasar ${ }^{219}$. SERRANO GÓMEZ y SERRANO MAÍLLO indican que este precepto conlleva una notable inseguridad jurídica, ya que en muchos casos serán cuestionables las situaciones de "no realizarlo" o "retrasarlo", así como "realizar en el ejercicio de su cargo un acto contrario a los deberes inherentes al mismo"220.

A nuestra manera de entender, la omisión a la que se refiere la norma sobre cohecho propio ha de considerarse existente toda vez que se pacte una no-realización del acto (o, en las hipótesis subsiguientes, que el acto no se haya realizado), mientras que el retraso existe siempre que el acto se realice fuera de plazo. Tanto la obligación de actuar en una situación legalmente definida, como el respeto de plazo son criterios de carácter material que hacen que las conductas de "no realizar" y "retrasar" tengan la misma intensidad que la de "realizar" a efectos de la aplicación del artículo 419 CPE. En cuanto a la postura adoptada por SERRANO GÓMEZ y SERRANO MAÍLLO, la inseguridad jurídica se encuentra en las subdivisiones bajo la anterior redacción, que dificultaban notablemente la prueba de los delitos cohecho donde no era fácil, por ejemplo, determinar si un soborno se había solicitado o pagado para cometer una simple irregularidad o una irregularidad de tal calibre que constituyera, por ejemplo, una prevaricación. La equiparación en la va-

\footnotetext{
${ }^{216}$ F. MORALES PRATS y Mํ. J. RODRÍGUEZ PUERTA, “Delitos...”, 2011, op. cit., pp. 1227-1229.

217 J QUERALT JIMÉNEZ, Derecho penal..., 2010, op. cit., p.1165. Añade el autor que por ello, la contrariedad a Derecho que estas conductas representan se entienden, al igual que la actuación positiva, como una oposición frontal al ordenamiento, de carácter material y no una mera desobediencia formal a las normas.

${ }^{218}$ Ibídem, op. cit., p. 1165.

${ }^{219}$ L. MORILLAS CUEVA, “Delitos...”, op. cit., p.959.

${ }^{220}$ A. SERRANO GÓMEZ y A. SERRANO MAÍLLO, Derecho Penal, Parte Especial...op. cit., pp. 837 y 838
} 
loración, por parte del legislador español, de las diferentes formas de obligaciones inherentes al cargo del funcionario tiene como corolario la equiparación de pena respecto al incumplimiento de las mismas.

Tanto el artículo 432-11 CPF como el 177 CPM hablan también de abstención en el cumplimiento de un acto propio de la función, del servicio o del mandato. En efecto, la doctrina francesa destaca que la abstención debe estar relacionada con los deberes inherentes al cargo. Es decir, la abstención atípica debe ser la obligada por las normas que rigen el cargo y debe estar fundamentada sobre los deberes de probidad, de discreción y de fidelidad ${ }^{22}$. Por el contrario, toda obligación de actuar que imponen los deberes del cargo y que no se ha cumplido a cambio de retribución integra una hipótesis del artículo 432-11 CPF222 y del 177 CPM. La jurisprudencia francesa adopta una posición bastante flexible en cuanto a la prueba de la abstención. En efecto, el Alto Tribunal ha considerado que la prueba o la constatación de que la abstención ha sido el resultado de una promesa, no es suficiente. Sin embargo, esta conducta constituye una presunción de corrupción y se establece su consumación si se revela la entrega de una retribución ${ }^{223}$. En caso de solicitación o aceptación, el delito será difícil de probar ${ }^{224}$. En la modalidad de abstención, los tribunales penales franceses se atribuyen un poder discrecional para apreciar el valor y el número de las presunciones o índices necesarios a efectos de constituir una prueba ${ }^{225}$.

En efecto, nos parece comprensible el deseo de los Tribunales penales franceses de facilitar la constitución de un delito tan difícil de probar como la corrupción pasiva. Sin embargo, el establecimiento de la prueba de una abstención típica no se debe hacer de cualquier manera, sino en consideración de los deberes del cargo. El uso de una presunción de abstención corrupta a partir de la entrega de la dádiva convertiría el delito de corrupción en un delito de sospecha que vulneraría la presunción de inocencia. A nuestro modo de ver, la existencia de una abstención típica debe ser siempre el resultado de una valoración objetiva de un incumplimiento de un deber de actuar en beneficio del particular corruptor. De aceptar esta postura, la entrega de alguna retribución, por muy sospechosa que sea, no podría constituir de por sí un indicio para afirmar una presunción de abstención corrupta.

\footnotetext{
${ }^{221}$ A. VITU, Corruption passive..., op. cit., p.19

222 Aunque la justicia o la injusticia del acto no es relevante para el legislador francés, se nota cierta confusión en el intento de distinguir entre la abstención justa y la injusta. VITU califica de justa la abstención cuando se trata de no realizar lo se que debería hacer, y de injusta cuando, a cambio de retribución, no se realiza lo que se debería evitar de cumplir (A. VITU, Corruption passive..., op. cit., p.19). A nuestro modo de entender, cuando el funcionario no realiza un acto que debería evitar, no se trata de una abstención injusta sino atípica.

${ }^{223}$ Cass. crim, 28-03-1955, citada por A. VITU, Corruption passive..., op. cit., p.18

${ }^{224}$ H. XIAO-YING, La lutte contre la corruption..., op. cit., p.71.

225 Cass. crim. 1-12-1992, no91-84.656 citada por H. XIAO-YING, La lutte contre la corruption..., op. cit., p.72.
} 
En cuanto al retraso, se puede preguntar si esta forma de comisión del delito de corrupción puede integrar un supuesto de corrupción pasiva en Derecho penal francés y malgache. En efecto, aunque, a diferencia del artículo 419 CPE, el legislador francés y malgache no hayan previsto de manera explícita esta modalidad, tanto el CPF como el CPM hablan de realización o abstención de un acto facilitado por la función, el servicio o el mandato ${ }^{226}$. El retraso podría encajar en la modalidad de abstención de un acto propio del cargo si este último prevé una obligación a su titular de actuar en un plazo determinado. Pero los preceptos en estudio, a nuestra manera de entender, van más allá de que si hay o no un plazo legal que respetar.

La doctrina francesa opina que es útil saber lo que es un acto facilitado por la función, el servicio o el mandato, no para distinguirlo mejor del acto de la función, sino para indicar y limitar el ámbito de aplicación del tipo de corrupción pasiva. VITU define el acto facilitado por la competencia como todo acto que, a pesar de que no forme parte de las atribuciones expresamente concedidas al titular del cargo por la ley y los reglamentos, ha sido posibilitado por las mismas debido a la relación estrecha que las une con el acto ${ }^{227}$. Añade DREYER que se trata de un acto que de ninguna manera se puede relacionar con el ejercicio normal de dichas atribuciones ${ }^{228}$. La jurisprudencia francesa analizada para extraer esta definición propuesta por la doctrina, revela que el agente público no era competente para cumplir el acto objeto del pacto corrupto, sin embargo, solía alcanzar el resultado perseguido de una manera que no puede más que levantar la sospecha ${ }^{229}$. En uno de los supuestos estudiados que ilustran la noción de acto facilitado, aparece el caso de un funcionario que recibe dinero para retrasar una peritación prevista por la Administración contra el particular corruptor ${ }^{230}$.

\footnotetext{
${ }^{226}$ En la doctrina española se puede encontrar la idea de "acto facilitado" cuando se define lo que es un "acto en el ejercicio del cargo". En palabras de RODRÍGUEZ PUERTA, "deben considerarse «actos realizados en el ejercicio del cargo» en el sentido de delito de cohecho, tanto aquellos para los que el funcionario es objetiva, territorial y materialmente competente, como aquellos otros que, sin ser específicamente para adoptarlos, no son totalmente ajenos a la órbita de sus competencias, de modo que de facto puede llevarlos a cabo bien porque éstos resultan facilitados por su posición en la Administración, bien porque su ejecución corresponde al órgano o entidad de la Administración donde él presta sus servicios, siempre y cuando, en este último caso, pueda establecerse alguna relación entre el acto objeto del cohecho y las genéricas funciones desempeñadas por el funcionario" (Ma. J. RODRÍGUEZ PUERTA, El delito de cohecho..., op. cit., p.206. La cursiva es nuestra).

227 A. VITU, Corruption passive..., op. cit., p.20. En el mismo sentido se ha pronunciado la doctrina francesa, véase, entre otros, M. VIGNAU, Le délit de corruption, op. cit., p.45; M. VÉRON, Droit pénal spécial, op. cit., p.389; F. CECCON, Contribution..., op. cit., p.42; M-P. LUCAS de LEYSSAC y A. MIHNAN, Droit pénal des affaires..., op. cit., no1029; J.-H. ROBERT y H. MATSOPOULOU, Traité... p.182.

${ }^{228}$ E. DREYER, Cours magistral..., op. cit., p.602.

229 Cass. crim. 21-11-1972, Bull. crim. no350; Cass. crim. 6-02-1969, JCP 1969, II, 16004, nota P. Chambon; Cass. crim. 3-06-1997, Dr. pén. 1997, no150, obs. M Véron.

${ }^{230}$ Cass. crim. 22-07-1954, Bull. crim no266.
} 
En este ejemplo la jurisprudencia francesa ha considerado el retraso como uno de los casos de actos facilitados por el cargo. A nuestro juicio, el ejercicio normal del cargo llevaría a su titular a no actuar más allá del límite de sus atribuciones y a respetar los deberes inherentes al mismo, entre ellos, el de respetar algún plazo fijado por las normas para determinadas actuaciones. Ahora bien, el no respetar dicho plazo a cambio de retribución supondría una abstención de un acto propio del cargo, sin embargo, si ninguna norma ha fijado plazo para llevar a cabo una determinada actuación, retrasar esta última o posponerla integraría un supuesto de acto facilitado ya que lo normal sería proceder a su ejecución en un plazo razonable. En este orden de ideas, creemos que la aceleración de los trámites administrativos podría incluirse en los casos de actos facilitados por el cargo, ya que provoca una estancación injustificada y anormal de otros asuntos administrativos.

La doctrina francesa reconoce la dificultad de encontrar casos de abstención de un acto facilitado por el cargo ya que todavía no existe un ejemplo jurisprudencial al respecto ${ }^{231}$. No obstante, VITU propone a título de ilustración, el caso del agente de policía que recibe una retribución para abstenerse de avisar a sus compañeros competentes de la existencia de una infracción que no tiene competencia para consta$\operatorname{tar}^{232}$. GARÇON sugiere que un parlamentario que acepta una retribución de un empresario para no apoyar a un competidor en una licitación pública, no comete el delito de corrupción pasiva en el sentido estricto de la palabra (no se trata aquí de una abstención de un acto del mandato), sino se abstiene de un acto facilitado por su función electiva, por tanto, se puede subsumir en el precepto en estudio ${ }^{233}$.

A nuestro juicio, se entiende la dificultad para la doctrina francesa de encontrar un ejemplo jurisprudencial respecto a esta modalidad de la corrupción pasiva ya que, a través de ella, se nota la intención del legislador francés de abarcar el mayor número de casos posibles, sin dejar ninguna laguna de impunidad, y de esta forma ha ampliado aún más el ámbito de aplicación del artículo 432-11 CPF. Se puede plantear la duda respecto a la capacidad lesiva de una abstención para un acto que no forma parte de las atribuciones expresamente concedidas al funcionario. Se podrá opinar que efectivamente este tipo de conducta puede lesionar el deber probidad, bien jurídico reconocido por el legislador francés. Sin embargo, se verifica aquí, una vez más, que el deber del cargo no puede ser bien jurídico a riesgo de no poder limitar el ius puniendi del Estado y de no respetar el principio de intervención mínima del Derecho penal234.

\section{II-Acto propio del cargo y acto de la competencia o facili- tado por ella}

\footnotetext{
${ }^{231}$ M-P. LUCAS de LEYSSAC y A. MIHNAN, Droit pénal des affaires..., op. cit., no1029.

232 A. VITU, Traité..., op. cit., p.293.

${ }^{233}$ E. GARÇON, Code pénal annoté, Tome I, op. cit., no 201, p.708.

${ }^{234}$ I. BERDUGO DE LA TORRE y otros, Curso de Derecho Penal, op. cit., pp.57 y 58.
} 


\section{A-OBSERVACIONES GENERALES}

\section{1-Evolución legislativa en el Derecho penal español}

En este precepto se ha producido una agrupación de conductas que caen en la órbita de la categoría de cohecho pasivo impropio. En efecto, antes, en el antiguo artículo $426 \mathrm{CPE}$, se castigaba a la autoridad o funcionario público que admitiere dádiva o regalo que el fueren ofrecidos para la consecución de un "acto no prohibido legalmente", mientras que, precisamente en el artículo $425.1 \mathrm{CPE}$, antes de la reforma, se incriminaba al funcionario o autoridad que solicitare dádiva o presente o admitiere promesa u ofrecimiento para realizar un "acto propio de su cargo" o como recompensa del ya realizado. En verdad podía entenderse que este "acto propio del cargo" y el "acto no prohibido legalmente" del antiguo artículo $426 \mathrm{CPE}$, a efectos penales, podían equipararse, ya que, primero, la realización de actos propios del cargo de una autoridad o funcionario, obviamente, no está prohibida, sino que es debida y, segundo, si alguien realiza un acto no prohibido por el ordenamiento por ejemplo, la adjudicación de un contrato - pero que no es propio de su cargo - porque, continuando con el mismo ejemplo, no sea administrativamente competente para adjudicarlo - pasaría automáticamente a estar prohibido, no, evidentemente, con carácter general, pero sí concretamente para él, porque no es competente para realizarlo ${ }^{235}$. La doctrina española piensa que siguiendo un razonamiento similar, el legislador español, en el ámbito del cohecho pasivo impropio, ha abandonado la doble definición acto no prohibido/acto propio del cargo, para quedarse sólo con esta última ${ }^{236}$.

\section{2-Inexistencia de la llamada "corrupción impropia" en Derecho penal francés y malgache}

En la actualidad, tanto el legislador francés como el legislador malgache no consideran necesario hacer la distinción entre acto justo o injusto. Ya antes de la reforma de 1994, el CPF precisaba que el acto de la competencia objeto del acuerdo corrupto podía ser "justo o no" y con ello, no se ha visto en la necesidad de graduar, en el precepto, la sanción penal al respecto. Las reformas legislativas posteriores ya no han introducido este tipo de precisión pero considera VITU que a pesar del mutismo del

\footnotetext{
235 E. ARRIBAS LÓPEZ, El cohecho impropio después de la reforma del Código Penal, La Ley, 09/2011, p.3.

236 Con interpretaciones diferentes, reconoce la doctrina española las dificultades en la interpretación de las expresiones acto no prohibido/acto propio del cargo bajo la anterior redacción del CPE (entre otros, M. DÍAZ Y GARCÍA CONLLEDO, "El delito de cohecho", op.cit., p.166) por lo que la reforma de 2010 ha sido acogida favorablemente. Véase C. MIR PUIG, El delito de cohecho en la reforma...op. cit., pp.47 y 48; C. RAMOS RUBIO, Del delito de cohecho... op. cit., p.346; E. ARRIBAS LÓPEZ, El cohecho impropio...op. cit., p.3; J. VIZUETA FERNÁNDEZ, Delitos..., op. cit., pp.250-264; G. D. M. CERINA, La lucha contra la corrupción, op. cit., pp.1078-1097.
} 
artículo 432-11 CPF, la solución legislativa anterior conserva su vali$\mathrm{dez}^{237}$.

A efectos de comparación destacaremos la interpretación de la doctrina y de la jurisprudencia francesa para dar un contenido concreto a la expresión "acto propio de su función, de su servicio o de su mandato"238.

\section{B-SIGNIFICADO DE LA EXPRESIÓN “ACTO PROPIO DEL CARGO” Y EQUIVALENCIA EN DERECHO PENAL FRANCÉS Y MALGACHE}

\section{1-Acto conforme a Derecho}

Hay un acuerdo en la doctrina española en considerar que en esta modalidad de cohecho se trata de realizar un acto que le compete al funcionario sin que tenga que variar en absoluto su actuación normal y sin sea ilícito el acto a realizar, al ser conforme a Derecho ${ }^{239}$. Precisan MORILLAS CUEVA y RODRÍGUEZ PUERTA que se trata de dar cabida a situaciones en las que la autoridad o el funcionario público se comprometen, a cambio de una ventaja, a adoptar un acto propio del cargo cuya valoración en términos de legalidad no conculca el Derecho administrativo aplicable al sector de actividad de la que se trate 240 .

La discrepancia se encuentra en la justificación de este tipo penal. Señala NIETO MARTÍN que, aunque resulte paradójico que se sancione a quien paga al funcionario por hacer lo que tiene que hacer, la corrupción impropia tiene una lesividad considerable 241 , ya que lo que se pena en este supuesto es la exigencia, en forma de dádiva, favor, retribución, ofrecimiento o promesa, para ejecutar el acto en sí ${ }^{242}$. Con esta perspectiva, según MORALES PRATS y RODRÍGUEZ PUERTA, el artículo 420 CPE se muestra como un tipo de recogida en relación al artículo 419 CPE, aplicable cuando no puede probarse que el acto ejecutado o comprometido por el funcionario o autoridad resulta contrario a las normas legales o a sus deberes inherentes al cargo ${ }^{243}$.

\footnotetext{
${ }^{237}$ A. VITU, Corruption passive..., op. cit., p.19.

${ }^{238}$ Es la traducción de la expresión "acte de sa fonction, de sa mission ou de son mandat" propuesta por Ma ${ }^{\text {a. J. }}$ RODRÍGUEZ PUERTA, El delito de cohecho..., op. cit., p.321. ARÁNGUEZ SÁNCHEZ y ALARCÓN NAVÍO traducen la misma expresión por "acto de su competencia" (C. ARÁNGUEZ SÁNCHEZ y E. ALARCÓN NAVÍO, El código penal francés, op. cit., p.206). Por razón de comodidad, se utilizará esta última traducción aunque se acudirá a la primera siempre que se necesite más precisión.

${ }^{239}$ Entre otros, J. CARDONA TORRES, Derecho Penal..., op. cit., p.505; E. ARRIBAS LÓPEZ, El cohecho impropio...op. cit., p.3; M… J. RODRÍGUEZ PUERTA, "Modificaciones..." op. cit., p.469; F. MUÑOZ CONDE, Derecho penal, Parte especial,...2010, op.cit., p.1023; I. ORTIZ DE URBINA GIMENO, “Delitos...", p.338.

240 L. MORILLAS CUEVA, “Delitos...”, op. cit., p.960; Ma . J. RODRÍGUEZ PUERTA, “Modificaciones..." op. cit., p.469.

${ }^{241}$ A. NIETO MARTÍN, “Corrupción y abuso...”, op. cit., p.761.

${ }^{242}$ L. MORILLAS CUEVA, “Delitos...”, op. cit., p.960.

${ }^{243}$ F. MORALES PRATS y Ma. J. RODRÍGUEZ PUERTA, “Delitos...”, 2011, op. cit., p.1234.
} 
Por su parte, MUÑOZ CONDE defiende que lo que se castiga aquí es el hecho de recibir o solicitar una recompensa económica a la que no se tiene derecho. En este caso, según el mismo autor, la pena (prisión de dos a cuatro años, multa de doce a veinticuatro meses e inhabilitación especial para empleo o cargo público por tiempo de tres a siete años) puede ser excesiva, si además no hay ningún perjuicio para la Administración, ni para el particular ${ }^{244}$. Explica CARDONA TORRES que lo que se castiga en este supuesto no es el acto realizado, porque tiene la competencia para dictarlo, al ser un acto propio del cargo, sino que se sanciona su falta de honradez profesional a la se debe todo servidor público, pues aquí el funcionario o la autoridad solicita o recibe dádiva, favor o retribución, aunque sea por hacer simplemente lo que le corresponde. Con el endurecimiento de la pena, el legislador español demuestra el extraordinario celo en hacer cumplir los mandatos previstos en la Constitución relativos a la imparcialidad y probidad de la conducta de los servidores públicos ${ }^{245}$. Por consiguiente, concluye VIZUETA FERNÁNDEZ que, con base en el principio de fragmentariedad ${ }^{246}$, podría justificarse el castigo de este supuesto con el argumento de que estamos ante una de las modalidades de ataque más graves contra tal bien jurídico. Este argumento, añade el autor, merecería una reflexión si no fuera porque aquel principio opera sobre bienes jurídicos que previamente han sido considerados merecedores de protección penal, señalando sus formas más graves de ataque ${ }^{247}$, y el bien jurídico honradez o integridad de la condición de funcionario público no alcanza este nivel. La investigación realizada por el autor y encaminada a averiguar si este bien jurídico merece protección penal, ha dado como resultado una respuesta negativa ${ }^{248}$, por lo que cualquier ataque al mismo, por más grave que sea, debe ser ajeno al Derecho penal. En definitiva, el autor es partidario de que esta modalidad de cohecho del actual artículo 420 CPE (que corresponde a las antiguas figuras recogidas en los anteriores artículos 425.1, inciso primero, y 426, inciso segundo) no se sancione penalmen$\mathrm{te}^{249}$.

A nuestra manera de entender, la aplicación del artículo 420 CPE implica la violación de un deber genérico, como la imparcialidad y no de un deber específico del cargo cuya violación integra un supuesto del artículo 419 CPE. Sin embargo, el hecho de no haber probado la contrariedad de un acto a Derecho no significa que la única opción que tiene el juez sea la subsunción de la conducta en el artículo 420 CPE. Convertir este precepto en una solución para cuestiones procesales puede tener un coste en términos de presunción de no culpabilidad.

${ }^{244}$ F. MUÑOZ CONDE, Derecho penal, Parte especial,...2010, op.cit., p.1023. En términos parecidos, M. POLAINO NAVARRETE, “Cohecho...”, op. cit., p. 325.

245 J. CARDONA TORRES, Derecho Penal..., op. cit., p.505.

246 S. MIR PUIG, Introducción..., op. cit., pp.126 y sS.; E. OCTAVIO DE TOLEDO Y UBIETO, Sobre el concepto..., op. cit., p.359 y 361; F. MUÑOZ CONDE, Introducción..., op. cit., pp.124, 125

${ }^{247}$ J. M. SILVA SÁNCHEZ, Aproximación..., op. cit., pp.286, 289 y 290.

248 J. VIZUETA FERNÁNDEZ, Delitos..., op. cit., pp. 237 y ss.

${ }^{249}$ Ibídem, op. cit., p.264. 


\section{PARTE II: ESTUDIOS DE LOS ELEMENTOS TÍPICOS...}

\section{malgache}

\section{2-Acto de la competencia en Derecho penal francés y}

Como ya hemos señalado anteriormente, la letra de los artículos 432-11 CPF y 177 CPM sólo contempla el acto de la competencia y el acto facilitado por ella. Si este segundo ha sido objeto de nuestro análisis en apartados anteriores, el primero será estudiado en esta parte de nuestro trabajo.

La traducción literal del artículo 432-11 CPE nos puede dar más información para comprender el alcance del precepto. En efecto, según la traducción propuesta por RODRÍGUEZ PUERTA, se trata aquí de un acto propio de la función, del servicio y del mandato del titular del cargo. La palabra "mandato" no supone mayor problema, ya que corresponde a "una persona investida de un mandato electivo público". Aunque un sector de la doctrina francesa intenta explicar la noción de mandato como un contrato previsto en los artículos 1984 del Código civil francés ${ }^{250}$, creemos que los adjetivos "electivo público" contradicen esta interpretación.

En cuanto a los términos "función" y "servicio", dan la impresión de ser sinónimos, sin embargo, el análisis del texto y de los trabajos preparatorios parece indicar que la noción de función implica una permanencia que no conlleva el término "servicio" o "misión". Así, defiende la doctrina francesa, la función es la tarea habitual y principalmente realizada, mientras que el servicio o la misión es más temporal y ocasional ${ }^{251}$.

La doctrina francesa define el acto de la competencia como el acto cuya realización, o abstención, es impuesta por las atribuciones del titular del cargo. Defiende VITU que se trata de verificar en cada caso los textos legales que rigen la función o las reglas aplicadas en la praxis. Como ya hemos señalado, la jurisprudencia francesa ha dado una interpretación extensiva a la noción de acto de la función y admite que el artículo 432$11 \mathrm{CPF}$ puede sancionar penalmente toda violación remunerada no sólo de los deberes de obediencia, de probidad, de discreción y de fidelidad que conlleva el cargo sino también de los que la disciplina y la deontología sin formular pero cierta, que se imponen al agente público ${ }^{252}$.

En cuanto a las personas que ostentan un mandato público electivo, precisa la doctrina francesa que su función consiste en emitir opiniones en asamblea, deliberar y votar, pero pueden también preparar informes para luego proceder a las deliberaciones. El acto de la competencia para

250 M. BÉNILLOUCHE, L'incrimination de la corruption en France, en M. DELMASMARTY (Dir.) Criminalité économique et atteinte à la dignité de la personne, Les processus d'internationalisation, T.VII, Éditions de la Maison des sciences de l'homme, Paris, 2001, p.45.

${ }^{251}$ F. CECCON, Contribution..., op. cit., p.41 ; M. BÉNILLOUCHE, L'incrimination..., op. cit.,. p.45.

252 A. VITU, Corruption passive..., op. cit., p.20 ; H. XIAO-YING, La lutte contre la corruption..., op. cit., p.71 ; M. VIGNAU, Le délit de corruption, op. cit., p.42. 
esta categoría de sujetos es todo acto que se relacione con estas actividades.

Por otra parte, poco importa que el funcionario o la persona elegida no tengan la potestad de realizar sólo el acto pero participen, a cambio de retribución, de un poder colectivo. Tampoco importa que el titular del cargo no tenga la potestad de realizar por sí mismo el acto si la preparación del mismo por medio de actos previos, informes, hace parte de sus atribuciones ${ }^{253}$. En palabras de LUCAS de LEYSSAC y MIHMAN, se trata de actos que el agente corrupto puede proponer, preparar o provo$\operatorname{car}^{254}$.

En efecto, todas estas propuestas de la doctrina francesa vienen del análisis de la jurisprudencia, que ha hecho una interpretación extensiva de la letra de la ley255 ampliando de una manera excesiva el ámbito de aplicación del precepto. El límite de tal extensión se alcanza cuando el acto objeto del pacto corrupto no tiene nada que ver con las atribuciones del titular del cargo.

En definitiva, el acto de la competencia o acto propio del cargo, no es sólo el acto previsto por los textos legales, reglamentarios y disciplinarios o las reglas aplicadas en la praxis, sino también cualquier acto que tiene algo que ver con la competencia genérica del sujeto activo, poco importa que sea justo o injusto. Le corresponde al juez penal de cada caso acabar la tarea del legislador, al precisar el respeto al principio de taxatividad conforme a la jurisprudencia constante en la materia y graduar las penas según el desvalor que merece cada acto. Para ello, debe acudir a criterios objetivos, entre otros, las normas escritas o no escritas que se aplican en el sector de actividad del titular del cargo y determinar la lesión que supone la realización del acto o su intento a las funciones públicas y no limitarse sólo a constatar la afectación al deber de probidad.

\section{reglados}

\section{3-Acto conforme a Derecho y actos discrecionales y}

Un sector de la doctrina española considera que en el ámbito del "acto propio del cargo", tendrán cabida tanto los actos reglados como discrecionales que se adoptaron conforme a las normas que disciplinan esta clase de actos públicos ${ }^{256}$. En estos últimos supuestos, el funcionario titular de la potestad discrecional goza de un margen más amplio de actuación, de modo que, son varias las posibles opciones que puede

${ }^{253}$ A. VITU, Corruption passive..., op. cit., pp.20 y 21 ; F. CECCON, Contribution..., op. cit., p.42 ; H. XIAO-YING, La lutte contre la corruption..., op. cit., p.71 ; M. VIGNAU, Le délit de corruption, op. cit., p.43 ;

${ }^{254}$ M-P. LUCAS de LEYSSAC y A. MIHNAN, Droit pénal des affaires..., op. cit., no 1028.

255 F. CECCON, Contribution..., op. cit., p.41.

${ }^{256}$ F. MORALES PRATS y Ma. J. RODRÍGUEZ PUERTA, “Delitos...”, 2011, op. cit., p.1234.; C. MIR PUIG, El delito de cohecho en la reforma...op. cit., p.47; M‥ J. RODRÍGUEZ PUERTA, "Modificaciones..." op. cit., p.469. 
adoptar sin contrariar por ello la legalidad. De la estimación subjetiva del funcionario depende, en buena medida, la concreta decisión; de este modo resulta posible que sobre ella incidan intereses ajenos a los públicos, como, por ejemplo el ánimo de lucro, que hagan que el asunto se resuelva en uno u otro sentido. Sin embargo, de no probarse que se infringieron elementos legalmente determinados o que no se utilizaron correctamente los poderes discrecionales, no podrá calificarse de injusta la decisión. Precisamente en esos casos deberá aplicarse el artículo $420 \mathrm{CPE}^{257}$.

Añaden MORALES PRATS y RODRÍGUEZ PUERTA que esta interpretación permite, a su juicio, valorar conforme a criterios de proporcionalidad situaciones que presentan un distinto contenido de injusto, puesto que el particular, a diferencia de lo que ocurre en la modalidad tipificada en el artículo $419 \mathrm{CPE}$, no obtiene ninguna ventaja indebida con el soborno aunque en los supuestos actos discrecionales lo pretende. Así cuando el objeto del cohecho es un acto discrecional, el respeto del principio de imparcialidad queda cuestionado, pues el funcionario se sitúa en una posición parcial respecto a su futura decisión, con independencia de que ésta finalmente se vea o no afectada por la dádiva; en estos casos, debe subsumirse la conducta en el artículo 419 CPE. Obviamente, si la dádiva perseguía la obtención de un acto de esta naturaleza y el funcionario se mostró dispuesto a no utilizar correctamente sus poderes discrecionales, el acto sería injusto objetivamente y vendría en aplicación la modalidad de cohecho del artículo 420 CPE258.

Ante esta postura y de acuerdo con CERINA, hay una confusión entre la imparcialidad en el procedimiento de toma de decisión con la imparcialidad del acto-resultado del mismo. En este marco, debe recordarse que el ordenamiento jurídico-penal cifra la ofensa de la primera en el acuerdo ilícito mientras que, respecto del acto objeto del pacto, distingue según la legalidad del mismo (y no según su parcialidad). Una vez demostrado que, incluso cuando el acto-finalidad del cohecho es reglado y conforme a Derecho, puede haberse seguido un procedimiento de toma de decisión parcial. Y, una vez acatado lo anterior, no queda espacio ninguno para intentos atomizadores, ya que tanto el acto reglado como el discrecional o bien son legales (justos) o bien no lo son (y, por ende, son injustos) y tertium non datur 259 .

${ }^{257}$ A. NIETO MARTÍN, “Corrupción y abuso...”, op. cit., p.761; F. MORALES PRATS y Ma J. RODRÍGUEZ PUERTA, “Delitos...”, 2011, op. cit., p.1234; L. MORILLAS CUEVA, “Delitos...", op. cit., p. 960 .

${ }^{258}$ F. MORALES PRATS y Ma. J. RODRÍGUEZ PUERTA, “Delitos...", 2011, op. cit., p.1234.

259 G. D. M. CERINA, La lucha contra la corrupción, op. cit., p.1085. Indica el autor que o bien decimos que existe parcialidad toda vez que, en el proceso de toma de decisión, ha intervenido un soborno o bien concluimos que el comportamiento del funcionario es parcial toda vez que el sujeto público se determina no ya con apoyo en su convencimiento a la hora de interpretar la ley, sino en el soborno mismo cuya finalidad es distinta respecto de su convencimiento. Si se acepta la primera opción, se debe concluir que, en ambos casos (tanto en el acto discrecional justo como en el acto reglado justo), existe parcialidad. Si, en cambio, se opta por la segunda alternativa, se deberá 
La postura de MORALES PRATS y RODRÍGUEZ PUERTA da a entender que de lo que se trata, en los supuestos de actos discrecionales, es de un soborno cuyo objeto es la obtención por parte del particular de un acto que, sin mediar el mismo, no habría obtenido. Dicho de otro modo, existiría lesión del principio de imparcialidad toda vez que el acto acordado por corrupto y corruptor sea distinto de aquél que se hubiese adoptado en ausencia de la ilícita remuneración. De ahí que, suponiendo que la finalidad del cohecho sea la obtención de un acto justo, obtendríamos que el mismo pudiera considerarse lesivo de imparcialidad sólo si, en el caso de acto discrecional, el funcionario, si no hubiera habido soborno, habría decidido diversamente. No habría, en cambio, ni lesión de la imparcialidad, ni por, por ende, cohecho punible, en la situación en la cual el acto justo coincide con el que el funcionario habría realizado sin que tuviera lugar el pactum sceleris.

Contesta esta postura un sector de la doctrina y toma como ejemplo el caso en el cual el funcionario público si no hubiera intervenido un soborno, habría optado por realizar el acto A justo, mientras que el particular, a cambio de una dádiva, le pide que realice el acto $B$ igualmente justo. Cabe imaginar que el sujeto público estuviese equivocado y que, finalmente, el acto B sea el más favorable para los intereses de la Administración pública y, por ende, de la colectividad. Si aceptáramos la tesis que aquí se critica, deberíamos admitir que el soborno cuya finalidad es la obtención de un acto más justo (en sentido material) podría ser sancionado más gravemente de aquello cuyo objeto sea la realización de un acto menos adecuado a los intereses colectivos que se pretende defen$\operatorname{der}^{260}$.

\section{4-Actos de menor importancia}

Un sector de la doctrina española entiende que el artículo $420 \mathrm{CPE}$ abarca los casos de adelanto o de retraso en algo legítimo ya que truncan tanto la transparencia como la igualdad de oportunidades de los ciudadanos, por tanto su castigo debe ser penal261. A nuestro juicio, siempre que la agilización o el retraso de un procedimiento administrativo o determinados trámites, no supongan una conculcación de un deber específico inherente al cargo del funcionario no vemos ninguna razón para rechazar esta postura.

Por otra parte, la agrupación de las conductas de los anteriores artículos 425.1 y 426 CPE hace pensar que el contenido propuesto por un sector de la doctrina española para interpretar la expresión "acto no prohibido legalmente" puede incluirse como supuestos del precepto en

negar que el funcionario haya decidido de forma parcial en los dos supuestos (p.1087).

260 I. OLAIZOLA NOGALES, El delito de cohecho, op. cit., p.288; G. D. M. CERINA, La lucha contra la corrupción, op. cit., p.1066.

261 J. QUERALT JIMÉNEZ, Derecho penal..., 2010, op. cit., p.1161; A. NIETO MARTÍN, “Corrupción y abuso...”, op. cit., p.761. 
estudio. En efecto, se ha sugerido que esta expresión pretendería sancionar los casos de cohecho impropio antecedente cuyo objeto es la realización de un acto de menor importancia, un comportamiento manual de sujetos que auxilian y apoyan el ejercicio de las funciones propias del organismo administrativo o a la realización de tareas materiales propias del mismo ${ }^{262}$. Si bien es cierto que esta postura ha sido criticada por su imprecisión o falta de claridad sobre cuáles son las actividades que deben calificarse de manuales y quiénes son los sujetos que las llevan a cabo ${ }^{263}$, la entrada en vigor de la reforma de 2010 parece, según defiende un sector de la doctrina española, haber resuelto la dificultad en la tarea de interpretación respecto a la diferencia entre "acto no prohibido legalmente" y "acto propio del cargo". Defiende RAMOS RUBIO que por lo que se refiere al cohecho del artículo 420 CPE 2010, al suprimirse la referencia contenida en el artículo 426 CPE 1995 al "acto no prohibido legalmente", se facilita la difícil tarea del intérprete en orden a la fijación de un criterio diferencial adecuado con el "acto propio de su cargo" del artículo 425.1 CPE 1995 (y del propio artículo 420 CPE 2010), lo que no impedirá que quienes vienen sosteniendo que representan ámbitos diferentes, reservando para aquéllos el propio de los actos menores, manuales, auxiliares y de apoyo al órgano administrativo, puedan entender ahora que la única consecuencia razonable habrá de ser la de su atipicidad, teniendo en cuenta, además, que, en caso contrario, se produciría un incremento sancionador incomprensible y desproporcionado (desde la multa de tres a seis meses hasta la prisión de dos a cuatro años, multa de doce a veinticuatro meses a inhabilitación especial para empleo o cargo público por tiempo de tres a siete años) 264 .

\section{5-Toma de postura}

A nuestra manera de entender, para no repetir los debates anteriores bajo la vigencia del CPE 1995, el legislador español ha elegido la simplificación, al clasificar los actos a partir de la dicotomía acto contrario a los deberes inherentes al cargo / acto propio del cargo. Creemos que el primer término de dicha dicotomía se refiere a los actos contrarios a los deberes específicos, mientras que el segundo alude a los actos contrarios a los deberes genéricos. Por lo tanto, los actos cuya emanación suponen un quebrantamiento de los deberes específicos del funcionario deben ser subsumibles, si es objeto de un soborno, en lo dispuesto por el artículo 419 CPE y no en el artículo 420 del mismo Código. De la anterior afirmación desciende que el acto objeto del acuerdo corrupto es justo (es decir, no injusto) cuando su emanación no contraviene a deberes específicos pero sí a deberes genéricos ya que, como se ha visto, todo acto objeto de acuerdo corrupto es contrario a los genéricos deberes, como la imparcialidad del funcionario público. Con lo cual, acatada esta

262 E. ORTS BERENGUER, “Delitos...”, op. cit., p.703.

${ }^{263}$ Ma. J. RODRÍGUEZ PUERTA, El delito de cohecho..., op. cit., p.280.

${ }^{264}$ C. RAMOS RUBIO, Del delito de cohecho... op. cit., pp.346 y 347; C. MIR PUIG, El delito de cohecho en la reforma...op. cit., p.48. 
diferenciación, la contraposición entre deberes genéricos y deberes específicos nos lleva al punto de partida: el artículo 419 CPE disciplina los casos en los que el acto supone un quebrantamiento de los deberes genéricos y específicos, mientras que el artículo $420 \mathrm{CPE}$ se ocupa de los sobornos cuya finalidad sea la emanación de un acto contrario a los deberes genéricos del funcionario, pero que no quebrantan los deberes específicos de la función ${ }^{265}$.

Por consiguiente, la aplicación de cada uno de estos preceptos depende del deber conculcado por el acto realizado en el ejercicio del cargo, objeto de acuerdo corrupto. En este sentido, vale la pena recordar que no se trata sólo de acto administrativo en sentido estricto sino de comportamientos o de actividades que entran dentro de la competencia genérica del funcionario ${ }^{266}$. Ya hemos señalado anteriormente que no se puede limitar el concepto de acto del cargo a actos recurribles ante la jurisdicción contencioso-administrativa ya que los sujetos activos previstos por el legislador de 2010 no pueden ser funcionarios públicos en el sentido del Derecho administrativo. Eso nos lleva a considerar que los actos del cargo penalmente relevantes pueden ser: actos de gobierno, de Derecho privado, el silencio, las operaciones, los comportamientos materiales, las asesorías, las peticiones, las propuestas, las resoluciones, etc. En unas palabras, cualquier concreta explicación de poderes o deberes inherentes al cargo. Desde luego esta lista incluye también los actos jurisdiccionales y legislativos ${ }^{267}$.

Por eso, no estamos de acuerdo con la idea defendida por RODRÍGUEZ PUERTA y MORILLAS CUEVA, según la cual el acto propio del cargo es un acto en sí adecuado a la normativa administrativa que lo regula 268 , esto es, un acto cuya valoración en términos de legalidad no conculca el Derecho administrativo aplicable al sector de actividad de la que se trate ${ }^{269}$. Ya hemos señalado anteriormente que para distinguir la hipótesis propia de la impropia, hay un quid pluris que debe cifrarse en el deber específico de uniformar los concretos actos del cargo o de la función a las normas de ley o a las otras directrices de la Administración Pública pero haciendo referencia a toda violación de la ley o de normas emitidas por la Administración Pública (reglamentos, circulares, instrucciones de servicio...y hasta costumbres). Eso nos lleva a la conclusión de que no se puede referir únicamente a la normativa administrativa, que regula el sector de actividad, a la hora de valorar la conformidad a Derecho de un acto propio del cargo. El Derecho administrativo no es la

\footnotetext{
${ }^{265}$ En términos parecidos, G. D. M. CERINA, La lucha contra la corrupción, op. cit., pp.1091 y 1092.

${ }_{266}$ En el mismo sentido, C. MIR PUIG, El delito de cohecho en la reforma...op. cit., p.47

${ }^{267}$ En este sentido, G. D. M. CERINA, La lucha contra la corrupción, op. cit., pp.998 y 999.

${ }^{268}$ L. MORILLAS CUEVA, “Delitos...”, op. cit., p.960.

${ }^{269}$ Ma. J. RODRÍGUEZ PUERTA, “Modificaciones...” op. cit., p.469.
} 


\section{PARTE II: ESTUDIOS DE LOS ELEMENTOS TÍPICOS...}

única normativa con la que cuenta el Estado para reglamentar todas sus actividades ${ }^{270}$.

En cuanto a los actos menores, pueden ser actos que el funcionario puede hacer debido a que su cargo le permite acceder a ellos con facilidad pero no son "propios" del funcionario ${ }^{271}$. Esta descripción nos hace pensar en los actos facilitados por la competencia en Derecho penal francés y malgache, con la diferencia de que el CPF sólo ha precisado el límite máximo de las penas, dejándole al juez penal bastante margen de maniobra para graduar la sanción de este tipo de acto.

Por otro lado, la doctrina española está de acuerdo en que estos actos tienen lesividad. Sin embargo hay discrepancia respecto a su entidad dependiendo del bien jurídico identificado por cada autor ${ }^{272}$.

A nuestro juicio, es comprensible la postura de los autores que defienden que el hecho de incluir estos actos menores en el ámbito de aplicación del artículo 420 CPE produciría un incremento sancionador incomprensible y desproporcionado ${ }^{273}$. Y estamos de acuerdo con la doctrina española en constatar que el legislador español de 2010 no sólo ha simplificado esta figura delictiva sino también ha endurecido la pena ${ }^{274}$ de manera excesiva ${ }^{275}$. Sin embargo, somos partidarios de la idea según la cual existiría una lesión del principio de imparcialidad con cierta relevancia en los casos de actos menores. Otra cosa diferente es que las penas previstas para este tipo sean excesivas. En efecto, el legislador ha demostrado, con esta reforma, un extraordinario celo en hacer cumplir los mandatos previstos en la Constitución española relativos a la imparcialidad de la conducta de los servidores públicos ${ }^{276}$. Por otra parte, vemos que el legislador español ha acogido la propuesta de lege ferenda de CERINA según la cual el criterio seguido para graduar la pena no debe ser la entidad del acto sino "la gravedad de la ilegalidad de la actuación objeto del acuerdo corrupto" 277 . En este mismo sentido se ha pro-

270 En este sentido se ha pronunciado OLAIZOLA NOGALES cuando se pregunta la razón por la que en los supuestos de actos injustos no se tiene en cuenta la competencia específica o genérica del funcionario y en los actos justos sí (I. OLAIZOLA NOGALES, El delito de cohecho, op. cit., p.304).

271 Ibídem, op. cit., p. 303.

272 Para NIETO MARTíN quien cifra el bien jurídico en la imparcialidad de los funcionarios públicos, aunque puede resultar paradójico, la corrupción impropia tiene una lesividad considerable (A. NIETO MARTÍN, “Corrupción y abuso...”, op. cit., p.761). En cambio, OLAIZOLA NOGALES para quien el delito trata de evitar que se perturben las condiciones básicas de funcionamiento necesarias para que la Administración pueda prestar un correcto servicio a los ciudadanos, defiende que el hecho de que el funcionario se compromete a realizar un acto que no entra dentro de su competencia específica suponga un menor desvalor, en el sentido de un menor peligro para el bien jurídico protegido (I. OLAIZOLA NOGALES, El delito de cohecho, op. cit., p.303).

273 C. RAMOS RUBIO, Del delito de cohecho... op. cit., pp.346 y 347; C. MIR PUIG, El delito de cohecho en la reforma...op. cit., p.48.

274 J. CARDONA TORRES, Derecho Penal..., op. cit., p.505.

275 F. MUÑOZ CONDE, Derecho penal, Parte especial,...2010, op.cit., p.1023.

276 J. CARDONA TORRES, Derecho Penal..., op. cit., p.505.

277 G. D. M. CERINA, La lucha contra la corrupción, op. cit., p.1089. 
nunciado, aunque en términos diferentes, MUÑOZ CONDE quien afirma que las penas, en el marco de esta última reforma, varían en función de la cualidad del acto relativo a su cargo que la autoridad o el funcionario se propone realizar278. Por lo tanto, con objeto de integrar efectivamente los actos menores en los supuestos del artículo $420 \mathrm{CPE}$, de lege ferenda, se podrá rebajar el límite mínimo de las penas respetando de esa forma el principio de proporcionalidad.

\section{Sección 4-La modalidad de cohecho sin acto}

En Derecho penal comparado, el CPE figura en la lista de los pocos Códigos penales que contemplan una prohibición general, dirigida a los funcionarios públicos, de aceptar regalos que les sean ofrecidos en consideración a sus cargos. Señala VÁZQUEZ-PORTOMEÑE SEIJAS que en la práctica totalidad de los restantes sistemas penales continentales, la disciplina del cohecho se asienta sobre la existencia de un acuerdo entre el funcionario y el particular, vinculado a un acto o actuación del cargo suficientemente determinados o, al menos, determinables ${ }^{279}$. En efecto, tanto el CPF como el CPM no han previsto esta figura delictiva, ya que ambos vinculan el concepto de corrupción con algún acto o actuación del agente público. Por tanto, a efectos de comparación el artículo 422 CPE llamado "cohecho de facilitación" no tiene equivalencia en esos Códigos, lo cual nos obligará a preguntarnos si este tipo de conducta puede tener alguna respuesta penal en Derecho penal francés y malgache.

\section{I-El cohecho llamado "de facilitación"280 en Derecho pe- nal español}

\section{A-CONSIDERACIONES GENERALES}

El artículo 422 CPE propone un nuevo tipo de cohecho pasivo impropio 281 , o "cohecho de facilitación", en el que se elimina la referencia alternativa, del anterior artículo 426 CPE, a conductas cuya valoración penal era distinta: cohecho cuya contraprestación es un "acto no prohi-

278 F. MUÑOZ CONDE, Derecho penal, Parte especial,...2010, op.cit., p.1022.

${ }^{279}$ F. VÁZQUEZ-PORTOMEÑE SEIJAS, Admisión de regalos y corrupción. Consideraciones político-criminales sobre el llamado "cohecho de facilitación" (artículo 422 CP), Revista de Derecho Penal y Criminología, 3a época, no6 (2011), pp.155 y 156.

280 Es RODRÍGUEZ PUERTA la que utiliza esta expresión para referirse al cohecho tipificado en el artículo 422 CPE. A nuestro manera de entender, la idea de "facilitación" no es sólo para diferenciar el precepto en estudio del artículo 420 CPE sino también revela la concepción de la autora cuando se trata de admitir ventajas en consideración al cargo o a la función (Ma a. J. RODRÍGUEZ PUERTA, "Modificaciones..." op. cit., p.470; F. MORALES PRATS y Ma. J. RODRÍGUEZ PUERTA, "Delitos...", 2011, op. cit., p.1237).

${ }^{281}$ Un sector de la doctrina española denomina esta modalidad de cohecho pasivo impropio, entre otros, L. MORILLAS CUEVA, "Delitos...", op. cit., p.961; F. MUÑOZ CONDE, Derecho penal, Parte especial,...2010, op.cit., p.1024; J. CARDONA TORRES, Derecho Penal..., op. cit., p.506. 
bido legalmente" y aquél que se entrega "en consideración a las funciones".

\section{1-Fundamentación del precepto}

Observa MUÑOZ CONDE que, aunque en el ejercicio de la función pública el funcionario no debe admitir del particular ningún tipo de contraprestación económica, ni siquiera indirecta, pertenece a los usos sociales, sobre todo en comunidades pequeñas, ofrecer al funcionario algún tipo de regalo en correspondencia a "pequeños favores" que éste puede hacer, que van desde ahorrarle al particular la pesada espera en la larga cola ante la ventanilla, hasta rellenarle el mismo funcionario los complicados formularios que el ciudadano tiene que rellenar para pedir un subsidio de desempleo. Realmente, nada de esto debería suceder si la Administración funcionara correctamente, pero es inevitable que el ciudadano quiera ahorrarse molestias e incomodidades y "gratifique" de algún modo al funcionario que le ayuda. Esta gratificación puede ir desde el ofrecimiento de un cigarrillo o un buen cigarro puro, hasta la invitación a un café o cerveza, o el envío de un ramo de flores. Ya más lejanos de la consecución de un acto concreto están los regalos de onomástica, cumpleaños, etc., que puntualmente suelen enviar los ciudadanos "agradecidos" a los funcionarios "benefactores" 282.

Añade MORILLAS CUEVA que la realidad histórica de las infracciones sancionadas por el actual artículo $422 \mathrm{CPE}$, ha sido de notable incidencia en la vida social y en la valoración doctrinal y jurisprudencial. En primer lugar, porque se ha entendido que se trata de un delito de cohecho "menor", ya que con él parece no comprometerse directamente la imparcialidad del funcionario público 283; en segundo lugar, porque, en determinadas ocasiones, se manifiesta más como conducta generalmente admitida por los usos sociales que una modalidad de corrupción pública; en tercer lugar, y precisamente por lo anterior, la dificultad que genera la delimitación del alcance de dicho precepto cuando se trata de evaluar la relevancia típica de acciones que están en una difícil frontera entre módulos sociales admitido, cortesía del funcionario con los ciudadanos que le quieren agradecer su hacer y el carácter punitivo de tales comportamientos ${ }^{284}$.

\footnotetext{
282 F. MUÑOZ CONDE, Derecho penal, Parte especial,...2010, op.cit., pp.1024 y 1025.

${ }^{283}$ En sentido contrario, J. QUERALT JIMÉNEZ, Derecho penal..., 2010, op. cit., p.1168.

${ }^{284}$ L. MORILLAS CUEVA, "Delitos...", op. cit., p.961. El autor cita notorios supuestos recientes en la jurisprudencia españolas, entre otras sentencias, SSTS 362/2008, 1106-08; 410/2010, 17-05-10. En este sentido se ha pronunciado QUERALT JIMÉNEZ para quien también se prohíbe bajo pena el que, en definitiva, el funcionario se deje querer por los particulares a los que debe servir o puede servir. Añade el mismo autor que la pulcritud debe presidir en todo momento en las relaciones entre funcionarios y particulares; pero con todo, si el regalo es poco significativo, y se obra como agradecimiento, puede considerarse impune, pues aún existe una cierta actitud social tendente a agasajar a los funcionarios. Lamentablemente, precisa el autor, esta excepción sigue siendo legal (artículo 54.6 de la Ley 7/2007) y, por tanto fuente de conflictos y de corrupción (J. QUERALT JIMÉNEZ, Derecho penal..., 2010, op. cit., p.1168).
} 
2-La técnica legislativa adoptada por la última refor-

ma

La admisión de dádivas o regalos en consideración al cargo o función queda desagregada, aislada, en un precepto independiente de la variante de cohecho pasivo impropio vinculada a la consecución de un acto ${ }^{285}$. La utilización del verbo "admitir", ha sido criticada por la doctrina española, en lugar de "recibir" (o "aceptar") para describir la conducta típica del funcionario público y se sigue echando falta una mención expresa de la solicitud no aceptada por la contraparte ${ }^{286}$.

En cuanto a lo admitido por la autoridad o funcionario, se utiliza la misma fórmula empleada en el antiguo artículo 426 CPE 1995: "dádiva o regalo". Según ARRIBAS LÓPEZ, podía haberse suprimido el término "regalo", ya que, en este ámbito, puede considerarse equivalente a "dádiva". Con referencia a la fórmula utilizada para el cohecho propio y para la variante anterior del impropio ("dádiva, favor o retribución"), se justifica plenamente que, ahora, no se haga referencia a "retribución" porque la donación no se admite como recompensa o pago de algo ${ }^{287}$, pero, sí se debería haber añadido la palabra "favor", ya que es perfectamente posible el sujeto activo admita lo que pueda tenerse como tal en consideración a su cargo o función ${ }^{288}$. Por otra parte, en el antiguo artículo 426 CPE 1995 se hablaba solo de la admisión de la dádiva o regalo "en consideración a su función"; ahora, se añada también "cargo" a los efectos considerativos que animan la donación. Al mismo autor le parece acertado el añadido aunque una comprensión amplia de "función" podía abarcar tanto el "cargo" como la función en sentido estricto 289 .

También ahora el CPE prevé la actuación de una persona interpuesta en la realización de la conducta típica. Por otro lado, igual que en la variante de cohecho pasivo impropio vinculada a la consecución de un acto, también, en ésta referida a la consideración al cargo o función desempeñada, se produce una ampliación del círculo de posibles beneficiarios de la dádiva o regalo, ya que su admisión puede ser "en provecho propio o de un tercero". La doctrina española ha valorado de manera positiva esta mejora respecto a la anterior redacción ${ }^{290}$.

\footnotetext{
285 E. ARRIBAS LÓPEZ, El cohecho impropio...op. cit., p.4

286 G. D. M. CERINA, La lucha contra la corrupción, op. cit., p.1210, J. QUERALT JIMÉNEZ, Derecho penal..., 2010, op. cit., p.1168.

287 C. MIR PUIG, El delito de cohecho en la reforma...op. cit., p.49. Para este autor, tanto la palabra "dádiva" como "regalo" expresa de manera elocuente el deseo legislativo de despejar cualquier duda acerca de la innecesariedad de un significado retributivo, por actos concretos, que inspire la entrega del presente con el que se quiere obsequiar al funcionario receptor.

288 E. ARRIBAS LÓPEZ, El cohecho impropio...op. cit., p.4.

${ }^{289}$ Ibídem, op. cit., p. 4.

290 C. MIR PUIG, El delito de cohecho en la reforma...op. cit., p.50; L. MORILLAS CUEVA, “Delitos...”, op. cit., p.962; E. ARRIBAS LÓPEZ, El cohecho impropio...op. cit., p.4. Relativiza CERINA respecto de estas expresiones, las cuales para el autor son influyentes de
} 
En cuanto a la respuesta penológica a esta variante de cohecho, los autores españoles notan un incremento punitivo evidente. En efecto, con anterioridad a la reforma, el artículo 426 CPE 1995 preveía una pena de multa de tres a seis meses, mientras el actual artículo 422 CPE lo que anuda a la infracción es una pena de prisión de seis meses a un año y suspensión de empleo y cargo público de uno a tres años ${ }^{291}$. ARRIBAS LÓPEZ hace una valoración positiva con respecto a la introducción de la pena de suspensión del empleo o cargo público, pero negativa por lo que toca a la privativa de libertad, ya que, además de posicionarse, en general, radicalmente en contra de la imposición de penas cortas de prisión para cualquier clase de delincuentes, el autor considera mucho más conveniente para este tipo de criminalidad la imposición de severas penas de multa, con incidencia importante en el patrimonio del sujeto activo 292 .

\section{B-EL ALCANCE DEL PRECEPTO}

\section{1-El debate sobre el bien jurídico protegido}

Hay una discrepancia en la doctrina española en cuanto al bien jurídico protegido en esta figura delictiva. Un sector de la doctrina destaca que el hecho de que este delito se circunscriba a aquellos comportamientos en los que se persigue gratificar al funcionario para tenerlo en buena disposición implica que este tipo de proceder no atenta en contra el principio de imparcialidad, por cuanto la entrega de dádivas a un empleado público por desempeñar sus funciones no persigue incidir en una decisión determinada o determinable. El sentido de este delito debe buscarse en la necesidad de evitar abusos y desviaciones en el ejercicio de funciones públicas, que sin ser tan graves como los supuestos de cohecho antes analizados, revelan un abuso por parte del funcionario que utiliza su cargo para fines distintos a los que le fueron encomendados $^{293}$. En sentido contrario se ha pronunciado NIETO MARTÍN, para quien la necesidad de castigar esta conducta viene de lo que en la criminología se denomina como "ceba" del funcionario público. Se trata de ganarse al funcionario para que llegado el momento realice una conducta favorable al particular. La aceptación o la solicitud de regalos es por ello una forma de vender o comprar al funcionario o autoridad y tenerlo al servicio del particular, con lo que el bien jurídico, la imparcialidad de la Administración queda notablemente afectada ${ }^{294}$.

cara a la disciplina aplicable aunque oportunas en tanto en cuanto resultan clarificadoras (G. D. M. CERINA, La lucha contra la corrupción, op. cit., p.1210).

291 C. RAMOS RUBIO, Del delito de cohecho... op. cit., p.348; C. MIR PUIG, El delito de cohecho en la reforma...op. cit., p.49. Para QUERALT JIMÉNEZ, tras la reforma de 2010, "el delito se ha vuelto serio" (J. QUERALT JIMÉNEZ, Derecho penal..., 2010, op. cit., p.1169).

292 E. ARRIBAS LÓPEZ, El cohecho impropio...op. cit., p.4.

${ }^{293}$ F. MORALES PRATS y Mà. J. RODRÍGUEZ PUERTA, “Delitos...”, 2011, op. cit., p.1238.

${ }^{294}$ A. NIETO MARTÍN, “Corrupción y abuso ...”, op. cit., p.763. 
Más recientemente en la doctrina española, se ha valorado el fundamento de esta modalidad de cohecho desde la imparcialidad de los procedimientos administrativos. VÁZQUEZ-PORTOMEÑE SEIJAS, uno de los defensores de este bien jurídico, destaca que la disciplina penal del cohecho, en todas sus modalidades, tiene como meta prevenir interferencias privadas en el ejercicio de las funciones de la Administración. La relevancia jurídico-penal de cualquier práctica corrupta pasará siempre, pues, por constatar la existencia de una suerte de conexión oportuna entre la admisión del regalo y la posible ejecución de determinadas actividades propias del cargo desempeñado por el funcionario. Según el autor, recurrir a cualquier otro planteamiento para legitimar la incriminación de la admisión de regalos supondría, pagar un precio considerable: el de arrumbar con algunas de las garantías irrenunciables en un Estado de Derecho 295 . El jurista acude a dos parámetros para explicar su postura.

El primero es objetivo: el concepto jurídico-penal de corrupción se asienta sobre una situación de contradicción de intereses (generales) que el funcionario debe perseguir, en virtud del cargo que desempeña, y aquellos otros (privados) a cuya consecución se orienta la entrega de la dádiva o regalo; una contradicción que no puede establecerse, además, de una manera abstracta, sino en consideración al ámbito de ejercicio de la función o de toma de decisiones que se aspira a "blindar" frente a influencias espurias 296 .

El segundo parámetro es subjetivo. Según el mismo autor, puede -y debe- requerirse que en el momento de su admisión, el funcionario asuma, cuando menos, la posibilidad de ser destinatario de futuras solicitudes o requerimientos relativos al ejercicio o materiales inherentes a su cargo, en un ámbito concreto de actividad administrativa ${ }^{297}$.

En efecto, aunque lo que plantea este último autor tiene pertinencia, no se debe olvidar que se trata de consideraciones desde una perspectiva de política criminal298, lo cual nos lleva a definir las condiciones de aplicación del precepto en estudio.

\section{2-Las condiciones de aplicación del artículo 422 CPE}

La mayoría de la doctrina española acude a la jurisprudencia para determinar los elementos típicos que configuran el delito en estudio. En este sentido, el Alto Tribunal español ha establecido una serie de requisitos imprescindibles para su realización, que obviamente son sacados

${ }^{295}$ F. VÁZQUEZ-PORTOMEÑE SEIJAS, Admisión de regalos y corrupción... op. cit., p.171. El autor realiza un análisis en su artículo a partir de otras propuestas de bien jurídico la función que cumple la admisión de regalos (pp.164-171) y concluye que ninguna de ellas es satisfactoria para explicar la intervención del Derecho penal en este tipo de cohecho.

296 Ibídem, op. cit., p. 171.

297 Ibídem, op. cit., p. 172.

${ }^{298}$ Ibídem, op. cit., p. 155. 
de la propia redacción típica: a) la cualidad en el sujeto activo de la condición de autoridad o funcionario público y el ejercicio de funciones públicas por parte del mismo; b) la aceptación por éste de dádiva o regalo; c) conexión causal entre la entrega de dicha dádiva o regalo y la función de autoridad o funcionario, pues la finalidad del regalo o dádiva ha de ser en atención a su cargo o función ${ }^{299}$.

La doctrina española ha acogido estos criterios para analizarlos y en algunos puntos se han encontrado algunas diferencias en sus valoraciones.

En cuanto al primer punto, precisan unos autores que pueden ser sujeto de este delito aquel funcionario o autoridad que tenga atribuidas competencias, cuanto menos genéricas, para adoptar decisiones que pueden incidir sobre el ámbito de actividad propio del particular que ofrece o entrega la dádiva, aunque es posible que se gratifique a un funcionario para que éste incida sobre otros o los predisponga positivamente. Si lo que se busca en este precepto es evitar los abusos y la instrumentalización del cargo para fines particulares, la competencia del empleado público para adoptar decisiones concretas resulta intrascendente. No será necesario, por tanto, constatar que el funcionario tiene pendiente de resolución asuntos que puedan afectar al particular que le ofreció la dádiva, bastaría pues con probar que el funcionario podría llegar a resolver sobre alguna clase de asunto, de forma directa o indirecta 300 . Además tendrían cabida también en esta modalidad los supuestos en los que resulta difícil de determinar el concreto contenido del acuerdo (existen tratos probados pero no se sabe con respecto a qué) entre el particular (obsequiante) y el funcionario (obsequiado) ${ }^{301}$.

VÁZQUEZ-PORTOMEÑE SEIJAS observa que esta postura es atinada y razonable en líneas generales con la condición de que no se considere la situación o la posición del funcionario en el momento de la admisión puesto que en este caso radiaría del tipo las entregas realizadas preexistiendo un evidente y estrecho contacto entre las actividades profesionales del funcionario a corromper y del particular corruptor y que, por ello, puede asociarse fácilmente a la posible formulación de exigencias, peticiones o solicitudes, o incluso, a la decisión del primero de favorecer de alguna manera, por propia iniciativa, en el ejercicio de su cargo, al segundo ${ }^{302}$. Por otro lado, advierte el mismo autor que, aun entendiendo el principio de imparcialidad de los procedimientos administrativos como bien jurídico, no parece posible hacer compatible esa comprensión del bien jurídico del cohecho con las notables diferencias penológicas sentadas por el CPE entre sus diversas modalidades, y que inducen a considerar los actos a realizar por el funcionario como un referente al que asociar su antijuridicidad material y a asignarle al co-

\footnotetext{
${ }^{299}$ Entre otras SSTS 362/2008, 11-06-08; 478/2010, 17-05-10

${ }^{300}$ En sentido contrario, J. CARDONA TORRES, Derecho Penal..., op. cit., p.506.

${ }^{301}$ F. MORALES PRATS y Ma . J. RODRÍGUEZ PUERTA, “Delitos...”, 2011, op. cit., p.1239.

302 F. VÁZQUEZ-PORTOMEÑE SEIJAS, Admisión de regalos y corrupción... op. cit., p.172.
} 
hecho de facilitación la naturaleza de delito de extensión de la intervención penal. Ya en otro sentido, entender suficiente la prueba de la recepción de los regalos para afirmar, de modo automático, la lesión del bien jurídico ${ }^{303}$ precipitaría el riesgo de inversión de la carga de la prueba, en contraste con las exigencias del principio de presunción de inocencia ${ }^{304}$.

Por su parte, NIETO MARTíN entiende que se trata aquí de ofrecer una ventaja al funcionario público en atención a su cargo o función, de tal forma que sin el desempeño de dicha función no se hubiese producido la entrega. No es necesario demostrar la existencia de conexión alguna entre el regalo y un determinado acto futuro en el ejercicio de la función o el cargo ${ }^{305}$. El término desempeño de su función debe entenderse de forma amplia, incluyendo el "círculo de influencia que puede desplegar

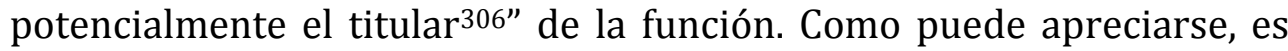
un término más amplio que el del ejercicio del cargo de los delitos de cohecho propio e impropio. Es decir, dentro de la función del cargo habría que atender también a la capacidad de influencia que tiene el cargo público sobre la Administración. De todas formas, no es preciso indagar en el delito de aceptación de regalos qué intención persigue el particular agasajando al funcionario ${ }^{307}$.

Respecto al segundo criterio, la letra del precepto habla de "admitir" lo que equivale, según MORALES PRATS y RODRÍGUEZ PUERTA, a recibir efectivamente las dádivas o regalos o su promesa. El Tribunal Supremo ha mantenido hasta ahora una interpretación amplia de la acción típica, de forma que abrazaba también la mera aceptación de promesa de dádiva o regalo, por parte del funcionario público, sin que se materializase su entrega ${ }^{308}$. A juicio de estos autores, lo esencial es circunscribir el ámbito de las conductas punibles a aquellas situaciones en las que se alcanza un acuerdo entre funcionario y particular, puesto que sólo en estos casos, y no cuando hay una mera oferta unilateral, puede afirmarse que nos encontramos frente a "engrasadores de la actividad administrativa", cuya conducta debe merecer intervención penal ${ }^{309}$.

En contra de esta postura se ha pronunciado POLAINO NAVARRETE, para quien el precepto en estudio integra un tipo de delito de resultado material, por virtud de la exigencia de admisión de un obsequio por parte de la autoridad o funcionario, que comporta la incorporación de

\footnotetext{
${ }^{303}$ Defiende esta postura J. CARDONA TORRES, Derecho Penal..., op. cit., p.506.

304 F. VÁZQUEZ-PORTOMEÑE SEIJAS, Admisión de regalos y corrupción..., op. cit., pp.170 y 171.

${ }^{305}$ En este mismo sentido C. MIR PUIG, El delito de cohecho en la reforma...op. cit., p.49. 306 STS 478/2010, 17-05-10.

307 A. NIETO MARTÍN, “Corrupción y abuso...”, op. cit., p.762

308 SSTS 2-02-1994 [1994, 759], 11-05-1994 [RJ 1994, 3687], 18-10-1994 [RJ 1994, 8026].

${ }^{309}$ F. MORALES PRATS y Mạ. J. RODRÍGUEZ PUERTA, “Delitos...”, 2011, op. cit., p.1239. En el mismo sentido E. CASAS BARQUERO, "Observaciones...", op. cit., p.898; C. MIR PUIG, El delito de cohecho en la reforma...op. cit., p.50.
} 
un valor económico al patrimonio de éstos, siendo evidentemente admisibles las formas imperfectas de ejecución ${ }^{310}$. En este orden de ideas, explica CERINA que la norma tan sólo hace mención del caso en el cual el sujeto público admite ofrecimientos, sin preocuparse, como hacen los demás preceptos previstos en materia de cohecho, de los casos en los cuales el intraneus "solicita" o "acepta promesas". Estima el autor que nada obsta para que los casos en los cuales el funcionario solicita una dádiva sin que su solicitud sea acatada por su destinatario sean penados como tentativas del delito. En este sentido, parece inclinarse la jurisprudencia mayoritaria ${ }^{311}$ que, por otra parte, tampoco parece diferenciar entre "ofrecimiento" o "promesa". Recuerda el jurista que una cosa es "ofrecer" y otra bien distinta es "prometer". Mientras que, quien ofrece, pone algo a disposición de alguien, quien promete, asume una obligación a ejecutar en el futuro. Ahora bien, el tenor literal del artículo 426 CPE 1995 (equivalente al actual artículo $422 \mathrm{CPE}$ ) permite subsumir en esta hipótesis delictiva los casos en los cuales existe un "ofrecimiento", pero no aquellos en los que media una simple "promesa". Y, según la máxima lex distinguit, etiam nos distinguere debemos: si el legislador hubiese querido subsumir en la hipótesis delictiva considerada también las promesas, lo hubiera dicho exactamente como lo ha hecho en los demás preceptos en materia de cohecho ${ }^{312}$. Concluye el mismo autor de la manera siguiente, por lo que atañe al cohecho pasivo tipificado por el artículo $422 \mathrm{CPE}$ :

1-Comete delito consumado el funcionario público que acepta un ofrecimiento o - lo que viene siendo lo mismo - que recibe dádiva o regalo.

2-Comete tentativa de delito el funcionario público que solicita que se le entreguen dádivas o regalos.

3-Es penalmente irrelevante la conducta del funcionario público que solicita que se le prometan dádivas o regalos o que acepta la promesa de dádivas o regalos "en consideración a su función" y sin que medie un acto de su oficio determinado o determinable como contrapartida de la promesa misma ${ }^{313}$.

\footnotetext{
310 M. POLAINO NAVARRETE, “Cohecho...”, op. cit., p. 327.

311 STS 883/1994, 10-05-1994; SAP de Barcelona 4219/1999, 31-05-1999; SAP de Gerona 456/2003, 3-10-2003.

312 En el mismo sentido, E. OCTAVIO DE TOLEDO Y UBIETO, “Derecho penal...", op. cit., p.875; E. CASAS BARQUERO, “Observaciones...", op. cit., p.898.

313 G. D. M. CERINA, La lucha contra la corrupción, op. cit., pp.971-973. Añade el autor que el hecho que se requiera aquí una traditio, por otra parte, se explica con cierta dificultad. Por un lado, en efecto, debe reconocerse que es más bien de laboratorio el caso en el cual un particular "promete" a un funcionario público una dádiva o regalo "en consideración a su función" pero sin pedir nada a cambio; por otro, sin embargo, quizás hubiese sido preferible mantener cierta simetría con las normas anteriores recordando además que, el ejemplo de quo, aparece sí difícil de producirse pero, en todo caso, no es imposible. Amén de ello, el hipotético caso en el cual el ofrecimiento sea sustituido por una promesa, el supuesto resultante no parece entrañar una menor lesividad del bien jurídico protegido ni tampoco una menor reprochabilidad de los sujetos que, respectivamente, prometen, o admiten la promesa.
} 
Respecto al tercer criterio que se refiere a la conexión causal entre la entrega de la dádiva o regalo y la función de autoridad o funcionario, la finalidad del regalo o dádiva ha de hacerse en atención a su cargo o función. Precisa POLAINO NAVARRETE que se trata de una conexión típica que representa el núcleo valorativo de la figura legal y es constitutiva de una relación ocasional según la cual el ofrecimiento del obsequio se ha de efectuar precisamente "en consideración" a la función pública que ostenta el destinatario del objeto económico que es admitido. Aunque el obsequio se efectúe en consideración a la función, es una autoridad o funcionario quien lo admite ${ }^{314}$.

Con detenimiento analiza CERINA la expresión "en consideración a su función"315. Para el autor, de acuerdo con la regulación legal, no son constitutivos de delito todos los supuestos en los que un funcionario público admite dádiva o regalo de un particular, sino que, de iure condito, interesan al Derecho penal tan sólo las hipótesis en las que los mismos se trasladan en consideración a la función pública desempeñada por el intraneus. Es decir, existirá corrupción antecedente siempre y cuando resulte que, sin la promesa de un acto futuro, la dádiva o presente no se hubiera dado, prometido u ofrecido; tendremos corrupción subsiguiente toda vez que quede acreditado que, si no existiese el acto de la función, tampoco habría recompensa. De la misma manera, para que haya delito, según lo establece el artículo 426 inciso I CPE 1995 (el equivalente al actual artículo $422 \mathrm{CPE}$ ), deberá demostrarse que, si el funcionario público no desempeñara la función pública que desempeña, aquellos mismos regalos no se le hubieran entregado ${ }^{316}$. Por otra parte, afirma el mismo autor que aunque no quedaran suficientemente acreditadas ninguna de estas finalidades o motivos y si se mantuviera que los beneficiarios de los regalos no eran competentes para dictar actos hacia los cuales los donantes tenían interés, el legislador, al redactar esta norma, no ha querido condicionar su aplicación a la existencia de una u otra finalidad que animen al sujeto público o al particular, de tal manera que, una vez demostrado que no concurre otro motivo para el regalo sino la función desempeñada por el funcionario, ya se ha cumplido con

\footnotetext{
${ }^{314}$ M. POLAINO NAVARRETE, “Cohecho...”, op. cit., p. 327

315 Es la expresión utilizada por el anterior artículo 426 CPE 1995, pero consideramos que su aportación al respeto no carece de validez para analizar el actual artículo 422.

316 G. D. M. CERINA, La lucha contra la corrupción, op. cit., pp.976 y 977 . Observa el autor que el acuerdo que existe acerca de este punto, podría hacer pensar que, con lo dicho, se resuelven todos los problemas aplicativos del precepto del que hablamos. En sentido contrario, recientes posturas asumidas por la jurisprudencia de mérito y de legitimidad han puesto de manifiesto que el acuerdo es más bien aparente. En efecto, una cosa es admitir que deba existir una relación de causalidad entre la función desempeñada y el regalo admitido y otra bien distinta es demostrar dicha relación. El peligro parece dúplice: si se exige "demasiado" para admitir la relación de causalidad, se corre el riesgo de aplicar el artículo 426 inciso I (actual artículo $422 \mathrm{CPE}$ ) en casos que, en realidad, son de cohecho propio o impropio; por otra parte, si se afirma con demasiada facilidad la existencia de una relación de causalidad entre la función y los regalos, se termina avalando una interpretatio abrogans del inciso "en consideración a su función", otorgando así al precepto en estudio una amplitud difícilmente compatible con los principios de intervención mínima, fragmentariedad y taxatividad.
} 
el requisito mínimo requerido por el tipo. Sin embargo, advierte el jurista que aceptando una interpretación tan amplia se terminan diluyendo los "limites inferiores" que separan lo que es penalmente irrelevante de lo que constituye delito a tenor de lo dispuesto por el artículo $422 \mathrm{CPE}$. Es decir, fuera del inseguro límite representado por la adecuación social, será extremadamente complicado argumentar la irrelevancia penal de los regalos otorgados a un funcionario público: incluso en el caso en el cual medie una relación de amistad entre el funcionario y el particular, siempre podrá argumentarse que el regalo entregado por el segundo al primero, tiene su causa principal en la función desempeñada por éste ${ }^{317}$.

Este último punto, señalado por CERINA, nos lleva a considerar el complicado criterio de la adecuación social.

\section{3-El problema de la "adecuación social"}

Existe un acuerdo en la doctrina española según el cual la aplicación del artículo $422 \mathrm{CPE}$ depende de si el regalo o la dádiva exceden o no de lo que se considera "adecuado socialmente" 318 . En palabras de MIR PUIG, si la dádiva o regalo es de entidad menor, cabe afirmar la atipicidad por los principios de insignificancia o de adecuación social. Según el mismo autor, ello sucede cuando la dádiva es de un valor tal que en modo alguno está en situación de influir en el ejercicio de la función pública y constituye un mero regalo de cortesía ${ }^{319}$. En efecto para valorar lo que puede ser adecuado socialmente, los autores españoles consideran que los términos "dádiva o regalo" deben tener naturaleza material y económica ${ }^{320}$, aunque se ha sugerido que sí se debería haber añadido la palabra "favor", ya que es perfectamente posible que el sujeto activo admita lo que pueda tenerse como tal en consideración a su cargo o función ${ }^{321}$. Por su parte, POLAINO NAVARRETE destaca la importancia

317 Ibídem, op. cit., p. 982. Añade el autor que tan sólo en contadas ocasiones podrá afirmarse con seguridad que el mismo regalo se hubiese entregado incluso si el funcionario no desempeñara la función que desempeña. Así las cosas, el riesgo que se llegue a una inversión de la carga de la prueba parece consistente: es verosímil esperar que, en la mayoría de los casos, serán el intraneus (que acepta el regalo) y el extraneus (que regala) los que deberán demostrar que la dádiva tiene una razón de ser distinta a la función pública desempeñada por el primero. Ahora, hay que entender una cosa: que el funcionario no acepte ningún regalo, y que no se le ofrezca nunca ninguna dádiva, es principio que puede, al límite, compartirse. Su quebrantamiento, sin embargo, no parece deberse encomendar tout court al derecho penal (p.983).

318 Entre otros, A. SERRANO GÓMEZ y A. SERRANO MAÍlLO, Derecho Penal, Parte Especial...op. cit., p.841; J. CARDONA TORRES, Derecho Penal..., op. cit., p.506, F. MUÑOZ CONDE, Derecho penal, Parte especial,...2010, op.cit., p.1025; M. POLAINO NAVARRETE, “Cohecho...", op. cit., p. 328; J. QUERALT JIMÉNEZ, Derecho penal..., 2010, op. cit., p.1169.

${ }_{319}$ C. MIR PUIG, El delito de cohecho en la reforma...op. cit., p.50.

${ }^{320}$ Entre otros, F. MORALES PRATS y Mํ. J. RODRÍGUEZ PUERTA, “Delitos...”, 2011, op. cit., p.1239.

${ }^{321}$ E. ARRIBAS LÓPEZ, El cohecho impropio...op. cit., p.4. Toma el autor el ejemplo de la concesión de un crédito hipotecario en condiciones ventajosas, distintas a las habitua- 
del contenido económico de la dádiva o del regalo. Afirma que singular relevancia ofrece, en orden a la apreciación de la significación penal del elemento típico integrado por la dádiva o regalo admitidos por el funcionario público, el contenido de su valor económico en relación a la función. La relación de conexión ocasional con la función pública viene fundamentada en dos elementos caracterizadores de esta relación: la significación objetivo-social del bien económico aceptado por el funcionario en consideración a su función y la eficacia subjetiva que el bien económico tenga en orden a la actuación funcionarial. El ofrecimiento y la aceptación de obsequios de contenido puramente simbólico, sean o no efectuados en consideración a la función o para la consecución de algún acto funcionarial, en la medida en que resulte socialmente adecuada su admisión, quedará privada de relevancia típica al ser cubierta por una causa de atipicidad que la deja fuera del marco descriptivo del ordenamiento penal ${ }^{322}$.

Precisamente acerca de este último punto, un sector de la doctrina española denuncia que el límite del valor de la dádiva o regalo para poder incriminar el acto dispuesto en este precepto, como venal, puede ser un escollo para perseguir tal infracción por la vía penal ${ }^{323}$. El problema es que es el mismo Código penal el que incluye incluso los regalos socialmente habituales y de cortesía ${ }^{324}$. En este orden de ideas, considera ARRIBAS LÓPEZ que el legislador español ha desaprovechado las últimas reformas para introducir alguna referencia a la adecuación social como criterio limitativo del perímetro típico. En efecto, la aceptación por parte de la autoridad y funcionario de cualquier obsequio, por insignificante que fuese, le convertiría en sujeto activo del delito de cohecho pasivo impropio en esta modalidad. Por lo tanto, el autor vuelve a decantarse por una modificación normativa que limite las conductas incriminadas a aquéllas que desborden los márgenes de lo socialmente adecuado. Por otro lado, partiendo del reproche penal que merece en todo caso el hecho de que, fuera de los usos y costumbres sociales comúnmente aceptados, una autoridad o funcionario admita dádivas o regalos que le fuesen ofrecidos en consideración a su cargo o función, estima el autor que es necesario distinguir entre infracciones penales tomando en consideración el valor económico de lo entregado. Desde el punto de vista de la proporcionalidad que debe animar la reacción penal, no es igual aceptar un regalo de 300 euros que otro de 30.000; por eso, partiendo de un mismo esquema delictivo típico ${ }^{325}$, el autor se decanta nuevamente porque si la dádiva o regalo no supera los 400 euros,

les del mercado para un cliente de similares características personales y patrimoniales (p.5).

322 M. POLAINO NAVARRETE, “Cohecho...”, op. cit., p. 328.

323 J. CARDONA TORRES, Derecho Penal..., op. cit., p.506.

${ }^{324}$ I. ORTIZ DE URBINA GIMENO, “Delitos...", p.338.

325 En el mismo sentido y con términos parecidos F. MUÑOZ CONDE, Derecho penal, Parte especial,...2010, op.cit., p.1025; J. CARDONA TORRES, Derecho Penal..., op. cit., p.506. 
la acción se considere una falta, mientras que si los sobrepasa fuese calificada como delito ${ }^{326}$.

Ante estas reclamaciones de la doctrina española, nos parecen llamativas las reflexiones de VÁZQUEZ-PORTOMEÑE SEIJAS acerca de los regalos socialmente adecuados en el marco del cohecho de facilitación. Recuerda el autor que, con arreglo al apartado 3oㅡ, núm. 6, párrafo primero, del Código de Buen Gobierno de los Miembros del Gobierno y de los Altos Cargos de la Administración General del Estado, aprobado por Acuerdo del Consejo de Ministros de 18 de febrero de 2005, «se rechazará cualquier regalo, favor o servicio en condiciones ventajosas que vaya más allá de los usos habituales, sociales y de cortesía». Esta disposición se cohonesta perfectamente con la línea de actuación de la doctrina y de la jurisprudencia españolas, tal como se ha señalado anteriormente. Sin embargo, opina el jurista, es discutible que, por sí sola, la distinción entre regalos socialmente inadecuados, por implicar el enriquecimiento del funcionario (un reloj de oro, un ordenador de última generación o la invitación para acudir a un congreso en otro país), y pequeñas atenciones de bagatela o de reconocimiento social habitual (la botella de vino entregada al cartero con motivo de las fiestas navideñas o la agenda con que se obsequia a quienes intervienen en una reunión) permita seleccionar, con la necesaria seguridad jurídica, el ámbito de lo penalmente relevante. Haciendo abstracción de los casos de manual, la valoración social nunca podrá ofrecer una respuesta unívoca sobre la proporcionalidad del regalo, que deberá hacerse depender, entre otros extremos, de las relaciones financieras típicas del ramo de la Administración al que pertenezca el funcionario de su propio rango jerárqui$\mathrm{co}^{327}$. De persistirse en la idea de que la teoría de la adecuación social represente el expediente idóneo para dar una respuesta satisfactoria al fenómeno jurídico-penal de los "regalos a funcionarios", deberá reducirse, en consecuencia, el casuismo y la complejidad de esta tarea de ponderación, bien limitando el acceso al tipo a regalos con un cierto perfil económico, bien recurriendo a un criterio político-criminal.

Explica el autor, que el criterio de la condición económica del regalo puede servir de base para elaborar un catálogo de directrices o pautas de actuación destinadas a los empleados públicos, en general, pero no permite dar cuenta -ni mucho menos- de todos los supuestos controvertidos. Por otra parte, dar concreción al concepto jurídico indeterminado "usos sociales", poniéndolo en relación con la cuantía del regalo, no se compadece bien con la denominada teoría cualitativa de la dádiva, a cuyo tenor, la tipicidad del instrumento del cohecho no se fía a su naturaleza o valor, sino a su idoneidad para asegurarle al particular una concreta actuación u omisión del funcionario. Tampoco serviría para precluir interpretaciones extensivas del tipo en contra del reo, pensando en casos como el de la enfermera que acepta la casa que le ha dejado

326 E. ARRIBAS LÓPEZ, El cohecho impropio...op. cit., p.4.

327 F. VÁZQUEZ-PORTOMEÑE SEIJAS, Admisión de regalos y corrupción..., op. cit., pp.160 y 161 . 
en herencia el anciano al que ha prestado cuidados en los últimos meses de su vida.

Atendiendo a estos argumentos, concluye el mismo autor que se impone la segunda de las opciones: lo único que permitirá dotar de una cierta coherencia interna al precepto contenido en el artículo $422 \mathrm{CPE}-\mathrm{y}$, acotar al propio tiempo, el ámbito de lo punible - es su interpretación con arreglo a parámetros vinculados a su ratio ${ }^{328}$. Dicho en otras palabras, ni la adecuación social del regalo puede servir de pretexto para excluir del ámbito típico conductas idóneas para afectar, de modo relevante, al bien jurídico que protege, ni su falta de adaptación a la ética social dominante puede justificar la conversión en delitos de cualesquiera prácticas que carecen de aquella virtualidad ${ }^{329}$.

Ante estas dificultades, unos autores han emitido propuestas de lege ferenda para acotar no sólo el alcance real del artículo 422 CPE sino también la intervención del Derecho penal en materia de regalos.

\section{4-Propuestas doctrinales de lege ferenda}

En esa óptica, CERINA propone que se considere la posibilidad de limitar el ámbito de aplicación del precepto en estudio a los casos en los que funcionario se compromete a actuar (que no a realizar un acto) en el ejercicio de sus funciones. De esta forma, podrán considerarse abarcados por el Derecho penal aquellos supuestos de indudable gravedad en los que existe sí una compraventa de algo público a cambio de un beneficio indebido, pero la prestación del funcionario público no resulta, en principio ni determinada ni determinable, ni siquiera en su genus: se avalaría, en otras palabras, una sanción penal para aquellos casos en los que, lo que se "vende", es la función entera ${ }^{330}$. Por otra parte, la existencia de una norma así configurada al lado de los tradicionales delitos de cohecho, permitiría excluir de lo penalmente relevante todos aquellos donativos cuya entrega a un funcionario no guarda relación ninguna con su futuro proceso de toma de decisiones ${ }^{331}$.

\footnotetext{
328 De esta misma opinión, entre otros, I. OLAIZOLA NOGALES, El delito de cohecho, op. cit., p.51, quien propone recurrir al criterio del hombre medial para establecer -ex ante y a partir de los conocimientos con que contaba el particular- si una determinada dádiva tiene capacidad corruptiva. A nuestro juicio, esta postura se parece a la defendida por POLAINO NAVARRETE quien afirma que el valor económico objetivo y la estimación subjetiva por parte del funcionario público recipendiario del obsequio constituirán claves fundamentales de la tipicidad de la acción, de suerte que en esta hipótesis de cohecho pasivo la admisión de obsequios de cortesía o deferencia sólo adquirirá relevancia típica cuando transcienda efectivamente en el ejercicio de la función pública (M. POLAINO NAVARRETE, “Cohecho...”, op. cit., p. 328).

${ }^{329}$ F. VÁZQUEZ-PORTOMEÑE SEIJAS, Admisión de regalos y corrupción..., op. cit., pp. 162-164.

${ }^{330}$ En términos parecidos, MIR PUIG habla de "la generalidad de actos propios de su función" (C. MIR PUIG, El delito de cohecho en la reforma...op. cit., p.49).

331 G. D. M. CERINA, La lucha contra la corrupción, op. cit., p.984.
} 
Por su parte, VÁZQUEZ-PORTOMEÑE SEIJAS señala que el preocupante fenómeno de la corrupción pública ha de atajarse de la mano de estrategias preventivas y de control plenamente respetuosas con el principio de subsidiariedad del Derecho penal, y no con la criminalización indiscriminada de las (posibles) actitudes internas de predisposición de los funcionarios a favor de los intereses de un particular o de un grupo de particulares. En tanto no aparezca vinculada a la realización de actividades interesadas, la venta de la receptividad, predisposición o simpatía de los funcionarios públicos no se corresponde con el campo de la corrupción. Para reprimir estas conductas, en lugar de encomendarse al Derecho penal para reforzar los Códigos de condena del cohecho y sus "costes morales", el legislador debería poner sus ojos, en primer lugar, en el Derecho disciplinario, como garante natural de la legalidad y transparencia de la actividad de la Administración Pública. Al autor le parece oportuno reivindicar, al hilo de ello, una reforma de los ilícitos disciplinarios que termine por asignarles la función preventiva de la que actualmente carecen. Apelar al carácter disuasorio del Derecho penal no puede servir de coartada, en un Estado social y democrático de Derecho, para mantener un sistema de sanciones desproporcionado, desequilibrado ${ }^{332}$.

Por otro lado, admite el autor que la incriminación del cohecho de facilitación sólo puede justificarse a partir de su peligrosidad - objetiva y subjetiva - para la correcta valoración de los intereses en conflicto, propia de todo procedimiento administrativo. Por ello, y teniendo en cuenta que el tenor literal del artículo $422 \mathrm{CPE}$ no se cohonesta bien con esta estructura de peligro, debe proponerse la sustitución de la cláusula "en consideración a su cargo o función" por la expresión "para el ejercicio de su cargo o función". Concluye el jurista al advertir que la introducción de figuras flexibles, capaces de penalizar indiscriminadamente, al mismo tiempo, fenómenos empíricamente conexos con el cohecho y cualesquiera infracciones de las normas del Derecho funcionarial que proscriben la admisión de regalos, se halla en línea con un ordenamiento punitivo que se deja guiar, exclusivamente, por la necesidad de descargar al juzgador de complejos problemas probatorios y que margina las garantías características del Derecho penal liberal, entre ellas, las representadas por los principios de legalidad y ofensividad ${ }^{333}$.

En el mismo sentido se ha pronunciado CERINA quien observa que la ratio de una norma como el artículo 426 I inciso CPE 1995 (es decir, el actual artículo 422 CPE 2010), no debe cifrarse en la posibilidad de sancionar penalmente los casos "residuales", difíciles de probar o particularmente leves sino en proporcionar al sistema una herramienta de lucha contra graves supuestos de corrupción que tenga en cuenta las nuevas manifestaciones de este fenómeno. A la vez de ello, un replanteamiento como el autor propone, demandaría, finalmente, un Derecho

332 F. VÁZQUEZ-PORTOMEÑE SEIJAS, Admisión de regalos y corrupción..., op. cit., pp.173 y 174 .

333 Ibídem, op. cit., pp.175 y 176. 
administrativo sancionador capaz de desempeñar un papel efectivo en la lucha contra la corrupción ${ }^{334}$.

\section{5-Toma de postura}

A nuestro modo de entender, es cierto que esta figura delictiva no atenta contra el principio de imparcialidad, ya que la entrega de dádiva o de regalo no pretende interferir sobre una decisión o un acto determinado y determinable. Tampoco se puede hablar de delito de peligro concreto ya que para saber cuándo se pone en peligro concreto el bien jurídico es preciso tener claro cuándo se produce la lesión, y para determinar ésta es necesario, si del principio de imparcialidad hablamos, conocer el concreto acto contrapartida de la dádiva ${ }^{335}$.

Estamos de acuerdo con VÁZQUEZ-PORTOMEÑE SEIJAS cuando afirma que el tenor literal del artículo $422 \mathrm{CPE}$ no se cohonesta bien con la estructura de peligro - objetivo y subjetivo - para la correcta valoración de los intereses en conflicto, propio de todo procedimiento administrativo. En efecto, la letra del precepto no exige la constatación de una suerte de conexión corrupta entre la admisión del regalo y la posible ejecución de determinadas actividades propias del funcionario para que se justifique la relevancia jurídico-penal de esta práctica ${ }^{336}$. Por lo tanto, si este peligro no puede existir en estos términos, entendemos que se puede cuestionar la intervención del Derecho penal en esta materia. Por otro lado, CERINA, otro defensor del principio de la imparcialidad procedimental, admite que es evidente que dicho procedimiento se ve alterado en el mismo momento en el cual interviene la injerencia privada: una vez que ha aceptado su inscripción en el abanico de sujetos "asalariados" por el particular, deberá en todo caso admitirse que el sujeto público ya ha alterado su capacidad de decidir de forma imparcial. Por consiguiente, el autor afirma que nos encontramos delante de un menoscabo del mismo interés, que se apoya ahora no ya en un intercambio "acto del oficio/dádiva", sino que implica una mucha menos definida compraventa cuyos términos son, por un lado, dádivas y, por otro, el global y general (pero eventual) ejercicio de la función pública337.

No nos parece convincente la postura de CERINA, ya que el autor parece adelantar el momento de la lesión del bien jurídico imparcialidad procedimental para justificar la razón de ser del artículo 422 CPE. A nuestra manera de entender, el precepto en estudio no pide al funcionario o a la autoridad que tome alguna decisión para un acto o una actuación determinada, por lo tanto no hay ninguna conexión causal entre la dádiva y una conducta del titular del cargo. El hecho de admitir por parte

\footnotetext{
334 G. D. M. CERINA, La lucha contra la corrupción, op. cit., p.984.

335 J. VIZUETA FERNÁNDEZ, Delitos..., op. cit., p.234. En contra de esta postura I. VALEIJE ÁLVAREZ “Consideraciones...”, op. cit., pp.367 y 368.

336 F. VÁZQUEZ-PORTOMEÑE SEIJAS, Admisión de regalos y corrupción..., op. cit., pp.171 y 173

337 G. D. M. CERINA, La lucha contra la corrupción, op. cit., pp.967 y 968.
} 
del funcionario no altera su capacidad de decisión, porque justamente en esta modalidad no se pide ninguna decisión. Puede que esta capacidad esté en peligro por ser alterada eventualmente por la admisión de regalo, pero en realidad no vemos ninguna lesión a este bien jurídico.

Por otro lado, tampoco estamos de acuerdo con el mismo autor cuando habla de venta o de compraventa del ejercicio de la función pública en el futuro. En efecto, esta postura se acerca a la defendida por OCTAVIO DE TOLEDO quien considera que el bien jurídico en el inciso primero del anterior artículo 426 CPE 1995 (el equivalente al actual artículo 422 $\mathrm{CPE}$ ), al igual que en el resto de las modalidades de cohecho, es la no venalidad del ejercicio de las funciones públicas, entendida la no venalidad, acogiéndose al Diccionario de la Lengua Española de la Real Academia, como la falta de la cualidad de vendible o expuesto a la venta ${ }^{338}$. Esta postura ha sido criticada por la doctrina española ${ }^{339}$, pero nos parecen contundentes las consideraciones formuladas por VIZUETA FERNÁNDEZ, quien defiende que aunque tal parecer puede ser sugestivo, presenta alguna dificultad que impide su validez para explicar todos los tipos de cohecho. La venalidad es la cualidad de venal, y venal significa, en una de sus acepciones, la utilizada por este autor, vendible o expuesto a la venta. El sustantivo adjetivado por estos calificativos, esto es, aquello que puede venderse o exponerse a la venta ha de ser algo determinado, concreto, requisito que no se da cuando el funcionario admite una dádiva o regalo ofrecido en consideración a su función en los casos en que tal ofrecimiento está desligado de un comportamiento concreto. Concluye el autor que la no venalidad del ejercicio de las funciones públicas ha de conllevar la licitud de la contrapartida de la dádiva, esto es, que el concreto comportamiento público que se expone a la venta sea lícito, pues sólo de las actuaciones públicas lícitas puede defenderse que no se vendan, su no comercialización. Defender la no venalidad de actuaciones ilícitas equivaldría a darles legitimidad. Un determinado comportamiento público lícito no ha de realizarse a cambio de una dádiva; un comportamiento relativo al ejercicio del cargo que sea ilícito, simplemente no ha de realizarse, ni con dádiva ni sin ella. Proteger la no venalidad de una actuación ilícita sería comparable a proteger la libre competencia en el tráfico de heroína ${ }^{340}$.

En cuanto a la justificación de la figura delictiva, estamos de acuerdo con el sector de la doctrina española que encuentra el fundamento de la sanción de la conducta tipificada en el abuso del cargo cometido por el funcionario que utiliza su puesto en la Administración para enriquecer$\mathrm{se}^{341}$. En efecto, éste último instrumentaliza sus funciones en cuanto

\footnotetext{
${ }^{338}$ E. OCTAVIO DE TOLEDO Y UBIETO, “Derecho penal...”, op. cit., pp.871 y 872.

339 Entre otros N. J. DE LA MATA BARRANCO, La respuesta..., op. cit., pp. 80 y ss.; I. OLAIZOLA NOGALES, El delito de cohecho, op. cit., pp.97-99.

340 J. VIZUETA FERNÁNDEZ, Delitos..., op. cit., pp.236 y 237; I. VALEIJE ÁLVAREZ “Consideraciones...", op. cit., p.352.

${ }^{341}$ F. MORALES PRATS y Ma. J. RODRÍGUEZ PUERTA, “Delitos...", 2011, op. cit., pp.1238 y 1239.
} 
acepte dádiva o regalo no compatible con su necesaria neutralidad administrativa y la interdicción de enriquecimiento por el propio ejercicio de su cargo o función, como no sea la retribución normativamente fija$\mathrm{da}^{342}$. En este sentido consideramos que la incriminación de este tipo de conducta debe implicar medidas y sanciones disciplinarias dejando los casos más graves al ordenamiento penal, con la condición de que el legislador penal añada más precisiones en el tipo penal para acotar el ámbito de aplicación del precepto.

Respecto a las iniciativas unilaterales, somos partidarios de la tesis según la cual el tipo se circunscribe a aquellas situaciones en las que se alcanza un acuerdo entre el funcionario y particular. A nuestro modo de ver, la gravedad de este tipo de conductas no se halla en la capacidad del obsequiante para predisponer favorablemente al funcionario, sino en la actitud receptiva que éste último demuestra ante el ofrecimiento del particular ${ }^{343}$. Creemos que desde esta perspectiva el legislador penal español no ha incluido la solicitud como conducta típica. Además, si el funcionario o la autoridad solicita alguna dádiva o regalo a un particular, la única consideración a su función no tiene por qué bastar para motivar al segundo. Para que la solicitud del titular del cargo público tenga más probabilidad de surtir efectos, deberá conllevar algo más o menos concreto que pueda beneficiar y motivar al particular, potencial obsequiante. En este caso, ya estamos ante uno de los supuestos que integra una de las modalidades del cohecho pasivo puesto que la solicitud tiene un contenido diferente de la mera consideración al cargo o función. Por otro lado, como señala NIETO MARTíN, no es preciso indagar en el delito de aceptación de regalos qué intención persigue el particular agasajando al funcionario. Si se probara que el regalo se entrega para un determinado acto habría que pensar en aplicar el cohecho propio, el impropio o, en otras ocasiones, en la figura del tráfico de influencias $^{344}$, sin que por eso, esta figura se convierta en un "atajo probatorio" exonerando a los acusadores de demostrar un elemento del tipo subjetivo.

Sobre este punto compartimos la tesis según la cual convertir una cuestión de prueba en una cuestión de Derecho sustantivo es práctica seguramente censurable ya que, en la mayoría de los casos, termina avalando inversiones de la carga de la prueba difícilmente compatibles con el principio de presunción de inocencia. Y el caso considerado por el artí-

\footnotetext{
${ }^{342}$ L. MORILLAS CUEVA, “Delitos...”, op. cit., pp.931 y 932.

${ }^{343}$ En este sentido se ha pronunciado A. NIETO MARTíN, “Corrupción y abuso...", op. cit., p.762, para quien el "plan del autor" no forma parte del tipo.

344 Ibídem, op. cit., pp.762 y 763. En este punto constatamos una asimetría en el tratamiento penal de las iniciativas unilaterales. En efecto cuando el objeto del delito es la consideración al cargo o a la función, el artículo 422 CPE no señala la posibilidad de sancionar la iniciativa unilateral del funcionario al solicitar dádiva o regalo. Sin embargo, el artículo 424 CPE sanciona la iniciativa del particular cuando ofrece dádiva en consideración al cargo o función del funcionario o autoridad. En efecto, para el particular tanto atender una solicitud como ofrecer sin recibir respuesta del funcionario le expone a la sanción penal.
} 
culo 422 CPE no representaría una excepción a dicha regla: si aceptáramos que la ratio de la norma es la de aliviar los esfuerzos probatorios de la jurisprudencia, estaríamos afirmando que, en este caso, el legislador presume iuris et de iure (o iuris tantum) que toda vez que un particular entrega algo al funcionario, lo hace para conseguir de él algo a cambio o por haberlo ya conseguido. Puesto que no se ha logrado identificar la contraprestación, el legislador avalaría, por tanto, una inaceptable política de "rebajas": para los acusadores, que resultan exonerados de demostrar un elemento del tipo subjetivo; y para los imputados, que se verán sí condenados, pero con una pena significativamente inferior a la que les correspondería si dicho elemento subjetivo resultara probado $^{345}$.

En cuanto a los regalos socialmente adecuados, estamos de acuerdo con VÁZQUEZ-PORTOMEÑE SEIJAS quien afirma que es discutible que, por sí sola, la distinción entre regalos socialmente inadecuados, por implicar el enriquecimiento del funcionario, y pequeñas atenciones de bagatela o de reconocimiento social habitual permita seleccionar, con la necesaria seguridad jurídica, el ámbito de lo penalmente relevante. Añade el autor que la valoración social nunca podrá ofrecer una respuesta unívoca. Por lo tanto, siendo partidario de la teoría cualitativa de la dádiva que supedita la tipicidad del instrumento del cohecho a su idoneidad, para asegurarle al particular una concreta actuación u omisión del funcionario, el autor propone interpretar el artículo $422 \mathrm{CPE}$ con arreglo a su ratio ${ }^{346}$. En cierta manera, tiene razón POLAINO NAVARRETE al defender que el valor económico objetivo y la estimación subjetiva por parte del funcionario público recipendiario del obsequio constituirán claves fundamentales de la tipicidad de la acción, de suerte que en esta hipótesis de cohecho pasivo la admisión de obsequios de cortesía o deferencia sólo adquirirá relevancia típica cuando transcienda efectivamente en el ejercicio de la función pública. El mismo autor aclara que este valor económico objetivo debe tener una significación objetivosocial, es decir, no puede ciertamente ser de carácter puramente simbólico $^{347}$. Esta postura es de recibo siempre que el obsequio pueda ser valorado económicamente.

A nuestro modo de ver, estos autores condicionan la tipicidad de la admisión del regalo cuando éste supera lo que objetivamente se considera simbólico y, a la vez, tiene la capacidad para condicionar de alguna manera al funcionario en el desempeño de su cargo. Aunque se trate de una manera acertada para acotar el ámbito de lo penalmente relevante, recuerda CARDONA TORRES que debe tenerse en cuenta que la ley no distingue ni especifica más; únicamente se indica, como criterio determinante, que la admisión del regalo tiene que ser en provecho propio o

\footnotetext{
345 G. D. M. CERINA, La lucha contra la corrupción, op. cit., p.965

346 F. VÁZQUEZ-PORTOMEÑE SEIJAS, Admisión de regalos y corrupción..., op. cit., pp. 161 y 163

${ }_{347}$ M. POLAINO NAVARRETE, “Cohecho...”, op. cit., p. 328.
} 
de tercero, siendo el significado de "provecho" el reporte de un beneficio o utilidad, lo que debe decidir el Juez ${ }^{348}$.

En efecto, en ausencia de previsión y precisión legales, siempre el contenido y la aplicación del artículo 422 CPE serán sujetos a debate y plantearán dificultades a la hora de interpretarlo. Por lo tanto, nos sumamos a la reivindicación de la doctrina española que opina de un lado que una modalidad delictiva de esta índole resultaría innecesaria si existieran códigos o programas de buen gobierno en el ámbito de la función pública que limitaran o prohibieran la aceptación, por parte del empleado público, de cualquier tipo de regalo o ventaja, aparejando a esta clase de prohibiciones sanciones disciplinarias eficaces ${ }^{349}$; y de otro lado que el legislador español de 2010 ha desechado una importante ocasión para profundizar en las oportunidades que le hubiera brindado una adecuada remodelación de este precepto ${ }^{350}$.

Por lo tanto, ante la rápida evolución del fenómeno de la corrupción al tomar una forma cada vez más sofisticada, creemos que el legislador debería proceder a una reforma del artículo 422 CPE acotando de manera precisa el tipo, a fin de identificar los supuestos más graves merecedores del aumento de pena dispuesto en el actual Código penal.

\section{II-Estado de la cuestión en Derecho penal francés y mal- gache}

\section{A-DERECHO PENAL FRANCÉS}

Como ha señalado VÁZQUEZ-PORTOMEÑE SEIJAS en su análisis del Derecho comparado en materia de cohecho facilitación, el CPF sigue la tendencia de los sistemas penales continentales en los que la disciplina del cohecho se asienta sobre la existencia de un acuerdo entre el funcionario y el particular, vinculado a un acto o actuación del cargo suficientemente determinados, o al menos, determinables. Constata el autor que la casuística jurisprudencial francesa ha ido trazando la línea divisoria entre los regalos destinados a influir en acciones concretas de los funcionarios públicos y los denominados regalos de cortesía (carentes de relevancia jurídico-penal) ${ }^{351}$. En efecto, el CPF no ha previsto ningún tipo penal para sancionar la admisión de regalos por un agente público en consideración de su cargo.

El Informe de la Comisión de reflexión para la prevención de conflictos de intereses en la vida pública, entregado al Presidente de la República francesa el 26 de enero de 2011, reconoce que Francia no tiene, en ma-

\footnotetext{
348 J. CARDONA TORRES, Derecho Penal..., op. cit., p.506.

${ }^{349}$ F. MORALES PRATS y Mà. J. RODRÍGUEZ PUERTA, “Delitos...”, 2011, op. cit., p.1238. En el mismo sentido F. VÁZQUEZ-PORTOMEÑE SEIJAS, Admisión de regalos y corrupción..., op. cit., p.174.

350 G. D. M. CERINA, La lucha contra la corrupción, op. cit., p.1210.

${ }^{351}$ F. VÁZQUEZ-PORTOMEÑE SEIJAS, Admisión de regalos y corrupción..., op. cit., p.156.
} 
teria de regalos e invitaciones, reglamentación general y está en la retaguardia respecto a los demás Estados de la OCDE ${ }^{352}$. Además, según el mismo documento, la aceptación de regalo por un agente público depende hoy en día, salvo reglamentación especial de una institución o un servicio ${ }^{353}$, de los comportamientos individuales y el conocimiento de las obligaciones generales impuestas a cada agente ${ }^{354}$.

Sin embargo, en su clase de Deontología de los funcionarios y principios de servicio público de la Educación nacional, TAILLEFAIT indica que la jurisdicción contencioso-administrativa recuerda regularmente al agente público su obligación de desinterés ${ }^{355}$ respecto al usuario del servicio público ${ }^{356}$.

La obligación de no recibir dádivas de parte de los administrados no era algo que se ha extraído de la Ley 83-634 del 13 de julio de 1983 relativa a los derechos y obligaciones de los funcionarios. Ya desde el año 1981 el Consejo de Estado francés destacaba esta obligación como principio que debe regir la actuación del funcionario público ${ }^{357}$. Señala TAILLEFAIT que recordar esta obligación es importante para el agente público, puesto que en cuanto haya alguna relación causal entre la dádiva o regalo del particular y la actuación del funcionario, ambos ya han entrado en el terreno del artículo 432-11 CPF358. Por lo tanto, para salir del ámbito penal habrá que probar que es un regalo de cortesía y que esa relación causal no existe. Eso significa que si el regalo se ha hecho en consideración al cargo, es decir, sin considerar una actuación concreta, su admisión no puede subsumirse en el delito de corrupción ni dentro de ningún tipo penal. La sanción de esta conducta dependerá de lo que prevé el código de deontología de cada sector del servicio público.

Por eso, la Comisión de reflexión para la prevención de conflictos de intereses en la vida pública ha propuesto que una ley prohíba el ofrecimiento de regalos, liberalidades e invitaciones a los actores públicos, a excepción de la hospitalidad "convencional" o los regalos de pequeña cuantía cuyo valor no debe superar un mínimo fijado por decreto. En caso de que el agente público no pueda rechazar el regalo, por razón protocolaria, y que su valor supere el mínimo previsto, se debería hacer una declaración ante la autoridad jerárquica. Si la dádiva no pudiera

\footnotetext{
352 Informe de la Comisión de reflexión para la prevención de conflictos de intereses en la vida pública, disponible en la red: http://www.conflits-interets.fr , p.61.

353 Según los redactores del informe, las referencias respecto a la no aceptación de regalos o invitaciones se encuentran en los Códigos de deontología (por ejemplo, en la Inspección general de asuntos sociales o en el Consejo superior del audiovisual) o una circular del Primer ministro que se aplica a los miembros del Gobierno.

${ }^{354}$ Informe de la Comisión de reflexión..., op. cit., p.62.

355 La sustancia de esta obligación está prevista en el artículo 25 de la Ley 83-634 del 13 de julio de 1983 relativa a los derechos y obligaciones de los funcionarios.

${ }^{356}$ CAA Paris, 10-02-1998, AJFP, 09-1998, p.27.

357 Cons. Ét. 24-09-1981, Rec CÉ, p.313.

358 A. TAILLEFAIT, Déontologie des fonctionnaires et principes du service public de l'Éducation nationale, disponible en la red: http://sti.ac-montpellier.fr , pp. 35 y 36.
} 
permanecer en el sector del servicio público que la ha recibido, debería ser entregada a la Administración local a la que pertenece el funcionario obsequiado, por tanto, no puede ser objeto de una apropiación personal 359 .

Lamentablemente, a pesar de la reforma legislativa introducida por la Ley 2011-525, del 17 de mayo de 2011, de simplificación y mejora de la calidad del Derecho, la propuesta de la comisión no ha sido objeto de alguna concreción de forma normativa para su introducción en el ordenamiento jurídico. Por otro lado, llama nuestra atención la falta de recomendación en materia de admisión de regalos por parte del GRECO. La evaluación de este órgano sobre el ordenamiento jurídico-penal francés en materia de corrupción no ha hecho ninguna referencia a esta cuestión ${ }^{360}$.

\section{B-DERECHO PENAL MALGACHE}

A pesar de la reforma legislativa de 2004 impulsada por el Convenio de la Unión Africana, relativo a la prevención y la lucha contra la corrupción, firmado en Maputo en julio de 2003, el legislador malgache sólo sigue teniendo en cuenta las retribuciones indebidas relacionadas con el fenómeno de la corrupción. En palabras de RAFOLISY, el CPM parece haber excluido las ventajas (o las dádivas) que no tienen conexión causal con actos de corrupción como por ejemplo los regalos que no tienen nada que ver con la función o el cargo del agente corrupto ${ }^{361}$. A nuestro modo de ver, el legislador penal malgache de 2004 sólo ha introducido en el CPM tipos penales que relacionan las dádivas con un acto o una actuación determinada y determinable del funcionario, por tanto, los regalos ofrecidos o entregados en consideración de la función o del cargo no se han contemplado en la última reforma. Esta situación se debe, al menos, a dos razones. En primer lugar, los tipos descritos en el Convenio de la Unión Africana no mencionan la conducta de ofrecer regalos o dádivas a un funcionario público por el desempeño de su cargo. Eso implica que el legislador malgache, que se ha inspirado de esta norma, tampoco ha considerado que este tipo de conducta merezca un tratamiento penal. En segundo lugar, se pueden avanzar razones culturales. Los regalos de agradecimiento llamados falim-po o fisaorana permiten desarrollar las relaciones e intercambiar favores con personas conocidas. Esta conducta parece razonable pero se ha pervertido con la corrupción generalizada. RAFOLISY destaca en su estudio que en África la práctica de regalos es parte de la manera de gobernar, calificada de corrupción suave. Un sondeo realizado en Madagascar revela que los fun-

\footnotetext{
359 Informe de la Comisión de reflexión..., op. cit., pp.84 y 85.

360 A diferencia de las recomendaciones del Informe de evaluación de GRECO a España, a las que ésta "acaba cediendo al incrementar la pena frente al anterior artículo 426 CPE 1995", según C. RAMOS RUBIO, Del delito de cohecho... op. cit., p.348.

${ }^{361}$ P. RAFOLISY, La protection juridique..., op. cit., p.181. Parece que el autor confunde un regalo por "actos de corrupción" y un regalo por "la función o el cargo". Son dos cosas diferentes y ambos casos no han sido considerados por el legislador penal malgache de 2004.
} 
cionarios tienden a esperar o reclamar algún regalo antes de cumplir con el trabajo por el cual se les paga. En efecto, según el mismo autor, estos regalos no se consideran tan graves como si fueran sobornos, sin embargo, su incriminación supone una medida eficaz contra la corrupción ${ }^{362}$.

El trabajo de RAFOLISY y los estudios realizados sobre los regalos que este mismo autor informa, nos demuestran que culturalmente la dádiva constituye o un aliciente o una recompensa por el trabajo del funcionario. Por lo tanto, sólo podemos constatar que la entrega de una dádiva sin pretender una actuación por parte del funcionario no es algo común. Desde esta óptica, creemos que aunque el legislador malgache haya querido incriminar la admisión de regalos a través del artículo 183, con la rúbrica "De los regalos", siempre ha relacionado esta conducta con un acto del cargo del agente público.

Por otro lado, existe una figura delictiva considerada como integrante del fenómeno de la corrupción y no necesita alguna conexión con alguna actuación. Se trata del enriquecimiento ilícito (artículo 183.1 CPM). Tanto el Convenio de la Unión Africana como el CPM lo consideran como un tipo de recogida que no necesita ni acuerdo, ni intento de acuerdo. El punto fundamental del tipo es que la autoridad o el funcionario ha recibido dádiva que implica un crecimiento notable de su patrimonio. En efecto, la tentación es grande para subsumir en este tipo los casos graves de costosos regalos cuando no se puede probar o no hay una actuación funcionarial de por medio. Sin embargo, la aplicación de esta figura delictiva supone más problemas de lo que parece.

En primer lugar, aunque los autores son los mismos que en el delito de corrupción pasiva, indica RAFOLISY que este delito sólo puede ser cometido por un círculo restringido de personas: los que ostentan un mandato electivo y los altos cargos de la Administración ${ }^{363}$. A nuestro juicio, esta interpretación es contra legem ya que no se puede defender una interpretación que abarque a varios funcionarios cuando se habla de los sujetos activos en el delito de corrupción pasiva y luego restringir la misma lista en el delito de enriquecimiento ilícito. En efecto, la expresión "toda persona constituida en autoridad pública, encargada de una misión de servicio público o que ostente un mandato electivo público" debe ser entendida de la misma manera en todo el Código penal. Además, el legislador ha añadido a otras personas en la lista de los potenciales sujetos activos del delito en estudio: "todo dirigente, mandatario o empleado de una empresa pública".

En segundo lugar, el sujeto activo "no puede justificar razonablemente un aumento sustancial de su patrimonio respecto a sus legítimos ingresos". Según RAFOLISY, habrá que preguntarse lo que el legislador entiende por aumento sustancial del patrimonio. En un país donde hasta

362 Ibídem, op. cit., pp.248 y 249.

363 Ibídem, op. cit., p.275. 
los empleados públicos participan de la economía sumergida es muy difícil justificar los ingresos. También habrá que preguntarse cómo apreciar la sustancialidad del aumento, sin la cual la justificación no será necesaria ${ }^{364}$.

En tercer lugar, este tipo ha sido objeto de muchas críticas. En efecto, se trata de un delito de sospecha puesto que la oficina de lucha contra la corrupción (BIANCO) puede pedir a la persona sospechada establecer una declaración escrita y detallada sobre sus bienes, la cual podrá servir de prueba en su contra y una declaración escrita en cuanto al movimiento de su patrimonio durante los tres últimos años ${ }^{365}$. También se ha criticado la violación del principio de presunción de inocencia, ya que es la persona sobre la que recae la sospecha, la que tiene que aportar la prueba de la licitud de su enriquecimiento ${ }^{366}$. Por último, se puede preguntar si, según la letra de la ley, el aumento que no se puede justificar se presume como ilícito. Para RAFOLISY, la incriminación no busca establecer la ilicitud del origen de los bienes sino la incapacidad de justificar el aumento patrimonial inexplicado ${ }^{367}$. A nuestro juicio, la presunción de ilicitud en cuanto a este aumento injustificado existe en el tipo, ya que la prueba que se requiere es la demostración de la licitud del enriquecimiento. En otras palabras, no le basta al legislador con que se justifique el enriquecimiento, le interesa también saber si la adquisición de los bienes viene o no de actividades lícitas. Por lo tanto, la incriminación pretende más evitar un aumento sustancioso ilícito del sujeto activo que conseguir una justificación en sí de este aumento. Si no fuera el caso, el legislador malgache habría puesto como rúbrica del artículo 183.1, no "Del enriquecimiento ilícito" sino "Del enriquecimiento injustificado".

Ante estas dificultades y la falta de reglamentación para los regalos no vinculados a algún acto o actuación, de lege ferenda se puede proponer la elaboración de normas generales, y no sólo sectoriales, que establezcan reglas para los regalos a nivel disciplinario para todas las categorías de agentes públicos. Por otro lado, se puede sugerir la reforma del artículo 183 del CPM, al introducir un párrafo o un inciso para las dádivas no relacionadas con ningún acto o actuación del funcionario sino en consideración de su cargo con las precisiones requeridas por el principio de taxatividad permitiendo de esta manera distinguir los casos graves merecedores de sanción penal de los menos graves que sólo necesitan la intervención del Derecho disciplinario.

364 Ibídem, op. cit., p.278.

365 Ibídem, op. cit., p.279

366 Ibídem, op. cit., pp.280 y ss.

367 Ibídem, op. cit., p.290. 



\section{CAPÍTULO VII: TIPO OBJETIVO (IV). EL OBJETO DEL COHECHO}

El estudio del objeto de la corrupción plantea dos cuestiones importantes: su naturaleza cualitativa y sus características cuantitativas. En esta materia la doctrina española ha desarrollado debates interesantes conforme a la técnica utilizada por el legislador. Por otro lado, los autores franceses sólo han tratado este tema de manera superficial, lo cual no ha generado ningún debate. Tampoco hemos encontrado opinión sobre esta misma cuestión dentro de la doctrina malgache. Por lo tanto, para no desequilibrar este apartado, sería preferible repasar y resumir, aunque sea en exceso, los puntos importantes destacados en el debate de la doctrina española para luego intentar proponer nuevos enfoques para la doctrina francesa y malgache.

\section{Sección 1-Características cualitativas del ob- jeto material de la conducta}

\section{II-Derecho español}

Con el fin de facilitar la exposición de las diferentes propuestas doctrinales, se considerará como punto de referencia la reforma penal de 2010. En efecto, antes de esa fecha el legislador penal español utilizaba una técnica que suscitó interpretaciones contradictorias de parte de los autores. Sin embargo, con la última reforma del CPE el legislador parece haber zanjado esta cuestión disipando las dudas sobre la naturaleza cualitativa del objeto material del cohecho.

\section{A-ANTES DE LA REFORMA DE 2010}

\section{española}

\section{1-Los puntos de convergencia dentro de la doctrina}

Con la redacción del anterior CPE, el legislador español utilizaba los términos "dadiva", "presente", "ofrecimiento", "promesa" y "regalo". El primer punto de convergencia es la idea según la cual "promesa" es todo lo que es susceptible de ser prometido y "ofrecimiento" es todo lo que puede ser ofrecido ${ }^{1}$. Esta anotación, de por sí, tiene escasa importancia puesto que se ofrece o promete algo que luego debe darse y recibirse y ya que el objeto del verbo recibir son dádivas y presentes, debe entenderse que también lo que se promete u ofrece tiene que ser "dádiva" o "presente". Esta observación lleva al meollo de la cuestión: el problema inherente a la definición del objeto material del delito de cohecho

${ }^{1}$ A. MARTÍNEZ ARRIETA, "Comentario a los arts. 419-427", C. CONDE-PUMPIDO TURÓN (Dir.), J. LÓPEZ BARJA DE QUIROGA (Coord.), Comentarios al Código penal, T. IV, Bosch, Barcelona, 2007, p.3108. 


\section{PARTE II: ESTUDIOS DE LOS ELEMENTOS TÍPICOS...}

así como tipificado por el legislador español de 1995 se corresponde, en síntesis, con el alcance de los términos "dádiva" y "presente"2.

En segundo lugar, la doctrina española está de acuerdo en calificar estas expresiones de obsoletas y arcaicas (sobre todo el término "dádiva"), por lo tanto, se ha pedido reiteradamente su sustitución por otras con un significado más preciso ${ }^{3}$. Por otra parte, en la acotación del sentido literal de los términos "dádiva", "presente" y "regalo", existe prácticamente unanimidad en afirmar que los tres términos son sinónimos ${ }^{4}$, de tal manera que pueden reducirse a uno: dádiva 5 .

\section{2-Debate doctrinal sobre el alcance de los términos "dádiva" y "presente"}

Esta ineficaz técnica legislativa ha producido una interminable discusión entre los autores españoles sobre el exacto alcance que debe de atribuirse a dichas expresiones. Si un sector de la doctrina española entiende que "desde su definición estos términos nos parecen indicar que se trata de objetos materiales" 6 , otro sector defiende que "en relación a la letra, importa observar que "dádiva" y "presente" lo es tanto la de signo económico, como la de naturaleza distinta"7. La inexistencia de un acuerdo ni tan siquiera respecto del significado literal de las palabras dificulta la tarea de proporcionar una interpretación teleológica y sistemáticamente aceptable y compartida de las mismas. En este sentido, observa CERINA que una propuesta interpretativa que parta del significado literal de las palabras empleadas parece ser el camino obligado que se tiene que recorrer: la litera legis es el primer e irrenunciable bosquejo a partir del cual ha de empezar la labor interpretativa ${ }^{8}$.

Nos parece interesante repasar, aunque sea brevemente, los debates doctrinales en el intento de acotar los términos "dádiva" y "presente" desde el criterio gramatical-literal.

${ }^{2}$ G. D. M. CERINA, La lucha contra la corrupción, op. cit., p.880. Véase también Mạ. J. RODRÍGUEZ PUERTA, El delito de cohecho..., op. cit., pp.184 y ss., quien enfoca exclusivamente su análisis en estos dos términos.

3 Entre otros, I. VALEIJE ÁLVAREZ, El tratamiento..., op. cit., p.145; A. MARTÍNEZ ARRIETA, “Comentario...", op. cit., p.3109; M‥ J. RODRÍGUEZ PUERTA, El delito de cohecho..., op. cit., p.184; G. D. M. CERINA, La lucha contra la corrupción, op. cit., p.881.

4 Entre otros, C. GRANADOS PEREZ, "El instrumento en el delito de cohecho", en Cuadernos de derecho judicial, Consejo General del Poder Judicial, 1994, pp. 136, 137 y 144; Ma. J. RODRÍGUEZ PUERTA, El delito de cohecho..., op. cit., p.186; E. OCTAVIO DE TOLEDO Y UBIETO, “Derecho penal...”, op. cit., p.874; G. D. M. CERINA, La lucha contra la corrupción, op. cit., p.881.

5 E. OCTAVIO DE TOLEDO Y UBIETO, “Derecho penal...”, op. cit., p.874.

${ }^{6}$ I. VALEIJE ÁLVAREZ, El tratamiento..., op. cit., p.145; E. CASAS BARQUERO, “Observaciones...”, op. cit., p.889; I. OLAIZOLA NOGALES, El delito de cohecho, op. cit., p.327.

7 J. CÓRDOBA RODA, "Del cohecho", en J. CÓRDOBA RODA y M. GARCÍA ARÁN (Dirs), Comentarios al Código penal, parte especial, Tomo II, Marcial Pons, Madrid-Barcelona, 2004, pp.1998 y 2001; J. BUSTOS RAMÍREZ, Manual... Parte especial, op. cit., p.375.

8 G. D. M. CERINA, La lucha contra la corrupción, op. cit., p.882. 
Así, OLAIZOLA NOGALES acude al Diccionario de la Lengua Española, de la Real Academia (DRALE) que define la dádiva como "como cualquier cosa que se da graciosamente, que se regala". El presente es "el don o regalo que una persona hace a otra". Desde su definición, estos términos parecen indicar que se trata de objetos materiales y, por tanto, se pueden considerar sinónimos. En este sentido, según la autora, es diferente de la regulación alemana e italiana que hacen referencia, respectivamente a la "ventaja" y el "dinero u otra utilidad". El DRALE define ventaja como: "la superioridad o mejoría de una persona o cosa respecto de otra. La excelencia o condición favorable que una persona o cosa tiene" y utilidad como: "Provecho, conveniencia, interés o fruto que se saca de una cosa". Por tanto, defiende la misma autora, no se pueden aplicar los criterios extensivos defendidos por la mayoría de la doctrina alemana e italiana, a la hora de interpretar los posibles medios de corrupción, a la regulación española donde los términos típicos utilizados son mucho más concretos. El entender que en la regulación del delito de cohecho en el CPE cabe cualquier tipo de mejora material o inmaterial o cualquier tipo de satisfacción de una necesidad humana, constituiría una interpretación extensiva de los tipos penales contraria a los principios básicos del Derecho penal ${ }^{9}$.

En cuanto a la pena de multa, la jurista defiende que no se trata de un elemento típico, pero sí que puede dar algunas pistas para interpretar la voluntad del legislador. En el CPE 1995, todas las multas son de carácter proporcional salvo la que establece el artículo 426, pero que, siguiendo la dinámica general del delito de cohecho, lo lógico es que al imponerla, el juez tenga en cuenta, además de la capacidad económica del sujeto, la cuantía de la dádiva o del regalo, que será indicativa de la gravedad del hecho, y que es otro criterio que tendrá que tener en cuenta el juez. El argumento del carácter material de la dádiva ha sido reforzado por el sistema de multas, el sistema días-multa ${ }^{10}$.

Frente a esta postura, defiende CERINA que para una correcta interpretación gramatical de las palabras utilizadas por el legislador español, puede partirse del significado que el Diccionario de la Real Academia proporciona respecto del término "dádiva": "cosa que se da gratuitamente"11. En el delito de cohecho, es evidente y no precisa de ulteriores argumentos que nada se da "gratuitamente", sino todo lo contrario: el particular da algo a cambio de un acto de la función; el funcionario público "da" un acto de su función a cambio de algo. Así las cosas, deberá definirse la palabra dádiva prescindiendo del adverbio "gratuitamente": dádiva es, en otras palabras, "cualquier cosa que se da". Siempre según el DRALE, "cosa" es "todo lo que tiene entidad, ya sea corporal o espiritual, natural o artificial, real o abstracta"12. Para el autor, con un elemental silogismo, se obtiene que, con la palabra "dádiva" así como utili-

\footnotetext{
${ }^{9}$ I. OLAIZOLA NOGALES, El delito de cohecho, op. cit., p.327.

10 Ibídem, op. cit., p.328.

11 www.rae.es

12 Ibídem, op. cit.
} 
zada en los artículos 419 y siguientes CPE 1995, se quiere significar "todo lo que se da", con independencia de que sea material, tangible o intangible. Todo ello es perfectamente extensible a la palabra "presente" que, de acuerdo con el DRALE, indica un "un obsequio, regalo que alguien da a otra persona en señal de reconocimiento o de afecto" 13 . Puesto que, en el cohecho, nadie da por afecto (sí podría darse "en señal de reconocimiento" pero sólo en el cohecho subsiguiente) ni, mucho menos, "regala" a nadie, debe entenderse que esta expresión (así como utilizada por los artículos 419 y siguientes CPE 1995) es efectivamente sinónima de la anterior ${ }^{14}$. Concluye el autor que con los términos dádivas y presentes, entendidos en su sentido literal, el legislador hace referencia a cualquier entidad, ya sea corporal natural o artificial, real o abstracta que el particular da al sujeto público ${ }^{15}$.

En cuanto a la envergadura del objeto material del delito de cohecho en España respecto de lo que se considera en Italia o en Alemania, el jurista observa que, aunque haya diferencia, ésta no implica un espectro de aplicación más reducido de la norma española sino todo lo contrario. En efecto, las palabras dádiva y presente (así como son empleadas), no contienen (a menos de introducirlo en vía interpretativa) ningún tipo de matiz valorativo, a diferencia de lo que ocurre con "utilidad" y "ventaja". De por sí, el concepto de dádiva no implica un beneficio ni una ventaja para quien lo recibe; de igual manera, un presente o regalo no necesariamente son "ventajosos" o "útiles" para quien los acepta ${ }^{16}$.

Desde una perspectiva teleológica, destaca OLAIZOLA NOGALES que el delito de cohecho supone un ataque a las condiciones de funcionamiento básicas para la vigencia e indemnidad de la Administración Pública. Este bien jurídico parece que puede ser puesto en peligro tanto con una contraprestación de carácter material como con una prestación de carácter inmaterial, por ejemplo la solicitud o el ofrecimiento o promesa de una prestación sexual. Sin embargo, históricamente el delito de cohecho se ha entendido como la aceptación por parte del funcionario de un precio, de un beneficio económico a cambio de su actuación. Y se constata que la formulación de la regulación española no permite encajar prestaciones de carácter inmaterial ${ }^{17}$. Por ello, aunque desde el punto de vista del bien jurídico protegido nada impediría aceptar que la prestación pudiera tener carácter inmaterial, se puede concluir que no toda motivación que lleva al funcionario a ser parcial o falto de objetividad va a cumplir el delito de cohecho, sino sólo cuando esta falta de objetividad o de imparcialidad tenga como causa la mezcla de intereses

\footnotetext{
13 Ibídem, op. cit.

${ }^{14}$ G. D. M. CERINA, La lucha contra la corrupción, op. cit., p.883.

15 Ibídem, op. cit., p.884.

16 Ibídem, op. cit., p.885.

17 I. OLAIZOLA NOGALES, El delito de cohecho, op. cit., p.329.
} 
privados que supongan para él una mejora económica directa e indire$\operatorname{cta}^{18}$.

Añade la autora que se justifica esta idea además en virtud de criterios de merecimiento de pena. Estamos ante un bien jurídico instrumental y por tanto será preciso valorar qué conductas recogen un desvalor de hecho suficiente para poner en peligro el bien jurídico protegido. Sociológicamente se constata la vulnerabilidad de la Administración a beneficios económicos. Con el delito de cohecho se trata de evitar que la Administración se convierta en un ente público adulterado en cuanto a sus servicios a los ciudadanos, de manera que éstos tengan que contar con medios que posibiliten sobornar a los funcionarios para obtener sus legítimos derechos. Que los ciudadanos no encuentren en la Administración su garante de derechos, sino que esté al servicio del que tenga más poder.

Por tanto, concluye la autora que los medios de corrupción en el delito de cohecho serán aquellas prestaciones de carácter material, es decir valorables económicamente, con valor de marcado. Se excluyen aquellas prestaciones que satisfagan la ambición, la vanidad o el placer personal del funcionario, sin que le reporten un beneficio objetivamente mensurable ${ }^{19}$.

Desde otro punto de vista y argumentando desde el criterio teleológico, otro sector de la doctrina defiende que si lo que se trata de tutelar es el imparcial desarrollo del proceso de decisión del funcionario público, resulta evidente que, una vez establecido por el legislador que el pacto remuneratorio con apoyo en el cual el funcionario vende un acto es merecedor de un reproche penal, debe concluirse que cualquier "precio" pagado a cambio (cualitativamente hablando), lesiona el bien jurídico protegido de igual manera ${ }^{20}$. Observa RODRÍGUEZ PUERTA que desde el punto de vista del bien jurídico protegido, lo esencial es que lo solicitado u ofrecido tenga capacidad para excluir la obligación del funcionario de actuar de forma imparcial21.

Respecto de la afirmación según la cual, "este argumento, que obvia al significado gramatical de los términos dádiva y presente, supone una penetración anticipada del momento axiológico en la valoración formal de los conceptos (dádiva y presente)"22, opina CERINA que esta afirmación de principio debe seguramente compartirse: la interpretación te-

\footnotetext{
18 Refiriéndose a esta postura, CERINA no consigue apreciar, desde el punto de vista del menoscabo del bien jurídico protegido, en qué se diferencia el caso del funcionario que se compromete a realizar un acto injusto a cambio de una prestación sexual de aquél en el cual asume el mismo compromiso por 1000 euros (G. D. M. CERINA, La lucha contra la corrupción, op. cit., p.883).

${ }^{19}$ I. OLAIZOLA NOGALES, El delito de cohecho, op. cit., p.330.

${ }^{20}$ G. D. M. CERINA, La lucha contra la corrupción, op. cit., p.886.

${ }^{21}$ Ma . J. RODRÍGUEZ PUERTA, El delito de cohecho..., op. cit., p. 191. En el mismo sentido, E. CASAS BARQUERO, “Observaciones...”, op. cit., pp.887 y ss.

${ }^{22}$ I. VALEIJE ÁLVAREZ, El tratamiento..., op. cit., p.145.
} 
leológica, en ningún caso puede motivar una exégesis que se aparte del significado gramatical de las palabras empleadas por el legislador. Explica el autor que el significado gramatical de las palabras "dádiva" y "presente" es perfectamente compatible con una interpretación que tenga en cuenta las posibles modalidades de lesión del bien jurídico protegido: en otras palabras, la "intuición" (según la cual no hay quien no vea que la imparcialidad de un funcionario puede verse mermada gravemente tras un ofrecimiento no económicamente relevante), encuentra confirmación en cuanto ya sugiere el significado de las palabras y no induce a interpretaciones analógicas o, lo que sería incluso peor, contra legem ${ }^{23}$.

\section{nal}

3-Algunas cuestiones destacadas en el debate doctri-

Uno de los puntos relevantes que han dado lugar a intenso debate dentro de la doctrina española, es el argumento a favor de la tesis restrictiva, según la cual el objeto material de la conducta de cohecho debería consistir en una entidad material y susceptible de ser evaluada económicamente, basándose en la configuración legal de la pena de multa como proporcional al valor de la dádiva. En efecto, bajo la vigencia del CPE 1995, el legislador conmina una "multa del tanto al triple del valor de la dádiva" (artículos 419, 420 y 425.1) o bien "del tanto del duplo del valor de la dádiva" (artículo 421). Además, el artículo 431 del mismo Código dispone que en "en todos los casos previstos en este capítulo y en el anterior, las dádivas, presentes o regalos caerán en decomiso". Todo ellos, según un sector de la doctrina española, sería prueba irrefutable de que el legislador ha entendido que lo que se da, ofrece, promete, solicita, recibe... tiene que ser susceptible de valorarse en dinero (para así poderse imponer la multa correspondiente) y tiene que consistir en algo material (para poderse decomisar) ${ }^{24}$. DÍAZ Y GARCÍA CONLLEDO considera incluso que esta interpretación es "políticocriminalmente preferible"25.

Según otro sector de la doctrina, sin embargo, el argumento no sería decisivo. Se defiende que, toda vez que no concurrieran los requisitos anteriores (materialidad y/o valoración económica), sencillamente el juez deberá proceder a no aplicar la pena de multa y/o el decomiso ${ }^{26}$.

Frente a estas posturas, la doctrina más reciente se muestra crítica respecto de las consecuencias de dicha orientación interpretativa. En efecto, si se entendiera compatible el actual sistema de multas con la rele-

${ }^{23}$ G. D. M. CERINA, La lucha contra la corrupción, op. cit., p.887

${ }^{24}$ E. CASAS BARQUERO, "Observaciones...", op. cit., pp.894 y ss.; F. MUÑOZ CONDE, Derecho penal, Parte especial, 2009, op. cit., p.936. M. DÍAZ Y GARCÍA CONLLEDO considera incluso que esta interpretación es "político-criminalmente preferible" "El delito de cohecho", op.cit., p.166

${ }^{25}$ M. DÍAZ Y GARCÍA CONLLEDO “El delito de cohecho", op.cit., p.162.

${ }^{26}$ Mà. J. RODRÍGUEZ PUERTA, El delito de cohecho..., op. cit., p. 190; A. MARTíNEZ ARRIETA, “Comentario...", op. cit., p.3108. 
vancia penal de dádivas o presentes de naturaleza inmaterial y no susceptibles de ser inmediatamente cuantificados en dinero, se terminaría por avalar una diferencia de tratamiento sancionador entre conductas que lesionan de la misma manera el bien jurídico protegido y no deberían implicar un mayor o menor reproche personal para ninguna de los dos autores ${ }^{27}$.

Entre los puntos de debate doctrinal en España, se destaca la cuestión de saber si es posible o no considerar como cohecho algunos tipos de dádivas subsumibles en otras normas. En efecto, parte de la doctrina española ha puesto el acento sobre la posibilidad de acotar la amplitud de los conceptos de dádiva y presente haciendo referencia a otras normas que incriminan supuestos de hecho "colindantes" con aquellos subsumibles en los artículos 419 y siguientes.

Una de estas normas es el delito de tráfico de influencias. Afirma RODRÍGUEZ PUERTA que "los delitos tipificados en los artículos 428 y 429 (CPE 1995) recortan implícitamente el ámbito típico de las distintas modalidades de cohecho en lo que al medio para conseguir la actuación del funcionario se refiere"28. Aunque esta autora comparta la tesis según la cual todo tipo de ventaja es idónea para incidir en la actuación imparcial del funcionario público, observa que la tutela de este bien jurídico (imparcialidad) frente a ataques que consisten en un compraventa, no queda limitada, en el CPE, al delito de cohecho, sino que el texto legal la parte en dos: por un lado, el delito de cohecho sancionaría todo tipo de compraventa que tenga como contraprestación una dádiva material y económicamente evaluable; por otro lado, el tráfico de influencias debería aplicarse toda vez que la prestación del extraneus consistiese en "ventajas de carácter inmaterial y subjetivas" 29.

Otro sector de la doctrina ha criticado esta postura, y observa que el delito de tráfico de influencias, así como aparece tipificado por el legislador, no parece abarcar todas las posibles hipótesis de cohecho en las que lo que se solicita, promete, acepta...es un beneficio no económicamente evaluable y/o inmaterial. En este sentido, CERINA destaca tres puntos. En primer lugar, en el tráfico de influencias resulta punible sólo quien "influye" mientras que lo mismo no puede decirse respecto de

\footnotetext{
${ }^{27}$ G. D. M. CERINA, La lucha contra la corrupción, op. cit., pp.888 y 889. El autor toma el ejemplo dos hipótesis de cohecho antecedente: por un lado, el particular que ofrece 1000 euros a cambio de la futura realización de un acto injusto y, por otro, el mismo particular que, a cambio del mismo acto, ofrece una prestación sexual. De acuerdo con la interpretación defendida por el segundo grupo de la doctrina española, al primero, se le impondrá, además de la pena de prisión prevista por el artículo 420 CPE 1995, también una pena de multa de 3000 euros, mientras que en el segundo caso, deberá considerarse suficiente la pena de prisión. Lo mismo acontecería para el funcionario público: no obstante su conducta parezca, a todas luces, igualmente reprochable, en el segundo caso, no se le impondría una pena de multa.

${ }^{28}$ Mà. J. RODRÍGUEZ PUERTA, El delito de cohecho..., op. cit., p. 191. En el mismo sentido F. MUÑOZ CONDE, Derecho penal, Parte especial, 2009, op. cit., p.937.

${ }^{29}$ Ma. J. RODRÍGUEZ PUERTA, El delito de cohecho..., op. cit., p. 191.
} 
quien es influido. En otras palabras, sólo el tráfico de influencias activo es comportamiento penalmente relevante ${ }^{30}$. En segundo lugar, hay que distinguir según si el autor de la conducta típica de tráfico de influencias es un funcionario público o un particular. En el primer caso, es típica la conducta de "influir en otro funcionario o autoridad prevaliéndose del ejercicio de las facultades de su cargo". Las diferencias con el cohecho, son evidentes: mientras que, en el tráfico de influencias, se "influye", en el cohecho se da, promete, ofrece, acepta, recibe... y parece que se puede "influir" sin realizar ninguna de estas acciones. Por otra parte, para que haya tráfico de influencias, es preciso que el sujeto activo del delito se halle previamente en una determinada relación "personal o jerárquica" con el funcionario objeto de sus influencias o bien que "se prevalga de las facultades de su cargo"31. Cuando autor del delito es un particular, para que realice la conducta típica, es preciso que influya en el funcionario público. Debe necesariamente pre-existir una "relación personal" entre el particular y un funcionario público y dicha relación es el instrumento mediante el cual se influye. En el delito de cohecho, nada de todo esto es preciso.

El tercer punto que subraya el jurista es el elemento subjetivo del delito de tráfico de influencias activo, que consiste en "conseguir una resolución". El término "resolución" ha de entenderse en sentido manifiestamente más reducido respecto del "acto" objeto del dolo específico en el delito de cohecho activo antecedente. Además, se exige aquí la finalidad de obtener un "beneficio económico" por parte de quien influye. En efecto, ahí donde los artículos 428 y 429 utilizan la expresión "beneficio económico", los artículos 419-421 CPE 1995 hablan de "provecho". Ubi lex distinguit, etiam nos distinguere debemos. Concluye el autor que, con independencia de la relación concursal entre cohecho y tráfico de influencias ${ }^{32}$, algunos casos de compraventa de un acto propio del cargo podrán considerarse como tráfico de influencias. Ello, sin embargo, no resuelve completamente el problema, ya que el tenor literal de las normas impide subsumir en el tráfico de influencias todas las compraventas de actos públicos caracterizadas por una dádiva o presente no evaluables económicamente ${ }^{33}$.

Por último, nos parece interesante repasar brevemente el debate doctrinal sobre la solicitud de prestaciones sexuales tipificadas por el artículo 443 CPE 1995 y su relación con el delito de cohecho. Según algunos autores, los supuestos en los que el pactum sceleris entre corrupto y corruptor se apoya en favores sexuales, puede subsumirse en artículo 443 CPE $1995^{34}$. La pena establecida por esta norma para el funcionario

\footnotetext{
${ }^{30}$ G. D. M. CERINA, La lucha contra la corrupción, op. cit., p.900.

31 Ibídem, op. cit., p. 901.

${ }^{32}$ Sobre este punto, véase I. OLAIZOLA NOGALES, El delito de cohecho, op. cit., pp. 462 y ss.

${ }_{33}$ G. D. M. CERINA, La lucha contra la corrupción, op. cit., p.902.

${ }^{34}$ F. MUÑOZ CONDE, Derecho penal, Parte especial, 2009, op. cit., p.937; E. BACIGALUPO ZAPATER, "Sobre la reforma de los delitos de funcionarios", en Documentación Jurí-
} 
público (inferior a la prevista en materia de cohecho pasivo propio antecedente), representaría una prueba ulterior del hecho que las prestaciones sexuales resultan menos insidiosas para la imparcialidad del funcionario público respecto de las prestaciones económicamente evaluables.

A ello se ha objetado que el ámbito de aplicación del artículo $443 \mathrm{CPE}$ 1995 es muchísimo más reducido respecto al del cohecho. En efecto, podrá sancionarse penalmente la solicitud de una prestación sexual sólo en aquellos casos en los que el funcionario toma la iniciativa y el solicitado se encuentra en una de las situaciones mencionadas por el precepto en estudio (tener pretensiones pendientes de resolución, guarda, etc. ${ }^{35}$. Para todos los demás supuestos de intercambio entre acto de oficio y prestación sexual esta norma no resultaría útil para la solución del problema que aquí se plantea ${ }^{36}$ : seguiría abierta la pregunta de si los términos dádiva o presente, utilizados por los artículos 419 y siguientes CPE 1995, abarcan a los favores sexuales.

Un sector de la doctrina responde a esta objeción, alegando que el supuesto en el que el precio por un acto del oficio es una prestación sexual, es de una gravedad tan reducida (respecto del otro en el cual la prestación del particular tiene contenido económico) que el legislador lo ha considerado merecedor de sanción tan sólo en los gravísimos casos que toma en consideración el artículo 443 CPE 1995 y en los cuales se considera lesionada, aparte del bien jurídico protegido por el delito de cohecho, también la libertad de autodeterminarse sexualmente del particular. Fuera de estos casos, por tanto, debe considerarse penalmente irrelevante la solicitud o concesión de prestaciones sexuales a un funcionario público a cambio de un acto del cargo ${ }^{37}$.

Otro sector de la doctrina española ha observado, en sentido contrario, que el artículo 443 CPE 1995 contempla hipótesis en las que el particular es "víctima" del funcionario. De ahí que, toda vez que el mismo supuesto objetivo descrito por el artículo 443 CPE 1995 no ofende el bien jurídico "libre autodeterminación" del particular y, al contrario, éste accede a la solicitud en vista de un interés propio, ya no puede considerarse como víctima, sino que debe responder por cohecho activo así como el intraneus responderá por cohecho pasivo ${ }^{38}$.

dica. Monográfico dedicado a la propuesta de anteproyecto del Nuevo Código Penal, nำ2, 1983, p. 1101.

35 Ma. J. RODRÍGUEZ PUERTA, El delito de cohecho..., op. cit., p. 193.

${ }^{36}$ I. OLAIZOLA NOGALES, El delito de cohecho, op. cit., p.334; I. VALEIJE ÁLVAREZ, El tratamiento..., op. cit., p.153; Mà. J. RODRÍGUEZ PUERTA, El delito de cohecho..., op. cit., p. 193.

${ }^{37}$ I. OLAIZOLA NOGALES, El delito de cohecho, op. cit., p.334.

38 Ma. J. RODRÍGUEZ PUERTA, El delito de cohecho..., op. cit., p. 193. La aceptación del planteamiento de esta autor debe llevar a admitir que dádiva y presente, en el delito de cohecho, son también las prestaciones sexuales. 
Respecto a esta última postura, observa CERINA que su inconveniente es que si, por un lado, consigue proponer un criterio satisfactorio respecto de la sanción del extraneus, plantea problemas de compatibilidad entre la pena a conminarse al funcionario y el principio de proporcionalidad. En efecto, se terminaría sancionando más al funcionario público que, con su actuación, tan sólo menoscaba un bien jurídico (su imparcialidad) respecto de aquél otro que atenta a la vez contra la imparcialidad de la Administración Pública y la libertad de autodeterminarse sexualmente del particular.

Según el mismo autor este problema puede atenuarse si se matiza el criterio discernidor entre cohecho y concusión. Toda vez que hay metus, se trata de un abuso de la función con la finalidad de obtener una prestación sexual, mientras que, cuando el particular actúa sin "miedo", se trata de cohecho ${ }^{39}$.

\section{B- A PARTIR DE LA REFORMA DE 2010}

La reforma de 2010 ha aportado novedades en materia de objeto material del delito de cohecho. Bajo la presión de los Convenios internacionales, la LO 5/2010 ha resuelto la polémica acerca de si la contraprestación ofrecida o prometida por el particular tenía o no que tener naturaleza económica ${ }^{40}$. A pesar de los cambios introducidos, la doctrina española no es unánime en cuanto a la interpretación del contenido cualitativo del instrumento del cohecho.

\section{1-La postura mayoritaria}

Con la reforma de 2010, la mayoría de los autores españoles defiende que el legislador español ha optado por la máxima amplitud de los medios empleados ${ }^{41}$, lo cual ha sido considerado con favor por este sector de la doctrina, ya que con ello se ha zanjado la interminable discusión

${ }^{39}$ G. D. M. CERINA, La lucha contra la corrupción, op. cit., p.905. Añade el autor el corolario de este criterio que normalmente, el acto para el cual se paga, en la concusión, es el que el particular tendría de todas maneras derecho a obtener, mientras que, en el cohecho, es injusto. De ahí que se defiende que, toda vez que, a cambio de la prestación sexual, el funcionario promete un acto justo, se asumirá que el particular ha accedido porque obligado y se aplicará el artículo 433 CPE 1995. Cuando, a cambio del favor sexual el funcionario promete un acto injusto, se dirá que el segundo se enriquece y que, por ende, encontrarán aplicación los artículos 419 y siguientes CPE. Ahora bien, puesto que la pena prevista por el artículo 443 CPE 1995 para el funcionario es superior a la prevista en materia de cohecho pasivo impropio antecedente, el hecho que la solicitud de prestación sexual a la que el particular accede sin metus es constitutiva de delito de cohecho propio resuelve los problemas de proporcionalidad. Bien puede el legislador español considerar más grave el intercambio de favores si supone la realización (o promesa de realización) de un acto contrario a los deberes del oficio, respecto de la solicitud con constreñimiento ambiental a la concesión de prestaciones sexuales a cambio de un acto propio del cargo y no legalmente prohibido (p.906).

${ }^{40}$ A. NIETO MARTÍN, “Corrupción y abuso...”, op. cit., p.755.

41 Entre otros, J. CARDONA TORRES, Derecho Penal..., op. cit., p.504; L. MORILLAS CUEVA, "Delitos...", op. cit., p.957; C. MIR PUIG, El delito de cohecho en la reforma...op. cit., p.45. 
en esta materia. Los artículos 419 y siguientes así como aparecen reformulados por la LO 5/2010 dejan espacio a pocas dudas acerca de la amplitud cualitativa del objeto material de la conducta puesto que el legislador aclara que deberá considerarse como constitutiva de delito cualquier solicitud, recepción, aceptación, ofrecimiento, promesa cuyo objeto sea una "retribución de cualquier clase" 42 .

Por otra parte, se recordará que, como obstáculo para la posibilidad de interpretar en sentido amplio la normativa anterior, se citaba la configuración de la pena de multa que asume, vigentes los anteriores artículos 419 y siguientes CPE 1995, un carácter proporcional al valor de la dádiva. Pues bien, de forma muy oportuna, la reforma abandona este sistema de determinación de la cuantía de la multa ${ }^{43}$ de modo que es posible interpretar que se admite como dádiva otro tipo de contraprestaciones ${ }^{4}$.

\section{2-La postura minoritaria}

Una parte de la doctrina española valora positivamente la ampliación del alcance de los términos utilizados por el legislador para identificar la contrapartida, objeto de la corrupción, pero insiste en que su contenido debe ser esencialmente patrimonial. En este sentido, reconocen MORALES PRATS y RODRÍGUEZ PUERTA que el CPE emplea los términos "dádiva, favor o retribución de cualquier clase" para, de este modo, pretender "ampliar" el alcance de la contraprestación perseguida por el funcionario en la línea de lo demandado por la normativa internacional. Añaden estos autores que la nueva redacción posibilita la consideración de dádiva, a los efectos del cohecho, de cualquier ventaja o retribución con independencia de la naturaleza que ésta tenga, pecuniaria o no, material o inmaterial ${ }^{45}$. Otros autores sólo constatan el cambio de redacción operada por la reforma y siguen insistiendo en que los términos dádiva, favor o retribución deben ser de contenido económico. Estos autores parecen no dar la importancia que merece a la expresión "de cualquier clase" después del término retribución ${ }^{46}$.

\footnotetext{
${ }^{42}$ G. D. M. CERINA, La lucha contra la corrupción, op. cit., p.1196; C. RAMOS RUBIO, Del delito de cohecho... op. cit., p.345. Ciertos autores destacan también la novedad que supone la palabra "favor", en este sentido véase J. QUERALT JIMÉNEZ, Derecho penal..., 2010, op. cit., p.1163; C. MIR PUIG, El delito de cohecho en la reforma...op. cit., p.45; L. MORILLAS CUEVA, “Delitos...”, op. cit., p.957.

43 C. MIR PUIG, El delito de cohecho en la reforma...op. cit., p.45; G. D. M. CERINA, La lucha contra la corrupción, op. cit., p.1196.

${ }^{44}$ I. ORTIZ DE URBINA GIMENO, "Delitos...", p.338. Sobre este punto véase C. RAMOS RUBIO, Del delito de cohecho... op. cit., p.343, quien aprecia la novedad introducida por la reforma por "su simplicidad", mientras que desecha que de la misma puedan "extraerse otras consecuencias relacionadas con la interpretación de los tipos penales".

${ }^{45}$ F. MORALES PRATS y Ma. J. RODRÍGUEZ PUERTA, “Delitos...”, 2011, op. cit., p.1219.

${ }^{46}$ F. MUÑOZ CONDE, Derecho penal, Parte especial,...2010, op.cit., p.1021; M. POLAINO NAVARRETE, “Cohecho...", op. cit., pp.322 y 323.
} 
Las razones que este sector de la doctrina española avanza para justificar su postura, tienen como base una interpretación sistemática. En este sentido, afirman MORALES PRATS y RODRÍGUEZ PUERTA que, a pesar de esta ampliación operada por la nueva redacción, en su opinión, "una interpretación sistemática de los citados vocablos conduce a restringir su ámbito únicamente a aquellas prestaciones de carácter material valorables económicamente" 47 . Estos autores siguen defendiendo la idea según la cual el CPE otorga protección al principio de imparcialidad no sólo a través de la tipificación del delito de cohecho sino también del de tráfico de influencias. Por lo tanto, los delitos previstos en artículos 428 y 429 CPE recortan implícitamente el ámbito típico de las modalidades de cohecho en lo que al medio para conseguir la actuación del funcionario se refiere. Defienden estos autores que quedarían relegadas al ámbito de tráfico de influencias el resto de ventajas de carácter inmaterial y subjetivo ${ }^{48}$. En cuanto a los favores sexuales que no suponen ni ventajas objetivas, ni tampoco pueden ser cualificadas como ventajas de carácter subjetivo, la posibilidad de incluir tales favores en el ámbito del delito de cohecho o en el de los artículos 443 y 444 CPE va a depender de la finalidad que con su prestación se persiga y del sujeto del que parta la iniciativa ${ }^{49}$.

Por su parte, POLAINO NAVARRETE opina que la significación patrimonial del objeto material del delito se aprecia en la expresión "en provecho propio o de un tercero", delimitadora de un elemento del tipo indicativo de la cualidad económica de la dádiva, favor o retribución y del ofrecimiento o promesa. Añade el autor que la estructura del tipo incorpora la característica de actuar "en provecho", que constituye un elemento subjetivo del injusto revelador del ánimo de lucro que inspira la conducta del funcionario ${ }^{50}$.

Más adelante valoraremos estas posturas, no sin antes presentar las críticas emitidas por la doctrina española respecto a esta parte de la reforma de 2010.

\section{español de 2010}

3-Las críticas a la técnica utilizada por el legislador

Ya hemos señalado anteriormente que la mayoría de la doctrina española ha acogido favorablemente la reforma introducida por el legislador respecto al instrumento del delito de cohecho. Sin embargo, tal consideración no ha impedido a una parte de la doctrina emitir críticas sobre la técnica legislativa elegida.

\footnotetext{
${ }^{47}$ F. MORALES PRATS y Ma. J. RODRÍGUEZ PUERTA, “Delitos...”, 2011, op. cit., p.1219; Mà. J. RODRÍGUEZ PUERTA, "Modificaciones..." op. cit., p.468.

${ }^{48}$ F. MORALES PRATS y Ma. J. RODRÍGUEZ PUERTA, “Delitos...”, 2011, op. cit., p.1219.

${ }^{49}$ Ibídem, op. cit., p.1220.

${ }^{50}$ M. POLAINO NAVARRETE, “Cohecho...”, op. cit., pp.323 y 324.
} 
Según CERINA, el inciso "dádiva, favor o retribución de cualquier" parece defectuoso. Aun prescindiendo del anacronismo del término "dádiva", se pregunta el autor si realmente, DRALE en mano, debe mantenerse que existe alguna diferencia semántica entre "dádiva" y "favor" que justifique el empleo simultáneo de ambas palabras ${ }^{51}$. Si, favor es "ayuda, socorro que se concede a alguien" 52 o bien una "honra, beneficio, gracia"53, y la dádiva es "cosa que se da gratuitamente" 54 parece que, por un lado, ninguno de los dos términos resulta particularmente apto para describir la situación que se pretende (ya que ni el soborno se otorga "gratuitamente", ni se trata de un "socorro" o "ayuda" ni necesariamente de una "honra o gracia"); por otra parte, no resulta tan clara la existencia de una diferencia entre ellos que justifique su contemporánea presencia $(y$, en efecto, en materia de cohecho activo el legislador se limita a hacer referencia a las dádivas o a la retribución, omitiendo los "favores") 55 .

Tanto BLANCO CORDERO como CERINA convienen que, probablemente, con la inclusión de la palabra "favor", se persiga incluir ventajas de tipo inmaterial, incluso que carezca de valoración económica ${ }^{56}$ puesto que "favor" es cualquier beneficio, con independencia de que resulte tangible o intangible, evaluable económicamente o $\mathrm{no}^{57}$.

En cuanto a la palabra retribución, no parece aportar nada a la descripción del objeto material ${ }^{58}$. Lo que ocurre es, señala CERINA, que el término "retribución", se esperaba como calificativo de la dádiva o favor y no como alternativo a estos ${ }^{59}$. En efecto, si dádiva y favor son altrum respecto de la retribución, es muy cuestionable que puedan ocupar un lugar en el objeto material del delito de cohecho ${ }^{60}$. El carácter retributivo de la contraprestación del particular en el delito de cohecho, se deduce de la propia naturaleza del negocio jurídico ilícito y debe postularse siempre y en todos los casos, con independencia de la referencia legislativa expresa al término "retribución".

En cuanto al inciso "de cualquier clase", el autor indica que resultaría muy oportuno, si no fuera porque el mismo resulta referido sólo a la retribución y no a las dádivas y favores. De acuerdo con una interpretación literal, en efecto cabría afirmar que, según las intenciones del legis-

\footnotetext{
51 En este mismo sentido, I. BLANCO CORDERO, La reforma..., op.cit., p.26. Para este autor no se entiende muy bien qué añade el término favor al tipo penal, pues puede confundirse claramente con el concepto de dádiva.

52 www.rae.es

53 Ibídem, op. cit.

${ }^{54}$ Ibídem, op. cit.

55 G. D. M. CERINA, La lucha contra la corrupción, op. cit., pp.1196 y 1197. En sentido contrario, J. QUERALT JIMÉNEZ, Derecho penal..., 2010, op. cit., p.1163.

56 I. BLANCO CORDERO, La reforma..., op.cit., p.26.

57 G. D. M. CERINA, La lucha contra la corrupción, op. cit., p.1197. En el mismo sentido, J. QUERALT JIMÉNEZ, Derecho penal..., 2010, op. cit., p.1163

58 I. BLANCO CORDERO, La reforma..., op.cit., p.26.

${ }^{59}$ Ibídem, op. cit., p.26.

${ }^{60}$ En este sentido, J. QUERALT JIMÉNEZ, Derecho penal..., 2010, op. cit., p.1163.
} 
lador, dádiva o favor cubren los casos en los que el objeto material del delito es material y/o económicamente evaluable mientras que bienes o prestaciones inmateriales y/o no económicamente evaluables podrían considerarse como "retribución de cualquier clase". Así las cosas, por otra parte, al autor le parece que la segunda dicción ("retribución de cualquier clase") ya incluye a la primera, convirtiéndola así en pleonástica ${ }^{61 .}$

Por último, este mismo sector de la doctrina española manifiesta su insatisfacción en cuanto a la elección de estas expresiones utilizadas por el legislador español de 2010. Observa BLANCO CORDERO que si el objetivo de la reforma ha sido acomodar la regulación a los convenios internacionales, quizás hubiese sido más conveniente utilizar la expresión empleada en ellos de "beneficio indebido", y aclarar que el mismo comprende el de cualquier clase ${ }^{62}$. Por su parte, CERINA no comprende las razones que impidieron al legislador español prescindir finalmente del término dádiva, cuya utilización en el tipo objetivo de cohecho resulta tanto tradicional como anacrónica: así como proponen los convenios internacionales considerados, hubiera sido preferible la utilización de sustantivo "ventaja" o "beneficio", pudiéndose aclarar que el mismo releva en tanto en cuanto constituye una retribución de un acto del cargo y con independencia de su clase o naturaleza. 0, para utilizar un lenguaje más adherente al empleado por los legisladores de la reforma, hubiera sido preferible que el legislador español se limitara a mencionar la "retribución de cualquier clase"63.

\section{II-Derecho francés y malgache}

Como ya hemos señalado anteriormente, los vínculos históricos entre ambos ordenamientos han llevado a que, antes de las reformas sucedidas respectivamente en 1994 en Francia y en 2004 en Madagascar, tanto el CPF como el CPM tuvieran la misma redacción respecto al objeto material de la conducta. Esta similitud sigue existiendo en la actualidad después de estas reformas, lo cual facilitará nuestro análisis.

A-ESTADO DE LA CUESTIÓN ANTES DE LAS REFORMAS DE 1994

\section{Y 2004}

Es de notar que, a diferencia de la doctrina española, los autores franceses no han dedicado ningún debate sobre el instrumento de la corrupción. Lo que significa que no hay discrepancia en esta materia ni división de la doctrina francesa. En cuanto a la doctrina malgache no existe

\footnotetext{
${ }^{61}$ G. D. M. CERINA, La lucha contra la corrupción, op. cit., p.1198. En este mismo sentido se ha pronunciado I. BLANCO CORDERO en La reforma..., op.cit., p.26, quien afirma que retribuciones de cualquier clase comprenden no sólo las valorables económicamente sino cualquier otra ventaja de contenido patrimonial o personal (incluidas, por lo tanto, las de carácter sexual).

62 I. BLANCO CORDERO, La reforma..., op.cit., p.26.

${ }^{63}$ G. D. M. CERINA, La lucha contra la corrupción, op. cit., p.1198.
} 
ni siquiera alguna referencia a esta cuestión, por tanto, el presente trabajo, probablemente, constituirá un estudio pionero en este sentido.

\section{1-Los términos utilizados}

Antes de la reforma francesa de 1994 y malgache de 2004, tanto el CPF como el CPM utilizaban los términos "ofertas" o "promesas" que debían ser solicitadas o aceptadas y "dádivas" o "presentes" que debían ser, a su vez, solicitados o recibidos. En efecto, se trataba de cuatro elementos distintos. No hemos encontrado en la doctrina francesa ninguna crítica ni intento de acotar el alcance de estos términos. Hubiera sido interesante saber el objeto de las ofertas o de las promesas. A falta de especificación, VITU entiende que ofertas, promesas, dádivas y presentes son remuneraciones que el funcionario solicita pero, si los dos primeros elementos sólo se aceptan y los dos últimos sólo se reciben, es por una cuestión de cumplimiento en el tiempo. Por lo tanto, a nuestra manera de entender, se deduce que, aunque el disfrute de estos elementos se separe en el tiempo, realmente se refiere a una misma idea, algo capaz de remunerar ${ }^{64}$. En este orden de ideas, la doctrina francesa observa que no hay delito de corrupción si el funcionario viola su deber del cargo en respuesta a ruegos o recomendaciones sin que por ello reciba, finalmente, una cantidad de dinero ${ }^{65}$ al solicitar o aceptar ofertas o promesas, o al solicitar o recibir dádivas o presentes ${ }^{66}$.

Para poder acotar el alcance de estos términos les autores franceses acuden a la jurisprudencia sobre la cual han basado todos sus comentarios.

\section{2-El alcance de los términos "ofertas", "promesas", “dádivas" y "presentes" según la jurisprudencia francesa}

Antes de la reforma de 1994, la jurisprudencia francesa había precisado en varias sentencias la naturaleza del objeto de la corrupción. En efecto, podían ser instrumentos del delito de corrupción cosas materiales entregadas directamente tales como dinero en efectivo ${ }^{67}$, objetos valio$\operatorname{sos}^{68}$, mercancías diversas ${ }^{69}$, pero también servicios o favores realizados indirectamente como pago de deudas del funcionario ${ }^{70}$, concesión de crédito y de préstamo ${ }^{71} \mathrm{o}$ trabajos realizados en el terreno del funcionario $^{72}$. La doctrina francesa indica que la jurisprudencia, al aplicar

\footnotetext{
${ }^{64}$ A. VITU, Traité..., op. cit., p. 291.

65 Ibídem, op. cit., p.290.

${ }^{66}$ E. GARÇON, Code pénal annoté, Tome I, op. cit., no 89, p.697. En este mismo sentido, M. DELMAS-MARTY y G. GIUDICELLI-DELAGE, Droit pénal des affaires, op. cit., p.289.

67 Entre otras sentencias, Cass. crim. 30-05-1955, Bull. crim. no330; 6-02-1969, Bull. crim. nำ67; 23-01-1973, Bull. crim. nำ29.

68 Cass. crim. 7-01-1808, Bull. crim. no3.

${ }^{69}$ Cass. crim. 16-01-1812, Bull.crim no8; 4-07-1974, Bull. crim. nํ249;

70 Cass. crim. 7-09-1935, Gaz. Pal. 1935, 2, jurispr. p. 694.

${ }^{71}$ Cass. crim. 25-12-1923, Bull. crim. no434; 27-08-1968, Bull. crim. no277

72 Cass. crim. 04-07-1974, Bull. crim. no90.
} 
el anterior artículo $177 \mathrm{CPF}$, demostraba una postura bastante extensiva que correspondía a la política criminal de abarcar mayor número de supuestos de corrupción ${ }^{73}$. La pregunta que se hacía bajo la vigencia del anterior CPF era si esos términos utilizados para designar el instrumento del delito podían abarcar otro tipo de ventaja que no fuera de naturaleza económica ${ }^{74}$.

La jurisprudencia francesa tuvo la oportunidad de contestar a esta pregunta al afirmar, en una de sus sentencias, que "los términos ofertas o promesas... tienen un alcance general y pueden abarcar legalmente ventajas no materiales, tales como las ventajas de orden social, moral o intelectual, siempre que no sean puramente subjetivas"75. La misma sentencia indica que la "satisfacción del odio" es una de estas ventajas puramente subjetivas. En cambio, una jurisdicción de menores había considerado que podía formar parte de los instrumentos del delito de corrupción la promesa de relaciones sexuales que un funcionario había exigido como precio de su corrupción ${ }^{76}$. El análisis del conjunto de estas sentencias, lleva a VITU a concluir que los términos "ofertas, promesas" utilizados por el anterior artículo 177 CPF parecían bastante abiertos para incluir en su ámbito hasta ventajas inmateriales ${ }^{77}$.

A nuestro parecer, la jurisprudencia francesa optaba por una interpretación extensiva reconociendo que los términos ofertas, promesas, dádivas o presentes se referían tanto a ventajas objetivas evaluables económicamente como a ventajas subjetivas no evaluables económicamente. El problema reside en saber en qué criterio se ha basado el Alto Tribunal francés para poder distinguir una ventaja "simplemente" subjetiva de una ventaja "puramente" subjetiva. La falta de debate doctrinal en esta materia plantea el peligro de dejar a los jueces el monopolio de la interpretación de la ley al poder de esta manera acotar, ellos mismos, el alcance del tipo. Es cierto que la jurisprudencia francesa manifestaba su deseo de no ir más allá de una interpretación extensiva, pero esta autolimitación debería ser motivada o aclarada por algún principio objetivo para preservar la seguridad jurídica de los justiciables.

\section{B-EL ÁMBITO DE APLICACIÓN DE LOS ARTÍCULOS 432-11 CPF Y 177 CPM}

Ante esta indecisión de la jurisprudencia, el legislador francés intervino por medio de la reforma de 1994 para disipar las dudas. Con la expresión "ventajas de cualquier tipo"78, la doctrina francesa está de acuerdo en que esta fórmula introducida por la reforma, es de una imprecisión

${ }^{73}$ E. REURER, Des atteintes..., op. cit., p.95.

${ }^{74}$ A. VITU, Corruption passive..., op. cit., p.16.

${ }^{75}$ Cass. crim. 14-10-1975, Bull. crim. no214.

76 T. Enfants Sarreguemines, 11-05-1967, JCP G, 1968, II, 15359. En sentido contrario, C. AMBROISE-CASTÉROT, Droit pénal..., op. cit., p.367.

${ }^{77}$ A. VITU, Corruption passive..., op. cit., p.16.

${ }^{78}$ Traducción propuesta por Mํ. J. RODRÍGUEZ PUERTA, El delito de cohecho..., op. cit., p. 312 . 
tal que permite las interpretaciones más amplias ${ }^{79}$. La nueva redacción, según los autores franceses, ya no permite interpretación que limite el instrumento del delito a elementos estrictamente objetivos ${ }^{80}$ o ventajas pecuniarias $^{81}$. Hoy en día, precisan LUCAS de LEYSSAC y MIHMAN, los términos "de cualquier tipo" traen como consecuencia que una ventaja inmaterial pueda bastar para cumplir con las exigencias del tipo ${ }^{82}$. La doctrina más destacada indica que este tipo de ventaja puede abarcar: la promesa de facilitación de trámite, la promesa de votar en un sentido determinado o la oferta de relaciones sexuales ${ }^{83}$.

La redacción del artículo 177 CPM, respecto al objeto material del delito de corrupción, se refiere también a ofertas, promesas, dádivas, presentes o ventajas de cualquier tipo. A falta de doctrina y de jurisprudencia, creemos que a pesar de las dificultades y las críticas en su elaboración ${ }^{84}$, la ley 2004-030 ha sido redactada conforme a las recomendaciones contenidas en el Convenio de la Unión Africana relativo a la prevención y la lucha contra la corrupción, que prevé como instrumentos del delito de corrupción y de las infracciones asimiladas: "bien que tiene valor monetario o todo tipo de ventaja tal como una dádiva, un favor, una promesa o un beneficio". A nuestro juicio, no cabe duda alguna de que el objeto material del delito de corrupción en Derecho malgache debe incluir tanto ventaja material y/o pecuniaria como ventaja inmaterial o subjetiva. Toda interpretación contraria violaría no sólo el espíritu sino también la letra del precepto.

\section{Sección 2-Características cuantitativas del objeto material de la conducta}

\section{I-El problema de la existencia de un mínimo cuantitativo}

\section{LA}

A-PRINCIPALES DEBATES DENTRO DE LA DOCTRINA ESPAÑO-

Ya hemos visto, tanto en la doctrina española como en la francesa la idea de remuneración o de retribución que relaciona la contraprestación del particular con el acto del cargo esperado del agente público. Ahora el problema que se plantea es saber si existe un mínimo cuantitativo debajo del cual no existe delito de cohecho. En otras palabras, se trata de determinar un criterio para la existencia de un umbral debajo del cual la contraprestación del particular no pueda ser típica.

\footnotetext{
${ }^{79}$ Entre otros, F. CECCON, Contribution..., op. cit., p.68; C. AMBROISE-CASTÉROT, Droit pénal.., op. cit., p.366; E. DREYER, Cours magistral..., op. cit., p.604.

${ }^{80}$ E. REURER, Des atteintes..., op. cit., p.96.

81 V. MALABAT, Droit pénal spécial, op. cit. p.528.

82 M-P. LUCAS de LEYSSAC y A. MIHNAN, Droit pénal des affaires..., op. cit., no1025.

${ }^{83}$ A. VITU, Corruption passive..., op. cit., p.16.

${ }^{84}$ A. RAODINA, La production..., op. cit., pp.73 y 74; P. RAFOLISY, La protection juridique..., op. cit., pp.208 y ss.
} 
Frente a algunos que mantienen que es absolutamente y totalmente indiferente la cantidad del objeto material del delito ${ }^{85}$, la gran mayoría de la doctrina española más reciente considera que no todo tipo de ofrecimiento, promesa o solicitud es típica a efectos del delito de cohecho. Se ha defendido que "un criterio de interpretación apoyado en máximas de experiencia jurídica y respetuosa con el carácter fragmentario del Derecho penal indica que, en el cohecho, es preciso que un funcionario público reciba cierta cantidad de dinero o cosa que lo represente por ejecutar un acto en el ejercicio del cargo. De no ser así, no estaría justificada la imposición de una pena, siempre y cuando el funcionario obtuviera o pactara una cantidad mínima que, a juicio de un espectador objetivo, pudiera decirse que no guarda ninguna correspondencia retributiva con el acto ofrecido o ejecutado"86. Con algún matiz, se ha observado que "el ofrecimiento o recibo de dádivas, presentes, ofrecimientos o promesas, constituye el móvil, el interés o el motor de la posterior conducta del funcionario, de manera que entre la dádiva, promesa u ofrecimiento y el posterior acto del funcionario debe existir una relación de causalidad"87. En este mismo sentido, se ha afirmado que "la ventaja deberá ser objetivamente idónea «ex ante» para conseguir lesionar o poner en peligro el bien jurídico"88. Según otros autores, "quizás no se debe exigir una capacidad objetiva para corromper en abstracto ni una estricta proporcionalidad entre la dádiva y el acto, sino una capacidad objetiva para motivar a actuar al funcionario en el caso concreto" ${ }^{89}$. En opinión de VALEIJE ÁLVAREZ, quien defiende la necesidad de comprobar la existencia de un ánimo de lucro, "difícilmente se podrá castigar a un funcionario por cohecho pasivo propio cuando admita una cantidad mínima por un acto contrario al cargo, puesto que difícilmente se podrá llegar a la convicción de que actuaba con un propósito de enriquecimiento (sobre todo si las reglas de experiencia aconsejan que es mucho más de lo obtenido lo que pudo lograr a cambio), o cuando exista un gran desequilibrio entre ambas prestaciones. En estos supuestos en que el ánimo de lucro no pueda ser puesto de manifiesto a través de los hechos realizados, desde nuestro punto de vista, procesalmente debe ser tenidos como inexistentes"90.

Se puede decir que la mayoría de la doctrina española parece concorde en rechazar la posibilidad de distinguir los munuscula penalmente irrelevantes de las dádivas y presentes constitutivos de cohecho, apoyándose en el criterio de la proporcionalidad. En este sentido, un sector de la misma doctrina indica que "el exigir con carácter general el requisito de equivalencia o de proporcionalidad podría llevar a no penar como delito de cohecho aquel caso en el que el funcionario reciba una peque-

85 Entre otros, E. CASAS BARQUERO, “Observaciones...”, op. cit., p.890, J. BUSTOS RAMÍREZ, Manual... Parte especial, op. cit., p.375; J. M. RODRÍGUEZ DEVESA y A. SERRANO GÓMEZ, Derecho penal español, Parte especial, op. cit., p.1171.

${ }^{86}$ A. MARTÍNEZ ARRIETA, “Comentario...”, op. cit., p.3109.

${ }^{87}$ Ibídem, op. cit., p.3108;

88.M‥ J. RODRÍGUEZ PUERTA, El delito de cohecho..., op. cit., p. 200.

${ }^{89}$ I. OLAIZOLA NOGALES, El delito de cohecho, op. cit., p. 346.

${ }^{90}$ I. VALEIJE ÁLVAREZ, El tratamiento..., op. cit., p.167. 
ña suma de dinero por realizar un acto oficial importante y lo acepte debido a que atraviesa por una mala racha económica y para él es suficiente" 91 . Otros autores, en cambio argumentan que "la inevitable subjetividad de los baremos que han de regir el enjuiciamiento y la valoración de las dos pretensiones pone en peligro la igualdad en la aplicación del Derecho" y cuando se trata de prestaciones heterogéneas, el juicio de proporcionalidad es muy complicado ${ }^{92}$.

A partir de estos argumentos se llega a defender que, en una interpretación que tenga en la debida cuenta el objeto jurídico del delito, deberá admitirse que éste "peligrará desde que el funcionario está motivado a realizar una determinada actividad oficial a cambio de un elemento extraño, la dádiva" de lo que se deduce que "no es necesario que la dádiva y el acto oficial estén en relación de equivalencia o de proporcionalidad, [sino que] es suficiente con que [la dádiva] objetivamente, desde el punto de vista del medio ideal, sea suficiente para motivar al funcionario"93.

Por último, VALEIJE ÁLVAREZ observa respecto a la "causalidad adecuada" (la dádiva debe ser causa de la aceptación para ser penalmente relevante) que este criterio presupone que la aceptación del sujeto público es el resultado del ofrecimiento o promesa del particular y que, indirectamente, está defendiendo que el cohecho activo es un delito de resultado. Según la autora, si el caso que se pretende analizar, sin embargo, es de cohecho pasivo, "al contrario de lo que pueda parecer, este criterio no encuentra aplicación práctica: una vez que lo único que está en juego es la aceptación del funcionario (delito de mera actividad), ya no se trata de verificar resultado material alguno, sino la violación del bien jurídico (provocando una identificación con el quebrantamiento del deber funcional). Con arreglo a esta posición, la circunstancia de que la gratificación recibida por el funcionario sea de una entidad modesta, no impide nunca que su aceptación ofenda al bien jurídico protegido (puesto que la dádiva es idónea para producir su aceptación), verificándose igualmente un delito de cohecho pasivo. En una palabra, de la mano del criterio criticado, valoraremos de distinta forma el comportamiento del funcionario y el comportamiento del particular"94. Siempre según esta autora, merecen ser criticadas todas aquellas posturas que argumentan la irrelevancia de la conducta con apoyo en la adecuación social de la dádiva o presente: en primer lugar, el hecho que ciertos "regalos" a funcionarios públicos sean socialmente aceptados no es lago que el Derecho penal deba avalar, sino todo lo contrario: se trata de costumbres que, desde un punto de vista racional, deben ser erradicadas; en segundo lugar, siempre según la jurista, el argumento de la adecua-

${ }^{91}$ I. OLAIZOLA NOGALES, El delito de cohecho, op. cit., p. 345.

${ }^{22}$ I. VALEIJE ÁLVAREZ, El tratamiento..., op. cit., p.157.

93 I. OLAIZOLA NOGALES, El delito de cohecho, op. cit., p. 345. La autor matiza que el criterio del hombre ideal, en una óptica rigurosamente ex ante, es aceptable sólo si tienen en cuenta todas las características del caso concreto (p.346). Habla de necesaria relación causal entre la dádiva o presente y el acto a realizar, F. MUÑOZ CONDE, Derecho penal, Parte especial, 2009, op. cit., p. 936.

${ }^{94}$ I. VALEIJE ÁLVAREZ, El tratamiento..., op. cit., p.158. 
ción social es inútil ya que, lo que es socialmente adecuado, es lo que, según el sentir social, no incide sobre la imparcialidad del funcionario público ${ }^{95}$. Por todas esas razones, VALEIJE ÁLVAREZ prefiere defender el criterio según el cual, en el caso de ofrecimiento de demasiado escaso valor, debe negarse su tipicidad por la ausencia del ánimo de lucro.

Antes estas críticas, CERINA sostiene que éstas carecen de fundamento, pero curiosamente llevan a la misma conclusión. Al criticar el principio de proporcionalidad y sus baremos subjetivos, el autor recuerda las propias palabras de VALEIJE ÁLVAREZ quien "excluye el delito de cohecho "cuando exista un gran desequilibrio entres ambas prestaciones" 96. Y se pregunta el autor: " ¿acaso no es "desequilibrio" lo mismo que "desproporción"? »97. En cuanto al criterio de la "causalidad adecuada", según el autor, si se afirma que, en el caso de cohecho activo, para que haya lesión del bien jurídico protegido, dádiva o presente deben ser causa de la aceptación del funcionario, deberá decirse que, en el cohecho pasivo, la entidad de la dádiva o presente solicitados por el funcionario público, debe ser idónea para que el particular dé, ofrezca o prometa y se produzca así la misma lesión para el bien jurídico. Lo que no procede es, como hace VALEIJE ÁLVAREZ, afirmar que, mientras que, en el cohecho activo, se ofrece o promete, en el cohecho pasivo, se acepta. En ambos casos, en realidad, se "propone" y se "acepta"98. En lo que concierne al criterio de adecuación social, el mismo autor defiende que una vez se ha establecido que la dádiva es causa del pactum sceleris y que el Derecho penal apunta a sancionar todos los casos en los que existe un pactum sceleris que se apoye en una dádiva que sea su causa, no puede luego decirse que el pactum no es típico si la dádiva es adecuada socialmente. Por otra parte, con apoyo en la adecuación social de la dádiva, no se pretende excluir de la relevancia penal conductas objetiva y subjetivamente típicas, sino proponer un criterio con apoyo en el cual evaluar cuándo la dádiva es idónea para ser causa de un pactum ${ }^{99}$.

Tomando postura, CERINA concluye que debe considerarse irrelevante la solicitud, aceptación, dación, recepción, ofrecimiento, promesa, admisión de una dádiva o presente, si, con arreglo a un juicio ex ante pero que tenga en cuenta todas las peculiaridades del caso concreto, el objeto material de la conducta no parece idóneo a causar la conclusión del pactum sceleris. Para valorar esta relación de causalidad entre la pro-

\footnotetext{
${ }^{95}$ Ibídem, op. cit., pp.160-161.

${ }^{96}$ Ibídem, op. cit., p.167.

97 G. D. M. CERINA, La lucha contra la corrupción, op. cit., p.944.

${ }^{98}$ Ibídem, op. cit., p.945.

${ }_{99}$ Ibídem, op. cit., p.946. El autor añade que ofrecer una caja de puros a cambio de una licencia millonaria no parece conducta penalmente relevante, se está simplemente afirmando que, de acuerdo con las reglas de experiencia", la manifiesta desproporción entre el ofrecimiento y el acto pedido a cambio excluye que, en condiciones normales, pueda haber lugar un pacto. En este caso, de haberse aceptado la caja de puros, podrá decirse que la misma se ha entregado en ocasión de la concesión de la licencia pero, en condiciones normales, no parece poderse argumentar que la caja de puros pretende ser causa de la misma.
} 
puesta de pacto y la conclusión del mismo (o, si se prefiere, la idoneidad de la solicitud, ofrecimiento o promesa de la dádiva para generar el acuerdo en el cual se cifra la lesión del bien jurídico), pueden tenerse en cuenta aquellos elementos que se consideran normalmente en materia de imputación objetiva: así, la solicitud, propuesta u ofrecimiento de la dádiva, debe ser idóneas para representar la conditio sine qua non del pacto en el que se cifra la lesión del bien jurídico; de la misma manera, solicitud, ofrecimiento o promesa de la dádiva, deben generar un riesgo no permitido ni socialmente adecuado para que la misma sea aceptada en el marco de un pacto que implica la lesión del bien jurídico protegi$\mathrm{do}^{100}$.

\section{B-AUSENCIA DE ESTE DEBATE DENTRO DE LA DOCTRINA FRANCESA Y MALGACHE}

Al exponer la postura de la doctrina francesa respecto a la existencia de un mínimo cuantitativo debajo del cual no se puede caracterizar el delito de corrupción, nos parece que los autores franceses han ignorado este punto del debate. Es cierto que en los manuales de Derecho penal especial o de Derecho penal de los negocios, se pueden hallar algunos puntos que unos autores enfatizan más que otros y que generalmente no hay posturas diferentes o divergentes, sin embargo, la cuestión de la naturaleza cuantitativa de la contrapartida del acto del cargo no se plantea entre los autores franceses. Se pueden avanzar algunas razones para explicar esta situación.

En primer lugar, como ya hemos señalado a lo largo de este trabajo, la doctrina francesa no defiende una postura claramente diferente a la de la jurisprudencia. Los autores siempre se han referido a la interpretación de los tribunales para luego intentar sintetizar las reglas destacadas por las sentencias y presentarlas en los manuales sin criticarlas. En materia del delito de corrupción, la tentación es grande para afirmar

100 Ibídem, op. cit., pp.947 y 948. Añade el autor que de ahí no existe contradicción entre los que afirman que la dádiva tiene que ser idónea para motivar al funcionario o al particular (o, lo que es lo mismo, tiene que ser causa de la determinación) para que acceda al pactum sceleris y los que defienden que dicha idoneidad tiene que evaluarse a la luz de las peculiaridades del caso concreto, teniendo en cuenta los usos sociales y, ¿por qué no? La existencia de una mínima proporcionalidad entre las dos prestaciones a las que se obligan los dos pactantes (dádiva o presente por un lado, acto del cargo por el otro). Para el mismo es el criterio de VALEIJE ÁLVAREZ (el ánimo de lucro) el que plantea mayores dificultades: una vez aceptado que existe cohecho toda vez que existe ánimo de lucro, también deberá reconocerse que es "lucro" cualquier ventaja, incluso si es de escaso valor. Todo lo más, podrá decirse que, un beneficio "pequeño", implicará un lucro igualmente pequeño, pero en ningún caso podrá afirmarse que una utilidad, por muy insignificante que sea, no implica un lucro para quien la pretende: incluso 1 céntimo de euro representa indiscutiblemente un lucro. Dicho en otras palabras, existe un propósito de enriquecerse tanto en el funcionario que adelanta un trámite cobrando a cambio de 2000 euros, como en el caso del funcionario que concede una licencia edilicia a cambio de un ramo de flores del valor económico de 10 euros. En ambos casos, el funcionario actúa para aumentar su patrimonio (esto es, lucrarse): la única diferencia que existe entre los dos ejemplos, es que, en el primero, el aumento será importante, mientras que, en el segundo, será pequeño (pp.948 y 949). 
que el Derecho penal en materia de corrupción, por lo menos, se ha convertido en un Derecho jurisprudencial. Se puede preguntar la razón de esta falta de actitud crítica de la doctrina francesa para con las decisiones de los jueces. No es necesario repetir aquí las observaciones hechas al principio de este trabajo, pero realmente la ausencia de este tipo de debate se debe a la falta de herramientas dogmáticas y a la casi impermeabilidad del sistema jurídico, que, impiden a éste último abrirse al método de análisis del Derecho comparado.

En este orden de ideas, ya que la jurisprudencia francesa se ha convertido en la fuente de interpretación por excelencia en la materia, llama nuestra atención el hecho de que, del análisis de las sentencias en materia de corrupción, sólo se desprenda una que se refiere a la dádiva de precio nimio. En efecto, el Alto Tribunal juzgó que las dádivas de insignificante valor no podían constituir el objeto material del pacto de corrupción y de esta manera, confirmó la absolución del imputado ${ }^{101}$. La sentencia ponderaba el valor del beneficio económico que se esperaba del acuerdo corrupto y el valor de lo que se entregó por parte del particular. De esta sentencia se puede deducir que los jueces fueron partidarios del principio de proporcionalidad. Lamentablemente, no se ha encontrado más sentencias que puedan afianzar esta postura. Se puede suponer que la falta de precisión por parte de la jurisprudencia francesa respecto a esta cuestión es una de las razones del desinterés manifestado por los autores sobre la misma ${ }^{102}$.

Por otra parte, la doctrina francesa más destacada se refiere a las pequeñas cantidades de dinero o las munuscula desde una perspectiva procesal. Recordemos la postura de los autores franceses en general, quienes defienden la existencia de una presunción de corrupción en cuanto haya una entrega de la dádiva por parte del particular corruptor. En este orden de ideas, observa VITU que la importancia de la cantidad de la dádiva recibida facilitará la prueba del delito, ya que ésta puede dejar algunos rastros. En cambio, si la dádiva es irrisoria será difícil probar los actos de corrupción. En efecto, señala el mismo autor que casos de corrupción se quedan sin sancionar por la insignificancia del objeto material ${ }^{103}$. De ello se puede deducir que la preocupación del autor no es determinar una cuantidad mínima para determinar luego si existe o no delito de corrupción sino la dificultad de probar la dádiva de precio nimio que impide procesar el delito en estudio.

\section{II-La irrelevancia de un mínimo cuantitativo en todas las modalidades del cohecho}

En España existen opiniones divergentes respecto de si deben requerirse ciertos requisitos cuantitativos para que la dádiva resulte penalmen-

101 Cass. crim. 12-10-1993, Dr. pénal, 1994, comm.4.

102 El único autor que menciona esta sentencia en su manual es C. AMBROISECASTÉROT, Droit pénal..., op. cit., p.367.

${ }^{103}$ A. VITU, Corruption passive..., op. cit., p.16. 
te relevante sólo en el cohecho impropio o también en el propio. Un sector de la doctrina española defiende una opinión restrictiva. Así OLAIZOLA NOGALES, bajo la vigencia del anterior CPE, señaló que "no se podrán, sin embargo, aplicar esos principios a los supuestos del delito de cohecho pasivo propio, porque no se puede considerar insignificante o tolerada socialmente aquella dádiva entregada al funcionario con el fin de que realice un acto injusto por un acto injusto ya realizado"104. Frente a esta postura, otro sector de la doctrina española defiende que "el elemento típico «dádiva o presente» constituye en todo caso la contrapartida por la realización de un acto propio del cargo, justo o injusto" 105 .

Dentro de la doctrina francesa y malgache, no existe este debate ya que los artículos 432-11 CPF y 177 CPM no diferencian la corrupción pasiva según los actos objeto del acuerdo corruptor. Ya hemos visto la irrelevancia de las munuscula para la doctrina francesa que se preocupa más por probarlas que por cuantificarlas.

\section{Sección 3-Toma de postura}

\section{II-Respecto a las características cualitativas}

\section{A-DERECHO ESPAÑOL}

Al repasar los debates doctrinales sobre la característica cualitativa del objeto material del delito, constatamos que la postura mayoritaria en España era la que defiende una interpretación restrictiva, es decir, la que sólo admite contraprestación de naturaleza objetiva, patrimonial o evaluable económicamente. A nuestra manera de entender, ya con el CPE 1995 se podía defender una interpretación amplia. En efecto, las palabras "dádiva" o "presente", dos palabras sinónimas, siempre se refieren a una cosa. Y es justamente la interpretación de esta "cosa que se da" la que hace que una interpretación amplia pueda ser defendible. Ya que "cosa" significa "todo lo que tiene entidad, ya sea corporal o espiritual, natural o artificial, real o abstracta"106, pues la dádiva o presente se refiere a todo lo que conlleva esta definición. Por otra parte, desde una perspectiva teleológica, si lo que se pretende tutelar es el principio de imparcialidad, no hay ningún impedimento para que el pacto se pueda concluir con una contraprestación que no tenga carácter económico. El intercambio de prestaciones entre el particular y el funcionario no puede limitarse en términos evaluables económicamente como si tratara de un mero contrato comercial. A nuestro juicio, "cualquier cosa" económicamente evaluable o no, tiene la capacidad para vulnerar este bien jurí-

104 I. OLAIZOLA NOGALES, El delito de cohecho, op. cit., pp.344 y 345. En el mismo sentido J. CÓRDOBA RODA, "Del cohecho", op.cit., p.2001; E. CASAS BARQUERO, "Observaciones...", op. cit., p.901.

105 Ma. J. RODRÍGUEZ PUERTA, El delito de cohecho..., op. cit., p. 196. En el mismo sentido G. D. M. CERINA, La lucha contra la corrupción, op. cit., pp.949 y 950.

${ }^{106}$ www.rae.es 
dico protegido. En este sentido, estamos de acuerdo con RODRÍGUEZ PUERTA quien observa que "desde el punto de vista del bien jurídico protegido, lo esencial es que lo solicitado u ofrecido tenga capacidad para excluir la obligación del funcionario de actuar de una forma imparcial"107. Aunque la defensa de esta postura se hizo difícil con los argumentos de la pena de multa y del comiso, entre otros, con la reforma de 2010 el legislador español ha facilitado la interpretación en esta materia.

La nueva redacción de los artículos 419 y siguientes CPE ha zanjado la discusión sobre la naturaleza cualitativa del objeto material del delito. En efecto, los términos "dádiva, favor, retribución de cualquier clase" no dejan espacio a ninguna duda acerca de la amplitud cualitativa del objeto material de la conducta ${ }^{108}$. Por otra parte, el legislador español ha abandonado el sistema de determinación de la multa proporcionalmente al valor de la dádiva, lo cual manifiesta la intención del legislador de abarcar más formas de contraprestación.

A pesar de la claridad con la que se ha resuelto el debate en esta materia, no entendemos las posturas que siguen defendiendo una interpretación restrictiva respecto a estos nuevos términos ${ }^{109}$. Si bien es cierto que algunos reconocen la ampliación del alcance de la contraprestación perseguida por el funcionario, observan que una interpretación sistemática de los vocablos "dádivas, favor o retribución de cualquier clase" conduce a restringir su ámbito únicamente a aquellas prestaciones de carácter material valorables económicamente ${ }^{110}$. Tampoco entendemos la postura que admite la ampliación del objeto material pero considera que quedan excluidas las ventajas de carácter sexual ${ }^{111}$.

La interpretación sistemática propuesta por MORALES PRATS y. RODRÍGUEZ PUERTA consiste en colocar en el ámbito de aplicación del delito de tráfico de influencias las prestaciones del particular, de carácter inmaterial y subjetivo, reservando al delito de cohecho las de carácter material y valorables económicamente. En cuanto a los favores sexuales, estos autores proponen incluirlos en el ámbito del cohecho dependiendo de la finalidad que con su prestación se persigue y del sujeto del que parta la iniciativa. Aunque reconocen que la nueva terminología empleada por el Código facilita la inclusión de esta clase de ventaja, defienden que no suele integrar el prototipo de soborno cuya prevención y persecución interesa por cuanto su gravedad y significación, en términos cuantitativos, es escasa ${ }^{112}$.

\footnotetext{
107 Mํ. J. RODRÍGUEZ PUERTA, El delito de cohecho..., op. cit., p. 191.

108 G. D. M. CERINA, La lucha contra la corrupción, op. cit., p.1196.

${ }^{109}$ Entre otros, F. MUÑOZ CONDE, Derecho penal, Parte especial,...2010, op.cit., p.1021; M. POLAINO NAVARRETE, "Cohecho...", op. cit., pp.322 y 323.

${ }^{110}$ F. MORALES PRATS y Mํ. J. RODRÍGUEZ PUERTA, “Delitos...”, 2011, op. cit., p.1219;

111 J. QUERALT JIMÉNEZ, Derecho penal..., 2010, op. cit., p.1163.

112 F. MORALES PRATS y Ma. J. RODRÍGUEZ PUERTA, "Delitos...", 2011, op. cit., pp.1219 y 1220 .
} 
Remitiéndonos a las críticas realizadas por CERINA sobre este punto, hay que destacar en el delito de tráfico de influencias tres puntos: 1) sólo es punible el que influye; 2) el verbo "influir" con el sentido de "prevaler" tiene un alcance diferente según se trate de un funcionario o de un particular; 3) el objeto del delito es conseguir una "resolución" para obtener "un beneficio económico". Es cierto que habrá casos de cohecho que podrán considerarse tráfico de influencias, lo cual se resolverá con las reglas de concurso, sin embargo, el tenor literal del precepto de tráfico de influencias impide subsumir en su ámbito de aplicación todos los pactos de corrupción cuyo objeto material consiste en una dádiva o presente o retribución no valorables económicamente. Estamos de acuerdo con la conclusión de CERINA, quien observa que "no parece del todo correcta la idea con apoyo en el cual la diferencia entre cohecho y tráfico de influencias debe cifrarse exclusivamente en el diferente medio a través del cual se corrompe"113.

Por otra parte, con el ámbito reducido del artículo 443 CPE sólo se podrá sancionar la solicitud de una prestación en aquellos casos en los que el funcionario toma la iniciativa y el solicitado se encuentre en una de las situaciones mencionadas en este precepto (tener pretensiones pendientes de resolución, guarda...). Para todos los demás supuestos de intercambio entre acto de oficio y prestación sexual, esta norma no resultaría útil para la solución del problema. A nuestra manera de entender, desde la reforma de 2010, la nueva redacción de los artículos 419 y siguientes CPE ha resuelto esta discusión. A partir del momento en que el particular ofrece, promete prestación sexual para concluir un pacto corrupto, la expresión legal "retribución cualquier clase" permite subsumir la aceptación del funcionario dentro del ámbito del delito de cohecho, independientemente de que el acto objeto del acuerdo sea conforme o contrario a los deberes inherentes de su cargo.

No estamos de acuerdo con la postura que rechaza la prestación sexual como ventaja subsumible en el cohecho por cuanto su gravedad y significación en términos cuantitativos, es escasa. Con la nueva redacción introducida por la reforma de 2010, el legislador español no pretende clasificar cuantitativamente las retribuciones para determinar su tipicidad, sino ampliar cualitativamente el elenco de los instrumentos del delito. Una interpretación en sentido contrario superaría la letra de la ley.

Por último, la insistencia de algunos autores en seguir dando una interpretación restrictiva a los términos utilizados por el legislador español de 2010 se explica, a nuestro juicio, por no valorar la importancia que merece el inciso legal "de cualquier clase".

En cuanto a la técnica legislativa, aunque la palabra "favor" no añade nada al tipo, salvo que se entiende que la intención del legislador es dar cabida a aquellas dádivas con carácter inmaterial. Por otro lado, la pa-

113 G. D. M. CERINA, La lucha contra la corrupción, op. cit., p.903. 
labra "dádiva" peca de anacronismo y necesita alguna precisión respecto a su posible alcance. Por si fuera poco, el legislador añadió la expresión "retribución de cualquier clase", actuando literalmente como una tercera alternativa. Sin embargo, hubiera sido correcto poner la partícula "como" en vez de "o", para que, de esta manera, se le considerara como calificativo de la dádiva o favor. A nuestra manera de entender, sólo la expresión "retribución de cualquier clase" hubiera sido suficiente, ya que abarca los diferentes aspectos que pueda tener el objeto material de la conducta.

\section{B-DERECHO FRANCÉS Y MALGACHE}

La amplitud de los términos utilizados por el CPF y el CPM no deja lugar a duda respecto a la naturaleza cualitativa del instrumento del delito de corrupción. A nuestro juicio, antes de las reformas de 1994 y 2004, era plenamente válida la interpretación amplia realizada por la jurisprudencia francesa. Desde una perspectiva literal, las palabras utilizadas en el artículo 177 del CPF y el CPM, "ofrecimientos", "promesas", "dádivas" y "presentes" daban a entender la posibilidad de incluir ventajas subjetivas. En efecto, si "ofrecimiento" es la "acción de proponer algo ${ }^{114 "}$ y "promesa" es la acción de prometer algo ${ }^{115}$ ", la pregunta es saber en qué consiste este "algo". La respuesta podría encontrarse en las palabras "don" que es "la acción de dar o ceder algo 116" o "presente" que significa "objeto que se ofrece como regalo"117. El único término que no se refiere a "algo" es "presente", el cual se refiere a objeto que significa "cosa concreta, perceptible por la vista y el tacto"118. Debemos precisar que "algo" se traduce en francés por "quelque chose" y su sentido depende de la palabra "chose". Los tres primeros términos que se refieren a "algo" en francés dependen de lo que significa la palabra "chose", la cual se define, según el diccionario Larousse, como "todo objeto concreto" o "una entidad abstracta, una acción, un evento"119. Se puede concluir que gramaticalmente, la interpretación amplia realizada por los tribunales franceses tiene fundamento. En cuanto a la perspectiva teleológica, tanto la probidad, bien jurídico cifrado por el legislador francés y malgache, como la imparcialidad, bien jurídico que se defiende en este trabajo, pueden ser lesionados de la misma manera por una ventaja material, objetiva y valorable económicamente que por una ventaja inmaterial, subjetiva y no valorable económicamente. Lo que no se entiende es la indecisión de la jurisprudencia francesa cuando hace la diferencia entre ventaja subjetiva y ventaja "puramente" subjetiva.

Las reformas legislativas de 1994 en Francia y de 2004 en Madagascar, han disipado las dudas al introducir la expresión "ventaja de cualquier

\footnotetext{
114 www.larousse.fr

115 Ibídem, op. cit.

116 Ibídem, op. cit.

117 Ibídem, op. cit.

118 Ibídem, op. cit.

${ }^{119}$ Ibídem, op. cit.
} 
tipo". Estamos de acuerdo con la doctrina francesa en reconocer que dicha expresión debe permitir las interpretaciones más amplias y que, por ello, la jurisprudencia francesa no tiene por qué diferenciar entre las ventajas subjetivas. No hay problemas en incluir los favores sexuales como supuestos del delito de cohecho siempre que la iniciativa de solicitar esta clase de favor no parta del funcionario. En caso contrario, se aplicarían los artículos 222-33 CPF y 333 bis CPM relativos al acoso sexual ${ }^{120}$.

Por último, la técnica legislativa parece defectuosa. En efecto, la descripción literal de los instrumentos del delito de corrupción pone como elementos alternativos ofertas, promesas, dádivas, presentes, ventajas de cualquier tipo. Se puede preguntar si los dos primeros términos (ofertas y promesas) pueden entenderse sin referirse a los tres últimos. El repaso de los manuales doctrinales ha mostrado que los autores franceses consideran que las ofertas y promesas son elementos que no necesitan ulteriores precisiones. A nuestra manera de entender, lo que se puede ofrecer o prometer no puede ser algo que no sea previsto por el tipo penal. En otras palabras, el objeto de los verbos "ofrecer" y "prometer" debe ser o dádivas o presentes o ventajas de cualquier tipo. En efecto, tal como hemos señalado al criticar la técnica legislativa utilizada en España, las palabras "dádivas, presentes o ventajas de cualquier tipo" no deben ser elementos alternativos a "ofertas" y "promesas", sino sus calificativos o, simplemente, sus objetos. Por lo tanto, en vez de enumerarlos y separarlos con una coma, hubiera sido preferible la siguiente redacción: "ofertas o promesas de dádivas, de presentes o de ventajas de cualquier tipo"121.

\section{II-Respecto a las características cuantitativas}

\section{A-DERECHO ESPAÑOL}

Sin entrar, otra vez, en los debates y las críticas sobre los criterios (entre otros, de proporcionalidad, de adecuación casual o de adecuación social) para determinar un mínimo cuantitativo debajo del cual no existe delito de cohecho, a nuestro parecer, estos criterios han sido el fruto de un punto de vista puramente patrimonial, objetivo o restrictivo del objeto del delito en estudio. A partir del momento en que la mayoría de la doctrina defiende esta interpretación, este debate ocupa una buena parte de la contribución de los autores. En efecto, sólo se puede valorar un mínimo a algo que se pueda cuantificar. Llama nuestra atención el

\footnotetext{
${ }^{120}$ La diferencia entre la redacción de este delito en ambos códigos es la mención en el $\mathrm{CPF}$ de expresiones como amenazas, coacciones o presiones graves. En cuanto al CPM, se refiere a una "exigencia". Por lo tanto, estos términos aluden a algo más que una simple solicitación, poniendo al particular en una posición más bien de "víctima".

121 Esta propuesta de lege ferenda es la traducción propuesta por $\mathrm{M}^{\mathrm{a}}$. J. JODRÍGUEZ PUERTA para la actual redacción del precepto, por tanto, es criticable desde una pers-

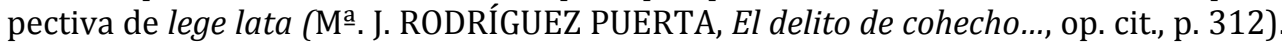
Nos parece más correcta la traducción propuesta por C. ARÁNGUEZ SÁNCHEZ y E. ALARCÓN NAVÍO, El código penal francés, op. cit., p.206.
} 
criterio propuesto por VALEIJE ÁLVAREZ quien defiende el ánimo de lucro como móvil del funcionario y cuya prueba se demostrará en el ámbito procesal según la cantidad o el valor de la dádiva, presente o promesa recibida ${ }^{122}$. Si lucro es "ganancia o provecho que se saca de algo"123 no hace falta que sea mucho. Incluso en las dádivas de escaso valor se puede decir que hay lucro, por lo tanto no nos parece convincente la observación de la autora según la cual "la mayor o menor importancia de la dádiva será un indico probatorio para probar el ánimo de lucro que mueve al funcionario"124.

Respecto al criterio de la adecuación social, la mayoría de los autores lo utilizan para justificar la atipicidad de un pacto de corrupción por un valor cuantificable. A nuestra manera de entender, la adecuación social es un criterio movedizo que no proporciona solución de cuantificabilidad. Es decir, no es papel de este criterio diferenciar, de manera segura, la cuantidad adecuada socialmente y la que merece sanción penal. En efecto, el pacto corruptor considerado en su conjunto, da lugar a una lesión del bien jurídico socialmente tolerada, pero se deberá tener en cuenta no tanto la cantidad de la dádiva, sino, más bien, la gravedad del pacto. La adecuación social finalmente no hace más que proponer un criterio de valoración de la dádiva idónea para causar un pacto de corrupción ${ }^{125}$. Evidentemente, por medio de este criterio, la gravedad del pacto no dependerá siempre de la cantidad de la dádiva ofrecida o prometida.

A partir de la reforma de 2010, se debería atender a otros criterios que no se enfocan en la mera característica cuantitativa del objeto del delito de cohecho. Con la amplitud cualitativa prevista por la nueva redacción de los artículos 419 y siguientes, las posturas defendidas por la doctrina más reciente pueden abarcar dádiva o retribución de carácter inmaterial. El criterio del hombre medio ideal defendido por OLAIZOLA NOGALES ya constituye un paso importante dentro de la doctrina española. Según la autora, "habrá que ver si un hombre medio, ex ante y con los conocimientos del sujeto, estima que una determinada dádiva tiene capacidad de corromper"126. En efecto, este criterio deberá tener en cuenta todas características del caso concreto que actuará como marco de valoración de la capacidad objetiva de la retribución para motivar al funcionario a actuar.

Más preciso aún es el criterio de la idoneidad de la ventaja defendida por RODRÍGUEZ PUERTA según el cual "la ventaja deberá ser objetivamente idónea «ex ante» para conseguir lesionar o poner en peligro el bien jurídico [...] aunque ello deberá comprobarse caso por caso"127.

\footnotetext{
122 I. VALEIJE ÁLVAREZ, El tratamiento..., op. cit., p.167.

123 www.rae.es

${ }^{124}$ I. VALEIJE ÁLVAREZ, El tratamiento..., op. cit., p.167.

125 G. D. M. CERINA, La lucha contra la corrupción, op. cit., p.946.

${ }^{126}$ I. OLAIZOLA NOGALES, El delito de cohecho, op. cit., p.346.

127 Mà. J. RODRÍGUEZ PUERTA, El delito de cohecho..., op. cit., p. 200.
} 
Lo que intentan estos dos criterios es definir un criterio objetivo para valorar la tipicidad del instrumento del delito. A nuestro juicio, la retribución capaz objetivamente de motivar al funcionario es, en realidad, la ventaja idónea ex ante para conseguir lesionar o poner en peligro el bien jurídico. La diferencia entre ambos criterios es la perspectiva desde la cual se hace la valoración. Si OLAIZOLA NOGALES plantea su propuesta desde la valoración del hombre medio ideal, RODRÍGUEZ PUERTA fundamenta su criterio a partir del bien jurídico protegido.

Se puede preguntar la utilidad del baremo del hombre medio ideal en el delito en estudio, si se trata de categoría utilizada en los delitos de imprudencia. En otras palabras, se puede preguntar si es adecuado aplicar la categoría del hombre medio ideal para valorar el comportamiento de un sujeto que conceptualmente está llamado a actuar con un plus de responsabilidad por su obligación jurídica de servir al interés público.

Más convincente nos parece la postura que valora la idoneidad de la solicitud, ofrecimiento o promesa de la dádiva para generar el acuerdo al tener en cuenta los elementos considerados en materia de imputación objetiva. Es decir, la solicitud, propuesta u ofrecimiento de la dádiva, deben ser idóneos para representar la conditio sine qua non del pacto en el que se cifra el bien jurídico protegido. De la misma manera, solicitud, ofrecimiento o promesa de la dádiva, deben generar un riesgo no permitido ni socialmente adecuado para que la misma sea aceptada en el marco de un pacto que implique la lesión del bien jurídico protegido ${ }^{128}$.

A nuestra manera de entender, el que hace que esta idoneidad pueda ser valorada de manera objetiva ex ante y que, así, la retribución pueda ser considerada como conditio sine qua non del pacto, es el bien jurídico protegido y no algún otro elemento del tipo. El principio de imparcialidad debería ser el hilo conductor para valorar si la retribución es idónea para motivar al funcionario y si, siendo idónea, puede ser adecuada o no socialmente, considerando las características específicas del caso concreto. Desde la perspectiva del mismo principio nada impide apreciar si, según el caso concreto, un juicio de proporcionalidad puede ser planteado para valorar las dos prestaciones en juego en el pacto corruptor.

\section{B-DERECHO FRANCÉS Y MALGACHE}

Este debate debería extenderse a la doctrina francesa y malgache que no cuentan con herramienta para determinar si existe un mínimo cuantitativo debajo del cual no existe delito de corrupción. A nuestro juicio, esta situación se debe a dos razones, entre otras. En primer lugar, como ya venimos diciendo, la doctrina francesa no ha desarrollado en la parte general del Derecho penal ningún concepto de antijuridicidad material en la teoría general de la infracción. Por eso, el estudio de un delito de la

${ }^{128}$ G. D. M. CERINA, La lucha contra la corrupción, op. cit., pp. 947 y 948. 
parte especial no se refiere a una lesión o una puesta en peligro de un bien jurídico. Así, si hay que valorar la existencia de este mínimo cuantitativo, esta valoración se hará a partir de elementos tales como la proporcionalidad de las prestaciones o el ánimo de lucro del agente público. En segundo lugar, la interpretación bastante amplia de los instrumentos del delito de corrupción por la jurisprudencia francesa al incluir algunas ventajas subjetivas, ha llevado al manifiesto desinterés de los jueces y de los autores franceses en precisar un mínimo cuantitativo. En efecto, ya hemos señalado el carácter jurisprudencial del Derecho penal francés en materia de corrupción. Es decir, si los jueces quienes tienen que aplicar el precepto en estudio no establecen los criterios para fijar un eventual mínimo cuantitativo, la doctrina francesa entiende, por pragmatismo, que estos no son necesarios.

A nuestro juicio, las reformas legislativas de 1994 y de 2004, respectivamente en Francia y en Madagascar, con las que se ha introducido la expresión "ventaja de cualquier tipo" hacen necesario un criterio que fije la condición con la que la retribución solicitada, aceptada, o propuesta es capaz de corromper al agente público. Esta necesidad se justifica por dos razones. En primer lugar, la expresión legal "ventaja de cualquier tipo" permite una interpretación aún más amplia de lo que se hacía antes de la reforma legislativa en ambos ordenamientos. Dicha expresión abarca todas, y no algunas, las ventajas inmateriales y subjetivas. La jurisprudencia francesa ya no tiene la posibilidad de diferenciar entre ventajas subjetivas y ventajas "puramente" subjetivas. En segundo lugar, la teoría francesa de la infracción no ha desarrollado principios que limitan la potestad punitiva del Estado tales como el principio de subsidiariedad o de fragmentariedad. Tampoco forman parte de esta teoría los principios de insignificancia, de adecuación social, de merecimiento y de necesidad de pena.

Por lo tanto, un criterio objetivo que establece la idoneidad de la ventaja para motivar al agente público a acceder al pacto corruptor es más que deseable puesto que ello, por un lado, permitirá a la jurisprudencia a acotar el amplísimo ámbito de aplicación de los artículos 432-11 CPF y 177 CPM y, por otro lado, ayudará a armonizar las respuestas del Derecho penal y del Derecho disciplinario en la materia respetando, de esta manera, los principios de intervención mínima y de ultima ratio del ordenamiento jurídico-penal. Evidentemente, se debe hacer la valoración de este criterio desde la perspectiva del bien jurídico protegido. 


\title{
CAPÍTULO VIII: TIPO SUBJETIVO
}

\section{Sección 1-Exigencia del dolo}

Tanto en el CPE como en el CPF y CPM, no es posible contemplar una comisión culposa o imprudente. La conexión finalística entre la dádiva y el acto propio del cargo y el hecho de que los CPE y CPF sólo castigan hechos imprudentes cuando así se disponga expresamente, hacen que este tipo de comisión se descarte en el estudio de este delito. Respecto a este punto no hay precisión en Derecho penal malgache. Sin embargo, es claro que el delito de cohecho sólo podrá castigarse en aquellos supuestos en los que el sujeto actúe con dolo, porque bien no se han tipificado en los textos legales la comisión imprudente del delito de cohecho o de corrupción ${ }^{1}$ o la configuración de la incriminación dificulta este tipo de comisión.

\section{I-El delito de cohecho desde la perspectiva subjetiva o del elemento moral}

\author{
A-DERECHO ESPAÑOL
}

\section{1-El delito de cohecho como tipo subjetivamente in- congruente}

Para la doctrina española, en el delito de cohecho el funcionario y el particular son portadores de elementos subjetivos distintos del dolo. En este sentido, al lado de las normales exigencias que supone su caracterización como doloso (volición y representación del tipo objetivo), se requiere la existencia de una finalidad ulterior por parte de los sujetos intervinientes. En efecto, para que el delito esté completo de todos sus elementos típicos, no es preciso que dicha finalidad se realice pero es necesario sea objeto de representación. Así, la doctrina española incluye el cohecho en el conjunto de aquellos tipos "subjetivamente incongruentes"2.

Desde esta perspectiva, el cohecho pasivo pertenece a la categoría de tipos mutilados de dos actos pues el autor, al ejecutar la acción típica, se dirige a realizar otra actividad posterior a la que el mismo debe dar cumplimiento. En cuanto al cohecho activo, es una figura delictiva que pertenece a la categoría de tipos denominados de resultado cortado

\footnotetext{
${ }^{1}$ I. OLAIZOLA NOGALES, El delito de cohecho, op. cit., p.367; Ma. J. RODRÍGUEZ PUERTA, El delito de cohecho..., op. cit., p. 249; J. QUERALT JIMÉNEZ, Derecho penal..., 2010, op. cit., p.1163. También I. VALEIJE ÁLVAREZ, El tratamiento..., op. cit., p.227, aunque esta autora matiza su postura aceptando la incriminación culposa en algunos casos. De manera explícita en la doctrina francesa H. XIAO-YING, La lutte contre la corruption..., op. cit., p.74; A. VITU, Corruption passive..., op. cit., p.10.

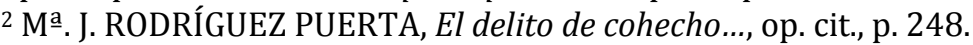


puesto que la realización de la acción ulterior que persigue el sujeto activo no depende de él mismo ${ }^{3}$. Insiste la doctrina española que la necesidad de la intención del autor de obtener un segundo resultado o actividad, va a resultar esencial para subsumir la conducta de ambos sujetos en el delito analizado. Esta idea nos lleva a pensar si es apropiado hablar de dolo específico.

\section{2-Posibilidad de un dolo específico}

Es cierto que la mayoría de los autores españoles no precisan explícitamente si cabe tal posibilidad y la lectura de su postura sugiere que basta con un dolo, sin más precisión ${ }^{4}$. Sin embargo, como bien apunta CERINA, en la vertiente antecedente del delito, es preciso que los sujetos involucrados se representen como finalidad de su acuerdo la realización, por parte del intraneus, de un acto de su función y que la realización de dicho acto no es necesaria para que pueda configurarse cohecho antecedente punible. Esta ulterior finalidad que tiene que estar presente para que exista cohecho antecedente típico, tiene que ser objeto de representación por parte de ambos intervinientes 5 . Para el mismo autor, si dolo es volición y representación, entonces en el marco de este delito se trata de una particular configuración del elemento subjetivo que se puede llamar dolo específico. Por ello, sin que este debate entrañe mayor relevancia práctica, la ausencia de representación de esta ulterior finalidad, determinará la ausencia de dolo específico y no falta de un elemento subjetivo ulterior diferente al dolo 6 . A nuestro parecer, es la postura más lógica cuando se refiere a delitos de tipo mutilado de dos actos y de resultado cortado como el delito de cohecho.

\section{B-DERECHO FRANCÉS Y MALGACHE}

\section{1-El delito de corrupción como delito intencional}

Desde la perspectiva del elemento moral, hay unanimidad dentro de la doctrina francesa en considerar el delito de corrupción como delito intencional. En efecto, para este tipo de delito, los autores han clasificado la intensidad de la intención a partir de la graduación del dolo. En el caso de la corrupción pasiva, la intención del agente público exige una acción voluntaria y un conocimiento ${ }^{7}$ o la consciencia en su actuación ${ }^{8}$. Evidentemente, la intención delictiva debe abarcar todos los elementos

\footnotetext{
${ }^{3}$ Ibídem, op. cit., p. 248

${ }^{4}$ Entre otros, C. MIR PUIG, El delito de cohecho en la reforma...op. cit., p.46; F. MUÑOZ CONDE, Derecho penal, Parte especial,...2010, op.cit., p.1023; A. NIETO MARTíN, “Corrupción y abuso...", op. cit., p.756.

${ }^{5}$ En sentido contrario, I. VALEIJE ÁLVAREZ, El tratamiento..., op. cit., p.236.

${ }^{6}$ G. D. M. CERINA, La lucha contra la corrupción, op. cit., p.1124. En el mismo sentido I. OLAIZOLA NOGALES, El delito de cohecho, op. cit., p.368; M. POLAINO NAVARRETE, "Cohecho...", op. cit., p.324.

7 V. MALABAT, Droit pénal spécial, op. cit. p.529; C. AMBROISE-CASTÉROT, Droit pénal..., op. cit., p.368

8 M. DELMAS-MARTY y G. GIUDICELLI-DELAGE, Droit pénal des affaires, op. cit., p.290.
} 


\section{CAPÍTULO VIII: TIPO SUBJETIVO}

de la figura delictiva o, como se diría en la teoría general francesa del delito, los elementos materiales. Estas observaciones conciernen también al delito corrupción del artículo 177 CPM que es un delito intencional. Sin embargo, los autores franceses muestran una preocupación especial por la manera de probar el dolo del funcionario. Defienden categóricamente que la prueba de este elemento moral resultará del cumplimiento del elemento material ${ }^{9}$. Precisa VITU que la intención delictiva se halla implícitamente en la combinación de los demás elementos del tipo ${ }^{10}$. Por lo tanto, según el mismo autor, es imposible no considerar animado por una voluntad delictiva el sujeto que tiene la determinación de cumplir el acto pactado bajo el efecto de una promesa de ventaja personal ${ }^{11}$.

A nuestro parecer, no es de recibo esta postura de la doctrina francesa según la cual el elemento moral se deduce del cumplimiento del elemento material. Ya hemos señalado anteriormente la tendencia de los autores franceses a considerar la constitución del delito en cuanto haya una entrega de la dádiva o de la ventaja. Si bien es cierto que se puede entender el pragmatismo y el sentido práctico que animan a estos autores, ya que la prueba de este tipo de delito puede resultar muy complicada, este hecho no debe llevar a sacrificar el rigor conceptual que requiere la aplicación de las normas penales. En efecto, si se presume la consumación del delito de corrupción pasiva cuando hay una entrega material de la dádiva, eso significa que se presume la existencia de una intención delictiva. El problema se plantea cuando estos actos constitutivos del elemento material del delito no dejan rastros externos. Aparte de la dificultad de probar el contenido del pacto, que suele ser oculto, la contraprestación aportada por el particular a dicho pacto puede ser una simple promesa o una ventaja inmaterial. Por lo tanto, la existencia del dolo no se puede deducir únicamente por el elemento material. La imposibilidad de demostrar, en el ámbito procesal, actos materiales no significa conceptualmente la ausencia de la intención delictiva. Ya hemos indicado el coste de este tipo de postura en materia de presunción de no culpabilidad.

\section{2-Posibilidad de un dolo especial}

La doctrina francesa define el dolo general como la voluntad de cumplir un acto que el autor sabe que es prohibido por la ley, pero no siempre es suficiente. A veces, la ley supedita la existencia de la infracción a una voluntad criminal más precisa que se llama dolo especial o dolo específico $^{12}$. Unos autores franceses ven en el delito de corrupción pasiva la

\footnotetext{
${ }^{9}$ Entre todos, V. MALABAT, Droit pénal spécial, op. cit. p.529.

${ }^{10}$ En el mismo sentido, H. XIAO-YING, La lutte contre la corruption..., op. cit., p.74.

${ }^{11}$ A. VITU, Corruption passive..., op. cit., p.10. Defiende otra postura J.-H. ROBERT y H. MATSOPOULOU, Traité... p.182.

12 G. STEFANI, G. LEVASSEUR y B. BOULOC, Droit pénal général, Dalloz, 2007, (20aㅗ ed.), p.244; J.-H. ROBERT, Droit pénal général, Thémis, P.U.F, 2005, (6aed.), pp.321 y 323.
} 
necesidad de añadir un dolo especial. En efecto, además de la intención de cometer el acto delictivo, hay algo más que persigue el autor. El problema es la identificación de este plus en la intencionalidad del agente público. DREYER sugiere que el dolo especial consistiría en la voluntad de obtener una ventaja determinada ${ }^{13}$. Por su parte, XIAO-YING defiende que el dolo especial del delito de corrupción estará caracterizado por el propósito de realizar o de abstenerse de realizar un acto de la función ${ }^{14}$. A nuestra manera de entender, si es cierto que el ánimo lucro puede formar parte del elemento subjetivo, la finalidad que caracteriza el delito de corrupción y que debe ser el objeto de representación en los intervinientes, es la realización o la abstención de un acto propio del cargo. La ausencia de esta representación significará ausencia del dolo específico.

\section{II- El delito de cohecho y el dolo eventual}

\section{A-POSICIÓN DE LA DOCTRINA ESPAÑOLA}

Un sector de la doctrina española admite la posibilidad de sancionar tanto la conducta del particular como la del funcionario público si ha sido realizada con dolo eventual. Indica RODRÍGUEZ PUERTA que si el dolo debe abarcar todos los elementos típicos del delito, esto es, el conocimiento de actuar como funcionario, la conducta típica (solicitación, aceptación, etc.) orientada hacia la realización de un acto propio del cargo, la naturaleza del mismo, es posible, en algunos casos, que el funcionario acepte la dádiva por realizar un acto determinado, sabiendo únicamente que éste no es el que hubiera correspondido conforme a Derecho, pero sin reparar en su carácter contrario a los deberes inherentes a su cargo ${ }^{15}$. Por su parte, OLAIZOLA NOGALES no ve problema en admitir el delito de cohecho en aquellos casos en los que el funcionario acepte la oferta de una dádiva de un particular sin estar seguro de que tal oferta es una contraprestación a un determinado acto, pero representándose la posibilidad y conformándose con la misma. Lo mismo es trasladable para aquellos supuestos de abstención en los que el funcionario duda sobre si el acto que no va a realizar es debido o no y se conforma ${ }^{16}$. Según estas autoras, estos supuestos, entre otros tantos, deberían resolverse a través del dolo eventual ${ }^{17}$.

Otro sector de la misma doctrina defiende que la no punición expresa de la imprudencia y la propia estructura subjetiva de las infracciones, hacen de ellas delitos dolosos exclusivamente, en los que difícilmente puede asumirse incluso el dolo eventual ${ }^{18}$. Otros autores observan que

${ }^{13}$ E. DREYER, Cours magistral..., op. cit., p.605.

${ }^{14}$ H. XIAO-YING, La lutte contre la corruption..., op. cit., p.75.

${ }^{15} \mathrm{M}$ a . J. RODRÍGUEZ PUERTA, El delito de cohecho..., op. cit., p. 250.

16 I. OLAIZOLA NOGALES, El delito de cohecho, op. cit., p.368.

${ }^{17} \mathrm{~A}$ favor de la posibilidad de contemplar el dolo eventual en el delito de cohecho G. D. M. CERINA, La lucha contra la corrupción, op. cit., p.1125; F. MORALES PRATS y Ma. J. RODRÍGUEZ PUERTA, “Delitos...”, 2011, op. cit., p.1229.

${ }^{18}$ L. MORILLAS CUEVA, “Delitos...”, op. cit., p.958. 


\section{CAPÍTULO VIII: TIPO SUBJETIVO}

la autoridad o funcionario público actúa conscientemente cuando solicita, recibe o acepta. Por lo tanto, estas referencias legales de "solicitare", "recibiere" o "aceptare" cierran el paso al dolo eventual ${ }^{19}$.

A nuestro juicio, si no hay indicaciones legislativas que apunten en un sentido contrario, esto es, si el tipo no contiene un adverbio que pide un plus de intencionalidad, no hay argumento jurídico para negar que el delito de cohecho pueda cometerse bajo el elemento subjetivo de dolo eventual.

\section{B-AUSENCIA DEL DEBATE EN LA DOCTRINA FRANCESA Y MAL- GACHE}

La doctrina francesa no se refiere a la posibilidad del dolo eventual como elemento moral del delito de corrupción. La doctrina malgache tampoco ha hecho un estudio sobre el elemento subjetivo del mismo delito. Antes de sugerir algunas razones en cuanto a la ausencia de este debate, quizás sea conveniente recordar cómo la doctrina francesa maneja el concepto de dolo eventual. Explica ROBERT que la referencia a esta clase de dolo se plantea ante el problema jurídico de la determinación del grado de probabilidad a partir del cual se considera que el sujeto activo se ha representado correctamente las consecuencias de su actuación cuando, al mismo tiempo, dicho sujeto alega o demuestra la imprecisión de sus ideas. El problema es saber si habrá que dar al dolo eventual los mismos efectos que el dolo general. Esta pregunta no se ha resuelto en la doctrina francesa. Sin embargo, el mismo autor observa que la intención, aunque sea imprecisa, será asimilada al dolo general cuando el culpable no ha tenido el propósito de cometer el delito, pero sabiendo que, con toda probabilidad, su conducta causaría un daño grave, ha querido eventualmente este mal y ha preferido asumir la consecuencia de su actuación en vez de renunciar a su proyecto, aun a riesgo del resultado previsto ${ }^{20}$. La doctrina francesa está de acuerdo en considerar que el dolo eventual se sitúa entre la intención propiamente dicha y la imprudencia o la negligencia, que no supone ni la aceptación eventual del resultado ilícito, ni la búsqueda de tal resultado. La frontera entre ambos extremos es sinuosa, ya que es difícil precisar los efectos a dar en cada caso ${ }^{21}$.

A nuestra manera de entender, la ausencia del debate para saber si cabe contemplar el dolo eventual como elemento moral del delito de corrupción en Derecho penal francés, se debe a la interpretación del artículo 121-3 del CPF que dispone que "no hay delito grave o menos grave sin intención de cometerlo". Hay unanimidad en considerar que el conjunto de este precepto recoge un sistema de incriminación de la imprudencia

\footnotetext{
${ }^{19}$ A. SERRANO GÓMEZ y A. SERRANO MAíllo, Derecho Penal, Parte Especial...op. cit., p.838.

${ }^{20}$ J.-H. ROBERT, Droit pénal général,..., 2005, op. cit., pp.324 y 325.

${ }^{21}$ Ibídem, op. cit.,, p. 326; G. STEFANI, G. LEVASSEUR y B. BOULOC, Droit pénal général,..., 2007, op. cit., p.246.
} 
numerus clausus, y no una fórmula abierta de castigo de la imprudencia. Por lo tanto, si es imposible la comisión culposa en el delito de cohecho, se entiende que es inconcebible que la intención del funcionario pueda aproximarse a la culpa en materia de delito imprudente. Por otro lado, recuperando la observación de VALEIJE ÁLVAREZ al defender la posibilidad de una incriminación culposa en el marco del delito de cohecho ${ }^{22}$, el artículo 432-11 CPF no lleva una profusión de elementos normativos al describir las conductas típicas, ya que se trata de un sólo artículo que abarca dos tipos delictivos (la corrupción pasiva y el tráfico de influencia). A esta característica hay que añadir la amplitud con la que se pueden interpretar los términos utilizados por el legislador francés, lo cual evitará la falta de congruencia entre los elementos objetivos del delito y el dolo del agente dificultando, de esta manera, la imprecisión de la intención y, por ende, el recurso al dolo eventual y, mucho menos, a la incriminación culposa.

La ausencia de un precepto equivalente al artículo 121-3 CPF en el CPM abre la posibilidad de sancionar como delito imprudente los tipos que no prevén de manera expresa una comisión culposa. Es cierto que el artículo 177 CPM requiere una intención delictiva para su comisión, sin embargo, creemos que no hay nada en el texto legal que impida la posibilidad de cifrar el elemento subjetivo del delito de corrupción en el $\mathrm{CPM}$, en un dolo eventual.

\section{III-El problema de los actos simulados}

Se ha planteado en la doctrina española el problema de saber si constituye delito de cohecho o no aquel caso en el que el funcionario solicita o recibe una dádiva o presente por realizar un acto del ejercicio de su cargo sin tener la intención real de realizarlo. En efecto, si la motivación para llevar a cabo el acto objeto del pacto corruptor en el funcionario es esencial ${ }^{23}$, su ausencia determinará la existencia o no de un delito de cohecho. Por otra parte, habrá que diferenciar este tipo de supuestos de aquellos en los que el funcionario en el momento de solicitar o de recibir la dádiva sí tenía la intención de realizar el acto, y posteriormente decide no ejecutarlo, ya que en ese momento el delito ya está consumado y ese cambio de opinión del funcionario únicamente afecta a la fase del agotamiento del delito 24 .

\section{A-LA FALTA DE VOLUNTAD POR PARTE DEL FUNCIONARIO DE DAR CUMPLIMIENTO A LO PACTADO}

La doctrina española está dividida sobre esta cuestión. Del bien jurídico que se considere protegido en el delito de cohecho depende la solución propuesta. Para aquellos autores que consideran como objetos protegidos en el delito de cohecho el prestigio o la incorruptibilidad de la Ad-

22 I. VALEIJE ÁLVAREZ, El tratamiento..., op. cit., p.228

${ }^{23}$ Mà. J. RODRÍGUEZ PUERTA, El delito de cohecho..., op. cit., p. 251.

24 I. OLAIZOLA NOGALES, El delito de cohecho, op. cit., p.369. 


\section{CAPÍTULO VIII: TIPO SUBJETIVO}

ministración o la confianza de la generalidad en el correcto funcionamiento de la misma, será indiferente la reserva mental del funcionario, puesto que se perturban dichos bienes jurídicos desde el momento en que se produce el pacto entre el funcionario y el particular, independientemente de cuál sea la voluntad real de los sujetos intervinientes en el mismo ${ }^{25}$. Para aquel grupo que considera bien jurídico la imparcialidad o el no falseamiento de la voluntad estatal, no se podrán considerar delito de cohecho aquellos casos en los que el funcionario no tenga intención de realizar el acto, porque ni siquiera se pondrá en peligro el bien jurídico ${ }^{26}$.

A nuestro juicio, ya que el bien jurídico defendido en el marco de este trabajo es el principio de imparcialidad, nos decantamos por la segunda postura. En efecto, la necesaria concurrencia del elemento subjetivo integrado por la voluntad de llevar a cabo el acto propio del cargo objeto del delito de cohecho, impide apreciar esta infracción delictiva en aquellos en los que el funcionario, pese a haber manifestado la intención de ejecutar el acto a cambio de la dádiva -incluso tras haber recibido ésta-, logra probarse que en ningún caso era esa su intención. Estos supuestos excluyen la calificación de cohecho por falta del elemento subjetivo del injusto. No obstante, esta clase de comportamiento deberá subsumirse en el delito de estafa tipificado en artículo $438 \mathrm{CPE}^{27}$. La misma solución debería ser aplicada en el Derecho penal francés y malgache aplicando los artículos 313-1 CPF y 405 CPM. En cuanto al particular, propone CERINA que será autor de cohecho intentado, a la vista de la concurrencia, en su actuación, de todos los elementos típicos, objetivos y subjetivos, de esta figura delictiva. Sin embargo, nos parece más adecuado, aunque se pueda considerar como una tentativa, aplicar en este caso el delito de cohecho activo consumado. Es también la solución, a nuestro modo de ver, más apropiada en el Derecho francés y malgache.

\section{B-LA IMPOSIBLIDAD DE REALIZAR EL ACTO OBJETO DEL DELI- TO DE COHECHO}

También se plantean, en la doctrina española, los supuestos en los que el funcionario no fuera competente para llevar a cabo el acto propio del cargo, pues tampoco su conducta colmaría las exigencias típicas del delito de cohecho, pues en tales hipótesis, el funcionario, conociendo $a b$ initio la falsedad de su manifestación, creó una situación engañosa para obtener una ventaja indebida. En este supuesto, la falta de competencia del funcionario será el indicio que permita determinar la ausencia del

25 J. BUSTOS RAMÍREZ, Manual... Parte especial, op. cit., p.375; I. OLAIZOLA NOGALES, El delito de cohecho, op. cit., pp.372 y ss.

${ }^{26}$ E. CASAS BARQUERO, “Observaciones...”, op. cit., p.892; J. M. RODRÍGUEZ DEVESA y A. SERRANO GÓMEZ, Derecho penal español, Parte especial, op. cit., p.1176; I. VALEIJE ÁLVAREZ, El tratamiento..., op. cit., pp. 185 y ss.

27 G. D. M. CERINA, La lucha contra la corrupción, op. cit., p.1141; Ma. J. RODRÍGUEZ PUERTA, El delito de cohecho..., op. cit., p. 251. 
elemento subjetivo del injusto requerido por esta figura delictiva: la intención de llevar a cabo el acto prometido. Así también en estas hipótesis la calificación más adecuada, según la doctrina española, será la de estafa del artículo $438 \mathrm{CPE}$, siempre y cuando se pruebe además la concurrencia del resto de elementos típicos del delito de estafa, esto es, un acto de disposición patrimonial por parte del particular en perjuicio suyo o ajeno ${ }^{28}$.

En estos supuestos la doctrina francesa adopta la misma postura ${ }^{29}$ con la diferencia de que el CPF no contempla un delito de estafa agravada equivalente al artículo 438 CPE y se tendrá que recurrir al artículo 313$1 \mathrm{CPF}$. La solución en Derecho penal malgache debería ser la misma al aplicar el artículo $405 \mathrm{CPM}$, puesto que es el único precepto que prevé el delito de estafa. Por lo tanto, cabe plantear la necesidad de introducir este tipo de figura delictiva en el Derecho penal francés y malgache ya que el delito de concusión o de exacciones ilegales no cubre el desvalor de la conducta engañosa del agente público.

\section{Sección 2-Los problemas de error}

Antes de tratar los posibles supuestos de error en el marco del delito de cohecho, sería conveniente hacer un repaso de la categoría del error en los tres ordenamientos en estudio.

\section{I-Observaciones generales}

El lugar que ocupa el error en los tres Códigos penales ha influido sobre su estudio teórico.

\section{A-EL ERROR EN DERECHO ESPAÑOL}

El artículo 14 del CPE parece ser el que tiene más contenido. Con sus tres incisos la doctrina española ha elaborado varias clasificaciones según, entre otras, su objeto, su vencibilidad, su relevancia ${ }^{30}$. Una de las clasificaciones más importante que se destaca de la literatura jurídica española versa sobre la distinción entre el error de tipo y el error de prohibición. Error de tipo es aquél que recae sobre los elementos que integran el tipo objetivo, es decir, sobre alguno de los elementos necesarios para que un comportamiento sea penalmente relevante, para que pueda subsumirse en alguna infracción penal. Hay error de tipo cuando

\footnotetext{
${ }^{28}$ Mà. J. RODRÍGUEZ PUERTA, El delito de cohecho..., op. cit., p. 252; G. D. M. CERINA, La lucha contra la corrupción, op. cit., p.1141.

${ }^{29}$ A. VITU, Corruption passive..., op. cit., pp. 4 y 5.

${ }^{30}$ M. MARTÍNEZ ESCAMILLA; M. MARTÍN LORENZO; M. VALLE MARISCAL DE GANTE, Derecho penal, Introducción Teoría jurídica del delito, Materiales para su docencia y aprendizaje, Universidad Complutense de Madrid, Madrid, 2012, pp. 138 y ss.; I. BERDUGO DE LA TORRE y otros, Curso de Derecho Penal, op. cit., pp.199 y ss.
} 


\section{CAPÍTULO VIII: TIPO SUBJETIVO}

el sujeto ignora que en su conducta concurren todos o algunos de los elementos que definen un tipo penal ${ }^{31}$. Antiguamente se hablaba de error de hecho o sobre los hechos, ya que no se captaba que en los tipos había además de elemento de hecho, elementos normativos y jurídi$\cos ^{32}$. Error de prohibición es aquel que recae sobre la antijuridicidad de la conducta. El sujeto conoce la realidad, sabe lo que hace, pero desconoce que está prohibido, es decir, piensa que su comportamiento está permitido cuando en realidad está prohibido. Si bien el artículo 6 del Código Civil español establece en su punto primero que "la ignorancia de las leyes no exime de su cumplimiento", continúa señalando que "el error de derecho producirá únicamente aquellos efectos que las leyes determinen", otorgando el artículo 14 del CPE relevancia a esta clase de error ${ }^{33}$. Por otra parte, la calificación del error como vencible o invencible dependerá de si se ha actuado o no con el cuidado debido. Tal y como determina el artículo $14 \mathrm{CP}$, el error invencible sobre un elemento esencial del tipo penal excluye la responsabilidad penal, es decir, el sujeto no responde penalmente. Si, por el contrario, el error es vencible, el referido precepto determina que "la infracción será castigada, en su caso, como imprudente" 34 .

Por último, el error puede recaer o proyectarse sobre elementos típicos de diferente significación y, así, se distinguen los errores sobre el objeto de la acción, sobre la relación de causalidad, el error en el golpe y el error sobre el momento de la consumación. El error sobre el objeto de la acción, resulta en principio irrelevante, mientras hay que considerar relevante cuando se trata de los mismos objetos pero con diferente protección jurídica de objetos heterogéneos. En los supuestos de error sobre el curso causal de los acontecimientos, es preciso distinguir los casos en los que el resultado sigue siendo objetivamente imputable al autor y los que no. El error que recae sobre un hecho que cualifique la infracción o sobre una circunstancia agravante, impedirá, según el artículo 14-2 CPE, la apreciación de dicha cualificación o agravación. Es decir, se castigará el delito sin cualificar o sin agravar ${ }^{35}$.

\section{B-EL ERROR EN DERECHO FRANCÉS}

\footnotetext{
31 M. MARTÍNEZ ESCAMILLA y otros, Derecho penal,..., op.cit, p. 138

32 I. BERDUGO DE LA TORRE y otros, Curso de Derecho Penal, op. cit., p.199.

${ }_{33}$ M. MARTÍNEZ ESCAMILLA y otros, Derecho penal,..., op.cit, p. 138; C. VÁZQUEZ IRUZUBIETA, Comentario al Código Penal, La Ley, 2010, p.97.

34 M. MARTÍNEZ ESCAMILLA y otros, Derecho penal,..., op.cit, pp. 141 y 142. En el mismo sentido I. BERDUGO DE LA TORRE y otros, Curso de Derecho Penal, op. cit., p.200. Precisan estos autores que el error se considera invencible cuando no hubiera conseguido evitarlo ni una persona cuidadosa y diligente. Por el contrario se considera vencible cuando se hubiera llegado a evitar aplicando normas elementales de diligencia y cuidado. Parece lógico que se excluya la responsabilidad penal cuando una persona diligente y cuidadosa no hubiera evitado el error, y parece lógico también que al que erró por falta de cuidado se le castigue.

35 I. BERDUGO DE LA TORRE y otros, Curso de Derecho Penal, op. cit., pp.200 y 201.
} 
El CPF dispone, en su artículo 122-3, que "no responderán penalmente los que justifiquen haber creído, por un error invencible en cuanto al derecho, poder realizar legítimamente la acción". La doctrina francesa reconoce que el error de derecho tiene reconocimiento legal, pero ello no significa que se debe apartar la cuestión del error de hecho ${ }^{36}$. Ambos pueden ser causa de inimputabilidad si han sido inevitables ${ }^{37}$.

Se ha defendido que el error de derecho puede consistir en la ignorancia de la ley penal o en la mala interpretación de sus disposiciones. En cuanto a la primera hipótesis, se ha observado la dificultad de constituirla ya que el principio "Nemo censetur ignorare legem" se aplica con un rigor particular en Derecho penal francés. Ni la equivocación sobre la ley penal ni su desconocimiento consiguen flexibilizar esta presunción de conocimiento de la ley. Respecto a la inexacta interpretación, se trata de supuestos en los que el sujeto no desconoce la ley penal, sino tiene dificultad en entender su alcance. Por tanto, se esfuerza por obtener informaciones sobre todo ante las administraciones. En la aplicación jurisprudencial sólo se pueden citar dos sentencias en las que la Corte de Casación francesa ha admitido el error invencible ${ }^{38}$. En la mayoría de los casos un error en la interpretación de la ley no podía constituir ni siquiera una excusa legal. La reforma legislativa de 1994, al redactar el artículo 122-3, no ha cambiado la situación ${ }^{39}$. En efecto, el error inevitable de derecho no se puede alegar ni con un simple aviso dado por un profesional del Derecho ${ }^{40}$, ni por la existencia de una divergencia de interpretación entre dos salas de la Corte de Casación ${ }^{41}$. Concluye ROBERT que la letra del artículo 122-3 CPF marca bien el carácter excepcional de la causa de inimputabilidad generada por el error de derecho. Es decir, su probabilidad de éxito como medio de defensa es ínfima ${ }^{42}$.

En cuanto al error de hecho, se trata de un error que recae sobre una de las circunstancias del tipo. Aunque no goce de un reconocimiento del $\mathrm{CPF}$, la doctrina francesa entiende que cuando, a pesar de las precauciones posibles, el sujeto no ha podido darse una representación exacta de las circunstancias en las que actuaba, se plantea la pregunta de saber si semejante error exonera la responsabilidad penal. Hay acuerdo entre los autores franceses en considerar que en los delitos intencionales, el error suprime el dolo sobre todo cuando se proyecta sobre un elemento esencial de la infracción, sea un elemento constitutivo, sea una circunstancia agravante. Es decir, transforma el delito intencional en delito de

\footnotetext{
36 J.-H. ROBERT, Droit pénal général,..., 2005, op. cit., p.312; G. STEFANI, G. LEVASSEUR y B. BOULOC, Droit pénal général,..., 2007, op. cit., p.373.

37 J.-H. ROBERT, Droit pénal général,..., 2005, op. cit., p.312.

38 Cass. crim 9-12-1958, Gaz. Pal, 1958-II-319; Cass. crim. 30-12-1958, Bull. crim. nํ-360.

39 G. STEFANI, G. LEVASSEUR y B. BOULOC, Droit pénal général,..., 2007, op. cit., pp.373-376.

${ }^{40}$ Cass. crim. 7-01-2004, Bull. crim. no5

${ }^{41}$ Cass. crim. 11-05-2004, Bull. crim. no113.

${ }^{42}$ J.-H. ROBERT, Droit pénal général,..., 2005, op. cit., pp. 313 y 314.
} 


\section{CAPÍTULO VIII: TIPO SUBJETIVO}

imprudencia o impide la agravación de la pena que resulta de la circunstancia agravante ${ }^{43}$. Insiste ROBERT que para que el error de hecho tenga efecto exoneratorio de responsabilidad penal no hace falta que sea invencible. Cuando la ley exige el dolo general como condición de imputación, el error sobre los hechos es una causa de inimputabilidad si por medio de él, el sujeto no ha podido representar de manera exacta su entorno o el impacto de su conducta, pues el juez tendrá que comparar esta representación con la descripción abstracta dada por la incriminación. Se deduce que algunos errores de hecho no son exoneratorios porque no atañen a elementos esenciales del tipo penal. Concluye el autor que estas soluciones no son más que el resultado de la asimilación del dolo impreciso (o eventual) al dolo general ${ }^{44}$.

Sin embargo, la respuesta es diferente cuando se trata de delitos imprudentes ya que el elemento moral constituido por la culpa por imprudencia o negligencia no desaparece con el error de hecho ${ }^{45}$.

A nuestro juicio, el planteamiento del error de hecho es una construcción doctrinal propuesta por los autores franceses a partir del estudio de la jurisprudencia de la Corte de Casación. 0 es el legislador francés el que ha desaprovechado la oportunidad para incluir en las últimas reformas del CPF el error de hecho u otra ampliación del concepto de error, o son los tribunales penales franceses los que dan una interpretación extensiva a esta categoría. Este desfase entre la jurisprudencia y el legislador debe ser superado a riesgo de ver la primera sustituir al segundo, lo cual es inaceptable sobre todo en materia penal.

\section{C-AUSENCIA DEL ERROR EN DERECHO MALGACHE}

El CPM no conoce el concepto de error. Ninguna disposición o categoría de este texto legal se acerca a la idea del posible desconocimiento en el autor de la concurrencia o realización de alguno o de todos los elementos del tipo de injusto. En otras palabras, el legislador malgache no ha previsto la falta de congruencia entre los elementos objetivos del tipo de un delito y el dolo del agente. Es cierto que la doctrina malgache no desconoce la categoría del error ${ }^{46}$, pero su falta de consagración legal o de construcción jurisprudencial ${ }^{47}$ impide a los autores malgaches hacer una elaboración diferente de lo que se puede importar del Derecho comparado y concretamente de la doctrina y del Derecho francés. El

\footnotetext{
${ }^{43}$ G. STEFANI, G. LEVASSEUR y B. BOULOC, Droit pénal général,..., 2007, op. cit., pp.376 y 377; J.-H. ROBERT, Droit pénal général,..., 2005, op. cit., p.315.

44 J.-H. ROBERT, Droit pénal général,..., 2005, op. cit., pp.327 y 328

${ }^{45}$ G. STEFANI, G. LEVASSEUR y B. BOULOC, Droit pénal général,..., 2007, op. cit., p.377.

46 En su trabajo RAFOLISY lo menciona desde su repaso del derecho histórico mencionado luego el alcance de esta categoría en el derecho francés (Véase P. RAFOLISY, La protection juridique..., op. cit., pp.77, 269, 287).

47 Es de observar que RAFOLISY aparte de ser investigador es además miembro del poder judicial de la República de Madagascar. Su fácil acceso a las sentencias del Corte Supremo no revela ninguna información sobre el error aunque sea en materia de delitos llamados de corrupción.
} 
problema que se plantea es saber cómo resolver los casos de error en Derecho penal malgache. A nuestro juicio, a pesar de que el error no haya sido previsto por el CPM, eso no impide al juez valorar la intención del sujeto y apreciar la congruencia entre los elementos objetivos del tipo y el dolo del agente para decidir si un déficit objetivo o subjetivo suscita una responsabilidad por tentativa o frustración en el primer caso o una potencial responsabilidad por imprudencia en el segundo.

\section{II-Supuestos de error}

En el marco del delito de cohecho, se ha señalado anteriormente la compatibilidad de esta figura delictiva con el dolo eventual en España. Esta situación, según la doctrina española, implica la reducción considerable de los supuestos de error que, en la práctica, tendrán un carácter meramente residual ${ }^{48}$. El problema se plantea en el Derecho francés y malgache. En Derecho francés la dificultad de poner en marcha el error de derecho y la asimilación del dolo impreciso (o eventual) al dolo general para justificar un error de hecho, no permiten analizar muchos casos de error. Sin embargo, en Derecho malgache, como el error no ha sido previsto por el CPM, entendemos que el dolo eventual cubrirá todos los supuestos que deberían solventarse a través de esta institución.

\section{A-ERROR SOBRE EL CARÁCTER INDEBIDO DE LA DÁDIVA}

En el supuesto de cohecho impropio, se trataría de error de tipo y no de prohibición. Sin embargo, estamos de acuerdo con la postura que distingue dos casos diferentes. Si el particular da (o promete, ofrece...) algo a un funcionario para que éste realice (o por haber realizado) un acto de su cargo, creyendo que tiene la facultad o incluso el deber de darlo, prometerlo, solicitarlo, ofrecerlo, etc. el error versa sobre un elemento normativo del tipo objetivo, de tal manera que se trata de error de tipo (artículos 14.1 y 14.2 CPE). Si, en cambio, el funcionario (o el particular), sabiendo que lo que se da, promete, ofrece... es indebido, es decir, que no existe una norma jurídica distinta a los artículos 419 y siguientes que le faculte para dar, prometer, ofrecer...; sabiendo que da, ofrece, promete... una retribución para un acto del cargo; si aun conociendo todo ello, cree que su comportamiento es penalmente irrelevante (y no ya jurídicamente ilícito), entonces existirá error de prohibición y encontrará aplicación el párrafo 3 del artículo $14 \mathrm{CPE}^{49}$. Por otra parte, si el funcionario no capta realmente el sentido o no se da cuenta de lo que el particular le pide a cambio, entonces es evidente que se elimina el dolo del funcionario y se tratará de error de tipo ${ }^{50}$.

\footnotetext{
${ }^{48}$ G. D. M. CERINA, La lucha contra la corrupción, op. cit., p.1135; Ma. J. RODRÍGUEZ PUERTA, El delito de cohecho..., op. cit., p. 253.

49 G. D. M. CERINA, La lucha contra la corrupción, op. cit., pp.1135 y 1136. En sentido similar se ha pronunciado I. OLAIZOLA NOGALES, El delito de cohecho, op. cit., pp.396 y 397; I. ORTIZ DE URBINA GIMENO, "Delitos...", p.338. En sentido contrario, J. QUERALT JIMÉNEZ, Derecho penal..., 2010, op. cit., p.1163.

${ }^{50}$ I. OLAIZOLA NOGALES, El delito de cohecho, op. cit., pp.397 y 398.
} 


\section{CAPÍTULO VIII: TIPO SUBJETIVO}

En Derecho francés, este supuesto trata de un error sobre un elemento esencial de la infracción. Por lo tanto, se podría alegar un error de hecho que suprime el dolo (que sea general o impreciso) con la condición de que se demuestre su invencibilidad. En efecto, resulta inaceptable el error de derecho, ya que se trata de un ámbito profesional propio. La misma solución debe ser observada en Derecho malgache ya que el dolo se elimina tanto si se cree erróneamente que tiene la facultad o el deber de solicitar, aceptar, etc. la retribución, como si se cree que el comportamiento es amparado por los principios de insignificancia o de tolerancia.

\section{B-ERROR SOBRE LA CONFORMIDAD A DERECHO DEL ACTO OB- JETO DEL DELITO DE COHECHO}

Con la última reforma del CPE, deviene irrelevante el error sobre la naturaleza delictiva o no delictiva del acto objeto del acuerdo ya que la nueva redacción ha simplificado los adjetivos calificativos. En la actualidad, el error sobre el carácter conforme o contrario del acto respecto de los deberes del cargo implicará la subsunción del supuesto en el delito tipificado por el artículo 420 en su nueva formulación.

En Derecho francés y malgache este tipo de error no tiene relevancia alguna ya que el legislador penal de ambos países ha decidido dejar fuera toda distinción o cualificación del acto objeto del delito.

\section{C-ERROR SOBRE LA RELACIÓN TEMPORAL ENTRE ACTO Y PACTO}

Plantea CERINA el supuesto en el cual el funcionario o el particular yerran sobre la relación temporal (o causal/final) entre el acto y el pacto. Es decir, se retiene erróneamente que la retribución para un acto a realizarse en el futuro es una recompensa por un acto ya realizado; o viceversa, se retiene que el acto recompensado está por realizarse, mientras que, en realidad, ya ha sido ejecutado ${ }^{51}$. A nuestro juicio, el artículo 421 CPE vino a resolver los conflictos de interpretación que se generaban ante el error sobre la relación temporal entre el acto y el pacto en los casos de cohecho propio. Previendo para cualquier caso de cohecho, la expresa tipificación del acuerdo pactado para el acto a realizar o como recompensa del ya realizado, vuelve irrelevante el error de cualquier de los sujetos activos respecto del tiempo del acto objeto del pacto corruptor.

En Derecho francés, la nueva redacción del artículo 432-11 CPF ha disipado las dudas sobre la tipificación de la corrupción pasiva subsiguiente. El error sobre la relación temporal entre pacto y acto será también irrelevante y no tendrá efecto sobre la responsabilidad penal de los intervinientes.

${ }^{51}$ G. D. M. CERINA, La lucha contra la corrupción, op. cit., p.1138 
En Derecho malgache, hay que recordar que el delito de corrupción pasiva subsiguiente no está tipificado y tampoco existe un tipo de recogida equivalente al artículo $422 \mathrm{CPE}$. Al no estar previsto ningún error de tipo, ya que el error sobre una conducta excluye siempre la responsabilidad criminal, sea vencible o no, el supuesto planteado por CERINA quedará impune por respeto al principio de legalidad en materia penal. Si no hay dolo (no se puede representar un delito que no existe) y tampoco se puede aplicar algún concepto de error por falta de previsión legal, a nuestro juicio, no se podrá sancionar a los intervinientes. Esta situación nos lleva a reclamar la reforma urgente del CPM. 




\section{CONCLUSIÓN}

\section{CONCLUSIÓN}

\section{1-Sobre el concepto de antijuridicidad en España y en Francia}

El estudio de la teoría general del delito en España y en Francia presenta unas diferencias de aproximación. La recepción por la doctrina penal española del modelo alemán le ha dotado de herramientas de análisis dogmático del delito. Una de ellas es el concepto de antijuricidad, en su aspecto material, que permite entender la figura delictiva como medio de protección de un bien jurídico. En Francia, la noción de antijuridicidad no ha sido desarrollada por los autores y su utilización incidental y furtiva no ha permitido la elaboración de un concepto francés de la antijuridicidad. Esta situación implica consecuencias importantes en el tratamiento de un tipo penal. Al formar parte el sistema jurídico malgache de la "familia" jurídica francesa, por motivos históricos, las observaciones que se hace sobre la doctrina francesa valen, en la mayoría de los casos, para la doctrina malgache.

\section{2-Sobre la relación entre los bienes jurídicos y la Constitución}

Los bienes jurídicos susceptibles de ser protegidos por el Derecho penal no tienen por qué ser expresados de manera explícita en la Constitución. Sin embargo, el legislador no puede legislar contra los principios constitucionales. La norma fundamental debe constituir un límite negativo al ius puniendi del Estado. En el caso de que esta norma se refiera de manera inmediata a un bien jurídico, su protección por el Derecho penal se debe hacer conforme a los principios rectores diseñados por los redactores de la misma.

El bien jurídico debe girar en torno al individuo, sujeto integrante de un sistema social. Se le puede considerar como valor social en la medida que ello influye en la autorrealización del individuo.

3-Sobre el concepto de bien jurídico y la utilidad de la introducción de un concepto material de la antijuridicidad en Francia y en Madagascar

Tanto en Francia como en Madagascar el concepto de bien jurídico no es desconocido por los autores sino poco utilizado. Entienden por bien jurídico un valor social considerado como particularmente valioso y cuya protección debe ser constitucionalmente reservada al Derecho penal. La introducción en la doctrina francesa y malgache de un estudio 
más profundo de la antijuridicidad material con la finalidad de hacer entender que el delito es una lesión o puesta en peligro de un bien jurídico y que el Derecho penal tiene la función de proteger los bienes jurídicos permitirá, por un lado, dotar a la doctrina, a la jurisprudencia y al legislador de criterios objetivos de análisis de las figuras delictivas $y$, por otro lado, superar la utilización oportunista del concepto del bien jurídico y la idea según la cual el delito es una violación o una lesión a la ley.

\section{4-Sobre el bien jurídico protegido en el Título XIX "Delitos contra la Administración Pública"}

El bien jurídico protegido en el Título XIX "Delitos contra la Administración pública" del CPE es la función pública ejercida dentro de la legalidad. El concepto de Administración Pública comprende todas las funciones públicas de los distintos poderes del Estado. El identificar este bien jurídico implica mejorar o depurar el contenido del Título XIX, al sacar los delitos que no tienen nada que ver con las funciones públicas e introducir las figuras fuera de él que protegen bienes jurídicos en estrecha relación con ellas.

\section{5-Sobre el bien jurídico protegido en los Capítulos II y III del título III del libro IV del CPF}

En Derecho francés, la Administración ha sido considerada únicamente como vicaria del Gobierno. Los redactores de la CF y del bloque de constitucionalidad, han asumido que su papel se limitaría a ser un instrumento de los órganos políticos. Sin embargo, una interpretación sistemática lleva a la conclusión de que si el preámbulo de la CF de 1946 reconoce que "La Nación proporciona al individuo y a la familia las condiciones necesarias para su desarrollo" y la Nación, según la doctrina constitucionalista, tiene como componente principal el Estado con todos sus órganos, incluso la Administración, entonces, la lectura del CPF a la luz de esta interpretación coloca a la Administración como garante de estas condiciones y por tanto, digna de tutela penal. En consecuencia, cada vez que el CPF se refiere a la Administración Pública, lo que se protege no es su poder ni su prestigio, sino su correcto y recto funcionamiento precisando en cada figura delictiva reagrupada bajo esta expresión, el aspecto concreto de la tutela. El problema reside en que, a pesar del esfuerzo del legislador francés, tanto en el Capítulo II (De los delitos contra la Administración Pública cometidos por personas que desempeñen una función pública) como en el Capítulo III (De los delitos contra la Administración Pública cometidos por los particulares), del título III del libro IV del CPF, existen delitos que protegen otros bienes jurídicos. Por lo tanto, se puede mejorar la clasificación de los delitos pertenecientes a estos grupos. 


\section{CONCLUSIÓN}

\section{6-Sobre el posible bien jurídico protegido en la Sección II del Capítu- lo III del Título I del Libro III del CPM}

En cuanto al Derecho malgache, la clasificación de los delitos no sigue ningún principio director. Es difícil, incluso imposible, sugerir un bien jurídico categorial los tipos reagrupados en la Sección II (De la "forfaiture" y de los crímenes y delitos de los funcionarios en el ejercicio de sus cargos) del Capítulo III del Título I del Libro III del CPM. La reforma legislativa de 2004 ha sido desaprovechada para dar una nueva presentación al "viejo" Código malgache, que arrastra las presentaciones y los principios que han inspirado los redactores del CPF de 1810. Por otro lado, la lectura atenta del artículo 39 de la CM consagra la Administración como objeto de tutela penal. La exposición de los motivos de la Ley 2004-030 relativa a la lucha contra la corrupción, conforta los valores y principios constitucionales para justificar una mejor protección de la Administración. Aunque es evidente que tanto los redactores de la CM como el legislador penal de 2004 han tenido la intención de proteger el correcto funcionamiento de la Administración Pública, la técnica legislativa utilizada para alcanzar esta finalidad no está a la altura de su pretensión, lo cual significa que se entiende necesaria otra reforma legislativa.

\section{7-Sobre el bien jurídico protegido en el delito de cohecho o de co- rrupción}

El bien jurídico protegido en el delito de cohecho es el principio de imparcialidad, entendido como ausencia de interferencias en la adopción de decisiones públicas. La imparcialidad no tiene que reflejarse en el acto tomado por el funcionario, sino que se refiere más bien al proceso de toma de decisión por éste último. Cuando se alcanza un acuerdo para la obtención de un acto determinado y determinable, tanto la conducta del funcionario como el del particular atentan contra el principio de imparcialidad. Si se considera que el pacto corruptor es el núcleo del delito de cohecho o de corrupción, la solicitud debería ser sancionada como tentativa y no equiparar su sanción como si fuera ya delito consumado. Como la solicitud es un intento de llegar a un acuerdo, en caso de que no reciba aceptación, se trata de una puesta en peligro del bien jurídico. Por lo tanto, esta equiparación de pena chocaría contra el principio de proporcionalidad.

\section{8-Sobre el cohecho subsiguiente y el principio de imparcialidad}


Cabe preguntarse si el cohecho subsiguiente lesiona el principio de imparcialidad. En efecto, en esta figura, la decisión ya ha sido tomada, por tanto, no se puede hablar de lesión propiamente dicha. Sin embargo, se puede contemplar una puesta en peligro abstracto en el sentido de que el funcionario peligra la imparcialidad de la toma de decisión del funcionario en el futuro. En consecuencia, se puede criticar la equiparación de pena prevista por el CPE y el CPF para la modalidad antecedente y subsiguiente.

No es de recibo la postura doctrinal según la cual la modalidad subsiguiente tiene como finalidad la sanción de un cohecho antecedente que no se ha logrado probar, sobre todo si la dádiva ya ha sido entregada. Esta postura chocaría contra la presunción de inocencia puesto que se presume la existencia de un acuerdo anterior al acto.

De lege ferenda, habrá que introducir la corrupción a posteriori en el CPM ya que es una modalidad prevista por el Convenio de la Unión Africana ratificado por el Estado malgache.

\section{9-Sobre el bien jurídico protegido la Sección 3, del Capítulo II del Título III del Libro IV del CPF}

Es criticable la postura del legislador francés al alzar como bien categorial de los delitos agrupados en la Sección 3, del Capítulo II del Título III del Libro IV, el deber de probidad. Este deber funcionarial no es exclusivo para los delitos agrupados en la dicha sección, sino que es compartido por todas las figuras delictivas del Capítulo II (De los delitos contra la Administración Pública cometidos por personas que desempeñen una función pública) del Título III del Libro IV. Además, siendo demasiado genérico este deber, no cumple con la función de límite al ius puniendi estatal que todo bien jurídico tiene atribuida.

\section{0-Sobre la rúbrica del Parágrafo 4, de la Sección II del Capítulo II del Título I del Libro III del CPM}

Como el CPM no sigue ningún principio director que permita presentar de manera ordenada los distintos tipos penales, este texto legal agrupa en el Parágrafo 4, de la Sección II del Capítulo II del Título I del Libro III, los delitos de corrupción de los funcionarios públicos y de los empleados de las empresas privadas. Ante la dificultad de extraer un bien jurídico con esta agrupación, es comprensible que la doctrina malgache cifre como objeto de protección la buena conducta de los funcionarios o su incorruptibilidad en el delito de cohecho pasivo. Lo que no se puede compartir es la idea según la cual el valor que el legislador malgache quiere proteger con la Ley 2004-030 relativa a la lucha contra la co- 


\section{CONCLUSIÓN}

rrupción es la integridad no sólo de los agentes públicos sino también de los particulares que se mencionan en todos los delitos que ha modificado o traído la reforma del CPM.

\section{1-Sobre el principio de imparcialidad en Derecho malgache}

Tanto la probidad en el Derecho francés como la integridad en el Derecho malgache, aparte de ser demasiado amplias para apreciar objetivamente el desvalor de la conducta del que tiene alguna sujeción especial con la Administración Pública respecto al que no la tiene, vehiculan connotaciones morales difícilmente conciliables con el papel del Derecho penal.

El principio de imparcialidad como objeto de tutela en el delito de corrupción y que vincula tanto a los poderes públicos como a los ciudadanos en cuanto destinatarios de las actividades de éstos primeros, es un valor reconocido por la CM que garantiza en su artículo 39 la neutralidad política de la Administración Pública y su protección contra la desviación de su misión para fines personales o políticos.

\section{2-Sobre otros valores protegidos por el delito de corrupción}

Por otro lado, los autores franceses y malgaches asumen que el delito de corrupción no debe tener como objeto de tutela sólo la Administración Pública y su actuación, sino también otros valores como el desarrollo económico o la libre competencia. En efecto, la estrecha conexión entre los diferentes sectores de actividad (público y privado, nacional e internacional) hace que la figura de la corrupción sea pluriofensiva. Este tipo de planteamiento debería ser madurado al considerar el equilibrio entre el concepto de Estado democrático y de Derecho, por un lado, y la competitividad económica, de otro lado.

\section{3-Sobre la estructura del delito de cohecho y de corrupción}

El delito de cohecho o de corrupción es un delito unilateral. En los tres ordenamientos en estudio, la consumación de este delito no depende de la existencia de un acuerdo de voluntad entre el funcionario y el particular. La implicación de ambas partes en algunas modalidades es irrelevante, ya que la conducta de cada parte dará lugar a dos tipificaciones diferentes: el particular que ofrece la dádiva o acepta la solicitud del funcionario cometerá el delito de cohecho activo y el funcionario que acepta o solicita dádiva o retribución responderá por el delito de cohecho pasivo. Por lo tanto, si no se requiere la existencia de un pacto, bas- 


\section{SOBORNO DE LOS GOBERNANTES}

ta, para la tipicidad, el acto unilateral de cada uno de los sujetos activos hipotéticos de las respectivas incriminaciones contenidas en el delito de cohecho o de corrupción.

Cabe preguntarse si el delito de cohecho es un delito de emprendimiento, es decir, un tipo que se caracteriza por realizar una equiparación típica entre tentativa y consumación. El obstáculo se plantea respecto a la existencia de una modalidad de tentativa a un delito intentado considerado como delito consumado. Aunque un sector de la doctrina española defienda la posibilidad de contemplar formas de tentativa respecto a las conductas de solicitud o de ofrecimiento, la mención de estas dos conductas debe explicarse con la intención del legislador de agravar la respuesta sancionadora que la disciplina general había determinado para sus autores. Lo que han hecho los tres legisladores, es una equiparación de pena entre la situación para los sujetos en situación de búsqueda de acuerdo, que éste se alcance o no, lo cual es dudosamente compatible con el principio de proporcionalidad.

No se puede aceptar la punibilidad de una tentativa de cohecho o de corrupción fuera de los casos expresamente previstos por el legislador. En efecto, la solicitud y el ofrecimiento no aceptados configuran hipótesis delictivas en las que se sanciona con una pena más grave un principio de ejecución de la acción lesiva del bien jurídico, que, en ese supuesto no resulta lesionado, sino tan sólo puesto en peligro. Admitir la sanción de una tentativa de solicitar significaría admitir la sanción de una tentativa de la tentativa, lo cual chocaría contra el principio de lesividad.

El hecho de que la solicitud o el ofrecimiento sean mencionados con el delito consumado, esto es, cuando se alcanza un acuerdo de corrupción, no significa que sean equivalentes a esta última hipótesis. En efecto, independientemente de si la iniciativa unilateral ha sido aceptada o no, el bien jurídico se lesiona únicamente cuando se llega a un acuerdo. Por lo tanto, es difícil clasificar el delito de cohecho o de corrupción entre los tipos de emprendimiento.

Es comprensible la interpretación de la doctrina francesa que defiende la punibilidad de la solicitud y de la propuesta de corrupción sin que lleguen a su destinatario como si se tratara de un caso de encuentro de voluntades entre las partes, sin embargo, nos parece totalmente desproporcionado el castigo del solo acto de solicitar o de ofrecer.

Por otra parte, habrá que reclamar de manera urgente la reforma del CPM que no concede el beneficio del desistimiento voluntario a los que cometen delitos menos graves como el delito de corrupción. No tiene justificación ni dogmática ni de política criminal la restricción de esta institución a los delitos graves. 


\section{CONCLUSIÓN}

\section{4- Sobre el concepto de funcionario público a efectos penales y los demás sujetos activos del delito de cohecho pasivo}

En Derecho español, para delimitar el concepto de funcionario público a efectos penales a partir de la noción de participación en el ejercicio de la función pública, se deberá utilizar un criterio objetivo-formal. Para ser sujeto activo del delito de cohecho pasivo, es necesario desempeñar cierta función que se caracteriza por ser pública. Por tanto, el punto de partida es que, una vez individualizadas aquellas funciones que son públicas, todo sujeto que las desempeña, con independencia de para quién, en nombre de quién, por cuenta de quién lo haga, es sujeto activo del delito de cohecho pasivo. Por otro lado, ya que el criterio basado sobre el contenido de la actividad es de difícil acotación, habrá que centrarse en las formas en las cuales dicha actividad se realiza. Será entonces función pública la actividad disciplinada por normas de Derecho público y/o determinados actos administrativos.

Ante la dificultad de dar a la palabra "ley", estipulada en artículo 24 $\mathrm{CPE}$, un sentido estricto ya que la disposición legal, por sí sola, no habilita inmediatamente absolutamente nada, el artículo 24.2 CPE no configura títulos de "adscripción" a la función pública sino títulos de participación en el ejercicio de las funciones públicas. Si "participar en el ejercicio de una función pública" no presupone el incorporar a un Ente público, sino el desempeñar una actividad disciplinada por normas de Derecho público y/ o determinados actos administrativos, debe concluirse que es funcionario público, quien en virtud de una disposición inmediata de la ley, desempeña una actividad disciplinada por normas de Derecho público y/o determinados actos administrativos.

Respecto a la relación entre los artículos 423 y 24 CPE, debería hacerse una interpretación extensiva del artículo 24 y restrictiva del artículo $423 \mathrm{CPE}$. En efecto, esta última norma es pleonástica e inútil, ya que los sujetos mencionados en ella, en el ejercicio de sus funciones, son autoridades (jurados) y funcionarios (peritos, árbitros, administradores o interventores designados judicialmente) a efectos penales. Por lo tanto, se puede proponer la eliminación del artículo 423 CPE para sustituirlo por una fórmula ampliatoria que no debe recogerse de manera aislada en la parte especial y en relación a un delito especial, sino que debe estudiarse la posibilidad de que en la parte general del Código figure, junto al funcionario un concepto de encargado de servicio público o de una función pública.

\section{5-Sobre los sujetos activos del delito de corrupción pasiva en Dere- cho francés y malgache}

En Derecho francés y malgache, la incoherencia interpretativa por parte de la doctrina y de la jurisprudencia de las expresiones "persona depo- 
sitaria de autoridad pública", "persona encargada de una misión de servicio público" y "persona que ostente un mandato público electivo" lleva a reclamar la intervención del legislador de ambos países para introducir, en la parte general del CPF y del CPM un artículo que recoge estas expresiones y que precisa su sentido y su alcance. En efecto, este artículo podrá garantizar la seguridad jurídica de los destinatarios de todas las normas en las que se refieren a estas expresiones como sujetos activos en la parte especial del Código penal. En el mismo artículo se podrá precisar la noción de misión de servicio público o de funciones públicas a efectos penales, acogiendo una aproximación formal-objetiva, para que, de esta manera, se facilite la tarea del intérprete.

\section{6- Sobre la modalidad típica "Solicitar"}

El estudio de la modalidad típica "solicitar" destaca la voluntad de los tres legisladores de sancionar todo intento, materializado por una manifestación de una voluntad exteriorizada, de alcanzar un acuerdo. Sin embargo, la manera de solicitar ha abierto el debate dentro de la doctrina sobre la necesidad de diferenciar mediante otros tipos delictivos la variedad de actitudes del funcionario ante el particular. En este sentido, los delitos de exacción ilegal o de amenaza o de estafa no cubren las situaciones de miedo al poder público, las cuales no han sido resueltas con la figura del cohecho. Por lo tanto, habrá que plantearse la introducción del delito de concusión tal como se entiende en Derecho penal italiano, en los tres ordenamientos en estudio.

Por otro lado, los tres legisladores, al prever la solicitud en el delito de cohecho o de corrupción, no han condicionado su tipicidad con otros elementos tales como el conocimiento del destinatario del contenido exacto de la solicitud ni de la capacidad de éste último para desempeñar el papel de sujeto activo del delito de cohecho activo. Estos elementos deberían ser señalados en el precepto legal, de otra manera, las interpretaciones doctrinales en ese sentido superarían la letra de la norma.

\section{7-Sobre el papel de la persona interpuesta}

Respecto a la persona interpuesta, para que haya delito de cohecho o de corrupción el tercero intermediario debe actuar no por su propia cuenta sino en beneficio del funcionario. Tampoco el beneficiario del pacto corruptor tiene que ser directamente el propio funcionario; puede ser un tercero pero habrá que demostrar un interés, aun mediato del primero para caracterizar la finalidad de una solicitud típica. De lege ferenda, se puede proponer la introducción de la expresión "en provecho propio o de un tercero" en el artículo 177 del CPM para precisar el ámbito de aplicación de este precepto. 


\section{CONCLUSIÓN}

\section{8-Sobre la modalidad típica "Recibir"}

La modalidad típica "recibir" ha sido prevista por el legislador español. Más allá de una transferencia de un acto de apoderamiento, la recepción típica no puede limitarse a un acto de entrega por parte del particular, sino debe incluir el pleno conocimiento de la finalidad de dicho acto por parte del funcionario o de la persona que lo representa. Sin embargo, antes de recibir, el funcionario debe decidir si asume o no las consecuencias de tal conocimiento. Esta asunción no significa otra cosa que "aceptar". Es la razón por la cual tanto el CPF como el CPM no contemplan la modalidad "recibir". En efecto, lo que se pretende con el delito de corrupción pasiva no es castigar actos de disposición patrimonial, sino evitar el encuentro de voluntades susceptible de dar nacimiento a un pacto de corrupción. La responsabilidad penal de la persona intermediaria depende de su grado de participación en la comisión del delito, tanto si ha actuado para entablar y negociar los términos del pacto corruptor como si se ha conformado con ser el beneficiario del mismo.

\section{9-Sobre la modalidad típica "Aceptar"}

En cuanto a la modalidad típica "aceptar" es comprensible que el debate dentro de la doctrina española se desplace hacia el carácter futurible o inmaterial de la contraprestación puesto que de esta manera se podrá diferenciar esta modalidad de la de "recibir". Sin embargo, con independencia del carácter de la retribución que se ofrece o se promete, la aceptación es en realidad el estadio temporal anterior al de la recepción de la dádiva o el presente. Es decir, una aceptación típica debe preceder siempre una recepción típica. En Derecho francés y malgache, la aceptación es la única modalidad típica que supone una conducta pasiva de parte del funcionario. El debate doctrinal no se enfoca en la naturaleza o el carácter de la retribución entregada, ofrecida o prometida, sino en la consumación del delito al alcanzar un acuerdo de voluntades entre las partes, esto es, el momento en que la iniciativa del particular encuentra la adhesión del funcionario.

La aceptación típica consiste en un asentimiento por parte del funcionario de la propuesta del particular. Este asentimiento deberá abarcar el conocimiento de la pretensión del corruptor de retribuir a cambio de un acto del cargo. Respecto de su forma, debe tener un carácter eminentemente activo, asumiendo que la falta de rechazo o el silencio sólo pueden ser asimilados a una aceptación tácita después de haber estudiado las circunstancias de cada caso.

La inidoneidad de la promesa o del ofrecimiento puede implicar un delito imposible según la doctrina española. Sin embargo, habrá que deter- 
minar en cada caso si la idoneidad ha sido aparente o si las circunstancias en las que el particular no ha podido cumplir su promesa, pueden afectar a la tipicidad de la aceptación. La cuestión de la idoneidad o no de la promesa o de la oferta se trata de manera diferente en Derecho francés y malgache, puesto que el delito imposible se considera como una tentativa. Y si la tentativa no se admite en el delito de corrupción, entonces se castigará el delito imposible como si fuera delito "posible" consumado, a pesar de la inidoneidad de la promesa o del ofrecimiento. En efecto, al legislador francés y malgache no les interesa el carácter idóneo o no de la promesa, sino la intención y la decisión de las partes para llegar a un compromiso de corrupción. Esta posición puede ser la más lógica ya que el carácter de la promesa y de la oferta no determina por sí sola la conculcación o no del bien jurídico protegido sobre todo cuando se alcanza un acuerdo.

\section{0-Sobre el acto objeto del acuerdo}

Si el acto debe tener una conexión finalística con la retribución, mayor aún debe ser con la actividad desempeñada por el funcionario. En otras palabras, los actos realizados en el ejercicio del cargo deben abarcar no sólo los que entran dentro de la competencia objetiva, territorial y material del funcionario sino también los que no son totalmente ajenos a la órbita de sus atribuciones, de modo que de facto puede llevarlos a cabo. Esta postura parece ser compartida por la mayoría de los autores españoles y todos los autores franceses. El problema en el debate doctrinal español se plantea al preguntar si un acto que resulta viciado por incompetencia integra un supuesto de cohecho propio o impropio según que este vicio afecte al fondo del acto o a aspectos formales y procedimentales del mismo. Para resolver este problema, el legislador penal español de 2010 ha categorizado dos clases de acto: el "acto contrario a los deberes inherentes al cargo" y el "acto propio del cargo". Por lo tanto, integrará una hipótesis de cohecho propio todo acto viciado por incompetencia relativa (y anulable) mientras que no representará un caso de cohecho punible, el acto totalmente ajeno al ámbito competencial del funcionario (incompetencia absoluta con consiguiente nulidad).

En Derecho francés y malgache si el acto viciado por incompetencia tiene algún vínculo o cierta proximidad con la competencia personal del funcionario, dicho acto puede integrar un supuesto de corrupción pasiva, de lo contrario, habrá que subsumirlo bajo otra calificación penal.

\section{1- Sobre los deberes inherentes al cargo}

Ante la violación de un deber del cargo, tanto el acto "realizar" como el "no realizar" tienen el mismo desvalor y deberán ser castigados con la 


\section{CONCLUSIÓN}

misma pena. Para acotar el ámbito de aplicación de la expresión "deberes inherentes al cargo", habrá que diferenciarla de otros deberes generales que se podrían violar con el precepto del artículo $420 \mathrm{CPE}$, tales como el deber de no lesionar el bien jurídico protegido. Se trata entonces de deberes específicos de uniformar los concretos actos del cargo o de la función a las normas de la ley o a las otras directrices de la Administración Pública pero haciendo referencia a toda violación de la ley o normas emitidas por la Administración Pública (reglamentos, circulares, instrucciones de servicio... y hasta costumbres).

En Derecho francés y malgache, aunque no se contempla la distinción de corrupción propia e impropia, la identificación de estos deberes específicos permitirá aislar los supuestos de corrupción de los otros delitos de la misma sección o capítulo, que pretenden sancionar la violación de un deber general. Por otra parte, en derecho español, esta identificación servirá para integrar los actos discrecionales y no realizados en el ámbito de aplicación del cohecho propio siempre que se demuestre que el funcionario hace un uso incorrecto o ilegal de su poder discrecional.

Con la reforma penal en España de 2010, al utilizar la expresión "acto contrario a los deberes del cargo" es posible castigar con el artículo 419 CPE los casos de "transfuguismo retribuido" con independencia de la categoría del sujeto activo y de los actos jurídicos tomados, al considerar la desviación de los fines que legitiman las atribuciones del dicho sujeto.

\section{2-Sobre la abstención y el retraso}

En cuanto a la abstención, será típica siempre y cuando el acto corrupto tenga por objeto un incumplimiento de un deber de actuar. Del mismo modo, el retraso típico se verifica cuando el acto se realice fuera del plazo previsto por los deberes inherentes al cargo. En Derecho francés y malgache habrá que diferenciar si el plazo ha sido establecido o no por las normas que conforman el sector de actividad. El no respetar dicho plazo a cambio de retribución supondría una abstención de un acto propio del cargo. En caso de que ningún plazo haya sido previsto por las normas, entonces el retraso integraría un supuesto de acto facilitado por la competencia ya que el ejercicio normal del cargo sería proceder a la ejecución del acto en un plazo razonable.

\section{3-Sobre el acto propio del cargo}

El acto propio del cargo es un acto conforme a Derecho y a los deberes genéricos del mismo. No se trata de una conformidad al Derecho administrativo, ya que los sujetos activos del cohecho pasivo pueden tomar 
actos diferentes o se puede tratar de una actuación. En el caso de que el acto objeto del pacto corruptor proceda del poder discrecional del funcionario, no hay que confundir la parcialidad del acto-resultado con la parcialidad del proceso de toma de decisión del funcionario. En lo que se refiere a los actos menores, pueden lesionar con cierta relevancia el principio de imparcialidad, lo cual supone la aplicación del artículo 420 CPE. Sin embargo, las penas previstas en este tipo de precepto no permitirán que los actos de menor importancia encajen en él sin una nueva reforma legislativa que rebaje el límite mínimo de las mismas respetando de esa forma el principio de proporcionalidad.

\section{4-Sobre la aceptación de regalos en Derecho español}

En el cohecho llamado "de facilitación" o "de aceptación de regalos" previsto en el artículo $422 \mathrm{CPE}$, no se lesiona ni se pone en peligro el principio de imparcialidad ya que el tipo no requiere una conexión entre un acto o una actuación y el obsequio. En efecto, el fundamento de la sanción de la admisión de regalo se encuentra en el abuso del cargo cometido por el funcionario que instrumentaliza sus funciones al admitir el obsequio, lo cual no es compatible a su necesaria neutralidad administrativa y a la interdicción de enriquecimiento por el propio ejercicio de su cargo. Esta situación exige medidas y sanciones disciplinarias reservando al ordenamiento penal los casos más graves. Por otra parte, las iniciativas unilaterales no son punibles. Es evidente que lo importante para el legislador español es que ambas partes alcancen un punto en el que sus voluntades se encuentren. En cuanto al regalo, el principio de adecuación social no es un criterio seguro para seleccionar lo penalmente relevante. Ante la generalidad de los términos utilizados, el legislador deberá intervenir para acotar de manera precisa el alcance del artículo $422 \mathrm{CPE}$, a fin de identificar los respectivos ámbitos de intervención del Derecho disciplinario y del Derecho penal.

\section{5-Sobre la aceptación de regalos en Derecho francés y malgache}

En Derecho francés, la admisión de regalos no es un delito, sino una falta administrativa según el código deontológico de cada sector del servicio público. Los excesos en los regalos de cortesía han llevado a la Comisión de reflexión para la prevención de conflictos de intereses en la vida pública a reclamar la intervención del legislador francés para reglamentar los obsequios recibidos por los funcionarios o agentes públicos. El legislador francés deberá atender esta reclamación.

En Derecho malgache, la figura del delito de enriquecimiento ilícito puede ser de utilidad para no dejar la admisión de regalos sin castigo. Sin embargo, este tipo sólo se refiere a un aumento sustancial del pa- 


\section{CONCLUSIÓN}

trimonio del funcionario, de otra manera no se puede hablar de enriquecimiento. La recepción de obsequio que no supone o no implica este aumento queda totalmente fuera del ámbito penal. Por lo tanto, de lege ferenda, se puede proponer la introducción en el artículo 183 CPM de un párrafo para reprimir las dádivas no relacionadas con acto o actuación del funcionario sino en consideración del cargo del funcionario, con las precisiones requeridas por el principio de taxatividad distinguiendo los casos merecedores de sanción penal.

\section{6-Sobre el objeto del cohecho en Derecho español}

En Derecho español, con la introducción de la expresión "retribución de cualquier clase", por medio de la reforma penal de 2010, el objeto material del delito de cohecho puede tener carácter tanto material, objetivo y patrimonial como inmaterial, subjetivo y no valorable económicamente. No hay motivo para colocar en la órbita de otros tipos penales las contraprestaciones que no son directamente valorables pecuniariamente, salvo en los casos en los que los mismos lo requieran. En cuanto a la técnica legislativa, hubiera sido preferible que la misma expresión fuera separada por la partícula "como" en vez de "o" de los términos "dádiva" y "favor" para que se le considere como calificativo de éstos. Si no, hubiera sido mejor utilizarla únicamente.

\section{7-Sobre el instrumento de la corrupción en Derecho francés y mal- gache}

En Derecho francés y malgache la amplitud de la expresión "ventaja de cualquier tipo" no deja lugar a dudas respecto a la naturaleza cualitativa del instrumento del delito de corrupción. Con esta expresión, la jurisprudencia francesa ya no tiene motivo para distinguir las ventajas subjetivas de las "puramente" subjetivas. En lo que se refiere a la técnica legislativa, las ofertas y promesas no son elementos alternativos respecto a dádivas, presentes y ventajas de cualquier tipo. Estos tres últimos elementos deberían ser calificativos u objetos de los dos primeros. Por lo tanto, la redacción hubiera sido más adecuada de versar: "ofertas o promesas de dádivas, de presentes o de ventajas de cualquier tipo".

\section{8-Sobre las características cuantitativas del objeto de la conducta}

El hecho de considerar un mínimo cuantitativo debajo del cual no existe el delito de cohecho ha sido superado por la nueva redacción formulada por la reforma del CPE de 2010. En efecto, este debate ya no tiene su razón de ser si se acepta que la ventaja acordada en el pacto corruptor 


\section{SOBORNO DE LOS GOBERNANTES}

puede tener carácter inmaterial o subjetivo $\mathrm{y}$, por tanto, no cuantificable. No obstante, para determinar objetivamente la tipicidad de la retribución, se debería valorar ex ante su idoneidad para lesionar el bien jurídico. Es decir, la solicitud, propuesta u ofrecimiento de la dádiva deben ser idóneos para representar la conditio sine qua non del pacto en el que se cifra el bien jurídico protegido y, de la misma manera, deben generar un riesgo no permitido ni socialmente adecuado para que la misma sea aceptada en el marco de un pacto que implica la lesión del bien jurídico protegido. Este mismo criterio debería ser utilizado por la doctrina y la jurisprudencia francesa y malgache para acotar lo penalmente relevante ante la amplitud del elenco de los instrumentos del delito de corrupción.

\section{9-Sobre el tipo subjetivo}

En lo que concierne al tipo subjetivo, el delito de cohecho o de corrupción no se puede cometer por imprudencia. La doctrina española lo clasifica entre los tipos "subjetivamente incongruentes". El cohecho pasivo, a su vez, pertenece a los tipos mutilados de dos actos. Con la exigencia de una finalidad ulterior al hecho de alcanzar un acuerdo de corrupción, se puede hablar de dolo específico. En Derecho español y malgache se puede concebir la comisión del delito de cohecho pasivo con el dolo eventual mientras que en Derecho francés, la falta de precisión conceptual respecto al dolo impreciso llevará a asimilar éste último al dolo general.

En cuanto a la institución del error, el legislador francés deberá ampliar los supuestos de error en la parte general del CPF para no restringir sus efectos al error de derecho, el cual no abarca los errores sobre los hechos. Por consiguiente, se debería atender el reclamo de la doctrina y de la jurisprudencia francesa al introducir en el CPF los casos de error que recae sobre los hechos y los elementos esenciales del tipo. De la misma manera, la introducción de esta institución en todos sus aspectos en el CPM facilitará la tarea del juez y proveerá más seguridad jurídica a los justiciables. 




\section{APÉNDICE}

\section{Código penal francés}

\section{Sección 3, Capítulo II, Títu- lo III, Libro IV}

\$2. De la corrupción pasiva y del tráfico de influencias cometido por personas que ejercen una función

\section{Artículo 432-11 (modificado por la Ley 2011-525 del 17 de mayo de 2011, artículo 154)}

Será castigada con la pena de diez años de prisión y 150 000 euros de multa toda persona depositaria de la autoridad pública, encargada de una misión de servicio público o que ostente un mandato público electivo, que solicite o acepte de alguien, sin tener derecho a ello, en cualquier momento, directa 0 indirectamente, ofertas, promesas, dádivas, regalos o ventajas cualesquiera, en provecho propio o de un tercero:

1. Bien para realizar o por haber realizado, para dejar de realizar o por haber dejado de realizar un acto de su función, de su cargo o de su mandato o facilitado por su función, su cargo o su mandato;

2. Bien para abusar o por haber abusado de su influencia real o supuesta con vistas de conseguir de una autoridad o de una administración pública condecora- ciones, empleos, contratas o cualquier otra decisión favorable.

Capítulo III, Título III, Libro IV

Sección 1a- De la corrupción activa y del tráfico de influencias cometidos por particulares

Artículo 433-1 (modificado por la Ley 2011-525 del 17 de mayo de 2011, artículo 154)

Será castigado con la pena de diez años de prisión y 150 000 euros de multa el que proponga sin tener derecho a ello, en cualquier momento, directa o indirectamente, ofertas, promesas, dádivas, regalo o ventajas cualesquiera a una persona depositaria de la autoridad pública, encargada de una misión de servicio público o que ostente un mandato público electivo, en provecho propio o de un tercero:

1. Bien para que realice o se abstenga de realizar o porque ha realizado o se ha abstenido de realizar un acto de su función, de su cargo o de su mandato o facilitado por su función, su cargo o su mandato;

2. Bien para que abuse o porque ha abusado de su influencia real o supuesta con vistas de conseguir de una autoridad o de una adminis- 
tración pública condecoraciones, empleos, contratas o cualquier otra decisión favorable.

Será castigado con las mismas penas el que conceda ofertas, promesas, dádivas, regalos o ventajas cualesquiera a una persona depositaria de la autoridad pública, encargada de una misión de servicio público o que ostente un mandato público electivo, cuando se los haya solicitado sin tener derecho a ello, en cualquier momento, directa o indirectamente, en provecho propio o de un tercero, para realizar o por haber realizado, para abstenerse o por haberse abstenido de realizar un acto señalado en el apartado $1^{\text {o }}$ o para abusar o por haber abusado de su influencia en las condiciones señaladas en el apartado 2 ‥

\section{Código penal malgache}

Artículo 177 (modificado por la Ley 2004-030, del 9 de septiembre de 2004), De la corrupción pasiva de las personas que ejercen una función pública

Será castigada con la pena de dos a diez años de prisión y de 1000000 a 200000000 Ariary de multa o de una de las dos, toda persona depositaria de la autoridad pública, encargada de una misión de servicio público o que ostente un mandato público electivo, que solicite o acepte de alguien, sin tener derecho a ello, directamente o por persona interpuesta, ofertas, promesas, dádivas, regalos 0 ventajas cualesquiera, para realizar o dejar de realizar un acto de su función, de su cargo o de su mandato o facilitado por su función, su cargo o su mandato.

Artículo 177.1 (modificado por la Ley 2004-030, del 9 de septiembre de 2004), De la corrupción activa

Será castigado con la pena de dos a diez años de prisión y de 1000000 a 200000000 Ariary de multa o de una de las dos, el que proponga sin derecho a ello, directamente o por persona interpuesta, ofertas, promesas, dádivas, regalo o ventajas cualesquiera a una persona depositaria de la autoridad pública, encargada de una misión de servicio público o que ostente un mandato público electivo:

1. Bien para que realice o se abstenga de realizar un acto de su función, de su cargo o de su mandato;

2. Bien para que facilite por su función, su cargo o su mandato la realización o no de este acto;

3. Bien para que abuse de su influencia real o supuesta con vistas de conseguir de una autoridad o de una administración pública condecoraciones, empleos, contratas o cualquier otra decisión favorable.

Será castigado con las mismas penas el que conceda ofertas, promesas, dádivas, regalos o ventajas cualesquiera a una persona depositaria de la 


\section{APÉNDICE}

autoridad pública, encargada de una misión de servicio público o que ostente un mandato público electivo, cuando se los haya solicitado sin tener derecho a ello, directamente o por persona interpuesta, para realizar o abstenerse de realizar los actos señalados en los apartados $1^{\mathrm{o}}$ y $2^{\circ} \mathrm{o}$ para abusar de su influencia en las condiciones señaladas en el apartado $3^{\circ}$.

Será castigado con las mismas penas toda persona que haya intermediado en la comisión de las infracciones previstas en el presente artículo. 



\section{BIBLIOGRAFÍA}

\section{BIBLIOGRAFÍA}

ÁLVAREZ GARCÍA, F. J.: Bien jurídico y Constitución, Cuadernos de Política Criminal (CPC), no 43, 1991, pp. 5 y ss.

AMBOS, K.: Observaciones a la doctrina francesa del hecho punible desde la perspectiva alemana, Indret, julio 2008, n을

http://www.indret.com.

AMBROISE-CASTÉROT, C.: Droit pénal spécial et des affaires, Lextenso éditions, 2008.

ANCEL, M.: Utilité et méthode du droit comparé, Ides et Calendes, Neuchâtel, 1971.

ARÁNGUEZ SÁNCHEZ, C. y ALARCÓN NAVÍO, E.: El código penal francés, traducido y anotado, Comares, Granada, 2003.

ARRIBAS LÓPEZ, E.: El cohecho impropio después de la reforma del Código Penal, La Ley, 09/2011, pp.3-5.

ASUA BATARRITA, A.: La tutela penal del correcto funcionamiento de la Administración, en Delitos contra la Administración Pública, IVAP, 1997.

ATULLY, R.: Le droit pénal de Madagascar, Thèse de droit, Université de Paris, Ed. LMDJ, 1924.

BACIGALUPO, E.:

- "Sobre la reforma de los delitos de funcionarios", en Documentación Jurídica. Monográfico dedicado a la propuesta de anteproyecto del Nuevo Código Penal, n²2, 1983, pp.1095-1105.

-Teoría y práctica del derecho penal, Tomo I, Instituto Universitario de Investigación Ortega y Gasset, Marcial Pons, Madrid, 2009.

BARBEROS SANTOS, M.: "El bandolerismo en la legislación vigente", Anuario de Derecho Penal y Ciencias Penales, 1970, pp. 255-286.

BÉNILLOUCHE, M.: L'incrimination de la corruption en France, en. DELMAS-MARTY, M. (Dir.), Criminalité économique et atteinte à la dignité de la personne, Les processus d'internationalisation, T.VII, Éditions de la Maison des sciences de l'homme, Paris, 2001, pp.45-51.

BERDUGO DE LA TORRE, I. y otros:

-Curso de Derecho Penal, Parte General, Ediciones Praxis, Barcelona, 1999.

-Curso de Derecho Penal, Parte General, Coordinación: RODRÍGUEZ YAGÜE, C., Ediciones Experiencia, 2004. 


\section{SOBORNO DE LOS GOBERNANTES}

BERNAL DEL CASTILLO, J.: Derecho penal comparado, Atelier, Barcelona, 2011.

BLANCO CORDERO, I.: La reforma de los delitos de corrupción mediante la Ley Orgánica 5/2010: nuevos delitos y aumento de penas, La Ley, 12/2010, pp.23-27.

BLANCO LOZANO, C.: Tratado de Derecho Penal Español, Tomo II, Volumen 2, Bosch, 2005.

BONFILS, P.:

-«La corruption en droit pénal», en La corruption, Librairie de l'Université d'Aix-en-Provence, éd. 2005, pp.223-240.

-Droit pénal des affaires, Cours et travaux dirigés, Montchrestien, 2009.

BORGHI, M.: Droits de l'homme: fondement universel pour une loi anticorruption; le cas de la Suisse; en M. BORGHI y P. MEYER-BISCH (eds.), La corruption, l'envers des droits de l'homme, Éditions Universitaires Fribourg Suisse, Friburgo, 1995, pp.3-33.

BORREL, G.: Le Code des 305 Articles de Madagascar, Thèse de droit, Université de Paris, Ed. Domat-Montchrestien, 1931.

BUSTOS GISBERT, R.: La recuperación de la responsabilidad política en la lucha contra la corrupción de los gobernantes: una tarea pendiente, en E. A. FABIÁN CAPARRÓS y N. RODRÍGUEZ GARCÍA (coords.), La corrupción en un mundo globalizado, Ratio legis, Salamanca, 2003, pp.6785.

BUSTOS RAMÍREZ, J.:

-Manual de derecho penal, Parte especial, Barcelona, 1991, (2 ${ }^{\mathrm{a}}$ ed.).

-Manual de derecho penal. Parte general, Promociones y Publicaciones Universitarias, Barcelona, 1994, (4⿳⺈ ed.).

CARBAJO CASCÓN, F.: Corrupción pública, corrupción privada y derecho patrimonial., en E. A. FABIÁN CAPARRÓS y N. RODRÍGUEZ GARCÍA (coords.), La corrupción en un mundo globalizado, Ratio legis, Salamanca, 2003, pp.127-156.

CARBONELL MATEU, J.C.: Derecho penal: concepto y principios constitucionales, Tirant lo Blanch, Valencia 1996, (2 ${ }^{\mathrm{a}}$ ed.).

CARDONA TORRES, J.: Derecho Penal, Parte Especial, Bosch, 2010.

CARRASCO ANDRINO, M… D. M.: Los delitos plurisubjetivos y la participación necesaria, Comares, Granada, 2002. 


\section{BIBLIOGRAFÍA}

CARTIER, M. E. y MAURO, C.: La loi relative à la lutte contre la corruption des fonctionnaires étrangers, Revue de science criminelle et de droit pénal comparé, no 4, 2000, pp. 737 y ss.

CARTIER-BRESSON, J.: Les réseaux de corruption et la stratégie des « $3 \mathrm{~S}$ » : Sleep-Silence-Smile, en M. BORGHI y P. MEYER-BISCH (eds.), La corruption, l'envers des droits de l'homme, Éditions Universitaires Fribourg Suisse, Friburgo, 1995, pp.81-106.

CASAS BARQUERO, E.: "Observaciones técnico-jurídicas sobre la incriminación del cohecho en el Código Penal Español", Documentación Jurídica, julio-septiembre, 1978, pp.855-921.

CASTEJÓN Y MARTÍNEZ DE ARIZALA, F.: Derecho Penal, Tomo I, Reus, Madrid, 1931.

CECCON, F.: Contribution à l'étude de la lutte contre la corruption, Thèse droit privé et sciences criminelles, dir.. SORDINO, M-C, Université de Montpellier I, 2005.

CERINA, G. D. M.: "La lucha contra la corrupción en el siglo XXI: el papel del derecho penal. Estudio crítico del delito de cohecho en Italia y en España", Tesis doctoral, dir. FABIÁN CAPARRÓS, E. A., Universidad de Salamanca, 2010.

CHEVALLIER, J.: L'administration subordonnée? en La Constitution de la $V$ République, Réflexions pour un cinquantenaire (dir. JAN, P.), La documentation française, París, 2008.

COBO DEL ROSAL, M.:

-Examen crítico del párrafo 3. o del art. 119 del Código penal español (sobre el concepto de funcionario público a efectos penales), Revista General de Legislación y Jurisprudencia, 1962, pp.213-255

- "Sobre la naturaleza pluripersonal del delito de adulterio (art.449 del Código penal)", Anuario de Derecho Penal y Ciencias Penales, 1967, pp.147-167.

COBO DEL ROSAL, M. y VIVES ANTON, T.S.:

-Derecho penal: parte general, Tirant lo Blanch, Valencia, 1991, (3ra ed.) -Derecho penal: parte general, Tirant lo Blanch, Valencia, 1999, (5 a ed.).

COBO DEL ROSAL, M. y QUINTANAR DÍEZ, M.: “Comentario al artículo 24 del Código Penal Español”, en Comentarios al Código Penal (Dir. COBO DEL ROSAL, M.), Tomo III, Edersa, 2000, pp.27 y ss.

CONTE, P.: "L'art de légiférer se perd-il ? Réflexions en forme de pamphlet à partir de quelques illustrations de droit pénal ", Mélanges LapoyadeDeschamps, Presses Universitaires de Bordeaux, 2003, pp.307-314. 


\section{SOBORNO DE LOS GOBERNANTES}

CONTE P. y MAISTRE DU CHAMBON, P.: Droit pénal général, Coll. Sirey, Armand Collin, 2004, (7 éd).

CONSTANTINESCO, L.-J.: Tratado de Derecho comparado, Tecnos, Madrid, 1981.

CÓRDOBA RODA, J.: "Del cohecho", en J. CÓRDOBA RODA y M. GARCÍA ARÁN (Dirs), Comentarios al Código penal, parte especial, Tomo II, Marcial Pons, Madrid-Barcelona, 2004, pp.1994 y ss.

CRESPO BARQUERO, P.: “Corrupción y tráfico de influencias" en El nuevo Código penal y su aplicación a empresas y profesionales. Manuel teórico y práctico (III), Recoletos, Madrid, 1996, pp.483-525.

\section{CUELLO CALÓN E.:}

-Derecho penal conforme al Texto Refundido de 1944, t. II, Barcelona, 1952 (8a ed.).

-Derecho penal conforme al Texto Refundido de 1944, t. II, Barcelona, 1957 (10 a ed.).

CUGAT MAURI, M.: La desviación del interés general y el tráfico de influencia, Cedecs, Barcelona, 1997.

DANA, A.-C.: Essai sur la notion d'infraction pénale, Librairie général de Droit et de Jurisprudence, Paris, 1982.

DARGENTAS, E.: « La norme pénale et la recherche autonome des valeurs dignes de la protection pénale», Revue pénitentiaire et de droit pénal, 1977, p. 411 y ss.

DE LA MATA BARRANCO, N. J.: La respuesta a la corrupción pública, tratamiento penal de la conducta de los particulares que contribuyen a ella, Comares, Granada, 2004.

DEL TORO MARZAL, A.: “Comentario al artículo 119”, en CÓRDOBA RODA J. y otros, Comentarios al Código penal, Tomo II, Ariel, Barcelona, 1972, pp.725 y ss.

DELMAS SAINT-HILAIRE, J.-P.:

-«Sans nécessité, la loi pénale ne vaut», Politeïa no 5, 113-124.

-Chroniques, Revue de science criminelle et de droit pénal comparé (RSC), 2004, pp.91-94.

DELMAS-MARTY, M.:

- «L'enjeu d'un Code pénal, réflexions à propos de l'inflation des lois pénales en France», Mélanges Legros, éd. de l'Université de Bruxelles, 1985, pp. 165 y ss.

-Avant-propos, Revue de science criminelle et de droit pénal comparé, no 3, 1993, pp.433-443. 


\section{BIBLIOGRAFÍA}

DELMAS-MARTY, M. y MANACORDA, S.: La corruption, un défi pour l État de Droit et la société démocratique. Revue de science criminelle et de droit pénal comparé, julio-sept. 1997, pp.696-706.

DEMETRIO CRESPO, E.:

-“Corrupción y delitos contra la Administración Pública”, en. FABIÁN CAPARRÓS, E. A (coord.), La corrupción: aspectos jurídicos y económicos, Ratio Legis, Salamanca, 2000, pp.69 y ss.

-La corrupción como freno decisivo a la consolidación del Estado de Derecho: respuesta penal; en I. BERDUGO DE LA TORRES y R RIVERO ORTEGA (Eds), El Estado de derecho latinoamericano: integración económica y seguridad jurídica en Iberoamérica, Ediciones Universidad de Salamanca, Salamanca, 2003, pp.45-67.

DESPORTES, F. y LE GUNEHEC, F.: Droit pénal général, coll. Corpus droit privé, Economica, 2008, (15 éd).

DÍAZ Y GARCÍA CONLLEDO, M.: "El delito de cohecho", en ASUA BATARRITA A. (dir.), Delitos contra la Administración Pública, IVAP, 1997, pp.161-170.

DOMMEL, D.: Face à la corruption, Karthala, 2003.

DOUCET, J.- P.:

- LLa doctrine est-elle une source du droit ?» http://ledroitcriminel.free.fr.

-Précis de droit pénal général, éd. Faculté de Liège, 1976.

DREYER, E. : Cours magistral, Droit pénal spécial, Ellipses, 2008.

DUPUIS, G.: comentando la segunda línea del art.20, en La constitution de la république française, dir. LUCHAIRE, F. et CONAC, G. Economica, 1980, p.366.

DUVERGER, M. : comentando la primera línea del art.20 , en La constitution de la république française, dir. LUCHAIRE, F. et. CONAC, G., Economica, 1980, pp.363 y ss.

ESCRIVÁ GREGORY, J. M.: Papers, 13, Barcelona, 1980, pp 157 y ss.

FABIÁN CAPARRÓS, E. A.: La corrupción de agente público extranjero e internacional, Tiranch lo blanch, Valencia, 2003.

FAROUZ-CHOPIN, F.: La lutte contre la corruption, Presses universitaires de Perpignan, 2003.

FARRÉ TREPAT, E.: La tentativa del delito, Bosch, Barcelona, 1986. 


\section{SOBORNO DE LOS GOBERNANTES}

FAURE-GAUSSEL, C. : Droit pénal des affaires: étude comparative francoespagnole de l'infraction, Fondation Varenne y L.G.D.J., 2006.

FEIJÓo SANCHEZ, B.: "Cohecho" en Comentarios al Código penal, dir. RODRÍGUEZ MOURULLO, G. y JORGE BARREIRO, A., Civitas, 1997. pp.1125-1143.

FERNÁNDEZ, G. D.: Bien jurídico y sistema del delito, B de F, Buenos Aires, 2004.

FERNÁNDEZ RÍOS, L.: Psicología de la corrupción y los corruptos, Grupo Editorial Universitario, 1999.

FERRER SAMA A.: Comentarios al Código penal, t. IV, Madrid, 1956, (1ra ed.).

FITZGERALD, P.: "Les dispositifs juridiques internationaux de lutte contre la corruption des agents publics étrangers", Thèse de droit public, dir. M. GOUNELLE, Université du Sud Toulon-Var, 2011.

FORGES, M.: Droit de la fonction publique, Paris, 1986.

FRIER, P.-L.: Précis de droit administratif, Montchrestien, 2004.

GAËTAN DI MARINO, M.:"Recours aux objectifs de la loi pénale pour ce qui est de son application », Revue de science criminelle et droit pénal comparé, 1991, pp.505 y ss.

GARCÍA ARÁN, M.: La prevaricación judicial, Ed. Tecnos Madrid, 1990.

GARCÍA MEXÍA, P.: Los conflictos de intereses y la corrupción contemporánea, Aranzadi, Pamplona, 2001.

GARCÍA-PABLOS DE MOLINA, A.: Introducción al Derecho Penal, Editorial universitaria Ramón Areces, Madrid, 2005.

GARÇON, E.: Code pénal annoté, Tome I, Recueil Sirey, 1952.

GARRAUD, R.:

-Précis de droit criminel, Larose et Forcel, 1888, (1ํㅡㄹ. ed.).

-Traité théorique et pratique du droit pénal français, Tome I, Larose et Forcel, Paris, 1888.

-Traité théorique et pratique du droit pénal français, Tome III, Larose et Forcel, Paris, 1889.

-Traité théorique et pratique du droit pénal français, Tome II, Sirey, 1914, (3 ${ }^{\mathrm{a}}$ ed.).

-Précis de droit criminel, Sirey, 1934, (15a ed.).

-Traité théorique et pratique du droit pénal français, Tome IV, Sirey,

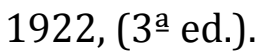




\section{BIBLIOGRAFÍA}

GARRIDO FALLA, F., CAZORLA, L. M., ETRENA, R. y otros: Comentarios a la Constitución Española, Madrid, Civitas, 1985, (2ª ed.).

GIUDICELLI-DELAGE, G.: Livre IV. Les crimes et les délits contre la nation, l'Etat et la paix publique, Revue de science criminelle et de droit pénal comparé, no 3, 1993, pp.493-510.

GOMÉZ BENÍTEZ, J. M.: Estudios penales, Colex, 2001.

GONZALEZ CUSSAC, J. L.: El delito de prevaricación de autoridades y funcionarios públicos, Tirant Lo Blanch, Valencia, 1997.

GONZÁLEZ RUS, J. J.:

-Seminario sobre bien jurídico y reforma de la parte especial, Crónicas extranjeras, Anuario de Derecho Penal, no 35, 1982, pp. 717 y ss.

-Bien jurídico y Constitución, Fundación Juan March, Madrid 1983.

GOYET, F.: Droit pénal spécial, Sirey, 1972, (8ª̣ éd.).

GRANADOS PEREZ, C.: "El instrumento en el delito de cohecho", en Cuadernos de derecho judicial, Consejo General del Poder Judicial, 1994, pp.129-152.

GRAVEN, P. y STRAÜLI, B.: L'infraction pénale punissable, Staempfli+Cie, Berne, 1995, (2 ${ }^{\mathrm{a}}$ ed.).

GROIZARD Y GÓMEZ DE LA SERNA, A.: El código penal de 1870 concordado y comentado, Tomo IV, Salamanca, 1891.

GUTTERIDGE, H. C.: El derecho comparado, Instituto de derecho comparado, Barcelona, 1954.

HAURIOU, M.: Précis de droit administratif, Dalloz, 2002.

HENRI, B.: La corruption: un mal endémique, L’Hermès, 2002.

HERNÁNDEZ HERNÁNDEZ, R.: Malversación, La ley 2/1996, D-112, pp.1454 y ss.

HÉZARD, G.: Le juge pénal et l'acte administratif, Mémoire de DEA de droit pénal et de sciences criminelles, dir. A. DECOCQ, Université de Panthéon-Assas (Paris II), 1999/2000.

HORMAZÁBAL MALARÉE, H.: Bien jurídico y Estado Social y Democrático de Derecho, (El objeto protegido por la norma), LexisNexis, Santiago de Chile 2006, (2 ${ }^{\mathrm{a}}$ ed.). 


\section{SOBORNO DE LOS GOBERNANTES}

JEANDIDIER, W.: Du délit de corruption et des défauts qui l'affectent, JCP, G, no 39, 25 septembre 2002, pp.1667-1674.

JASO ROLDÁN, T. en ANTÓN ONECA, J. y RODRÍGUEZ MUÑOZ, J. A.: Derecho penal. Parte especial, tomo II, Madrid, 1949.

JOLY, E.: Est-ce que dans ce monde-là que nous voulons vivre ?, Les arènes, 2003.

KOENIG, G.: Les discrètes vertus de la corruption, Grasset, 2009.

LACAZE, M.: Réflexions sur le concept de bien juridique protégé par le droit pénal, Thèse Droit privé et sciences criminelles, dir. D’HAUTEVILLE, A., Université de Montpellier I, 2009.

LARGUIER, J.: Droit pénal général, Mémento, Dalloz, 2001, (18ª̣ ed.).

LARGUIER, J.; CONTE, P. y LARGUIER, A.-M.: Droit pénal spécial, 14è éd., Dalloz, 2008.

LEVASSEUR, G.; CHAVANNE, A. y MONTREUIL, J.: Droit pénal général et procédure pénale, Sirey, 1994.

LOOS, F.: Zum "Rechtsgut" der Bestechungsdelikte, en: Fs-Hans Welzel, 1974.

LOPEZ-REY Y ARROJO, M.: Derecho Penal, Tomo II, Parte Especial, Reus, Madrid, 1935.

LUCAS de LEYSSAC, M-P. y MIHNAN, A.: Droit pénal des affaires, Manuel théorique et pratique, Economica, 2009.

LUCHAIRE, F.: comentando el Preámbulo, CF, en La constitution de la république française, dir. LUCHAIRE, F. et. CONAC, G., Economica, 1980, pp.38 y ss.

LUZÓN PEÑA, D.-M.: Curso de Derecho Penal, Parte General I, Editorial Universitas, 1996.

MAESTRE, J.-C.: comentando el artículo 2, CF, en La constitution de la république française, dir. LUCHAIRE, F. et. CONAC, G., Economica, 1980, pp.85, 86.

MAISTRE DU CHAMBON, P.; LAPAGE, A. y SALOMON, R.: Droit pénal des affaires, Litec, 2008.

MALABAT, V.: Droit pénal spécial, HyperCours Dalloz, 2007, (3ª ed.). 


\section{BIBLIOGRAFÍA}

MARÉCHAL, J.-Y.: «Essai sur le résultat dans la théorie de l'infraction pénale», L'Harmattan, 2003.

MARON, A., ROBERT, J.-H. y VÉRON, M., Chronique de droit pénal, JCP éd. G. 2001, I, 289.

MARTÍNEZ ARRIETA, A. "Comentario a los arts. 419-427", C. CONDEPUMPIDO TURÓN (Dir.), J. LÓPEZ BARJA DE QUIROGA (Coord.), Comentarios al Código penal, T. IV, Bosch, Barcelona, 2007, pp.3108 y ss.

MARTÍNEZ ESCAMILLA, M.; MARTÍN LORENZO, M. y VALLE MARISCAL DE GANTE, M.: Derecho penal, Introducción Teoría jurídica del delito, Materiales para su docencia y aprendizaje, Universidad Complutense de Madrid, Madrid, 2012.

MAYAUD, Y.: "Ratio legis et incrimination", Revue de science criminelle et de droit pénal comparé, 1983, pp. 596 y ss.

MÉDARD, J.-F.: "La corruption politique et administrative et les différenciations du public et du privé" en M. BORGHI y P. MEYER-BISCH (eds.), La corruption, l'envers des droits de l'homme, Éditions Universitaires Fribourg Suisse, Friburgo, 1995, pp.37-46

MERLE R. y VITU A.: «Traité de Droit criminel, problèmes généraux de la science criminelle, Droit pénal général », Tome I, Cujas, 1997, (7ª ed.).

MEYER, M.: Corruption et coopération au développement: que faire pour en réduire l'incidence ? en M. BORGHI y P. MEYER-BISCH (eds.), La corruption, l'envers des droits de l'homme, Éditions Universitaires Fribourg Suisse, Friburgo, 1995, pp.139-146.

MEZGER, E.: Tratado de Derecho Penal, Tomo I, nueva ed., revisada y puesta al día por RODRIGUEZ MUÑOZ, J. A., Editorial revista de derecho privado, Madrid, 1955.

MIR PUIG, C.:

- Los delitos contra la Administración pública en el nuevo Código penal, Bosch, Barcelona, 2000.

-El delito de cohecho en la reforma del Código penal (I), Iuris, febrero de 2011, pp.42-50.

MIR PUIG, S.:

-Introducción a las bases del derecho penal, concepto y método, Bosch, Barcelona, 1976.

-El derecho penal en el Estado social y democrático de derecho, Ariel Derecho, Barcelona, 1994.

-Derecho penal, parte general, Editorial Reppertor, Barcelona, 2005, (7ํㅗ ed.). 


\section{SOBORNO DE LOS GOBERNANTES}

MORALES PRATS, F.: en QUINTERO OLIVARES, G.: Manual de Derecho Penal, Parte General, Aranzadi, 2002, (3ra ed.).

MORALES PRATS, F. y RODRÍGUEZ PUERTA, M. J.:

- "Delitos contra la Administración Pública" en G. QUINTERO OLIVARES (dir.), Comentarios a la Parte Especial del Derecho Penal, Thomson/Aranzadi, 2008, (7a ed.), pp. 1585-1705.

-"Delitos contra la Administración Pública" en G. QUINTERO OLIVARES (dir.), Comentarios al Código Penal Español, Thomson/Aranzadi, 2011; (6ª ed.), pp. 1205-1252.

MORESO, J. J.: Principio de legalidad y causas de justificación, Cuadernos de Filosofía del Derecho, Universidad de Alicante, disponible en la red: http://publicaciones.ua.es .

MORILLAS CUEVA, L.: "Delitos contra la administración pública (V). Cohecho", en Sistema de Derecho Penal español, Parte Especial, Dykinson, Madrid, 2011, pp.953 y ss.

MUÑOZ CONDE, F.:

-Introducción al Derecho penal, BOSCH, Barcelona, 1975.

-Derecho penal y control social, Temis, Bogotá, 2004.

-Teoría general del delito, Tirant lo blanch, Valencia, 2007, (4⿳亠丷a ed.).

-Derecho penal, Parte especial, Tirant lo Blanch, Valencia, 2009, (17 a ed.).

-Derecho penal, Parte especial, Tirant lo Blanch, Valencia, 2010, (18 ${ }^{\text {a }}$ ed.).

MUÑOZ CONDE, F. y GARCÍA ARÁN, M.: Derecho penal, parte general, Tirant lo Blanch, Valencia, 2010, (9aㅡ ed.).

MURIEL PATINO, M. V.: "Economía, corrupción y desarrollo" en E. A. FABIÁN CAPARRÓS (coord.), La corrupción: aspectos jurídicos y económicos, Ratio Legis, Salamanca, 2000, pp.27-31.

NIETO, A.: Corrupción en la España democrática, Ariel, Barcelona, 1997.

NIETO MARTÍN, A.: "Corrupción y abuso de poder" en C. GÓMEZ RIVERO (coord.), Nociones fundamentales de Derecho penal. Parte Especial, Tecnos, Madrid, 2010, pp.751 y ss.

OCTAVIO DE TOLEDO Y UBIETO, E.:

- La prevaricación del funcionario público, Ed. Civitas, Madrid, 1980.

-Sobre el concepto del Derecho penal, Universidad de Madrid, Agisa, Madrid, 1981.

-Función y límites del principio de exclusiva protección de bienes jurídicos, Anuario de Derecho Penal y Ciencias Penales, no 43, 1990, pp. 10 y SS. 


\section{BIBLIOGRAFÍA}

- "Derecho penal, poderes públicos y negocios (con especial referencia a los delitos de cohecho)", en El nuevo Código penal: presupuesto y fundamentos. Libro en homenaje al Profesor Doctor Don Ángel Torío López, Comares, Granada, 1999, pp.861-887.

\section{OLAIZOLA NOGALES, I.:}

- "Cohecho y amenazas: la relación entre ambos delitos (A propósito de la STS de 17 de marzo de 1992)", en Poder Judicial, 2a época, núm.40, 1995, pp.425-471.

-El delito de cohecho, Tirant lo Blanch, Valencia, 1999.

ORTIZ DE URBINA GIMENO, I.: "Delitos contra la Administración pública”, en J.M. SILVA SÁNCHEZ (dir.); R. RAGUÉS I VALLÉS (coord.), Lecciones de derecho penal. Parte especial, Atelier, Barcelona, 2011, (3ª ed.), pp.327-342.

ORTS BERENGUER, E.: "Delitos contra la Administración (y II)", en VIVES, BOIX, CARBONELL y GONZALEZ, Derecho penal, parte especial, Tirant lo Blanch, Valencia, 1996, (2 ${ }^{\mathrm{a}}$ ed. revisada).

PACHECO, J. F.: El código penal concordado y comentado, Tomo II, Madrid, 1848.

PAVÍA CARDELL, J.: Responsabilidad penal en el ejercicio de la función pública de jurado, Comares, Granada, 2004.

PIN, X.: Droit pénal général, Dalloz, Paris, 2005.

PIÑEYRO, R.: "La corruption entre le désir et la mort du politique", Thèse de sociologie, dir. B. LAUTIER, Université Paris 1-Panthéon-Sorbonne.

POLAINO NAVARRETE, M.:

-El bien jurídico en el derecho penal, Anales de la Universidad Hispalense, Publicación de la Universidad de Sevilla, № 19, 1974.

-Derecho Penal, Parte General, Tomo I: Fundamentos científicos del Derecho Penal, BOSCH, Barcelona, 1996.

- "Delitos contra la Administración pública" en COBO DEL ROSAL (Dir.), Curso de Derecho penal. Parte especial II, Marcial Pons, Madrid, 1997, p. 267 y ss.

-"Cohecho. Tráfico de influencias. Malversación de caudales públicos." en M. POLAINO NAVARRETE (dir.) Lecciones de Derecho penal, Parte especial, Tomo II, Tecnos, 2011, pp.321 y ss.

PRADEL, J.:

-Traité de Droit pénal et de science criminelle comparée, Tome 1, Introduction général, Droit pénal général, Cujas, 1999, (12ª ed.),

-Manuel de droit pénal général, Cujas, 2002, (14ª ed).

-Droit pénal comparé, Dalloz, 2008. 


\section{SOBORNO DE LOS GOBERNANTES}

PRADEL J. y DANTI-JUAN, M.: Droit pénal spécial, Cujas, 2010, (5ae ed.).

PROVOST, M.: L'évolution du Droit et de la Justice dans les matières pénales à Madagascar d'octobre 1958 à octobre 1960, Thèse de droit, Université d'Aix-Marseille, 1963.

PUECH, M.: Droit pénal général, Litec, 1988, p. 249.

PUIG PEÑA, F.; Derecho penal, parte especial, t. III, Vol. I, Barcelona, 1959, (5⿳亠丷厂 ed.).

\section{QUERALT JIMÉNEZ, J.:}

- "El concepto penal de funcionario público", en Cuadernos de Política Criminal, no 27, 1985, pp.477 y ss.

-Derecho penal español, Parte especial, Atelier, 2010.

\section{QUINTANO RIPOLLÉS, A.:}

-Comentarios al Código penal, Revista de Derecho Privado, Madrid, 1966.

- Tratado de la Parte Especial del Derecho Penal, Tomo I, Editorial Revista de Derecho Privado, Madrid, 1972, (2ª ed.).

QUINTERO OLIVARES, G.: Curso de derecho penal, parte general, Cedecs, Barcelona, 1996.

RAFOLISY, P.: La protection juridique de l'intégrité morale et développement durable : le cas de Madagascar, Thèse droit privé et sciences criminelles, dir. BAYLE, M., Université de Limoges, 2008.

RAMBELOARISON, J.: Le contrôle juridictionnel de l'Administration à Madagascar, Doctorat d' État de Droit public, dir. CONAC, G., Université de Paris 1, 1984.

RAMOS RUBIO, C.: Del delito de cohecho: mano "más" dura "todavía" contra la corrupción nacional e internacional (arts. 419, 420, 421, 422, 423, 424, 425, 426, 427, 428, 429, 430, 439 y 445) en G. QUINTERO OLIVARES (Dir.) La Reforma Penal de 2010: Análisis y Comentarios, Aranzadi, Pamplona, 2010, pp.337-342.

RAODINA, A.: La production de la loi de politique publique, la loi 2004030 sur la lutte contre la corruption à Madagascar, Mémoire Master 2 de Sciences politiques, études africaines, dir. BANÉGAS, R., Université Paris 1-Panthéon Sorbonne, 2006.

RASSAT, M.-L.: Droit pénal général, PUF, 1987.

RAUTER, M.: Traité théorique et pratique du droit criminel français ou Cours de législation criminelle, Tome I, Charles Hingray, Paris, 1836. 


\section{BIBLIOGRAFÍA}

REURER, E.: Des atteintes à l'administration publique: la corruption passive et le trafic d'influence, Mémoire de DEA de droit pénal et sciences criminelles, dir. DI MARINO, G., Université d'Aix-Marseille, 1993.

RIVERO, J. y WALINE, J. : Droit administratif, Dalloz, 2004.

ROBERT, J.-H.:

-Droit pénal général, Thémis, P.U.F, 2001.

-Droit pénal général, Thémis, P.U.F, 2005 (6ª ed.).

-L'histoire des éléments de l'infraction, Revue de science criminelle et de droit pénal comparé, 1977, pp.278 y ss.

ROBERT, J.-H. y MATSOPOULOU, H.:Traité de droit pénal des affaires, PUF, 2004.

RODRÍGUEZ DEVESA, J. M.: “Cohecho” en Nueva Enciclopedia Jurídica, t. IV, Barcelona, 1952.

RODRÍGUEZ DEVESA, J. M. y SERRANO GÓMEZ, A.: Derecho penal español, Parte general, 17ª ed., Ed. Dykinson, Madrid, 1994.

RODRÍGUEZ LÓPEZ, F.:"Introducción al análisis económico de la corrupción”, en E. A. FABIÁN CAPARRÓS (coord.), La corrupción: aspectos jurídicos y económicos, Ratio Legis, Salamanca, 2000, pp.21-26.

RODRÍGUEZ LÓPEZ, P. y SOBRINO MARTÍNEZ, A. I.: Delitos contra la administración pública, delincuencia administrativa. Cuando el representante de la Administración participa en el delito, Bosch, 2008.

RODRÍGUEZ MONTAÑES, T.: Delitos de peligro, dolo e imprudencia, Ed. Universidad Complutense de Madrid-Centro de Estudios Judiciales, Madrid, 1994.

RODRÍGUEZ PUERTA, Mạ. J.:

-El delito de cohecho: Problemática jurídico-penal del soborno de funcionarios, Aranzadi, Pamplona, 1999.

-"Modificaciones en materia de cohecho", en F. ÁLVAREZ GARCÍA y J. GONZÁLEZ CUSSAC (Dirs.), Comentarios a la Reforma penal de 2010, Tirant Lo Blanch, Valencia, 2010, pp.465-473

ROUX, J.-A.: Cours de Droit pénal et de procédure pénale, Sirey, 1920, (1ra ed.).

ROVERSI MÓNACO, F.: "Breves consideraciones sobre el Gobierno y la Administración", en La Constitución española de 1978, dir. PEDRIERI, A. y GARCÍA DE ENTERRÍA, E., Madrid, Civitas, 1980. 


\section{SOBORNO DE LOS GOBERNANTES}

RUEDA MARTIN, Ma . A.: "Reflexiones sobre la participación de extraños en los delitos contra la Administración Pública”, en Revista de Derecho Penal y Criminología, núm 8, 2ª época, 2001, pp.128-164.

SABÁN GODOY, A.: El marco jurídico de la corrupción, Civitas, Madrid, 1991.

SALVAGE, P.: Droit pénal général, P.U.G, 2001, (5ª ed.).

SALVAIRE, J.: «Le concours idéal de contraventions », JCP éd. G. 1960, I, 1588.

SÁNCHEZ MORÓN, M. en Comentarios a la Constitución Española, dir. CASAS BAAMONDE, M. E. y RODRÍGUEZ-PIÑERO Y BRAVO-FERRER, M. Fundación Wolters Kluwer, Madrid, 2009.

SAPIN, M.: Documents de l’Assemblée Nationale nº 2083.

SARASSORO, H.: La corruption des fonctionnaires en Afrique, Étude de Droit pénal comparé, Economica 1980.

SERRANO GÓMEZ A. y SERRANO MAÍlLO, A.: Derecho Penal, Parte Especial, Dykinson, Madrid, 2010, (15ª ed.).

SILVA SÁNCHEZ, J. M.: Aproximación al derecho penal contemporáneo, BOSCH, Barcelona, 1992, pp. 274 y ss.

STEFANI, G., LEVASSEUR, G. y BOULOC, B.:

-Droit pénal général, Dalloz, 1984, (12ª ed.)

-Droit pénal général, Dalloz, 2007, (20ª ed.).

SUÁREZ-MIRA RODRÍGUEZ, C. y otros: Manual de derecho penal, parte especial, Tomo II, Thomson-Civitas, 2008(5aㅡ ed.).

TAILLEFAIT, A.: Déontologie des fonctionnaires et principes du service public de l'Éducation nationale, disponible en la red: http://sti.acmontpellier.fr.

TEJERINA, S.: Derecho penal español, t. II, parte especial, los delitos y las faltas en particular y sus penas, obra ajustada al Código penal de 1944, Madrid, 1950.

VALEIJE ALVAREZ, I.:

-"Aspectos problemáticos del delito de concusión (diferencias con el cohecho)", Revista general de derecho, 1994, pp.6517-6542.

- "Consideraciones sobre el bien jurídico protegido en el delito de cohecho", en Estudios penales y Criminológicos, T.XVIII, 1994-1995, pp.259369. 


\section{BIBLIOGRAFÍA}

-El tratamiento penal de la corrupción del funcionario: el delito de cohecho, Edersa, Madrid, 1996.

- "Reflexiones sobre los conceptos penales de funcionario público, función pública y "personas que desempeñan una función pública»", Cuadernos de Política Criminal, 1997, pp.435-507.

VÁZQUEZ IRUZUBIETA, C.: Comentario al Código Penal, La Ley, 2010.

VÁZQUEZ-PORTOMEÑE SEIJAS, F.:

-Delitos contra la Administración Pública. Teoría general, INAP, Universidade de Santiago de Compostela, 2003.

-Admisión de regalos y corrupción. Consideraciones político-criminales sobre el llamado "cohecho de facilitación" (artículo 422 CP), Revista de Derecho Penal y Criminología, 3a época, no6 (2011), pp.151-179.

VELÁSQUEZ VELÁSQUEZ, F.: Derecho penal parte general, Temis, Santa fe de Bogotá, 1995, (2ª ed.).

VERHAEGEN, J.: «Le fait qualifié infraction», Mélanges LEGROS, éd. de l'Université de Bruxelles, 1985.

VÉRON, M.: Droit pénal spécial, Sirey, 2010, (13ª ed.).

VIADA Y VILLASECA, S.: Código penal de 1870, concordado y anotado, t. III, Madrid, 1926, (5ํe ed.).

VIGNAU, M.: Le délit de corruption, Mémoire de DEA de droit pénal et sciences criminelles, dir. LECUYER, Université de MontesquieuBordeaux IV, 1996/1997.

VILLET, M. y NERDRUM, L.: La corruption: un dysfonctionnement du marché de l'information, en M. BORGHI y P. MEYER-BISCH (eds.), $L a$ corruption, l'envers des droits de l'homme, Éditions Universitaires Fribourg Suisse, Friburgo, 1995, pp.107-119.

VITU, A. en MERLE, R. y VITU, A.: Traité de Droit Criminel, Droit pénal spécial, Paris, 1982.

VITU, A.:

-L'illicéité comme élément de la responsabilité en Droit pénal, in 2èmes journées juridiques franco-helléniques,( Nancy, 14-18 mai 1984), Revue International de droit comparé, 3-1984, pp.631 y ss.

-Corruption passive et trafic d'influence commis par des personnes exerçant une fonction publique, en Juris-Classeur, Droit pénal, 2004, art.43211, fasc. 10.

VIVES ANTÓN, T.S.: La detención: delitos cometidos por los funcionarios públicos contra el ejercicio de los derechos de la persona reconocidos por las leyes: detenciones ilegales, Bosch, Barcelona, 1977. 


\section{SOBORNO DE LOS GOBERNANTES}

VIZMANOS T. M. y ALVAREZ MARTINÉZ, C.: Comentarios al código penal, Tomo II, Madrid, 1848.

VIZUETA FERNÁNDEZ, J.: Delitos contra la administración pública: estudio crítico del delito de cohecho, Comares, 2003.

VOUIN, M. R.: Droit pénal général et criminologie, Thémis, PUF, 1956.

WALTHER, J.: L'antijuridicité en droit pénal comparé franco-allemand, Thèse de Droit privé, dir. A. VITU, Université de Nancy II, 2003.

XIAO-YING, H.: La lutte contre la corruption en politique criminelle, étude comparée entre la France et la Chine, Thèse Droit, dir. MATSOPOULOU, H., Université de Paris 1-Panthéon Sorbonne, 2005. 